UNIVERSIDADE DE SÃO PAULO

ESCOLA DE COMUNICAÇÕES E ARTES

LUIZ CARLOS GONÇALVES DE OLIVEIRA JÚNIOR

\title{
Vertigo, a teoria artística de Alfred Hitchcock e seus desdobramentos no cinema moderno
}





\title{
Vertigo, a teoria artística de Alfred Hitchcock e seus desdobramentos no cinema moderno
}

\author{
Tese apresentada à Escola de Comunicações e \\ Artes da Universidade de São Paulo, para \\ obtenção do título de Doutor em Meios e \\ Processos Audiovisuais. \\ Área de Concentração: Meios e Processos \\ Audiovisuais
}

Orientador: Prof. Dr. Ismail Norberto Xavier 
Autorizo a reprodução e divulgação total ou parcial deste trabalho, por qualquer meio convencional ou eletrônico, para fins de estudo e pesquisa, desde que citada a fonte.

Oliveira Jr., Luiz Carlos Gonçalves de

Vertigo, a teoria artística de Alfred Hitchcock e seus desdobramentos no cinema moderno / Luiz Carlos Gonçalves de Oliveira Júnior -- São Paulo, 2015.

412 p. : il.

Tese (Doutorado) - Departamento de Cinema, Rádio e Televisão / Escola de Comunicações e Artes/USP.

Orientador: Prof. Dr. Ismail Norberto Xavier

Bibliografia

1. Estética cinematográfica 2. História e teoria do cinema 3. Alfred Hitchcock - Vertigo 4. Epistemologia estética 5. Cinema e pintura 6. Cinema moderno I. Xavier, Ismail Norberto II. Título.

CDD 21.ed. - 791.43 


\section{FOLHA DE APROVAÇÃO}

Luiz Carlos Gonçalves de Oliveira Júnior

Vertigo, a teoria artística de Alfred Hitchcock e seus desdobramentos no cinema moderno

Tese apresentada ao Programa de Pós-Graduação em Meios e Processos Audiovisuais, para obtenção do título de Doutor.

Área de Concentração: Meios e Processos Audiovisuais.

Linha de Pesquisa: História, Teoria e Crítica.

Orientador: Prof. Dr. Ismail Norberto Xavier.

Aprovado em:

Banca examinadora:

Prof. Dr.

Instituição:

Assinatura:

Prof. Dr.

Instituição:

Assinatura:

Prof. Dr.

Instituição:

Assinatura:

Prof. Dr.

Instituição:

Assinatura:

Prof. Dr.

Instituição: Assinatura: 


\section{Agradecimentos:}

Ao Prof. Dr. Ismail Xavier, pela orientação dedicada e zelosa, pela sabedoria, pela leitura sempre apta a iluminar o percurso que eu havia tateado no escuro, pela convivência durante esses anos, pela confiança que sempre me passou.

Ao Conselho Nacional de Desenvolvimento Científico e Tecnológico - CNPq, pela bolsa de doutorado concedida e pelo apoio financeiro para a realização desta pesquisa.

À Coordenação de Aperfeiçoamento de Pessoal de Nível Superior - CAPES, pela concessão da bolsa de Doutorado Sanduíche no Exterior, que me permitiu realizar um estágio de pesquisa em Paris, etapa fundamental de construção da tese e de ampliação de minha formação como pesquisador.

Ao Prof. Dr. Philippe Dubois, que me acolheu como co-orientador estrangeiro durante o doutorado-sanduíche na Université Sorbonne Nouvelle - Paris 3 e se apresentou como um interlocutor interessado e entusiasmado em nossas reuniões.

Ao Prof. Dr. Cristian Borges e à Profa. Dra. Yanet Aguilera Viruéz Franklin de Matos, pelas sábias observações durante a banca de qualificação, que me ajudaram a aprimorar o trabalho, a ampliar as referências bibliográficas e a repensar de forma decisiva a estrutura da tese e seus objetivos. 


\section{RESUMO}

OLIVEIRA Jr., L. C. G. Vertigo, a teoria artística de Alfred Hitchcock e seus desdobramentos no cinema moderno. 2015. 412 p. il. Tese (Doutorado) - Escola de Comunicações e Artes, Universidade de São Paulo, São Paulo, 2015.

A tese investiga a recorrência do filme Um corpo que cai (Vertigo, 1958), de Alfred Hitchcock, como esquema matricial de uma reflexão meta-artística que, tomando como objeto a própria imagem (cinematográfica, pictórica, fotográfica, digital), atravessa toda a história moderna do cinema. Depois de definir e analisar a teoria artística proposta por Vertigo, a tese verifica os desdobramentos dessa teoria em uma série de filmes realizados desde o começo da década de 1960 até os anos 2000. Dentre os filmes analisados se acham La Jetée (Chris Marker, 1962), Blow up (Michelangelo Antonioni, 1966), Trágica obsessão (Obsession, Brian De Palma, 1975), Special Effects (Larry Cohen, 1984), Síndrome mortal (La Sindrome di Stendhal, Dario Argento, 1996), Estrada perdida (Lost Highway, David Lynch, 1997), A prisioneira (La captive, Chantal Akerman, 2000) e Na cidade de Sylvia (En la ciudad de Sylvia, José Luis Guerín, 2007).

Palavras-chave: Estética cinematográfica. Alfred Hitchcock. Vertigo. Cinema moderno. Epistemologia estética. 


\begin{abstract}
OLIVEIRA Jr., L. C. G. Vertigo, Alfred Hitchcock's artistic theory and its extensions in modern cinema. 2015. 412 p. il. Thesis (Doctorate) - Escola de Comunicações e Artes, Universidade de São Paulo, São Paulo, 2015.

The thesis investigates the recurrence of Alfred Hitchcock's Vertigo (1958) as the matrix scheme of a meta-artistic reflection that crosses all the modern history of cinema. It includes a series of films whose subject is the image itself (cinematographic, pictorial, photographic, as well as digital image). After defining and analyzing the artistic theory proposed by Vertigo, the thesis verifies the developments of this theory in many modern and contemporary films made since the beginning of the 1960's. Among the films analyzed one will find La Jetée (Chris Marker, 1962), Blow up (Michelangelo Antonioni, 1966), Obsession (Brian De Palma, 1975), Special Effects (Larry Cohen, 1984), The Stendhal Syndrome (Dario Argento, 1996), Lost Highway (David Lynch, 1997), La captive (Chantal Akerman, 2000), and In the city of Sylvia (En la ciudad de Sylvia, José Luis Guerín, 2007).
\end{abstract}

Key words: Film aesthetics. Alfred Hitchcock. Vertigo. Modern cinema. Aesthetical epistemology. 


\section{SUMÁRIO}

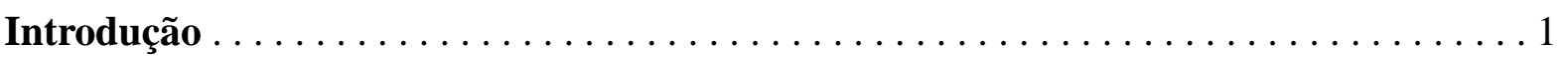

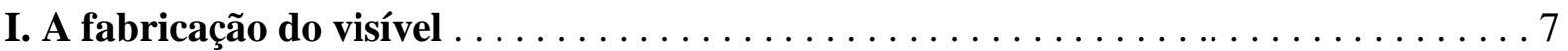

\section{A teoria artística em Vertigo}

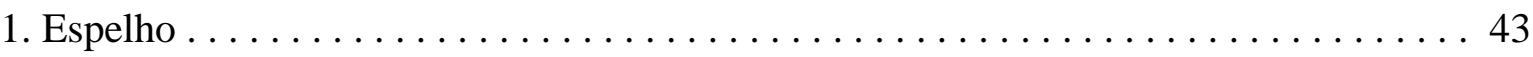

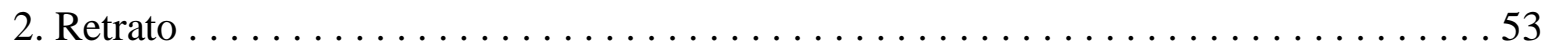

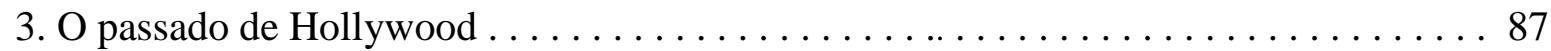

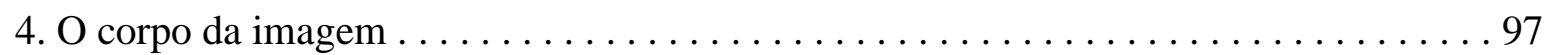

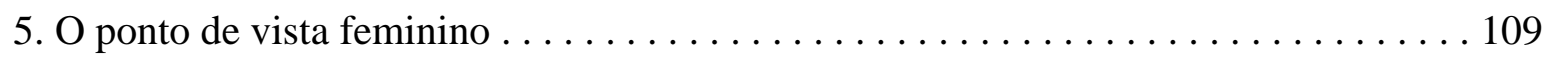

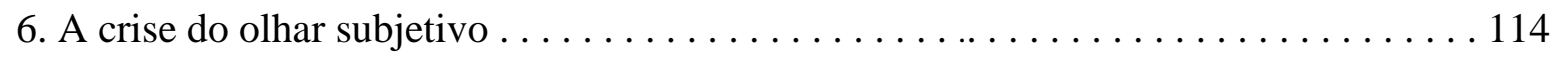

7. Uma teoria maneirista da arte? . . . . . . . . . . . . . . . . . . 124

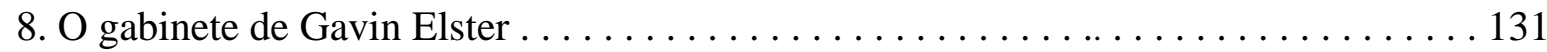

\section{A cena escondida}

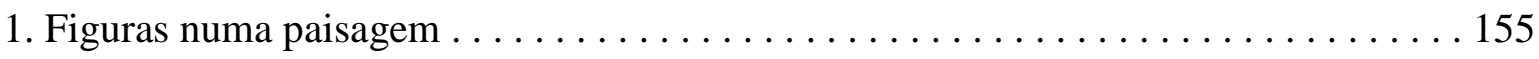

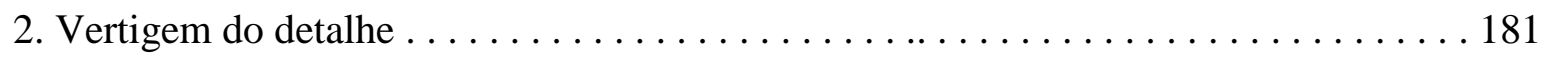

\section{O museu imaginário}

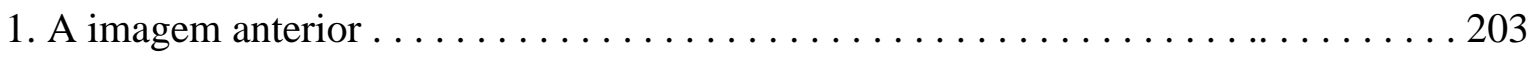

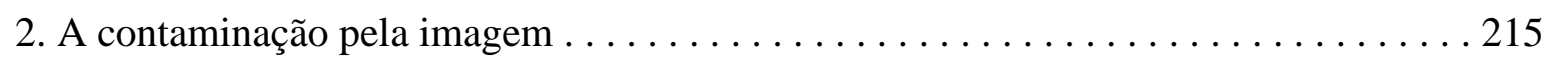

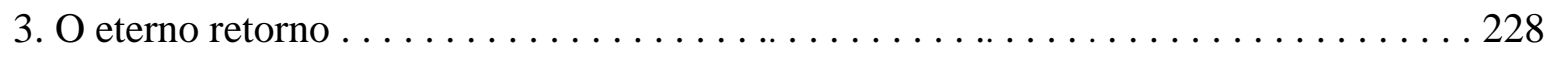




\section{Da paranoia à pornografia}

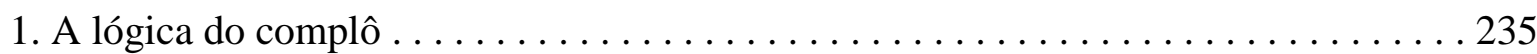

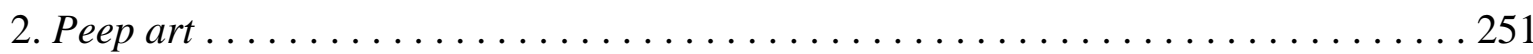

3. A visão em excesso . . . . . . . . . . . . . . . . . . . . . . . . . . . 259

4. A imagem anticlássica . . . . . . . . . . . . . . . . . . . . 268

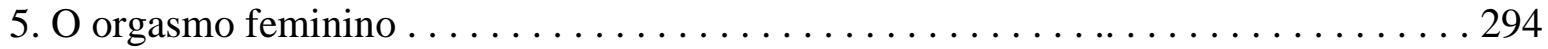

6. O outro lado de Madeleine . . . . . . . . . . . . . . . . . . . . . . . . . 306

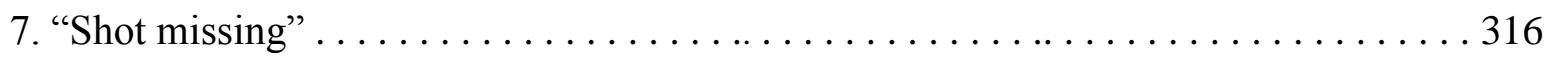

\section{A imagem-fantasma}

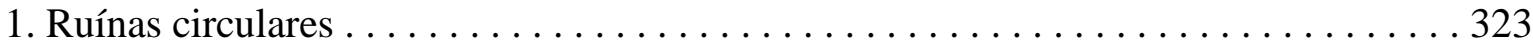

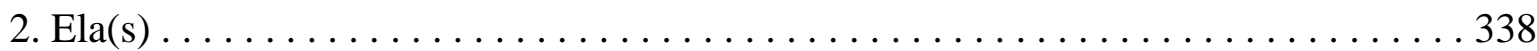

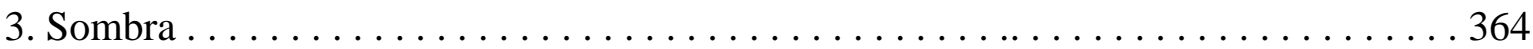

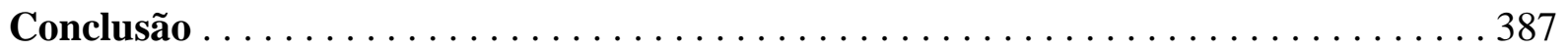

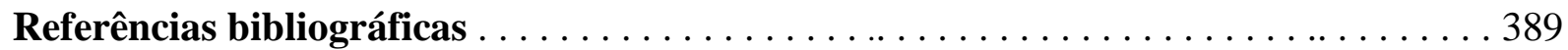


Como não se submeter a Tlön, à minuciosa e vasta evidência de um planeta ordenado?

Jorge Luis Borges, “Tlön, Uqbar, Orbis Tertius”, Ficções

Ninguém lembra como Joan Fontaine foi parar na beira de um penhasco. E o que Joel McCrea foi fazer na Holanda. E qual era o segredo guardado a sete chaves por Montgomery Clift. E por que Janet Leigh se hospeda no Bates Motel. E por que Theresa Wright continua apaixonada pelo Tio Charlie. Esquecemos o crime pelo qual Henry Fonda não era inteiramente culpado. E por que exatamente o governo americano contratou Ingrid Bergman. Mas nos lembramos de uma bolsa. Mas nos lembramos de um ônibus no deserto. Mas nos lembramos de um copo de leite, da hélice de um moinho, de uma escova de cabelo. Mas nos lembramos de garrafas enfileiradas, de um par de óculos, de uma partitura musical, de um molho de chaves. Porque através deles e com eles Hitchcock triunfou lá onde Alexandre, Júlio Cesar, Hitler e Napoleão fracassaram: em tomar o controle do universo. Tomar o controle do universo... Talvez umas 10 mil pessoas se lembrem da maçã de Cézanne. Mas 1 bilhão de espectadores se lembram do isqueiro de Pacto Sinistro. E se Hitchcock é o único poeta maldito a ter conhecido o sucesso, é porque ele foi o grande criador de formas do século $X X$, e são as formas que nos dizem, afinal, o que há no fundo das coisas.

Jean-Luc Godard, Histoire(s) du Cinéma, episódio 4A 



\section{Introdução}

De todos os inventores de formas do período clássico do cinema, Alfred Hitchcock foi certamente o mais revisitado pelos cineastas (e videoartistas) que vieram depois dele, de Brian De Palma a José Luis Guerín, passando por Gus Van Sant, Claude Chabrol, François Truffaut, John Carpenter, Dario Argento, Lucio Fulci, Rob Reiner, Chantal Akerman, Paul Verhoeven, David Lynch, Pierre Huyghe, Douglas Gordon, Laurent Fiévet, Christoph Draegger e tantos outros. Filmes como Janela indiscreta (Rear Window, 1954), Um corpo que cai (Vertigo, 1958), Intriga internacional (North by Northwest, 1959), Psicose (Psycho, 1960) e Os pássaros (The Birds, 1963) foram retomados, em cenas isoladas ou mesmo em narrativas inteiras, por diversos realizadores desde os anos 1960. É possível traçar toda uma história das formas cinematográficas dos últimos cinquenta anos tão somente a partir das inúmeras releituras e diálogos que a obra de Hitchcock engendrou.

As imagens de Hitchcock - e os sons, pois as notas cortantes de Psicose ou o barulho aterrorizante d'Os pássaros são algumas das construções sonoras que outros filmes reutilizariam incessantemente - parecem naturalmente destinadas à repetição, ao eterno retorno. São imagens que voltam - tanto no interior da própria obra de Hitchcock (gestos, composições, motivos formais que se repetem de um filme para outro) quanto nas obras de outros artistas.

Um filme em especial, Vertigo ${ }^{1}$, tem sido ao longo das décadas objeto recorrente de revisões, remakes, plágios, reprises, instalações videoartísticas etc. Fundado no caráter cativante e ilusório das aparências, Vertigo é um filme cujo próprio enredo já é pautado na repetição, no retorno de uma imagem que obceca - a imagem da mulher que fascina a personagem de James Stewart. Igualmente fascinados (ou até mesmo obcecados) com o filme, diversos diretores vêm dando sua versão particular de Vertigo. Podemos mesmo dizer que Vertigo se tornou uma imagem-matriz, um modelo formal que atravessa toda a história moderna do cinema. La Jetée (Chris Marker, 1962), A lenda de Lylah Clare (The Legend of Lylah Clare, Robert Aldrich, 1968), Una sull'altra (Fulci, 1969), Trágica obsessão

\footnotetext{
${ }^{1}$ Iremos preferir, ao longo deste trabalho, o título original do filme à sua versão brasileira (Um corpo que cai).
} 
(Obsession, De Palma, 1975), Special Effects (Larry Cohen, 1984), Instinto selvagem (Basic Instinct, Verhoeven, 1992), Síndrome mortal (La Sindrome di Stendhal, Argento, 1996), Estrada perdida (Lost Highway, Lynch, 1997), The Blackout (Abel Ferrara 1997), A prisioneira (La captive, Akerman, 2000) e Na cidade de Sylvia (En la ciudad de Sylvia, Guerín, 2007) são apenas alguns dos filmes que nos permitem atravessar cinco décadas de cinema tendo Vertigo como referência central. A espiral que sai lentamente de um olho feminino na sequência de créditos iniciais de Vertigo parece já determinar o destino fatal das imagens do filme: prolongar-se em trajetórias cíclicas que se adensam no tempo, como as ruínas circulares de uma obra que nunca vai deixar de recolocar indefinidamente seu mistério.

Há, portanto, uma espécie de série-Vertigo a ser identificada e analisada nesta tese: um conjunto de filmes que, sempre reverberando Vertigo de alguma forma, constituem um percurso singular dentro da trama mais vasta composta pela história do cinema em seu conjunto. Antes de se apresentarem numa trajetória linear e sucessiva, esses filmes formam um labirinto de imagens no qual podemos transitar em múltiplas direções, usando o filme de Hitchcock como fio de Ariadne. Embora partam de um mesmo modelo - seja de forma declarada e evidente, seja de forma mais secreta e escondida -, os filmes que compõem a série-Vertigo, uma vez analisados, provam-se profundamente distintos uns dos outros. Contudo, se há uma coisa que esses filmes trazem em comum é o fato de que, em sua grande maioria, eles encaram Vertigo como um modelo de reflexão sobre o poder da imagem cinematográfica (e de outras imagens: pintura, fotografia, vídeo, mais recentemente a imagem digital). Ou seja, a série-Vertigo diz respeito, acima de tudo, a filmes que, servindo-se dos dispositivos visuais e narrativos de Hitchcock como esquema matricial de um discurso que visa à reflexão meta-artística, tomam como objeto (implícita ou explicitamente) a própria arte, a própria imagem.

Já não é novidade que os filmes de Hitchcock, sobretudo aqueles realizados em sua fase mais experimental (que se dá entre 1948 e 1963), são reflexões sobre a natureza do espetáculo cinematográfico e os poderes específicos da imagem em movimento; já não resta dúvida de que há uma clara consciência teórica em Hitchcock. Se observarmos com cuidado, porém, veremos que o lado reflexivo de sua obra é ainda mais ambicioso do que parece, extrapolando as análises já publicadas por seus exegetas, bem como os axiomas do próprio diretor, a maioria deles concentrada nas páginas do famoso livro de entrevistas HitchcockTruffaut. Há, nos filmes que Hitchcock dirigiu em sua fase áurea, uma dimensão metacinematográfica que, em Vertigo, atinge um escopo mais amplo, tornando-se metaartística. Trata-se aí de uma verdadeira epistemologia estética, que Hitchcock desenvolve com 
os meios expressivos do cinema, fazendo da sua mise en scène um ato de reflexão teórica sobre a imagem clássica e o olhar que ela solicita (e isso sem sacrificar os atrativos do espetáculo e a fluidez narrativa do suspense).

A hipótese aqui apresentada, então, é a de que há uma teoria artística na obra de Hitchcock dos anos 1950. Essa teoria ganha contornos mais nítidos em Janela indiscreta e irá se cristalizar em Vertigo, filme atravessado de uma ponta à outra por uma discussão acerca dos critérios performativos e dos dispositivos de representação do cinema clássico hollywoodiano, cuja linguagem "transparente" é colocada em xeque por Hitchcock. Tal discussão presente no filme, que fique claro, não se expressa na linguagem verbal, em enunciados ou falas, mas nas próprias imagens, que se apresentam como "formas pensantes", respostas dadas através de signos icônicos a problemas que são de ordem não só dramatúrgico-ficcional como também teórico-conceitual. ${ }^{2}$

Muito do fascínio de Vertigo vem de sua beleza crepuscular. Filme-charneira, situado bem na curva entre o fim do cinema clássico e o advento do moderno, Vertigo acumula em seu tecido uma mesma quantidade de forças de permanência e de ruptura, de pulsões de conservação e de invenção. Último raio solar da Antiga Hollywood ou filme inaugural do maneirismo cinematográfico? Ocaso do classicismo ou primeiro filme moderno norteamericano? Provavelmente as duas coisas ao mesmo tempo: tanto a quintessência da forma clássica e a perfeição suprema do estilo romanesco hollywoodiano como a decadência do seu imaginário e o prenúncio de um esgotamento, de uma exaustão dos esquemas psicológicos e narrativos que constituem o arcabouço desse sistema de representação. Em outras apalavras, tanto o apogeu da Hollywood clássica como o início do seu declínio.

Mas a questão não se limita ao cinema: produto de uma época culturalmente avançada ou tardia, bem como da erudição de seu realizador, Vertigo é um aglomerado de ascendências, de formas e motivos oriundos da história pregressa do cinema e das outras artes, acumulando referências que vão da literatura romântica ao cinema expressionista alemão, do teatro vitoriano à pintura simbolista, dos gabinetes de curiosidades do século XVII à iconografia do film noir dos anos 1940, dos padrões formais do retrato renascentista aos códigos figurativos do star system de Hollywood - sem falar na alusão aos mitos fundadores do imaginário artístico ocidental, já que Vertigo evoca também a fábula de Plínio sobre a origem da pintura e o mito de Pigmalião descrito por Ovídio nas Metamorfoses. Hitchcock inscreve seu filme,

\footnotetext{
${ }^{2}$ Sobre a questão da possibilidade de um filme ser um ato de teoria, há dois artigos interessantes de Jacques Aumont: "Le cinéma comme acte de théorie: Notes sur l'oeuvre de Kurt Kren" (Revue Cinémathèque, n. 11, primavera de 1997, pp. 93-107) e "Un film peut-il être un acte de théorie?" (CiNéMAS, vol. 17, n. 2/3, pp. 193-209).
} 
assim, numa história das formas artísticas que remonta à Antiguidade e que se dispõe a discutir a relação historicamente constituída pelo homem com a imagem.

Em linhas gerais (o assunto será tratado em minúcias no segundo capítulo), podemos dizer que Vertigo repõe uma crise moderna da imagem, questão que marca a história da arte desde pelo menos a iconoclastia reformista do século XVI, e que retorna com força na contemporaneidade na esteira dos novos questionamentos trazidos pelas novas tecnologias de imagem. Por isso mesmo, por remeter a problemáticas que atravessam toda a história da representação no Ocidente, Vertigo não pode ser visto como um simples ponto de partida, mas antes como um ponto de irradiação: a série-Vertigo não inclui apenas filmes feitos depois de 1958 e que se reportam à obra de Hitchcock: ela abarca também pinturas de diferentes épocas (Ghirlandaio, Rubens, Hoogstraten, Manet), obras literárias do século XIX (Poe, Hoffmann, Balzac), filmes realizados um pouco antes de Vertigo (como Picnic, de Joshua Logan, Os amores de Pandora, de Albert Lewin, Tarde demais para esquecer, de Leo McCarey), ou na década de 1920 (Fantasma, de Murnau), ou até mesmo na década de 1910 (Gryozy, de Evgenii Bauer). A pequena história das formas que aqui nos interessa não caminha num sentido unilinear (do "modelo" em direção às "imitações"): ela se irradia, espalha-se numa rede complexa. Mapeando essas migrações multidirecionais das imagens de Vertigo, obteremos um percurso tão irregular quanto estimulante, cheio de avanços e recuos, passagens subterrâneas, ligações inusitadas, mesclas temporais. O que une os filmes e forja uma continuidade, nessa perspectiva, é menos a sucessão cronológica do que o trajeto visual que as imagens formam quando convidadas a dialogar entre elas. Surge então todo um espelhamento de gestos, de motivos visuais e composicionais, de dispositivos ópticos retrabalhados não necessariamente de modo pensado e deliberado, mas muitas vezes por um processo inconsciente de memória artística das formas.

Um filme que se impõe como travessia obrigatória nesse percurso é Blow up, de Michelangelo Antonioni, realizado em 1966. Como Hitchcock fizera em Janela indiscreta e Vertigo, Antonioni questiona os limites do olhar e da representação. Mas ele desloca a trama para a análise de uma imagem, de uma fotografia, trazendo a primeiro plano a temática epistemológica que ficava, de certo modo, "disfarçada" em Hitchcock. A investigação óptica da imagem fotográfica se apresenta, em Blow up, como uma reflexão sobre o privilégio da visão na cultura ocidental, isto é, a consagração da visão como ferramenta central da inspeção científica (ver para conhecer) - e a crise do visível decorrente do colapso desse paradigma. Antonioni concretiza de vez o projeto de filme-tese da modernidade que Vertigo apenas prefigurava. 
Não à toa, Blow up teve múltiplas releituras já a partir do final dos anos 1960, deflagrando no cinema moderno uma "síndrome Blow up" complementar à "síndrome Vertigo". De Dario Argento a Francis Ford Coppola, de Brian De Palma a David Fincher, passando por Ridley Scott numa célebre sequência de Blade Runner e Mel Brooks numa ótima gag de Alta ansiedade, foram muitos os cineastas que citaram, reciclaram ou parodiaram o filme de Antonioni. Há, portanto, uma série-Blow up, que se entrecruza com a série-Vertigo em alguns pontos, conforme veremos.

Nosso primeiro desafio consistirá em definir a teoria artística de Hitchcock, em apreender seus contornos, em identificar os conceitos estéticos que a constituem, assim como suas eventuais semelhanças com ideias artísticas do passado (as teorias do retrato no Renascimento italiano, os tratados maneiristas do Cinquecento, a retórica visual das pinturas de gabinetes etc.). Depois de definida e analisada essa meditação estética de Hitchcock, buscaremos entender de que forma ela foi prolongada e - às vezes - aprofundada por outros cineastas (Antonioni, Marker, De Palma, Argento, Ruiz, Lynch, Ferrara, Guerín).

O núcleo da reflexão artística hitchcockiana, como já dissemos, acha-se em Vertigo, que merecerá, logicamente, uma análise detida. O objetivo não é fornecer uma interpretação definitiva deste que já é um dos filmes mais admirados e analisados da história do cinema; tal empreitada seria ilusória e não faria o menor sentido a esta altura do campeonato. Nossa análise, embora detalhada e extensa, terá um foco bastante preciso, privilegiando os aspectos metarreflexivos do filme, as ferramentas plásticas e os dispositivos de encenação pelos quais ele constrói tanto um comentário crítico sobre o imaginário hollywoodiano quanto um discurso alegórico sobre a criação artística.

O primeiro capítulo, que ainda não entrará em Vertigo, pode parecer um adiamento do problema. Mas ele é, na verdade, um preâmbulo mais do que necessário, na medida em que situa o universo hitchcockiano no quadro específico de nossa problemática e analisa questões apresentadas por outros filmes (Janela indiscreta, principalmente) que serão cruciais para alcançar o desenho completo da tese. Vertigo é a figura central do trabalho, mas não exclusiva. Há uma série de elementos tipicamente hitchcockianos que sequer aparecem em Vertigo e que, no entanto, são partes fundamentais do percurso que estamos tentando delimitar e acompanhar. É preciso, portanto, começar por uma avaliação mais abrangente da obra de Hitchcock, para depois concentrar a discussão em Vertigo e em suas ressonâncias (fílmicas e extrafílmicas). No melhor estilo hitchcockiano, iremos do plano de conjunto ao plano-detalhe. 
Em diversos momentos, a análise será guiada por motivos plástico-visuais muito específicos: espelhos, retratos, sombras, perfis, arranjos de composição e de enquadramento. A escolha de um motivo extraído de Vertigo ou de outro filme de Hitchcock e a consideração de suas transformações e reelaborações pelos demais cineastas abordados na tese pode nos permitir encontrar novas brechas de entrada no universo das ideias estéticas sobre o cinema e, deste modo, repensar sua história. O método, que deve muito à "iconologia analítica" panofskyana, tem se mostrado de grande relevância na história da arte, como confirmam os trabalhos de Daniel Arasse e Victor I. Stoichita, dois autores fundamentais na bibliografia.

O percurso assim construído, fazendo jus ao tema, é uma espécie de vertigem das formas. Uma espiral que poderia se prolongar ad infinitum, mas que procuramos circunscrever da maneira mais coesa possível. 


\section{I.}

\section{A fabricação do visível}

Um dos planos célebres de Hitchcock é aquela grua que desce da parte mais alta do interior de uma mansão (onde ocorre uma festança) e chega até a mão de Ingrid Bergman, focalizando a chave que ela está trazendo em segredo e que será o objeto-pivô do ponto de virada da trama de Interlúdio (Notorious, 1946). O plano é literalmente uma plongée, um mergulho na cena. A câmera vai da tomada geral ao plano-detalhe em um movimento preciso, decidido, enfático, resumindo perfeitamente o movimento dos filmes de Hitchcock: "da paisagem em direção à mancha, do plano de conjunto ao primeiro plano". ${ }^{1}$ Em meio a todas aquelas pessoas e todos aqueles objetos, a câmera sabe exatamente o que buscar. Ela seleciona, aproxima e indica para o espectador o objeto que mais importa naquele ambiente e naquele momento. Hitchcock conduz nosso olhar, dirige nossa atenção para um ponto específico.

Em outro momento de Interlúdio, posterior à sequência da festa, uma xícara contendo café envenenado é oferecida à personagem de Ingrid Bergman, que ainda não desconfia que seus enjoos vêm sendo provocados por uma substância que o marido - já tendo descoberto que ela é uma espiã a serviço do governo americano - adiciona às suas bebidas. A câmera enquadra de perto a xícara de café e acompanha seu trajeto enquanto ela é servida. Depois, a fluência da cena é parcialmente quebrada por um enquadramento extravagante, para não dizer anômalo: a xícara, repousada sobre uma mesinha, aparece gigantesca em primeiro plano, interpondo-se aos atores. Pela proximidade excessiva, esse objeto comum de todos os dias de repente se torna estranho, quase monstruoso. Passamos do registro objetivo ao subjetivo, da realidade ao pesadelo. A xícara se põe ali como um agente perturbador da visão, um objeto que ressai do conjunto por uma súbita acromegalia. O quadro destaca do cenário o elemento que indica o crime, exclama para o público o que a personagem está prestes a descobrir (o café contém veneno!).

\footnotetext{
${ }^{1}$ Cf. Pascal Bonitzer, "Le suspense hitchcockien”, in Le champ aveugle: essais sur le cinéma, Paris: Gallimard; Cahiers du cinéma, 1982, p. 61.
} 
Godard disse certa vez que existem dois tipos de cineastas: os que veem, permitindo que o olhar flane pelo espaço, e os que miram, fixando sua atenção num ponto preciso que lhes interessa. "Quando se dispõem a rodar um filme, o enquadramento dos primeiros é aéreo, fluido (Rossellini); o dos segundos está calculado ao milímetro (Hitchcock)". 2 Ao contrário do Rossellini de Índia, Stromboli ou Viagem à Itália, que deixa a câmera vagar pelo mundo imantada a um sentimento do espaço ou ao movimento de um corpo, o olhar de Hitchcock marca a cada instante seu controle, seu poder, "sua capacidade cortante de enquadrar e de centrar, de desenhar por uma exacerbação ou uma exorbitância simbólicas um fragmento de mundo subitamente inchado por uma atenção humana". ${ }^{3}$ O plano hitchcockiano é dotado de uma força de indexação, de demarcação exata do seu objeto. A narrativa calcada em deambulações e esperas, a paciência mediterrânica de Rossellini cede lugar a uma focalização incisiva. Hitchcock não aguarda pelas formas que se tecem na trama imanente do tempo. Ele se antecipa às coisas, impõe-lhes a ação de seu pensamento. Hitchcock não vê, ele mira.

Do ponto de vista de uma história das formas cinematográficas, seria preciso situar a origem da "mirada" hitchcockiana num momento anterior à própria existência da obra de Hitchcock (que começa por volta de 1925). A exploração narrativa da montagem e o uso psicológico do primeiro plano, necessários para a consolidação dos procedimentos que estariam na base do suspense hitchcockiano, remontam aos anos 1910, quando as metragens se alongam e as técnicas se refinam. Antes disso, o cinema contava suas histórias por meio de uma sucessão de "tableaux" que consistiam em cenas condensadas num bloco de ação fornecido por uma tomada geral do ambiente, com a câmera mantendo um único ponto de vista frontal e fixo. Herdeira menos da pintura do que de uma tradição de espetáculo cênico do século XIX (que incluía o teatro de boulevard, a pantomima, os esquetes de mágica, os museus de cera, as apresentações de music-hall), a estética do tableau ou do "quadro primitivo" funcionava como uma versão impressa do palco teatral, cada tableau constituindo no interior do filme uma pequena cena autônoma que representava com mais ou menos eficácia e clareza - ou, às vezes, de forma realmente caótica - um episódio da narrativa. As cenas se apresentavam em bloco, em plano de conjunto. Com a "virada griffithiana", elas passarão a se apresentar em pedaços. É a passagem do tableau ao plano, e da mera aglomeração ou acumulação de registros aos efeitos de montagem propriamente ditos. ${ }^{4}$

\footnotetext{
${ }^{2}$ Cf. J.-L. Godard, "Bergmanorama”, Cahiers du cinéma, no 85, julho de 1958.

${ }^{3}$ Jacques Aumont, "Le plan", in BAECQUE, Antoine de (org.), Cahiers du cinéma - Le siècle du cinéma, Horssérie, novembro de 2000, p. 38.

${ }^{4}$ Sabemos que a história é um tanto mais nuançada do que sugiro nesta passagem. A centena de filmes que Griffith realizou na Biograph entre 1908 e 1913 demonstra que o processo é gradativo, há uma arte da
} 
A decupagem técnica, isto é, a fragmentação da cena em planos, introduz no cinema um "princípio de economia narrativa": cada plano deve mostrar um aspecto necessário ao andamento da narrativa, e deve fazê-lo no tempo adequado; o cineasta deve identificar em cada cena os elementos mais importantes, depois isolá-los e organizá-los em uma ordem de planos seguindo uma certa lógica e uma certa hierarquia. Através da variação do ponto de vista, entra em jogo uma estética do centramento: "o espaço do plano não é mais um campo indiferenciado, ele é ao contrário hierarquizado, estratificado, centrado sobre um objeto, uma figura, um evento". 5 Diferentemente do tableau primitivo, que comportava um certo grau de confusão e ambiguidade, o plano é pensado de modo a dirigir, a centrar a atenção do espectador. Ele deve ser imediatamente decifrável, poupar o observador de todo esforço de interpretação da imagem e, principalmente, não distraí-lo do essencial. "É o começo do que Hitchcock chamaria de 'direção de espectador'.,"6

A mestria de Hitchcock consistirá justamente em levar ao extremo esse poder de centralização, essa arte de coordenação da atenção visual. O plano hitchcockiano é, ao mesmo tempo, a intensificação da função voyeurista do cinescópio de Edison e a perversão do efeito de realidade da vista Lumière (que não deve ser confundida com o tableau de que falávamos há pouco - em Lumière, trata-se já de outra coisa, de um "plano-olhar", de uma aventura da percepção, de uma consciência lançada no mundo): intensificação do voyeurismo porque o alcance do olho é redobrado pela precisão dos dispositivos ópticos que estão a serviço da narrativa (vide o já citado movimento de grua em Interlúdio); perversão da tomada de vista porque o suspense hitchcockiano nada mais é que a excitação de um exercício do olhar já presente em Lumière, uma reformulação maliciosa da interrogação que é endereçada pela câmera ao mundo visível, "um efeito exacerbado da realidade mais banal e mais tranquila"” não é preciso alterar a realidade, basta sondá-la ou investigá-la (o simples comportamento da câmera, ao demarcar a presença de um observador astuto, de um olhar intencionado, já põe em xeque a inocência, implica uma suspeita, instaura um "horror latente", uma tensão, uma dúvida).

montagem e do raccord sendo lentamente desbravada e lapidada. A transição direta que aqui esboço, indo da estética do tableau para o período de integração narrativa, é abertamente esquemática. É evidente que ocorreu ainda uma série de transformações intermediárias, como, por exemplo, os "filmes de perseguição", ou chase films, que pulularam entre 1903 e 1906 e forneceram um modelo de montagem que Griffith aprimoraria passando de um regime puramente mecânico para "um registro emocional, pelos jogos dos planos aproximados sobre os rostos dos protagonistas" (Bonitzer, op. cit., p. 45). Ademais, o cinema anterior a 1910, ou mesmo anterior a 1900, não necessariamente era "teatro filmado", "sem montagem" e desprovido de planos aproximados. Inúmeros exemplos, na verdade, atestam o contrário.

${ }_{6}^{5}$ Emmanuel Siety, Le plan, au commencement du cinéma, Paris: Cahiers du Cinéma/Scérén-CNDP, 2001, p. 58.

${ }^{6}$ Ibid.

${ }^{7}$ J. Aumont, $O$ olho interminável, São Paulo: Cosac \& Naify, 2004, p. 37. 
Se a vista lumièriana oferece um "transbordamento de realidade", um espaço ilimitado, o plano hitchcockiano, inversamente, fecha o campo visual sobre o objeto suspeito, aquele que, em meio à totalidade do real, torna-se um operador de ficção, um foco de intriga. $\mathrm{Na}$ vista Lumière, "o olhar passeia, se perde e se dissolve, em suma, se exerce em um campo" ; a profusão do real distrai o olhar (o vento nas folhas, a luz que cintila por toda parte, as figuras que passam). Já no plano hitchcockiano, o campo é recortado e focalizado de acordo com o movimento da atenção, da curiosidade e do desejo; o espetáculo efêmero e "inocente" da vida que passa é reestruturado num novo contexto visual que resulta da delimitação, da especialização do quadro em função de uma acuidade particularizada. Embora comece, via de regra, pelo plano geral, pela visão de conjunto, pela observação indiferente de uma situação qualquer, a montagem dos planos (ou o movimento de câmera) pouco a pouco desloca o olhar do espectador em direção àquele ponto do espaço em que um determinado elemento (às vezes, apenas um detalhe ínfimo) se insurge contra a normalidade reinante.

O cinema hitchcockiano se agencia assim: tudo anda normalmente, na média, mesmo na mediocridade e na insensibilidade gerais, até que alguém percebe que um elemento do conjunto, por um comportamento inexplicável, produz uma mancha. [...] É sempre em torno dessa mancha que se organizam os efeitos de mise en scène mais especificamente hitchcockianos. ${ }^{9}$

A teoria - de extração lacaniana - exposta por Pascal Bonitzer ${ }^{10}$ define uma característica central da construção visual dos filmes de Hitchcock: partindo de uma situação comum ou mesmo banal, o enquadramento progressivamente isola um objeto privilegiado ou destaca um elemento que, desviando o sentido primeiro da imagem (seu "estado de natureza"), surge como o alerta, em última análise, da presença ameaçadora de forças maléficas que permeiam o mundo cotidiano, o mundo das aparências e da sociabilidade. É o ponto vermelho no retângulo negro da janela de um dos apartamentos em Janela indiscreta, que nada mais é que um cigarro aceso furando a escuridão da madrugada, mas que, aos olhos intrigados da personagem de James Stewart, só pode ser o signo do mal, "o olhar do demônio emboscado nas trevas" $"$, o indício incontestável de que houve um crime naquela residência um crime acobertado pelo véu da vida social cotidiana.

\footnotetext{
${ }^{8}$ Ibid., p. 43.

${ }^{9}$ P. Bonitzer, op. cit., p. 53.

${ }^{10}$ A primeira versão dessa teoria, que se tornaria bastante influente (Slavoj Zizek que o diga), aparece num artigo intitulado "It's only a film ou La face de néant", publicado numa edição especial dos Cahiers du cinéma na ocasião da morte de Hitchcock, em 1980. Depois, no livro Le champ aveugle, Bonitzer reeditou o texto e o apresentou em versão alterada e ampliada, com o novo título "Le suspense hitchcockien".

${ }^{11}$ Charles Baudelaire, "O pintor da vida moderna", in __. A invenção da modernidade, Lisboa: Relógio D’Água, 2006, p. 315.
} 
Nos filmes de Hitchcock, todos "possuem alguma coisa a esconder, um ponto de abjeção dissimulado, que o elemento perverso, a mancha visível e dificilmente perceptível do crime vem revelar". 12 A especial atenção que o diretor concede a esse tipo de detalhe - ou seja, sua fascinação pelo elemento perverso - é comprovada "pela maneira como ele orquestra elaborados movimentos de câmera para distinguir e sublinhar a mancha"13 (na maioria das vezes, trata-se de um movimento na direção do ponto de fuga em que se encontra o objeto revelador). Um plano arrojado e complexo como aquele da chave em Interlúdio é uma forma de dramatizar, de enfatizar a aparição dessa mancha que faz o olhar passar de uma atitude distraída e pervagante para uma busca focada e obsessiva. A câmera percorre todo o espaço até chegar o mais perto que pode do objeto que se disfarçava sob a normalidade aparente da imagem, como se Hitchcock quisesse indicar a rachadura no verniz de um quadro que, à distância, parecia sem defeitos (o fato de que a cena acontece numa festa reforça essa ideia, já que se trata de um evento social em que as pessoas celebram as aparências e recalcam toda a sujeira que poderia colocar em risco os cerimoniais de respeitabilidade). As imagens lisas, envernizadas, meticulosamente compostas, valorizadas pela qualidade de iluminação e enquadramento, comuns no cinema de Hitchcock, não passam de um convite à perversão, como se, diante de um corpo belo e perfeito, que a princípio é contemplado com parcimônia, o observador fosse levado a descobrir o sinal na pele, o machucado, a mancha, o defeito que, pervertendo aquela beleza idealizada, mudará o comportamento do olhar e estimulará o desejo de ver mais, de saber mais.

A relação entre ideal estético e perversão é uma constante na obra de Hitchcock: suas imagens, criadas com perfeccionismo, às vezes realçadas por um brilho fetichista, têm a função de encobrir e, paradoxalmente, revelar a subcamada de sordidez do universo superficialmente límpido e impoluto das personagens. É a lógica mesma do fetiche, que Richard Allen, em seu livro sobre Hitchcock, resume com base em Freud: "O fetiche é um objeto que, através da idealização da superfície, simultaneamente revela e esconde um fundo de abjeção". ${ }^{14}$ Da mesma forma que, para dar ao crime seu peso e sua dimensão, o cinema de Hitchcock precisa, num primeiro momento, de um fundo de normalidade, de uma ordem natural do mundo a ser subvertida, ele precisa também de um quadro de beleza a ser maculado (como em $O$ terceiro tiro [The trouble with Harry, 1955]: no meio daquela paisagem bucólica no auge de seu esplendor, um cadáver é encontrado).

\footnotetext{
${ }^{12}$ P. Bonitzer, op. cit., p. 61.

${ }^{13}$ R. Allen, Hitchcock's romantic irony, Nova York: Columbia University Press, 2007, p. 207.

${ }^{14}$ Ibid., p. 125. Para compreender melhor o conceito freudiano, ver "Fetichismo", em Sigmund Freud, Escritos sobre a Psicologia do Inconsciente, volume 3: 1923-1940, Rio de Janeiro: Imago, 2007, pp. 161-166.
} 
A ficção hitchcockiana, a postulação a priori da morte e do crime produz, portanto, no próprio corpo do filme, na própria imagem, uma espécie de falha. O olhar, como a brasa de um cigarro - aquele de Janela indiscreta ou o charuto de Chantagem e confissão [Blackmail, 1929] -, faz um furo na impressão de realidade, na crença específica do cinema; rompe, pela inserção de um significado macabro, aquela coalescência natural do significante e do referente oferecida pela visão cinematográfica bruta. ${ }^{15}$

O efeito da "falha", ou da "mancha", é perturbar a contemplação pura, corrompê-la, e deslanchar um movimento mais agudo do pensamento, tragar o olhar num processo vertiginoso de desconfiança das aparências. O olhar pervertido é um olhar pensativo. "É próprio da perversidade traçar um caminho, um caminho de inteligência”, diz Jean Douchet (um hitchcockiano) a propósito de Éric Rohmer (outro hitchcockiano). ${ }^{16}$ "Em Rohmer, tudo é trajeto, inteligência, o que obrigatoriamente se tinge de perversidade". ${ }^{17}$ Naturalmente, o mesmo pode ser dito a respeito de Hitchcock, cujo intrincado sistema formal remete a todo um conjunto de maquinações intelectuais acionadas com o intuito de provocar e, a um só tempo, mascarar a engrenagem da perversão. Os enquadramentos e movimentos de câmera hitchcockianos são operações mentais transformadas em percursos visíveis, trajetórias no espaço material, construções de mise en scène que, paralelamente às ações necessárias ao andamento narrativo, perfazem o caminho secreto do pensamento obcecado, daí Edward Branigan dizer que "a câmera de Hitchcock é mais mental que física", guia-se mais pelo "olho penetrante do crítico", por suas ideias, do que pelos deslocamentos dos atores no espaço cênico. $^{18}$

Essa atividade mental da câmera é transferida ao espectador por meio de uma astuciosa técnica de manipulação da atenção e partilha do ponto de vista. A decupagem hitchcockiana "alimenta" o olhar - esse olhar glutão que o protagonista de Janela indiscreta encarna de forma paradigmática, e que é também, por extensão, nosso olhar -, satisfaz sua necessidade de "ver coisas", de achar significados no real insignificante. Hitchcock provoca uma perfeita coincidência entre o desejo de ver do espectador e a função de dar a ver do dispositivo cinematográfico. No suspense hitchcockiano, o espectador se identifica menos com esta ou aquela personagem do que com a própria capacidade de visão da máquinacinema, ou seja, menos com o mundo representado do que com aquilo que o torna visível.

\footnotetext{
${ }^{15}$ P. Bonitzer, "It's only a film ou La face de néant", in Jean Narboni (org.), Alfred Hitchcock, Paris, Éditions de l’Étoile/Cahiers du Cinéma, 1980, p. 17.

${ }^{16}$ J. Douchet, "Des Cahiers à Ma nuit chez Maud", entrevista realizada por Stéphane Delorme, em Cahiers du cinéma, $\mathrm{n}^{\circ} 653$, fevereiro de 2010, p. 12.

${ }^{17} \mathrm{Ibid}$.

${ }^{18}$ Cf. "Quand y a-t-il caméra ?", in Champs Visuels, n 12-13, janeiro de 1999, p. 25.
} 
Não à toa, os raccords de olhar e o plano-ponto-de-vista estão no cerne da mise en scène de Hitchcock. Vemos alguém que vê; vemos com ele e através dele - nosso olhar é incluído na cadeia de planos. Um dos fundamentos da decupagem cinematográfica, o plano-ponto-devista - "um plano em que a câmera assume a posição de um sujeito de modo a nos mostrar o que ele está vendo"19 - pouco a pouco vai se tornando a estrutura dominante do cinema de Hitchcock e, mais ainda, o próprio motor de suas ficções. Em filmes como Janela indiscreta, Vertigo e Os pássaros, o ato de olhar é em si o motivo, o "tema" da narrativa, além de ser o ponto nodal da decupagem e da trama. O olhar produz a ficção.

A primeira cena de Os pássaros resume tudo: Melanie (Tippi Hedren) atravessa uma rua no centro de São Francisco e, ao ouvir o som de um pássaro (logo após receber o assovio flertante de um garoto que passa pela calçada), ergue a cabeça na direção do céu, onde avista um bando de aves selvagens voando em círculo. É o primeiro plano-ponto-de-vista de $O s$ pássaros, e desde já o olhar de Melanie se apresenta como o desencadeador da cólera inexplicável e incontrolável das aves, ou como a fagulha que ativa a ficção. As principais cenas do filme serão quase que inteiramente articuladas em torno do olhar de Melanie, que vai a Bodega Bay movida pelo desejo, pela atração que sentiu por um homem. Na cena mais crucial, os ataques dos pássaros e o incêndio que se espalha por um posto de gasolina parecem obedecer às ordens do olhar de Melanie, como se ela tivesse poderes paranormais e os acionasse para se vingar do puritanismo um tanto hostil dos habitantes de Bodega Bay. $\mathrm{O}$ ápice da cena consiste numa rápida sucessão de planos alternando entre o rosto de Melanie, que assiste a tudo da janela de um restaurante, e o fogo se propagando num filete de combustível que corre pelo chão do posto. A cada olhar de Melanie (sempre paralisada em pose propositalmente artificial, praticamente "empalhada" pela câmera de Hitchcock), corresponde um plano do fogo se intensificando e se espalhando, até atingir uma bomba de gasolina que explode. O olhar se investe de uma potência devastadora. O pensamento da personagem (ou seu desejo inconsciente) se concretiza por intermédio da ação do olhar e do corte, da ligação sistemática e violenta entre os planos do rosto da atriz e os planos do fogo à frente dela. ${ }^{20}$ Auxiliado pela montagem, inflamado pelo desejo, o olhar age à distância, transfere pensamentos, impulsos, projeta no espaço os imperativos da mente. ${ }^{21}$

\footnotetext{
${ }^{19}$ E. Branigan, “O plano-ponto-de-vista”, in Fernão Pessoa Ramos (org.), Teoria Contemporânea do Cinema Volume II: Documentário e narratividade ficcional, São Paulo: Senac, 2005, p. 251.

${ }^{20}$ Para uma análise mais detalhada dessa cena, ver Luiz Carlos Oliveira Jr., A mise en scène no cinema: Do clássico ao cinema de fluxo, Campinas, SP: Papirus, 2013, pp. 193-194.

${ }^{21}$ A clássica sequência do baile em Carrie, a estranha (1976), de Brian De Palma, nada mais é que uma dilatação/radicalização dessa cena de Os pássaros. Idem para a cena da explosão do hotel no final de Zabriskie Point (Antonioni, 1970), cujo elenco conta, aliás, com Rod Taylor, ator de Os pássaros.
} 
Essa sequência de Os pássaros é um exemplo (entre muitos) do modo como Hitchcock consegue pegar uma ferramenta de linguagem relativamente simples (campo/contracampo, raccord de olhar, plano-ponto-de-vista) e empregá-la numa construção visual complexa, que atinge enorme intensidade plástica e notável riqueza de significação ao explorar em nível máximo os efeitos de montagem, a qualidade expressiva das imagens e os arranjos de sentido produzidos pela relação entre elas.

As mais conhecidas análises e interpretações teóricas da obra de Hitchcock sempre se empenharam em demonstrar a não gratuidade dos efeitos visuais e da extravagância técnica do diretor, procurando provar que cada traço de um plano rodado por ele tinha sua meta precisamente determinada no programa textual e simbólico do filme. Uma vez interpretado e - como frequentemente é o caso - superinterpretado, o plano hitchcockiano se revelaria não apenas uma unidade narrativa, mas a manifestação sensível de uma ideia, a exposição detalhada de um pensamento. De acordo com essa lógica, que repousa sobre a evidência de que o quadro, em filmes como Janela indiscreta, Intriga internacional ou Vertigo, é o lugar de inscrição ou de "execução de um complexo de ideias"22, o cinema de Hitchcock não seria o espaço do acaso e da contemplação despretensiosa, mas antes da visão angustiada e da pulsão epistemológica, da perfuração das aparências e da investigação óptica.

$* * *$

No conto A janela de esquina do meu primo, última narrativa de E.T.A. Hoffmann, encontra-se o que pode ser considerado um ancestral literário da escopofilia hitchcockiana. $\mathrm{O}$ conto é narrado por um homem que visita o apartamento de seu primo, escritor que, após perder completamente a força dos pés "devido a uma obstinada doença”, foi obrigado a passar o resto dos dias numa cadeira de rodas sem sair de casa para nada. A moradia do primo fica num prédio de esquina localizado em frente à praça do mercado: “da janela de um pequeno gabinete ele abarca num lance de olhos todo o panorama da grandiosa praça". 23 É através dessa janela que o primo encontra consolo para a "tenebrosa melancolia" provocada pela doença, já que se diverte observando a multidão nas ruas, o movimento incessante na feira, a "vida alegre" que desfila perante seus olhos. Com uma luneta, ele isola e aumenta as figuras e as ações que mais lhe interessam, tecendo narrativas a partir do que enxerga à distância, como

\footnotetext{
${ }^{22}$ Cf. Robin Wood, "Retrospective", in DEUTELBAUM, Marshall e POAGUE, Leland (orgs.), A Hitchcock reader, Ames: Iowa State University Press, 1986, p. 33.

${ }^{23}$ E.T.A. Hoffmann, A janela de esquina do meu primo, São Paulo: Cosac Naify, 2010, p. 11.
} 
se deslizasse o olhar por um quadro de Bosch munido de uma lupa: aqui e ali, o observador para e examina um detalhe, especula sobre o que se estará representando numa daquelas inúmeras cenas espalhadas pela caótica mistura de cores e formas. Da massa humana amorfa e indistinta que se move na praça em frente ao seu prédio, o escritor consegue isolar um detalhe e acompanhá-lo, a exemplo do lenço amarelo de uma mulher, que serve de guia para o olho enquanto ela se embrenha no meio da multidão. A estratégia consiste em fixar o olhar num elemento e prospectar o drama que daí se desenvolve. O gestual, a fisionomia, as roupas, as mercadorias compradas na feira, enfim, a aparência e o comportamento das pessoas observadas pelo escritor fornecem a matéria de que ele precisa para iniciar suas confabulações. Juntando essas informações visuais, ele traça um perfil social e psicológico detalhado de pessoas que nem sequer conhece. Onde aparentemente se tem apenas "a visão de um colorido e alucinante amontoado de gente se movendo num afã insignificante", o escritor afirma existir "um cenário variado da vida burguesa". Para apreciá-lo, basta um olho, mas um olho "que realmente enxergue!". E o que seria esse olho que realmente enxerga? Seria, na lógica do escritor, um olho que sabe não apenas demarcar precisamente o objeto de sua atenção (“fixar o olhar propicia o enxergar nítido"), mas também somar às percepções visuais a atividade intelectual. As informações colhidas pela visão devem ser processadas pela mente e resultar em hipóteses interpretativas. Tão importante quanto o apuro visual é a força imaginativa do pensamento. Não por acaso, uma das figuras que Hoffmann destaca da multidão é um cego que permanece "com a cabeça elevada como se estivesse mirando o firmamento. Os crepúsculos da vida se puseram para a pobre criatura, porém o seu olho interior aspira a enxergar a luz eterna, que lhe brilha no além plena de consolo, esperança e bem-aventurança” (p. 42). Hoffmann exalta, no cego, a perseverança da visão interior, que continua a iluminar seus pensamentos.

Se o narrador do conto, a princípio, parece relutante em realmente se interessar pelo passatempo do primo, no decorrer do extenso diálogo que compõe a narrativa ele vai se deixando levar pelo prazer visual que a técnica de apuramento do olhar desenvolvida pelo escritor proporciona, sendo introduzido nas “primícias da arte de enxergar”.

Espécie de pedagogia moderna de uma certa forma de olhar, essa narrativa de Hoffmann, como facilmente se nota, apresenta o modelo aprofundado por Hitchcock em Janela indiscreta. O repórter-fotógrafo interpretado por James Stewart assume o lugar que, no conto, cabia ao escritor. O trajeto que o olhar deve fazer no filme de Hitchcock é o mesmo proposto em A janela de esquina do meu primo: do painel coletivo aos dramas individuais, do cotidiano amorfo ao detalhe significativo, da paisagem indiferente à "mancha que precipita o 
olhar e provoca a ficção". ${ }^{24}$ A atenção da personagem flutua pelo variado quadro que sua visão lhe oferece, até se fixar num ponto e lá se aprofundar (a fixação da atenção faz com que o olhar se torne penetrante, percuciente). Analogamente ao retrato que Hoffmann produziu da fauna humana do Gendarmenmarkt de Berlim, Hitchcock mostra "algumas das espécies que compõem a fauna de Greenwich-Village, em particular, e de uma grande cidade em geral"25, ilustrando uma visão de conjunto da vida urbana ao mesmo tempo realista e caricatural. Além disso, o conto de Hoffmann já contém uma das premissas do cinema de Hitchcock: a elaboração secundária (isto é, oriunda do pensamento e não da percepção imediata) de uma visão subjetiva que, pelo poder de convencimento do autor, confunde-se à realidade objetiva. No conto, o narrador confessa: "Caro primo, pode ser que nenhuma das combinações que você me apresenta seja minimamente verdadeira; mas, graças à sua animada exposição, à medida que vou contemplando as mulheres, tudo se torna tão plausível para mim que sou obrigado a acreditar em suas palavras, quer eu queira ou não" (p. 21). Em Janela indiscreta, também somos carregados pela exposição de Jeff (James Stewart) - no caso, sua convicção de que há um criminoso na vizinhança -, por mais escassas que sejam as evidências em que se apoia. É partindo de poucos indícios, mas contando com muita engenhosidade, que Jeff chega à conclusão de que houve um crime no apartamento da frente, acontecimento que ele parece mais desejar do que propriamente ver. Com o auxílio de binóculos e de uma lente teleobjetiva ("todos esses aparatos que não são senão extensões desse instrumento emblemático da escopofilia: o buraco da fechadura, através do qual se pode não simplesmente ver, mas ver, sobretudo, o que é reservado ou proibido" ${ }^{26}$ ), Jeff "se aproxima" dos vizinhos, transpõe a distância que o separa deles, fixando e aumentando os aspectos da cena privilegiados por sua atenção. "Sempre que a atenção se fixa em alguma coisa específica, todo o resto se ajusta, elimina-se o que não interessa". ${ }^{27}$ Assim, Jeff descobre no espaço de convívio social-afetivo diário do seu prédio as emanações externas dos pensamentos que se agitam em sua mente: "a teleobjetiva simboliza o 'mundo intelectual', que religa o 'mundo cotidiano' ao 'mundo do

\footnotetext{
${ }^{24}$ P. Bonitzer, op. cit., p. 53.

${ }^{25}$ Claude Chabrol e Éric Rohmer, Hitchcock, Paris: Éditions Ramsay, 2011, p. 126.

${ }^{26}$ Arlindo Machado, O sujeito na tela, São Paulo: Paulus, 2007, p. 45.

27 Hugo Munsterberg, "A atenção", in Ismail Xavier (org.), A experiência do cinema, Rio de Janeiro: Graal/Embrafilme, 1983, p. 35. Em seu livro publicado em 1916 (e intitulado Photoplay: a psychological study), Munsterberg afirma ser próprio do cinema subordinar-se não às "exigências concretas dos acontecimentos externos mas às leis psicológicas da associação de ideias [...] vemos o curso natural dos acontecimentos modificado pelo poder da mente". Sua análise envolve a estética e a psicologia da representação cinematográfica, levando à conclusão de que o cinema funciona de forma análoga aos processos mentais do homem: "O cinema, ao invés de obedecer as leis do mundo exterior, obedece as da mente" (cf. "A memória e a imaginação", op. cit., p. 38). Embora a precedam em cerca de uma década, as questões desenvolvidas por Munsterberg são extremamente úteis para se compreender a obra de Hitchcock.
} 
desejo". ${ }^{28}$ O campo escópico se apresenta, então, como espaço conjectural (de interpretação dos signos que levam à especulação sobre o crime) e libidinal (de circulação do desejo e das energias pulsionais).

A profissão da personagem de James Stewart é se aventurar pelo mundo fotografando realidades radicalmente distantes da vida levada por sua namorada, a modelo e socialite Lisa (Grace Kelly), que frequenta os endereços mais chiques da alta roda nova-iorquina. Lisa tenta persuadir Jeff a trocar sua vida nômade e arriscada (tão arriscada que lhe valeu um acidente de trabalho e algumas semanas na cadeira de rodas) por atividade mais pacata, como fotógrafo de moda e celebridades. Mas seus argumentos não parecem convencê-lo. No decorrer do filme, é ele quem vai transportar Lisa para o seu mundo (não inteiramente, como sugere a ironia do plano final ${ }^{29}$ ), envolvendo-a na "investigação" sobre o assassinato e fazendo-a entrar no apartamento do suspeito, onde, emoldurada pela janela, ela se arrisca para a lente de Jeff, que a observa do outro lado do pátio, pela teleobjetiva. Jeff reenquadra Lisa, retira-a das páginas glamourosas da revista de moda e a incrusta no lugar do crime, na "outra cena" (a “obs-cena”, diria Serge Daney), no mundo que lhe interessa espiar. A partir daí, toda a atração que ele parecia ter deixado de sentir por ela retorna com força. A pulsão erótica se curtocircuita com a pulsão de morte, ambas subsumidas no prazer escópico.

Numa cena mais para o começo, a genial Stella (Thelma Ritter), enfermeira e massagista de Jeff, diz que sabe muito bem que ele ficou a noite inteira em claro bisbilhotando os demais apartamentos, pois seus olhos estão vermelhos - olhos inflamados, sobrecarregados pela atividade excessiva. Em Hitchcock, a visão está sempre em excesso; o olhar não consegue deixar a realidade tranquila. Por isso Jeff interpreta, investiga, busca significados nas "cenas" que observa da janela. O que ele vê acontecer no prédio em frente é um assassinato ou apenas uma série de coincidências? Assim como Lina (Joan Fontaine), a heroína de Suspeita (Suspicion, 1941), Jeff está constantemente articulando as coisas que vê, somando informações, interpretando signos. Ambos praticamente só participam da mise en scène através do olhar; estão condenados à imobilidade, à inação. Lina porque paralisada internamente, impotente, dividida entre a paixão pelo marido e a desconfiança de que ele seja um assassino. Jeff porque quebrou a perna e está numa cadeira de rodas. Só o olho e a mente trabalham. Em Suspeita, Lina acaba percebendo que sua desconfiança do marido era infundada (ele não queria matá-la); ela havia "visto demais", e o "ver demais", às vezes,

\footnotetext{
${ }^{28}$ J. Douchet, "Hitch et son public", in Cahiers du cinéma, no 113, novembro de 1960, p. 9.

${ }^{29}$ Lisa lê um livro de aventura jornalística intitulado "Além do Himalaia", mas, ao perceber que Jeff (agora com as duas pernas engessadas) adormeceu, troca o livro por uma revista de moda.
} 
desemboca na cegueira, na opacidade da visão. ${ }^{30}$ Em Janela indiscreta, diferentemente, Jeff descobre que suas suspeitas procediam (o homem do apartamento da frente era de fato um assassino e havia matado e esquartejado a esposa). Mas a verdade é que a única condição para que algo de extraordinário acontecesse já estava dada na simples situação em que ele se encontrava: em Hitchcock, para que haja o crime, basta um olhar disposto a transpassar a superfície falsamente tranquila das aparências e captar o detalhe que destoa do espetáculo monótono do cotidiano. A partir do momento em que Jeff percebe o elemento desviante, todo o resto pode seguir a ação de seu raciocínio. Por uma espécie de regressão à concepção mágica e animista do universo, os pensamentos e desejos de Jeff parecem exercer influência sobre a realidade circundante, e sua vontade de achar indícios que comprovem a hipótese do crime começa a se projetar no espaço da cena.

Como muito já se falou, o filme traz uma reflexão sobre "a força do desejo no olhar"31 e o mecanismo de projeção/identificação no cinema: sentado em sua cadeira de rodas, na penumbra de seu apartamento, com motricidade limitada e atenção hipertrofiada, Jeff está em situação semelhante à do espectador. $\mathrm{O}$ cenário construído em estúdio reproduz o próprio dispositivo da sala de exibição, o apartamento de Jeff sendo a cabine de projeção e o imóvel em frente, a tela.

Mas essa geometria do espetáculo, conforme Ismail Xavier aponta, não diz respeito somente à experiência do cinema:

Faz tanto ou mais sentido pensar em Jeff olhando da janela como alguém que vai ao teatro e observa tudo de um ponto relativamente fixo (qualquer mobilidade dependeria da mobilidade do seu corpo). E isso ganha força quando lembramos que o elemento que separa Jeff da cena em frente é essa espécie de "fosso" constituído pelo pátio, lá embaixo, a uma certa distância do seu "camarote". 32

Michel Chion, que também destaca a importância da referência ao teatro em Janela indiscreta, fala de uma "foraclusão" da "quarta parede" representada pela fachada do prédio

\footnotetext{
${ }^{30}$ Reciprocamente, o "ver de menos" pode estar associado à transparência. Um exemplo é a cena de Sabotador (Saboteur, 1942) em que Barry, jovem trabalhador acusado injustamente de um ato de sabotagem e perseguido por todas as autoridades do país, refugia-se na casa de um senhor que é cego. Quando a sobrinha do gentil senhor chega para visitá-lo, ela vê as algemas de Barry, nota que ele é o homem procurado pelas autoridades e imediatamente tem o ímpeto de entregá-lo à polícia. Entretanto, seu tio a impede, afirmando que Barry é um rapaz bom e não pode ter cometido crime algum. Ele diz que sua condição de cego lhe permite ver "coisas intangíveis", como a inocência. Ele possui um dom muito estimado na obra de Hitchcock: a visão interior.

${ }^{31}$ Cf. Ismail Xavier, "O lugar do crime: a noção clássica de representação e a teoria do espetáculo, de Griffith a Hitchcock", in O olhar e a cena, São Paulo: Companhia das Letras, 2003, p. 75.

${ }^{32}$ Ibid., p. 74.
} 
do protagonista, que nunca é mostrada e permanece banida do sistema espacial do filme praticamente até o último momento (a cena do desenlace final): o próprio funcionamento da ficção depende do recalcamento dessa quarta parede, pois é preciso fazer da posição de Jeff o ponto de vista privilegiado, o que implica certa idealização/fantasmatização de seu lugar de observador. Os demais moradores daquela parte do prédio (que teriam uma vista semelhante à de Jeff, ou até mesmo melhor que a dele) nunca podem aparecer. Tudo é reduzido a um único olhar. Se os outros apartamentos situados naquela mesma parede fizessem parte do filme, criariam a imagem de uma multiplicidade de focos de visão que não rima com o pressuposto de um "espectador ideal", que Hitchcock conscientemente mobiliza. Com a oclusão da quarta parede, o espaço assume a "forma imaginária de um cone" cujo vértice é o olho de Jeff. ${ }^{33} \mathrm{O}$ pátio externo - e o mundo diegético como um todo - surge como extensão de sua mente.

A fantasmatização do lugar de onde se irradia a visão apenas intensifica o desempenho do voyeur e reforça sua crença alucinatória na onipotência do pensamento. Jeff - e, por conseguinte, o espectador do filme - deve estar o mais próximo possível daquela noção de "sujeito transcendental" que, segundo Jean-Louis Baudry, é o que confere unidade sintética ao mundo representado, num esquema que retroalimenta o "modelo topológico do idealismo" historicamente cultivado pelo homem ocidental. ${ }^{34}$

O que Chion designa como a "conjuração da quarta parede", portanto, faz parte da lógica que inscreve o olhar do protagonista em uma posição ideal na qual sua capacidade de visão é proporcional à sua vantagem de permanecer invisível para os outros. Mas há um momento no filme, não mencionado pelo crítico, em que ocorre a quebra desse sistema que mantinha a quarta parede ao mesmo tempo ausente do jogo (já que nunca era mostrada) e

\footnotetext{
${ }^{33}$ Cf. M. Chion, "The fourth side", in Slavoj Zizek (org.), Everything you always wanted to know about Lacan... but were afraid to ask Hitchcock, Londres/Nova York: Verso, 1992, p. 157.

${ }^{34}$ J.-L. Baudry, "Cinema: efeitos ideológicos produzidos pelo aparelho de base", in I. Xavier (org.), A experiência do cinema, pp. 383-399. O famoso artigo de Baudry critica a base ideológica (enraizada na metafísica ocidental) e a tradição artística (derivada dos modelos de figuração pós-renascentistas) que sustentam a construção da ilusão de realidade no cinema. O esforço empreendido pelo conjunto das técnicas cinematográficas no sentido de forjar a sensação de continuidade apesar da descontinuidade original do material (fotogramas estáticos a que a projeção restitui a mobilidade aparente; planos captados separadamente a que a montagem confere um sistema de ligação que torna os cortes "imperceptíveis") só pode corresponder, na visão de Baudry, a pressupostos ideológicos que atendem aos mecanismos da indústria cultural. O cinema desenvolve assim seu ilusionismo e "mima" o espectador com a sensação de que ele ocupa a posição ideal de um puro olhar sem corpo, centro do espetáculo da percepção total do mundo: "gerando uma fantasmatização do sujeito, o cinema colabora com segura eficácia para a manutenção do idealismo" (p. 398). É improvável que Hitchcock almejasse, em seu filme, uma crítica à ideologia burguesa dominante colocada nesses termos, ou uma denúncia dos processos de alienação que o cinema reforçaria por meio de seu aparato ilusionista. Mas o fato é que a noção de um espectador ideal e transcendente está lá, problematizada, quiçá colocada em crise, o que torna relevante trazer para a discussão o texto de Baudry, mesmo sabendo das ressalvas que devem ser feitas a seu diagnóstico totalizante e, em certos aspectos, impreciso (ele insere o cinema num certo determinismo histórico, não levando em conta uma série de forças que escapam aos programas do sistema e da indústria). Para uma discussão mais detalhada sobre o artigo, ver I. Xavier, O olhar e a cena, pp. 47-51, e A experiência do cinema, pp. 360-361.
} 
atuante (pois, ao não participar do cenário senão imaginariamente, funcionava como um escudo que impedia o voyeur de ser descoberto enquanto bisbilhotava). Trata-se do plano surpreendente em que o assassino olha para a câmera. Ele aparece enquadrado em primeiro plano, no espaço circular que restringe o campo e demarca a visão de Jeff através da teleobjetiva (o que remete também, mesmo que indiretamente, a um procedimento comum no cinema silencioso: o fechamento parcial da íris quando do destaque a alguma personagem ou objeto). O plano acontece em meio à confusão armada depois que o vilão flagra Lisa vasculhando seu apartamento. Ela havia encontrado, junto com as demais joias da mulher assassinada, a aliança de casamento. Com a aliança no dedo, enquanto se explica para a polícia, Lisa faz um sinal para Jeff (muitos interpretam essa cena como o noivado simbólico dos dois), que assiste a tudo a distância, impotente e atônito, "preso" à cadeira de rodas. O assassino percebe o gesto de Grace Kelly e olha na direção para a qual ela sinaliza, ou seja, na direção de Jeff. Por se tratar de um plano-ponto-de-vista, esse olhar se cruza com o nosso. Assim como Jeff, o espectador é pego de surpresa pelo olhar do assassino e se sente desnudado. Se antes o filme lhe dava a garantia de ver sem ser visto (pedra angular do voyeurismo), agora a situação é outra: ele descobre que sua posição não é (nunca foi) invulnerável; o abrigo secreto do espectador é vasado pelo olhar amedrontador que vem da tela; seu esconderijo é invadido.

O "olhar câmera" é apontado por Antoine de Baecque como um dos gestos fundadores do cinema moderno, "a forma por excelência de um cinema que quer questionar o outro". ${ }^{35}$ Esse olhar, "tão frontal que nos petrifica", aparece em diferentes filmes no decorrer dos anos 1950, ora com a tarefa de provocar, de desafiar o espectador e - por que não? - flertar com ele e seduzi-lo (Monika e o desejo, de Ingmar Bergman), ora com o tom mais grave de um olhar que retorna do fundo da história, do além-túmulo, dos horrores da Segunda Guerra, do que é indizível e irrepresentável e, no entanto, nos olha de frente (Noite e nevoeiro e Hiroshima, mon amour, de Alain Resnais), ou com a intensidade frontal da alteridade absoluta, quiçá da loucura (Europa 51, de Rossellini). "O olhar para a câmera é um olhar ambíguo, um compromisso entre o bom e o mau encontro", um olhar indeciso entre o efeito de sua presença e a afirmação de uma ausência. ${ }^{36}$ Como parte de uma intrincada rede de significação, o olharcâmera pode instaurar um processo menos de diálogo e troca do que de impossibilidade comunicativa, de imposição de realidades inacessíveis: "O que se vê no olhar para a câmera é

\footnotetext{
${ }^{35}$ A. de Baecque, L'histoire-caméra, Paris: Gallimard, 2008, p. 58.

${ }^{36}$ Marc Vernet, Figures de l'absence, Paris: Éditions de l'Étoile, 1988, p. 20.
} 
o invisível, o Alhures, a Morte". ${ }^{37}$ Existia um olhar-câmera desimpedido e recorrente no cinema dos primórdios, na comédia burlesca, na "cinematografia-atração", enfim, nos filmes em que o espectador era convidado a ser cúmplice do riso e do espetáculo exibicionista que se oferecia abertamente para ele. Com a "evolução" das narrativas, o exibicionismo se troca por voyeurismo, e as regras sagradas da ficção cinematográfica proíbem o ator de olhar para a câmera, salvo nos gêneros (especialmente o musical) que mais explicitamente mantêm o vínculo com o cinema de atrações. O olhar-câmera se torna um tabu nos sets de filmagem: entre o mundo do espectador e o mundo da ficção a que ele assiste deve haver uma barreira que é a condição do efeito-janela do retângulo cinematográfico e, consequentemente, da ilusão de realidade alimentada pela experiência do cinema em sua versão mais comum. Seria preciso esperar pelos cinemas modernos do pós-guerra para que o olhar-câmera fosse não apenas desrecalcado e reabilitado na mise en scène, mas, sobretudo, acrescido de potência e significação novas.

Teleologia modernista à parte, a recorrência do olhar-câmera no cinema dos anos 1950 e 1960 engendra, de fato - pela inserção de uma falha ou fissura no sistema da decupagem clássica -, um efeito inesperado ou desconcertante. No caso específico de Janela indiscreta, o olhar-câmera adquire um aspecto perturbador não por nos confrontar com a morte ou revelar os horrores da História, mas por se imiscuir na cadeia significante de um filme cujo tema é justamente o voyeurismo. O olhar-câmera de Janela indiscreta bloqueia momentaneamente a pulsão escópica e desarma o espectador, expõe o ponto cego da ficção voyeurista. Como seria de praxe no cinema moderno, nosso olhar "é devolvido pela tela como uma bala por um muro". ${ }^{38} \mathrm{O}$ espectador é moralmente implicado no filme, interpelado no próprio ato de ver, de assistir (que não é mais um ato inocente). O processo de identificação do olhar do espectador com o do protagonista chega a seu termo, revela sua razão mais profunda.

Com efeito, vemos todo o filme do ponto de vista de Jeff, ou melhor, quase todo, pois há uma exceção: a cena em que ele cochila enquanto Thorwald, o suposto assassino, sai de casa acompanhado de uma mulher. Tal exceção é extremamente importante:

a mulher poderia ser a Sra. Thorwald, o que nos leva a considerar que Jefferies poderia estar errado: ao tornar a identificação do espectador com a consciência de Jefferies quase completa, Hitchcock permite que sintamos um pequeno mal-estar, o suficiente para que questionemos a moralidade do que ele está fazendo - e nossa própria moralidade, já que estamos espiando com ele, partilhando do seu voyeurismo compulsivo e fascinado. ${ }^{39}$

\footnotetext{
${ }^{37}$ Ibid., p. 25.

${ }^{38}$ Serge Daney, A rampa, São Paulo: Cosac Naify, 2007, p. 232.

${ }^{39}$ R. Wood, Hitchcock's films revisited, Nova York/Oxford: Columbia University Press, 1989, p. 103.
} 
Hitchcock problematiza, portanto, o prazer do voyeur, que é intrinsecamente transgressor (afinal, como Stella faz questão de lembrar, existem punições contra as pessoas que invadem a privacidade alheia). Mais amplamente, ele põe em causa todo o jogo perverso do par olhar-desejo, no qual personagem $e$ espectador voluntariamente se enredam. Num cinema em que o olho e o olhar estão no centro de tudo, a escopofilia - o "prazer de tomar o outro como objeto, submetendo-o a um olhar fixo e curioso" básico do espetáculo, mas a problemática mesma dos filmes. O que Janela indiscreta e Um corpo que cai exibem senão um "drama do olhar" e seus desdobramentos?

Um elemento essencial de Janela indiscreta é o fato de que o crime não é mostrado: ele é "montado" na cabeça de Jeff pela articulação de informações estanques. O crime não é dado a priori na imagem, mas construído pela soma de ideias, pela montagem.

No conhecido livro-entrevista, Hitchcock admite para Truffaut que toda a dinâmica de Janela indiscreta se pauta no "efeito Kulechov", ou seja, na justaposição de um plano do rosto do ator, sempre com a mesma expressão ${ }^{41}$, e diferentes contraplanos que mostram diferentes situações. As cenas se articulam assim: o primeiro plano mostra James Stewart olhando pela janela, o segundo mostra o que ele está vendo e o terceiro, sua reação. A cada nova articulação, um novo sentido se atribui à expressão do ator, que, todavia, manteve-se praticamente inalterada. Em outras palavras, é a montagem - ou, se tomarmos a operação em sua origem, a decupagem - que cria o sentido; o filme só se constrói de verdade na mente do espectador, pela soma de imagens que, vistas isoladamente, não teriam o mesmo significado.

Desde o princípio de sua carreira, Hitchcock abraçou a ideia de que o cinema é uma interpretação deliberada do mundo e de que seu material não se acha na realidade, mas é já uma leitura dela, uma transformação. A câmera é produtiva, os cortes são inventivos, o mundo filmado é acrescido de significados que não existiam originalmente. ${ }^{42} \mathrm{Um}$ aspecto central da montagem soviética, absorvido por Hitchcock já em seus primeiros filmes, reside na "criação de conceitos que não necessariamente possuem equivalentes fenomenológicos no que foi colocado na frente da câmera". ${ }^{43}$ Para Hitchcock, assim como para Eisenstein, "a montagem é 'intelectual', ou seja, ela está no olho, no pensamento". ${ }^{44}$ As coisas não estão aí, é preciso inventá-las. "A realidade que o cinema impressiona, trata-se para ele de dobrá-la na forma e

\footnotetext{
${ }^{40}$ A. Machado, op. cit., p. 48.

${ }^{41}$ Não tão mesma assim: há variações, ainda que discretas.

${ }^{42}$ Ver, a propósito disso, o instigante artigo de Jacques Aumont, "Alfred Hitchcock tel que je l'imagine", in Matière d'images, Paris: Éditions Images Modernes, 2005.

${ }^{43}$ R. Wood, art. cit., p. 28.

${ }^{44}$ P. Bonitzer, "Les morceaux de la réalité", op. cit., p. 124.
} 
no sentido desejados; o cinema é cosa mentale". ${ }^{45}$

Como dizia Béla Balázs mais ou menos na mesma época em que Hitchcock dava seus primeiros passos na indústria do cinema, todo filme é a "expressão viva de uma intenção". tal intencionalidade é bilateral: não só o filme encadeia sentidos pela montagem como também a plateia, consciente de que assiste a "um conjunto de planos reunidos para atingir determinado fim", pressupõe que tudo o que aparece na tela possui um sentido a ser buscado: "Mesmo diante de um aglomerado de fenômenos acidentais, a nossa consciência tende a procurar um significado. O que o trabalho de montagem deve fazer é dar uma direção definida a esta procura, pois para isto ela tem grande poder de manipulação". ${ }^{47} \mathrm{O}$ cinema, para Balázs - numa linha a que se oporia, mais tarde, o realismo baziniano calcado na ontologia da imagem fotoquímica e na fenomenologia do plano-sequência -, não se define pela reprodução automática das aparências, pelo registro objetivo da realidade, pela abertura e disponibilidade do olhar ao mundo fenomênico, e sim pela transfusão das correntes de energia do pensamento humano para as imagens. Temperado pela intenção do diretor e pelos estados de espírito das personagens, o olho mecânico da câmera não apenas recebe a realidade, mas a transforma. Balázs enfatiza o caráter enunciativo das técnicas cinematográficas, a tarefa de fabricar os significados através da "arte da angulação e do enquadramento", a qual ele compara àquilo que a noção de estilo representa na literatura e na pintura, isto é, "a personalidade do artista criativo", sua capacidade de inventar formas. A imagem, em vez de neutra, deve ser expressiva: "Cada ângulo visual significa uma atitude interior. Não há nada mais subjetivo do que o objetivo". ${ }^{48} \mathrm{O}$ que o cinema oferece, e que Balázs considera "o único assunto possível de toda a arte"49, é "uma visão humana da realidade, ou seja, uma representação em perspectiva mediada por uma subjetividade". 50

Coube ao expressionismo alemão, mais do que a qualquer outra escola estética dos anos 1920, o fito de explorar as formas plásticas e os recursos estilísticos através dos quais a imagem cinematográfica, "inerentemente" realista e objetiva, poderia se dedicar à expressão subjetiva e à revelação das realidades mentais, interiores. Para Hitchcock (que chegou a passar pelos estúdios da U.F.A. entre 1924 e 1926), o expressionismo seria uma influência ainda mais determinante que a teoria da montagem.

\footnotetext{
${ }^{45}$ Ibid., p. 127.

${ }^{46}$ Cf. I. Xavier, $O$ discurso cinematográfico: a opacidade e a transparência, $2^{\text {a }}$ ed., São Paulo: Paz e Terra, 2008, p. 54

${ }^{47}$ Ibid., p. 54.

${ }^{48}$ Béla Balázs, "Subjetividade do objeto", in Xavier (org.), A experiência do cinema, p. 97.

${ }^{49}$ Ibid., p. 99.

${ }^{50}$ I. Xavier, $O$ discurso cinematográfico, p. 56.
} 
$\mathrm{Na}$ ótica do expressionismo, é inútil representar o mundo tal como ele é: a imagem do mundo só existe no interior de nós mesmos, a arte deve refletir a "realidade profunda da alma" e não a realidade exterior e objetiva; é o espírito que deve enformar a matéria. Todo o trabalho plástico do expressionismo visa "a tradução sensível, sensorial, da ideia"51.

A influência da estética expressionista nos filmes de Hitchcock se observa não apenas no conflito entre luz e sombra, fonte de algumas de suas mais belas invenções visuais, ou na experimentação com a entfesselte Kamera (a câmera solta, desvencilhada, que assume grande liberdade de movimento e, muitas vezes, é responsável por salientar ou até mesmo produzir o sentido de uma cena), mas, sobretudo, na tendência a situar a câmera segundo uma lógica subjetiva: ela não simplesmente reproduz, mas reflete as coisas. A realidade é uma construção do sujeito - é uma imagem intencional. O mundo mostrado na tela é a ampliação/projeção de uma paisagem essencialmente psicológica; "o espaço é o movimento de um desejo". 52

No período 1945-1960, quando Hitchcock realizou a maioria de suas obras-primas, duas vertentes opostas do cinema hollywoodiano viveram seu auge. A primeira, cristalizada nos filmes de Howard Hawks, representava o cinema da ação, da "evidência do olhar",53, do combate corporal, do conflito visível no plano - o cinema americano por excelência. Esse cinema exigia uma mise en scène retilínea, direta, capaz de mostrar imediatamente, sem entraves simbólicos, o mundo físico da ação. Tudo era evidente e claro. "A evidência é a marca do gênio de Hawks", para citar o famoso artigo de Rivette: "Ele prova o movimento ao andar, a existência ao respirar. O que é, é." 54

A segunda vertente é aquela encontrada em Hitchcock, Jacques Tourneur, Robert Siodmak, Douglas Sirk, cineastas imigrantes talhados numa cultura europeia ainda repleta de reminiscências do romance gótico, do teatro vitoriano, da literatura fantástica do século XIX, dos últimos avatares do espírito romântico e da primazia da subjetividade. Adeptos do pensamento e da reflexão crítica, mas incumbidos também do entretenimento, eles utilizaram o cinema de gênero - o suspense, o terror, o film noir, o melodrama - como forma de, ao percorrer caminhos já conhecidos do grande público, passar do familiar, do já assimilado e codificado, ao desconhecido e subterrâneo. Ao contrário de Hawks, a quem só atraía o que é evidente, esses cineastas estavam interessados em sondar as profundezas, em captar as sombras e os rumores de mundos ocultos, em sobrecarregar de significados densos o mundo

\footnotetext{
${ }^{51}$ J. Aumont, "O ponto de vista”, in Eduardo Geada (org.), Estéticas do cinema, Lisboa: Dom Quixote, 1985, p. 137.

52 J.-L. Godard, "Suprématie du sujet", in Cahiers du Cinéma no 10, março de 1952.

${ }^{53}$ Ver J. Douchet, "Les années 50 ou l'évidence du regard”, in Cahiers du Cinéma, no 443/444, maio de 1991, pp. 103-108.

${ }^{54}$ Ver Jacques Rivette, “Génie de Howard Hawks”, Cahiers du Cinéma, n’ 23, maio de 1953, p. 23.
} 
em que vivemos a fim de trazer à tona a inquietante estranheza do cotidiano. Por mais gratuitas e superficiais que sejam as ações mostradas nos filmes, elas servem de pretexto para investigar as entrelinhas da existência humana e explorar os abismos da mente (os desejos reclusos, os pensamentos interditos). A mise en scène, nesse caso, nada mais é que "a coreografia dos signos e símbolos que emanam do "jardim secreto do cérebro". ${ }^{55}$ Em Hawks, a verdade se expõe corporalmente, a substância moral da vida se deixa ver na própria parcela física do drama, no registro objetivo da luta dos homens com a natureza e com os outros homens, nos encontros e afrontamentos dos corpos. Como disse Rohmer, "não há [em Hawks] oposição entre o ser e o parecer. Tampouco entre o ser e o nada; é o ser oposto ao ser" ${ }^{56}$ Em Hitchcock, Tourneur, Siodmak, Sirk, os caminhos já são mais obscuros, a linguagem é menos direta e mais cifrada, o que é nem sempre é; o visível pode ser apenas um véu - o papel da câmera não é simplesmente registrar, mas transcrever na sofisticada composição plástica dos planos a complexidade da vida interior. ${ }^{57}$

Hitchcock pertence, então, a uma "escola" da dramaturgia do profundo, do olhar que vasculha as forças ocultas, os universos secretos, os desejos aprisionados. Mas ele é também um realista, um cronista da vida moderna. A estilização expressionista e o realismo prosaico, em vez de se atritarem, interpenetram-se e conjugam-se na obra hitchcockiana formando uma linguagem fluida, contínua, perfeitamente adequada à ação ininterrupta do suspense. Sobretudo na fase hollywoodiana, Hitchcock sutiliza as deformações plásticas do expressionismo integrando-as ao estilo narrativo clássico. O estado psicológico de uma personagem hitchcockiana, na maioria das vezes, não é registrado através de angulações de câmera bizarras ou distorções do espaço cênico, mas por meio de estruturas de plano-pontode-vista que, mesmo mostrando aspectos objetivos da realidade, constituem uma forma de "psicologizar o olhar" e expressar conteúdos mentais pela relação que se estabelece entre o plano do sujeito que vê e o contraplano do objeto (ou do sujeito) visto. ${ }^{58}$ É o que Richard

${ }^{55}$ Michael Henry Wilson, Jacques Tourneur ou la magie de la suggestion, Paris: Éditions du Centre Pompidou, 2003, p. 16.

${ }^{56}$ Cf. Rohmer, Le goût de la beauté, Paris: Éditions de l'Étoile/Flammarion, 1989, p. 21.

57 Cabe mencionar, como quebra desse dualismo, a posição singular de Fritz Lang, que, em sua fase hollywoodiana, transitou em ambos os registros, ora recorrendo à mise en scène frontal e direta (que prevalece nos filmes de crítica social, sobretudo os dos anos 1950: Gardênia azul, Desejo humano, Só a mulher peca, Suplício de uma alma etc.), ora mergulhando nas sombras e nos reflexos perturbadores, como se vê na série de filmes psicanalíticos que realizou no período 1944-50, dos quais O Segredo da Porta Fechada (1947) é o mais emblemático.

${ }^{58} \mathrm{O}$ elogio de Béla Balázs ao plano-ponto-de-vista (termo que não aparece em seus textos, pois pertence a um vocabulário fílmico posterior) já ia por aí: “A câmera olha para os outros personagens e para seus ambientes a partir dos olhos de um personagem [...] vemos o espaço da ação de seu interior, com os olhos dos dramatis personae, e sabemos como eles se sentem nele" (cf. "Subjetividade do objeto", in A experiência do cinema, op. cit., p. 97). 
Allen chama de "expressionismo analítico", diferenciando-o do "expressionismo subjetivo": enquanto este último evidencia as convenções simbólicas da representação (estilizando ostensivamente os elementos que formam a realidade profílmica), o primeiro dilui a carga expressionista pelo uso das estratégias de montagem e narração "invisível” do cinema clássico. Seguindo essa mesma lógica, quando Hitchcock deseja destacar do ambiente um objeto e imbuí-lo de significação extra ou de função psicológica, ele não recorre ao simbolismo carregado, explícito: os eventuais sentidos suplementares e conotações do objeto são aclimatados dentro do próprio contexto naturalista da representação, num princípio que remete ao que Erwin Panofsky designava como disguised symbolism, ou simbolismo disfarçado, esse simbolismo que, com a transformação do espaço pictórico catalisada pela técnica da perspectiva linear, impõe-se na pintura flamenga do século XV sob a demanda de uma figuração "naturalista" ou, como Jacques Aumont prefere colocar, "opticamente realista". ${ }^{59}$ O simbolismo não mais se apresentaria de forma tão declarada como no século precedente, e sim disfarçado "por conta da potência do efeito de realidade e da exigência óptica que estão ligadas à invenção perspectiva, e que obrigam os símbolos a se fazerem opticamente aceitáveis, possíveis e verossímeis". ${ }^{60}$ Os símbolos se diluem e se naturalizam no espaço da representação. Ora, não é difícil deduzir as consequências da aplicação generalizada desse princípio: se o simbolismo é disfarçado, todo e qualquer objeto presente num quadro, por mais banal e gratuito que pareça a priori, pode estar ali para simbolizar ou metaforizar algo. A potência do simbolismo invade todo o campo da representação, e tudo se torna potencialmente simbolizável.

Como Panofsky salienta, a pintura espiritual fundada nesse simbolismo disfarçado, que não põe em perigo a representação "naturalista", implica que inversamente tudo o que há no mundo esteja virtualmente carregado de sentido, seja virtualmente símbolo; nessa concepção do mundo como representável, todo objeto representado me faz signo misteriosamente, em virtude de um metaforismo generalizado que o historiador da arte situa sob a chancela da fórmula de São Tomás de Aquino, spiritualia sub metaphoris corporalium, as coisas espirituais sob a metáfora das corporais. ${ }^{61}$

Uma vez que a noção de disguised symbolism se aplica ao cinema de Hitchcock, é natural que também constatemos nele esse "metaforismo generalizado", essa sensação de que qualquer elemento em quadro pode fazer parte, mesmo que subsidiariamente, de um sistema simbólico. Embora não evocassem a iconologia panofskyana, Chabrol e Rohmer já insistiam

\footnotetext{
${ }^{59}$ J. Aumont, "Vanités", in Matière d'images, op. cit., p. 48.

${ }^{60}$ Ibid., p. 49.

61 Ibid., p. 49.
} 
bastante, em seu livro pioneiro (publicado em 1957), sobre a questão de que, dentro das regras mais usuais do realismo, Hitchcock encenava, na verdade, um drama cósmico embasado na metafísica e na simbologia cristãs. Cada peça do universo hitchcockiano, incluindo as situações banais que antecedem o desencadeamento do suspense, estaria entranhada de significados morais latentes, de verdades espirituais que se disfarçam sob a realidade corpórea do mundo captado pela câmera. Nos objetos mais triviais da vida moderna, Hitchcock teria investido "o poder de significar os mecanismos mais escondidos, mais íntimos, mais secretos e incompreensíveis dos comportamentos humanos". ${ }^{62}$

Dando sequência a essa linha de interpretação, o livro de Jean Douchet (escrito entre 1963 e 1966, e publicado pela primeira vez em 1967) debruça-se com ainda mais ênfase sobre o simbolismo hitchcockiano: tudo que é “devorado" pela câmera de Hitchcock, segundo Douchet, "deixa de ser objetivo para participar de sua visão de mundo subjetiva, angustiada, mágica"; cada elemento que aparece na tela se vê transformado em signo carregado de sentidos múltiplos. ${ }^{63}$ Douchet destaca não apenas a filiação de Hitchcock à doutrina espiritual do catolicismo, mas principalmente sua afinidade com o idealismo platônico. Ele afirma que o estilo do diretor se estabelece entre "a vontade de respeitar aparentemente o aspecto documental e objetivo da matéria" e a tendência a empregar a trucagem e a técnica do cinema de animação para negar a realidade da coisa filmada e afirmar a ideia que lhe preside. A realidade material aparece como "inimiga de um artista que adora conceber seus filmes inteiramente no papel, imaginar as formas por elas mesmas, filmar apenas a ideia". ${ }^{64}$

É conhecida aquela história (ou mito?) de que Hitchcock já chegava no set com o filme todo pronto na cabeça, a filmagem sendo apenas a etapa necessária para materializar uma ideia ou um desenho perfeito que ele trazia na mente. Com a cumplicidade dos depoimentos de seus colaboradores e estudiosos, Hitchcock ganhou a fama de um controlador obsessivo que pré-planejava cada detalhe de seus filmes, um artista "alérgico a surpresas", que fazia de tudo para se proteger do imprevisível mundo real e preferia se trancar em estúdios "onde seus sonhos podiam ser traduzidos diretamente de sua mente para o celuloide, com um mínimo de fatores externos". ${ }^{65}$ Antes mesmo de a câmera começar a rodar, a mise en scène já havia sido concebida. Os atores eram apenas peças encaixáveis no grande esquema; a improvisação era algo impossível nesse universo em que cada imagem e cada gesto estavam

\footnotetext{
62 J. Aumont, "L'objet cinématographique et la chose filmique", in Cinémas, vol. 14, $\mathrm{n}^{\circ}$ 1, setembro-novembro de 2003, p. 190.

${ }^{63}$ J. Douchet, Hitchcock, Paris: Ed. Cahiers du Cinéma, 2006, p. 221.

${ }^{64}$ Ibid., p. 222.

${ }^{65}$ Cf. Bill Khron, Hitchcock at work, Londres/Nova York: Phaidon, 2000.
} 
preordenados. O material bruto que o montador recebia já continha praticamente o filme editado, pois as ligações entre planos só fariam sentido se montadas de uma única forma pensada por Hitchcock no ato da decupagem. Os membros da equipe recebiam storyboards que representavam todos os planos do filme de maneira irretocável, com todos os ângulos, movimentos, linhas, formas, tudo predeterminado. E por aí vai. De texto em texto, de entrevista em entrevista, foi assim que se descreveu o método de trabalho de Hitchcock e seu comportamento no set, ou seja, foi assim que se difundiu sua imagem de diretor.

Imagem que Bill Krohn, em seu livro Hitchcock at work, busca desmistificar. Logo na introdução do livro, ele contrasta as histórias e os axiomas mais famosos que se atribuem ao "mestre do suspense" com as constatações a que chegou por meio de sua pesquisa (feita a partir de diários de produção, planos de filmagem, orçamentos, relatórios, cartas, roteiros, storyboards, anotações sobre casting etc.). Krohn conclui que o Alfred Hitchcock de que sempre ouvira falar é um mito, promovido primeiramente pelo próprio cineasta, mas propagado e aumentado pelas pessoas que escreveram sobre ele. Com base em sua pesquisa, Krohn opõe à mitologia que cerca a figura de Hitchcock alguns dados factuais: em quase todos os filmes, Hitchcock reescrevia partes do roteiro durante as filmagens, ou até mesmo rodava cenas que não constavam no roteiro; os storyboards não eram impostos ditatorialmente aos diretores de fotografia, mas funcionavam como ferramentas de comunicação entre os membros criativos da equipe, havendo certa margem de manobra na composição dos planos (insights momentâneos podiam mudar a cena pré-desenhada); Hitchcock fazia, às vezes, takes alternativos de um mesmo plano, deixando para escolher o melhor na sala de montagem; ele gostava de filmar em locações reais, o que contraria a história de que encarava como um martírio ter de abandonar o estúdio onde podia controlar tudo e criar uma visão estilizada do mundo. A história que Bill Krohn propõe para substituir o mito, portanto, é a de um diretor muito mais pragmático e flexível do que aquele que consta no retrato que costumam pintar.

Mas, como o próprio crítico admite, o mito tem suas raízes no fato: “Temperamentalmente desconfortável com o elemento caótico da realização de filmes, Hitchcock aspirava a eliminá-lo e estava realmente mais inclinado que a maioria a préplanejar cada detalhe de seus filmes". O ponto que Bill Khron procura deixar claro é que "o caos era um colaborador frequente [nas produções de Hitchcock], às vezes a convite do próprio diretor", e que "talvez essa tensão seja parte do que faz seus filmes eternamente fascinantes". 66

\footnotetext{
${ }^{66}$ Ibid., p. 10.
} 
Decerto, o conflito entre cálculo e imprevisto, ordem racional e caos sensível, e mais profundamente entre a obsessão de controle e o risco de perdê-lo, não se restringe, em Hitchcock, ao processo de realização dos filmes, possuindo também uma extensão temática:

O desejo de controle, o pavor de perder o controle: tais frases descrevem não apenas a relação consciente de Hitchcock com a técnica e com seus espectadores, mas também o centro temático de seus filmes. As relações pessoais que fascinam Hitchcock invariavelmente envolvem o exercício do poder ou seu avesso, a impotência; em muitos casos, uma pulsão de poder que busca esconder, negar ou compensar uma impotência temida. ${ }^{67}$

De Festim diabólico a Vertigo, de Pacto sinistro a Psicose, de Disque M para matar a Frenesi, passando por Interlúdio, Sob o signo de capricórnio, Marnie, enfim, são muitos os filmes de Hitchcock em que esse padrão de relacionamento humano, fundado no binômio dominação-impotência, espelha a própria tensão inerente ao olhar do diretor sobre as personagens e o mundo que ele filma - tensão que afeta o espectador, entre outras coisas, pelo uso recorrente da câmera subjetiva. Por ser um filme cujo protagonista personifica tanto o espectador quanto, de certo modo, o diretor de cinema, Janela indiscreta pode ser visto, no conjunto, como a elaboração mais emblemática deste princípio: as pessoas que James Stewart observa estão ao mesmo tempo "dominadas imaginativamente por sua consciência e totalmente fora do seu controle". ${ }^{68}$ O pensamento, por meio do olhar, almeja enlaçar a realidade, dominá-la em seu campo de visão, submetê-la à esfera íntima da ação mental - mas as leis do mundo exterior nem sempre se dobram àquelas que regem a vida psíquica.

A primeira imagem de Janela indiscreta consiste na cortina da sala de estar do apartamento de Jeff se abrindo e revelando uma visão panorâmica da vizinhança. Essa imagem, que repete o ritual de início da própria sessão de cinema (a abertura da cortina que cobria a tela), inscreve o filme, desde já, numa chave reflexiva (o que veremos a partir de então será a teoria do espetáculo segundo Alfred Hitchcock). Depois que todos os três segmentos da cortina estão abertos, a câmera desliza num ansioso travelling para frente, quase como se quisesse sair pela janela e passear pelos apartamentos vizinhos. Esse travelling é o suficiente para materializar o movimento de curiosidade, a voracidade de visão e a pulsão de

\footnotetext{
${ }^{67}$ R. Wood, art. cit., p. 35.

${ }^{68}$ Ibid., p. 36.
} 
saber que movem o espectador na direção daquele retângulo de imagem oferecido pela tela. Ademais, o simples gesto de descortinar, de abrir o olhar para o que ainda há pouco se achava velado, bloqueado à visão, evoca em si a ideia de uma realidade escondida, secreta, que agora iremos explorar. O visível se encontra, a princípio, fechado, envelopado, ou melhor, o visível é o próprio véu que mantém a verdade das coisas inacessível à apreensão imediata. Somente atravessando as aparências se chega ao sentido desejado. Se existe um sentido profundo na vida, ele não se dá a ver diretamente, é preciso prospectá-lo, buscá-lo nas figuras e nos sinais que a trama do visível escamoteia tanto quanto mostra. $\mathrm{O}$ mundo está cheio de zonas de opacidade, de escuridão, de invisibilidade, esses limites reais e, todavia, simbólicos cuja tarefa é barrar o olhar que quer ir até o fundo das coisas. É aí que entra o poder da visão obcecada, pervertida, daquele olhar fixo e insistente que, conforme nos dizia Bonitzer, fura a pele do real como a ponta de um cigarro queimando um tecido pelo contato prolongado. A visão é requisitada em suas propriedades mais ativas, em sua capacidade de raspar a superfície das coisas, de investigar e interpretar as formas do mundo. O que está em jogo, aqui, é a passagem da visão sensível à visão mental, ou a coincidência entre o ver e o pensar. $\mathrm{O}$ estado contemplativo e descritivo do olhar, que pauta as primeiras panorâmicas da câmera de Hitchcock mostrando a vizinhança de Jeff, logo cede lugar a uma postura mais invasiva e até mesmo impaciente: o ato perceptivo adentra o fascinante mundo da conjectura, da análise; o esforço de captar o sentido se confunde à avidez de dissipar a ambiguidade inerente à percepção bruta. Ora, a melhor forma de desfazer essa ambiguidade é filtrá-la através dos esquemas racionais da consciência, traduzi-la para uma linguagem inteligível. No limite, porém, o olhar que teme a ambiguidade se contamina com a própria imaginação que o assombra e se torna um olhar produtivo, que aquiesce à reinvenção da realidade e aos devaneios da visão. O real e seu fantasma se misturam. Não por acaso, ao final do movimento circular que, logo no início do filme, percorre o espaço da vizinhança (como a nos apresentar o palco das ações) e termina recuando para dentro do apartamento de Jeff, este é mostrado dormindo, com o rosto voltado para dentro de casa e a nuca virada para o lado de fora, ou seja, de costas para o pátio externo, imerso em sonhos. Talvez a realidade exterior esteja sendo definida, desde o começo, como superfície de projeção para as imagens que se formam em pensamento ou em sonho. "Ver' significa adivinhar o que está lá fora”, já nos afirmou Gombrich. ${ }^{69}$ Se a visão tem origem na mente, em nossas reações ao mundo mais que no mundo visível em si, então o cinema, máquina de visão, é também máquina de fabricação da

\footnotetext{
${ }^{69}$ E. H. Gombrich, Arte e ilusão, $4^{\mathrm{a}}$ ed., São Paulo: WMF Martins Fontes, 2007, p. 254.
} 
realidade: ele não apenas vê, mas, "em obediência a uma palavra de ordem da arte do século XX, fabrica o visível", 70

Em A janela de esquina do meu primo (o conto de Hoffmann que, como vimos anteriormente, prefigura o dispositivo de Janela indiscreta), já havia um elogio da fabulação da realidade operada pelo sinergismo do olhar e do pensamento. Escrito em 1822, o conto pertence a um momento histórico decisivo, no qual, como explica Jonathan Crary, ocorre uma verdadeira reorganização da visão na modernidade. ${ }^{71}$ A mudança de paradigma que pode ser observada com maior nitidez a partir das décadas de 1820 e 1830 diz respeito a uma passagem do modelo da câmara escura, que predominara entre a Renascença e o século XVIII com a função de garantir uma apreensão objetiva da realidade e de figurá-la com o máximo de fidelidade mimética, para uma série de outros instrumentos ópticos e modelos de observação que valorizam a visão subjetiva, a produtividade do observador. Se, da Renascença ao Iluminismo, havia-se buscado uma racionalização da visão, uma concepção do visível fora das circunstâncias corpóreas e subjetivas do observador, na primeira metade do século XIX, inversamente, seria reconhecida a participação do sujeito na constituição das formas visíveis do mundo e, com isso, permitida uma "liberação da visão". 72

Tal como A janela de esquina do meu primo, Janela indiscreta ilustra, no fundo, a passagem de um regime de observação a outro, ou seja, do modelo epistemológico da câmara escura como base objetiva da visão e como meio de obtenção de uma imagem "verdadeira" do mundo exterior, passa-se a um outro modelo, que identifica na contribuição singular do observador - sua sensibilidade, sua inteligência, seus "erros humanos" - a instância de produção ativa da experiência óptica (em outras palavras, vai-se do racionalismo iluminista ao subjetivismo romântico).

A princípio, o apartamento de Jeff, e mais especificamente a sala de estar, funciona como uma câmara escura: "o que se mostra na sala deste lado da janela é precisamente a imagem invertida do que se mostra pela janela [do apartamento de Thorwald] no lado oposto do pátio". ${ }^{73}$ Do lado de cá, vê-se Jeff imobilizado na cadeira de rodas e Lisa se movimentando livremente pelo cenário; lá, Sra. Thorwald está de cama por conta da doença e seu marido fica indo e voltando sem parar (essa dinâmica de espelhamento é onipresente no filme, não deixando dúvida de que o casal Jeff-Lisa é a imagem invertida dos Thorwald). A janela do

\footnotetext{
${ }^{70}$ J. Aumont, "L'objet cinématographique et la chose filmique", art. cit., p. 196.

${ }^{71}$ Jonathan Crary, Técnicas do observador: visão e modernidade no século XIX, Rio de Janeiro: Contraponto, 2012.

72 Ibid., p. 32.

${ }^{73}$ Miran Bozovic, “The Man Behind His Own Retina”, in Slavoj Zizek (org.), op. cit., p. 162.
} 
apartamento de Jeff, entretanto, além de representar o orifício de abertura da câmara escura, metaforiza também a área do olho humano sensível aos raios luminosos, isto é, a fronteira entre a realidade exterior e a região interna da mente, a porta que comunica o mundo visível com o mundo das ideias, o que faz com que toda a matéria visual que compõe o filme seja concebida tanto no plano da percepção objetiva de uma realidade testemunhada por Jeff como na esfera visionária de uma fantasia do desejo. As imagens provenientes de fora, tão logo atravessem a janela, projetam-se distorcidas na parede de fundo do apartamento de Jeff (para onde sua cabeça está voltada - enquanto ele dorme - na cena de abertura do filme). O modelo, aqui, já não é a objetividade, a operacionalidade racionalista da câmara escura, e sim o expressivismo da visão romântica, o idealismo subjetivo de uma visão que se forma sob a influência dos conteúdos superabundantes do pensamento, dos sentimentos e da vida espiritual como um todo: o que Jeff colhe da realidade são já projeções, elaborações, interpretações.

$\mathrm{Na}$ posição em que se encontra de início, então, Jeff se apresenta como "um observador isolado, recluso e autônomo em seus confins obscuros". ${ }^{74}$ É próprio desse tipo de observador, que se identifica com o aparato da câmara escura, definir-se como um "sujeito privatizado", confinado em um espaço doméstico, "apartado de um mundo exterior público" ${ }^{75}$ Há um "distanciamento do mundo", ao qual se segue uma descorporificação da visão: o ato de ver é separado do corpo para se "corrigir", isto é, para se afastar dos sentidos (encarados, nessa lógica, como enganosos, mentirosos). O que importa, na câmara escura, é a representação ordenada, o espaço racionalizado oferecido pela objetividade do aparato, independentemente da situação fisiológica ou sensorial dos sujeitos perceptivos: "O predomínio do paradigma da câmara escura implica um privilégio dado à visão, mas é a visão que está, a priori, a serviço de uma faculdade não sensível do entendimento, a única que fornece uma concepção verdadeira do mundo" ${ }^{76} \mathrm{O}$ olho ideal forjado pela câmara escura, de certa forma, neutraliza o corpo, "marginalizando-o como um espectro a fim de estabelecer um espaço da razão". ${ }^{77}$

Mas essa similaridade inicial do apartamento de Jeff com o modelo da câmara escura deve aqui ser relativizada: se, por um lado, Jeff personifica aquele observador distanciado do mundo, por outro, sua visão não é exatamente descorporificada. A ficção de Janela indiscreta não anula o corpo do protagonista. Pelo contrário: todo o confinamento do filme se deve à

\footnotetext{
${ }^{74}$ J. Crary, Técnicas do observador: visão e modernidade no século XIX, op. cit., p. 45.

${ }^{75} \mathrm{Ibid}$., p. 45.

${ }^{76} \mathrm{Ibid}$., p. 61.

${ }^{77}$ Ibid., p. 47.
} 
situação singular desse corpo, cuja realidade física é ressaltada, por exemplo, durante as sessões de massagem (o estado enfermo, aliás, é justamente uma das formas de que o corpo dispõe para reclamar sua proeminência, sua presença inelutável, e impor cuidados). A perna engessada de Jeff ocupa ostensivamente o quadro em alguns momentos, sobretudo quando afetada pelas coceiras que surgem sempre que o assunto "casamento" vem à tona. A visão, portanto, está mais do que nunca condicionada ao corpo, mas a um corpo arrancado do mundo da ação (palco predileto do fotógrafo aventureiro) e conduzido a um repouso forçado, em que predomina o ver à distância e o ver sem mover. É menos uma visão descorporificada do que desmotorizada.

Jeff é, por assim dizer, o anti-burlesco. Em Chaplin, Keaton, Lloyd, a apresentação cinematográfica das relações do homem com o mundo à sua volta é essencialmente tátil e corpórea. Tocar, mexer nas coisas, tirar tudo do lugar, empenhar toda a superfície do corpo no contato físico permanente com a realidade circundante, eis a regra capital do homem burlesco. Mesmo quando se trata de exprimir sua subjetividade, a riqueza de sua imaginação, ele traduz tudo em agitação exterior. A própria percepção do espaço visual passa menos pelo olhar do que pelo dispêndio físico, pela proeza performática, pela hiperatividade atlética do comediante. O herói interpretado por Buster Keaton em Sherlock Jr., por exemplo, trabalha como projecionista num cinema, mas sonha em se tornar detetive. Ele é quase uma versão burlesca de Jeff, que projeta um crime no quadro enfadonho de sua vida diária e banca o detetive amador para tentar solucioná-lo. No meio de uma sessão, Keaton adormece. Um duplo fantasmático se desprende então de seu corpo, sai da cabine de projeção, caminha até a tela e, como quem cruza uma fronteira clandestinamente, entra no mundo do filme dentro do filme, onde faz o papel do herói e protagoniza uma série de peripécias que incluem algumas das mais incríveis gags acrobáticas de Keaton. Se, em Janela indiscreta, o corpo que Jeff projeta no apartamento da frente (na tela) não é o seu, mas o de sua namorada (que efetivamente invade a casa de Thorwald), em Sherlock $J r$., o corpo que Keaton projeta na história de detetive imaginada não é outro senão o seu (o filme incorpora radicalmente "o fantasma identificatório do face a face do espectador com a imagem" ${ }^{78}$ ). Ele se inscreve no lugar da ação, ao passo que Jeff permanece na posição de quem apenas assiste. De Sherlock $J r$. a Janela indiscreta, da comédia burlesca ao suspense hitchcockiano, do exibicionismo ao voyeurismo, a aventura inesgotável do corpo se trocou pela atividade inquieta, porém interiorizada, do olho. Restrito à cadeira de rodas e ao perímetro de um cômodo, o corpo não

${ }^{78}$ Philippe Dubois, "Les face-à-face du corps et de l'image", in J. Aumont (org.), L'invention de la figure humaine, Paris: Cinémathèque Française, 1995, p. 188. 
mais se locomove: todas as energias estão concentradas no olhar. Ao excesso de ação se substitui o excesso de visão. Quando finalmente o corpo de Jeff é incluído no teatro das ações, na cena em que Thorwald invade seu apartamento e tenta matá-lo (jogando-o pela janela, como não poderia deixar de ser), tudo se dá como pesadelo, naquele duelo entre a luz lancinante dos flashes que Jeff dispara com seu aparato fotográfico e a massa sombria de Thorwald, que se aproxima de forma ameaçadora. Para além dos significados teológicos aí expressos como uma batalha metafísica entre a luz e as trevas ${ }^{79}$, a cena cria um efeito visual que beira o delírio, comprovando que a ação, uma vez expulsa desse reduto do puro olhar, só pode retornar como alucinação.

A imagem de Jeff sendo defenestrado talvez signifique uma negação violenta da ideia - implícita no código hermenêutico da câmara escura - de que a visão poderia prescindir do corpo e acontecer de maneira não circunstanciada. A cena não apenas retira o observador dessa posição pré-fenomenológica como ainda promove o colapso entre os espaços interior e exterior, já mesclados no plano psicológico, mas até então separados no dispositivo cênico.

Em termos de uma história do olhar na modernidade, a superação da câmara escura como sistema óptico e como figura epistemológica se vincula, no começo do século XIX, a uma representação do mundo em que visão interior e realidade exterior já não respeitam muito suas antigas fronteiras. É o momento em que Goethe elabora a Doutrina das cores, afirmando que os fenômenos cromáticos dependem mais do olho do que da realidade em si, a subjetividade corpórea do observador sendo fundamental para a formação da visão.

Se o discurso acerca da visualidade nos séculos XVII e XVIII reprimiu e ocultou o que ameaçava a transparência de um sistema óptico, Goethe sinaliza uma inversão e propõe a opacidade do observador como condição necessária para o aparecimento dos fenômenos. A percepção ocorre no âmbito daquilo que Goethe chama de das Trübe - o turvo, ensombrecido ou sombrio. ${ }^{80}$

$\mathrm{Na}$ teoria goethiana das cores, contemporânea de uma série de desenvolvimentos no campo da física e da fisiologia ópticas, delineia-se uma forma de visão subjetiva que já insinua aquele observador - alerta, ativo, "a um só tempo o lugar e o produtor de sensações" "81 - que virá transformar a experiência visual nas sociedades modernas e industriais. A visão, no

\footnotetext{
${ }^{79}$ Cf. J. Douchet, "La troisième clé d'Hitchcock", in Cahiers du cinéma, no 99, setembro de 1959, p. 48.

${ }^{80}$ J. Crary, Técnicas do observador, op. cit., p. 74.

${ }^{81}$ Ibid., p. 78.
} 
período clássico, aspirava a um conhecimento espontâneo das coisas, a um saber imediato cujo método estava ligado à nomeação do visível e à sua ordenação numa grade classificatória, num "quadro". ${ }^{82} \mathrm{Na}$ era romântica, em oposição a essa transparência que o pensamento clássico estabelece entre o mundo oferecido ao olhar e os signos que o ordenam, a visão começa a se enturvar e a se embrenhar na obscuridade. A ênfase não recai mais sobre a realidade perceptível ou diretamente acessível, e sim sobre o "demônio da obstinação" (título de um conto de Edgar Allan Poe publicado em 1845) que se encarna no olhar ávido por sensações e visões novas, disposto a explorar as zonas abissais para conhecer o que não está dado espontaneamente no mundo. $\mathrm{O}$ culto oitocentista à imaginação, à descoberta das paisagens - reais ou simbólicas - escondidas por nevoeiros, à reabertura dos veios mágicos e místicos obstruídos pela razão clássica, cristaliza-se tanto na literatura fantástica como na pintura romântica e simbolista (Friedrich, Böcklin, Spitzweg). Baudelaire, no Salão de 1846, afirma que o romantismo não nasce da realidade admirada e contemplada a céu aberto, mas das "profundas meditações do atelier", dos "olhares de fantasia submersos nos horizontes cinzentos". ${ }^{83}$ Mais tarde, no Salão de 1859, ele amplia suas considerações acerca do "governo da imaginação" e da potência criadora do artista: em vez de somente imitar a natureza exterior, a arte deve transformá-la, alterar sua fisionomia, utilizá-la como um dicionário do qual se extraem os elementos capazes de "iluminar a ideia geradora": "Todo o universo visível não é mais que um armazém de imagens e de sinais aos quais a imaginação irá atribuir um lugar e um valor relativo: é uma espécie de pasto que a imaginação tem de digerir e de transformar". 84

Em consonância com essa disposição romântica elogiada por Baudelaire e definida como traço crucial da modernidade (afinal, "quem diz romantismo diz arte moderna" ${ }^{\$ 5}$ ), os instrumentos ópticos surgidos na primeira metade do século XIX, a exemplo do estereoscópio e do fenacistoscópio, trazem uma nova lógica de funcionamento na qual compete ao observador, interagindo com o aparato, produzir o campo visual. Tais instrumentos deixam de servir apenas para o observador aferir o que é real e passam a oferecer-lhe a possibilidade de reelaborar ou até mesmo inventar o "real". Na imagem vista através do estereoscópio, a produção do efeito de realidade - a ilusão de profundidade e relevo - coloca-se como "evento subjetivo", explicitando "a natureza alucinante e fabricada da experiência". ${ }^{86}$ Se a imagem

\footnotetext{
${ }^{82}$ Ver Michel Foucault, As palavras e as coisas, $9^{\mathrm{a}}$ ed., São Paulo: Martins Fontes, 2007.

${ }^{83}$ Ch. Baudelaire, op. cit., pp. 26-27.

${ }^{84}$ Ibid., p. 164.

${ }^{85}$ Ibid., p. 26.

${ }^{86}$ J. Crary, op. cit., p. 126.
} 
resulta de um processo de combinação e síntese desencadeado dentro do sujeito a partir dos estímulos do aparato, a construção do visível doravante inclui a equivocidade natural do olho humano, sua propensão à ilusão e à especulação sem limites. A título de uma genealogia das formas hitchcockianas, não custa lembrar que a percepção do crime em Janela indiscreta deriva das articulações visuais e mentais a que Jeff chega com a ajuda de seus binóculos e de sua lente teleobjetiva - a lógica, portanto, é a mesma já contida em embrião no dispositivo do estereoscópio, que possuía, segundo Crary, algo de "inerentemente obsceno". 87

Esse olhar ativo, que é promovido ao centro da ciência e do entretenimento na curva dos séculos XVIII e XIX, faz-se um dos assuntos prediletos não só da literatura (já analisamos o exemplo de Hoffmann) como também da pintura do período, que tem na questão do olhar e do ponto de vista motivos pictóricos recorrentes: "Desde o fim do século XVIII, e até o impressionismo, e talvez até mesmo além dele, são muitos os quadros que arremedam o exercício do olhar, solitário de preferência, a um só tempo todo-poderoso e desesperadamente limitado". ${ }^{88}$ Em épocas anteriores, artistas como Dürer, van Eyck e Velásquez já haviam tomado como tema de algumas de suas obras a própria investigação acerca das condições em que se dava a visão e se constituía o olhar sobre as coisas. Mas é no limiar da modernidade, e ao longo dela, que essa reflexão inclui de maneira mais sistemática a figura do observador, do indivíduo ocupado da visão de alguma coisa, inserido na imagem como "sujeito que olha": "o centro de gravidade se deslocou do objeto ou da cena pintados ao olhar sobre eles, depois ao portador desse olhar, o espectador, às vezes redobrado materialmente no quadro". ${ }^{89}$ Podemos pensar no contemplador de paisagens que aparece nos quadros de Caspar David Friedrich, aquele observador que, situado no topo do mundo, mira o espetáculo grandioso da natureza. Mas há também o observador enredado no espetáculo corriqueiro da vida moderna, seja investindo sua atenção em algum evento efêmero, seja fitando algo ou alguém que não necessariamente está no quadro (um pensamento, uma ausência, um flerte). Em Manet, por exemplo, assim como em Fantin-Latour, há um misterioso teatro de olhares que é talvez o grande tema de sua pintura.

Hitchcock herda e atualiza esse espectador-dentro-do-quadro e, questionando o significado e a função do olhar, problematizando na diegese nossa relação com a figuração, resvala no tema do conhecimento pela visão e pelas aparências, "que é o tema do século XIX,

\footnotetext{
${ }^{87}$ Ibid., p. 124.

${ }^{88} \mathrm{~J}$. Aumont, $O$ olho interminável, p. 58.

${ }^{89}$ Ibid., p. 60.
} 
e o do cinema". ${ }^{90} \mathrm{O}$ olhar compenetrado de Louis Pasteur examinando cuidadosamente o visível para extrair-lhe as respostas que procura, conforme retratado no magnífico quadro de Albert Edelfelt, vale também para o artista que, à semelhança do cientista, "é o homem que aprendeu a ver criticamente, a aprofundar suas percepções com interpretações alternativas, tanto de brincadeira como a sério". ${ }^{91} \mathrm{O}$ olho apto a captar o sentido e decifrar os criptogramas desse enorme texto que o mundo oferece sob a crosta vibrante de sua fenomenalidade não é o "olho inocente", passivo, que aceita as aparências em estado puro: "só a mente curiosa, que sabe sondar as ambiguidades da visão" ${ }^{\text {, }}$, pode levar adiante tal empreitada:

[...] precisa-se aí de uma acuidade do olhar, mas também de um desejo de investigação e de descoberta [...] uma confiança nova dada à visão como instrumento de conhecimento, e por que não de ciência. Aprender olhando, aprender a olhar: é o tema, também gombrichiano, da "descoberta do visual por meio da arte", da similitude entre ver e compreender. ${ }^{93}$

Encarada como ferramenta de conhecimento do mundo, portanto, a visão requer todo um aprendizado, toda uma formação. Inútil "fazer da mente um vácuo inocente em que a Natureza inscreva os seus segredos"; é preciso, antes de tudo, ter uma visão ativa. "Toda observação", escreve Gombrich, "é o resultado de uma pergunta que fazemos à Natureza, e toda pergunta implica uma hipótese tentativa". ${ }^{94} \mathrm{O}$ ponto de partida de um registro visual é a conjectura.

No cinema, e sobretudo nos filmes de diretores como Hitchcock, que tratam a imagem como um precipitado de ideias, a própria operação de enquadramento já é uma forma de interrogar as coisas e de intensificar nossa atividade perceptiva e interpretativa. Enquadrar é pensar, ou melhor, é colocar o pensamento em ação, em trabalho: "O enquadramento desempenha tradicionalmente o papel de decupagem do espaço profílmico em um fragmento pensado, composto". 95 O que é enquadrado não é o real, mas um pensamento, uma imagem formada a partir de uma percepção/interpretação da realidade: "O quadro restringe a vista do sujeito-espectador a um objeto já percebido visualmente pelo sujeito da enunciação no momento da filmagem". ${ }^{96}$ A ação do enquadramento consistiria, então, em retirar as coisas de seu estado primitivo, bruto, em arrancá-las daquela realidade pré-predicativa a que Merleau-

\footnotetext{
${ }^{90}$ Ibid., p. 51.

${ }^{91}$ E. H. Gombrich, op. cit., p. 264.

${ }^{92}$ Ibid., p. 331.

${ }^{93}$ J. Aumont, $O$ olho interminável, p. 51.

${ }^{94}$ E. H. Gombrich, op. cit., p. 271.

95 Odile Bachler, "Cadre et découpage spatial”, in Champs visuels, $\mathrm{n}^{\circ}$ 12-13, janeiro de 1999, p. 57.

${ }^{96}$ Ibid., p. 62.
} 
Ponty se refere em sua fenomenologia do visível. Ou seria o cinema, ao contrário disso, um olhar contemplativo que recupera algo da visão "pré-consciente", pré-reflexiva, estabelecendo com as coisas uma relação de imediaticidade que as devolve a seu estado de assignificância primordial, de não pertencimento ao mundo da linguagem?

Aumont afirma que "o jogo do quadro móvel, do recorte variável do campo fenomenal, é o primeiro gesto que instaura uma relação de atenção entre o cinema e 'seu' objeto. Como designar um objeto? Isolando-o, e para tal o quadro parece ser a primeira ferramenta". ${ }^{97} \mathrm{O}$ enquadramento cinematográfico pode estar associado, assim, ao desejo de organizar o visível como um domínio do saber, de "englobar o real, de circunscrevê-lo em limites coerentes para melhor compreendê-lo e controlá-lo". ${ }^{98}$ Mas pode também ser um simples acesso momentâneo a um espaço que se estende para além das fronteiras impostas pela delimitação do campo, apontando - por meio de uma constante tensão entre o visto e o não visto, entre o dentro e o fora de quadro - a existência de uma dimensão da realidade que nos escapa. Um filme, em sua sucessão de vistas parciais e incompletas, dá sempre testemunho de uma condição estrutural da câmera: toda operação de enquadramento " $a$ um só tempo limita e abre, demarca um lugar e explora um mundo". 99 A história dos estilos no cinema tem a ver, em grande parte, com a definição de qual desses dois aspectos constitutivos do enquadramento o cineasta privilegia - a restrição do campo visual como forma de agenciamento e controle, de um lado, e sua abertura para o caráter volúvel da realidade enfocada, do outro. Jean Narboni opõe o estilo de Hitchcock ao de Jean Renoir exatamente nesses termos:

[...] em Renoir, a ação atravessa a tela, não está encerrada no quadro; existe uma área dramática global independente da câmera, que nela passeia como uma lente de aumento seletiva; um espaço contínuo e homogêneo ao da tela prolonga-o para além dos limites do quadro. [...] Em Hitchcock, ao contrário, o plano e seus limites são soberanos, não há um espaço de jogo que exceda nosso campo visual. ${ }^{100}$

É mais ou menos a mesma diferenciação, feita por Robin Wood, entre um "cinema centrado no ator" e um "cinema centrado na imagem", ou "entre diretores que trabalham em colaboração com os atores e diretores que os utilizam para executar um plano ou uma ideia

\footnotetext{
${ }^{97}$ J. Aumont, "L'objet cinématographique et la chose filmique”, p. 186.

${ }^{98}$ O. Bachler, "Cadre et découpage spatial", p. 62.

${ }^{99}$ Cf. Jean-Pierre Esquenazi, "Du cadre au cadrage", in Champs visuels, no 12-13, janeiro de 1999, p. 185.

${ }^{100}$ Jean Narboni, "Visages d'Hitchcock”, in ___ (org.), Alfred Hitchcock, Paris, Éditions de l'Étoile/Cahiers du Cinéma, 1980, p. 37.
} 
preconcebida: Renoir, Hawks, McCarey contra von Sternberg, Antonioni, Hitchcock". ${ }^{101}$ Em Renoir, o quadro é o lugar provisório de uma ação que o transborda, mostrando-se relativamente suscetível às irrupções imprevistas; em Hitchcock, é a definição de um espaço "fechado" e estilizado, cuja expansão-contração é determinada não pela ação dos corpos em cena, mas pela inteligência que confere forma e direção a tudo o que se dá no interior desse espaço. Em Hawks e McCarey, a câmera se move, em geral, para acompanhar ou reenquadrar os atores, que desfrutam certa liberdade de ação. ${ }^{102}$ Em Hitchcock, ela adora se mover independentemente de qualquer deslocamento dos corpos encenados - é a câmera que é livre, não o ator. Em filmes como Jejum de amor (His Girl Friday, Hawks, 1940) e Era uma lua de mel (Once Upon a Honeymoon, McCarey, 1942), os cenários são iluminados de maneira homogênea e clara; tudo o que precisa ser visto - basicamente, as performances de Cary Grant, Rosalind Russell, Ginger Rogers - acha-se no centro do quadro; a câmera se atém à materialidade dos corpos e dos lugares diegéticos e não se importa muito com o que extrapola a realidade aparente. Já em Pacto sinistro, A sombra de uma dúvida, Janela indiscreta ou $O$ homem errado, o espaço é denso, turvo, recortado por sombras; a visão encontra obstáculos, a realidade é alusiva e enigmática, as coisas se esquivam de seus significados imediatos; a câmera é sensível às sugestões, aos sinais de que algo pode estar dissimulado sob as aparências.

A delimitação rigorosa do quadro, nos filmes de Hitchcock, não afeta apenas a composição dramática (o trabalho com os atores e a cena e sua organização no espaço): ela consiste, antes, na estratégia de conduzir a atenção do espectador e solicitá-la em dobro, tornando perceptíveis na estrutura da imagem as menores mudanças e variações do ambiente, os mais discretos signos antecipatórios. É toda uma "meteorologia da suspeita" ${ }^{103}$ Assistir a um filme de Hitchcock é penetrar num universo em que tudo - objetos, paisagens, rostos - faz signo. O quadro parece esconder alguma coisa atrás de seu arranjo formal minucioso, como se fosse o mapa de um labirinto. Instigado pela lei misteriosa que comanda a construção desses planos, o olhar varre a superfície plástica da imagem à cata dos significados ocultos no

\footnotetext{
${ }^{101}$ R. Wood, art. cit., p. 32.

${ }^{102}$ Há exceções marcantes, evidentemente, como o travelling que, em Onde começa o inferno (Rio Bravo, Hawks, 1959), aproxima-se do sangue gotejando na caneca de cerveja durante uma cena em que os protagonistas confrontam um bando de caubóis enquanto procuram por um bandido que se escondeu em algum lugar do saloon onde a sequência acontece: até então, a câmera se movera seguindo as demandas dos atores; naquele momento em particular, ela ganha a autonomia de, embora correspondendo a uma percepção da personagem de Dean Martin, mover-se "por conta própria" com o objetivo de sublinhar e estilizar para o espectador o detalhe revelador da cena, isto é, as gotas de sangue - a "mancha", poderíamos muito bem dizer - pingando e se diluindo na cerveja. É quase um plano hitchcockiano em pleno universo hawksiano.

${ }^{103}$ Narboni, art. cit., p. 34.
} 
visível, como faz a personagem de Cary Grant na cena mais famosa de Intriga internacional, em que, em situação de espera, de pura expectativa, passeia os olhos pelo espaço e observa os elementos a seu redor - a estrada, o milharal, o ônibus, o avião ao longe, a fumaça no céu como um conjunto de presságios, de hieróglifos, de mensagens secretas a serem decodificadas. A qualidade abstrata da locação - planície vazia no meio do nada - incita o olhar a considerar cada evento esparso como sinal relevante, a enxergar em cada elemento que surge no campo uma charada visual a ser decifrada.

Hitchcock sempre declarou seu desprezo pela lógica de engrenagem narrativa das ficções detetivescas do tipo whodunit, que mobilizam a atividade racional numa enquete policial que visa tão somente à descoberta do autor do crime e à sua resolução. A coleta das provas, a montagem do quebra-cabeça investigativo e o desmascaramento do assassino "concluem o movimento de um pensamento controlado"104, reestabilizado após o desenlace do caso, reconciliado com a verdade e a justiça, motivado pelo senso de dever cumprido ou pela devoção estoica ao trabalho (valor comumente retratado no cinema policial, mesmo quando o herói abusa da autoridade, recorre a métodos escusos e está longe, portanto, de ser um exemplo de profissional virtuoso ou "correto"). Não é disso, de uma trama resolutiva e conciliatória, que trata a ficção hitchcockiana, cujas personagens agem "sob o efeito de uma paixão e de um desejo incontroláveis, mediante os quais a investigação do objeto e sua possessão se confundem". ${ }^{105}$ Os filmes de Hitchcock são "máquinas que compelem o pensamento a pensar segundo movimentos, trajetos e velocidades tornadas elas próprias visíveis". ${ }^{106} \mathrm{O}$ protagonista hitchcockiano típico é aquele que, como Cary Grant em Intriga internacional ou James Stewart em Janela indiscreta, está constantemente imerso em articulações, em suspeitas, não em razão de um compromisso com a revelação da verdade, e sim porque foi contaminado por uma febre de interpretação e decifração, por uma ânsia de visão e conhecimento. Os signos sensíveis do mundo atiçam seu pensamento, não o deixam descansar: "Janela indiscreta não descreve apenas a história de uma paixão voyeurística nem de uma projeção de desejos, mas a de uma máquina interpretativa, máquina de associação que pouco a pouco, perante nossos olhos, foge ao controle de um sujeito para desembocar na construção de um universo em que a interpretação se torna tudo e o real, quase nada". ${ }^{107} \mathrm{E}$ menos um thriller de mistério do que uma aventura epistemológica.

\footnotetext{
${ }^{104}$ Ibid., p. 32.

105 Ibid.

${ }^{106}$ Ibid., p. 31.

${ }^{107}$ Ibid., pp. 31-32.
} 
A "signalética" do suspense hitchcockiano prescreve uma leitura exaustiva do mundo a fim de descobrir segredos, de perscrutar os sintomas do mal subjacente às primeiras aparências, de "fazer aflorar à superfície o que se dispõe em camadas na profundidade". 108 Para tanto, requer um olhar que "avança nas dimensões do oculto", que é analítico, sensível à diferença, que está acostumado à comparação e à combinação, que sabe "apreender as cores, as variações, as ínfimas anomalias, mantendo-se sempre à espreita do desviante"109; que possui, em suma, curioso parentesco com aquele olhar clínico formado no começo do século XIX a partir do que Foucault descreve como uma mutação do olhar propriamente dito - o qual implica um campo de leitura e visibilidade aberto e exige do observador uma atitude comparável à paciência da escuta - para o golpe de vista - "que não é mais o ouvido atento para uma linguagem; é o índice que apalpa as profundezas". 110

O golpe de vista não sobrevoa um campo: atinge um ponto, que tem o privilégio de ser o ponto central ou decisivo; o olhar é indefinidamente modulado, o golpe de vista vai direto: escolhe, e a linha que traça sem interrupção opera, em um instante, a divisão do essencial; vai, portanto, além do que vê; as formas imediatas do sensível não o enganam porque sabe atravessá-las; ele é por essência desmistificador. Se atinge algo, em sua retidão violenta, é para quebrar, levantar, retirar a aparência. ${ }^{111}$

Essa descrição do "golpe de vista" define uma forma de atuação do olhar e de desvelamento do visível que coincide com o modus operandi do plano hitchcockiano: depois de estudar o espaço e estabelecer o plano de clivagem, o olho enquadra e centraliza com agudez e precisão o ponto nevrálgico em que se localiza a "mancha", a nódoa, o elemento suspeito, o foco de irradiação (da doença, do crime). O estilo de Hitchcock, em analogia com a prática clínica, reclama um olhar que "vai além do que vê", olhar "ferino" que desrespeita os limites impostos pelas aparências imediatas e "queima as coisas até sua extrema verdade". 112

"O detetive faz o diagnóstico", o próprio Hitchcock já dizia: "Sua mestria se mede por sua sensibilidade às anomalias, sua capacidade de observar os minúsculos detalhes negligenciados pelo operador". ${ }^{113}$ Mas, assim como a semiologia médica - ao realojar o saber clínico (antes atrelado a certo grau de fantasia e ilusão) na espessura concreta dos órgãos, nas

\footnotetext{
${ }^{108}$ M. Foucault, $O$ nascimento da clínica, $7^{\mathrm{a}}$ ed., Rio de Janeiro: Forense Universitária, 2011, p. 179.

${ }^{109}$ Ibid., p. 97.

${ }^{110}$ Ibid., p. 135.

111 Ibid., p. 134.

${ }_{112}$ Ibid., p. 132.

${ }^{113}$ A. Hitchcock, "Préface", in Cahiers du cinéma, no 39, outubro de 1954, p. 12.
} 
consistências tissulares, nas formas vistas e percebidas graças ao rigoroso método de observação da anatomopatologia - depara com uma nova opacidade (que não é mais a da pele ou da superfície externa do corpo), com um espaço “em que a visibilidade se torna espessa, se perturba, e em que o olhar se choca com massas obscuras, com volumes impenetráveis, com a pedra negra do corpo" ${ }^{114}$, assim também o plano hitchcockiano descobre que, no extremo da visibilidade, no ponto de iminente fusão entre o ver e o saber, justamente aí o nó se desata, reencontra-se o imponderável e inescrutável; a noite retorna, o mundo se cala novamente, a cortina se fecha - a mesma cortina que se abrira aos poucos no primeiro plano de Janela indiscreta. Por um lado, essa opacidade interrompe e limita a visão; por outro, oferece-se como "uma tela de projeção para o oculto", para o que só pode ser fixado na escuridão do não visto e do não percebido, do que se passa atrás da linha do visível: “A verdade que, por direito de natureza, é feita para o olho, lhe é arrebatada, mas logo sub-repticiamente revelada por aquilo que procura esquivá-lo". ${ }^{115}$

O mistério de Madeleine em Vertigo começa aí, nesse retorno da opacidade que se pensava ter vencido com um "golpe de vista".

\footnotetext{
${ }^{114}$ M. Foucault, O nascimento da clínica, p. 130.

${ }^{115}$ Ibid., p. 183.
} 


\section{II.}

\section{A teoria artística em Vertigo}

\section{Espelho}

"Uma loira sem sutiã, perseguida por um detetive que sofre de vertigem, trará a prova de que o cinema é a infância da arte". É mais ou menos assim que Godard resume Vertigo em um dos episódios de Histoire(s) du cinéma.

Podemos ampliar um pouco: o detetive em questão é Scottie (James Stewart), expolicial afastado do ofício por conta de um episódio de acrofobia que custou a vida de um colega (conforme mostrado no prólogo do filme); a loira se chama Madeleine (Kim Novak), casada com Gavin Elster, antigo companheiro de faculdade de Scottie. Embora não se vejam há muito tempo, Gavin convoca Scottie para uma conversa e, sob o pretexto de que precisa de alguém de confiança, revela que o objetivo do reencontro é contratá-lo como detetive. Gavin quer investigar o estranho comportamento de sua jovem esposa, que ele acredita estar desenvolvendo tendências suicidas, talvez sob a influência de algum espírito maligno. Após certa relutância e ceticismo, Scottie aceita a proposta e passa a perseguir Madeleine pelas curvas e ladeiras de São Francisco. Ele logo descobre que a bela e misteriosa loira tem fixação por Carlotta Valdez, mulher do século XIX cujo retrato se acha num museu. O detetive a observa enquanto ela fica lá sentada em silêncio, hipnotizada pelo quadro. Ele nota que Madeleine imita o penteado (um coque em espiral) e a pose de Carlotta, além de trazer um buquê de flores idêntico ao da figura no retrato. Com a ajuda de um livreiro recomendado por sua fiel amiga Midge (Barbara Bel Geddes), Scottie conhece um pouco mais sobre os antepassados de Carlotta e, por extensão, sobre a formação histórica da cidade de São Francisco. Carlotta, como ele virá a descobrir, é uma ancestral de Madeleine que foi criada numa missão católica construída por colonizadores espanhóis. Ela cometeu suicídio em 1857 (o filme é rodado em 1957) depois de ser abandonada pelo amante e ter seu filho levado embora (essa tragédia delineia um fundo histórico-político para as relações de poder e de 
dominação homem-mulher situadas na base da trama). Na medida em que a investigação avança, Scottie se sente cada vez mais atraído por Madeleine, que parece ter, por seu turno, irresistível fascínio pela morte, como fica comprovado na cena em que ela tenta se matar mergulhando na Baía de São Francisco. O detetive a salva do afogamento e a leva para casa. Ela acorda do desmaio e eles conversam. No dia seguinte, passeiam juntos num parque repleto de sequoias. Tornam-se amantes. No meio da madrugada, ela chega à casa de Scottie aflita por conta de um pesadelo em que uma força inconsciente a impelia na direção do abismo. Disposto a curá-la dos fantasmas do passado, Scottie vai com ela até a antiga missão espanhola, situada a alguns quilômetros de São Francisco, pois lá parece residir a origem dos sonhos e lembranças que a atormentam. Ele crê haver uma explicação racional para tudo, e almeja encontrá-la. No estábulo localizado na missão, as peças do mistério começam a se encaixar na cabeça de Scottie, que se mostra otimista. Os dois se beijam apaixonadamente. Mas ela interrompe o beijo e corre para a igreja, subindo até o campanário. Paralisado pelo medo de altura, Scottie não consegue alcançá-la. Resta-lhe ouvir um grito e ver o corpo da moça se estatelando.

Absolvido no tribunal, mas arrasado psicologicamente, traumatizado, transtornado pelo peso moral da culpa, Scottie é internado numa clínica. Midge tenta consolá-lo, em vão. Depois que recebe alta, ele vaga pelas ruas e revisita os lugares onde esteve com Madeleine, sempre enxergando sua reaparição (mas, toda vez que se aproxima, percebe que a confundiu com outra mulher: a miragem se dissipa). Um belo dia, parado em frente à loja de flores em que outrora assistira a Madeleine comprando um buquê, avista uma mulher quase idêntica à morta. O corte e a cor do cabelo são diferentes, assim como as vestimentas. As maneiras, o linguajar e o jeito de caminhar também não têm mais a aura elegante de Madeleine. De resto, é tudo inacreditavelmente parecido. Scottie a segue até o hotel barato em que ela mora. Conversam. Ela se chama Judy Barton e trabalha como vendedora numa loja qualquer. Ele a convence a sair para jantar. Ela pede um tempo para se arrumar. Num flashback narrado do ponto de vista de Judy, ficamos sabendo que ela e Madeleine são a mesma pessoa. Gavin armara o plano perfeito para se livrar da esposa forjando a cena de um suicídio cuja testemunha ideal seria Scottie: a acrofobia o impediria de subir à torre do sino, de onde a verdadeira Madeleine, já morta, seria jogada. O plano deu certo, e Scottie testemunhou a queda de uma posição em que o assassinato se passou por suicídio. Só uma coisa, segundo Judy, não ocorreu conforme o planejado: ela se apaixonou de verdade por Scottie. Tudo isso é explicado numa carta endereçada ao ex-policial. Mas ela desiste de entregá-la, movida pela esperança de que talvez Scottie possa vir a gostar dela por aquilo que verdadeiramente é. 
Saem para jantar. Scottie a persuade a faltar ao trabalho no dia seguinte, para que fiquem juntos. Aos poucos, tenta moldá-la à imagem de Madeleine. Veste-a com o tailleur cinza, muda a cor do cabelo, insiste para que faça o carrapito em espiral; transforma-a, enfim, numa cópia fiel da morta. Ela se submete, não sem antes resistir. Consumada a metamorfose, Scottie abraça e beija Judy/Madeleine, numa atmosfera delirante. Na cena posterior, tudo parece bem, ela se arruma, eles se preparam para ir jantar fora. Até que um detalhe (o colar que ela está usando, o mesmo visto no retrato de Carlotta) desencadeia a reviravolta: Scottie começa a entender que fora vítima de um complô, e que a mulher por quem se apaixonara era Judy disfarçada de Madeleine. Ferido em seu orgulho, ele se dirige à missão espanhola em plena noite, e arrasta Judy escadaria acima rumo à torre da igreja, sem dar ouvidos às explicações dela. Vencendo a acrofobia, consegue chegar ao campanário. Lá, Judy tenta acalmá-lo e reconquistá-lo. "Por favor, Scottie, você me amava", suplica. "Tarde demais. Não há como trazê-la de volta", ele retruca. Quando finalmente esboçam uma reconciliação e se beijam, uma sombra se aproxima. Assustada, Judy recua e cai da torre. Scottie dá um passo à frente e encara o vazio. "Que Deus tenha piedade".

Em linhas gerais, é essa a história contada por Hitchcock em Um corpo que cai, fazendo "coincidir o relato de uma maquinação intelectual com a encenação de um fascínio visual", 1

Difícil, perante filme tão rico em possibilidades de análise, tentar condensá-lo num único quadro/composição. Mas arrisco dizer que há um plano de Vertigo que parece ser sua imagem-síntese, e tal plano não consiste em nenhuma das aparições daquela espiral que, para usar a expressão de Rohmer (retomada por Douchet), é a "figura-mãe" de Vertigo, seu "postulado formal", o motivo plástico que traduz sua ideia diretriz. ${ }^{2} \mathrm{O}$ plano que considero a cristalização do dispositivo visual do filme é de outra natureza, e ocorre no meio daquela cena em que Scottie observa Madeleine pela porta entreaberta nos fundos de uma loja de flores. Ela havia entrado na loja de forma nada convencional, parando o carro num beco vazio e utilizando a porta dos fundos, provavelmente reservada a funcionários e a manobras de carga e descarga. Scottie vai atrás dela e, cautelosamente, abre - somente o suficiente para ter um bom campo de visão - a porta que liga a sombria área de serviço ao interior da loja. Em seu casulo de voyeur, ele vê Madeleine falar algo com a vendedora, que sai de quadro (mais tarde, ela voltará com o buquê de flores que, no decorrer da trama, constataremos ser igual ao que

\footnotetext{
${ }^{1}$ Jacques Rancière, As distâncias do cinema, Rio de Janeiro: Contraponto, 2012, p. 21.

${ }^{2}$ Cf. Chabrol e Rohmer, op. cit., p. 14; Douchet, op. cit., pp. 14-15.
} 
Carlotta segura no retrato exposto no museu). No plano crucial a que me refiro, Madeleine aparece refletida num espelho; Scottie, escondido no compartimento obscuro, tem mais de metade do rosto obstruído pela porta e coberto pela sombra (só o seu olho se destaca). O plano dura cerca de cinco segundos e acontece com pouco mais de vinte minutos de filme, na primeira das longas sequências silenciosas de perseguição a Madeleine.

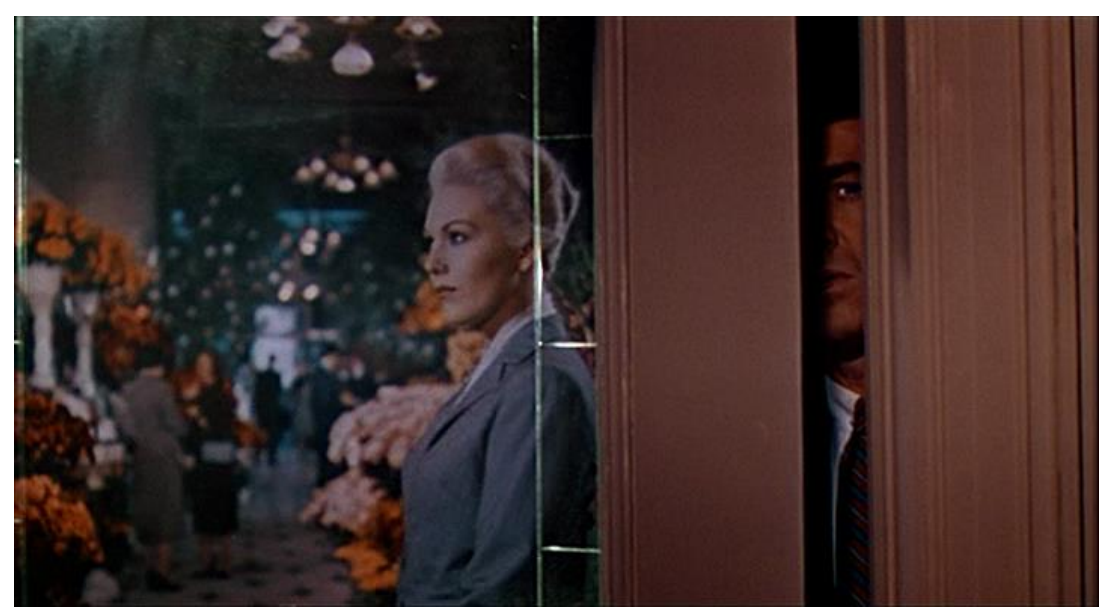

A personagem de Kim Novak, centro luminoso do espaço visual da cena, aproxima-se lenta e sensualmente do espelho. Ela oferece seu perfil ao olhar de Scottie e, em seguida, retorna à posição anterior. Sua movimentação é muito parecida com a de uma modelo num desfile; tudo se dá como espetáculo hipnótico para o olhar fascinado de Scottie. A música de Bernard Herrmann intensifica o clima de mistério e sedução.

Há um ardiloso sistema visual na composição do plano: Scottie, ao olhar para Madeleine, intercepta a câmera - e, por conseguinte, o espectador (que acaba sendo o grande alvo desse olhar). Madeleine não se faz presente no quadro senão de maneira indireta, pois o que o espectador vê não é exatamente ela, mas sua imagem refletida no espelho - ela está, na verdade, ausente do plano, ou melhor, presente-ausente (personificando, assim, a própria natureza da imagem cinematográfica). O espelho traz ao campo algo que, do contrário, ficaria fora de campo; restitui a visibilidade ao que se furtaria ao nosso olhar. O ponto fixado por Scottie é a convergência de, no mínimo, duas instâncias que se ligam na dinâmica de representação acionada pelo enquadramento: Madeleine, a "modelo" que finge não se reconhecer vigiada, mas que joga com o olhar do outro, e o espectador, frontalmente atingido pelo olhar de Scottie e incluído, desse modo, na rede de trocas visuais e simbólicas (talvez também devêssemos inserir no esquema o autor, Hitchcock, que, atrás da câmera, organiza o 
quadro e dirige a cena). Monta-se, assim, um intrincado circuito envolvendo nossa visão e a de Scottie. É como se Hitchcock aglutinasse num só enquadramento os dois componentes de um raccord de ponto de vista: em vez de assistirmos a dois planos diferentes justapostos na montagem, um mostrando o olhar de Scottie e o outro o objeto desse olhar, vemos uma única composição que já contém ambos os elementos (com o detalhe de que o "contraplano" não é o conteúdo imediato da visão de Scottie, mas seu rebatimento no espelho - há um desvio), produzindo um efeito de split-screen que cumpre o papel de sutura e, ao mesmo tempo, fratura das relações espaciais e dos investimentos subjetivos mantidos pelo jogo de olhares. Essa divisão interna do quadro nada mais é que "a esquize contida em todo desejo em que o outro é tanto objeto quanto sujeito",3, como é o caso em Vertigo, ao menos na sua primeira metade (Madeleine é objeto do olhar de Scottie? Ou sujeito que age sobre ele? Ou as duas coisas simultaneamente?). Por um lado, o dispositivo reforça o mecanismo de identificação e a cumplicidade voyeurística entre espectador e personagem; por outro, divorcia seus olhares, já que o espectador, nesse plano, enxerga além de Scottie, percebendo Madeleine como o que ela é de fato: um reflexo enganador, um falso semblante. Espectador e personagem assistem a um mesmo espetáculo, mas em versões diferentes.

O plano opera uma conversão óptica de Madeleine, que, em seu jogo ambivalente de aproximação-distanciamento, vai de corpo a ícone. A superfície cristalina do espelho potencializa sua radiação de energia luminosa, sublinhando sua aura enigmática, sua beleza quase irreal. A cena representa, nesse misto de idealização fetichista e veneração religiosa, um dos momentos de culminância do encanto visual experimentado por Scottie. O filme construíra, até ali, uma progressão: na primeira vez em que viu Madeleine, na clássica cena no Ernie's, ela estava, a princípio, de costas, no fundo do cenário, realçada pelo insinuante decote de seu vestido; depois, caminhou na direção da saída do restaurante e, ao passar por Scottie, parou ao lado dele, permanecendo de perfil; eles não trocaram olhares, fingiram não perceber a presença um do outro - mais que isso: deliberadamente evitaram-se, cada um por um motivo diferente (ele para manter sua qualidade de observador "invisível”, ela para seguir o script da cena planejada e ensaiada). Scottie, tendo de diluir-se no ambiente, não pôde ver o rosto de Madeleine no momento em que ela parou ao seu lado, cabendo-lhe então imaginá-lo, idealizá-lo. Depois, na primeira cena de perseguição pelas ruas, Scottie só a viu a distância, de dentro do seu carro, naquelas lentas baladas contemplativas e circulares. Agora, na loja de

\footnotetext{
${ }^{3}$ Philippe Arnaud, "L'engendrement des images: Vertigo d'Alfred Hitchcock", in Les paupières du visible, Yellow Now, 2001, p. 177.
} 
flores, tem a oportunidade de vê-la de perto (com a vantagem de não ser visto). Essa visão, no entanto, já chega insuflada por todo o investimento fantasmático das "visões" anteriores. Se Hitchcock recorre ao jogo de espelho e à valorização maneirista do efeito-quadro, é menos por virtuosismo estético do que para melhor enunciar a fantasmatização do campo visual de Scottie. O caprichado enquadramento, na mesma medida em que avizinha o olhar do detetive à imagem de Madeleine, separa-os visualmente, coloca-os em dimensões distintas. Ainda que plenamente justificável em termos de verossimilhança óptica e coerência lógica na disposição dos atores no cenário, o reflexo de Madeleine surge, de certo modo, como visão subjetiva de Scottie, projeção mental da ilusão romântica de que ele já se demonstra cativo. Ou, se pensarmos em termos não de romantismo, mas dos aspectos intrinsecamente "pornográficos" da experiência do cinema (que Hitchcock explora a tal ponto que "até mesmo a afirmação do amor romântico ganha um ar de perversão"4), a imagem no espelho aparece como o desenho invertido do desejo, o disfarce exterior de um pensamento obsceno. ${ }^{5}$

A cena causa uma suspensão provisória do relato romanesco para que surja um momento de pura atração. De certo modo, a situação de Scottie nesse plano é a de um espectador do cinetoscópio: ele põe o olho no visor e assiste a uma pequena performance que lhe é destinada com exclusividade. Há um elemento perverso, obsceno, mas há também um simples desejo de fruição do olhar, de ver não importa o quê. Daí sua suscetibilidade, sua posição de presa fácil. Antecipando-se à própria conflagração da intriga, o plano insinua a maquinação ilusionista em que Scottie está se deixando envolver. Afinal de contas, o que ele vê nessa cena não é Madeleine, mas Judy interpretando Madeleine interpretando Carlotta. Madeleine não passa de uma ilusão fabricada sob medida para a captura do seu olhar. Refratando o ponto de vista de Scottie por meio do reflexo de Kim Novak no espelho, Hitchcock já formula visualmente a sobreposição de simulacros que o protagonista, todavia, só descobrirá no final do filme. A mise en abyme da representação está expressa na própria conformação do quadro. O efeito metafigurativo do espelho evidencia o fato de que Scottie se apaixona não por uma mulher, mas por uma imagem, ou melhor, pela imitação de uma imagem, a cópia da cópia - cujo original nos é desconhecido. “A imagem no espelho provoca

\footnotetext{
${ }^{4}$ R. Allen, op. cit., p. 20.

${ }^{5}$ Talvez essa cena de fascinação seja apenas o substituto eufêmico de uma cena de masturbação: "Fascinus é o deus latino guardião da ereção do sexo masculino", lembra-nos Philippe Arnaud (op. cit., p. 178). Hitchcock tornaria essa situação mais explícita em Psicose, na cena em que Norman Bates, através de um buraco secreto na parede, observa Marion Crane se despindo no quarto do hotel - vale notar que o buraco ficava escondido por um quadro pendurado na parede (que é mostrado muito fugidiamente; o estilo remete ao barroco do século XVII, e a cena bíblica representada é uma variação em torno do episódio conhecido como "Susana e os velhos", basicamente uma história de voyeurismo e estupro: dois homens, após bisbilhotar Susana enquanto ela se despe e se prepara para tomar banho, tentam violentá-la).
} 
uma espécie de vertigem. Dividida, duplicada, multiplicada, ela nos faz crer que o visível é apenas um sonho muito complicado, um pesadelo aprofundado: atrás da imagem, outra imagem, e assim infinitamente". ${ }^{6}$ No quadro-dispositivo concebido por Hitchcock, o espelho aponta Madeleine como emanação espectral de algo cuja fonte é inacessível, quiçá inexistente. Não há um fim para a imagem de Madeleine, pois, desprovida de origem (logo, de destino), seu trajeto se dá no intermundo das imagens sem referentes no real, puras aparências que se autorreproduzem até a exaustão. Se a imitação de Judy convence, é em parte porque o original não existe (ou, se existe, permanece oculto). A função do espelho nesse plano, entre outras coisas, é justamente acusar a ausência fundamental de Madeleine - ausência que é a causa mesma da atração que ela exerce sobre Scottie, e que é a própria definição da vertigem: a aspiração do olhar pelo vazio. Hitchcock instala, portanto, "uma visão e uma interpretação pervertidas da imagem transformada em ídolo por um olhar que esqueceu que está vendo através do espelho". 7 Por ignorar que o objeto de sua contemplação nunca se mostra diretamente, mas sempre de viés, mediante reflexos, sombras, inversões, Scottie cai na armadilha óptica plantada por Gavin Elster.

A tradição cristã, conforme Agnès Minazzoli observa, atribui ao espelho "o valor negativo de todas as imperfeições e de todas as distorções através das quais a realidade das coisas nos chega". ${ }^{8}$ Cioso dessa tradição, Hitchcock filma o reflexo de Madeleine no espelho como um índice de erro, de defasagem perceptiva, de refração consentida. Mas ele não apresenta essa imagem somente como um engano do olhar: ele a encena, também, como uma aparição, no sentido religioso da palavra, ou ainda, como uma Anunciação. Aqui, porém, há uma inversão dos papéis e dos sentidos: não é Maria quem diz "sim" após ouvir a mensagem proferida pelo Anjo, permitindo que o Amor se encarne; é Scottie, essa espécie de anjo caído, quem "escuta" Madeleine e diz "sim" ao amor que os conduzirá não à luz e à graça, mas às trevas e ao precipício. Tal como nas representações pictóricas da Anunciação, Hitchcock organiza o quadro de modo a tornar sensível uma fronteira, uma demarcação de dois domínios de visibilidade que não se comunicam senão indireta e provisoriamente: “A lógica figurativa da Anunciação é a copresença de duas entidades ontologicamente heterogêneas, às custas de um trabalho de costura paradoxal do espaço visível". 9

\footnotetext{
${ }^{6}$ Agnès Minazzoli, La première ombre: Réflexion sur le miroir et la pensée, Paris: Les Éditions de Minuit, 1990, p. 174.

${ }^{7}$ Ibid., p. 132.

${ }^{8}$ Ibid., p. 47.

${ }^{9}$ J. Aumont, “Annonciations”, in Matière d'images, Paris: Éditions Images Modernes, 2005, p. 72.
} 
Ao romper a homogeneidade do quadro, o espelho provoca um questionamento interno da imagem, em cujo espaço ele escava uma nova profundidade, quer dizer, uma nova ilusão de profundidade, que tem por corolário a desestabilização do visível: a transparência se troca por reflexividade, dando início a uma cadeia ilimitada de visões e di-visões. O que o espelho liso e reluzente escolhido por Hitchcock interroga é menos a forma das coisas (não se trata, afinal, de um espelho deformante) do que o caminho entre elas e o olhar. Ele é como um hiato que se interpõe nesse caminho, um intervalo por onde se infiltra o enigma que está na origem da fascinação de Scottie.

Não deixa de haver aí uma atualização da vocação hermenêutica do espelho, a qual se pode verificar, sobretudo, na história da pintura compreendida entre o Quattrocento e o barroco do século XVII, quando recorrentemente se lhe consignou a tarefa de desenvolver nos quadros uma dimensão reflexiva. O espelho, comumente situado no centro nevrálgico da imagem, acumulava em sua "água" as questões relativas ao tipo de saber - e de ilusão - que a visão estruturada a partir do Renascimento tornava possível. Na pintura holandesa, assim como no caso já abundantemente estudado de As meninas de Velásquez, o espelho se oferece como sede de figurações nebulosas e de especulações perspectivas que transformam o quadro numa autorreflexão sobre as técnicas e os paradigmas da representação pictórica. $\mathrm{O}$ espelho concede aos artistas a chance de reduplicar o conteúdo visual da pintura recompondo-o, reconstruindo-o num quadro-dentro-do-quadro que funciona não só como "metáfora do dispositivo perspectivo", mas também como "um modelo de vigilância e um espaço de questionamento". ${ }^{10}$ Velásquez, em As meninas, retoma de alguns mestres flamengos do século $\mathrm{XV}$ a estratégia visual de engastar o espelho precisamente no ponto de fuga da composição (o exemplo mais conhecido é $O$ casal Arnolfini, de Jan van Eyck, que Hubert Damisch coteja com As meninas na parte final de sua valiosa investigação arqueológica sobre a origem da perspectiva $^{11}$ ). Mas o pintor espanhol reinventa e ressignifica essa estratégia de tal modo que, de acordo com a célebre análise de Michel Foucault, ao invés de simplesmente fazer ver "a mesma coisa que na primeira instância do quadro, porém decomposta e recomposta segundo uma outra lei" ${ }^{\prime 2}$, dedica-se, antes, a revelar as próprias condições de possibilidade da representação clássica.

O espelho como metáfora da pintura e como sinônimo da mimesis não é uma novidade do século XVII: já havia toda uma tradição artística de longa data que identificava a imagem

\footnotetext{
${ }^{10}$ A. Minazzoli, op. cit., p. 139.

${ }^{11}$ H. Damisch, L'origine de la perspective, Paris: Flammarion, 1987, 1993, pp. 451-452.

${ }^{12}$ M. Foucault, As palavras e as coisas, p. 9.
} 
pictórica europeia à imagem especular, designando os quadros como "espelhos da realidade". ${ }^{13}$ Numa cultura fortemente marcada pelo critério da semelhança, era natural que o espelho se tornasse não apenas uma espécie de emblema do paradigma mimético e do trabalho figurativo que o acompanha, mas, sobretudo, uma ferramenta efetiva das máquinas de visão construídas com tal finalidade (a exemplo do dispositivo perspectivo de Brunelleschi). A novidade trazida pela pintura do século XVII, portanto, não reside em usar o espelho como metáfora e ferramenta da mimesis, mas em anexar à imagem especular "conotações suplementares" que fazem dela um "instrumento semiótico". ${ }^{14}$ Nos quadros de pintores como Velásquez, Vermeer, Nicolaes Maes e Ludolf de Jongh, a imagem no espelho cria um duplo da representação, um segundo conteúdo figurativo, quiçá uma segunda força de figuração que nos obriga a reavaliar o restante do quadro, a vê-lo por outro ângulo, a duvidar de tudo o que ele dá a ver. O espelho é um artefato que permite à imagem se pensar e se afirmar como tal, isto é, tomar consciência de si mesma como superfície de representação, como arranjo plástico concebido a partir de determinado ponto de vista e segundo certos critérios de formação e significação. Apesar de manter uma aparência convencional, o quadro com espelho se prova, nas entrelinhas, um autêntico objeto teórico, uma investigação sobre as potências e os limites de um sistema de representação - a saber, o sistema das formas pictóricas desenvolvidas no Renascimento - já considerado, àquela altura, como clássico, ou seja, "como depósito inesgotável de soluções e de achados exemplares". 15

No plano do espelho em Vertigo, Hitchcock também faz do quadro um dispositivo epistemológico, uma reabertura ou dobra do visível que, para além de um "encantamento do duplo"16, dá à imagem a possibilidade de conter sua própria exegese, de figurar sua própria decifração teórica. Assim como, no período barroco subsequente ao classicismo renascentista, o espelho aparece na pintura como "dispositivo de reflexão sobre a mise en scène pictórica"17, em Vertigo, que pertence a um momento de transição na história do cinema, na charneira entre o cinema clássico e o moderno, o espelho aciona uma série de hipóteses plásticas que questionam a natureza do espaço visível e dos corpos ali inscritos, suscitando uma meditação - mais ou menos assumida como discurso meta-artístico - sobre os princípios estruturais da mise en scène cinematográfica (a escolha do ponto de vista, a organização da cena no espaço, a distribuição dos corpos dentro e fora de quadro, a geometria dos olhares etc.).

\footnotetext{
${ }^{13}$ Cf. Victor I. Stoichita, L'instauration du tableau: Métapeinture à l'aube des temps modernes, Genebra: Droz, 1999 , p. 250.

14 Ibid.

${ }^{15}$ Ibid., p. 75.

${ }^{16}$ M. Foucault, As palavras e as coisas, p. 8.

${ }^{17}$ J. Aumont, "Spéculations", in Matières d'images, redux, Paris: Éditions de la Différence, 2009, p. 87.
} 
Analisando esse mesmo plano de Vertigo, e reconhecendo nele a mesma importância que lhe atribuo na estruturação visual das ideias do filme, Julien Achemchame igualmente identifica no enquadramento de Hitchcock "um discurso reflexivo sobre a forma cinematográfica". ${ }^{18}$ Aquela porta entreaberta por Scottie, na qual está afixado o espelho com a “imagem inapreensível” de Madeleine, conduziria o espectador "rumo a um segredo, uma revelação íntima sobre a essência do cinema"19.

Madeleine, essa personagem fascinante e inapreensível, irreal e fantasmática, revela o segredo da essência do cinema. Aparentemente possuída por uma morta, atriz modelada e manipulada, Madeleine não se deixa apreender pelo olhar. [...] ela é a imagem projetada e visível de uma ausência [...] ela encarna magicamente a ontologia do corpo cinematográfico. Morta antes de ter nascido, ela pode assim retornar indefinidamente, sempre diferente e idêntica. Ela pode imprimir melhor o tempo cinefílico da presença. Pois é isso o que acontece com a personagem de Madeleine, e mais ainda nesse plano do espelho: passamos da representação à presença. ${ }^{20}$

Se o espelho permite que passemos da representação à presença, ou seja, que recuemos à primeira imagem, à imagem ainda não re-presentada, é porque seu reflexo, $a$ priori, não é uma representação, não é um signo, mas um acontecimento "natural", uma consequência imediata da presença de algo ou de alguém diante de uma superfície bem polida. Diferentemente da imagem pictórica, a imagem no espelho depende da "copresença do representando e do representante" 21 ; tão $\log$ o o ser ou a coisa representada se afastem do espelho, sua imagem desaparece.

A mise en scène do espelho na pintura instaurava um paradoxo: "se o espelho é 'imagem' somente enquanto alguém (ou alguma coisa) se encontra diante dele, o espelho pintado, por sua vez, continua a refletir mesmo que o objeto desse reflexo já esteja há muito tempo "alhures". ${ }^{22}$ No cinema, tal paradoxo se dissipa, e a lógica se inverte: a imagem em movimento reforça o estatuto provisório e passageiro do reflexo no espelho. Num cenário com espelho(s), a movimentação dos atores, da câmera e/ou da própria superfície especular determina toda uma dinâmica de aparição e desaparição/reaparição das figuras, delineando um teatro de duplos que o metteur en scène criativo pode explorar a seu bel-prazer. O espelho torna a dialética presença-ausência, fundamental para o cinema, um componente ativo da imagem. Ao contrário da pintura, o cinema não engendra, pelo jogo do reflexo, a permanência

\footnotetext{
${ }^{18}$ J. Achemchame, "Essence du cinéma en miroir: regarder le désir en face", in Cinergon, no 19-20, 2010, p. 30.

${ }^{19}$ Ibid., p. 32.

${ }^{20}$ Ibid., p. 32-33.

${ }^{21}$ V. I. Stoichita, L'instauration du tableau, p. 249.

${ }^{22}$ Ibid., p. 263.
} 
de uma imagem que estava fadada a ser fugidia: ele antecipa a fuga dessa imagem, na mesma medida em que possibilita - e até promete - seu retorno (pois, dependendo do contexto óptico da cena, uma figura que sai de quadro pode muito bem ressurgir refletida no espelho). $\mathrm{O}$ espelho filmado, em resumo, tanto pode funcionar como um prolongamento do campo, aportando à imagem alguma coisa que, na ausência do espelho, não faria parte do espaço do quadro, quanto pode também mostrar por um novo ângulo algum elemento já contido no campo. O plano do reflexo de Madeleine na loja de flores pertence ao primeiro caso: a imagem especular atualiza um espaço exterior ao quadro, mas a ele contíguo; ela introduz no campo a presença atuante de um fora de campo, religando o visível ao seu campo cego. ${ }^{23}$

A importância do espelho no cinema é evidente, e sua história, tão antiga quanto a do próprio cinematógrafo. É possível "escrever uma história do cinema perseguindo de perto, em inúmeros filmes, em todos os lugares e em todas as épocas, a presença do espelho". ${ }^{24}$

Em razão de sua posição semioticamente complexa (entre a mimesis e a semiosis), os espelhos nos filmes são ambíguos, sugestivos, não raro perturbadores; eles comportam sempre uma zona de nebulosidade, um reflexo dúbio. O que aparece no espelho filmado, no fim das contas, "nunca é totalmente discernível do resto da imagem; é sempre um suplemento da imagem, que vem complicá-la e às vezes cindi-la". ${ }^{25}$ Some-se a isso um aspecto intrínseco do espelho, sua potência mágica primordial, que já alimentou tantas ficções de fantasmas e de duplos: por mais que reproduza o mundo visível forjando "um signo natural dotado da maior semelhança possível", ele inverte as coisas e comunica com o desconhecido (quem atravessa o espelho penetra num mundo parecido com o nosso, mas essencialmente estranho). Em vez de ser um agente de integração simbólica, um organizador da experiência óptica, o espelho, no cinema, é lugar da aporia e da dúvida ontológica.

\section{Retrato}

A cena na loja de flores não é a única em que Hitchcock joga com as propriedades evocativas do espelho. Outros planos de espelho ocorrem em Vertigo e são igualmente importantes para a sua compreensão. ${ }^{26} \mathrm{O}$ corpo de Judy em si mesmo pode ser visto, ao longo

\footnotetext{
${ }^{23}$ Cf. P. Dubois, O ato fotográfico e outros ensaios, $14^{\text {a }}$ ed., Campinas, SP: Papirus, 2012, pp. 196-199.

${ }^{24}$ Maxime Scheinfeigel, "Revenir dans les miroirs du cinéma", in Cinergon, no 19-20, 2010, p. 7.

${ }^{25}$ Aumont, Matières d'images, redux, p. 95.

${ }^{26}$ Chamaria atenção, em especial, para o plano em que Judy e Scottie têm seus perfis duplicados por um espelho na loja de roupa chique em que ele compra para ela o tailleur e o sapato iguais aos de Madeleine - a imagem
} 
do filme, como um "espelho de carne", um corpo-espelho que se oferece como suporte para a reflexão da imagem de Madeleine. Gavin e Scottie, na primeira e na segunda parte do filme, respectivamente, seriam os fabricantes desse espelho, talhando, lapidando, polindo a superfície do material até torná-la passível de refletir a luz e a imagem desejadas.

Mas a representação nunca é apenas a reduplicação maníaca do visível: ela é também a “evocação do escondido". ${ }^{27}$ Daí Madeleine fazer questão de posar de perfil para Scottie em diversas passagens do filme, provocando um efeito tomado de empréstimo à iconografia da face de Janus: o enigma atraente de uma metade oculta, eclipsada, não vista, quiçá de uma metade diabólica contrastante com o rosto angelical à mostra. ${ }^{28}$ "Se, em princípio, um plano frontal exibe confrontação, diálogo, troca, o perfil é puro espetáculo". ${ }^{29}$

Em sua análise de Vertigo, Dominique Païni informa que a palavra "perfil" vem do latim Filum, e joga com o duplo sentido do termo francês "filature", que pode significar tanto a ação de perseguir alguém quanto a de trabalhar os fios de uma matéria têxtil. Ele nota que as três sequências que terminam com Madeleine posando de perfil para o olhar de James Stewart (a do Ernie's, a do florista e a do cemitério com a lápide de Carlotta) “articulam-se ao longo de uma perseguição [filature] na qual Scottie tenta descobrir o mistério de Madeleine. Filum engendra bordado, contorno, desvio, desviar, fazer a volta, perfilar, desenhar os contornos". ${ }^{30}$ Enquanto persegue Madeleine em suas errâncias, idas e vindas, desvios e retornos, Scottie tece, inconscientemente, um desenho que se vai tornar mais nítido quando ele chegar ao museu: o retrato de Carlotta aparecerá, então, como a confirmação da figura que ele e Madeleine vinham traçando pelas ruas e pelos lugares visitados por ela ao longo de seu rito fúnebre de aproximação da morte. Carlotta é o passado desvaído guardado na perenidade da forma, a face fugidia da vida esculpida no cristal translúcido da morte. Ela é como as sequoias, as árvores gigantescas do parque que Madeleine visita num momento de melancolia: sobrevive ao tempo, atravessa os séculos, enquanto o corpo humano perece um pouco mais a cada dia. A Forma é imperecível e imutável (ainda que o suporte que a sustém se deteriore e se modifique, mas isso é já outra história), ao passo que os corpos surgem e desaparecem, passam e deixam de existir, não permanecem muito tempo num único e mesmo estado.

representa não só a remodelagem de Judy a partir da lembrança de Madeleine, como também a duplicação da personalidade de Scottie, que mostra um lado obscuro e cruel na sua empreitada obsessiva de recriação da mulher morta. Richard Allen destaca, a respeito dessa imagem, uma possível correlação entre Scottie e Judy como duplos um do outro (cf. Hitchcock's romantic irony, p. 195).

${ }^{27}$ P. Bonitzer, apud Jacques Jusselle, "Un rectangle nommé Ménines ou sage comme une image", in Champs visuels, $\mathrm{n}^{\circ} 12-13$, janeiro de 1999, p. 88.

${ }^{28}$ Ver R. Allen, op. cit., p. 193.

${ }^{29}$ Stoichita, O efeito Pigmalião: para uma antropologia histórica dos simulacros, Lisboa: KKYM, 2011, p. 206.

${ }^{30}$ Païni. "Le portrait". In: Le cinéma, un art moderne. Paris: Ed. Cahiers du Cinéma, 1997, p. 51. 
Somente no mundo das formas puras, aquele mundo habitado por Carlotta, tem-se o poder da permanência. Talvez seja isso o que Madeleine inveja em Carlotta: o fato de que ela permanecerá jovem e bela, de que não sofrerá a decrepitude dos anos (estaria Madeleine acometida por uma "síndrome de Dorian Gray"?).

Nos diversos filmes que usam um retrato como peça-chave de suas narrativas, a pintura quase que invariavelmente se coloca como imobilidade atemporal, em contraste com os seres que, movendo-se no espaço e na duração, traçam o arco de sua existência numa linha temporal finita.

O retrato é sempre o que fica, infalivelmente. Como se a particularidade da pintura no cinema consistisse em não sofrer as alterações do tempo, a imobilidade se tornando o índice da perenidade. [...] Ele [o retrato] viria, assim, realizar a fantasia de André Bazin de uma imagem embalsamante que impede o envelhecimento ou, no mínimo, a desaparição. O retrato é o que não se extingue, o que não pode desaparecer. [...] Sua impermeável permanência faz dele uma representação do Ideal, de seu mistério imponente, de seu inesgotável segredo. ${ }^{31}$

Como representante das "antigas imagens" (a pintura) e dos antigos entes (os ancestrais, as gerações pregressas, os heróis da História, os amores perdidos, os mortos), o retrato reclama a perseverança dos modelos artísticos e humanos do passado, convocando o espectador a crer nos poderes mágicos da representação - mesmo que somente para fins "práticos", de funcionamento do espetáculo, ou seja, sem crer realmente - e a ver a imagem pintada como moradia dos fantasmas e das projeções psíquicas mais arcaicas. Os retratos são "vetores do tempo passado". ${ }^{32}$ Opondo "o único contra o múltiplo, o imóvel contra o móvel, o antigo contra o moderno" ${ }^{, 33}$, o retrato traz uma dupla ideia de anterioridade e perenidade. Ele representa algo que é anterior não apenas ao filme e às personagens, mas ao próprio cinema: uma ancestralidade reverenciável e até mesmo temível, um peso da imagem que remete a uma época pré-cinematográfica. Entra em jogo uma certa imponência da obra de arte conservada e exposta como objeto único, singular, irreprodutível: “o retrato é, no cinema, a imagem antes de ela entrar na era de sua reprodutibilidade" ${ }^{34}$; ele é o signo ostentatório de um passado que projeta sua sombra no presente. É assim que o retrato aparece em Vertigo, em Rebecca (Hitchcock, 1940), em O fantasma apaixonado (The Ghost and Mrs. Muir, Joseph L. Mankiewicz, 1947), em L'aigle à deux têtes (Jean Cocteau, 1948).

\footnotetext{
${ }^{31}$ Marc Vernet, "Inextinguible regard", Iris, n. 14-15, outono de 1992, p. 7.

${ }^{32}$ Olivier Gallon, "Hitchcock en miroir", in Cinergon, n. 19-20, p. 71.

${ }^{33}$ M. Vernet, "Dictatures du pignoché: les fictions du portrait", Iris, n. 14-15, outono de 1992, p. 45.

${ }^{34}$ Ibid., p. 45.
} 
"Mas o que realmente impressiona", diz Marc Vernet, "é que o retrato figura uma personagem portadora do olhar, um olhar que, como raramente ocorre, pode se endereçar 'à câmera". ${ }^{35}$ Um tipo muito peculiar de olhar-câmera se observa nos filmes de retrato, a exemplo do olhar medusante de Carlotta numa das principais cenas de Vertigo:
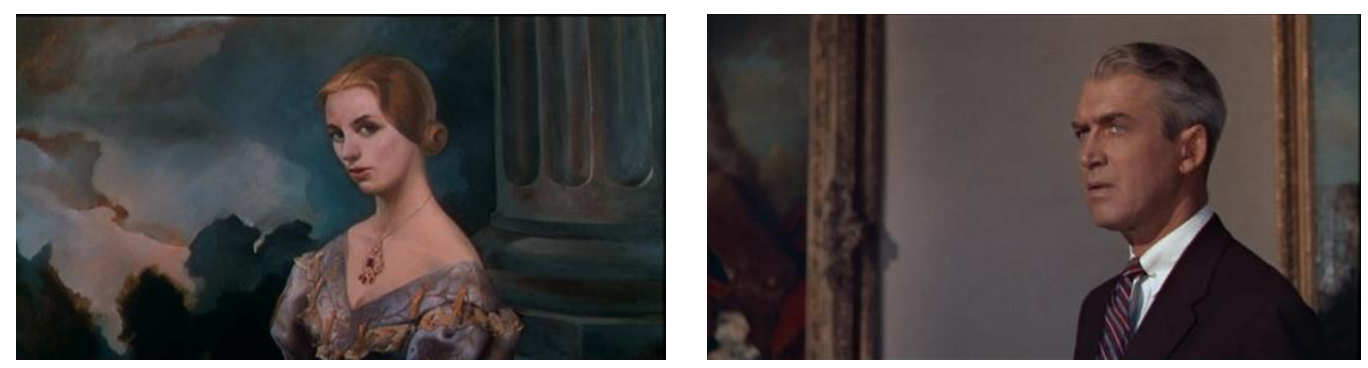

A imagem de Carlotta cativa infalivelmente o olhar de Scottie, que compara a pintura a Madeleine, a "cópia viva” (nessa inversão temporal da ordem da criação, pois é a figura no retrato, aqui, quem precede e determina a forma do corpo vivente), notando as intrigantes semelhanças, das quais se destacam o buquê de flores e o carrapito em espiral:
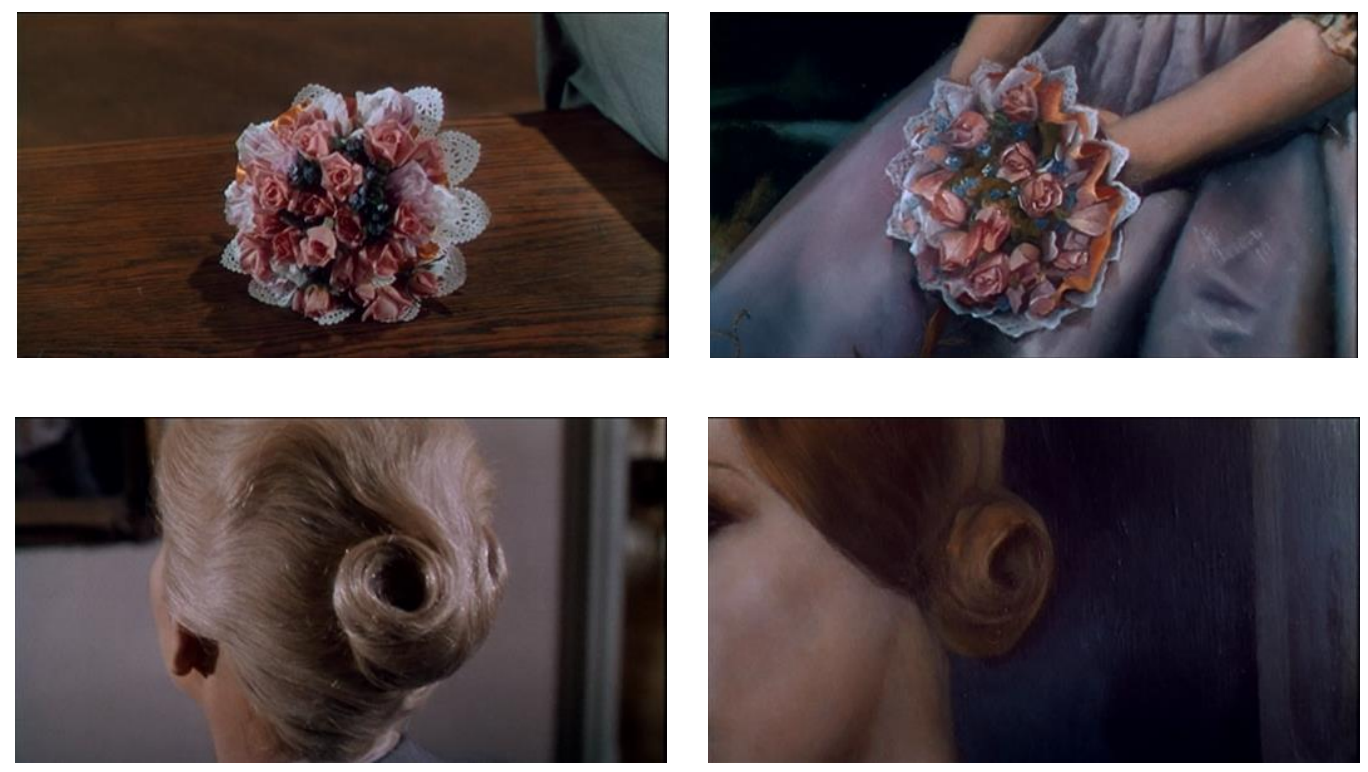

A ausência de contato visual que marcara todas as cenas anteriores entre Scottie e Madeleine começa a se desfazer: introduz-se entre eles um terceiro termo, o retrato, que intermediará esse diálogo mudo. Nesse espaço potencialmente erótico que é o museu, espaço

\footnotetext{
${ }^{35}$ Ibid., p. 47.
} 
repleto de formas sensuais, de nus, de campos de atração, de energias libidinais que exalam das obras, enfim, nesse ambiente em que "o interesse pela arte autoriza um perturbador exercício da pulsão escópica em estado puro" ${ }^{\text {- }}$ - mas que mantém uma aparência respeitosa e asséptica, enfatizada pela mise en scène de Hitchcock (estamos na mais perfeita lógica hitchcockiana da limpidez e da arrumação que mascaram a perversão e o erotismo) -, é como se Scottie, ao trocar olhares com o quadro de Carlotta, flertasse com Madeleine utilizando o caminho indireto de um reflexo num espelho (espelho este, contudo, que não reflete a luz, mas a absorve para si). Carlotta se impõe como a passagem obrigatória entre o olhar de Scottie e o rosto de Madeleine (que é vista somente de perfil e de costas nessa cena, nunca de frente).

O comportamento de Madeleine - hipnotizada, enfeitiçada por uma imagem que pouco a pouco toma posse de sua existência - coopta e contagia Scottie, que rapidamente adere ao teatro de olhares induzido não só por ela (e, implicitamente, por Gavin Elster), mas, sobretudo, pelo próprio dispositivo museológico. No plano que encerra essa sequência, a relação escópica estabelecida entre Scottie e Madeleine é resumida num enquadramento que forma um discurso figurativo sobre a atração do olhar pela imagem e a construção da situação do espectador no cinema:

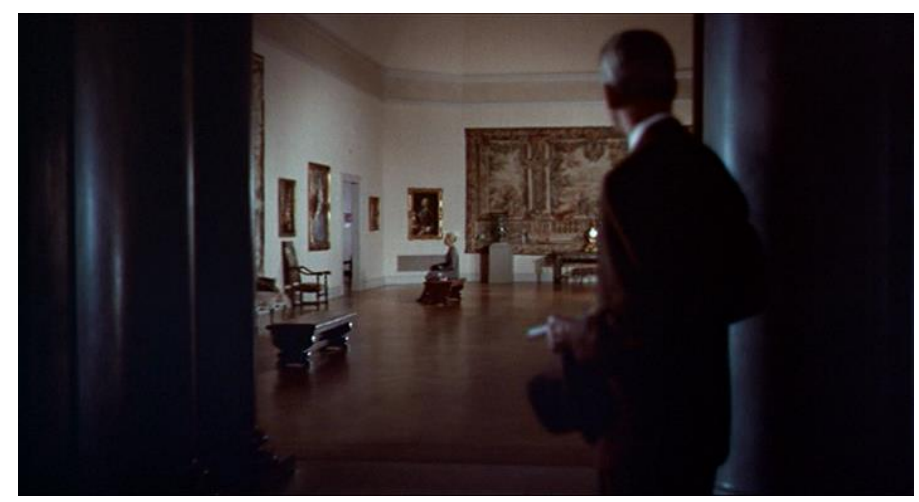

Madeleine lá consta como uma das imagens em exposição no museu, uma peça em destaque no meio de uma coleção de obras de arte. A distância percorrida pelo olhar de Scottie - ou seja, a distância que o separa de Madeleine - instaura um espaço tão concreto quanto fantasmático, um sítio de ação para as potências afetivas e mentais, para as forças visuais e psíquicas que transitam no campo escópico. Essa distância é diretamente figurada na imagem através de um sobre-enquadramento - cujas bordas são fornecidas pela colunata que

\footnotetext{
${ }^{36}$ René Démoris, “L’Héritage de la peinture: le portrait impossible”, Iris, n. 14-15, p. 20.
} 
ornamenta a arquitetura do museu -, o qual reforça o caráter planimétrico da composição, de modo a sublinhar a separação e, ao mesmo tempo, a continuidade entre um primeiro plano identificado ao lugar de observação de Scottie e um segundo plano situado na profundidade de campo. O detetive ali se coloca como um intermediário entre o espectador e a cena-dentroda-cena. Naquela penumbra, naquele lusco-fusco em que ele se encontra, o limite entre campo imaginário e campo óptico fica literalmente obscurecido. A comunicação dos ambientes cria um diálogo ambíguo entre as duas regiões do quadro, a saber, a zona escura ocupada por Scottie e aquela outra, bem iluminada, onde se acha Madeleine, confrontando assim dois princípios que, no fundo, se complementam na dinâmica do espaço museal: a atenção especial, o investimento passional e erótico que a imagem exposta solicita do observador, e a concomitante e paradoxal proibição de tocá-la ou de aproximar-se dela excessivamente. A imagem não deve ser tocada senão pelo olhar. "Nessa mistura de imposição, interdição e sedução, reencontra-se, espelhado, o dispositivo cinematográfico com suas imagens ao mesmo tempo oferecidas e inacessíveis". ${ }^{37}$

A cena sugere, indiretamente, um espectador de cinema sendo absorvido pela diegese (a maneira como se encena a contemplação de uma pintura num filme costuma ser "um pretexto bastante lógico para as cenas em que se trata de situar uma personagem na condição fílmica sem que ela esteja diante de um filme, ${ }^{, 38}$ ). A imagem que conclui a cena refaz o ponto de vista com que se a iniciara, mas em escala mais fechada (lá, o detetive era apanhado num plano geral; aqui, num plano americano). Esse enquadramento final, mostrando Scottie imerso num ambiente escuro, parado diante do recorte quadrangular de um outro espaço que vibra luminosamente para os seus olhos, inscreve na imagem o próprio contexto de recepção da obra cinematográfica (como Hitchcock já fizera, por caminho diferente, no plano do espelho na loja de flores).

Para chegar numa posição em que pudesse ver o retrato de Carlotta de frente, Scottie precisou cruzar aquela fronteira configurada pela área de sombra que dá para o salão onde o retrato está exposto. Ele precisou "entrar na tela". Mas, conforme Païni salienta, "é exatamente isso [a crença do espectador, a fruição do espetáculo] o que um retrato pintado vem perturbar num filme. Por ser uma ilusão declarada, uma representação fortemente significada [sur-signifiée], um retrato pintado devolve bruscamente o espectador a seu estatuto de observador externo". ${ }^{39} \mathrm{Na}$ mesma medida em que é atraído para dentro da

\footnotetext{
${ }^{37}$ M. Vernet, art. cit., p. 47-48.

${ }^{38}$ J. Aumont, Le montreur d'ombre, Paris: Vrin, 2012, p. 66.

${ }^{39}$ D. Païni, “Un Détour pour le regard", Iris, n. 14-15, outono de 1992, p. 3.
} 
imagem, o espectador é mantido a distância - como acontece com Scottie, vidrado na imagem de Madeleine-Carlotta, mas apartado dela por um intervalo que é tanto um "fosso" (a separação plateia-palco, que estabelece a identidade da ficção teatral ao distingui-la do espaço do espectador) quanto uma "moldura" (a "instituição" do quadro, a convenção que delimita a unidade de percepção da obra pictórica).

O retrato de Carlotta, como a maioria dos retratos usados nos filmes hollywoodianos clássicos, nada traz de especial em termos formais, sendo até mesmo de fatura medíocre, ou melhor, propositalmente medíocre: o esteta e erudito Hitchcock sabe que a fascinação que as personagens manifestam pelo quadro deve provir não de uma qualidade pictórica propriamente dita, mas do espírito que o anima, e que é tributário da energia que ele rouba dos corpos postados diante dele:

[...] é no imaginário de uma personagem do filme que o retrato deve agir, não no nosso. Nossa confiança nos efeitos desse retrato passa pela identificação com o ou os heróis. Essa situação possibilitada pelas virtudes catárticas do cinema clássico nos convida, por delegação, a "respeitar" esses retratos pintados. Se eles nos fascinam, é somente em virtude do processo da representação dramatúrgica. ${ }^{40}$

Desprovidos de uma força plástica ou emotiva, de uma "convicção estética" que os credencie como obra de arte, os retratos que aparecem nos filmes acabam funcionando, na maior parte das vezes, como formas genéricas encarregadas de representar valores maiúsculos (a Arte, o Belo, o Ideal, o Amor) e de sugerir uma ligação das personagens com um alhures, com um fora de quadro, com um vazio estruturante que o espectador é chamado a preencher imaginariamente.

A magia e o poder de fascinação do retrato utilizado em Vertigo, seguindo essa lógica, não estão na pintura em si, mas no que ela simboliza. Se o retrato desempenha um papel fundamental na narrativa, não é por sua composição plástica nem por sua qualidade técnica, mas pela forma como se encaixa no dispositivo simbólico do filme. O retrato de Carlotta, no fim das contas, é apenas mais um exemplo de "má pintura", como tantos outros que podem ser enumerados no cinema clássico. O verdadeiro retrato em jogo, construído pela decupagem, é o de Madeleine, que, absorta na contemplação do quadro no museu, ocupa um limiar entre duas molduras, a da porta à sua direita e a do retrato de Carlotta à esquerda, duas 
fronteiras com significações espaciais e temporais distintas. O rebaixamento formal do retrato reforça dialeticamente o que está fora da sua moldura: "a tensão que se instaura entre o corpo de Madeleine (todo presente no olhar, mas sem rosto) e o corpo (tal como o rosto) do quadro produz um certo efeito de espelho distorcido". ${ }^{41}$

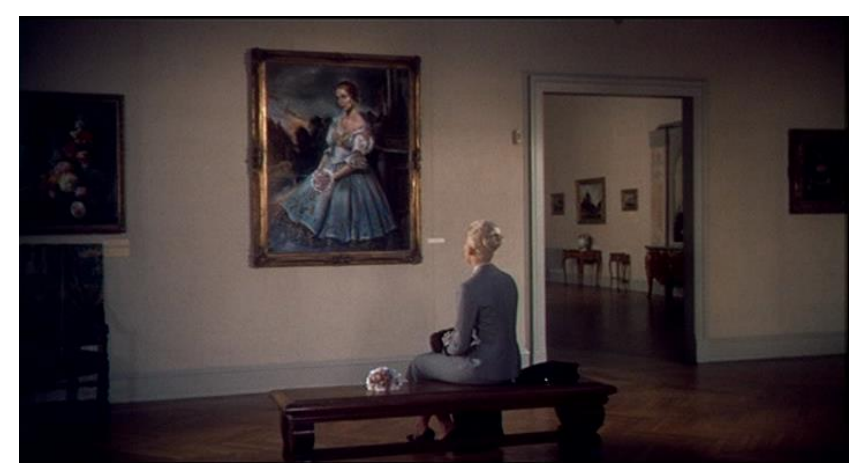

A cena do museu em Vertigo se constrói sobre a ideia de que "o amor resulta de um enquadramento, de uma fetichização fulgurante, sem duração". ${ }^{42}$ A interação de Scottie com o retrato de Carlotta ilustra esse "nascimento do amor" derivado de um trabalho de seleção, focalização e recorte, que remete inequivocamente à operação de mise en cadre no cinema.

"Porém, nesse ponto fixo que o retrato constitui no seio da imagem cinematográfica, reencontra-se também a rigidez do cadáver (todos os retratos possuem relação com a morte)". ${ }^{43}$ A fixidez do retrato engendra sua inelutável heterogeneidade na mise en scène fílmica: “aquela 'imagem dentro da imagem' (o 'quadro dentro do filme') implica uma complexa mise en abyme, pois encaixa uma imagem fixa numa imagem móvel [...] à imagem móvel corresponde a ação, o movimento, a vida; à imagem fixa, a morte". ${ }^{4}$ A cena evoca, assim, o fascínio estético (e erótico) pela morte, que pauta uma grande parcela da arte oitocentista e perdura no século XX, entre outras coisas, como núcleo de um tipo de enredo romântico-simbolista recorrente em Hollywood - enredo do qual Vertigo pretende ser, a um só tempo, a quintessência e a superação.

O retrato pintado ocupa, no cinema, uma espécie de "limbo figurativo" imagem fixa e a imagem em movimento, entre o objeto real e a fantasmagoria, entre a ideia trabalhada progressivamente pelo pintor e a realidade registrada automaticamente pela

\footnotetext{
${ }^{41}$ V. I. Stoichita, O efeito Pigmalião, p. 205.

${ }^{42}$ D. Païni, art. cit., p. 4.

${ }^{43}$ M. Vernet, art. cit., p. 48.

${ }^{44}$ V. I. Stoichita, $O$ efeito Pigmalião, p. 204.

${ }^{45}$ Expressão que tomo emprestada de Aumont (cf. Le montreur d'ombre, p. 158).
} 
câmera. "O retrato é a outra tela que inscreve no interior do filme o movimento mental entre diegese e realidade, 'projetado' pelo espectador". ${ }^{46}$ De mera convenção narrativa, o retrato pode se transformar em ativador de reflexão metatextual. "A suspensão do encadeamento narrativo - 'a inquietante estranheza' dessa imobilidade - leva o filme a se voltar sobre si mesmo". ${ }^{47}$ Assim como o espelho, o retrato estimula o cinema a repensar sua teoria e a refazer seus dispositivos de encenação. Com a diferença de que a pintura - ao descer um degrau na escala da mimese, ao dilatar a fenda entre o signo e a coisa significada, ao perder a conexão física/óptica com o que é figurado, em suma, ao ser um signo "menos natural" que a imagem no espelho - insere outras modalidades de representação e de questionamento visual na narrativa fílmica. Estamos, doravante, em algum lugar entre a semelhança e a perda do referente, entre o familiar e o unheimlich.

Vertigo não foi - está longe de ter sido - o primeiro nem o único filme a trabalhar a fundo a temática do duplo e a pôr um retrato no centro da sua trama. Há toda uma leva de filmes dos anos 1940 e 1950 que têm no retrato, sobretudo no retrato feminino, a pedra de toque de seus dispositivos narrativos e plásticos. A começar por Laura (1944), de Otto Preminger, marco do cinema noir que possui uma série de pontos de contato com Vertigo. Dana Andrews faz o papel do detetive McPherson, que investiga a morte de Laura (Gene Tierney), jovem e bem-sucedida publicitária brutalmente assassinada em circunstâncias enigmáticas. A primeira meia-hora do filme consiste basicamente no relato de Waldo Lydecker, intelectual pedante, colecionador de arte, mentor pigmaliônico de Laura, que narra para McPherson o modo como a conheceu e a talhou para a alta sociedade nova-iorquina. A narração, transformada em flashbacks com voz over, vai traçando na cabeça do detetive a personalidade e o espírito de Laura, cujo retrato, pintado por um artista desprezível aos olhos de Lydecker (que o enxerga como rival, preferindo a imagem de Laura - de glacial beleza que ele mesmo criou ao moldá-la para a vida de aparências exigida pelo pertencimento à elite), acha-se pendurado no apartamento em que ela morava. O retrato fica na sala de estar, emblematicamente acima da lareira, como se uma chama lhe emprestasse vida. A partir dessa imagem, e das descrições de Lydecker, McPherson se apaixona por essa mulher que nunca conheceu - e que está morta. Numa noite chuvosa, a pretexto de investigação, ele vai para o

\footnotetext{
${ }^{46}$ D. Païni, art. cit., p. 4.

${ }^{47}$ Ibid.
} 
apartamento de Laura e fica lendo seu diário, fuxicando seus objetos, explorando o ambiente, enfim, apreciando o "quadro de existência" em que ela estava acondicionada. Após beber algumas doses de uísque, McPherson adormece no sofá da sala. Como que saída diretamente dos sonhos do detetive, Laura ressurge pela porta: ela está viva, foi outra pessoa quem morreu no seu lugar. A cena tem uma atmosfera ambígua, equalizando naturalismo e onirismo. A partir de então, o filme se dividirá entre a trama policialesca (a elucidação do crime) e a formação do par romântico McPherson/Laura, que o reingresso dela no universo dos vivos não conseguirá livrar por completo da dimensão fantasmagórica e até mesmo necrófila antes instaurada. A força da obra se deve, em larga medida, à forma como se constroem suas primeiras sequências, quando o filme se propõe a desenhar, cinematograficamente, pelos recursos da narração em off e do flashback (típicos do film noir), o retrato de uma mulher.

No mesmo ano de Laura, Fritz Lang realizou Um retrato de mulher (The Woman in the Window), que mostra um professor de criminologia, Wanley, aventurando-se com uma femme fatale que ele conhece depois de sair do clube em que se reúne com seus amigos. $\mathrm{Na}$ cena do encontro que mudará seu destino, ele está parado diante da vitrine de uma galeria de arte, onde se expõe o tal retrato feminino do título. De repente, vê surgir no vidro o reflexo da mulher que serviu de modelo para o quadro. Ele olha para trás e confirma que não se trata de um delírio: a mulher não só está realmente presente como engata uma conversa e ainda o convida para um drinque. Mas a fantasia erótica rapidamente se transforma em pesadelo, e Wanley, casado, pai de família (na semana em que se envolve com a mulher do retrato, a esposa e os filhos estão viajando), é enredado num esquema de crime e chantagem. Mais do que em qualquer outro filme, o retrato feminino é aí tomado como a figuração de uma tentação diabólica, de uma influência maléfica a incidir sobre as pulsões e os desejos do homem, arrastando-o para a ruína segundo o movimento implacável da mecânica languiana.

Em outro filme de 1944, Idílio perigoso (Experiment Perilous), de Jacques Tourneur, a potência visual e narrativa do retrato é trabalhada de uma maneira que, sob muitos aspectos, aparenta-o a Vertigo. A história se passa em 1903. Um médico, Dr. Bailey, conhece uma estranha e insegura mulher numa viagem de trem em noite de tempestade. Ela pertence aos Bederaux, família de aristocratas de boa reputação que vivem numa mansão de estilo gótico em Nova York. No dia seguinte ao encontro fortuito no trem, ela morre de ataque cardíaco. Por intermédio de um amigo, o médico é convidado a uma festa na casa dos Bederaux. "Parece um cenário de romance de Júlio Verne", ele diz ao entrar, vendo-se rodeado por esculturas, pinturas, armaduras medievais, aquários. "É o único lugar da cidade em que nunca se sabe em qual século se está entrando", comenta o amigo escultor, que, em cena anterior, 
havia recomendado que ele fosse ao museu de arte moderna ver o retrato de Allida (Hedy Lamarr), a jovem esposa de Nick Bederaux. "Há algo de fatal em Allida. Vá ver o retrato", dissera. Bailey seguiu a sugestão e, de fato, achou o quadro bastante perturbador. "Há algo na expressão dos olhos...”, relatou ao amigo. Na festa, ao conhecer a verdadeira Allida depois de ter visto o retrato no museu, o médico forma outra ideia, que contrasta com a imagem representada no quadro: numa quase telepatia, ele a imagina num campo florido com margaridas - mais tarde, descobrirá que é assim que ela também se imagina, nostálgica da vida que levava na fazenda do pai em Vermont, antes de se casar com Nick. Ela está vestida, na festa, exatamente como no quadro visto no museu, e sentada na mesma poltrona, rodeada pelos mesmos objetos, repetindo a mesma pose. Segundo o marido, "Allida gosta tanto do retrato que usa sempre o mesmo vestido, e até o mesmo penteado" (o que nos remete à repetição do coque de Carlotta em Madeleine-Judy). "Não sem sadismo, em Idílio perigoso, como em Vertigo, o homem força a mulher a repetir o quadro". ${ }^{48} \mathrm{O}$ médico percebe que há algo de misterioso naquela família, e começa a suspeitar que a irmã de Nick, a mulher que conhecera no trem, não morreu de ataque cardíaco. Numa cena parecida com aquela em que Gavin recebe Scottie em seu escritório para uma conversa, Nick procura Bailey no consultório e se diz preocupado com o comportamento anômalo de Allida, que vive mandando flores para si mesma e se sente perseguida quando sai para fazer compras. Isso estaria acarretando enormes prejuízos psicológicos para o filho do casal (personagem que permanece envolta por uma bruma de interditos, sem aparecer até quase ao final do filme). Nick quer a ajuda do médico, que, àquela altura, já está apaixonado por Allida - já estava desde que viu o retrato. Em seu credo positivista, Bailey afirma haver uma explicação simples e lógica para todo fenômeno. Mas o segredo dos Bederaux desafia seu entendimento e o leva a abandonar parcialmente o interesse médico-científico em benefício de outra motivação, a paixão por Allida. Na principal cena do filme, Bailey lê o diário da irmã de Nick, no qual ela revela a verdade por trás da família. Lá constam os segredos a respeito do comportamento monstruoso do irmão, que mantém Allida prisioneira (Idílio perigoso é desses filmes que promoveram, na Hollywood dos anos 1940, o encontro entre as almas atormentadas do cinema mudo alemão e as figuras femininas reprimidas do melodrama gótico). No diário, a irmã descreve a forma doentia como Nick se empenhou em transformar a jovem interiorana em uma mulher refinada e culta: "Às vezes, era quase cruel o modo como Nick dirigia a alma de Allida. Ele sabia que encontrara uma joia, e estava resolvido a lapidá-la e poli-la até a perfeição”. Como Lydecker,

\footnotetext{
${ }^{48}$ M. Vernet, Figures de l'absence, Paris: Éditions de l'Étoile, 1988, p. 95.
} 
em versão menos tirana, fizera com Laura; como Gavin, menos psicopata, porém mais maquiavélico, fará com Judy. Cabe a Bailey, em Idílio perigoso, libertar a amada da loucura do marido, tirá-la da mansão-mausoléu e levá-la de volta para o campo florido de Vermont. Em outras palavras, ele deve mudar o pano de fundo do retrato: do cenário lúgubre vinculado ao imaginário gótico para um plein air impressionista.

Mais de vinte anos depois de Idílio perigoso, em Monstros da cidade submarina (WarGods of the Deep, 1965), que é seu último filme, Jacques Tourneur volta a contar uma história transcorrida em 1903, desta vez em pleno universo do cinema fantástico, entrecruzando ficção-científica e exploração do sobrenatural. Numa mansão situada à beira de um penhasco na costa da Cornuália, no sudoeste da Inglaterra, horripilantes criaturas marinhas invadem a biblioteca e roubam o livro no interior do qual um pintor guardou um esboço de Jill, a jovem que se hospeda na mansão. Uma criatura volta no meio da madrugada para sequestrar a moça. $\mathrm{O}$ pintor e um engenheiro (que, assim como Jill, é norte-americano - o filme trata, entre outras coisas, de um colapso entre o Velho e o Novo Mundo) descobrem a passagem secreta na biblioteca e vão ao resgate de Jill. Depois de atravessar longos túneis e mergulhar num redemoinho, eles chegam a uma cidade submersa, elo perdido entre a Babilônia, o Antigo Egito e Metropolis. Na cidade, além das criaturas subaquáticas, vive a tripulação de um navio que naufragou naquela encosta cem anos antes, provavelmente numa daquelas furiosas tormentas pintadas por Turner e William Hodges. Sob o regime despótico do Capitão (Vincent Price), os homens vivem paralisados no tempo, sem envelhecer. O tempo, lá embaixo, age tão lentamente sobre a matéria que seus corpos levarão uma eternidade para começar a se decompor. Eles estão imunes ao tempo. No entanto, caso tentem voltar à superfície, como alguns já tentaram, envelhecerão instantaneamente e morrerão.

O motivo pelo qual Jill foi sequestrada é revelado quando o Capitão abre a cortina que protegia o retrato de sua falecida esposa, permitindo que contemplemos a imagem. Percebemos então que Jill é idêntica a ela. O Capitão havia descoberto a semelhança através do esboço que veio junto com o livro roubado da biblioteca. Para ele - que, não custa sublinhar, pertence à era romântica -, Jill é a sua esposa trazida de volta pelo redemoinho do tempo. A vertigem amorosa se coaduna à vertigem temporal.

O uso da cortina como acessório simbólico da imagem ou como objeto que ritualiza a aparição de um quadro remonta a uma longa história, cujas nuances escapam ao nosso propósito. ${ }^{49}$ Aqui, devemos apenas notar que a função da cortina, mais do que proteger o

\footnotetext{
${ }^{49}$ Ver Stoichita, L'instauration du tableau, pp. 91-95.
} 
retrato (do acúmulo de poeira, do excesso de luz etc.), é reservar a imagem da amada para a apreciação íntima do seu único dono, resguardando-a do eventual assédio dos demais olhares masculinos. Além da tarefa de assegurar proteção/posse, esse velum funciona como instrumento de supervalorização e teatralização da pintura, criando suspense em torno de sua revelação e forjando um impacto que o quadro, em si, talvez não tivesse. É na própria aura da pintura, quiçá em sua sacralidade, que a presença da cortina influi.

Inspirado na novela "City in the Sea", de Edgar Allan Poe, o filme de Tourneur nos faz lembrar, principalmente, que o romantismo é contemporâneo do fetiche pelas ruínas, das escavações arqueológicas em sítios que guardam os segredos da Antiguidade, os tesouros escondidos das civilizações passadas, as inscrições em paredes repletas de hieróglifos que, em sua obscuridade milenaríssima, derrotam - provisoriamente ou não - a mente racionalista e o olhar erudito do homem de ciência. Essa febre de arqueologia logo incitou a imaginação romântica a vislumbrar todo um universo de cidades submersas, de civilizações perdidas no tempo, de arquiteturas colossais nunca antes vistas, conservadas nas regiões de penumbra da História. Tourneur adora dialogar com essas camadas de civilização esquecidas no tempo, com essas forças que ameaçam desestabilizar o presente, que causam, no subsolo, um tremor que afeta a superfície (há um vulcão submarinho entrando em erupção no final de War-Gods of the Deep): "Se o passado aflora no presente, e frequentemente o envenena, é porque ainda não foi elucidado. Ou porque deve ser exorcizado". 50 (O que vale também para o plano psicanalítico: Freud chegou a recorrer a metáforas arqueológicas para se referir às camadas mais profundas da vida psíquica, aos medos, traumas e pulsões mais antigos, que influenciam as decisões conscientes.) A cidade submarinha de War-Gods of the Deep é como a São Francisco do século XIX evocada em Vertigo: um passado histórico mal resolvido que, através de um "simples" retrato feminino, vem tragar o presente, o que fica claramente expresso num plano da cena do museu em que a câmera se aproxima da madeixa espiralada de Carlotta até ser quase engolida por ela.

A vertigem do tempo e o regresso de uma imagem do passado são também o assunto de Os amores de Pandora (Pandora and the Flying Dutchman, 1951), um dos filmes mais peculiares dos anos 1950, a meio caminho entre a extravagância kitsch e uma estilização ornamental recheada de referências eruditas. Dirigido por Albert Lewin (que havia realizado, em 1945, uma bela adaptação de $O$ retrato de Dorian Gray), o filme recupera a lenda do Holandês Voador e a transporta para uma vila espanhola em pleno século XX (a estória se

\footnotetext{
${ }^{50}$ Michael Henry Wilson, Jacques Tourneur ou la magie de la suggestion, op. cit., p. 117.
} 
passa em 1930), num contexto tão realista quanto folclórico. Entre ruínas antigas (colunas gregas, pedaços de estátuas) e praias exuberantes, as personagens habitam uma espécie de mundo-pintura em que a estética surrealista, amplificada pelo Technicolor, mescla-se a um estilo decorativo barroco. No auge da beleza e da fama, Ava Gardner interpreta a personagem-título, mulher sensual e blasée que desperta paixões avassaladoras em todos os homens que a ela se achegam. Seu destino começa a mudar quando um barco conduzido por um misterioso e charmoso navegante holandês, de quem muitas histórias se contam, ancora próximo à praia. Numa noite enluarada, Pandora, cheia de curiosidade e desejo, nada até o barco. Dentro da cabine, encontra a personagem de James Mason pintando um retrato feminino. Para a surpresa de Pandora, a mulher contida no quadro é ela própria. Mesmo sem nunca tê-la visto, o holandês a representou em seu quadro (pintado à maneira de De Chirico $^{51}$ ). Mais tarde, descobre-se que Pandora é idêntica à antiga amada do navegante, assassinada no século XVII por conta de um ciúme doentio. Desde então, o holandês fora condenado a errar pelos sete mares, até encontrar uma mulher disposta a se sacrificar por amor, libertando-o do fardo da eternidade. Pandora será essa mulher. A imagem que o lendário navegante pintou no quadro, conclui-se, provinha de sua memória, que não só guardava os traços da mulher morta como antecipava seu "retorno" ("numa relação especular em que a tela se substitui ao espelho, [Pandora] descobre seu duplo nesse quadro à espera de seu modelo",52). A pintura como escrita rememorativa, aqui, tem caráter não apenas retrospectivo, mas, sobretudo, prospectivo: seu conteúdo não se limita ao que aconteceu, pois inclui o que está prometido, o que vai acontecer. ${ }^{53} \mathrm{O}$ retrato de Pandora jaz entre uma visão passada e uma reaparição futura. Lewin demonstra um genuíno saber iconológico, permitindo-se ultrapassar a esfera da mera citação para construir um "sistema hermenêutico",54 que redimensiona o diálogo cinema-pintura já estabelecido pelas outras cenas: é o filme em seu conjunto que se expressa e se ressignifica por meio dessa entrada no mundo da pintura e, mais especificamente, no universo enigmático, de essência metafísica, da obra dechiriquiana.

$\mathrm{Na}$ cena em que vê o retrato, tomada de certa raiva infantil após uma discussão, Pandora estraga a pintura, desfigurando o rosto com um borrão de tinta branca. O holandês, em vez de se irritar, agradece pela contribuição "acidental", e modela a mancha branca até obter uma forma oval, uma face neutra que representa, segundo ele, a origem indefinida de

\footnotetext{
${ }^{51}$ Para uma análise mais aprofundada dessa cena do retrato em Pandora, e para uma comparação detalhada entre a atmosfera do filme e o universo pictórico de De Chirico, ver Alain Bonfand, Le cinéma saturé: Essai sur les relations de la peinture et des images en mouvement, Paris: PUF, 2007, pp. 15-32.

${ }^{52}$ Ibid., p. 17.

${ }^{53}$ Cf. Hans Belting, Likeness and Presence, Chicago: The University of Chicago Press, 1994, p. 10.

${ }^{54}$ A. Bonfand, op. cit., p. 20.
} 
todos os rostos femininos, a fonte universal da beleza (o "ovo" de onde saem todas as Vênus). Embora tido aí como sinal de plenitude e absoluto, esse "apagamento" do rosto significa também um vazio aberto no próprio coração da imagem, uma lacuna central, uma ausência que dá margem a todo tipo de fantasia. O rosto se torna um espaço em branco que cada observador preenche com a imagem do seu modelo ideal, ou da sua assombração mais renitente. "Esse gesto de rasura significa ao mesmo tempo o advento da pintura no cinema e o acontecimento de sua anexação. Primeiro efeito de uma estranha Aufhebung em que o filme conserva este passado, a pintura, como passado interiorizado, mas conferindo-lhe a potência de uma efígie soberana". 55

Essa dimensão do retrato como suporte de inscrição do fantasma, aliada à concepção da tela de cinema como superfície mnemônica que absorve os espectros das artes precedentes, é desenvolvida de maneira fulgurante em $O$ retrato de Jennie (Portrait of Jennie, William Dieterle, 1948), que, apesar de se enquadrar facilmente na tradição hollywoodiana do woman's picture, apresenta uma série de particularidades e até mesmo de estripulias estéticas que o distinguem dos demais filmes do gênero. A narrativa, muito resumidamente, consiste numa série de encontros entre um pintor fracassado e a moça que serve de modelo para seu quadro mais famoso, o "Retrato de Jennie" a que o título do filme se refere. Na primeira vez em que se veem, no frio inverno de Nova York, ela é uma pré-adolescente. No segundo encontro, dias depois, Jennie demonstra ter crescido e amadurecido alguns anos. No terceiro, já é uma jovem recém-saída da universidade. E assim por diante: a cada vez que o pintor a reencontra, ela parece ter dado um salto no tempo. Investigando o passado da moça, ele descobre que ela já havia morrido muito antes de se conhecerem, atingida por uma onda gigante enquanto velejava em alto mar no meio de uma tempestade. Sem aceitar que a pessoa por quem se apaixonou, e a cujo retrato se dedica obstinadamente, seja apenas um fantasma inacessível, ele tenta trazê-la de volta à vida, até perceber que a única forma de consegui-lo é através da pintura. A arte se faz conciliadora desse amor fora do tempo. Na abertura do filme, um narrador em off discorre filosoficamente: "A ciência nos diz que nada nunca morre, apenas se transforma, que o próprio tempo não passa, mas se dobra ao nosso redor, e que o passado e o futuro estão juntos para sempre ao nosso lado". Anuncia-se, deste modo, uma estória romântica que pressupõe o tempo como uma espiral sem começo nem fim.

A fábula tem seu encanto, mas o que mais importa no filme, de fato, é seu inventivo tratamento visual. As premissas narrativas são praticamente pretextos para a pesquisa plástica

\footnotetext{
${ }^{55}$ Ibid., p. 31.
} 
com a luz, a textura, os filtros, a emulsão etc. Em suas aparições, Jennie é constantemente exposta a efeitos de iluminação (contraluz, flair, sombreado, sfumato) que imprimem seu estado fantasmático na própria matéria da imagem. O cinema sempre teve afinidade com "os limbos e seus habitantes". ${ }^{56} \mathrm{Em} O$ retrato de Jennie, essa abertura para o mundo dos fantasmas, das sombras, dos espectros, amplia-se pela fusão entre a matéria fílmica e a pictórica, tal como se constata nos planos plasticamente mais interessantes do filme, aqueles em que o rosto de Jennie ou as paisagens urbanas de Nova York são captados por trás de uma trama irregular que simula a textura da tela utilizada pelos pintores: a imagem cinematográfica é assim filtrada pelo suporte da pintura e enturvada pela malha que multiplica as inconstâncias de um olhar siderado na visão do fantasma. É como se o campo visual precisasse se adensar para que o pintor pudesse realmente vislumbrar a presença de Jennie, que resultaria, então, de uma ambiguidade do espaço figurativo, de uma dissolução dos contornos, de uma confusão entre realidade e alucinação. A visibilidade da figura fantasmática depende não da clareza e da limpidez, mas da turvação, da nebulosidade, do espessamento da atmosfera. É preciso, de certa forma, desfazer o espaço da visão para instaurar o espaço da aparição. Filmado por trás da membrana translúcida interposta entre a atriz e a câmera, o rosto de Jennie assume uma forma ao mesmo tempo refinada e desviada da fotogenia clássica. Há também, nesses registros, algo semelhante ao tênue tecido luminoso, ao véu aurático que, em muitas fotografias do século XIX, envolve os corpos numa névoa de luz, dir-se-ia, saída de suas próprias almas.

Todo o trabalho visual do filme, em preto e branco na sua maior parte, culmina no surgimento abrupto e arbitrário da cor, que irrompe junto com um dos raios da tempestade na sequência em que o pintor vai a um farol marítimo para tentar salvar Jennie (dentro do farol, há um plano em contra-plongée que já joga com a relação metafórica - sistematicamente repetida em Vertigo - entre as curvas do tempo e o leitmotiv da espiral). A princípio, a invasão da cor reside unicamente numa aplicação monocromática, que começa com o verde e, passada a borrasca, muda para magenta. Somente no plano final as cores aparecem em toda a sua variedade, realçando a beleza do "Retrato de Jennie" exposto no Metropolitan Museum.

Se o aproveitamento estético do retrato e a exegese da relação cinema-pintura, no filme de Dieterle, são trabalhados no nível mais da sensibilidade plástica do que da construção cênica, em Tarde demais para esquecer (An affair to remember, 1957), célebre melodrama de

\footnotetext{
${ }^{56}$ Cf. Aumont, Le montreur d'ombre, p. 89.
} 
Leo McCarey - que é um remake de Duas vidas (Love affair), realizado pelo mesmo diretor em 1939 -, a estratégia já é outra: o recurso à pintura rende, sobretudo, um jogo de decomposição analítica do ponto de vista. Embora não seja um assunto central no filme, o retrato feminino participa da narrativa de maneira decisiva, principalmente na cena final, que esclarece o fatídico desencontro do casal de protagonistas. Nickie Ferrante (Cary Grant) e Terry McKay (Deborah Kerr) haviam se conhecido num transatlântico. Apaixonaram-se perdidamente, mas ambos já estavam comprometidos. Chegando a Nova York, combinaram que se reencontrariam dali a seis meses no topo do Empire State Building, "o lugar mais perto do paraíso". A caminho do icônico edifício, contudo, ela sofre um acidente que a deixa paraplégica. Nickie não fica sabendo do que aconteceu. Para ele, Terry simplesmente desistiu de ir ao seu encontro. Com esperanças de voltar a andar, ela decide que só irá procurá-lo quando estiver curada. Passado algum tempo, no entanto, Nickie descobre onde ela está morando e faz uma visita-surpresa no dia do Natal. Durante toda a conversa, Terry permanece sentada no sofá e com o corpo coberto por uma manta. Quando já está para sair, Nickie, que resolveu se dedicar com mais afinco à pintura depois da decepção amorosa, fala de um retrato que pintou de memória, inspirado numa cena ocorrida no meio do filme, na visita que fizeram à avó dele no sul da França. Ele havia flagrado Terry rezando perante a imagem de uma santa, dentro da capela que existia na casa da avó. O quadro que retrata essa cena foi caridosamente doado pelo dono de uma galeria para uma moça numa cadeira de rodas. Conectando os pontos, e concluindo qual seria a verdadeira razão pela qual Terry faltou ao encontro, Nickie se encaminha ao quarto dela, onde vê o retrato pendurado na parede, confirmando que a tal mulher de cadeira de rodas que ganhara o quadro era Terry.

O plano que mostra o momento em que Nickie avista a pintura reúne os principais motivos composicionais que nos ocuparam até aqui: o espelho ${ }^{57}$, o retrato, o quadro dentro do quadro, a imagem cujo tema é a própria imagem:

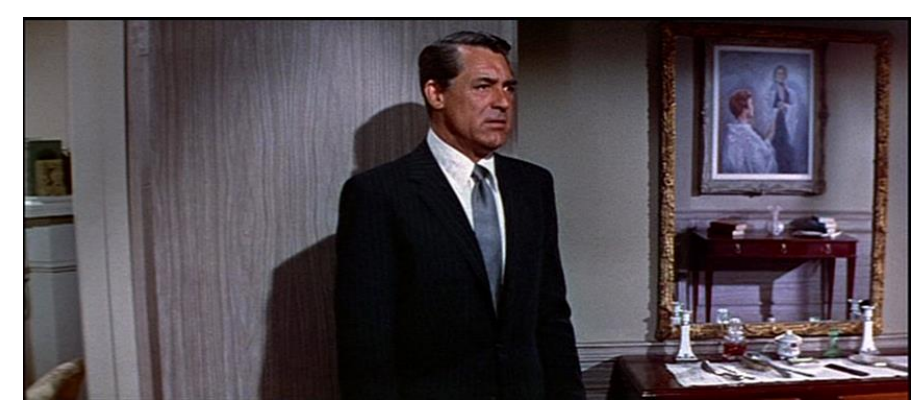

${ }^{57}$ Coroando uma série de outras composições baseadas em espelhamentos, que McCarey usa com maestria (a própria estrutura narrativa do filme é construída de forma espelhada, dividida em duas partes antinômicas). 
O espelho em que o retrato aparece refletido cumpre uma função cênica muito clara, que já havíamos notado no plano-espelho da loja de flores em Vertigo: permite que se registre num mesmo plano o olhar e seu objeto. Mas, se o olhar de James Stewart era pura fascinação, o de Cary Grant já se mostra completamente atordoado: seu corpo inteiro reage àquela visão, numa espécie de convulsão dramática do olhar. A composição do plano repete - de forma espelhada, invertida - o mesmo arranjo da cena em que Nickie observara Terry na capela:

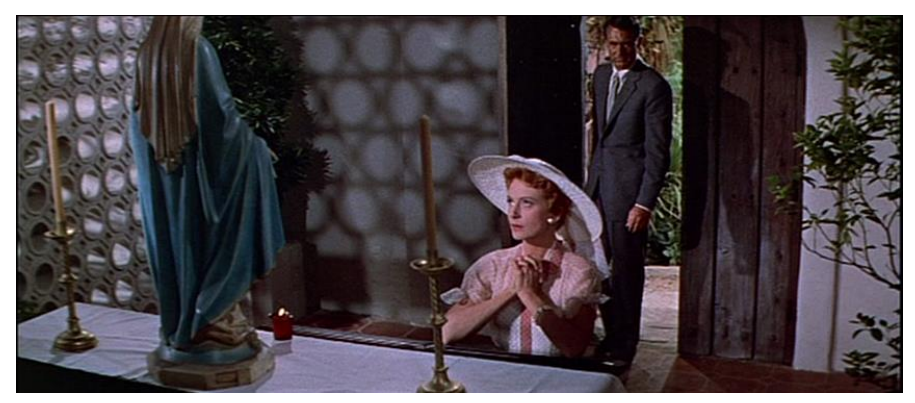

A cena final, todavia, é mais do que um espelhamento: McCarey desdobra analiticamente o ponto de vista de Nickie. A imagem no espelho não só recompõe o ângulo de visão de Cary Grant na capela (já que o retrato pintado reproduz o ponto de vista que ele tinha naquela cena), como ainda soma a essa visão uma nova camada, que corresponde a um novo momento da narrativa, diametralmente oposto. A cena da capela estreitava os laços espirituais entre as personagens (sob a aprovação da santa); a do retrato no quarto de Terry as reunifica após um período de separação - mas já existe entre elas uma cicatriz indelével, uma cesura dramática, um trauma. A acoplagem espelho-retrato propicia uma cuidadosa reduplicação visual da cena. A penteadeira sob o espelho e a mesinha de canto sob o retrato substituem o altar da santa, reduplicando-o. A moldura dourada do espelho também reduplica a moldura do retrato, como se quisesse figurar sua aura. O lugar que antes cabia à imagem religiosa é agora ocupado pelo retrato. Talvez Terry já esteja no céu, "mais perto do paraíso", e só reste a Nickie rezar por ela.

Não há no filme, a bem da verdade, uma reflexão sobre a pintura ou sobre a atividade do pintor. Não vemos Nickie pintando, não há imagens de ateliê, muito menos discussões conceituais sobre a arte. Os quadros feitos por ele são mostrados de forma relapsa. O próprio retrato de Terry aparece muito pouco. A pintura, aqui, não ocasiona situações de contemplação, ao contrário do que se vê em Vertigo e em outros filmes de retrato. No fundo, custamos a crer que Nickie - caracterizado, a princípio, como um playboy excêntrico e desocupado - tenha realmente um talento para a pintura e esteja disposto a desenvolvê-lo com 
disciplina e tenacidade. A pintura, no fim das contas, é o fora de campo do filme, seu ponto cego, seu fantasma. "Se você pode pintar, eu posso andar", diz Terry ao final. Leia-se: "você conseguir pintar é tão ilusório quanto eu voltar a andar”. E, no entanto, a pintura está lá na cena clímax, com todo o peso simbólico a que tem direito - colocada no altar, como via de acesso ao sublime e ao sagrado. No plano em que Nickie vê o retrato, este não aparece de imediato: a câmera precisa fazer uma panorâmica à direita para buscá-lo no fora de quadro. É como se o retrato fosse, de fato, uma atualização do virtual, uma materialização do invisível, uma duplicação da realidade por seu fantasma.

A mística do retrato, portanto, foi um dos topoi do cinema clássico (muitos outros exemplos poderiam ainda ser lembrados), não constituindo nenhuma exclusividade para Vertigo. Mesmo em outros filmes de Hitchcock, a pintura e o retrato já tinham papel de destaque: é o quadro com o retrato do pai de Lina em Suspeita, que, sobretudo depois que ele morre, transfixa as personagens, parecendo observá-las de cima, como um superego que não dá folga ("o retrato vem amiúde ocupar no cinema o lugar do Nome-do-Pai, o poder do Pai morto que dita a Lei de forma intangível, em sua condição de imagem fixa” ${ }^{, 58}$ ); é o retrato feminino em que a segunda Sra. de Winter se inspira para usar o mesmo vestido que Rebecca, a primeira esposa do seu marido, havia usado antes de morrer, tornando ainda mais presente e perturbador o fantasma dessa mulher que todos dizem que era uma esposa perfeita e insubstituível.

Em Vertigo, porém, a coisa vai mais longe, porquanto o retrato ocupa o cerne da narrativa e da própria elaboração visual das cenas. O filme como um todo possui uma construção “em retrato”. "É, antes de tudo, o dispositivo da mise en scène que 'faz' retrato em Vertigo, que "é' retrato". ${ }^{59}$ E se a morte surge, nas duas partes do filme, como o traço final aplicado ao desenho, como o último detalhe acrescido à figura, é porque o retrato está mesmo ligado a uma "verdade da alma" que só se revela, só se dá a ver no espelho da morte - ou de uma ausência equivalente à morte.

Desde o primeiro plano-ponto-de-vista a mostrar Madeleine do ângulo de visão de Scottie, Hitchcock já a filma como num retrato: ela aparece de perfil, destacada por uma dupla

\footnotetext{
${ }^{58}$ M. Vernet, art. cit., p. 47.

${ }^{59}$ D. Païni, op. cit., p. 52.
} 
moldura (uma no primeiro plano e outra ao fundo) que é também um duplo afastamento, já configurando a construção en abyme da identidade de Madeleine. O casal Elster está para ir embora do restaurante. Gavin, no mais antigo código do cavalheirismo, levanta-se primeiro, dá a volta na mesa e ajuda a mulher a se levantar. Em seguida, recua um pouco, o suficiente para deixá-la sozinha no espaço retangular que lhe está reservado como moldura, num gesto tão sutil quanto calculado - é o artista exibindo sua obra para um observador que ele sabe muito bem onde se encontra. O "retrato" de Madeleine, então, vê-se adornado por uma espécie de cornija que simultaneamente o realça e o protege. O jogo do quadro dentro do quadro multiplica a carga de investimento afetivo por parte do observador, atraindo o olhar para dentro da imagem com mais intensidade e curiosidade do que o normal:

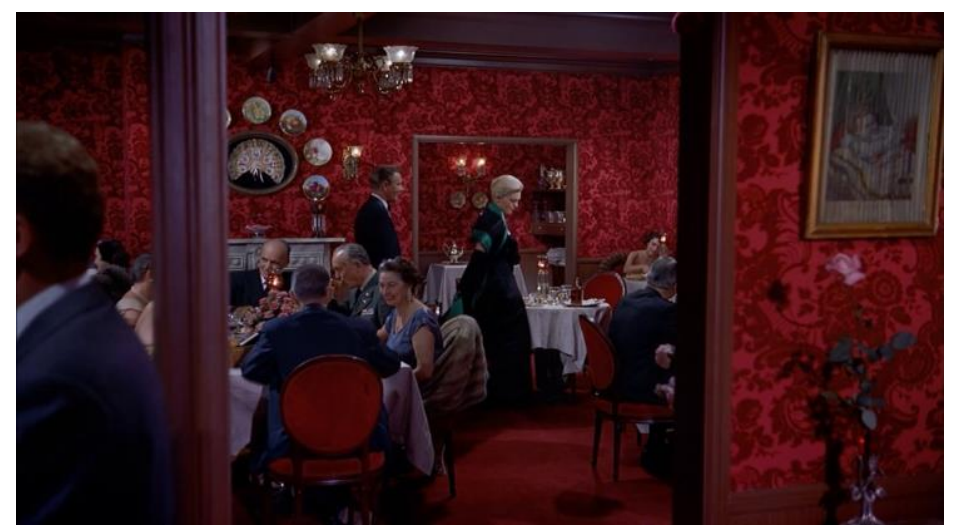

Para alcançar Madeleine, o olhar de Scottie tem de transgredir essas duas distâncias, esse espaço em profundidade reduplicada, que os separa em mundos diferentes. Para passar por Scottie, por sua vez, Madeleine tem de fazer o caminho inverso e vir em direção ao primeiro plano, como uma imagem que emerge do fundo (da memória, do passado, do inconsciente) e, à medida que se aproxima, torna-se mais e mais pregnante.

Ao conceber a entrada em cena de Madeleine como uma questão prioritariamente de enquadramento, Hitchcock faz da mise en scène uma "apresentação da representação", isto é, uma representação que expõe seu ato de representar, de mostrar ou exibir alguma coisa para alguém. A intensificação dos efeitos de enquadramento é uma forma de assumir a consciência do ato representacional. Como disse Louis Marin, "o quadro, os operadores e os processos de enquadramento, bem como suas figuras, [encontram-se] entre esses dispositivos que toda representação comporta para se apresentar em sua função, seu funcionamento, quiçá sua funcionalidade de representação". ${ }^{60}$ Esses dispositivos passam tão mais despercebidos quanto

\footnotetext{
${ }^{60}$ L. Marin, De la représentation, Paris: Gallimard/Le Seuil, 1994, p. 343.
} 
maior for a "sedução da transparência 'mimética', a pregnância da imagem, quanto maior for o poder com que os jogos e os prazeres da substituição ocupam a atenção do olhar e cativam seu desejo". 61

Em Vertigo, que comprova esta última afirmação, assiste-se a uma dupla operacionalização do dispositivo do quadro, como disparador de reflexividade, de um lado, e como enaltecedor do espetáculo visual, do outro. Embora se assuma como operação de transformação do objeto percebido em objeto teórico, instaurando uma "mise en abyme da representação e de sua mise en scène",62, o efeito-quadro buscado por Hitchcock não se quer como ferramenta inibidora da mimese, pelo contrário: ele visa também a ampliar o poder de sedução da imagem.

Poussin, o grande pintor francês do século XVII, recomendou a um amigo a quem deu de presente um de seus quadros:

Quando receber o quadro, não deixe de orná-lo com uma cornija, pois ele necessita de uma, para que, considerando-o em todas as suas partes, os raios do olho se concentrem e não se dispersem alhures ao receber as influências dos outros objetos vizinhos que vêm aleatoriamente se confundir com as coisas pintadas. ${ }^{63}$

A recomendação de Poussin esclarece a função do quadro, artefato a meio caminho "entre suplemento e complemento, ornamento gratuito e dispositivo necessário". ${ }^{64}$ O quadro, como Marin afirmou, "autonomiza a obra no espaço visível, põe a representação em estado de presença exclusiva": a representação só se identifica como tal "ao excluir do campo do olhar todo outro objeto. Pelo quadro, a pintura não é simplesmente dada a ver em meio a outros objetos: ela se torna objeto de contemplação". ${ }^{65}$

A cena da apresentação de Madeleine no restaurante Ernie's parece seguir à risca a recomendação de Poussin. A estratégia utilizada por Hitchcock reside não apenas em progressivamente isolar Madeleine (o quadro e o foco vão se fechando aos poucos sobre ela) e diferenciá-la das figuras circundantes, definindo assim as condições de recepção visual em que a imagem terá seu máximo impacto, mas também em valorizar - pelo misto de efeito decorativo e necessidade estrutural dos quadros dentro do quadro - o próprio mecanismo da representação, o próprio gesto do representar.

\footnotetext{
${ }^{61} \mathrm{Ibid}$

${ }^{62}$ Ibid., p. 357.

${ }^{63}$ Nicolas Poussin, apud L. Marin, De la représentation, op. cit., p. 347.

${ }^{64}$ Ibid., p. 346.

${ }^{65}$ Ibid., p. 347.
} 
O ponto culminante da cena é o momento em que Madeleine, parando perto de Scottie, é captada em primeiro plano e de perfil, com o rosto esvaziado de expressão, retomando o padrão formal dos retratos de perfil renascentistas:

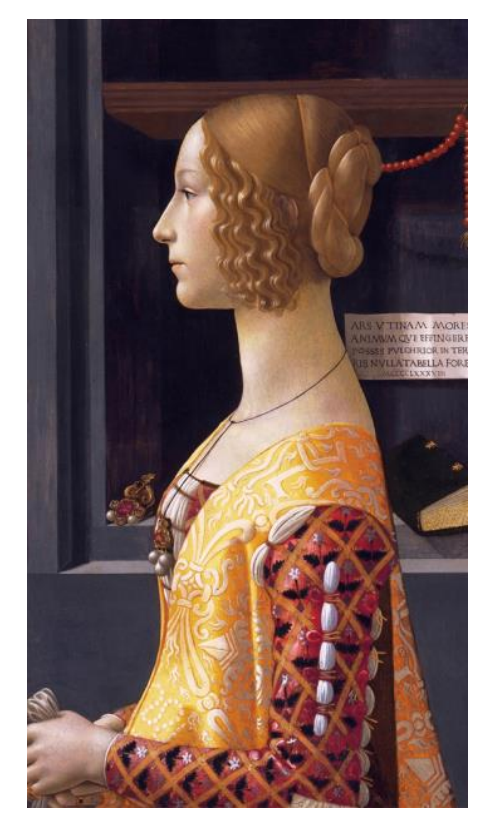

Domenico Ghirlandaio,

Retrato de Giovanna Tornabuoni, 1489-90

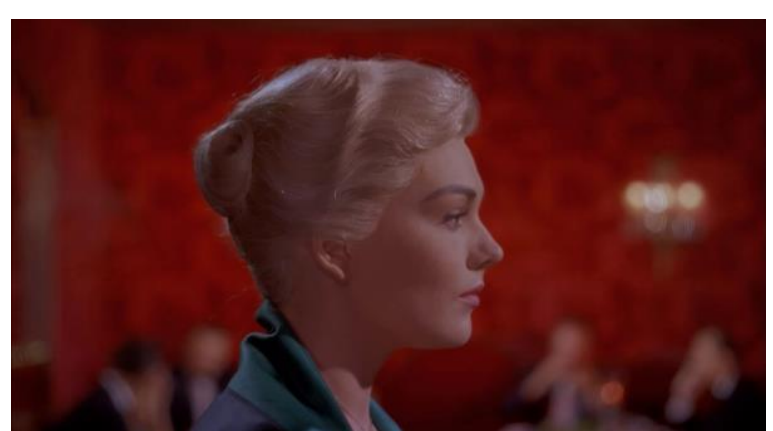

"Retrato" de Madeleine em Vertigo

Nesta colocação de Madeleine como um "ícone de perfil"66, é importante notar o modo como o próprio cenário absorve o efeito da impressão causada por ela no olho inebriado da câmera: a iluminação do plano muda sensivelmente, aumenta sua intensidade, e o vermelho da parede lateja: “O cenário já não é apenas o restaurante Ernie’s, mas uma matéria pictórica inflamada pela aparição do perfil [de Madeleine]". 67

O diálogo de Hitchcock com as convenções pictóricas do retrato renascentista não é gratuito nem muito menos inocente. Prova disso é sua insistente exploração das possibilidades expressivas do perfil. O retrato de perfil se impôs, desde o Renascimento, "principalmente como ‘imagem da memória' e como forma predileta das efígies mortuárias". ${ }^{68}$ Uma longeva tradição figurativa, que se reporta à Antiguidade, prescreve o retrato de perfil como a forma mais adequada à evocação da imagem-lembrança, situando sua origem no reino das sombras.

\footnotetext{
${ }^{66} \mathrm{O}$ que é quase um oximoro (já que os ícones são sempre representados de frente), mas faz bastante sentido na lógica de construção da imagem de Madeleine, conforme Jean-Pierre Esquenazi analisa em Hitchcock et l'aventure de Vertigo, Paris: CNRS Éditions, 2001, pp. 127-128.

${ }^{67}$ Ibid., p. 127.

${ }^{68}$ V. I. Stoichita, O efeito Pigmalião, p. 207.
} 
A história, contada por Plínio, o Velho, é já bastante conhecida: a filha de um oleiro de Corinto queria guardar a imagem do jovem por quem era apaixonada, e que partia para o estrangeiro por tempo indeterminado; então, à luz de uma lamparina, ela traçou na parede o contorno da sombra do rapaz, projetada de perfil. ${ }^{69}$ A arte do retrato emergia, assim, da sombra e do desejo louco de lutar contra uma ausência. "De Plínio a Alberti e Rousseau, a tradição ocidental enxerga a delineação da sombra de um ser humano projetada num muro como o gesto inaugural da pintura, o ato fundador (no sentido fenomenológico do termo) em que se anuncia o modo de historicidade próprio a essa prática no Ocidente". ${ }^{70}$

A pintura - como demonstram os exemplos de Regnault, Suvée, David Allan, Eduard Daege, Joseph Wright - diversas vezes se apropriou desse mito de fundação como motivo iconográfico e morfológico:

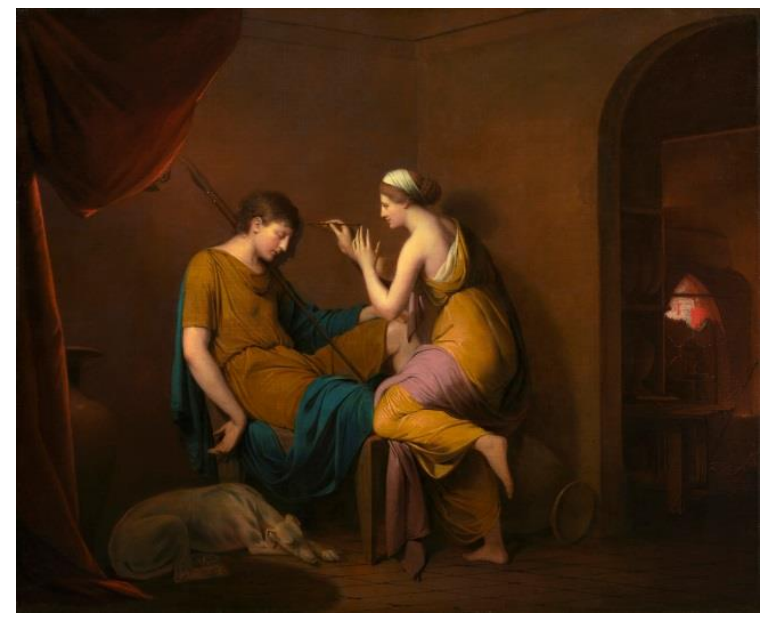

Joseph Wright, The Corinthian Maid, 1782-1784

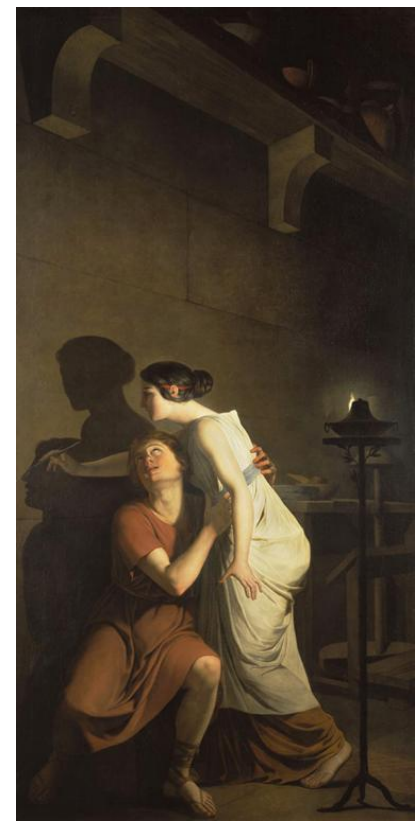

Suvée, De uitvinding van de tekenkunst, 1791

No cinema, a fábula já rendeu pelo menos uma cena diretamente extraída de seu dispositivo inaugural: a brilhante cena de O fantasma apaixonado em que a Sra. Muir (Gene Tierney) vê pela primeira vez o fantasma do Capitão Gregg (Rex Harrison), o antigo morador da casa para a qual a jovem viúva se mudou com a filha. A princípio, ele está totalmente na

\footnotetext{
${ }^{69}$ Cf. Plínio, o Velho, "História natural (Livro 35)", in Jacqueline Lichtenstein (org.), A Pintura: textos essenciais - Vol. 1: O mito da pintura, São Paulo: Ed. 34, 2004, p. 86.

${ }^{70}$ H. Damisch. Théorie du nuage. Paris: Éditions du Seuil, 1972, p. 55 (nota).
} 
sombra, só se ouve sua voz intimidadora ordenando que a Sra. Muir acenda uma vela. Depois que ela obedece, a silhueta do Capitão começa a se destacar da sombra à medida que, um tanto estupefata, a moça se vira em sua direção:
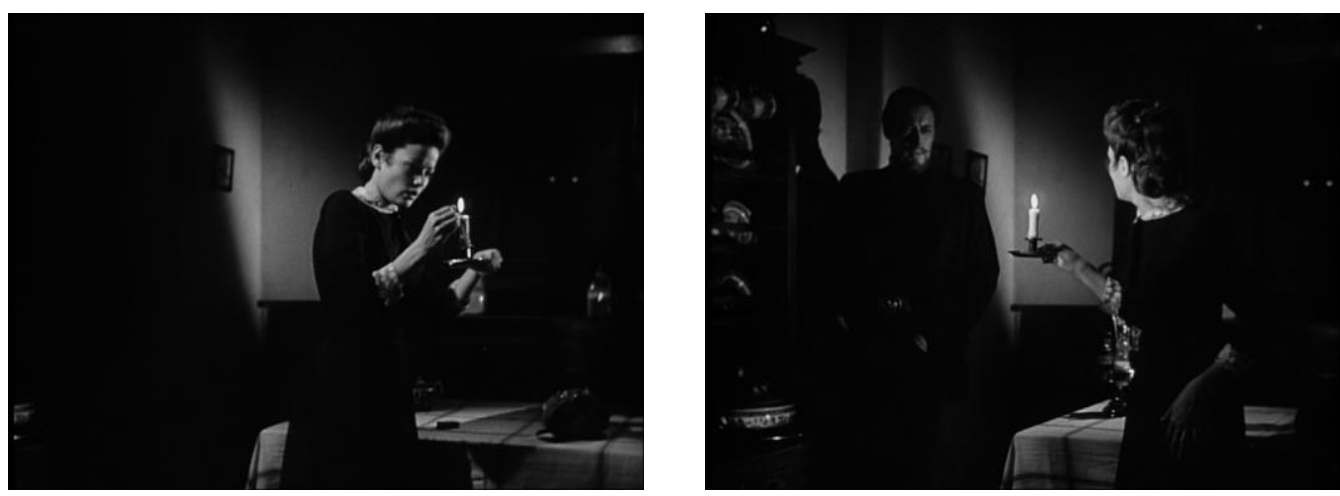

A cena expõe o papel primordial da luz na modelação do espaço visível e na formação da figura. A ação de Gene Tierney, virando a chama da vela na direção de Gregg, é o gesto figurativo que instaura a imagem, que a descobre (quase no sentido literal, pois é como se a personagem retirasse o cobertor, abrisse a cortina de sombra atrás da qual o fantasma se escondia). A decupagem de Mankiewicz ainda intensifica o efeito desse jogo de iluminação, num plano-contraplano que destaca, de um lado, a Sra. Muir com a vela, e, do outro, o fantasma de Gregg (que dizem ter se suicidado) com seu perfil duplicado pela sombra:
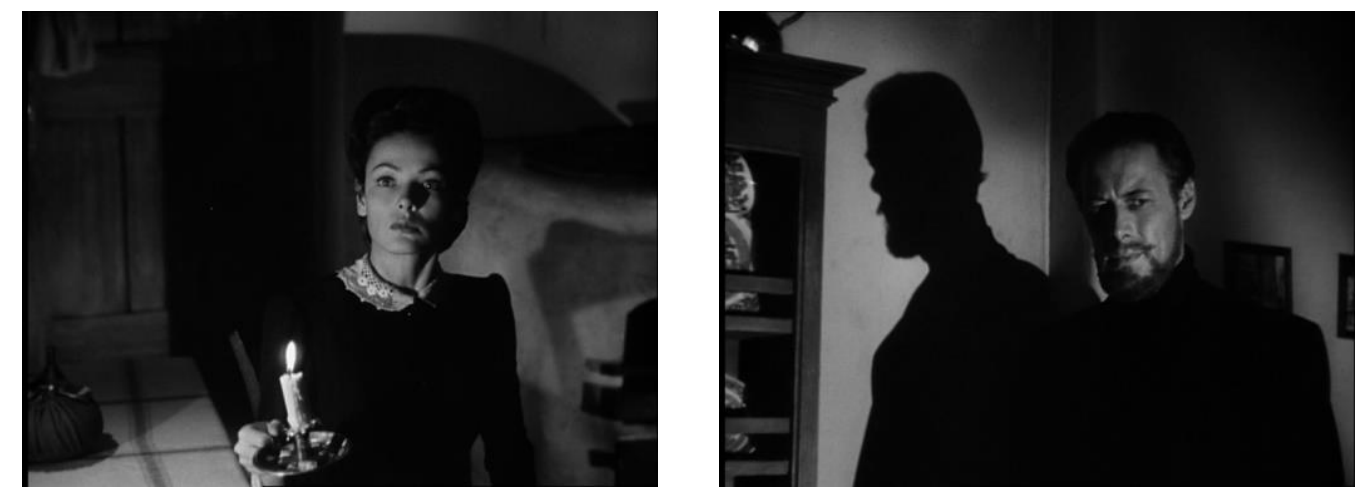

"Desenhada" pela luz da vela, a sombra se projeta na parede com perfeição e nitidez. A potência de figuração derivada da interação luz-sombra se afirma com força total. Se a distribuição perspectiva da luz é a condição de aparição da figura, a sombra, por sua vez, é a própria figura: é ela que "sai do corpo" para se projetar na parede fornecendo um duplo do morto, um fantasma de substituição. É na porção da imagem em que a luz não consegue 
chegar - a porção que permanece na sombra - que a "verdadeira" figura se forma e se origina. O corpo de Gregg é apenas o anteparo necessário para que a sombra seja recortada no muro (parte da luz precisa ser bloqueada para que a figura se constitua): a posição que ele ocupa na cena é intermediária, e não central como se poderia crer num primeiro momento. Mankiewicz criou todo esse jogo para que pudéssemos ver menos o rosto do que a sombra de Gregg. $\mathrm{O}$ rosto, aliás, já aparecera no retrato que a Sra. Muir tinha visto numa cena anterior (retrato este que se tornaria praticamente onipresente no filme):

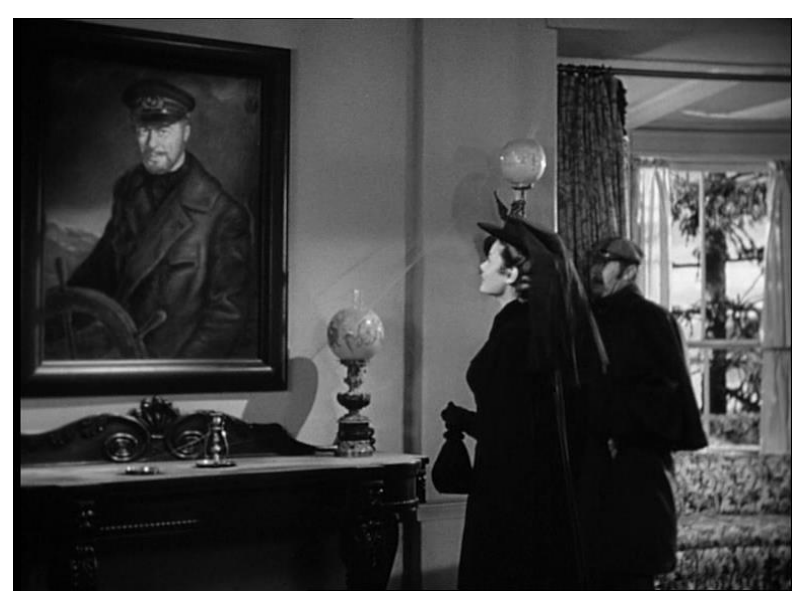

O corretor de imóveis que a levara até lá abriu a cortina da sala para que a luz entrasse e irrigasse melhor o ambiente, permitindo a contemplação do quadro (que quase todas as personagens do filme qualificam como pintura "ruim" ou "de mau gosto" - "It's a very poor painting”, diz a própria Sra. Muir). A lógica é mais ou menos a mesma da cena comentada anteriormente: a luz é necessária para que a figura se destaque da sombra. Aqui, porém, a luz simplesmente se distribui pela superfície em que a imagem já está inscrita, ao passo que, na cena em que a Sra. Muir vê o fantasma, a luz provoca a aparição da imagem, esculpindo-a na matéria-sombra (ela retira da massa de sombra o que não pertence à figura, como um escultor retiraria do bloco de pedra tudo o que não pertencesse à escultura). Isso se deve ao fato de que a luz, na cena do fantasma, não se espalha pelo espaço de forma homogênea, mas é intercalada pela sombra, e esta, tal como a luz, possui uma "força de formação (gestaltende Kraft)"," devendo ser igualmente encarada como "um fator de estruturação, de in-formação da imagem". ${ }^{72} \mathrm{Na}$ cena do retrato, a imagem tão somente se mostra; na cena do fantasma, ela se forma, e um novo retrato de Gregg é fabricado, desta vez com os materiais específicos do cinema.

\footnotetext{
${ }_{71}^{71}$ J. Aumont, Le montreur d'ombre, p. 154.

${ }^{72}$ Ibid., p. 150.
} 
Se Mankiewicz evoca o mito do nascimento da pintura, é porque as circunstâncias amorosas do filme remetem à fábula narrada por Plínio: o amor irrealizável entre o fantasma e a Sra. Muir cria um dilema de ausência que eles buscam contornar (no duplo sentido de traçar o contorno e superar). Gregg é o "fantasma do desejo" que a recatada viúva guarda para si. Enquanto escreve a biografia do Capitão (as memórias de marinheiro que ele mesmo dita para ela), a Sra. Muir se apaixona por ele e, de certa forma, refaz seu retrato (com palavras e não pinceladas), numa versão mais interessante e menos toscamente narcisista que aquela do quadro exibido na casa. Como a jovem do texto de Plínio, ela fixa a imagem de um rosto amado na iminência de partir (pois é próprio dos fantasmas - assim como dos "homens do mar" - aparecer de tempos em tempos, somente para depois sumir novamente). Naquele momento em que a Sra. Muir topou com o fantasma pela primeira vez e projetou na parede, com a ajuda de uma vela, a sombra do seu perfil, restituindo a cena inaugural do mito fundador da pintura, Mankiewicz já estava colocando o filme sob o signo de uma ausência que a arte do retrato (pintado, filmado, falado, escrito) viria preencher com as formas ditadas pelo desejo.

Em Vertigo, trata-se também de reencontrar um rosto perdido ou ausente, de salvá-lo da sombra do esquecimento, "o que faz do filme em sua totalidade um retrato, uma mise en scène que se identifica ao ato do retrato enquanto ato de representação por meio de um contorno retraçado a partir da sombra projetada de um perfil". ${ }^{73}$ Neste sentido, o mais importante perfil mostrado em Vertigo é aquele de Judy em contraluz no quarto do Empire Hotel, já no terço final do filme:

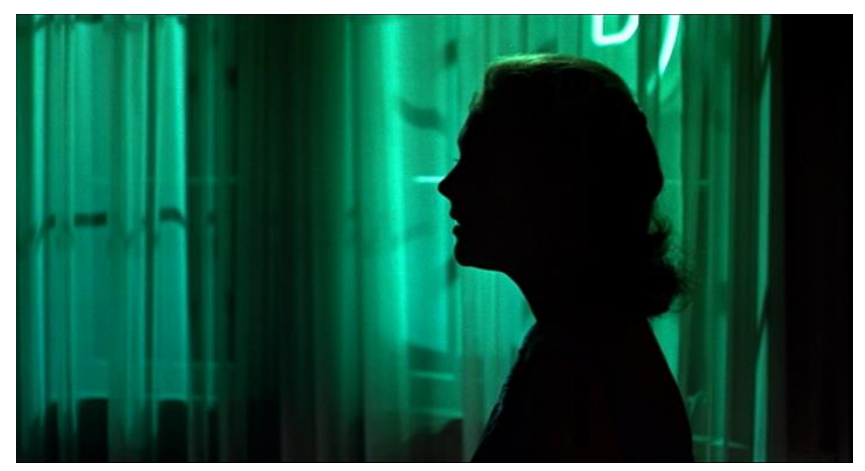

Judy e Scottie haviam saído para jantar no Ernie's; agora, Scottie tenta convencê-la a passar o dia seguinte ao lado dele; Judy aceitará, e terá início o processo de transformação que

${ }^{73}$ D. Païni, op. cit., p. 49. 
Scottie conduzirá com determinação inabalável, sem descansar antes de ver a obra acabada. Naquele breve momento em que tem a silhueta completamente afundada na sombra, Judy ocupa o limbo entre sua identidade atual e o retorno do fantasma de Madeleine. É apreendendo o contorno dessa sombra que Scottie, conectando-se às origens míticas da pintura, começará a recuperar a imagem do amor perdido. “É todo o 'passado' que 'regressa'", 74

A imagem de Judy em contraluz, rosto virado para a esquerda, com a janela inundada pelo verde do néon ao fundo (cor que, de acordo com uma tradição do teatro vitoriano, está ligada à representação da morte), é como o negativo do plano de perfil que coroara a deslumbrante entrada em cena de Madeleine no Ernie's. Comparado àquele perfil de Madeleine sobre o fundo carmesim do restaurante, o de Judy na penumbra do seu quarto no hotel Empire está "em posição de contraprova". "Mas em Vertigo, tal como na arte da fotografia e do cinema, o negativo é que é o original, e o positivo a contrafacção". ${ }^{75}$

Naquela sua primeira aparição no Ernie's, Madeleine pertencia ainda ao mundo das "beldades supra-sensoriais" "76 que costumam figurar nas narrativas de duplos. Uma longa expectativa e um complicado trajeto sinuoso precederiam o momento em que Scottie poderia, enfim, tocá-la, após salvá-la do afogamento. Era como se houvesse nela, a princípio, algo de sagrado e intangível. Mas, como diz Lorde Henry em O retrato de Dorian Gray, "somente as coisas sagradas merecem ser tocadas".

Por terem relação, muitas vezes, com esse tipo de representação da beleza como algo indefectível, no limiar do inalcançável e do imaterializável, as "ficções de retrato" frequentemente mostram a obstinação e a insistência quase doentia do pintor, que luta para extrair do modelo a forma idealizada. É o que Marc Vernet define como a "ditadura do ideal". ${ }^{77}$ Fazer a ideia se encarnar na cor pode significar um sacrifício irreparável, como ocorre nas diversas narrativas em que "a pintura mata seu modelo, espreme-o como um limão para fazê-lo desaparecer em benefício do que é representado". ${ }^{78}$ A arte rouba do modelo o

\footnotetext{
${ }^{74}$ V. I. Stoichita, O efeito Pigmalião, p. 208.

${ }^{75}$ Ibid., p. 208.

${ }^{76}$ Ibid., p. 98.

${ }^{77}$ M. Vernet, art. cit., p. 48.

${ }^{78}$ Ibid., p. 49.
} 
sumo, a substância que instila vida nas formas. "Se a vida passa para o retrato, a morte invade o modelo". 79

Em Inspiração trágica (The Two Mrs. Carrolls, Peter Godfrey, 1947), o adoecimento progressivo da esposa do pintor coincide com o aperfeiçoamento do retrato que ele faz dela. Numa trama, por assim dizer, sub-hitchcockiana, o pintor (interpretado por Humphrey Bogart) repete com sua segunda esposa o que havia feito com a primeira: enquanto prepara o retrato para o qual ela posou (e que a representa com feições absolutamente macabras), ele a envenena paulatinamente. Para piorar, envolve-se com outra mulher, que será modelo do próximo quadro. A mulher é tomada aí como metáfora da inspiração do artista: a cada novo estágio de sua obra, o pintor precisa de um novo turno de inspiração, ou seja, de uma nova mulher. O demônio da forma, uma vez tendo extraído todas as forças do modelo, precisa migrar para outro corpo.

A arte vampiriza. O pincel fere: em A queda da casa de Usher (La chute de la maison Usher, 1928), Jean Epstein corta do plano-detalhe de uma pincelada aplicada ao rosto da figura no quadro para um primeiro plano da esposa-modelo do pintor, que sente o gesto pictórico como se fosse um tapa - antes uma agressão do que uma carícia erótica - naquela mesma região do rosto, numa relação especular que iguala a tela à pele. $\mathrm{O}$ corte seco da montagem potencializa a impetuosidade do "golpe de pincel".
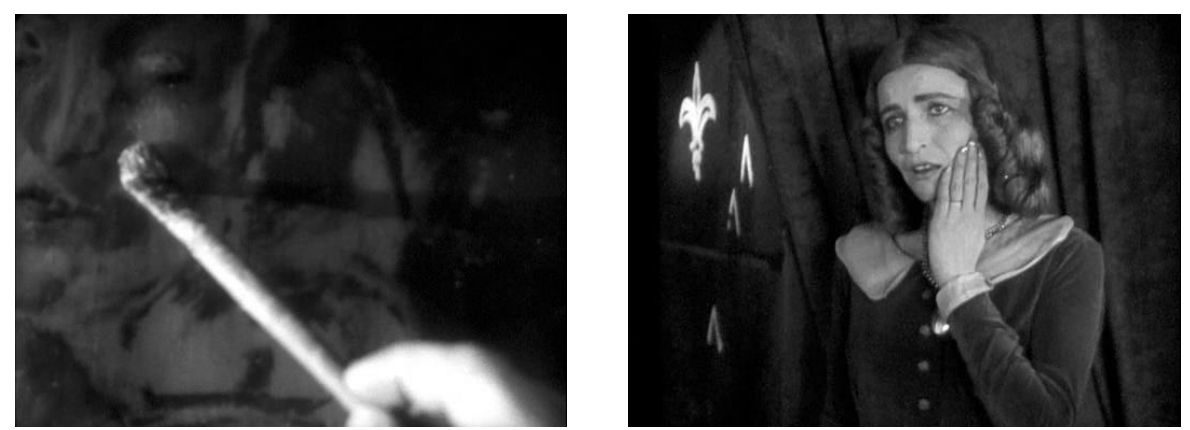

Pintar, nessa lógica, é sugar a vida do modelo para injetá-la no quadro. O modelo sente na carne o processo que consiste em ter sua alma capturada pelo retrato, tal como difundido pela velha crença de que a imagem consome a vida na representação. A matriz eterna, neste caso, é um dos contos mais famosos de Edgar Allan Poe, “O retrato oval”, que o cinema já vem visitando há muitas décadas (a exemplo do próprio A queda da casa de Usher). O conto começa com um homem chegando a um castelo abandonado e se instalando num aposento 
repleto de pinturas, onde decide pernoitar. Ele se entrega, por horas a fio, à contemplação dos quadros e à leitura de um pequeno tomo que foi deixado sobre o travesseiro, e que consiste num livro contendo críticas e histórias sobre as pinturas ali presentes. Quando desloca o candelabro para melhor enxergar as páginas do livro, os raios das inúmeras velas iluminam, de forma inesperada, um quadro que até então, "envolto na densa sombra de uma das colunas da cama”, passara-lhe despercebido: o retrato de uma jovem mulher. Após cerca de uma hora refletindo sobre o motivo de sua estupefação em face da pintura, ele conclui que "o encanto do quadro residia na perfeição absoluta da expressão naquele rosto que parecia vivo". ${ }^{80}$ Procura com avidez, no volume que discorre sobre as pinturas e suas histórias, o número que corresponde ao retrato oval. O que lê o deixa ainda mais perplexo: a moça, casada com um jovem e renomado pintor, aceitara posar para ele dia e noite, hora após hora, semana após semana, encarcerada num torreão solitário onde sua saúde piorava sensível e gradativamente. Só o marido não percebia essa debilitação da esposa, embevecido que estava com a tela e as tintas. Na medida em que o trabalho se aproximava do fim, o pintor tomava-se de arrebatamento cada vez maior e "mal despregava os olhos da tela, mesmo que fosse para olhar o rosto da esposa" (p. 69). Depois da última pincelada, "o pintor ficou em transe diante da obra que executara; mas no momento seguinte, ainda olhando a pintura, ficou pálido e começou a tremer; horrorizado, gritou: 'Isso é a própria Vida!' e virou-se para contemplar a amada: Ela estava morta!"' (p. 69).

O primeiro aspecto que liga esse conto a Vertigo é o fato de que o retrato oval é uma representação na representação, uma imagem dentro da imagem: toda a primeira parte do conto, descrevendo o espaço do castelo e a forma como o homem aí se instala e começa a apreciar as pinturas, funciona como a suntuosa moldura do quadro que surgirá a seguir, e que é o verdadeiro núcleo da narrativa. Há, portanto, uma internalização da forma-retrato na própria estrutura do conto (já falamos da "mise en portrait" $" 81$ da narrativa de Vertigo). $\mathrm{O}$ segundo aspecto a se frisar é a progressiva idealização a que o retrato vai sendo submetido: em determinado momento, o pintor deixa de olhar para a esposa e passa a trabalhar guiado tão somente por uma imagem mental, por um desenho interior que, embora inspirado na realidade sensória, já dela se emancipou. Foi preciso dar as costas ao modelo real para extrair-lhe a beleza ideal. Todo retrato, ainda que individual, implica um tipo idealizado: na imagemretrato, "a semelhança deve ser produzida em virtude do encontro da imagem mimética com

\footnotetext{
${ }^{80}$ E. A. Poe, “O retrato oval”, in $O$ gato preto e outros contos, São Paulo: Hedra, 2008, p. 67.

${ }^{81}$ D. Païni, op. cit., p. 49.
} 
uma ideia do modelo". ${ }^{82}$ Acontece que a trama complicada da vida atrapalha o olho que quer chegar à beleza última e absoluta dos seres. É a morte, parceira da idealização, quem desobstrui o caminho para o desenho perfeito do artista: ao estancar e coagular o fluxo informe da existência, ela faz surgir o molde, a forma ideal, o eidos que orientará o pintor na concepção do retrato. Scottie, durante toda a remodelagem de Judy, age como a personagem do conto de Poe, e também se guia por uma imagem mental egressa da morte, por um investimento obsessivo na imagem-Madeleine que ele quer ver se materializar a todo custo. $\mathrm{O}$ pintor do retrato oval tinha "a Arte por esposa". Sua jovem mulher, "toda luz e sorrisos", que “amava e apegava-se a tudo, detestava somente a Arte, que era sua rival” (p. 68). Em Vertigo, é a mesma coisa: a rival de Judy não é nenhuma mulher de carne e osso, mas o fantasma introjetado na mente do "artista", o demônio da forma que instila a obsessão de Scottie de refazer Madeleine. Levada às últimas consequências, essa pulsão formativa se traduz num processo de criação radical que, como demonstrou o conto, consiste na vampirização das energias vitais da modelo, que são transferidas para a forma. Assim, à medida que a bela modelo definha, o quadro adquire mais e mais vida, brilho, vigor. $\mathrm{O}$ arremate final só pode significar que o ato de transfusão se deu por completo, e que toda a beleza e energia passaram da modelo para o quadro. Da mesma forma que o retrato oval só se completa com a morte da esposa do pintor (nada mais hitchcockiano, aliás, do que matar a esposa), o filme-retrato de Hitchcock só fica pronto quando sua modelo/atriz cai do alto da torre. O passo à frente dado por Scottie no último plano de Vertigo, fitando o abismo após a queda de Judy, equivale, apesar da inversão, ao passo para trás dado pelo pintor, que se afasta ligeiramente da tela para conferir a obra acabada.

Essa fixação da vida a partir da morte, que as ficções de retrato impõem quase como uma condição da representação, “exemplifica diretamente a dimensão reflexiva do signo. Todo signo, no momento mesmo em que torna presente um ser ausente ou morto, reduplica, reflete ou endossa a operação de representação". ${ }^{83} \mathrm{Se}$ "representar significa antes de tudo substituir alguma coisa presente por alguma coisa ausente (o que é, em linhas gerais, a estrutura do signo)" ${ }^{84}$, os "retratos mortais" da literatura e do cinema oferecem a forma exemplar da economia mimética dessa substituição: o representado é suprimido, para que só reste sua representação.

\footnotetext{
${ }^{82}$ J. Aumont, De l'esthétique au présent, Paris/Bruxelas: De Boeck Université, 1998, p. 113.

${ }^{83}$ L. Marin, De la représentation, op. cit., pp. 354-355.

${ }^{84}$ Ibid., p. 342.
} 
O historiador da arte Édouard Pommier afirma que "o retrato é signo de uma ausência, expressão de uma nostalgia, resposta à morte. [...] $\mathrm{O}$ retrato nasce sob o signo de uma memória trágica". ${ }^{85}$ Esse gênero pictórico está ligado, na arte ocidental, à morte - passada ou futura - do sujeito representado. Enquanto substituição do modelo por sua imagem, o retrato “implica, ao menos em longo prazo, a ausência do modelo e, portanto, virtualmente sua morte". ${ }^{86}$ E essa ausência deve ser vista não só como "ausência do modelo para o espectador do retrato, mas ausência do original para si mesmo": o retrato "converte a ausência da pessoa presente em presença da pessoa ausente". ${ }^{87}$ Ele poderia ser definido como "a imagem que se concebe pela retirada [retrait] daquele de que ela é imagem". 88

Há um filme anônimo da Gaumont, Le portrait inachevé ("O retrato inacabado"), de $1910^{89}$, que ilustra essa lógica com clareza e simplicidade. O protagonista, o marquês Pierre de Beaune, pintor nas horas vagas, dedica-se ao retrato da sua adorada esposa Jeanne. Numa tarde, eles saem para caçar e, por um descuido, o marquês mata a esposa acidentalmente, cumprindo o destino fatal do retrato (a retirada, a morte do retratado). Depois da tragédia, ele fica obcecado com a lembrança de Jeanne e, para imortalizá-la, decide terminar o retrato utilizando outra mulher como modelo. Enquanto trabalha no retrato, ele tem uma alucinação e vê a mulher se transformar em Jeanne. Pierre entra em desespero e desiste do retrato.
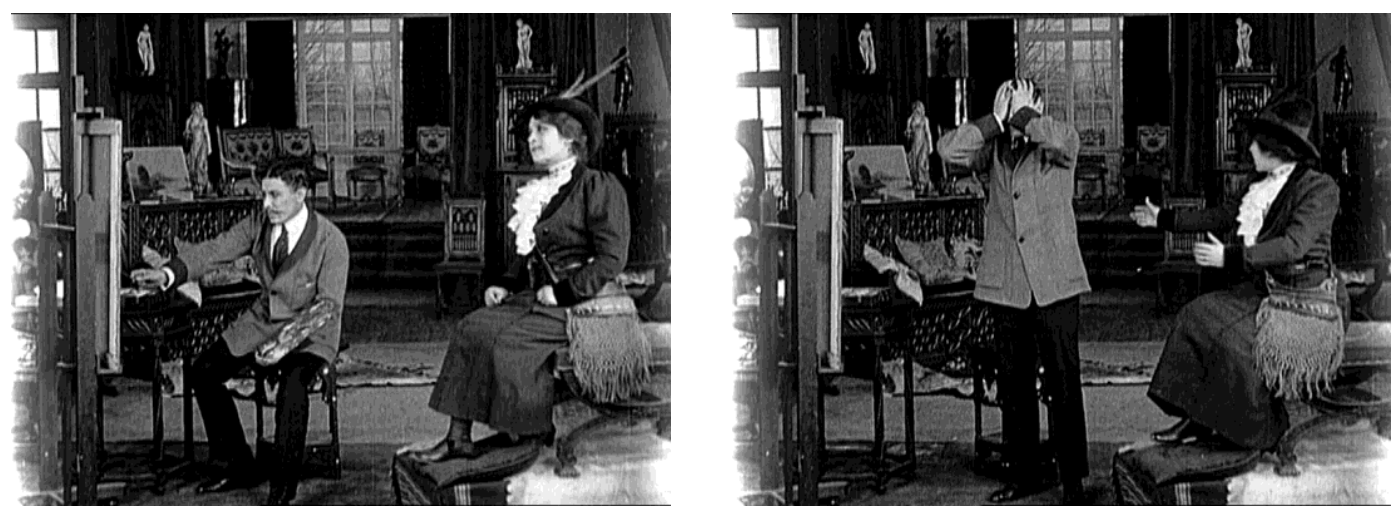

Numa cena posterior, seus amigos o levam para jantar num restaurante chique, onde ele avista uma sósia de Jeanne. Ele vai atrás da moça e descobre que ela se chama Madeleine.

\footnotetext{
${ }^{85}$ E. Pommier, Théories du portrait. De la Renaissance aux Lumières, Paris: Gallimard, 1998, p. 20.

${ }^{86}$ Jean-Luc Nancy, L'Autre Portrait, Paris: Galilée, 2014, p. 19.

${ }^{87}$ Ibid., p. 21.

${ }^{88}$ Ibid., p. 50.

${ }^{89}$ Eric de Kuyper, com base em uma cópia encontrada na cinemateca holandesa, identifica o filme como sendo de Léonce Perret e lhe atribui outro título, Le Portrait de Mireille (ver seu artigo "Le cinéma de la seconde époque: Le muet des années dix”, em Révue Cinémathèque, n. 1, maio de 1992, pp. 28-35).
} 
Faz-lhe uma visita no dia seguinte, mas, atordoado com a semelhança entre as duas mulheres e sentindo-se culpado por trair a memória de Jeanne com outra, Pierre vê o fantasma de sua falecida esposa aparecer para lhe reprovar.

O marquês acaba se casando com Madeleine. Sua vida conjugal, entretanto, não deslancha, pois ele vive atormentado pela lembrança da morta e não consegue ser feliz ao lado da nova esposa, que descobre um retrato de Jeanne (uma fotografia) e, percebendo sua semelhança com a morta, compreende a infelicidade do marido. Ela resolve então se vestir e se pentear como a primeira esposa do marquês, para deixá-lo feliz. Dois planos dela diante do espelho mostram os momentos em que descobre a semelhança e efetua a transformação:
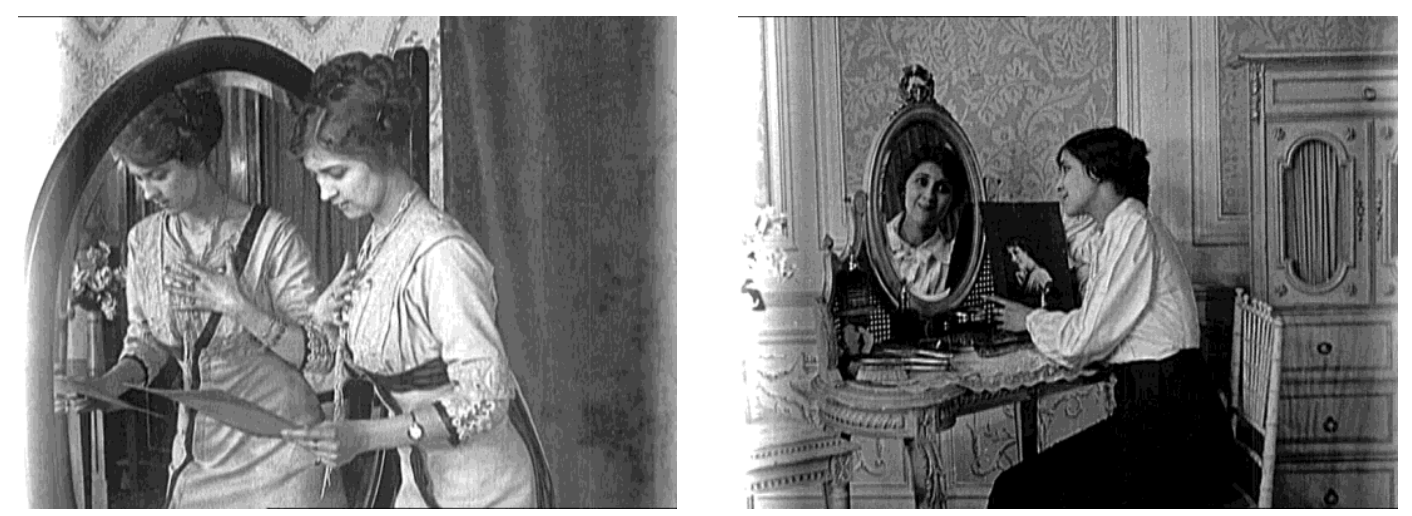

Pierre, ao ver Madeleine transformada em Jeanne, enxerga nisso uma autêntica prova de amor. A última cartela de intertítulos informa que, "consciente do amor que Madeleine lhe traz, Pierre poderá amá-la de volta”.

Não é preciso nenhum esforço para ver as semelhanças deste filme com Vertigo mesmo que o seu final seja feliz, ao contrário do desfecho trágico do filme de Hitchcock. Segundo Pierre-Henry Frangne, isso provavelmente se deve a uma origem literária comum: tanto Le portrait inachevé como Vertigo ecoariam o romance Bruges-a-morta (1892), do escritor simbolista belga Georges Rodenbach (o livro ficou conhecido, entre outras coisas, por ter sido a primeira obra literária de ficção ilustrada por fotografias). ${ }^{90} \mathrm{O}$ romance conta a história de um homem que, pouco tempo depois da morte da esposa, vai à cidade de Bruges em busca de silêncio e monotonia. Ele passa a maior parte do dia dentro de casa, onde guarda relíquias da mulher morta (incluindo uma mecha do seu cabelo). À noite, vaga pelas ruas e canais da pitoresca cidade histórica, que espelha o seu luto. Ao assistir a um espetáculo de

\footnotetext{
${ }^{90}$ Ver P.-H. Frangne, "The willing suspension of disbelief: La fiction cinématographique entre simulacre et simulation", in FIANT, Antony, FRANGNE, Pierre-Henry, MOUËLLIC, Gilles (orgs.), Les oeuvres d'art dans le cinéma de fiction, Presses Universitaires de Rennes, 2014, p. 307.
} 
ópera, percebe que uma das intérpretes é idêntica à sua esposa morta. Ele fica obcecado com ela e inicia uma relação. Mas, com o tempo, percebe que ela é bastante diferente da esposa, e tudo se encaminha para a tragédia.

No filme da Gaumont, que é "uma versão positiva e simplificada" do romance, como afirma Frangne, "manifesta-se aquilo a que Rodenbach chama o 'poder indefinível da semelhança' como uma potência de ressurreição e de presentificação sem os aspectos ilusórios e mortíferos que essa potência adquire no romance simbolista e [em Vertigo]". ${ }^{91} \mathrm{O}$ mais interessante, sem dúvida, é notar que Le portrait inachevé já apresenta os mesmos acessórios visuais e ficcionais - espelhos, retratos, fantasmas, duplos - da "mise en scène da magia das imagens" "92 que Vertigo e boa parte das ficções de retrato dos anos 1940-50 apenas desenvolveriam de maneira mais sofisticada. A produção da Gaumont já se baseia na força mágica do retrato e no seu diálogo com a morte, que seriam premissas reincidentes nesses filmes, como constatamos mais cedo.

Alguns anos depois de Le portrait inachevé, o cineasta russo Evgenii Bauer realizaria Gryozy (1915), uma adaptação mais nuançada do romance de Rodenbach. O filme começa com a profunda tristeza de Sergei após perder sua esposa Elena, de quem ele guarda muitos retratos e uma mecha de cabelo que obteve enquanto ela jazia no leito de morte. Um dia, numa caminhada melancólica pela rua, Sergei topa com uma mulher igualzinha a Elena. Ele a persegue até um teatro, onde ela é uma das dançarinas da ópera Robert le diable, de Meyerbeer (a mesma ópera a que o protagonista do livro de Rodenbach assiste). No clímax do espetáculo, uma mulher (interpretada pela sósia de Elena) levanta do túmulo, retorna do mundo dos mortos, mas depois é novamente devolvida a ele. Sergei assiste completamente extasiado à encenação, exclamando pelo nome de Elena quando a sua "substituta" surge no palco. A plateia do teatro o toma por louco. Terminada a ópera, ele vai aos bastidores falar com a atriz. Nos dias que se seguem, passa a ter encontros regulares com ela. Empolgado com o novo relacionamento, pede a um amigo pintor que faça o retrato da moça. A decepção começa quando ele a surpreende se atirando nos braços do pintor no ateliê deste último. Ela acusa Sergei de entediá-la com sua fascinação pela mulher morta. Ele tenta reatar o relacionamento, mas a tragédia se impõe quando ela debocha dos objetos de Elena que ele guarda como recordação. Ela pega a mecha de cabelo de Elena e começa a brincar, usando-a como cinto, tiara, cachecol. Sergei fica possesso, e a enforca com a própria mecha de cabelo.

\footnotetext{
${ }^{91}$ Ibid.

${ }^{92}$ Ibid., p. 309.
} 
Bauer resgata, portanto, o final trágico de Bruges-a-morta, que Le portrait inachevé havia trocado por um final feliz. Com o dobro da duração do filme da Gaumont, Gryozy conta com muito mais nuanças plásticas e narrativas. Os retratos, por exemplo, são integrados à composição dos planos de forma bem mais detalhada e pensada (o que não necessariamente deve ser visto como uma "evolução estética" que o cinema teria atingido entre 1910 e 1915).
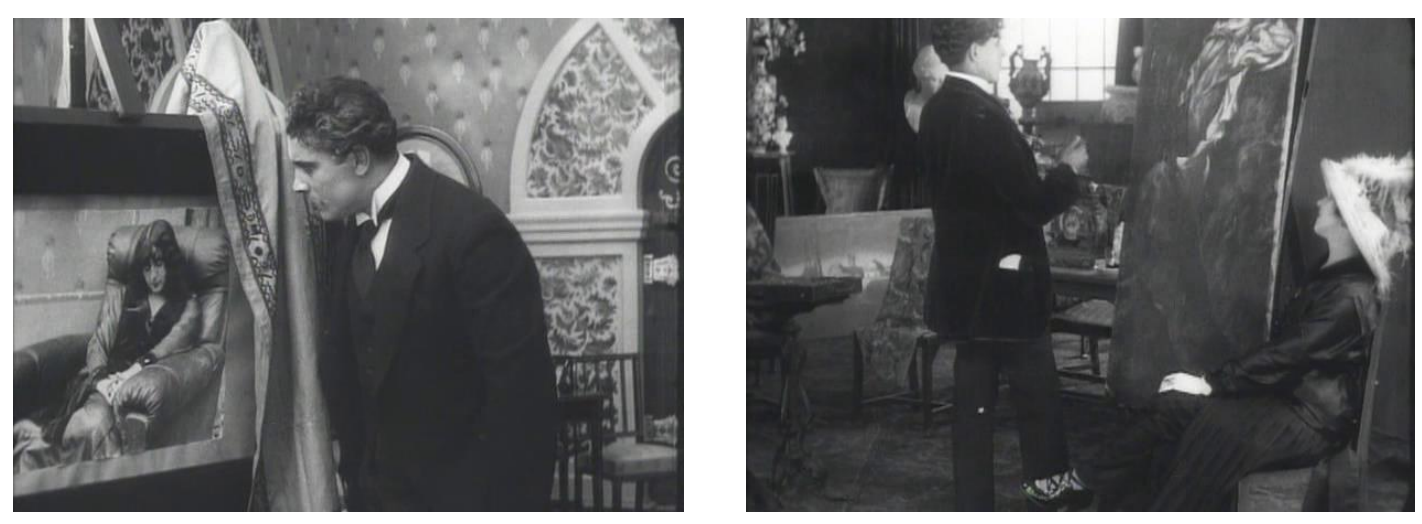

Assim como os espelhos, os retratos foram ferramentas visuais comuns no cinema russo dos anos 1910 - sobretudo quando associados a estórias místicas adaptadas de obras literárias de grande popularidade na época ${ }^{93}$-, e Evgenii Bauer foi provavelmente o mais engenhoso cineasta do período a fazer uso dessas ferramentas.

Em Gryozy, ele afirma o poder do retrato como meio de comunicação com os mortos. Bem no início, a faxineira de Sergei acidentalmente derruba com o espanador um dos retratos da falecida Elena. O retrato cai no chão e o vidro que o protegia se espatifa. É como se naquele momento o fantasma de Elena fosse libertado da imagem. Não por acaso, ela fará uma aparição espectral já na parte final do filme, como projeção da consciência atormentada de Sergei. O truque que inscreve o fantasma na cena é um efeito visual muito bem sucedido: a aparição é representada como imagem diáfana, corpo sem corpo, figura delgada tão mais presente e credível quanto menos palpável e real. Em Le portrait inachevé, a aparição do fantasma não diferia em nada do que se teria feito numa peça de teatro sem efeitos especiais: uma mulher com vestes brancas (convenção básica) surge por uma porta, uma entrada lateral do espaço cênico, e se aproxima do protagonista. Em Gryozy, é completamente diferente: o fantasma surge do interior mesmo da imagem, como uma segunda imagem que brota de dentro da primeira - uma imagem mais fina, mais delicada, uma figura de luz que pode (e vai) desaparecer a qualquer momento. É o próprio cinema (seu material, sua imagem) que se prova

\footnotetext{
${ }^{93}$ Cf. Yuri Tsivian, "Portraits, Mirrors, Death: On Some Decadent Clichés in Early Russian Films", in Iris, n. 14-15, outono de 1992, pp. 67-82.
} 
um lugar de fantasmas. Bauer encontra uma forma, por assim dizer, mais "especificamente cinematográfica" de filmar a aparição de um fantasma, ou uma maior cumplicidade entre o tema e o suporte em que ele é representado.
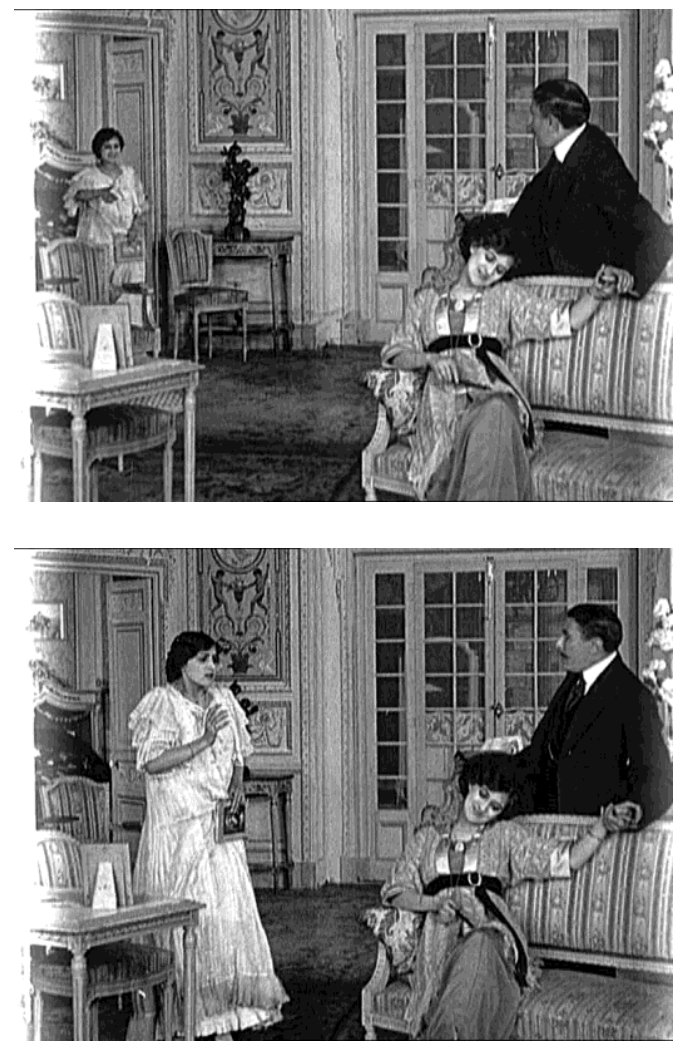

Le portrait inachevé, Léonce Perret (?), 1910
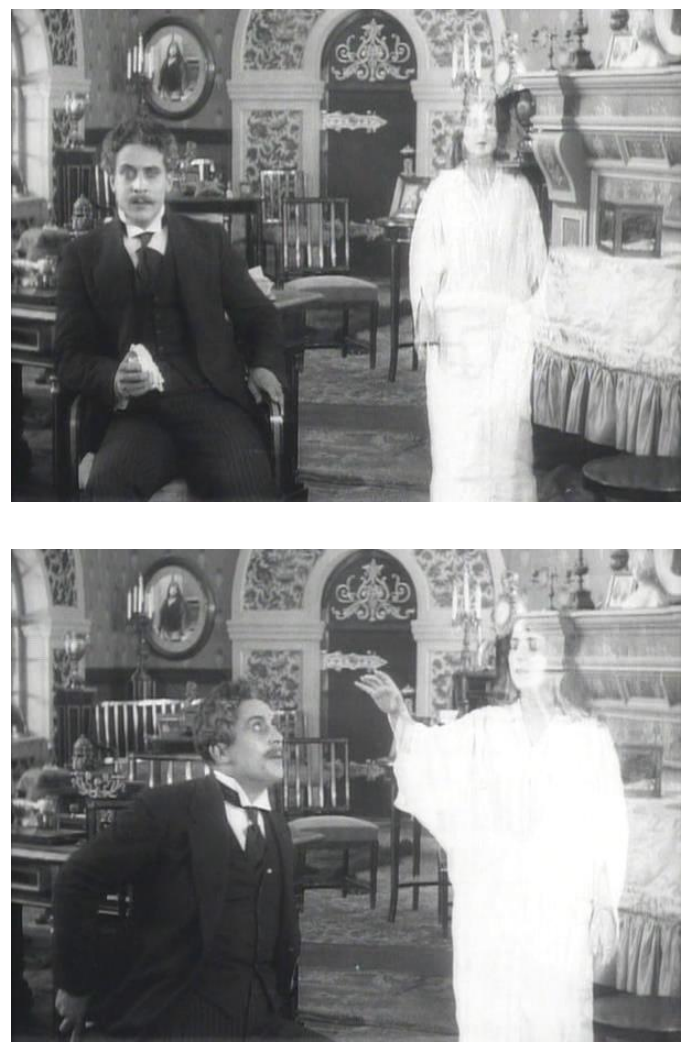

Gryozy, Evgenii Bauer, 1915

Para além desta ou daquela diferença entre os dois filmes, interessa-nos aqui constatar que tanto Gryozy como Le portrait inachevé fazem parte do variado conjunto de filmes realizados em diferentes países e épocas - que demonstram como a história de Vertigo começa bem antes dele próprio. Essa história, que extrapola a do próprio cinema, vai sendo anunciada de pouco em pouco, por intermédio de narrativas, imagens, motivos e fantasmas que retornam.

\section{O passado de Hollywood}

Na cena em que conhece Judy no hotel Empire, Scottie pergunta há quanto tempo ela vive em São Francisco. "Há três anos", ela responde. E onde vivia antes? Salina, Kansas. De fato, três anos antes de Vertigo, Kim Novak estava em Salina, Kansas, cidade do melodrama 
Férias de amor (Picnic, Joshua Logan, 1955), que ela protagonizou ao lado de William Holden. Numa das primeiras cenas do filme, há um enquadramento que segue a mesma lógica da representação “em retrato” de Madeleine no Ernie's:

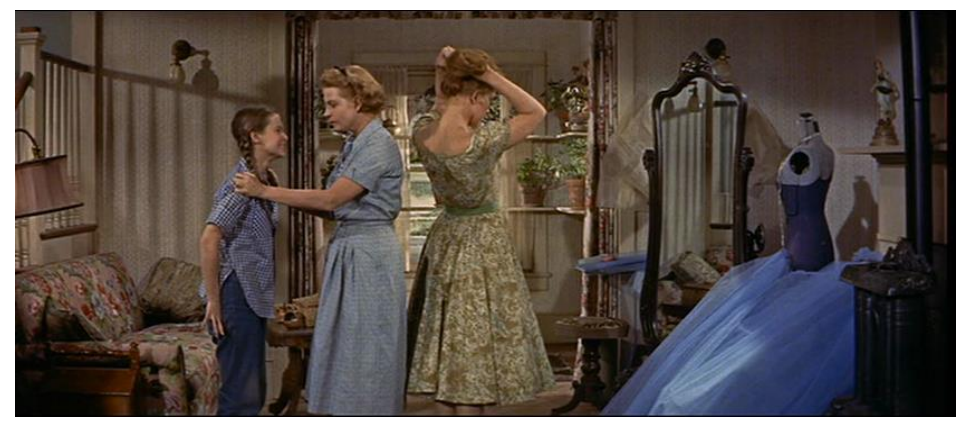

Madge (Novak) prende o cabelo em frente ao espelho (não vemos seu reflexo). À direita do quadro, há um manequim com o vestido azul que logo em seguida estará experimentando. Ela ocupa exatamente o centro do plano, emoldurada pelo recorte do ambiente mais ao fundo. Nem a mãe nem a irmã mais nova se ajustam à moldura; apenas Madge parece talhada para esse recorte extra, essa posição de destaque.

Quando Madge já está com o vestido azul, a mãe vira o espelho em sua direção (a composição rima vagamente com o plano do espelho na loja de flores em Vertigo).

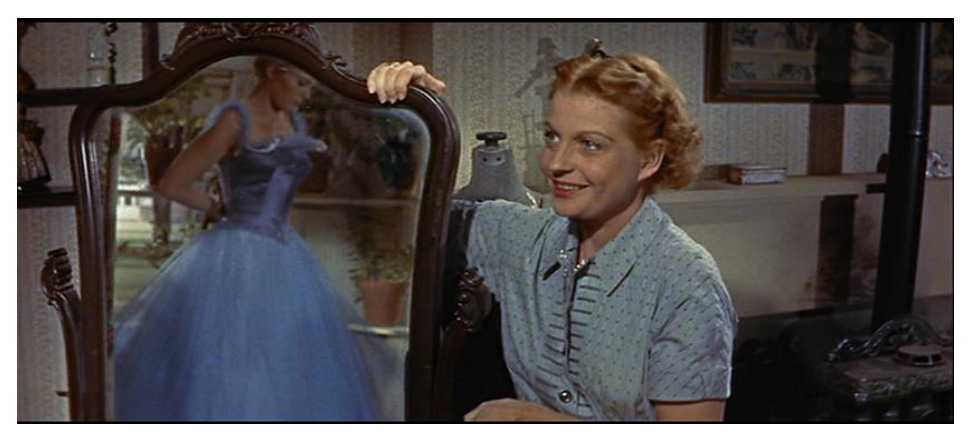

A rotação do espelho carrega os raios solares até Madge, que olha para o chão com ar melancólico. Sua aparente tristeza se justifica na imagem: ela está aprisionada pelas bordas do espelho, pelos contornos traçados por um certo código de beleza e comportamento. Em última análise, ela está aprisionada pela própria perfeição de sua silhueta.

Madge volta a estar frisada pela moldura no plano seguinte. O espelho, por sua vez, continua desviando os raios solares na direção dela, que se porta como se estivesse posando para um pintor (ou exposta numa vitrine?): 


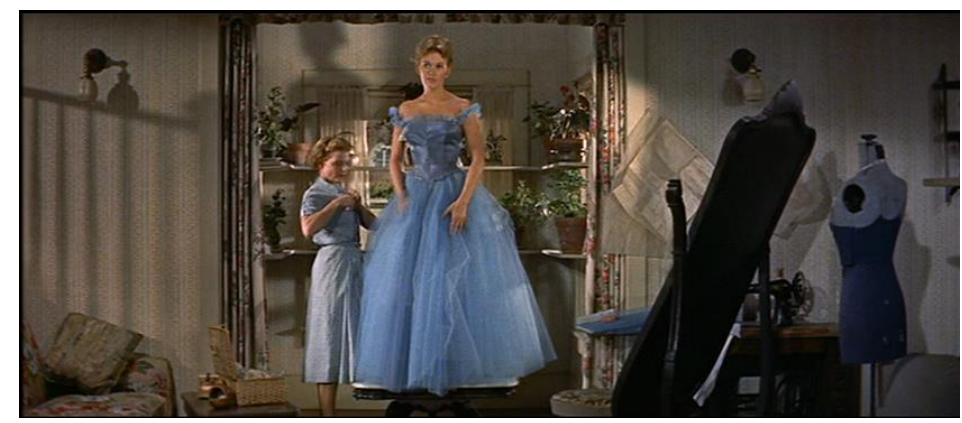

Há uma mudança fundamental nessa passagem de planos. Se, no plano anterior, o espelho continha a imagem refletida de Madge, neste agora, é o corpo de Madge que recebe a imagem que o espelho - subvertendo sua função original - projeta no quadro-dentro-doquadro. Colocada num pedestal, sob o holofote natural da luz solar, bela e cobiçada como nenhuma outra mulher da cidade, Madge é um objeto, uma obra de arte. O manequim no canto direito do plano é um comentário visual sobre a constrição do corpo de Madge a um padrão preestabelecido. "Talvez eu esteja cansada de apenas ser olhada", ela diz. É por perceber que as pessoas à sua volta a transformaram em imagem - e, portanto, desistiram de olhar para além de sua aparência - que Madge se diz cansada e revela aquela ponta de tristeza no olhar. Sua mãe, no diálogo que compõe a cena, dá conselhos para que a filha se case logo com Alan, filho do homem mais rico da região, dono de uma fábrica de grãos, insinuando até que ela aproveite a ocasião (é o dia do grande piquenique anual da cidade) para presenteá-lo com uns afagos a mais. Madge, pura energia sexual reprimida, fica magoada com os comentários da mãe e sobe ao quarto para chorar.

Tudo muda com a chegada de Hal (William Holden), ex-colega de faculdade de Alan, e seu oposto: atlético, atraente, pobre, desajustado, nômade. Ele e Madge se apaixonam, e ela foge atrás dele no final, pegando o primeiro ônibus para lugar nenhum.

Três anos depois, quando estiver em São Francisco, dirigindo um carrão e frequentando endereços chiques na pele da esposa de um grande industrial, a musa de Salina demonstrará que não escapou das molduras, da idealização de sua imagem, do devir-retrato, do olhar fetichizante dos homens. Ela terá encarnado, contudo, a fantasia de riqueza que sua mãe tentava lhe inculcar. Ela terá atravessado o espelho.

Do outro lado do espelho, ela encontra um mundo muito particular, um mundo de sonho (e de pesadelo) que recria reflexivamente - nas subcamadas do enredo de suspense, pela miríade de signos e falsas aparências provenientes de uma decantação dos elementos de base do film noir - o próprio universo de Hollywood, com seu código ficcional e seu sistema 
de produção específicos. O mundo de Vertigo seria uma recomposição - com substituição dos termos - do mundo encantado de Hollywood: em nenhum momento se enuncia de forma direta e indisfarçada que estamos numa reinvenção fantasista do universo do cinema dos estúdios, com suas estrelas, produtores, egos e orçamentos inflados, mas é lá que o filme nos coloca, no fim das contas. Vertigo, "paráfrase" de Hollywood?

Para Jean-Pierre Esquenazi, esta seria uma das questões centrais do filme: "pode-se ler no jogo visual das formas de Vertigo as relações de força e de dominação de que Hollywood é feita". ${ }^{94}$ Em sua "análise semiótica sociológica", Esquenazi explora o contexto de preparação e realização do filme, procurando definir a inventividade de Hitchcock segundo uma dupla atitude de submissão/subversão em face das regras do cinema de gênero e do estrelato hollywoodiano. Hitchcock teria elaborado, com Vertigo, uma grande parábola sobre a moral do sistema dos estúdios e, mais precisamente, sobre o modo de funcionamento de um de seus pilares econômicos e simbólicos: o star system.

$\mathrm{Na}$ "idade de ouro" de Hollywood, uma parte considerável da receita das majors provinha do frisson gerado em torno de suas principais vedetas, no que contribuíam, além dos filmes em si mesmos, os eficazes serviços de publicidade da indústria cinematográfica e o gigantesco fenômeno sócio-midiático representado pelas fan magazines. ${ }^{95}$ Por estas e outras razões, a aparição da estrela no filme era um momento aguardado e valorizado através de uma série de recursos visuais e narrativos:

Quando a estrela é realmente uma estrela, sozinha ou acompanhada, o momento em que aparece no ecrã é infinitamente precioso - momento em que o nome que brilhou no genérico se torna finalmente corpo, com todas as dificuldades que isso implica. Tornada num dos principais elementos do início do filme, a entrada em cena da estrela está, de certo modo, relacionada com a elipse. [Pois] é tudo uma questão de escolha entre mostrar e não mostrar, dizer e não dizer; criar o desejo enquanto se joga com a frustração. ${ }^{96}$

A aparição de Kim Novak em Vertigo, uma das entradas em cena mais memoráveis da história do cinema, "concebida segundo o princípio do deslumbramento" (ibid., p. 58), é um exemplo completo do que foi dito acima. Hitchcock toma todas as providências para que a cena tenha um impacto estético diferente dos outros momentos do filme; os efeitos de mise en scène (sobre-enquadramentos, câmera subjetiva, movimentação de atores pausada e orquestrada, uso enfático das cores e da trilha sonora) potencializam o surgimento da estrela.

\footnotetext{
94 J.-P. Esquenazi, Hitchcock et l'aventure de Vertigo, pp. 202-203.

${ }^{95}$ Cf. Jacqueline Nacache, O cinema clássico de Hollywood, Lisboa: Texto \& Grafia, 2012, p. 52.

${ }^{96}$ Ibid., p. 53.
} 
Na sequência imediatamente anterior, Gavin Elster havia divagado sobre Madeleine por meio de uma retórica infalível, empregando os ardis mais maliciosos para despertar em Scottie uma curiosidade enorme a respeito de quem seria essa mulher misteriosa. Ao fazer alguém falar da personagem antes de efetivamente mostrá-la, o filme prenuncia a aparição da estrela, mas guarda-a para o momento "certo":

Por definição, a estrela deve aparecer o mais cedo possível; ao mesmo tempo, esta aparição é um momento de tal valor que não deve ser estragado nem desperdiçado. Daí o cuidado em mostrá-la sem a mostrar, fazendo falar dela, ou revelando-a a pouco e pouco, tanto no sentido literal como no sentido figurativo. ${ }^{97}$

Quando a visão promissora finalmente se materializa no restaurante Ernie's, não há frustração, pelo contrário: diversos artifícios de iluminação e enquadramento logram destacar a figura de Madeleine do restante do espaço. No entanto, Hitchcock não pode deixar de lado a tarefa de fundi-la realisticamente nesse cenário concebido quase que exclusivamente para ela. Eis por que a introdução da estrela no universo diegético é uma operação delicada: o diretor deve trabalhar no limiar do puro maravilhamento a-narrativo e, ao mesmo tempo, cuidar para "que a vedeta encontre o seu lugar na ficção o mais naturalmente possível” (ibid., p. 54).

Realizado numa época de questionamento em torno das receitas habituais das majors hollywoodianas, Vertigo reformula - com a dose de ironia e reflexividade que os estúdios se permitiam naquele momento ${ }^{98}$ - alguns dos esquemas mais triviais da mise en scène clássica, a exemplo dessas "figuras de aparição" (Nacache), esses rituais de entrada em cena das estrelas, que marcam a forma como o estilo romanesco hollywoodiano incorporou as demandas do star system. Através de Madeleine, Gavin Elster conquista a "participação afetiva" de Scottie, exatamente como Hollywood garante a adesão de uma plateia a um filme tão somente pela presença destacada de uma estrela na tela: "interagir com o espectador, antecipar seus desejos, se assegurar de seu apoio e de seu engajamento antes mesmo de lhe contar uma história, é assim que as majors sempre procederam, e é este também o método utilizado por Elster, verdadeiro inventor de 'Madeleine",. 99 Vertigo expõe a maquinação que

\footnotetext{
${ }^{97}$ Ibid., p. 56.

${ }^{98}$ Os anos 1950 estão recheados de ficções metafílmicas ambientadas nos bastidores de Hollywood e na vida privada das estrelas (decadentes ou em ascensão): Crepúsculo dos deuses (Sunset Blvd., Billy Wilder, 1950), Assim estava escrito (The bad and the beautiful, Vincente Minnelli, 1952), Cantando na chuva (Singin' in the rain, Stanley Donen e Gene Kelly, 1952), A grande chantagem (The big knife, Robert Aldrich, 1955), A condessa descalça (The barefoot contessa, Mankiewicz, 1954), Nasce uma estrela (A star is born, George Cukor, 1954) etc.

99 J.-P. Esquenazi, Hitchcock et l'aventure de Vertigo, p. 202.
} 
está por trás do encanto e do sex appeal irresistível da estrela hollywoodiana, desvelando a engrenagem responsável por sua potência, sua força icônica: "O filme não descreve o star system; ele o desloca para fazer dele um instrumento menos da produção do que da narrativa". ${ }^{100}$ Hitchcock não conta a história de uma estrela que nasce: ele faz a estrela nascer nas próprias imagens do filme, graças a um jogo de ponto de vista que instala o espectador na mesma situação de Scottie (desejo e atenção inteiramente voltados para o charme poderoso de Madeleine). Gavin é como um produtor, um empresário da indústria cinematográfica, que encontra uma jovem promessa e resolve talhá-la para o mundo do cinema, mudando seu cabelo, suas maneiras, seu nome, enfim, fazendo tudo aquilo que era de praxe em Hollywood quando se tratava de transformar uma simples mulher numa "deusa moderna, uma estrela inacessível e, simultaneamente, tão próxima quanto possível", destinada à "adoração espectatorial". ${ }^{101}$ A narrativa de Vertigo constrói e reconstrói a figura icônica da estrela; o filme não simplesmente "faz uso" do star system: ele expõe seus mecanismos na própria forma de narração e mise en scène, deixando claro que "o objeto fascinante, a star, é essencialmente uma construção ou uma fabricação. Ela é uma armadilha da narrativa". ${ }^{102}$

Essa discussão sobre o modo como Hollywood fabrica suas celebridades e participa da moderna indústria de simulacros será revisitada e trabalhada de modo explícito em A lenda de Lylah Clare (The Legend of Lylah Clare, 1968), de Robert Aldrich.

Retomando não apenas a atriz principal de Vertigo, Kim Novak, como também a maioria de seus motivos e temas (transformados em pontos estratégicos para entrar nos meandros perversos do mundo do espetáculo), o filme reflete sobre a lógica cruel do estrelato e radiografa Hollywood em meio à decadência do sistema dos estúdios no final dos anos 1960. Aldrich já havia filmado o lado monstruoso e sombrio do universo do show business em O que aconteceu com Baby Jane? (Whatever Happened to Baby Jane?, 1962), terror psicológico cujo clima de pesadelo é acentuado pela estilizada fotografia em preto e branco e pelo aspecto calculadamente grotesco de um programa figurativo baseado no esgarçamento e na anamorfose dos signos da Antiga Hollywood. Mas A lenda de Lylah Clare vai ainda mais fundo nessa démarche crítica, descrevendo os bastidores do glamour hollywoodiano como um ambiente sórdido e putrefato. Assim como Na mira da morte (Targets, 1968), de Peter Bogdanovich (outro filme que pode ser visto como tecido de ligação entre a Hollywood

\footnotetext{
${ }^{100}$ Ibid., p. 198.

${ }^{101}$ Ibid., p. 179.

${ }^{102}$ Ibid., p. 181.
} 
clássica e a moderna), A lenda de Lylah Clare é concebido numa dialética entre a crise das velhas formas de suspense e a emergência de novos parâmetros narrativos, já pensados para um espectador cinéfilo, que "sabe demais".

Exatos dez anos depois de Vertigo, Kim Novak é mais uma vez envolvida numa engrenagem diabólica pautada na vertigem das imagens, na repetição de eventos, no retorno do passado e no poder da ilusão. Ela interpreta Elsa Brinkmann, jovem atriz escolhida para fazer o papel principal na cinebiografia de Lylah Clare, lendária estrela hollywoodiana morta vinte anos antes em circunstâncias mal esclarecidas. O motivo dessa escolha de casting é a incrível semelhança entre Elsa e Lylah (ambas interpretadas por Kim Novak). Ainda no começo do filme, Elsa caminha pela calçada da fama da Hollywood Boulevard e, num gesto que resume todo o (perigoso) jogo de encaixes de simulacros que lhe é proposto, põe os pés nas marcas das pegadas de Lylah Clare. Se, em Um corpo que cai, Novak já tinha de representar Judy, que representa Madeleine, que representa Carlotta, em A lenda de Lylah Clare, a sobreposição de personae dramáticas e de fantasmas substitutivos é potencializada por diversas razões. A primeira delas é o fato de que Novak acumula as personagens deste filme com as de Vertigo, formando uma imagem-palimpsesto condizente com a existência múltipla da estrela: "o ator vedeta é um ser compósito, detentor simultaneamente da realidade de um indivíduo, da imagem que dele dão os media, da galeria de personagens que interpretou anteriormente e da dimensão mítica resultante da reunião destes elementos díspares. Assim, a estrela beneficia daquilo a que Morin chama uma superpersonalidade ${ }^{103}$ A segunda razão está no engavetamento de histórias e personalidades composto pela narrativa, que comporta um filme dentro do filme, uma ficção dentro da ficção (estrutura clássica das narrativas en abyme). Em terceiro, há a questão evidente de que a personagem que Elsa está destinada a encarnar é a de uma celebridade, uma estrela, uma atriz que teve sua imagem multiplicada e difundida, difratada em diferentes direções, em diferentes papéis, espalhada pelos quatro cantos do mundo por conta da reprodução ad nauseam de suas fotografias, pôsteres, filmes. Por último, há o fato de que o próprio filme de Aldrich é uma imagem que reduplica outra, e que o faz de maneira consciente e sistemática, pondo-se em diálogo direto com Vertigo e com padrões estilísticos e regimes de expressão de uma era da indústria cinematográfica já percebida como ultrapassada e defunta, o que apenas mitifica sua beleza e aumenta seu mistério (a atração hipnótica que Scottie sentia por Madeleine reflete-se agora no fascínio que os cineastas modernos sentem pela obra-prima de Hitchcock).

${ }^{103}$ J. Nacache, op. cit., p. 55. 
O diretor do filme dentro do filme é Lewis Zarken (Peter Finch), ex-marido de Lylah, cineasta tido como brilhante, mas com fama de temperamental e sádico. Durante a preparação do filme, ele confina Elsa em sua mansão fantasmagórica e sepulcral, onde, no enorme hall de entrada, bem no alto da parede, acha-se um retrato pintado de Lylah Clare, como se aquele espaço fosse um templo de devoção à mulher morta. $\mathrm{O}$ processo de filmagem se mostrará destrutivo, infernal. Os momentos em que Elsa incorpora Lylah têm um ar de possessão demoníaca: ela muda o comportamento e o tom de voz, a menina meiga cede lugar à megera. O encadeamento irreversível dos eventos, decalcado do enredo de Vertigo, perde o caráter propriamente trágico (entre outras coisas, porque basta conhecer a matriz hitchcockiana para já poder antever o desfecho) e se torna uma descrição sociológica do círculo vicioso do espetáculo hollywoodiano, doravante condenado ao remake desencantado dos seus mitos e à eterna repetição dos seus erros. O "deslizamento fatal" da heroína, que era fruto de uma maquinação individual em Hitchcock, torna-se "manipulação estrutural na Hollywood retratada por Aldrich". ${ }^{104}$

Na primeira cena do filme, Elsa está assistindo a uma projeção de slides com fotos de Lylah Clare. Ela assiste, portanto, às imagens de seu duplo projetadas numa tela, com todas as consequências psicológicas aí implicadas. $\mathrm{O}$ antigo produtor dos filmes de Lylah, que se gaba por tê-la descoberto num açougue em Berlim (sabe-se que Kim Novak começou a carreira num anúncio de frigoríficos), é quem projeta os slides para Elsa, tentando convencê-la a aceitar o papel. A esposa do produtor pega no armário o vestido branco usado por Lylah num de seus trabalhos mais conhecidos. Quando ela mostra o vestido para Elsa, tapa sem querer a luz do projetor. A imagem projetada naquele momento, uma fotografia de Zarken, é então coberta por uma sombra que, imediatamente, adquire conotação de ameaça, de mau presságio. Zarken é desde já apresentado sob o signo do maléfico, do demoníaco (a associação entre o uso expressivo da sombra e a evocação do mal é uma das estratégias simbólicas mais antigas do cinema ${ }^{105}$ ).

Se a primeira visão que temos de Lylah se dá por meio de um conjunto de fotografias, imagens fixas, e não de um filme, imagens em movimento, é porque devemos penetrar no seu universo, primeiramente, pela figura do ícone imóvel, a qual define, melhor do que a pulsação inconstante da imagem cinematográfica, o espaço simbólico da celebridade e do ídolo pop.

$\mathrm{Na}$ cena seguinte, enquanto passeia pela calçada da fama, Elsa para em frente à vitrine de uma loja de eletrônicos e vê sua imagem multiplicada por diversos televisores. Sua pronta

\footnotetext{
${ }^{104}$ Jean-Baptiste Thoret, “Qui sont ces chiens?”, in Cahiers du cinéma, nº 649, outubro de 2009, p. 32.

${ }^{105}$ Ver J. Aumont, Le montreur d'ombre, pp. 126-130.
} 
reação é fazer uma careta. A cena consiste na primeira de uma série de menções à televisão, as quais, ao longo do filme, deixam clara a posição central adquirida na economia das imagens por esse "meio frio" (para retomar a famigerada terminologia de McLuhan), onde, entre um programa e outro, entre um comercial de patê para cães (como aquela bizarra vinheta enxertada ao final do filme) e outro, os clássicos do passado de Hollywood são deformados pelo tubo catódico e reprisados exaustivamente, perdendo parte de seu charme e, sobretudo, de sua aura. A repetição da imagem de Elsa em várias televisões justapostas, além de prefigurar sua inclusão no mundo do clichê e da fama, sugere uma formulação muito próxima daquela que já havia sido desenvolvida pelas serigrafias pop de Andy Warhol: a imagem da celebridade não é apenas da ordem do duplo, mas do serial e do múltiplo; é "réplica perpétua". 106

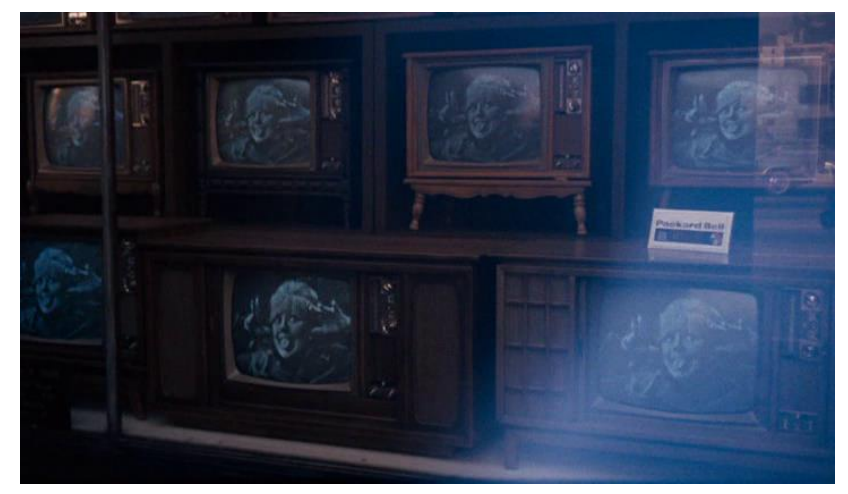

Na sala de projeção particular que possui em sua mansão, Zarken põe Elsa para assistir a um dos filmes dirigidos por ele. Percebendo que ela sabe de cor todas as falas da personagem de Lylah Clare (pois as repete em voz alta quase inconscientemente), Zarken vai diminuindo o volume do filme até tirar completamente o som, deixando apenas a voz de Elsa ecoando no ambiente ao dublar Lylah. O conluio demoníaco tem início. É como se aquela voz soprasse na imagem de Lylah Clare o espírito, o daimon que a fará ganhar vida novamente.

O colapso subjetivo de Elsa fica configurado por completo quando, no set de filmagem, ela chega a um cenário que é a reconstituição exata da casa de Zarken. Um grupo de assistentes traz uma réplica do retrato de Lylah e a posiciona no alto da escadaria de onde a famosa atriz teria caído, após uma crise de vertigem, no episódio que resultaria em sua morte. “O que acha disso?”, pergunta Zarken apontando para o quadro. "É idêntico!”, Elsa exclama. "Com a diferença de que esse é seu”, o diretor comenta. Segundo Zarken, portanto, o quadro

${ }^{106}$ V. I. Stoichita, O efeito Pigmalião, p. 209. 
que será usado no filme não é uma cópia do retrato de Lylah, mas um retrato de Elsa. Ao olhar para si mesma no retrato, porém, o que Elsa vê é um outro, ou melhor, a imitação de um outro. A linha divisória entre identidade e alteridade se dissolve. A cena continua, e um homem pede que Zarken escolha uma fotografia para a campanha publicitária do filme. Uma tomada em plongée mostra que eles estão rodeados de dezenas de fotos espalhadas pelo assoalho do set. Zarken pega uma delas e diz que não dá para saber se é uma foto da “verdadeira” Lylah Clare ou já uma imitação feita com Elsa. "É simples: essa aí sou eu”, Elsa afirma. Zarken, após ler a legenda no verso da foto, sorri e fala: "sim, e você fez esta foto há vinte e dois anos". Elsa se confundiu com a imagem de Lylah. A barreira da semelhança foi ultrapassada: da simples imitação, passou-se à substituição da pessoa viva pelo fantasma. Elsa se deixou transformar a ponto de não mais se pertencer. Nitidamente perturbada com a fratura de sua identidade, ela olha para o "seu" retrato no alto do cenário, enquadrada num plano geral filmado exatamente do lugar em que a pintura foi colocada:

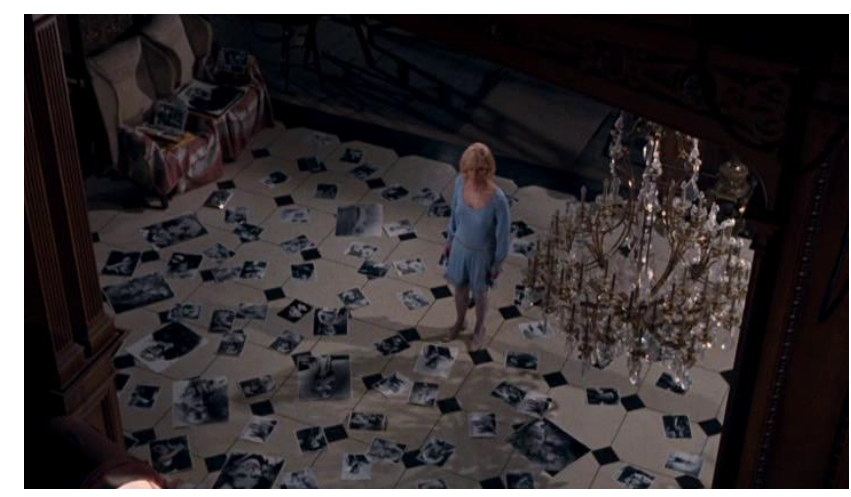

De uma posição que inverte a relação entre observador e imagem (pois, aqui, é a imagem que olha para o observador - ou que, pelo menos, devolve-lhe um olhar), esse enquadramento, espécie de plano-ponto-de-vista do retrato, ilustra a fratura do imaginário, a desintegração da ordem simbólica que o sustentava. O plano mostra, assim, o sujeito sendo expulso de si mesmo, o eu confrontado com sua própria divisão. As fotografias espalhadas no chão são como os diversos fragmentos de um espelho partido.

O destino de Elsa é previsível: ela será vítima da "virtude fatal do duplo"107, e morrerá como Lylah, "por uma repetição inquietante", último ato de uma imitação que só fica perfeita quando o referente real é sacrificado em nome do referente imaginário. Zarken se limita a

${ }^{107}$ R. Démoris, art. cit., p. 22. 
garantir que a câmera registre tudo, sem falha nem interrupção: sua obra-prima está pronta. Lei cruel do cinema: "manter as imagens a qualquer preço, incluindo a morte". ${ }^{108}$

\section{4. $O$ corpo da imagem}

A relação tirânica de Zarken (o diretor) com Lylah (a estrela) é nitidamente inspirada nas famosas histórias das querelas profissionais e afetivas de Hitchcock com suas atrizesfetiches:

Hitchcock parece nunca separar sua paixão por certas mulheres da vontade de filmá-las. [...] o cineasta age como um amante tirânico e quer regular toda a vida de sua protégée. Para que o filme seja bem sucedido, ela deve viver, tanto quanto possível, de acordo com as condições que ele impõe sobretudo depois que ele se tornou um produtor poderoso que mantém as atrizes sob contrato, ou seja, um pouco antes de rodar Vertigo. ${ }^{109}$

Pelo que consta no vasto anedotário acerca das filmagens de Vertigo, o conflito "artístico" vivido por Scottie enquanto esculpe Madeleine na matéria-prima de Judy reproduz diegeticamente a relação que Hitchcock desenvolveu com Kim Novak. Para encarnar sua personagem, a atriz precisou passar por uma repaginação completa. "Tudo nela tinha de ser alterado: os seus cabelos eram castanhos e ele queria-os loiros, as suas sobrancelhas eram finas e ele queria-as espessas... Em resumo, ele queria-a... 'outra'". ${ }^{110}$ A discussão sobre a manipulação das aparências e a produção de simulacros e duplos de substituição está incrustada, assim, na própria relação diretor-atriz, o que contribui para tornar Vertigo, nas palavras de Stoichita, "um caso limite do efeito Pigmalião" "111, isto é, uma obra que incorpora em sua própria feitura a "relação pigmaliônica" que, originada num dos mitos fundadores do imaginário ocidental, vem sendo retrabalhada de múltiplas maneiras pela cultura moderna.

Narrado por Ovídio no livro X das Metamorfoses, o mito de Pigmalião conta a história de um homem que, desencantado com os "vícios" que a natureza conferira às mulheres de carne e osso, esculpe uma estátua de marfim com as formas femininas mais perfeitas já vistas. Enamorado da estátua, ele enfeita-a com vestidos e joias, faz-lhe carícias, enche-a de

\footnotetext{
${ }^{108}$ J.-P. Esquenazi, Hitchcock et l'aventure de Vertigo, p. 194.

${ }^{109}$ Ibid., p. 71.

${ }^{110}$ V. I. Stoichita, O efeito Pigmalião, p. 210.

${ }^{111}$ Ibid., p. 203.
} 
presentes. No dia da festa de Vênus, pede aos deuses que lhe deem uma esposa semelhante à mulher de marfim. Vênus atende ao pedido. A estátua ganha vida e se casa com Pigmalião.

O "poder de Pigmalião", segundo Gombrich, é o de criar em vez de retratar: o mito ovidiano fala de uma função mais antiga da arte, que não está relacionada à imitação da Natureza, mas à capacidade de imaginar e inventar, o papel do artista sendo menos o de copiar a criação do que o de rivalizar com ela. $\mathrm{O}$ artista não apenas concebe a imagem, mas a projeta no mundo, fazendo-a ocupar o espaço da vida, ao qual termina por se confundir. A história de Pigmalião cristaliza a crença antiga nos poderes mágicos da arte, que trazem a promessa de que a obra vai adquirir vida, de que o ato da criação terá a capacidade de converter "o frio marfim num corpo vivo": "Sem a promessa subjacente desse mito, os secretos temores e esperanças que acompanham o ato de criação, talvez não houvesse arte tal como a entendemos". 112

Jean-Claude Lebensztejn, num ensaio que aborda algumas das muitas representações desta história (nas artes plásticas, na literatura, no cinema etc.), destaca a constante utilização do mito pigmaliônico como fábula meta-artística: a história do escultor apaixonado por sua escultura ressurge como expressão do amor pela arte, sobretudo a partir do século XVIII, dominado pelas teorias neoclássicas: "A tonalidade afetiva vai do especulativo (Burne-Jones) ao devasso (Gérôme), mas, em geral, subsiste a autocelebração de uma arte tornada todopoderosa pelo amor". ${ }^{113}$ Quatremère de Quincy, teórico do neoclassicismo, afirma que "às vezes uma intimidade real se forma entre o artista e sua obra; e é desta paixão mesma que a imagem recebe vida" (ibid., p. 37). O objeto do poema ovidiano seria, em última análise, a “imaginação transbordante" do artista, que confere ao simulacro o estatuto de realidade: "A percepção neoclássica é moldada por esse devir-real do ideal [...] Diderot, assim como Girodet, Winckelmann e os demais, sonha também com a aliança que funde num mesmo corpo o signo e a coisa, o ideal da arte e a verdade da natureza" (ibid., p. 41). O artista, segundo a filosofia estética do neoclassicismo, deve manipular a matéria para aí encontrar seu ideal (ou seu fantasma).

$\mathrm{Na}$ posterior era romântica, "Pigmalião abandona a cena mágico-mitológica para reencontrar o mundo cotidiano" $" 114$ : a história agora é a de um homem rico que educa e embeleza uma jovem mulher pobre para fazer dela sua esposa (o enredo de Vertigo - assim

\footnotetext{
${ }^{112}$ E. H. Gombrich, Arte e ilusão, p. 80.

113 J.-C. Lebensztejn, Pygmalion, Bruxelas: Les presses du réel, 2009, p. 24.

${ }^{114}$ Ibid., p. 70.
} 
como o de My Fair Lady, musical da Broadway que George Cukor adaptaria para o cinema em 1964, e que era baseado na peça Pigmalião, de Bernard Shaw - não está longe). "O novo Pigmalião não deixa de ser uma espécie de anti-Pigmalião: ao invés de tratar uma estátua como uma mulher, ele trata uma mulher como uma estátua, que ele modela ao seu gosto". ${ }^{115}$

No cinema, a história de Pigmalião já foi reencenada dezenas de vezes, explícita ou indiretamente, em cenários "reais" ou fantásticos, de Méliès a Hitchcock, de Preminger a Cukor, de uma comédia romântica despretensiosa (Manequim, Michael Gottlieb, 1987) a um thriller elaborado e denso (A pele que habito, Almodóvar, 2011).

Era natural que o cinema, desde seus primórdios, absorvesse a história de Pigmalião, uma vez que as imagens em movimento encarnam o próprio desejo de animar o inanimado: a ilusão de movimento, elemento-chave da percepção cinematográfica, é o que torna o cinema, de acordo com Michelle E. Bloom, um "espaço pigmalionesco" privilegiado. ${ }^{116}$ "A ligação de Pigmalião com o cinema não está somente na animação da imagem; ela está na animação da imagem pelo espectador, por uma projeção psíquica que duplica a projeção luminosa da imagem que foi impressa no celuloide - este suporte já obsoleto, já envolto por uma aura de nostalgia". 117 Ver um filme implica necessariamente uma "insanidade temporária": acreditamos assistir ao movimento, quando estamos lidando, na verdade, com imagens estáticas (fotogramas) projetadas em rápida sucessão; a sensação de movimento das imagens cinematográficas é um delírio coletivo; o "dinamismo ilusório" do filme faz dos espectadores descendentes tardios de Pigmalião. ${ }^{118}$

Um plano do começo de Falbalas, filme dirigido por Jacques Becker em 1944, sintetiza com perfeição a relação do cinema com a fábula pigmaliônica: a câmera, a princípio, mostra a figura estática de um manequim feminino; em seguida, realiza um travelling à esquerda, até enquadrar o estilista Philippe Clarence, que se encaminha a uma modelo e prende um alfinete no vestido que ela está usando, gesto acompanhado por um novo movimento de travelling. Ao longo do plano, portanto, a câmera vai da estátua à mulher de carne e osso, do objeto inanimado ao corpo vivo, tendo como intermediário o artista, Clarence, que faz ajustes em sua nova coleção de roupas. O espaço percorrido pela câmera é o espaço pigmalionesco por excelência: lugar de investimento fantasmático, de circulação de

\footnotetext{
${ }^{115}$ Ibid., p. 69.

${ }^{116}$ M. E. Bloom, "Pygmalionesque Delusions and Illusions of Mouvement: Animation from Hoffmann to Truffaut", Comparative Literature, 52, 4 (outono de 2000), p. 292.

${ }^{117}$ J.-C. Lebensztejn, op. cit., p. 71.

${ }^{118}$ Cf. M. E. Bloom, art. cit., p. 318.
} 
energias criativas, de corporificação do trabalho do artista. A câmera, entre seu ponto de partida e o de chegada, traça no espaço cênico a atividade do artista-Pigmalião, que é a de insuflar vida na matéria inerte, criar movimento onde não havia. Passamos da estátua ao corpo vivo no decorrer do plano; a metamorfose pigmaliônica não ocorre senão na mise en scène mesma, na dinâmica interna do plano.

Falbalas é um excelente exemplo da desilusão romântica que caracteriza muitas das representações modernas de Pigmalião. Clarence, além de renomado estilista, tem fama de mulherengo: entre um trabalho e outro, coleciona amantes que serão posteriormente descartadas. Uma mulher, no entanto, lhe desperta paixão verdadeira: Micheline, cuja semelhança com o manequim visto no início do filme é recorrentemente salientada pela câmera. Mesmo sabendo que ela está noiva de seu melhor amigo, Clarence a seduz. Seu charme, à primeira vista, funciona. Mas, depois de alguns quiproquós, a moça toma a decisão de deixá-lo. O golpe atinge Clarence em cheio. Desesperado, ele ignora os elogios pela apresentação de sua última coleção e se tranca no escritório. Lá, coloca no manequim o vestido de noiva que havia confeccionado para Micheline. Num delírio alucinatório, ele imagina o manequim adquirindo vida e se transformando em Micheline. A imagem, no momento em que ocorre a transmutação, fica embaçada, turva, correspondendo à visão subjetiva da perturbação interior de Clarence, que chama o manequim pelo nome de Micheline e o vê, em resposta, mover-se na sua direção e sorrir docemente. "A alucinação manifesta a impossibilidade de suportar o 'teste de realidade' - em Falbalas, o amor impossível". ${ }^{119}$ Clarence se abraça à estátua e se atira pela janela: "O Pigmalião romântico é anunciador de desastres; quando a ilusão atinge seu ápice e não deixa mais espaço para a realidade, é sinal de que a imaginação tornou-se loucura - e não seria esta a melhor destinação do romantismo?". ${ }^{120}$ A loucura e o suicídio, paroxismos da desilusão romântica, encerram o ciclo trágico engendrado pela febre pigmaliônica de Clarence.

O universo da moda retratado em Falbalas não está muito distante de Vertigo: a conversão de Judy em Madeleine começa justamente num salão de alta costura, com as sessões de provas de roupa, que "revestem-se do valor de criação fetichista de um corpo de substituição". ${ }^{121}$ Na narrativa de Ovídio, Pigmalião já enfeitava o corpo da estátua com vestidos, colares, adereços, mas o corpo desejado ainda era criado por "modelagem" e

\footnotetext{
${ }^{119}$ Dominique Chateau, La subjectivité au cinéma, Presses Universitaires de Rennes, 2011, p. 81.

${ }^{120}$ J.-C. Lebensztejn, op. cit., p. 78.

${ }^{121}$ V. I. Stoichita, $O$ efeito Pigmalião, p. 212.
} 
"carícia": "A sua qualidade principal era a de ser carne nua, enquanto as vestes e os adereços desempenhavam um papel adicional, ou mesmo de celebração da carne" (ibid.). No “pigmalionismo pós-victoriano de Scottie, que alia a pulsão de 'modelador' ao culto da roupa" (ibid., p. 213), o primeiro passo da transformação é a escolha da indumentária: "As roupas e a maquilhagem são tematizadas enquanto ações formadoras de um exterior - uma magnífica criação de aparências que Scottie dirige e que Hitchcock nos apresenta” (p. 211). A passagem da contemplação visual à "preensão háptica" só se dá no momento em que Scottie finalmente beija Judy, depois de vê-la retornar do banheiro com o penteado de Madeleine (último detalhe que faltava para a cópia se igualar ao "original"). Ali ocorre o verdadeiro reencontro; a imagem de Madeleine regressa, e o quarto do Empire Hotel acaba se tornando "um grande aparelho de projeção fantasmática" (p. 217), um lugar de confecção de um fantasma pessoal.

A cena é filmada com uma combinação de efeitos que conferem à visão de Scottie um caráter epifânico. A luz verde - mais intensa justamente na parte do cenário ocupada por Judy/Madeleine - tem sua consistência alterada por um filtro fog de alta densidade (que já havia sido usado na sequência do cemitério), realçando o aspecto fantasmático e impalpável desta reaparição de Madeleine - um objeto ambíguo, na fronteira entre o atual e o virtual, quase um holograma:

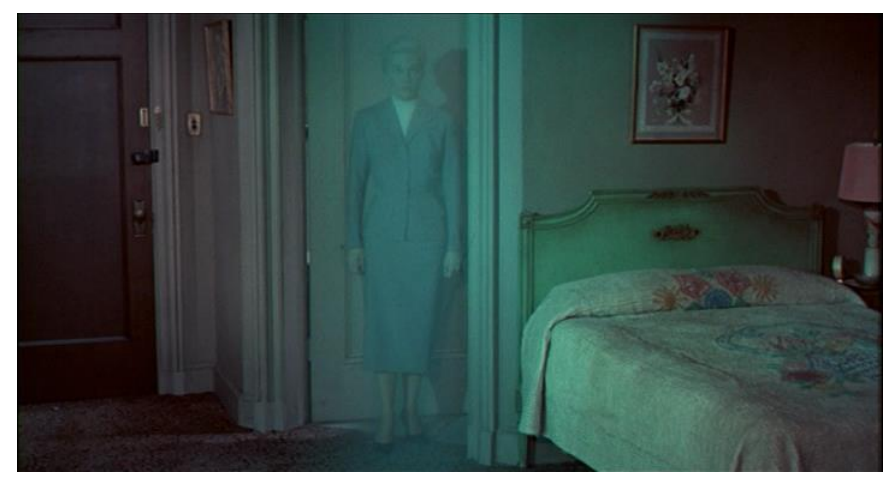

Trata-se da mais misteriosa (e laboriosa) das figurações de Kim Novak no filme. Como em diversos outros momentos, ela está posicionada num quadro dentro do quadro, aqui constituído pela porta do banheiro. A situação fronteiriça de Judy/Madeleine, prestes a cruzar a soleira da porta, reforça o fato de que ela está num limiar de visibilidade, suspensa entre dois espaços, entre duas luzes. Tal composição remonta a um motivo formal relativamente comum na pintura renascentista, em que portas, janelas e outras aberturas ou quadros dentro do quadro eram usados, muitas vezes, para "acentuar sensivelmente o efeito de surpresa, 
pondo em destaque a figura em aparição". ${ }^{122} \mathrm{O}$ recurso se aplica com especial pertinência "no repertório de formas da pintura religiosa inteiramente devotada a exaltar, a animar o registro do maravilhoso", sendo uma forma eficaz de "atrair a atenção para uma mensagem, uma aparição, uma silhueta apreendida entre o exterior e o interior". ${ }^{123}$ A figura no umbral suscita uma ideia tanto de revelação como de aparição fugidia, presença passageira de uma imagem sempre na iminência de retornar ao espaço off de onde surgiu. "A cultura clássica de Hitchcock, educado por jesuítas", como nota Stoichita, certamente o familiarizou com este tipo de representação: "Nos termos da 'sabedoria tradicional', Scottie está a viver uma visio smaragdina, uma visão teofânica, um encontro". ${ }^{124}$

Um plano com a mesma composição, mas sem os truques visuais e a aparência sobrenatural da cena do hotel, já acontecera no apartamento de Scottie, na sequência posterior àquela em que Madeleine tentara o suicídio na baía de São Francisco. No referido plano, ela sai do quarto de roupão e para no limiar da porta, como se hesitasse um instante antes de dar um passo à frente e se aproximar de Scottie, que a observa com olhos plenos de admiração.

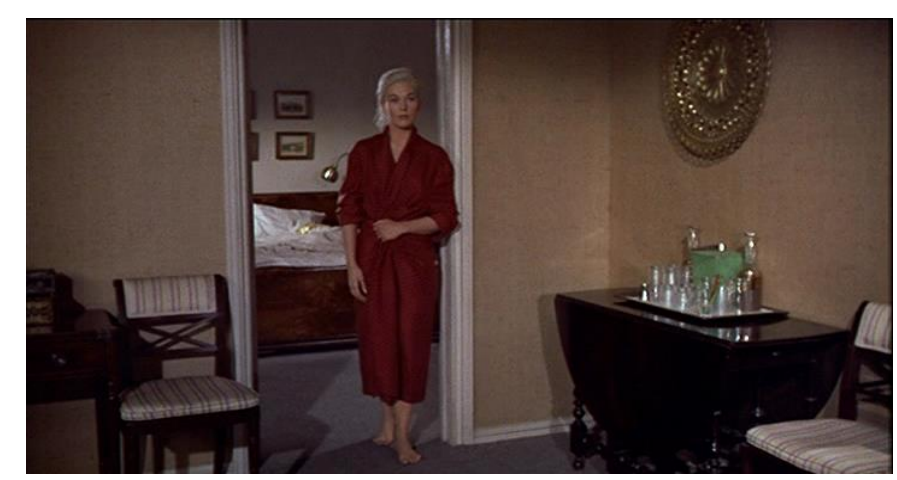

Scottie oferece café (bebida quente) e recomenda que ela se aqueça junto à lareira. A mesma recomendação será feita a Judy na parte final do filme, um pouco antes do início de sua transformação em Madeleine. Cabe mencionar que, em algumas representações de Pigmalião, a estátua é vestida e modelada perto de uma lareira: a ação de avivar o fogo e aquecer a estátua simboliza a vontade do escultor de "insuflar uma alma à sua criação". ${ }^{125}$

Enquanto se aquece, Madeleine aproveita para refazer o penteado. Ela e Scottie conversam e, aos poucos, adquirem intimidade. Em dado momento, ambos levam a mão a

\footnotetext{
${ }^{122}$ André Chastel, Le tableau dans le tableau, Paris: Flammarion, 1978, 2012, p. 86.

${ }^{123}$ Ibid., p. 84.

${ }^{124}$ V. I. Stoichita, O efeito Pigmalião, p. 220.

${ }^{125}$ Ibid., p. 55.
} 
uma mesma xícara simultaneamente, numa coincidência que propicia o primeiro verdadeiro contato entre eles. Por alguns segundos tão breves quanto intensos, Scottie e Madeleine (carrapito em espiral já devidamente refeito) comunicam-se através do olhar e do tato:

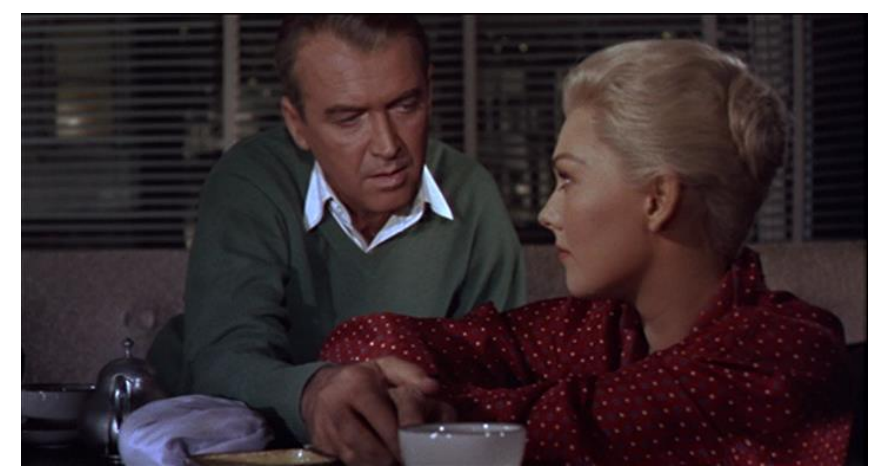

Na cena do "retorno de Madeleine" no Empire Hotel, a "progressão" é a mesma (do visual ao tátil, da projeção imaginária à presença sensível, da distância inicial à "intimidade real que se forma entre o artista e sua obra"), apenas tornada mais facilmente perceptível por conta dos instrumentos plásticos acionados por Hitchcock - o néon verde, a lente esfumaçada, a decoração e a iluminação sui generis do quarto -, que conferem à cena sua dimensão apoteótica. Madeleine, conforme já vimos, aparece primeiramente como uma figura desmaterializada, uma pura membrana de luz. Mas, na medida em que caminha em direção a Scottie, aproximando-se da câmera, a imagem de Madeleine se desanuvia, o espectro ganha corpo, impelindo o detetive a tocar a "imagem", a beijá-la, a enlaçá-la em seus braços. Atraído pelo "efeito de ressurreição" (ibid., p. 221) do simulacro, Scottie abraça e beija Judy/Madeleine durante aquele travelling circular que se tornaria um dos momentos mais emblemáticos do filme. Fantasma e realidade, passado e presente, verdade e impostura se embolam nesse famoso plano, "hipérbole absoluta do beijo hollywoodesco, por um lado, [e] dramatização sem precedentes de uma 'prova de verdade' fantasmática, por outro" (p. 218).
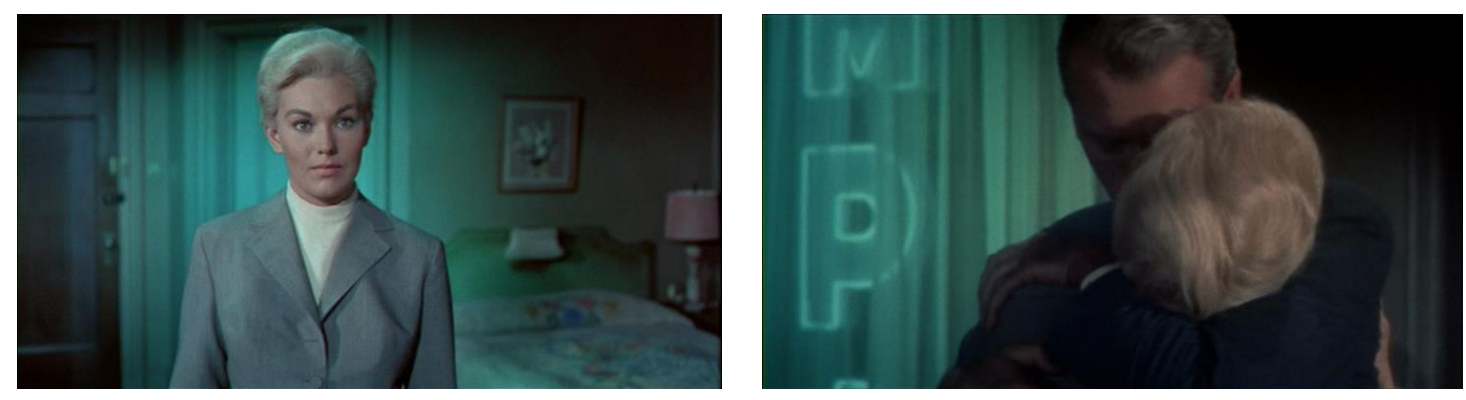
Já não se trata somente da imagem-cópia engendrada pela mimese: o atrativo, agora, é o corpo da imagem, ou a constatação daquilo a que Stoichita chama "um fenômeno de fronteira: o da imagem entendida como algo existente". ${ }^{126}$ A imagem-ícone se troca pela imagem-simulacro:

Construção artificial, desprovida de modelo original, o simulacro apresentase como existindo em e por si mesmo. Não copia necessariamente um objeto do mundo, mas projeta-se no mundo. Existe. [...] Na perspectiva da história das ideias estéticas, o simulacro proclama o triunfo dos artefatos-fantasmas e marca a crise da concepção da obra enquanto imitação de um modelo. ${ }^{127}$

Todos conhecem aquela passagem de $O$ sofista em que Platão distingue "duas formas de se fazer simulacros: a arte da cópia e a do fantasma". ${ }^{128}$ A primeira é propriamente mimética, e se dedica a reproduzir as proporções reais do modelo. A segunda, inversamente, "exige a modificação das proporções reais em nome de uma harmonia superior que leva em conta a relação da obra com seu espectador"129 (como naquela história da escultura que, vista de perto, parece desengonçada e disforme, mas, colocada no lugar para o qual foi planejada, a uma distância calculada, revela-se a mais harmoniosa das estátuas - o simulacro inclui em seu plano de construção o ângulo do observador, o ponto que ele deve ocupar para que a ilusão funcione a contento). É principalmente sobre esta segunda forma de fabricar imagens que pesará a condenação platônica. A imagem que produz o phantasma (simulacro) torna-se, já em Platão, o grande "outro" da história da arte, diferentemente da imagem-cópia, que estruturará o modelo dominante da representação ocidental, calcado nas leis da mimese. A imagem-fantasma, cujo estatuto na história das formas artísticas "permanecerá fundamentalmente vago e marcado por poderes obscuros" ${ }^{\text {"130 }}$, não é da ordem da cópia, mas da invenção de uma imagem que pode existir por si mesma, independentemente da sua relação mimética com um modelo, ou seja, uma imagem que é "um objeto feito, um 'artefato', que, no máximo, pode produzir um 'efeito de semelhança', ao mesmo tempo que mascara a ausência de um modelo por meio de um excesso da sua própria 'hiper-realidade'". ${ }^{131} \mathrm{O}$ simulacro se distingue da cópia na medida em que oferece apenas uma ilusão de semelhança, fingindo

\footnotetext{
${ }^{126}$ Ibid., p. 9.

${ }^{127}$ Ibid., pp. 10-11.

${ }^{128} \mathrm{O}$ trecho aqui citado encontra-se reproduzido em J. Lichtenstein (org.), A pintura - Vol. 5: Da imitação à expressão, São Paulo: Ed. 34, 2004, p. 22.

129 Aurélie Ledoux, L'ombre d'un doute: Le cinéma américain contemporain et ses trompe-l'oeil, Presses Universitaires de Rennes, 2012, pp. 22-23.

${ }^{130}$ V. I. Stoichita, $O$ efeito Pigmalião, p. 9.

${ }^{131}$ Ibid., p. 13.
} 
respeitar as aparências da natureza quando, no fundo, esconde uma dessemelhança fundamental, e o faz com a intenção tão somente de persuadir e impressionar (por isso os simulacros são, para Platão, os equivalentes imagéticos dos sofistas, que manipulam ardilosamente a linguagem não para exprimir uma verdade, mas para enganar). ${ }^{132}$ Conforme explica resumidamente Emmanuel Plasseraud: “A imitação, enquanto produtora de cópias, apoia-se num certo conhecimento da physis e do mundo inteligível das Ideias, do qual os pintores queriam fornecer uma imagem sensível, o que é um equívoco, mas não chega a ser uma infração. Já os criadores de simulacros não respeitam as proporções, pois [só] conhecem as técnicas destinadas a enganar os homens". ${ }^{133}$ O que Platão condena, portanto, não é a imitação em si, a mimesis, mas aquilo que ele designa como skiagraphia: grosso modo, a arte que visa a induzir o efeito de trompe-l'oeil, o qual "consiste em uma suposição de realidade. [O trompe-l'oeil] é simultaneamente crença em uma existência e ignorância de uma representação". ${ }^{134}$

Na teoria platônica, segundo Deleuze, o que está em jogo no fim das contas é separar as boas das más cópias, as que se baseiam na semelhança das que não se baseiam, lembrando que a semelhança não deve ser aí entendida como uma relação exterior, de uma coisa a outra coisa, mas como uma relação interior e espiritual, de uma coisa a uma Ideia. ${ }^{135}$ Ao contrário da cópia, que é uma imagem dotada de semelhança, o simulacro é uma imagem dessemelhante, uma imitação que ignora a Ideia. Ele é uma subversão da mimese. Daí seu caráter demoníaco: seu poder de simulação conduz a um efeito de semelhança meramente exterior e "improdutivo", obtido através de astúcia ou por subversão das aparências, sem o aporte espiritual da Ideia. O simulacro, conforme Platão concluiria, não é somente uma "cópia falsa", mas uma imagem que põe em xeque as próprias noções de cópia e de modelo. ${ }^{136}$

\footnotetext{
${ }^{132}$ Cabe aqui um esclarecimento um pouco mais nuançado: no diálogo de Teeteto com o Estrangeiro, Platão difere primeiramente as obras ditas de natureza, que são obras de uma arte divina, das obras que os homens compõem, e que constituem a arte humana. Em seguida, ele subdivide ambas. As duas obras da produção divina seriam as coisas, de um lado, e, do outro, as imagens que acompanham as coisas (os simulacros que se formam "espontaneamente": a sombra de um corpo ou seu reflexo numa superfície lisa e brilhante, por exemplo). Essa dualidade se repete para a ação criadora humana: de um lado, a produção de coisas; do outro, a produção de imagens. É dentro da arte de fabricação das imagens que se opera então a distinção que mais nos interessa: aquela entre a imitação que se baseia no conhecimento (= o imitador conhece o objeto que imita) e a imitação que não se baseia no conhecimento (= o imitador não conhece o objeto que imita). À arte que produz imagens por uma vaga noção do objeto imitado, sem verdadeiro conhecimento, Platão chama "doxomimética", considerando-a muito mais perigosa que a arte mimética propriamente dita (cf. Platão, Oeuvres complètes Tome VIII, $3^{e}$ partie: Le sophiste, Paris: Les Belles Lettres, 2003, p. 267e).

133 Cinéma Baroque, Presses Universitaires du Septentrion, 2001, p. 77.

${ }^{134}$ A. Ledoux, L'ombre d'un doute, p. 27.

${ }^{135}$ Cf. Gilles Deleuze, Logique du sens, Paris: Les Éditions du Minuit, 1969, p. 296.

136 Para Deleuze, o objetivo do platonismo, ao preferir as cópias-ícones aos simulacros-fantasmas, seria estabelecer os limites da representação, assinalar seu domínio, sua função, o que implica neutralizar a vertigem das aparências engendrada pela imagem-simulacro (ibid., pp. 298-299).
} 
Com base nestas definições, podemos inferir que a raiva de Scottie, ao se descobrir enganado na parte final de Vertigo, é a reação de um neoplatônico traído em suas convicções mais profundas. Seu grande desespero é constatar que se apaixonou não por uma simples imitação, mas por uma imagem duplamente enganadora, "um ser estranho, um artefato dotado de alma e de corpo - mas, não obstante, um fantasma. Um simulacro, justamente" ${ }^{137}$ Scottie estava contente com a cópia de Madeleine que ele havia obtido a partir de Judy. A raiva estoura quando ele percebe que não existia tal dicotomia entre cópia e original, imagem e modelo. Scottie pensava ter remodelado Judy com base na ideia de Madeleine, até entender que o que tomara por ideia era já uma aparência sensória sem verdade interior, uma imagem forjada com o único intuito de produzir efeitos ilusórios. A Madeleine que ele viu ressurgir no hotel Empire, e que beijou com ardor, não era uma imagem-cópia, uma imitação, mas uma imagem-fantasma, um simulacro, um objeto visual autônomo (o simulacro não representa, apenas é): "o esquema narrativo que corresponde à skiagraphia é precisamente o de Vertigo [...]; assim como em Platão, a loucura do desejo, em Vertigo, está no fato de que ele se destina a uma imagem". 138

Um último aspecto do simulacro é ainda identificável na trama de Vertigo, e diz respeito ao seu "caráter transgressivo". Desprovido de aura, o simulacro é uma "criação artística transgressiva": ele estimula o observador a transgredir o limite da experiência óptica, a desafiar o visual em nome do tátil. ${ }^{139}$ A recriação da amada morta por Scottie, sob este ponto de vista, é menos um ato necrófilo do que uma demonstração quase didática do fato de que as imagens fabricadas pelo homem são "receptáculos de poder, dispositivos de desejo, e que tanto a sua criação como a sua contemplação obedecem a pulsões, entre as quais as de ordem erótica são, se não as únicas, pelo menos das mais fortes". ${ }^{140}$ No pequeno quarto do hotel Empire, Scottie pode tocar e beijar a imagem, ou seja, pode fazer justamente aquilo que é proibido nos museus (a exemplo do museu em que se acha o retrato de Carlotta). Vertigo desrecalca a atração pelo simulacro, atração esta que, desde que "a arte foi relegada para o Museu" ${ }^{\prime 41}$, vem acompanhada de uma tarja de proibição. Madeleine, ou melhor, Judy refeita como Madeleine, é a imagem que pede para ser tocada. Eis o que conecta, mais profundamente, o filme de Hitchcock ao mito de Pigmalião (voltemos a ele), "a primeira grande história de simulacros da cultura ocidental [...], uma parábola sobre as origens do

\footnotetext{
${ }^{137}$ V. I. Stoichita, O efeito Pigmalião, p. 12.

${ }^{138}$ A. Ledoux, L'ombre d'un doute, p. 24.

${ }^{139}$ V. I. Stoichita, O efeito Pigmalião, p. 221.

${ }^{140}$ Ibid., p. 13.

${ }^{141}$ Ibid., p. 9.
} 
simulacro na própria transgressão da representação, na suspensão da mimese e nos desvios do desejo". ${ }^{142}$ Contrariamente a Narciso, Pigmalião pode abraçar a imagem que se tornou o objeto do seu amor. "O mito de Pigmalião não é apenas um mito da imagem (como o de Narciso); envolve também a imagem-obra ou, para sermos mais precisos, o seu corpo."

Ora, do reflexo narcisista à imagem-simulacro, ultrapassa-se a "cena do espelho", a projeção do corpo para fora de si mesmo, e assiste-se à sua aparição como outro; vai-se da semelhança à substituição (a representação passa para o lado do duplo). Antes da transformação, Judy (o corpo, a matéria) já se assemelhava a Madeleine (a imagem, a ideia), mas esta ainda permanecia como um duplo que se escondia dentro dela: as diferenças criavam uma "distância", uma defasagem que Scottie precisava compensar com a memória, com a fantasia, com o olhar e a projeção. O segredo, o enigma da semelhança alimentava o imaginário. O filme procedia de acordo com "a regra das aparências, por ilusão e elipse da presença". ${ }^{144} \mathrm{Na}$ ressurreição holográfica de Madeleine no quarto do Empire Hotel, o que muda é que já não há a parte de sombra do corpo, sua face ocultada, seu passado silencioso, mas uma pura apresentação, um fenômeno de hiperpresença. Madeleine já não surge de perfil, e sim de frente. Já não há relação com um "original”, porque a intensidade de aparição do duplo é tamanha que faz esquecer o próprio modelo ("nenhum modelo resiste à vertigem do simulacro" ${ }^{145}$ ). Já não há, enfim, semelhança, mas "hipersemelhança" 146 , "imagem perfeita e fim do imaginário" ${ }^{\text {147 }}$.

O simulacro não é a representação da coisa "real", mas sua apresentação como duplo; ele é a mimese em excesso. À imagem referencial e alusiva fornecida pela imitação, o simulacro substitui "a intransigente opacidade de uma Presença". ${ }^{148}$ Mas a presença que ele oferece não passa de um efeito de presença.

Se seguirmos a distinção que Clément Rosset propõe entre duplos de duplicação e duplos de substituição, deveremos situar Judy/Madeleine no segundo grupo. Pois os duplos de duplicação apenas copiam seus modelos, sem atentar contra a integridade dos originais (eles podem gerar uma confusão de quem é quem entre o duplo e o modelo, mas, de todo modo, sempre se saberá que há um duplo $e$ um modelo), ao passo que os duplos de substituição,

\footnotetext{
${ }^{142}$ Ibid., pp. 11-12.

${ }^{143}$ Ibid., p. 14.

${ }^{144}$ Cf. Jean Baudrillard, Simulacros e simulação, Lisboa: Relógio d’Água, 1991, p. 134.

${ }^{145}$ G. Deleuze, Logique du sens, p. 303.

${ }^{146}$ J. Baudrillard, Simulacros e simulação, p. 137.

${ }^{147}$ Ibid., p. 135.

${ }^{148}$ Pierre Charpentrat apud L. Marin, op. cit., p. 303.
} 
como no caso da personagem de Kim Novak em Vertigo, "têm por função eliminar o original, fazendo-se passar por ele e afirmando sua existência pela supressão do seu modelo [...]. A utilidade psicológica do recurso ao duplo fantasmático de substituição seria nula se este não eliminasse na operação seu duplo e seu perigoso rival, o real". ${ }^{149}$ Embora, a princípio, Judy apenas duplique a imagem de Madeleine, ela suprimirá seu modelo no decorrer da "operação" (planejada por Gavin Elster com o objetivo, justamente, de eliminar a Madeleine original). Por isso devemos considerá-la um duplo de substituição, e não somente de duplicação. Seu efeito de duplo é do tipo que suplanta o modelo, "mata" o original. "Matar é sem dúvida um termo excessivo: seria mais verdadeiro dizer que o duplo fantasmático se contenta geralmente em jogar um véu sobre o real" ${ }^{150}$; ele encobre a realidade temporariamente, faz esquecer o original, o modelo (e, com isso, faz esquecer também a natureza fabricada de sua aparência), mas o efeito geralmente dura pouco, "apenas uma curta pausa antes dos iminentes reencontros com a realidade" ${ }^{\prime 151}$, que não deixará de voltar - como na cena de Vertigo em que Scottie desmascara Judy e reage como um Pigmalião frustrado e enciumado, que quer destruir a estátua depois de descobrir que ela teve outro dono (isto é, outro amante) antes dele. Importante notar que a revelação da farsa irrompe depois de Scottie enxergar, refletido no espelho, o colar de Carlotta no pescoço de Judy. A imagem delatora vem à tona por conta de um retorno da imagem-espelho, do imaginário, que não é necessariamente a ilusão, a negação da realidade, mas antes seu prolongamento e, em muitos casos, sua estruturação reveladora.

A ira de Scottie se deve, em grande medida, à "perda do original", à descoberta de que sua imitação já era feita em cima de outra imitação. Tudo bem que Judy fosse uma cópia, desde que Madeleine permanecesse um original - o original desaparecido, cuja beleza misteriosa, ou desenho sublime, só ele havia guardado na memória e no espírito. Mas, a partir do momento em que Madeleine se prova um simulacro, uma imagem sem aura, sem origem, sem autenticidade ("a obra autêntica é aquela que é atribuível a uma origem exata", permitindo-nos conhecer "a história das condições e circunstâncias de sua fabricação",152), Scottie percebe que qualquer um - e não apenas ele - pode fazer quantas cópias de Madeleine bem entender: basta obter o "negativo" (Judy). Seria Vertigo uma parábola sobre a obra de arte na era de sua reprodutibilidade técnica?

\footnotetext{
${ }^{149}$ C. Rosset, Fantasmagories, Paris: Les Éditions de Minuit, 2006, p. 73.

${ }^{150}$ Ibid., p. 78.

${ }^{151}$ Ibid.

${ }^{152}$ J. Aumont, De l'esthétique au présent, p. 79.
} 


\section{O ponto de vista feminino}

No mesmo ano de Vertigo, Kim Novak e James Stewart atuaram juntos em outro filme, a comédia romântica Sortilégio do amor (Bell, Book and Candle), de Richard Quine. Novak interpreta Gillian Holroyd, jovem bruxa que possui uma galeria de arte dedicada às artes africanas e oceânicas, ou seja, às artes consideradas "primitivas" ou "exóticas". Stewart faz o papel de Shep Henderson, que é vizinho dela e trabalha como diretor executivo de uma editora. Gillian lança um feitiço sobre ele, que se apaixona por ela imediatamente. Um romance se inicia. O plano do primeiro beijo do casal é quase um espelhamento do começo do plano que mostra o grande beijo espetacular entre Scottie e Judy/Madeleine: mesma composição de imagem, mesmo tipo de elemento decorativo ou de preenchimento cenográfico (um quadro na parede), mas os lados estão invertidos (sem falar na iluminação e na paleta de cores, que é mais quente e carnal em Quine, mais fria e sombria em Hitchcock):
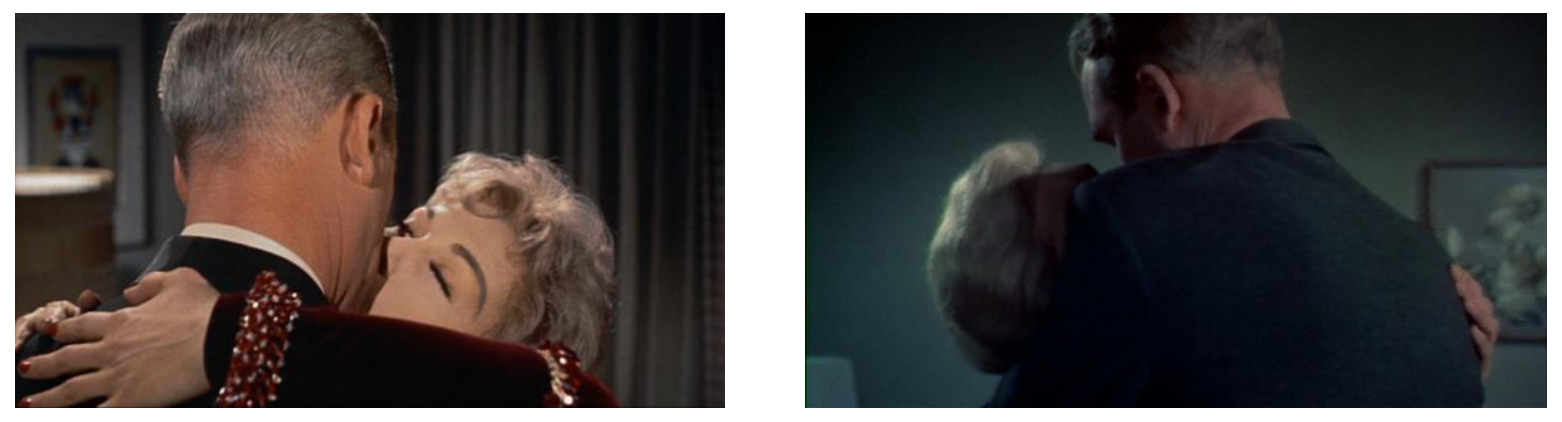

No beijo de Sortilégio do amor, a presença forte das mãos de Kim Novak, com as unhas pintadas de vermelho, atesta o poder que ela tem sobre Stewart: é ela quem o enlaça e o domina, e não o contrário (em Vertigo, os papéis se invertem).

De início, o namoro vai bem, até que um dia Gillian se arrepende da artimanha que usou e resolve contar a verdade. Shep, homem das letras, respeitado editor, recusa-se a acreditar: magia e bruxaria não fazem parte do seu repertório. "Prefiro a explicação racional", ele assegura. Mas, pouco depois, acaba por ser convencido de que foi enfeitiçado. Shep se revolta e recorre a uma outra bruxa para quebrar o encanto. Ele e Gillian se separam por um tempo. Na cena final, Shep vai à loja de Gillian devolver-lhe Pyewacket, seu esperto e divertido gato, que aparecera "inexplicavelmente" no escritório dele. No lugar da descolada galeria de arte, Gillian possui agora uma loja de enfeites kitsch; as formas intensamente sugestivas e até assustadoras das obras antes expostas cederam espaço a objetos inofensivos, inexpressivos, em suaves tons pastéis. Em vez de estar descalça e vestida com roupa preta e 
colada no corpo, como era de costume anteriormente, Gillian está com um traje típico de dona de casa dos anos 1950. A mulher cool, independente, sensual, formada em antropologia, avessa ao casamento (como ela havia dito num diálogo), reaparece em versão domesticada e comum. Shep percebe que o rosto de Gillian está corando e seus olhos se enchendo de lágrimas, o que, de acordo com a magia oculta (que ele agora tolera), só pode ter uma explicação: ela perdeu os poderes de bruxa, porque se apaixonou de verdade. Shep sente-se novamente encantado com Gillian, mas, desta vez, por conta própria, sem bruxaria. Eles se beijam, e o filme termina sinalizando que viverão felizes para sempre. A potência erótica e socialmente perturbadora da mulher "diferente" foi realocada e neutralizada no comportamento banal da mulher "comum" (que, nesta cena, chora como uma boa heroína dos melodramas da época). O homem pode finalmente aceitá-la sem correr nenhum risco. Shep consegue o que Scottie não conseguiu: um happy ending - por mais ambivalente que este happy ending se mostre caso analisado de um ponto de vista feminista, já que a mulher é anulada em sua singularidade/alteridade para satisfazer às preferências do homem.

Gillian ruborizar na cena do reencontro é um detalhe que merece atenção. O rubor demonstra que ela se sentiu encabulada ao rever Shep, o que é um sinal não só de sua "humanização", mas, sobretudo, de uma inocência readquirida. Se a ruborização do rosto, manifestação fisiológica indicativa de pudor, é o acontecimento que assevera a "regeneração" de Gillian, é porque o pudor, primeiro castigo aplicado ao homem depois da queda adâmica, representa no imaginário cristão uma qualidade humana relacionada ao reconhecimento do erro e à preparação para a virtude. Há aí, portanto, um aspecto de purificação, de renúncia ao desejo perverso. Mas o pudor, como escreve Georges Didi-Huberman, é também um dos momentos de expressão antitética do desejo, um "vacilo" do corpo olhado, que, em sua ruborização, "manifesta efetivamente aquilo mesmo que gostaria de resguardar". ${ }^{153} \mathrm{O}$ pudor indica um retraimento, um recuo em face do desejo do outro, ao mesmo tempo em que confirma a reciprocidade de tal desejo na sua própria dissimulação e recusa. Enquanto ruboriza pudicamente, Gillian recalca o desejo, inflamando-o; afirma a libido, negando-a. "[O pudor] não é tanto o acontecimento corporal de um segredo guardado individualmente por algum indivíduo subtraído aos olhares quanto o fenômeno-índice de um segredo da troca dos olhares". ${ }^{154} \mathrm{O}$ corpo de Gillian, agora vigiado pela ordem patriarcal, não mais se comunicará abertamente, mas pela falha, pela negação, pela incontinência do vermelho-desejo.

\footnotetext{
${ }^{153}$ G. Didi-Huberman, A pintura encarnada, São Paulo: Escuta, 2012, p. 86

${ }^{154}$ Ibid., p. 88.
} 
Vertigo e Sortilégio do amor, embora realizados no mesmo ano e com a mesma dupla de protagonistas, são filmes assaz diferentes, o que não os impede de ter alguns pontos em comum, a exemplo dessa adequação da mulher à imagem escolhida pelo homem, sua submissão às leis masculinas, também presente, e de forma mais elaborada, no filme de Hitchcock. Outra semelhança importante é o fato de que a personagem de Kim Novak, em ambos os filmes, aparece para James Stewart "como um puro desejo". ${ }^{155}$ Gillian, assim como Madeleine, põe a personagem de Stewart num estado de encantamento; as duas jogam um feitiço sobre Stewart - bruxaria num caso, encenação no outro. Tanto Shep quanto Scottie se demonstram alvos fáceis para os charmes de Novak, que, antes de ser um mero objeto passivo do olhar masculino, age conscientemente sobre o observador, o qual, por sua vez, mostra-se sujeito à passividade.

Isso contraria, em parte, a tese de Laura Mulvey exposta no texto "Prazer visual e cinema narrativo". ${ }^{156} \mathrm{O}$ artigo, uma das pedras fundadoras da teoria feminista, começa propondo a seguinte lógica: o cinema hollywoodiano "codificou o erótico dentro da

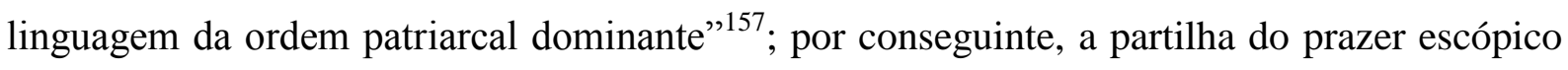
nas ficções de Hollywood se divide (desigualmente) entre dois polos, um ativo/masculino e um passivo/feminino (o homem como dono do olhar e a mulher como imagem). $\mathrm{O}$ voyeurismo e a escopofilia fetichista, que formam o arcabouço do cinema clássico, seriam as duas vias encontradas pelo inconsciente masculino para neutralizar a ameaça da castração que a mulher representa. Vertigo, analisado na parte final do texto, se provaria uma narrativa exemplar, porquanto construída na mescla daquelas duas vias: de um lado, investiga a mulher, desmistifica seu mistério, identifica-a com a culpa (ficção voyeurista que refaz "o caminho tipificado pelos temas do film noir ${ }^{" 158}$ ); do outro, transforma-a em ícone sublime (fascinação fetichista que acarreta "a supervalorização, o culto da star feminina"159). Segundo Mulvey, “Um corpo que cai concentra-se nas implicações da divisão que há entre o ativo/ aquele que olha e o passivo/ aquele que é olhado, em termos de diferenciação sexual e do poder simbólico masculino inscrito no herói". ${ }^{160}$ Todo o sistema visual do filme seria construído em função das demandas do olhar masculino, restando à mulher o papel de imagem-objeto.

Todavia, pode-se argumentar - como outros teóricos (William Rothman, Marian Keane) já o fizeram, rebatendo, inclusive, a análise de Mulvey - que há momentos em que a

\footnotetext{
${ }^{155}$ J. Douchet, Hitchcock, p. 26.

${ }^{156}$ Laura Mulvey, "Prazer visual e cinema narrativo", in Xavier [org.], A experiência do cinema, pp. 437-453.

${ }^{157}$ Ibid., p. 440.

${ }^{158}$ Ibid., p. 447.

${ }^{159} \mathrm{Ibid}$.

${ }^{160}$ Ibid., p. 451.
} 
câmera assume a posição da personagem de Kim Novak. O ponto de vista de Judy-Madeleine estaria, sim, inscrito na cadeia significante do filme, e num lugar tão central quanto o de Scottie (é pelo ponto de vista dela, por exemplo, que se mostra a grande reviravolta da narrativa, com a revelação do complô), o que faria da personagem de Novak uma heroína consciente, ativa, ainda que, como Mulvey já salientara, o controle do dinheiro e das palavras continuasse cabendo ao homem. ${ }^{161}$

Relendo as relações de Hitchcock com a teoria feminista, e aprofundando-as significativamente, Tania Modleski problematiza essa questão do ponto de vista em Vertigo, certamente a questão mais ambígua do filme, mais sujeita a controvérsias. ${ }^{162}$ Para a autora, o filme está longe de adotar exclusivamente o ponto de vista do herói masculino. Por mais que nos identifiquemos com Scottie, é preciso perceber que ele se identifica com Madeleine (a qual, por sua vez, se identifica com Carlotta): “A mulher se torna, assim, o ponto final de identificação para todos os espectadores do filme". ${ }^{163}$ Modleski vê em Scottie uma personalidade masculina em conflito, dividida entre o desejo por Madeleine e a identificação com ela. “Essa 'confusão de fronteiras' pode ser inquietante para o sujeito masculino que, à diferença do sujeito feminino, parece fundar sua identidade sobre a instauração de uma fronteira sólida entre ele e a mulher. Vertigo mostra a que ponto essa fronteira pode ser precária". ${ }^{164}$ Fazendo desse conflito o princípio mesmo da sua construção de ponto de vista, Hitchcock repassa para o espectador a inquietação de Scottie, que "vacila entre um modo passivo e um modo ativo, uma fascinação hipnótica e masoquista diante do desejo da mulher e uma tentativa sádica de controlá-la, de possuí-la". ${ }^{165}$

Modleski retoma uma observação de Donald Spoto sobre o plano-espelho na loja de flores (o plano que analisamos no início deste capítulo): “implicitamente, Scottie (e o

\footnotetext{
${ }^{161}$ Rothman vai mais longe e considera a segunda parte do filme como a execução de um plano de Judy, um plano que consiste em fazer Scottie perceber seu grande atributo, ou seja, sua "atuação". Ao usar o colar de Carlotta, permitindo a Scottie descobrir a verdade sobre ela, Judy cometeria menos um lapso do que um ato proposital, pensado, premeditado: ela queria que Scottie gostasse dela não como "Judy", mas como a atriz que se tornou após representar Madeleine. O beijo final no campanário da igreja seria o triunfo do plano de Judy, contrariado, porém, pelo surgimento abrupto do "fantasma de Madeleine" (a freira encoberta pela sombra). Cf. W. Rothman, "Scottie's dream, Judy's plan, Madeleine's revenge", in MAKKAI, Katalin (org.), Vertigo, Londres: Routledge, 2013, pp. 45-70.

${ }^{162}$ Lembrando que o ponto de vista, no cinema, é sempre uma construção múltipla. Aumont identifica pelo menos quatro significados para a definição de ponto de vista no cinema: 1) o lugar a partir do qual se olha, isto é, o lugar da câmera relativamente ao objeto olhado (que o cinema multiplica através da mudança de planos e da movimentação do aparelho); 2) a própria "vista", isto é, o quadro organizado pelo jogo da perspectiva centrada; 3) o ponto de vista narrativo, a representação de um olhar (do autor ou da personagem); 4) o juízo do narrador sobre o acontecimento. Cf. J. Aumont, "O ponto de vista", in GEADA, Eduardo, Estéticas do cinema, Lisboa: Dom Quixote, 1985, pp. 125-152.

${ }^{163}$ Tania Modleski, Hitchcock et la théorie féministe, Paris: L'Harmattan, 2002, p. 150.

${ }^{164}$ Ibid., p. 151.

${ }^{165}$ Ibid., p. 150.
} 
espectador) pode ser visto como o reflexo de Madeleine"; o plano seria, então, antecipatório com relação ao tipo de aproximação que se estabelecerá entre os dois: “apesar de suas repetidas tentativas de se assegurar do controle de Madeleine, Scottie será constantemente devolvido a uma relação de espelhamento, a uma identificação com ela e com seus desejos. Ao contrário de Elster, ou do amante de Carlotta, ele é incapaz de afirmar sua dominação sobre a mulher". ${ }^{166}$ Modleski considera, portanto, as duas instâncias do plano-espelho (Scottie na posição de quem vê e Madeleine na situação de quem se dá a ver) como complementares e análogas. Mas ela dá demasiado pouca importância ao conflito topológico instaurado pela composição do quadro, à marca divisória, à fratura corroborada pela linha vertical que o divide e que impõe, inversa e concomitantemente ao jogo de aproximação/espelhamento, uma descontinuidade espacial e visual entre o sujeito desejante e o corpo desejado. Aquele plano, conforme já analisado, junta numa mesma unidade de registro o olhar de Scottie e o corpo de Madeleine; mas, simultaneamente, ele os separa em espaços visuais descontínuos e diferentes. É todo o dispositivo escópico do filme que aí se enuncia. Feita esta ressalva, devo reforçar que a análise de Modleski é reveladora no que tange a compreensão da forma complexa pela qual a questão da diferença sexual é trabalhada no filme. Uma cena parece crucial para a confirmação desta leitura: aquela em que Scottie segue Madeleine por um itinerário particularmente complicado e tortuoso; a câmera retorna sempre ao rosto de Scottie, cada vez mais surpreso, pois o trajeto confirma que Madeleine está indo para a casa dele, onde deixará uma mensagem na caixa de correspondência. "A busca pelo Outro misterioso, à qual Scottie se dedica, leva-o inevitavelmente à própria casa: como Freud o demonstrou, a inquietante estranheza, o Unheimlich é precisamente o Heimlich, o familiar, tornado estranho pelo recalcamento". ${ }^{167}$ Essa cena, assim como o plano do espelho, exprime perfeitamente "a possibilidade de uma ligação entre [Scottie] e a inquietante alteridade da mulher, de uma semelhança intolerável porque coloca em questão a integridade do seu ser". ${ }^{168}$

Mais crucial ainda é a cena em que Judy, relembrando os acontecimentos, escreve sua carta para Scottie, a carta que nunca será entregue: "Hitchcock decide, contra todas as expectativas, nos dar o ponto de vista feminino, nos fazer partilhar os pensamentos e os sentimentos de Judy". ${ }^{169}$ Contra todas as expectativas, ou seja, tanto as do espectador habitual do film noir, que não está acostumado a ver a mulher como instância narradora que fala com ele quase que diretamente em primeira pessoa (Judy se dirige imaginariamente a Scottie, mas

\footnotetext{
166 Ibid., p. 140.

167 Ibid., p. 141.

168 Ibid., p. 140.

${ }^{169}$ Ibid., p. 152.
} 
é para a câmera que seu olhar se volta no início do flashback explicativo), quanto as das críticas feministas de Hitchcock, que não esperavam essa heterogeneidade do ponto de vista.

\section{A crise do olhar subjetivo}

Em todo filme noir, gênero ao qual Vertigo mal ou bem se filia, "uma mulher aparece, imagem sublime e intocável, puro espetáculo, imediatamente captada pelo olhar de um homem. Este se torna o herói do filme, que possuirá, ao final, a imagem sublime". ${ }^{170}$ Eis a "cena primitiva" do film noir, e de boa parte do cinema hollywoodiano no conjunto. Vertigo, já o dissemos, confere ares majestosos a essa "cena primitiva", como comprova a mise en scène da primeira aparição de Madeleine no Ernie's. A figura feminina que assim surge é a imagem que atrairá o herói para o mundo característico do film noir, com "sua temporalidade acidentada e sua espacialidade labiríntica". ${ }^{171} \mathrm{O}$ ícone feminino (a atração) é uma "imagem fascinante, mas prisioneira", sempre em movimento, mas sempre escoltada pelo homem, o que exprime a própria "relação que as empresas hollywoodianas mantinham com suas stars femininas, ao mesmo tempo joias preciosas e escravas da organização". ${ }^{172}$

A decupagem das principais sequências de perseguição de Vertigo nada mais é do que um esgarçamento do esquema básico do film noir, que consiste na articulação entre "o olhar fascinado de um homem e o corpo de uma mulher que se oferece como espetáculo". ${ }^{173}$ Mas, para que tal esquema deslanche, é necessária uma predisposição do olhar, uma disponibilidade/suscetibilidade que geralmente é dada pelos antecedentes do herói. Na primeira cena de Vertigo (sem contar o prólogo), composta por um longo diálogo no apartamento de Midge, Scottie é caracterizado como um convalescente, um homem que se recupera de um trauma - situação que, conforme descreve o narrador de "O homem da multidão", de Poe, desperta no sujeito uma sede de visão e de descoberta, um renovado e "inquisitivo" interesse por tudo: os olhos estão dispostos a se encantar novamente com o mundo, e se fazem receptivos a seus chamarizes.

\footnotetext{
${ }^{170}$ J.-P. Esquenazi, Hitchcock et l'aventure de Vertigo, p. 125.

${ }^{171}$ Ibid., pp. 128-129.

${ }^{172}$ Ibid., p. 125.

${ }^{173}$ Ibid.
} 
Por vários meses andara enfermo, mas já me encontrava em franca convalescença e, com a volta da saúde, sentia-me num daqueles felizes estados de espírito que são exatamente o oposto do ennui; estado de espírito da mais aguda apetência, no qual os olhos da mente se desanuviam e o intelecto, eletrificado, ultrapassa sua condição diária $[\ldots]^{174}$

Além da situação de convalescença, Scottie, no decorrer da conversa com Midge, revela um vazio mais profundamente enraizado, anterior às crises de vertigem e ao trauma vivido no início do filme. “O que você vai fazer agora que largou a polícia?”, Midge pergunta. "Nada, durante um tempo. Não esqueça que eu sou um homem de meios, independente", ele afirma, dando a entender que goza de situação financeira confortável e não precisa do trabalho para se sustentar. Pouco depois, falando a respeito da vida afetiva, define-se como "John Ferguson, o disponível". É sua última frase antes de trazer à conversa o nome de Gavin Elster.

A convalescença e a desistência do trabalho geram uma suspensão da vida cotidiana, uma ausência de afazeres, e isso leva a uma espécie de vacância do espírito. Scottie abre em sua existência diária uma lacuna a ser preenchida por Madeleine, que se oferecerá ao olhar do ex-policial "como a encarnação de seu desejo profundo". ${ }^{175}$ A disponibilidade de Scottie o expõe aos encantos da femme fatale e, por conseguinte, ao plano diabólico de Gavin Elster. Scottie representa o que Esquenazi denomina o "weak guy" do universo ficcional do noir: o herói impressionável, desguarnecido, exposto ao clarão hipnótico da mulher fatal. ${ }^{176}$

Embora esteja longe de ser brilhante intelectualmente, Scottie se encaixa na categoria do homem dedutivo, reflexivo, que, tal como Shep em Sortilégio do amor, prefere "a explicação racional". Mas ele será obrigado a se confrontar com forças que ultrapassam seu controle consciente, a começar pelo medo de altura. Paralelamente, provará uma "fascinação secreta pelo inexplicável"177, talvez movido por aquele "princípio inato e primitivo da ação humana, algo indefinível, paradoxal, a que podemos chamar de obstinação, na falta de um termo mais adequado". ${ }^{178}$ A obstinação, nota Poe, "é um móvel imotivado, motivação

\footnotetext{
${ }^{174}$ E.A. Poe, "O homem da multidão"; Contos de Edgar Allan Poe; tradução José Paulo Paes; $2^{a}$ ed., São Paulo: Cultrix, 1985, pp. 131-132. Mais à frente, no mesmo conto, Poe descreve o caminho adotado pela visão do convalescente, definindo uma forma de observação que se assemelha à vetorização do plano hitchcockiano, bem como às estratégias do observador de Hoffmann em "A janela de esquina do meu primo" (do geral ao detalhe, do plano de conjunto ao primeiro plano): "Olhava os transeuntes em massa e os encarava sob o aspecto de suas relações gregárias. Logo, no entanto, desci aos pormenores e comecei a observar, com minucioso interesse, as inúmeras variedades de figura, traje, ar, porte, semblante e expressão fisionômica" (p. 132).

${ }^{175}$ J. Douchet, op. cit., p. 26.

${ }^{176}$ Cf. J.-P. Esquenazi, Le film noir, Paris: CNRS Éditions, 2012, p. 224.

177 J. Douchet, op. cit., p. 19.

${ }^{178}$ E. A. Poe, "O demônio da obstinação", in $O$ gato preto e outros contos; tradução de Guilherme da Silva Braga; São Paulo: Hedra, 2008, p. 73.
} 
unmotiviert. Sua influência nos impele a agir na ausência de um objetivo compreensível; ou [...] a agir justamente porque não deveríamos" (ibid.). Tomado pela obstinação, pela ação irrefreável do pensamento e da curiosidade, "o homem com inclinações intelectuais ou lógicas" experimenta a vertigem do conhecimento. E quanto mais tenta dominá-la e conhecêla, mais se perde, pois não consegue suportar o vazio, isto é, a ausência de explicação para um fenômeno. Não seria esse o problema de Scottie, cuja acrofobia, na verdade, mascara os efeitos de uma pulsão de conhecimento mais perigosa que o próprio medo de altura? "Eu acho que posso dominar minha vertigem", ele diz. "Tenho uma teoria: se eu conseguir me acostumar à altura aos poucos, progressivamente, vou vencê-la”. Ele tenta mostrar a Midge o que está dizendo. Sobe num banquinho. "Olho para cima, olho para baixo, e não sinto nada!", exclama vitorioso. Midge pega um banco mais alto e o posiciona perto da janela. Scottie, sentindo-se confiante, sobe nesse outro banco. Mas, quando seu olhar intercepta a janela, ele percebe a altura em que se encontra em relação à rua, e uma nova crise de vertigem o faz quase desmaiar.

A afecção de Scottie é sentida, primeiramente, como uma perturbação visual, uma desregulação do olhar. "Eu olho para cima, olho para baixo, olho para cima, olho para baixo...”. Ele assim repete, até que, numa das olhadas, encontra o vazio. Quando fita o abismo, é tomado pela vertigem.

[A enfermidade de Scottie] afeta o órgão com o qual o herói hollywoodiano afirma em geral seu poder, ou seja, o olhar. Assim, a ameaça que pesa sobre a personagem atinge igualmente o sistema sintáxico mais comum de todo o cinema romanesco, a saber, o sistema do raccord subjetivo. O espectador vê o que a personagem vê, tal é o axioma do sistema. ${ }^{179}$

Frisamos, no primeiro capítulo, a importância da câmera subjetiva e do plano-pontode-vista no cinema de Hitchcock. O próprio diretor, numa conferência em Nova York, em 1939, afirmou a centralidade do raccord subjetivo em seu cinema, definindo dois tipos de suspense: o suspense objetivo, que é aquele visto nas cenas de perseguição tradicionais (ele cita como exemplo uma montagem paralela griffithiana), e o suspense subjetivo, que mostra a perseguição através do olhar dos personagens, inserindo o espectador "dentro" da cena. ${ }^{180} \mathrm{O}$ suspense hitchcockiano, evidentemente, pertence a esta segunda forma de suspense, que tem no raccord subjetivo sua principal estrutura de decupagem. E Vertigo, como muitos já destacaram, constitui o ápice da maestria de Hitchcock na utilização de tal recurso. Uma

\footnotetext{
${ }^{179}$ J.-P. Esquenazi, Hitchcock et l'aventure de Vertigo, p. 85.

${ }^{180}$ Cf. A. Hitchcock, "All about melodrama", in Cahiers du cinéma, n. 537, julho/agosto de 1999, p. 23.
} 
imensa parte dos planos do filme, sobretudo nas sequências não dialogadas, alterna entre o olhar de Scottie e o que ele está vendo.

Mas Hitchcock não lança mão dessa ferramenta simplesmente para se valer de sua eficácia: se ele a explora exaustivamente, é para deslocá-la e subvertê-la em seguida. É assim que, após alcançar uma espécie de forma-limite da ficção voyeurista nas cenas de perseguição da primeira metade do filme, dilatando o tempo de contemplação e reduzindo praticamente toda a ação narrativa a uma trama do olhar em estado puro, Hitchcock provoca, na segunda parte, uma fratura da relação escópica que identificava o espectador ao protagonista. Depois de sair da clínica psiquiátrica, Scottie erra pela cidade, visita os lugares em que Madeleine antes estivera (o estacionamento do prédio em que ela morava, o restaurante Ernie's, o museu onde está o retrato de Carlotta), e a vê em todo rosto feminino com que depara; quando se aproxima, porém, percebe que se enganou (era outra mulher). Uma falha é produzida no sistema do raccord subjetivo: os planos rodados do ponto de vista de Scottie não nos dão mais uma visão que sirva ao mesmo tempo como registro de um olhar pessoal e testemunho da realidade concreta que está diante dele. O filme "descredita" a visão do protagonista. "De certo modo, experienciamos através de Scottie a divisão que Freud diz ser característica da melancolia: de um lado, continuamos a nos identificar com ele, como antes, mas a reiterada desmistificação de sua visão acaba despertando nossa desconfiança, e nos tornamos mais distanciados do que fôramos previamente". ${ }^{181}$

Não somos mais associados ao olhar de Scottie, mas testemunhas de sua obsessão. [...] É toda a aliança da personagem masculina com a câmera, característica do film noir, que se acha aqui questionada. Vertigo põe em dúvida o próprio sistema do olhar subjetivo em que se baseia. Negando o objeto, compreendendo o ato de percepção como um ato de imaginação, ele parece recusar seu princípio de autenticação específico. ${ }^{182}$

O raccord subjetivo, como bem definiu Esquenazi, “é essa frase essencial do estilo romanesco hollywoodiano, que lhe permite mostrar uma imagem ao mesmo tempo como uma asserção sobre o mundo do filme e como uma emoção de um dos personagens". ${ }^{183}$ Mas, no caso de Vertigo, um desequilíbrio se estabelece. Se alguns planos subjetivos do filme mostram, no fundo, não mais que percepções objetivas de Scottie, outros, em contrapartida, são figurações de estados emotivos extremos. O exemplo mais óbvio consiste naquela

\footnotetext{
${ }^{181}$ T. Modleski, op. cit., p. 146.

182 J.-P. Esquenazi, Hitchcock et l'aventure de Vertigo, p. 174.

${ }^{183}$ Ibid., p. 122.
} 
combinação contraditória de zoom para frente e travelling para trás, uma das mais celebradas inovações técnicas de Hitchcock, que produz um efeito, de fato, vertiginoso, traduzindo visualmente, sensorialmente, os momentos de pane de Scottie. "Essa invenção tecnológica atrai nossa atenção para aquilo que, em geral, é apenas uma ferramenta da narrativa hollywoodiana, o olhar da personagem, que neste filme se torna a própria engrenagem da ficção". ${ }^{184}$ Os planos que mobilizam esse recurso correspondem ao ponto de vista de Scottie nas situações em que, de algum lugar alto, ele olha para baixo e sente a vertigem. "O olhar vertical constitui uma versão extrema de raccord subjetivo, em que a percepção se torna alucinação". ${ }^{185}$ Normalmente empregado para dominar o espaço e subjugar o que se acha no campo visual, o olhar vertical, aqui, é anamorfose patológica, impossibilidade de apreender o espaço ou estabilizar a visão.

Em $O$ alucinado $(E l, 1953)$, filme com o qual Vertigo mantém interessantíssimo diálogo ${ }^{186}$, Buñuel também filma a desestabilização do olhar subjetivo, mas de maneira mais “rudimentar" que Hitchcock. O protagonista do filme, enlouquecido de ciúme, vai a uma igreja onde pensa ter visto sua esposa entrar acompanhada de outro homem. Ele segue o casal até uma fileira de bancos próxima ao altar. Chegando lá, descobre que a mulher não era sua esposa; ele havia se confundido. Ouve a tosse de um senhor que passa ao lado: é o suficiente para sua imaginação começar um novo processo neurótico, já que ele toma a tosse por uma risada de escárnio. Olha ao redor e, convencido de que sua esposa é adultera, começa a achar que todos estão rindo dele, pois já ficaram sabendo da traição. Mesmo o padre, que é seu amigo e frequenta a sua casa, estaria rindo de deboche. Tudo é mostrado numa série de raccords de olhar: o protagonista olha para alguém; vemos a pessoa rezar ou prestar atenção na missa (percepção objetiva); um corte seco insere então um outro plano (rodado do mesmo lugar e com a mesma angulação e enquadramento) em que a pessoa está agora gargalhando, apontando para o protagonista e fazendo sinal de que ele é corno (distorção subjetiva). Buñuel insere a alucinação, portanto, como uma fratura da visão, um corte abrupto no fluxo perceptivo. A alucinação ganha forma pela montagem, pelo enxerto de registros heterogêneos.

Em Vertigo, a diferença é que a esquize do olhar se imiscui nas próprias regras do raccord de ponto de vista. Hitchcock não recorre ao corte brusco para expressar a divisão do

\footnotetext{
${ }^{184}$ Ibid., p. 117.

185 Ibid., p. 122.

${ }^{186}$ Entre Vertigo e $O$ alucinado há uma intensa migração de cenários, temas, motivos visuais etc. Para uma análise comparativa detalhada, ver Charles Tesson, Luis Buñuel, Paris: Cahiers du Cinéma/Éditions de l'Étoile, 1995, pp. 230-233.
} 
sujeito, que acontece de maneira mais sutil, por uma modulação da percepção, sem interferir no sistema de continuidade da montagem. É a própria fruição do plano-ponto-de-vista que nos mostra que, ao contrário do que ocorria na primeira parte do filme, este novo tipo de plano subjetivo, posterior à passagem de Scottie pela clínica, não garante mais a conexão do olhar com o objeto olhado: o que Scottie pensa estar vendo não é o que ele vê efetivamente, e isso é revelado por um raccord subjetivo aparentemente igual a qualquer outro. Uma cena no Ernie's, que retoma exatamente o mesmo esquema da primeira cena em que Scottie viu Madeleine, ilustra bem esse efeito: ele senta ao balcão do bar e, de lá, vê uma mulher idêntica a Madeleine se levantar da mesma mesa em que ela havia estado no começo do filme; ela vem em direção a ele, como ocorrera naquela cena; inicialmente, há um plano em que, de fato, é Kim Novak quem aparece, mas vista de longe; corta para o rosto de Scottie, impressionado com o que vê; corta de volta para a suposta Madeleine, que, agora mais perto da câmera, passa de uma área escura para uma melhor iluminada, revelando ser outra mulher (Novak foi substituída por outra atriz entre um plano e outro). Tudo é mostrado com fluidez, mantendo o raccord de olhar e de movimento. Percepção e alucinação, lucidez e devaneio se embaralham na montagem, expondo a visão de um sujeito suspenso entre a realidade e o fantasma.

Uma boa parcela do filme se constrói na indistinção entre o real e o mental. A câmera de Hitchcock procura representar "uma espécie de errância da subjetividade"187, desbravando o mistério de Madeleine por meio do ponto de vista de Scottie, que busca compreendê-lo com base nos argumentos racionais elaborados ao longo da investigação, mas é inevitavelmente levado pela emotividade. Quando o filme passa da contemplação à emoção, seu ponto de vista já não se refere apenas a um ângulo particular de percepção visual, e sim a um "conteúdo mental experimentado pelo indivíduo em seu foro íntimo". ${ }^{188}$ A partir desse momento, o raccord subjetivo perde sua comunicabilidade e "condena ao solipsismo". ${ }^{189}$

Essa crise do raccord subjetivo é um dos elementos que indicam a maneira como Vertigo internaliza em sua mise en scène uma clara consciência acerca do esgotamento iminente dos dispositivos formais do classicismo hollywoodiano, já prefigurando, em parte (pois é óbvio que se trata de uma equação bem mais complexa), a emergência das obras de ruptura dos anos 1960. Não por acaso, quando falar de uma "crise da imagem-ação" e apontar as formas antecipatórias de uma modernidade cinematográfica que se oporia ao cinema

\footnotetext{
${ }^{187}$ D. Chateau, op. cit., p. 128.

${ }^{188}$ Ibid., p. 70.

${ }^{189}$ Ibid.
} 
clássico pela subversão do seu sistema de raccords, pela perda dos ligantes, pela inserção de um vazio operante que implica uma nova forma de escansão do espaço-tempo fílmico, Deleuze utilizará justamente o exemplo de Hitchcock, e mais especificamente dos filmes Vertigo e Janela indiscreta, em que ele identifica ao mesmo tempo a eficácia máxima do sistema da imagem-movimento e o indício de sua crise. Tais filmes seriam o apogeu da forma do suspense hitchcockiano, mas já o prenúncio de sua superação. Ao procurar evitar uma crise do cinema tradicional, Hitchcock a teria precipitado por intermédio de suas inovações.

Para Deleuze, Hitchcock inventou no cinema a imagem mental, que ele qualifica também de “imagem-relação". Cada imagem de Hitchcock seria “a exposição de uma relação mental". ${ }^{190}$ Mais que um metafísico platônico e cristão (como queriam Chabrol e Rohmer) ou um psicólogo das profundezas (como Douchet o definiu), Hitchcock seria, segundo Deleuze, um cineasta das "cadeias de relações", das associações infinitas, criando imagens que estão sempre em condições de estabelecer conexões umas com as outras, pois todas provêm de uma mesma imagem mental (o postulado de base do filme) da qual cada uma delas é apenas uma variação ou uma gradação. Donde se poderia concluir que Hitchcock atinge o estágio último da narrativa clássica, levando ao limite a noção de unidade e de entrelaçamento dos elementos que constituem o filme. Cada plano representaria uma vista possível de uma totalidade que não existe senão como imagem mental, e o filme se desenvolveria "com uma necessidade matemática ou absoluta, apesar das inverossimilhanças da intriga e da ação". ${ }^{191}$ É a perfeição do sistema de estímulos e respostas da imagem-movimento.

“Todavia, alguns dos mais belos filmes de Hitchcock trazem o pressentimento de uma questão importante", afirma Deleuze: Vertigo, pela enfermidade de seu protagonista, que é paralisado no meio da ação pela acrofobia, instaura "um estranho estado de contemplação que se transmite a todo o filme e que é raro em Hitchcock". ${ }^{192}$ A mesma observação já fora feita por Truffaut, que comenta, na entrevista com Hitchcock, o "ritmo contemplativo" de Vertigo, em contraste com as reviravoltas e transições inesperadas dos outros filmes. A resposta de Hitchcock a esta observação é simples e esclarecedora: “isso é perfeitamente natural, já que a história é narrada do ponto de vista de um homem que está numa crise emocional". ${ }^{193}$ Segundo Hitchcock, portanto, a ralentação do ritmo e as cenas contemplativas são uma consequência natural da forma de focalização do drama (e de "ocularização", pois "vemos efetivamente pelos olhos da personagem", com "a câmera subjetiva simulando o exercício do

\footnotetext{
${ }^{190}$ L'Image-mouvement, Paris, Les Éditions de Minuit, 1983, p. 271.

191 Ibid., p. 273.

${ }^{192}$ Ibid., p. 276.

${ }^{193}$ Cf. Hitchcock-Truffaut, p. 246.
} 
seu olhar"194). Pode-se dizer que a decupagem de Vertigo é parasitada por um afeto subjetivo que provoca uma descompressão narrativa, uma flacidez do tempo.

A vertigem de Scottie, assim como a perna engessada de Jeff (Janela indiscreta), simboliza para Deleuze a paralisia do "esquema sensório-motor", a flagrante disfunção da imagem-movimento. De heróis ativos, eles se transformam em espectadores passivos, antecipando, assim, o ocaso da imagem-movimento e o advento da imagem-tempo. A hipótese formulada no final de Imagem-movimento, trocando em miúdos, é a de que a falha do sistema motor, notadamente em Vertigo, acarretaria uma estranha sideração do plano-pontode-vista, uma dilatação sobrecomum do registro contemplativo. Uma consequência parece então inevitável: “a imagem mental seria menos uma realização completa da imagem-ação [...] do que um questionamento de sua natureza e de seu estatuto. Mais ainda: é toda a imagem-movimento que se vê questionada pela ruptura das ligações sensório-motoras nesta ou naquela personagem". ${ }^{195}$ Deleuze faz uma associação direta, portanto, entre a "crise" da imagem-ação e a enfermidade de Scottie: a falha, a fenda, o abismo que seu medo de altura inscreve no centro da narrativa provoca sequências evacuadas de ação dramática propriamente falando, mas plenas do que o filósofo depois chamaria de situações ópticas puras, as quais seriam dilatadas e multiplicadas pela modernidade antonioniana.

Comentando a análise de Deleuze, e problematizando suas conclusões, Jacques Rancière afirma encontrar em Vertigo menos uma crise da imagem-ação do que uma forma exemplar de conciliação entre a narrativa movida pelo puro fascínio visual e o modelo aristotélico da intriga com reviravolta e revelação. A acrofobia de Scottie, em vez de arruinar a lógica da imagem-movimento, seria, ao contrário, a peça necessária para o sucesso da maquinação artístico-intelectual operada pelo filme. ${ }^{196}$ "Não vemos em que as perturbações motoras ou psicomotoras impedem as imagens de se encadear e a ação de avançar”, diz Rancière. ${ }^{197}$ “A ruptura do 'esquema sensório-motor' não se dá em parte alguma como processo assinalável por características precisas na constituição de um plano ou na relação de dois planos. Sempre, na verdade, o gesto que libera as potencialidades as encadeia novamente". ${ }^{198}$ Na vertigem de Scottie, o que a câmera encontra não é uma paralisia nem uma disjunção, mas antes um pretexto tanto para realizar trucagens ópticas que contribuem para os

\footnotetext{
${ }^{194}$ Cf. François Niney, Le subjectif de l'objetif, Paris: Klincksieck, 2014, p. 43.

${ }^{195}$ G. Deleuze, L'Image-mouvement, pp. 276-277.

${ }^{196} \mathrm{Cf}$. As distâncias do cinema, p. 32.

${ }^{197}$ La fable cinématographique, Paris, Éditions du Seuil, 2001, p. 155.

${ }^{198}$ Ibid., p. 158.
} 
efeitos do espetáculo quanto para reinventar a narrativa aristotélica e o enredo clássico. Segundo Rancière, então, a imagem não teria perdido seu prolongamento motor, como queria Deleuze, mas sim forjado as condições de uma grande maquinação narrativa e visual que só pode ocorrer por conta da incapacidade de Scottie:

A lógica da imagem-movimento não é em nada paralisada pela premissa ficcional. É preciso então considerar que essa paralisia é simbólica, que as situações ficcionais de paralisia são tratadas por Deleuze como simples alegorias para emblematizar a ruptura da imagem-ação e seu princípio: a ruptura da ligação sensório-motora. Mas se é preciso alegorizar essa ruptura na forma de emblemas ficcionais, não é porque ela é inencontrável como diferença efetiva entre dois tipos de imagens? Não é porque o teórico do cinema tem necessidade de encontrar uma encarnação visível para uma ruptura puramente ideal? A imagem-movimento está "em crise" porque o pensador necessita que ela esteja em crise. ${ }^{199}$

Rancière sugere, portanto, que a crise da imagem-movimento não é um dado "visível" em Vertigo. Para ele, os indícios da tal ruptura do esquema sensório-motor só seriam encontráveis no filme na forma de símbolos, e graças a toda uma abstração teórica.

De fato, ao identificar na acrofobia de Scottie o emblema da "crise da imagem-ação", Deleuze pode ter se precipitado. Mas que há uma ruptura em Vertigo, isso é inegável. Essa ruptura talvez não esteja exatamente num fracasso sensório-motor, tampouco num relaxamento ou exaurimento das energias de ligação das imagens - imagem-ação, imagemafecção, imagem-pulsão etc. - que Deleuze agrupou no paradigma da imagem-movimento. Talvez devamos procurá-la nos locais de fratura que o próprio filme demarca e expõe.

Pois Vertigo, conforme já frisamos, divide-se em duas partes muito bem diferenciadas entre si. Na primeira parte, embarcamos com Scottie na perseguição a Madeleine; o filme se apresenta, ali, como o suprassumo da ficção voyeurista, o exemplo absoluto de uma narrativa que parece unir magistralmente os afetos específicos da imagem cinematográfica e o projeto de elaboração de um mistério que se esconde sob as aparências, e cujo poder de fascinação se expressa no próprio desenrolar visual das imagens; enfim, "uma verdadeira experiência fenomenológica e cinematográfica do ver, que oscila entre a visão 'objetiva', o fantasma, a imaginação, a lembrança e a reminiscência". ${ }^{200} \mathrm{Na}$ segunda parte, que começa com a cena do julgamento de Scottie, logo após a morte de Madeleine, um inesperado distanciamentoestranhamento se cria. Pouco a pouco, o olhar do espectador se descola do olhar da personagem: primeiramente, pelo clima tedioso, frio, neutro, técnico - digamos logo: morto -

${ }^{199}$ Ibid., p. 155.

${ }^{200}$ J. Achemchame, art. cit., p. 32. 
da cena do tribunal; em seguida, pela perturbação do raccord subjetivo, que demonstra a alienação de Scottie; mais adiante, pela inversão de ponto de vista que se dá na cena em que a câmera deixa Scottie ir embora e fica com Judy no quarto do hotel, momento de confissão do que realmente se passou à revelia do herói (ali é todo o filme que se retorce sobre si mesmo); por fim, pelo comportamento cada vez mais doentio, cômico-obsessivo e até mesmo enervante do protagonista, que afasta dele o espectador (bloqueio da identificação afetiva). Passamos do estado de fruição ao estado de reflexão. A experiência do filme se transfaz numa interrogação sobre os meios, as maneiras, as ferramentas de construção daquela imagem que havíamos visto e admirado na primeira parte da narrativa. Mesmo sem abandonar a história ou desistir de explorar a trama até o fim, Hitchcock implanta o distanciamento necessário para refletir não só sobre as artimanhas do cinema e a situação do espectador, mas sobre a estruturação do imaginário artístico ocidental num sentido amplo (daí a alusão a alguns dos seus mitos fundadores). Se, na primeira parte, o filme nos seduz através das principais receitas da usina de sonhos hollywoodiana, é somente "para melhor denunciar [na segunda parte] suas maquinações e efeitos especiais...". 201

Em resumo: a primeira metade do filme se ocupa da arte, e a segunda, da teoria da arte. A intriga praticamente acaba (sobretudo depois que Judy revela o que de fato aconteceu, desfazendo o mistério); começa o julgamento, o juízo (moral, estético), a reflexão, a exegese do que vimos. E depois, na penumbra do Empire Hotel, com Scottie reconstruindo Madeleine, o que temos é quase um registro do artista em seu ateliê. Hitchcock se lança a uma espécie de poética de formação da imagem clássica. (Tudo isso, e aí jaz o segredo, sem abdicar do suspense, continuando a nutrir no espectador um desejo primordial de imagem e de espetáculo.)

Ora, esse tipo de discurso meta-artístico é característico de períodos de crise ou de passagem de estilos. Em Vertigo, ele significa a cristalização de um pensamento sobre a imagem (sua produção, sua inspiração, seu poder) numa época em que o cinema já possui uma história razoavelmente longa e já começa a se diluir numa cultura visual mais englobante, que ainda o mantém mais ou menos no centro, mas que já o ultrapassa. Hitchcock acusa, assim, o limiar histórico de um sistema de representação cuja forma quintessencial ele próprio se empenhou em atingir. Aí se acha a verdadeira fratura interna de Vertigo, filme tardio e precoce ao mesmo tempo, suspenso entre duas "idades" da imagem, num ponto de inflexão da história do cinema.

\footnotetext{
${ }^{201}$ F. Niney, op. cit., p. 74.
} 


\section{Uma teoria maneirista da arte?}

"Vertigo conta a história de um homem inteligente traído por sua razão, apegado a uma Ideia, que se torna sua ideia fixa" ${ }^{202}$ Esta frase de Jean Douchet, que abre o capítulo dedicado a Vertigo em seu livro sobre Hitchcock, retoma a tese central da crítica de Rohmer publicada nos Cahiers du cinéma em 1959. Madeleine, segundo Rohmer, encarna uma figura que sempre esteve presente no cinema de Hitchcock, mas nunca de maneira tão clara; personagem-fantasma, ela só existe no espírito do detetive - ela não é outra coisa senão uma ideia. “Assim como Janela indiscreta e $O$ homem que sabia demais, Vertigo é, portanto, uma espécie de parábola do conhecimento". ${ }^{203}$ Scottie, "apaixonado não por uma mulher, mas pela ideia de uma mulher", personifica o autêntico amor platônico. Sombras, reflexos e simulacros se sucedem e se misturam num "movimento inquietante": a narrativa em si mesma toma a forma daquela espiral que acompanhara os créditos de início. "Ideias e formas seguem o mesmo caminho, e uma vez que a forma é pura, bela, rigorosa, espantosamente rica e livre, podemos dizer que os filmes de Hitchcock, e Vertigo em primeiro lugar, têm por objeto [...] as Ideias, no sentido nobre, platônico do termo". ${ }^{204}$

O tema proposto por Rohmer não é novo. Esse estreitamento da relação entre Forma e Ideia, que ele destaca como o traço essencial de Vertigo (e como o platonismo incontornável de Hitchcock), remonta, evidentemente, à Antiguidade grega, onde já se encontra difundida a convicção de que o trabalho do artista não é apenas imitar a natureza e produzir sua ilusão, mas dar forma a uma ideia, a um "modelo exemplar" que ele encerra na mente, e para o qual pode voltar sua visão interior. ${ }^{205}$ Séculos depois, no Renascimento, "a Ideia é despojada de sua nobreza metafísica": o ideal da arte passa a ser buscado mais no mundo exterior do que na mente do artista ou num plano supraterrestre; o artista é mais do que nunca induzido a se inspirar na natureza, a respeitar "as leis que estão prefiguradas nas coisas", a se harmonizar com a realidade natural por meio do exercício da contemplação rigorosa e da experiência sensível. ${ }^{206}$ A teoria das Ideias só voltará a ter prioridade nos debates artísticos com o Maneirismo, que a revisita de modo sistemático, promovendo-a ao centro da teoria da arte na segunda metade do século XVI, "época que prepara simultaneamente o alto Barroco e o

\footnotetext{
${ }^{202}$ J. Douchet, Hitchcock, op. cit., p. 19.

${ }^{203}$ E. Rohmer, Le goût de la beauté, Paris, Cahiers du Cinéma, 2004, p. 269.

${ }^{204}$ Ibid., p. 273.

${ }^{205}$ Cf. Erwin Panofsky, Idea: a evolução do conceito de belo, São Paulo: Martins Fontes, 1994, pp. 15-34.

${ }^{206}$ Ibid., p. 65.
} 
Neoclassicismo". ${ }^{207}$ Assiste-se, então, ao ressurgimento das especulações metafísicas que as primeiras fases do Renascimento não levaram adiante. Donde o resgate do neoplatonismo, praticamente ignorado pela teoria renascentista da arte: "durante a segunda metade do Cinquecento, há uma disposição bem maior de acolhê-las [as teorias neoplatônicas], e são elas que impõem aos debates da teoria da arte sobre o problema da beleza um caráter tão singular". ${ }^{208} \mathrm{Na}$ cosmologia estética do Maneirismo, atribui-se novamente um papel central ao conceito de Beleza, que ganha uma formulação essencialmente metafísica. A obra de arte é aí definida como a manifestação externa e visível de uma Ideia ou "desenho interior" que se forma, primeiramente, no espírito do artista, cujo trabalho consiste em exteriorizar essa representação espiritual.

Ao antigo questionamento sobre a função da arte (imitar fielmente ou aperfeiçoar a natureza?), o Maneirismo fornece uma resposta mais firme que as dos períodos precedentes:

Vincenzo Danti, por exemplo, distingue expressamente o ato de "retratar", que reproduz a realidade tal como se vê, do ato de "imitar", que a reproduz tal como se deveria vê-la [...]; segundo ele, o procedimento do "retratar" é suficiente para representar as coisas que já são belas por si mesmas, ao passo que é preciso recorrer ao do "imitar" para representar as que são defeituosas. ${ }^{209}$

O mundo natural da matéria, para os pensadores de inspiração neoplatônica, aparece “como um princípio de feiura e malignidade. É a 'disposição viciosa da matéria' que doravante explica em profundidade as imperfeições e os erros das aparências naturais. [...] o artista deve, qual um 'diretor da graça divina', [...] restituir às coisas a perfeição e a beleza que elas perderam" quando deixaram de ser puras ideias e passaram à realidade sensória. ${ }^{210}$ Ou seja, o artista deve imitar, e não apenas retratar. "A beleza de uma obra de arte [...] depende da visão ideal de uma 'forma' que não existe em absoluto na realidade". ${ }^{211}$ Por isso é preciso que o artista confie não apenas em sua percepção sensível, mas, sobretudo, em seu "olhar interior".

Imitar, corrigir, aperfeiçoar. Trocar a aparência natural pela forma ideal. Representar a ideia e não a coisa. Não seria o papel de Scottie na segunda metade de Vertigo o de um

\footnotetext{
${ }^{207}$ Ibid., p. 72.

${ }^{208}$ Ibid., p. 91.

${ }^{209}$ Ibid., p. 79.

${ }^{210}$ Ibid., p. 93.

${ }^{211}$ Ibid.
} 
"imitador" tal como definido pela teoria maneirista da arte, isto é, o de alguém que ousa manipular as aparências, mudar o envelope sensível das coisas julgando poder modelá-las segundo uma Ideia? Tomando Judy como matéria bruta, dilapidada, Scottie não irá dobrá-la a uma forma captada pela visão sensível, mas posteriormente sedimentada pela memória e conservada como a imaginação ideal da Beleza?

Em Vertigo, com efeito, a imitação de Madeleine se define em consonância com as ideias estéticas do Maneirismo, ou seja, como uma démarche não somente de fixar as formas sensíveis, mas, sobretudo, de depurar, de "espiritualizar" aquilo que é representado: o modelo fornecido pela realidade (Judy) não é belo senão em potencial; Scottie deve então corrigir, reparar as imperfeiçoes de Judy, despi-la das sobras de matéria que encobrem a ideiaMadeleine. Após fazer Judy abdicar de sua "ganga material", de sua "grosseira aparência de ser humano", para recuperar o "aspecto angelical" de Madeleine, "Scottie se convence de ter realizado a grande obra [...] alçando a vulgar Judy ao patamar da pura aparência angelical". 212

O projeto de Scottie, ao recriar Madeleine, não é outro senão refazer o passado, redesenhar o destino, ter o que ninguém nunca tem: uma "segunda chance" ("This is my second chance", ele fala ao vencer a vertigem e puxar Judy para o topo da torre na cena final). Douchet demonstrou de que modo o pecado maior de Scottie, ao tentar reverter o tempo para trazer Madeleine de volta e reescrever sua história, é querer se apropriar, no fim das contas, do plano divino da criação. O que Scottie almeja pelo domínio das aparências, pela mestria da imitação (que se expressa por seu conhecimento exato de todos os atributos visíveis de Madeleine), é controlar a existência em sua estrutura mais profunda, agir sobre a ordem mesma da criação. Sob o pretexto de imitar as aparências sensórias, ele procura, na verdade, se apoderar da própria "potência criadora primordial". Arrogância tola - ou, pelo contrário, ingenuidade infantil - que só pode terminar em tragédia.

A cegueira de Scottie consiste em negligenciar que o conceito gerador da imagem que ele persegue e depois reconstrói não é Madeleine, mas Carlotta, ou seja, o próprio espírito cuja influência negativa sobre Madeleine ele tentava conjurar. Se há alguém que sofre a influência do espírito manipulador que habita o retrato feminino, este alguém é o próprio Scottie, que, ao provocar a morte de Judy, elimina a última rival de Carlotta.

De certa forma, a tríade Carlotta-Judy-Madeleine repõe a tríade conceito-matériaideia. Carlotta é o disegno, o concetto, o conteúdo espiritual do qual parte o artista; Judy, por sua vez, é a realidade sensível, a meio caminho entre "o suporte apropriado e dócil" descrito

\footnotetext{
${ }^{212}$ J. Douchet, Hitchcock, pp. 43-44.
} 
por um aristotélico como Federico Zuccari ${ }^{213}$ e a matéria que impõe resistência à forma ideal apontada pelos neoplatônicos; Madeleine, por fim, é a ideia, a comunhão perfeita do conceito e da matéria sensível, a fusão de Carlotta com Judy, a apresentação fenomênica de uma fantasia artística derivada de uma proposição ideal do belo.

À margem dessa tríade, encontra-se Midge. Uma cena tão enigmática quanto reveladora é aquela em que a brincadeira de Midge, que pinta uma cópia do retrato de Carlotta substituindo o rosto da figura pelo seu, recebe uma grave reprovação de Scottie. "No, it's not funny, Midge", ele afirma sério e desapontado. Arrependida, Midge estraga a pintura com três violentos golpes de tinta preta; depois, atira o pincel contra seu próprio reflexo no vidro da janela. Ela tentara transgredir seu papel na estrutura simbólica do filme, incrustando seu rosto na imagem que reconhece como o duplo de substituição do corpo desejado por Scottie (que há muito tempo, porém, já identificou Midge com a figura materna). A paródia do retrato de Carlotta, aos olhos de Scottie, soa como agressão psicológica ou, pior ainda, como profanação de uma "sacra immagine": iconoclastia. A obra de Midge, em suma, é um fiasco.

Mas o próprio Scottie é um "mau” imitador. Ele imita na incapacidade de criar; sua Madeleine não é a encarnação de uma ideia original: ela é uma imagem de segunda mão, uma forma reciclada, uma imitação puramente exterior (um simulacro). "A fatalidade do maneirista é que, ao se obstinar em repensar o original, ele só encontra cópias". ${ }^{214}$ Quando Scottie inicia seu trabalho de criação, ele o faz com a consciência de que toda a beleza e a perfeição já foram atingidas pela imagem de Madeleine concebida por Gavin Elster. Resta-lhe então tentar imitar e reinventar essa imagem, esse "fantasma original".

No texto introdutório de um dossiê que expõe o aspecto problemático e escorregadio do conceito de maneirismo quando aplicado ao domínio dos estudos de cinema ${ }^{215}$ (onde ele é menos uma tese cientificamente comprovada do que uma interessante ferramenta de trabalho), Philippe Roger recorre aos artigos em que Serge Daney tratou do assunto para chegar a uma definição do maneirismo como revisão melancólica do passado. A nostalgia do objeto perdido gera uma obsessão pela imagem que falta, o que faz do maneirista "uma espécie de intérprete melancólico de uma história que começou antes dele. Eis uma definição que cairia bem para o Scottie de Vertigo", conclui Roger, insinuando que o protagonista de Vertigo - e,

\footnotetext{
${ }^{213}$ Ver E. Panofsky, Idea: a evolução do conceito de belo, p. 93.

214 Philippe Roger, "L'art et la manière", in CAMPAN, Véronique e MENEGALDO, Gilles (orgs.), Du maniérisme au cinéma, Poitiers, La Licorne, 2003, p. 281.

${ }^{215}$ Já me detive sobre o problema em A mise en scène no cinema, op. cit., pp. 119-135.
} 
consequentemente, o filme no conjunto - poderia ser visto como o protótipo da sensibilidade maneirista no cinema. ${ }^{216}$

Assim como o Maneirismo pictórico surgira - numa fase tardia do Renascimento sob a atmosfera de "fim da arte" decorrente da constatação de que o estilo clássico renascentista já esgotara suas possibilidades, assim também Vertigo, conforme já observamos, traz a consciência de se situar no final do ciclo de um estilo (o estilo hollywoodiano clássico). A atitude de Hitchcock, no entanto, não é de negação, de se voltar contra esse estilo e tentar destruí-lo (não se trata de uma ruptura "modernizante"). Ele busca simplesmente encontrar sua forma-limite e enfrentar os desafios por ela colocados (com alguma melancolia, decerto, mas principalmente com distanciamento irônico). Tal atitude o leva a uma série de procedimentos tipicamente maneiristas: a construção de espaços irreais (o ápice é a variação do fundo do cenário - por uma técnica de back projection - durante a imagem rodopiante do beijo do casal no quarto do hotel, momento em que o espaço se torna totalmente subjetivo mas a verdade é que o filme inteiro está imerso numa bruma de sonho), a hipertrofia dos signos plásticos (o trabalho intenso com as luzes, os filtros, os reflexos, as sombras, os efeitos de enquadramento), a anamorfose (os planos da vertigem de Scottie). As cores, por vezes, como num quadro de Pontormo ou de Beccafumi, atingem níveis de saturação exorbitantes, perto da transgressão cromática e da completa inverossimilhança. Não se trata mais do expressionismo que, nos filmes precedentes, estava organicamente integrado ao processo de significação. Embora continuem alimentando a engrenagem textual, os efeitos de estilo passam a valer por si mesmos, quase que independentemente dos significados que carregam. A expressão plástica ameaça se desprender da produção de sentido. Triunfo das "maneiras".

Mas o que faz de Vertigo um verdadeiro caso à parte, e não somente mais um dos muitos filmes clássicos atravessados por pulsões maneiristas ou protobarrocas (basta pensar nas obras de Josef von Sternberg, Orson Welles, Max Ophüls, Douglas Sirk, William Wyler), é o seu obstinado trabalho "teórico", ou seja, o esforço de autorreflexão que está na origem de seus achados formais. Como afirma José Luis Castro de Paz, o que há de "exemplarmente maneirista" na fase da obra de Hitchcock que se inicia com Janela indiscreta (mas que já se prenunciara em seus filmes mais experimentais, como Festim diabólico e Sob o signo de capricórnio) é o fato de os filmes se assumirem como "uma escritura eminentemente teórica que se coloca constantes desafios de linguagem". ${ }^{217}$ Partindo de um relato "absolutamente clássico" (aparentemente, ao menos) e de um recurso (o ponto de vista subjetivo) "plenamente

\footnotetext{
${ }^{216}$ P. Roger, "Mise au point", in Campan e Menegaldo (orgs.), Du maniérisme au cinéma, op. cit., p. 18.

${ }^{217}$ J. L. Castro de Paz, Alfred Hitchcock, Madri: Cátedra, 2000, p. 112.
} 
integrado ao modelo hollywoodiano, Hitchcock sela um definitivo deslocamento, desmantelando ou descontruindo desde seu interior o sistema espacial em que [esse modelo] se sustentara". ${ }^{218}$ Se Hitchcock "perverte o cânone clássico", não é descartando os procedimentos convencionais nem rejeitando em bloco a "gramática" cinematográfica, mas submetendo-os a uma hipertrofia formal que desagua num tour de force técnico. Aliás, sempre foi essa sua principal forma de subverter as normas hollywoodianas: aceitando utilizar as convenções daquele regime particular de expressão, mas desafiando seus limites por meio de apostas formais cada vez mais ousadas. Por exemplo: filmar tudo em plano-sequência e respeitar rigorosamente a unidade de espaço, tempo e ação da narrativa, forjando a impressão de que o filme consiste num único take ininterrupto (Festim diabólico); situar um filme inteiro num barco salva-vidas, revertendo essa constrição em estímulo criativo (Um barco e nove destinos); construir uma trama complexa e mostrá-la quase que exclusivamente de um único ponto de vista que é o da janela de um apartamento (Janela indiscreta), etc. A realização cênica se torna uma performance em si, chamando tanta atenção quanto o drama e as personagens. Ao espectador são fornecidos “dispositivos distanciadores” que o instigam a uma leitura crítica da mise en scène clássica.

Esse esforço de definir e de compreender o que é a ilusão cinematográfica conduz Hitchcock a encarar o cinema dos grandes estúdios hollywoodianos, no momento em que ele realiza Vertigo, como uma era que se aproxima do fim, e que, por isso mesmo, se presta à sistematização do seu imaginário. Já não é questão somente de evidenciar - pela hipérbole formalista - a lógica e o sentido da escritura fílmica clássica, mas de admitir seu esgotamento, de demarcar no filme uma fronteira estética, um ponto a partir do qual aquela forma de expressão deixará de funcionar.

Tal disposição - de inscrever na obra uma reflexão sobre os limites internos e as últimas possibilidades comunicativas do regime de representação em que ela está inserida, fazendo conviver com a história contada um discurso metafílmico - é um dos sintomas da esclerose da forma clássica e do seu devir maneirista. $\mathrm{O}$ estado maneirista da imagem, como a história da pintura já havia demonstrado, implica a reflexividade: os artistas maneiristas "praticam uma arte consciente de si mesma, um 'stylish style', poderíamos dizer: tudo menos naïf". ${ }^{219}$ Eles seguem “a ideia de que a arte é uma experiência do pensamento, e não a simples aplicação de um savoir-faire". ${ }^{220}$ Além de uma paixão pela técnica e pela "inteligência

\footnotetext{
${ }^{218}$ Ibid., pp. 109-110.

${ }^{219}$ Patricia Falguières, Le maniérisme: une avant-garde au XVIe siécle, Paris, Gallimard, 2004, p. 53.

${ }^{220}$ Ibid., p. 55.
} 
fabricadora", há no maneirismo uma necessidade permanente de autoconsciência: uma obra de arte tem de ser sempre consciente tanto dos seus efeitos como das suas condições de possibilidade. "O maneirismo é intrinsecamente intelectual" ${ }^{221}$ : ele reconhece que a pintura “tornou-se adulta", e que a única forma de compreender essa maturidade é através de dialéticas complexas, de imagens de "segundo grau", de "programas iconográficos pesados, às vezes obscuros" ${ }^{222}$, que exigem observadores iniciados, cognoscenti, eruditos, aptos a decifrar as figurações alegóricas e herméticas da pintura maneirista. A "leitura" do quadro se torna indireta, disjuntiva, lacunar. É a própria noção de representação que se acha problematizada pelos maneiristas.

De acordo com Panofsky, é no Maneirismo que vemos "se colocar, pela primeira vez, o problema da possibilidade da representação artística enquanto tal", ${ }^{223}$ Não à toa, a criaçãoem-ato - seu processo, seu movimento, seu elã ao mesmo tempo libidinal e intelectual - é incluída na cena representada e se torna um tema recorrente na pintura do século XVI (prolongando-se no século seguinte). A figura do pintor trabalhando numa tela aparece em muitos quadros que atestam a tomada de consciência, na época do Maneirismo, sobre o ato pictural e as ideias (religiosas, estéticas, filosóficas, cosmogônicas) que podem a ele se associar. A meta-anamnese a que se entregam esses quadros "produz o equivalente de um tratado sobre a arte". ${ }^{224}$ A pintura doravante se esforça em elaborar um dispositivo suscetível de representar o artista no ato da criação, sem deixar, todavia, de veicular os conteúdos ligados aos gêneros pictóricos tradicionais - situação que vemos repetir-se, guardadas as proporções, em Vertigo, com Hitchcock tentando manter-se na esteira dos gêneros hollywoodianos convencionais, mas já se aventurando em especulações meta-artísticas cuja forma de enunciação é ao mesmo tempo disfarçada e evidente. Se Vertigo pode ser considerado "o filme inaugural do grande maneirismo cinematográfico"225, é não apenas porque mostra o trabalho obsessivo que um "artista" (Scottie) desenvolve a partir do "modelo clássico" (Madeleine) que o assombra, mas, sobretudo, porque elabora todo o seu dispositivo de mise en scène com base em uma consciência da representação. Além do mais, a relação que se estabelece entre Scottie, neo-pigmalião em busca da imagem viva do seu desejo, e Judy, suporte ideal da forma pensada ou sonhada pelo artista, pode tranquilamente ser encarada como uma alegoria sobre a origem da criação artística e o desejo da arte em geral.

\footnotetext{
${ }^{221}$ Patrick Mauriès, Maniéristes, Paris, Editions de la Lagune, 1995, p. 22.

222 Ibid., p. 35.

${ }^{223}$ E. Panofsky, Idea: a evolução do conceito de belo, p. 89.

${ }^{224}$ A. Chastel, Le tableau dans le tableau, op. cit., p. 29.

${ }^{225}$ P. Roger, "L'art et la manière", in Du maniérisme au cinéma, op. cit., p. 280.
} 
Não é o caso aqui de tentar provar que Vertigo é um filme maneirista, ou até mesmo que prefigura um maneirismo cinematográfico que seria a sucessão "natural" do classicismo. Afinal, o grande "mérito" dos esquemas evolutivos do tipo Classicismo-Maneirismo-Barroco, como bem colocou Stoichita, é a "comodidade". 226 Antes de querer aderir a uma esquematização da história dos estilos, o que procuro demonstrar é tão somente que, se há uma teoria da arte em Vertigo, essa teoria está em fase com os conceitos fundamentais do Maneirismo (sobretudo em sua vertente neoplatônica), o que não significa que estejamos lidando com uma obra que procura deliberadamente se filiar a um determinado programa estético e teórico, mas faz bastante sentido uma vez que se trata de um filme que, reconhecendo-se na extremidade do cinema clássico, cunhou a figura matricial de muitos dos maneirismos e modernismos que despontariam a partir dos anos 1960.

\section{O gabinete de Gavin Elster}

Uma das marcas de assinatura de Hitchcock são suas breves aparições nos filmes. Na maior parte das vezes, trata-se de um alívio cômico, de uma pequena gag recreativa sem maiores consequências. Às vezes, porém, sua participação pontua um momento importante da narrativa e se articula a algum significado mais profundo, como é o caso em Vertigo. Hitchcock aparece aos onze minutos de filme, cruzando o campo da esquerda para a direita, carregando uma maleta (ou um alto-falante? ou o quê?) de formato engraçado. Da direita, andando em direção oposta a Hitchcock, chega Scottie, que se encaminha ao escritório de Gavin Elster. O cenário industrial de fundo é um estaleiro de navios.

Hitchcock surge, portanto, no primeiro plano da sequência em que o filme nos apresentará Gavin Elster, o mestre das ilusões, o grande articulador/prestidigitador, figura mabusiana, mastermind que elabora a teia de eventos em que Scottie será envolvido, e que se assemelha, assim, ao próprio metteur en scène, ou seja, ao próprio Hitchcock. Fazendo sua aparição bem no início dessa sequência, Hitchcock avisa discretamente que o show vai começar, que a mise en scène de Elster será posta em ação; as cortinas se abrem para o espetáculo cuja estrela mor, Madeleine, terá, entretanto, de esperar pela sequência seguinte.

A cena no escritório de Elster é uma das mais longas e intrincadas do filme. Ela estabelece, inequivocamente, o lugar de Scottie na ficção. Do ponto de vista da realização, ela

${ }^{226}$ V. I. Stoichita, L'instauration du tableau, p. 353. 
é também a cena em que os deslocamentos dos atores e suas trocas de posições no cenário têm os significados mais claramente visíveis. A princípio, Scottie e Gavin conversam sobre trivialidades. $\mathrm{O}$ assunto que realmente motivou o encontro só emerge após alguns minutos. Gavin fala, então, do comportamento estranho da esposa, de suas crises de ausência; ele diz que precisa de Scottie para segui-la, para descobrir o que ela anda fazendo. "Você acredita que alguém do passado, uma pessoa morta, pode voltar para tomar possessão de uma pessoa viva?", Gavin pergunta com toda a seriedade. "Não", Scottie responde prontamente - e recusa a proposta, desdenhando do lado sobrenatural da história. Gavin o encaminha até a porta, pedindo desculpas por tê-lo feito perder tempo, mas lançando uma provocação que certamente mexe com Scottie: "você continua o mesmo cabeça-dura de sempre". A expressão de James Stewart muda neste momento. "Você acha que eu estou inventando tudo isso? Eu não saberia como...", Gavin continua, alegando que sua história é demasiado mirabolante para não ser verdade. Percebendo que finalmente afetou o detetive, ele discorre sobre as assombrações de Madeleine, deslocando-se para uma parte do escritório que fica num patamar mais elevado, onde se acha uma comprida mesa de reuniões. Separado do resto do espaço por um par de degraus e por uma espécie de moldura, esse anexo do escritório é como um palco teatral. Uma vez nele, Gavin anda de um lado para o outro, dá a volta na mesa, utiliza os recursos do espaço cênico enquanto prossegue com seu texto dramático sobre a melancólica Madeleine. Scottie, que estava próximo à porta de saída quando Gavin começou seu pequeno teatro, agora se mostra interessado, o que ele confirma ao sentar-se numa poltrona, acomodando-se para melhor apreciar o espetáculo (ele assume a posição de espectador). Os papéis entre quem comanda o show e quem assiste estão distribuídos. Estamos no coração do projeto reflexivo de Hitchcock, que filma, aqui, a mise en scène da mise en scène.

A partir do momento em que Scottie se deixa capturar pela encenação de Gavin, a engrenagem infernal é acionada. Gavin só aparecerá mais duas vezes: no clube onde toma um drinque com Scottie, passando-lhe informações adicionais sobre Madeleine, e no julgamento, onde se despede de Scottie (e do filme). Como bom metteur en scène, ele sabe que seu lugar é nos bastidores: sua presença na cena poria em risco a ilusão do espetáculo. Ele se prova o perfeito encenador de acordo com os parâmetros do cinema clássico: a instância invisível que organiza o espetáculo para um observador que, em estado de consciente inconsciência, deixase absorver pela ficção. Ausentando-se, Gavin se torna não apenas o "mestre escondido", mas principalmente "o grande outro de Scottie, o ideal inacessível de uma impossível mestria". 227

${ }^{227}$ P. Arnaud, op. cit., p. 172. 
Scottie, ao descobrir Judy, também vislumbrará a mestria de uma encenação, a execução de um plano. Mas ele é tão somente um espectador, só enxerga as coisas do ângulo escolhido pelo narrador: faltam-lhe informações ocultadas pelo condutor do espetáculo. Não à toa, irá fracassar nessa tentativa de assumir o lugar do diretor. Se a mise en scène de Gavin, que arquiteta o crime perfeito, sai exatamente como planejada, a de Scottie, que refaz a mulher morta a partir da viva (ignorando que as duas são a mesma pessoa), literalmente cai por terra. O filme ilustra 'os limites, quiçá o fracasso do 'director' fetichista e voyeur a partir do momento em que ele é submetido a um plano que lhe escapa, do qual ele não tem o controle". ${ }^{228}$ O ponto de vista de Scottie é demasiadamente limitado, falta-lhe a visão de conjunto. $\mathrm{O}$ filme nos mostra essa precondição narrativa de modo, por assim dizer, empírico, fechando-nos no ponto de vista subjetivo/circunstanciado de Scottie e arrastando-nos com ele para a vertigem das aparências (até o momento de colisão contra a parede que é a revelação do complô). Contrariamente a Scottie, Gavin, o gênio maligno, tem o controle (mesmo que parcial e temporário) sobre a visão do outro; ele é o responsável pelo agenciamento dos pontos de vista. Hitchcock sublinha, desta forma, uma das premissas centrais para o funcionamento do cinema clássico: a determinação do ponto de vista.

“A mise en scène clássica joga com dois tipos de pontos de vista: o do narrador, onisciente e exterior, e os que são atribuídos às personagens, os pontos de vista ditos "subjetivos",. 229 Gavin, enquanto duplo do diretor, domina ambos: ele tanto articula o desenho geral da trama (o ponto de vista "objetivo" do narrador) quanto determina a escolha do lugar do espectador, a posição que este deve ocupar para ver a cena do ângulo em que ela terá o efeito programado (os pontos de vista "subjetivos" em que personagem e espectador partilham uma mesma visão). Embora não se dê conta, Scottie, a cada nova situação, assume exatamente o ponto de vista pensado por Gavin. Ele assiste a um espetáculo cujo roteiro parece obedecer aos seus desejos, mas foi escrito por outro.

[Gavin] conhece o segredo maior, pois sua construção não se esgota na performance da cena, não envolve apenas o controle do lugar do crime. Exige o controle do lugar do espectador, pois é ele quem deve completar a geometria do espetáculo. $\mathrm{O}$ crime perfeito, como um filme clássico, é uma simulação de mundo que exige um espectador determinado, enquanto posição do olhar mas também enquanto desejo, pois está aí a articulação peculiar de que o percurso de Scottie se mostra paradigma. ${ }^{230}$

\footnotetext{
${ }^{228}$ J. Douchet, Hitchcock, p. 287.

${ }^{229}$ E. Plasseraud, Cinéma Baroque, op. cit., p. 73.

${ }^{230}$ I. Xavier, $O$ olhar e a cena, p. 82.
} 
Vertigo, como constatou Ismail Xavier, "é a trama da simulação por excelência"231, justamente porque faz a construção dramática coincidir com uma reflexão sobre o olhar e o ponto de vista, mostrando que "o processo de simulação não é o da imagem em si, mas o da sua relação com o sujeito". 232

O dispositivo montado estava todo apoiado nas posições recíprocas de observador e imagem [...] Tudo nas palavras e gestos de Judy/Madeleine ganha um novo sentido a partir de cada deslocamento do ponto de vista. $\mathrm{O}$ que não significa apenas uma questão de espaço e informação, mas inclui, de modo decisivo, uma disposição particular do observador $[. . .]^{233}$

O modelo que Hitchcock quer expor mediante toda essa maquinaria ilusionista, evidentemente, é o do próprio cinema: “O que é a filmagem senão a organização do 'acontecimento' para um ângulo de observação (o que se confunde com o da câmera e nenhum outro mais)? [...] O que é a ficção do cinema clássico senão uma simulação de mundo para o espectador identificado com o aparato?” (ibid., pp. 51-52). A “engenharia da simulação" desvelada por Vertigo não é outra senão "aquela acionada pelo olhar do filme clássico, a qual alia a força de sedução da cena à invisibilidade do aparato" (p. 57).

O cinema dota o seu espectador de uma "dupla-visão", como explica François Niney: "Sou eu [espectador] que vejo as paisagens, os cenários, as personagens, as ações filmadas. No entanto, o que vejo é comandado em segredo (segredo que dura apenas o tempo da projeção) pelo olhar de um outro". ${ }^{234}$ De algum lugar invisível, esse outro compôs, enquadrou e registrou tudo aquilo que o espectador pensa estar vendo por contra própria - da mesma forma que Madeleine, que Scottie acredita estar vendo e descobrindo por si mesmo, foi previamente enquadrada e dirigida por Gavin.

Na cena do escritório, como já apontamos, Gavin ainda não mostra Madeleine, apenas gera expectativa e interesse, joga com a curiosidade de Scottie. A palavra "curiosidade", como Christine Davenne esclarece, tem sua história marcada por uma significação moral: o termo designa, no latim dos tempos antigos, um desejo de saber tido como indiscrição, espionagem. O cristianismo também condena o curioso e prescreve o abandono do seu principal instrumento: o olhar. A curiosidade e a intenção de ver por ela impulsionada são

\footnotetext{
${ }^{231}$ Ibid., p. 52.

${ }^{232}$ Ibid., p. 51.

${ }^{233}$ Ibid., p. 56.

${ }^{234}$ F. Niney, op. cit., p. 79.
} 
uma falha capital dos homens, que os afasta da revelação divina: “O saber deve ser revelado na graça de sua invisibilidade"235 (por este prisma, não é difícil entender por que Scottie, o detetive, o "private eye", o profissional do olhar e da curiosidade, terminará o filme tão longe da graça e da revelação, tão perto das trevas).

Nossa ênfase na palavra "curiosidade" tem uma razão específica, que está ligada à própria configuração do escritório de Gavin Elster, espécie de museu histórico da cidade de São Francisco numa versão muito particular e pitoresca. Nas paredes de madeira envernizada e reluzente, estão expostos inúmeros quadros e fotografias que representam, em sua maioria, paisagens e mapas antigos de São Francisco. São dezenas de imagens, todas enquadradas; fragmentos de mundo acondicionados dentro de um frame, de um limite. Essa proliferação inflacionária de imagens envoltas por quadros e molduras comprova o desejo de Gavin de cercar e possuir alguns pedaços daquele universo (a velha São Francisco cujo encanto ele acredita ter sumido), para depois dispô-los em uma organização espacial instituída pela vontade pessoal do dono da coleção. O escritório - câmara de maravilhas onde Gavin pode "voltar no tempo" e recriar a São Francisco dos seus sonhos - é preenchido ainda por estatuetas, maquetes, móveis de talha rebuscada, luminárias luxuosas, instrumentos raros, objetos de colecionador. Em absolutamente tudo, esse cenário se assemelha aos antigos gabinetes de curiosidades.

Os gabinetes eram espaços destinados a conservar e exibir como troféus os símbolos das conquistas artísticas e científicas da época alavancada pelo Renascimento. Acumulando desde obras de arte até instrumentos de astronomia e de navegação, passando por pedras preciosas e animais exóticos empalhados, esses gabinetes, em todas as suas variantes (studiolo, Wunderkammer, Kunstkammer), dão o testemunho histórico de uma pulsão de catalogação e colecionismo que mais tarde se prolongaria como um dos traços característicos da modernidade (as Kunstkammern, os gabinetes de colecionadores de arte, nada mais são do que os precursores dos museus).

Há uma forma medieval predecessora do gabinete de curiosidades, como se pode constatar nos santuários e nas coleções de tesouros da Igreja e dos grandes castelos. Mas os primeiros gabinetes de estudo e de curiosidades propriamente ditos só aparecem no fim do século XV na Itália do Norte. Os studioli, como eram chamados, ficavam abrigados nas partes mais recônditas dos palácios dos príncipes. Na riqueza decorativa de seus ambientes, eles simbolizavam o trabalho intelectual, de um lado, e a arte e a curiosidade, do outro. "Tudo é

\footnotetext{
${ }^{235}$ C. Davenne, Modernité du cabinet de curiosités, Paris: L’Harmattan, 2004, p. 41.
} 
pensado e organizado em função de critérios de ostentação e prestígio." 236 Somente pessoas próximas, ou convidados ilustres, têm acesso ao studiolo. "É um lugar privilegiado, onde se desvela a figura do príncipe, líder humanista, e onde se exalta, através de seus emblemas, 'a intimidade do trabalho intelectual' e a 'glorificação do espírito humano' em geral - em suma, os valores da cultura dita "moderna'". 237

Depois de já consolidados na cultura europeia, os gabinetes de colecionadores e as câmaras de maravilhas passam a ser um tema comum na pintura, que aí encontra uma excelente ocasião para figurar sua própria mise en abyme. Espaços abarrotados de imagens, onde um discurso sobre a arte se constrói num sentido que se quer totalizante, os gabinetes se tornarão, eles próprios, assunto de imagem. Os quadros representando gabinetes de curiosidades e coleções de arte privadas se contam aos montes desde finais do século XVI até meados do XVII, tendo conhecido um grande desenvolvimento nos Países Baixos Meridionais, em virtude da popularidade do colecionismo na Flandres daquele período.

Comparando alguns desses quadros com planos do escritório de Gavin Elster, podemos notar as intrigantes semelhanças, reforçadas ainda pelo modo de enfoque adotado por Hitchcock (planos de conjunto que apreendem a abundância de detalhes e ornamentos):
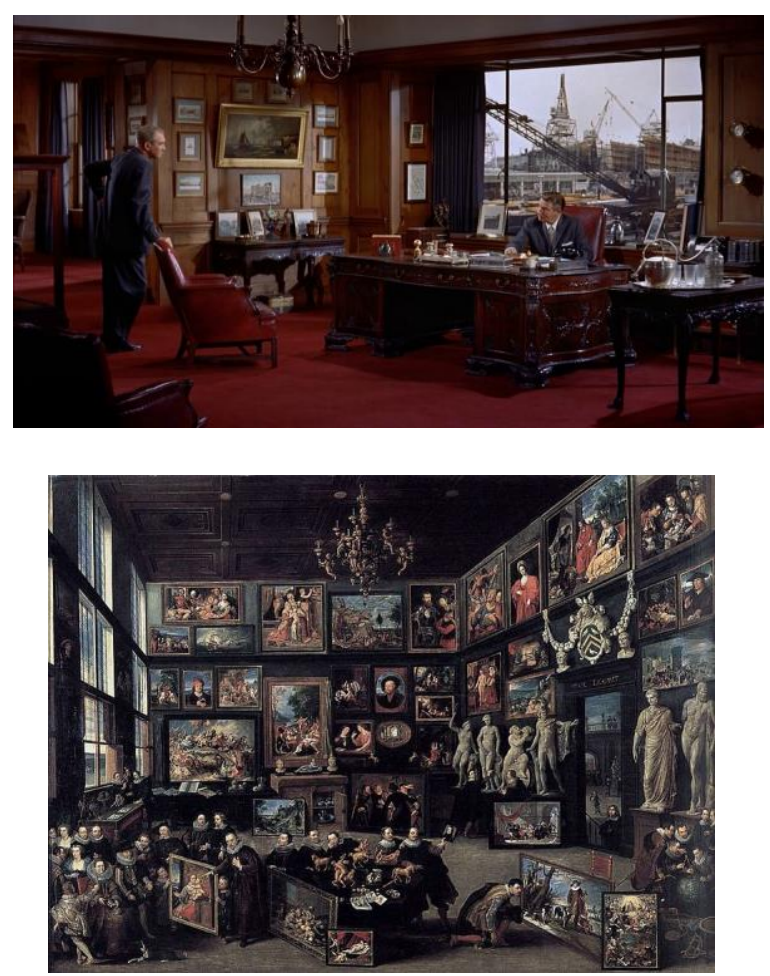

Willem van Haecht,

A galeria de Cornelis van der Geest, 1628
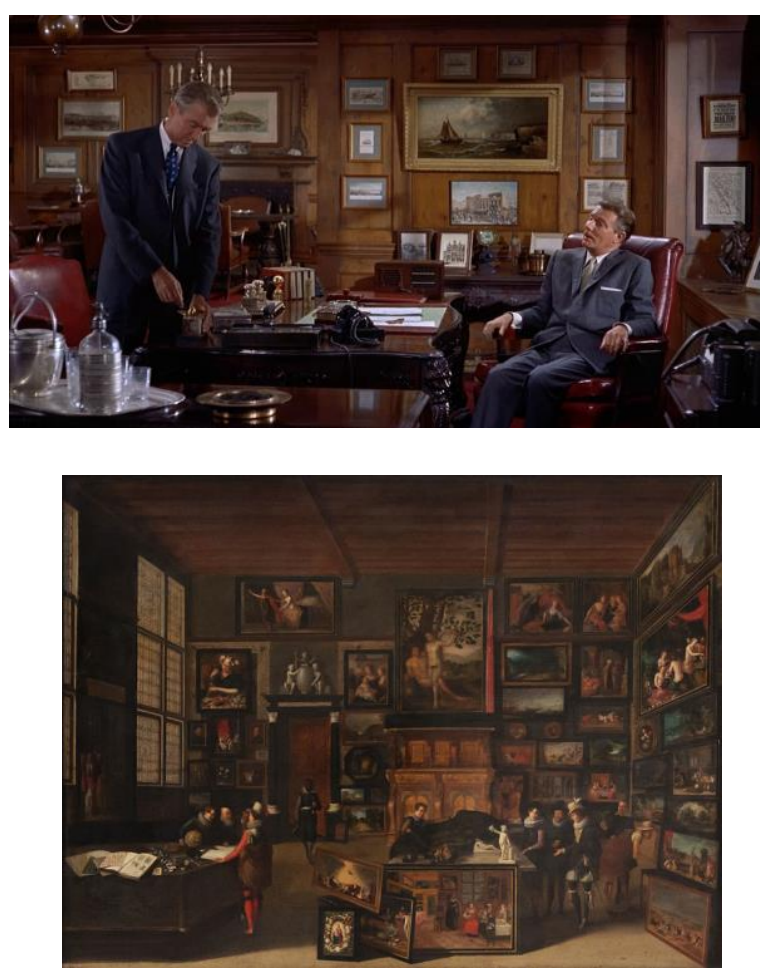

Hieronymus Francken II, Het kabinet van de kunstliefhebber, 1621

\footnotetext{
${ }^{236}$ P. Mauriès, Cabinets de curiosités, Paris: Gallimard, 2011, p. 55.

${ }^{237}$ Daniel Arasse, Le Sujet dans le tableau, Paris: Flammarion, 1997, 2006, p. 27.
} 
Assim como o escritório de Elster, os gabinetes constam de um excesso de signos visuais que acaba encobrindo a lógica subjacente à disposição das figuras, como se estas tivessem sido simplesmente acumuladas e arrumadas nos compartimentos do espaço de acordo com seu tamanho ou aspecto geral. À primeira vista, não se identifica nenhuma forma de enunciação nesse conjunto de imagens. Mas, como Daniel Arasse demonstrou em sua análise do studiolo de Federico de Montefeltro localizado no palácio ducal de Urbino, por trás dessa aparente desordem, há um discurso iconográfico muito bem pensado e articulado. A aparente falta de lógica não é senão o disfarce de uma ordem "superior", a ser encontrada não de forma gratuita e direta, mas após um esforço de leitura e compreensão da mensagem segredada naquele microcosmo composto pelas imagens e objetos expostos. Espaço de reflexão intelectual, de contemplação, "lugar da meditação do poder onde o príncipe toma por objeto sua própria interioridade"238, o studiolo é uma "fábrica de pensamento", um texto visual no qual se depositou uma mensagem cifrada, um conteúdo latente que, para ascender à figuração ou ganhar a forma de um discurso, deve ser submetido a um processamento intelectual dos mais sofisticados, o que só aumenta a autoridade de quem o concebeu, bem como a mística em torno do seu poder. "O studiolo italiano [é] antes de tudo uma ocasião para o príncipe se afirmar numa narrativa mitológica, num programa iconográfico". 239

Enquanto descendente dos gabinetes de curiosidades, o escritório de Gavin Elster deve ser visto também como o lugar em que ele afirma o seu programa iconográfico e exibe o teatro do seu poder, com direito a palco e recitação rebuscada (conforme já indicamos quando ressaltamos o comportamento teatral/performático de Gavin ao longo do diálogo com Scottie). O termo "teatro", durante muito tempo, foi empregado para designar esses espaços dos gabinetes: um teatro do mundo, da sabedoria (theatrum mundi, theatrum sapientiae), um teatro da memória. Os donos dos gabinetes buscam "um efeito sobre o espectador: impressioná-lo pela superabundância e a riqueza desse transbordamento, antes de passear de objeto em objeto, em meio a tantos motivos de estupefação ou de interrogação". 240 Ao materializar "o gosto da acumulação e do incremento ad infinitum"241, o gabinete é constantemente alimentado pela "necessidade crônica de acrescentar, de completar, de reagrupar, de juntar" ${ }^{242}$ (patologia de acumulação de que a cinefilia, com sua compulsão de repetição - ver três, quatro filmes por dia; ver todos os filmes de um autor, de um gênero, de

\footnotetext{
${ }^{238}$ Ibid., p. 48.

${ }^{239}$ P. Mauriès, Cabinets de curiosités, p. 65.

${ }^{240}$ Ibid., p. 67.

${ }^{241}$ Umberto Eco, A vertigem das listas, Rio de Janeiro: Record, 2010, p. 165.

${ }^{242}$ P. Mauriès, Cabinets de curiosités, p. 66.
} 
uma época -, seria uma legítima herdeira no século XX). Multiplicam-se os quadros, os nichos, as molduras, as gavetas, estabelece-se uma infinidade de compartimentos, de margens, de limites que expressam uma ambição de "se apropriar da desordem do mundo para invertêla no jogo, ainda que arbitrário, das simetrias e hierarquias". ${ }^{243}$

O gabinete é um cômodo secreto, "um lugar de estudo e de discussão, um espaço fechado (conclave) que organiza as imagens e o saber, um interior saturado de arte". ${ }^{244}$ Sob o "verniz das madeiras valiosas", ele recobre "toda a incoerência do real". 245 Cada parcela do espaço, "por uma necessidade de unidade interpretativa e estética", está codificada: "Por trás do mistério do objeto único, curioso, admirável, se encontraria um saber antigo, uma longínqua revelação cujo sentido estaria perdido, à espera tão somente da observação pontiaguda, apaixonada, do colecionador". ${ }^{246} \mathrm{O}$ interesse pelos gabinetes "se difunde plenamente na segunda metade do século XVI, na mesma época em que se abre o reservatório inesgotável de "maravilhas' que é o Novo Mundo". ${ }^{247}$ Como se sabe, a expansão marítima europeia acarreta uma intensa circulação transcontinental de objetos (de arte, consumo, curiosidade etc.); dentre os alimentos, mercadorias, tesouros e tudo o mais que é transportado, imiscuem-se também "objetos bizarros ou achados estupefacientes [...] que, retirados de seu contexto, parecem relatar histórias insanas". ${ }^{248}$ Os gabinetes de curiosidades não deixam de ser um produto desta desterritorialização das formas. Os achados (e as pilhagens) precisam ser realocados num novo espaço que, limitado entre quatro paredes, procura recuperar a harmonia do Universo, a sensação de mundo acabado, completo, a apaziguadora noção de finitude que as grandes descobertas dos séculos XV e XVI definitivamente pulverizaram.

O espaço impuro do gabinete de curiosidades encontra assim sua mais bela expressão no outono da Renascença, nesse momento de cesura - maneirista ou barroca? - em que se perde a ideia de uma clareza, de uma transparência humanista, em que se afirma uma pluralidade de mundos naturais e religiosos, em que se impõe o tema filosófico e estético do fundamento ilusório da realidade. A história do gabinete de curiosidades começa com a ideia de uma correspondência, mais ou menos secreta ou mágica, entre o homem e a natureza, entre micro e macrocosmo; ela se configura quando essa correspondência se revela impossível, quando o espaço regrado do gabinete de curiosidades não pode mais pretender refletir a diversidade do real, mas se limita a recolher alguns de seus restos: momento em que não se pode mais abarcar com o olhar a diversidade da criação. A tensão entre a

\footnotetext{
${ }^{243}$ Ibid., p. 12.

${ }^{244}$ V. I. Stoichita, L'instauration du tableau, p. 169.

${ }^{245}$ P. Mauriès, Cabinets de curiosités, p. 34.

${ }^{246}$ Ibid., p. 35.

${ }^{247}$ Ibid.

${ }^{248}$ U. Eco, A vertigem das listas, p. 203.
} 
vontade de esgotar o real, de contê-lo num espaço finito, e a impossibilidade de fazê-lo, que se torna cada vez mais clara, está no cerne da cultura da curiosidade. Vertigem borgesiana do cartógrafo que procura recobrir parte por parte os mínimos relevos e acidentes do terreno que ele pretende representar. ${ }^{249}$

O gabinete de curiosidades, como destacou Umberto Eco, "queria simbolizar um sonho de conhecimento científico total". ${ }^{250}$ Ele é uma máquina produtora de classificações e analogias, que cristaliza uma vontade de representação fundada na intercessão entre visão e conhecimento. Mas a vertigem de signos por ele engendrada tem como efeito colateral a obnubilação, a perda de foco e de centro: o observador é atropelado pelo excesso de imagens, ícones, símbolos, formas, formatos. Essa vertigem desfaz a tão sonhada transparência da representação clássica, instituindo em seu lugar uma nova opacidade, uma nova obscuridade do sentido. Em seu influente tratado De Pictura, de 1435, Leon Battista Alberti ressaltara a importância das leis da geometria na construção do campo pictural e definira o quadro renascentista com base nos princípios clássicos de unidade e clareza, consequentemente recusando a composição amontoada, a simultaneidade de detalhes que pautava o estilo de um Gentile ou de um Carpaccio. ${ }^{251}$ Ao imobilizar um fragmento do universo para a contemplação, ao estruturar o ponto de vista e centrar a ação do olhar, o quadro renascentista, na concepção albertiana, se pretendia uma janela que tornava o mundo inteligível. A partir do momento, porém, em que esses quadros se multiplicam vertiginosamente e se amontoam uns sobre os outros, tal como ocorre no espaço do gabinete, eles deixam de dar uma visão clara do mundo; eles formam, contrariamente, um painel tumultuoso, uma confusa vegetação de signos pictóricos, uma profusão de detalhes variados, infinitos - retorno triunfante, e elevado à enésima potência nos gabinetes do século XVII, do detalhe ornamental e "gratuito" refutado por Alberti no Quattrocento.

As "paredes de quadros" vistas nos gabinetes de pintura são fruto de uma concepção moderna da imagem, que desponta em torno de 1600 devido a uma série de fatores distintos. "O quadro como retângulo transportável, a generalização da tela como suporte, a simplificação das molduras, a voga do formato reduzido e o triunfo do colecionismo privado são suas razões mais importantes". ${ }^{252}$ Em flagrante contraste com a tradição clássica, as “paredes de quadros” rompem com a noção albertiana de janela: o que elas oferecem ao olhar,

\footnotetext{
${ }^{249}$ P. Mauriès, Cabinets de curiosités, pp. 35-43.

${ }^{250}$ A vertigem das listas, p. 205.

${ }^{251}$ Cf. D. Arasse, Le Détail. Pour une histoire rapprochée de la peinture, Paris: Flammarion, 1996, p. 149.

${ }^{252}$ V. I. Stoichita, L'instauration du tableau, p. 158.
} 
inversamente, é um labirinto de pintura, um conjunto de muros coloridos que encerram o espaço e miniaturizam o efeito perspectivo - uma vez que ele se manifesta mais nos quadros dentro do quadro do que na sua composição geral -, fazendo prevalecer um princípio de clausura. Curioso que haja frequentemente janelas nos quadros de gabinetes, mas janelas laterais, que dão para um espaço que não podemos contemplar pelo ângulo em que o pintor nos situou. No espaço que realmente se presta à visão, encontram-se as paredes repletas de quadros. As imagens pictóricas, outrora ferramentas de abertura do visível, invertem agora sua função e colonizam o espaço, recobrem os interiores do gabinete como uma espécie de papel de parede. O "espetáculo" do mundo, o grande "texto" da natureza, vedado ao homem na desordem empírica da sua vivência cotidiana, mas revelado a ele na narrativa visual da pintura, fecha-se sobre si mesmo novamente. Para voltar a ter na representação pictórica uma abertura para o significado latente das coisas, o olhar terá de aprender a ler as imagens em suas relações de conjunto, em suas interações, em sua engrenagem intertextual.

As pinturas que representam gabinetes de colecionadores de arte, na medida em que estabelecem uma decupagem da coleção, um recorte privilegiado, convidam o espectador a “imaginar o diálogo dos objetos e das imagens" ${ }^{253}$, sublinhando assim a rede de relações contextuais instaurada pelo gabinete. Tal como retratado nessas pinturas, o gabinete é um espaço sem paredes brancas nem zonas de vazio, e isso não somente por conta das imagens lá expostas, mas antes porque as paredes mesmas já estão cobertas por madeira ou por algum tipo de tecido: tudo está previamente transformado em imagem; o espaço em si é uma imagem que acolhe outras imagens, cada uma delas com sua própria moldura, seu próprio quadro dentro do quadro, numa mise en abyme a perder de vista. A representação de um gabinete em pintura é "um fenômeno de saturação óptica". 254

O tema principal das pinturas que mostram esses gabinetes de colecionadores, segundo Stoichita, é a "conversação": "O gabinete e seus anexos (sala de estátuas, biblioteca) formam um espaço de exposição e encontro". 255 Lugar de prosa intelectual, de discussão e debate entre connoisseurs, o gabinete quase nunca é mostrado vazio: há sempre um grupo de pessoas a interagir (entre elas e com as imagens). Mas o sentido de encontro e conversação observado nesses quadros vai além: "Uma estrutura dialógica atravessa a representação em seu conjunto". ${ }^{256}$ Não estamos diante de um simples elenco visual, de uma mera descrição ou

\footnotetext{
253 Ibid., p. 161 .

${ }^{254}$ Ibid., p. 158.

${ }^{255}$ Ibid., p. 160.

${ }^{256}$ Ibid.
} 
catalogação da coleção: há um embate de ideias estéticas implicado na própria disposição das imagens.

Essa disposição, no entanto, não permite uma apreensão clara das ideias que enuncia: a sobrecarga visual do quadro impede o olho de seguir um percurso linear, obrigando-o a operar por visões parciais e descontínuas, por saltos, "a ir incessantemente de um fragmento ao outro, de uma imagem à outra", enfim, a fazer uma "leitura intertextual". ${ }^{257}$ Mais do que simples documentos de época ou artefatos excêntricos, as pinturas de gabinetes "são os testemunhos mais complexos do triunfo da empreitada intertextual". ${ }^{258}$ Imagens formadas a partir de outras imagens, elas se apresentam como "a manifestação visível de um discurso sobre a arte". ${ }^{259}$ As pinturas de gabinetes expressam a "autoconsciência do sistema de imagens", aspecto determinante no processo pelo qual uma arte descobre sua modernidade. "A contextualidade operante numa coleção ocasiona - e até mesmo provoca - a situação autorreflexiva: perceber um quadro como 'figura' que se destaca de um 'fundo' é perceber uma obra de arte que se destaca (ou se projeta) de um (ou sobre um) 'fundo' que não é outro senão 'a arte'". 260

As cenas de galerias de colecionadores constituem, portanto, um caso-limite de discurso metapictural. Elas culminam num gênero novo, que tematiza diretamente a própria pintura (sua linguagem, seus estilos, suas hierarquias internas). Por meio de uma retórica visual refinada, as cenas de gabinete dão vazão a um acúmulo de conhecimento sobre a arte.

No meio das coleções enfocadas nas pinturas de gabinetes, algumas imagens em particular terão a função de frear o frenesi da visão e reter a atenção do espectador, levando-o a refletir sobre a lógica da contextualização e da arrumação do sistema figurativo do quadro. Imagens especiais, que se destacam do restante, seja pelo tema que representam, seja pela pura atração visual que exercem no observador, interrompendo a distração do olhar para iniciar uma contemplação aprofundada, que reorganiza todo o conjunto. Esse sinal de "pare", essa "imagem de exceção" pode ser indicada pelo pintor ao espectador de diversas maneiras: situando-a no chão, separada das demais imagens que se acham na parede; voltando para ela os olhares dos "curiosos" figurados na pintura; colocando-a no início ou no final de uma fileira, que são os locais de parada usual do olhar acostumado à leitura linear; adornando-a com uma moldura mais rica, mais vistosa etc.

\footnotetext{
257 Ibid., p. 161.

258 Ibid., p. 127.

${ }^{259}$ Ibid., p. 176.

${ }^{260}$ Ibid., p. 150.
} 
Com frequência, a imagem em destaque é uma imagem religiosa - mais precisamente, a imagem da Virgem. Um quadro da Madona (com ou sem o menino Jesus) posiciona-se amiúde no centro da coleção, como o sol que ilumina aquele sistema de imagens. A Madona deve ser percebida como uma imagem particular, uma figura eminente no interior da coleção. Surge, então, um problema tanto de ordem prática como conceitual: "Como se pode integrar uma imagem sagrada em tal contexto?". ${ }^{261}$ Embora precise estar num patamar figurativo elevado, a imagem da Virgem deve continuar sendo percebida como um quadro em meio a outros quadros, ou "como parte de um conjunto de imagens de coleção". ${ }^{262}$ Uma solução comum será o acréscimo, em volta dela, de uma moldura suplementar, ou melhor, de uma segunda marca de enquadramento - por exemplo: uma guirlanda, uma grinalda de flores a envolvê-la. "A guirlanda - que reproduz, em teoria, a decoração real de um ícone real - forma um segundo quadro, pintado, que duplica o quadro efetivo do ícone". ${ }^{263}$ A Virgem passa a estar, assim, em relevo, ocupando um lugar importante na figuração do gabinete, mas sem deixar de lá constar como obra de arte em meio a outras obras de arte.

Nos primeiros quadros de gabinetes de que se tem notícia, a presença da "Madona com guirlanda" é quase sempre garantida, "apesar de sua aparente falta de lugar":

Ela parece ter sido a última a chegar à coleção. Seu grau de contextualização é mínimo, quiçá problemático. Ela se acha constantemente na extremidade direita do espaço representado, a qual corresponde, seguindo a ordem de leitura tradicional, ao fim. Muito raramente pendurada na parede, ela está comumente apoiada no chão, como se o pintor (ou o colecionador) não tivesse ainda conseguido determinar seu lugar exato. ${ }^{264}$

A inclusão da Madona nesse novo contexto de existência da pintura (as galerias dos colecionadores de arte) revela-se, portanto, uma tarefa altamente problemática. A imagem sagrada não encontra de imediato seu lugar na coleção particular. Para ser contextualizada, ela demanda um trabalho reflexivo. "Enquanto a paisagem, a natureza morta e a pintura de gênero, numa coleção privada, estão em casa, o ícone aí aparece como um corpo estranho. É somente ao se definir como imagem consciente de seu caráter de imagem que ele pode então se aclimatar na coleção". 265

\footnotetext{
${ }^{261}$ Ibid., pp. 117-118.

262 Ibid., p. 123.

${ }^{263}$ Ibid., p. 117.

${ }^{264}$ Ibid., p. 123.

${ }^{265}$ Ibid., p. 130.
} 
O problema do encaixe de uma imagem sacra no ambiente profano de uma galeria de arte traz à tona o duplo dilema “da 'imagem' como objeto de adoração e do 'quadro' [tableau] como meio de apresentação". ${ }^{266}$ Tal problemática, que é de ordem tanto estrutural quanto iconográfica e teológica, está muito bem ilustrada numa pintura de Frans Francken II, um dos grandes especialistas na retórica das cenas de gabinete:

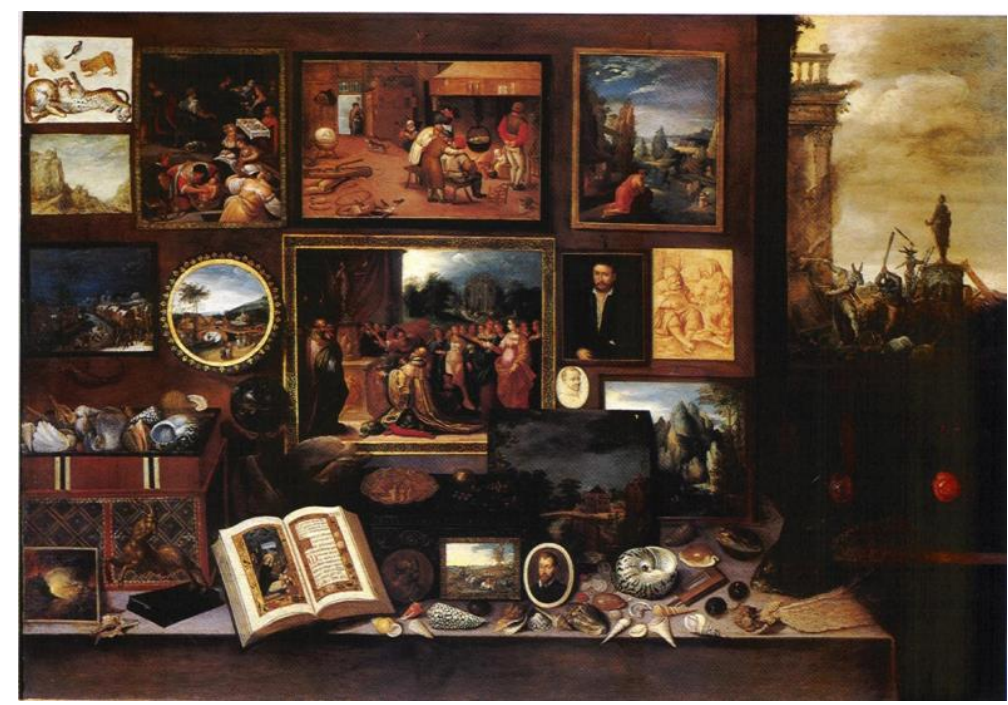

Frans Francken II, Preziosenwand, 1620-25

$\mathrm{Na}$ parede de quadros representada nesta pintura, imagens em diferentes tamanhos e formatos dão um painel de diversos gêneros pictóricos: paisagens, retratos, cena cotidiana à maneira de Brueghel, imagens religiosas etc. Espalhadas sobre a mesa e entulhadas na caixa situada na parte inferior-esquerda do quadro, vemos dezenas de conchas marítimas que, enquanto representantes das ciências naturais, atestam uma mistura, no gabinete, de arte e ciência, uma convivência de projetos epistemológicos e artísticos, que relembra a atmosfera conciliadora - a meio caminho entre fantasia e conhecimento científico - das Wunderkammern do alto Renascimento. Quanto à imagem da Virgem, ela não se faz presente no quadro senão por uma espécie de segundo grau de figuração, aparecendo estampada na bíblia aberta sobre a mesa. O destaque que lhe é dado é totalmente paradoxal: por um lado, a imagem está reproduzida em escala minúscula, podendo tranquilamente passar despercebida para um olhar que não tenha se disposto a percorrer todos os pontos da imagem; por outro, ela desfruta de um contexto único, ao qual nenhuma outra imagem tem direito, uma vez que está acolhida numa página da Bíblia, lado a lado com a escritura sagrada, sendo legitimada como ferramenta de transmissão da mensagem divina. O ícone religioso, aqui, surge amparado pelo

\footnotetext{
${ }^{266}$ Ibid., p. 113.
} 
texto bíblico, como se estivesse sustentado pelo grande volume de páginas que se acha sob ele. Talvez o quadro de Frans Francken II esteja buscando uma conciliação entre as duas instâncias separadas pela Reforma protestante: a imagem e a palavra. O calvinismo, cuja difusão nos Países Baixos é contemporânea à voga dos gabinetes de pintura, condenou a imagem e prescreveu que ela fosse banida das igrejas. A pintura, por suas qualidades intrinsecamente sensuais e ambíguas, não podia mais servir de acesso à presença divina. A evidência de Deus só se revelaria pela palavra, que, assim como o novo conceito de Deus que prevalece na Reforma, é pura abstração. A ordem, portanto, é destruir as imagens, e não venerá-las. O maior indício de que Francken II pode estar se reportando a essa polêmica se encontra na extremidade direita do quadro, naquela profundidade de campo que pode ser tomada tanto como uma cena vista da janela quanto como mais uma pintura dentro da pintura. Lá, testemunha-se um acontecimento grotesco: seres zoocéfalos, homens com cabeça de asno perpetram uma cena violenta, destruindo imagens e monumentos. Essas figuras híbridas, que aparecem também em outros quadros e desenhos do período, referem-se aos iconoclastas, aí representados com a cabeça de um animal historicamente associado a uma metáfora de estupidez e ignorância. Os "asnos iconoclastas" são vistos pelos pintores da época "como uma ameaça não somente à arte religiosa, mas também à arte e ao saber em geral". ${ }^{267}$ No quadro de Francken II, a bíblia aberta - com uma página exibindo a imagem da Virgem e a outra, os escritos sagrados - parece responder serenamente ao combate figurado à direita da coleção de pinturas. Harmonizando imagem e palavra, ícone e texto, essa bíblia placidamente posicionada no primeiro plano procura desqualificar a fúria iconoclasta expressa ao fundo, apontando como vã a polêmica suscitada pelo calvinismo.

A pintura de Francken II reflete um novo conceito de arte que emerge na rebarba dos conflitos instaurados pela Reforma. Segundo Hans Belting, a "crise da imagem" no século XVI abriu caminho para uma nova ideia da criação artística, resultante de "um novo grau de significação entre a aparência visual da imagem e a compreensão do observador". ${ }^{268}$ Se a imagem não serve mais como acesso à presença de Deus nem ao sentimento religioso, que sirva de acesso aos conceitos do artista e à meditação estética. Assumida como um objeto de reflexão artística, a imagem não deve ser decifrada unicamente de acordo com os significados religiosos que inspiraram sua narrativa, mas principalmente segundo as regras artísticas que guiaram seu trabalho de figuração. "A imagem se tornou um objeto de reflexão no momento em que convidou o observador a não interpretar seu assunto literalmente, mas a procurar pela

\footnotetext{
${ }^{267}$ Ibid., p. 169.

${ }^{268}$ H. Belting, op. cit., p. 16.
} 
ideia artística por trás da obra". ${ }^{269} \mathrm{O}$ arcabouço do diálogo entre imagem e observador não seria mais (ao menos não obrigatoriamente) a fé religiosa, e sim o interesse pela arte e seus conceitos estéticos.

Após essa necessária incursão no mundo das pinturas de gabinetes de colecionadores e em alguns de seus desdobramentos teóricos, é hora de voltar à cena de Vertigo ambientada no escritório de Gavin Elster para ratificar que a analogia aqui proposta (entre a referida cena e os quadros de gabinetes) não se esgota numa questão de efeitos cenográficos.

No meio da conversa, a atenção de Scottie se detém sobre um dos quadros da coleção de Gavin - como nas cenas de gabinete, em que o convidado, passado um primeiro momento de estupefação com a riqueza e a profusão do ambiente, começa a analisar os objetos individualmente, até se interessar por uma imagem em especial. O quadro que chama a atenção de Scottie mostra uma vista de São Francisco em formato panorâmico. Abaixo da imagem, lê-se uma inscrição: "São Francisco em julho de 1849”. O plano que apresenta o quadro (pendurado numa parede que até então não fora mostrada) consiste num travelling para frente acompanhando Scottie, que se levanta e vai até a imagem que o cativou. À medida que se aproxima do quadro, a câmera ajusta o foco lentamente, fazendo com que aquela vista panorâmica da antiga São Francisco surja aos poucos, ganhe nitidez gradativamente, como uma imagem que emerge do fundo do passado e da memória, uma imagem que talvez já tivesse sido esquecida e apagada, mas que agora retorna.
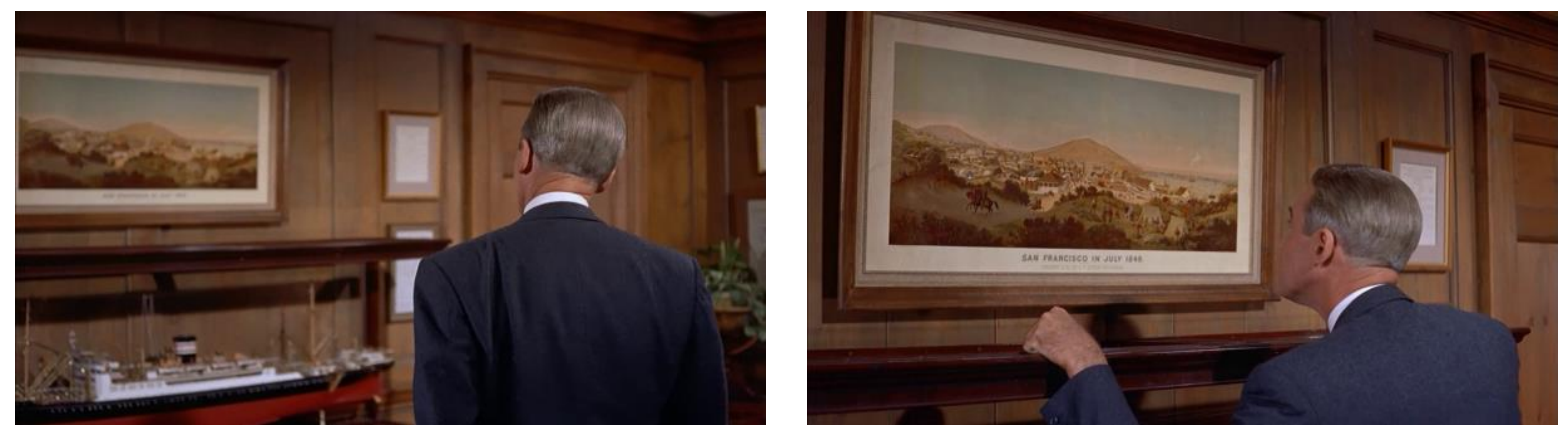

Este plano, tão prosaico quanto decisivo, já indica a verdadeira vertigem que atingirá Scottie, e que não é somente uma perturbação visual, mas uma vertigem do tempo. Hitchcock, neste plano, cria um novo desdobramento - conceitualmente mais complexo, ainda que menos espetacular e menos impressionante - da mesma ideia visual que resultou nos planos

${ }^{269}$ Ibid., p. 472. 
subjetivos da vertigem de Scottie. Se estes consistem num movimento óptico tecnicamente inovador (zoom para frente + travelling para trás, gerando a sensação alucinante de que o chão cresce), o que Hitchcock faz na cena do escritório é bem mais "simples": a câmera tão somente avança em travelling. Mas, enquanto avança no espaço, ela recua no tempo, pois se aproxima de uma imagem do passado, uma gravura com uma vista de São Francisco feita mais de cem anos antes. É a condensação visual da vertigem maior de que o filme tratará.

O quadro da antiga São Francisco surge num contexto em nada gratuito: Gavin acabara de dizer que as coisas que costumavam encantá-lo na cidade vinham desaparecendo. É então que Scottie, apontando para o quadro, pergunta se a São Francisco que Gavin admira não é aquela, perdida no tempo. "Sim, eu gostaria de ter vivido naquela época", Gavin confirma, elencando, em seguida, as quatro virtudes que a cidade a seu ver perdeu, e que ele gostaria de recuperar: "cor, excitação, poder, liberdade". Estas duas últimas palavras, "poder" e "liberdade", ecoarão mais tarde na voz de Pop Liebel, o livreiro especialista na "pequena história" de São Francisco, que ajudará Scottie na investigação. Ele conta para o detetive a triste história de Carlotta, dançarina de cabaré por quem um homem rico e poderoso ficou obcecado, dando a ela uma casa e fazendo-lhe uma filha que depois arrancaria dela. Carlotta terminaria abandonada à solidão e à loucura, até se matar em 1857.

A livraria de Liebel, tal como o escritório de Elster, é um cenário repleto de objetos de curiosidade (quadros, estátuas, fotos, vasos, miniaturas, máscaras exóticas, livros raros, compartimentos múltiplos, um globo terrestre etc.), e seu dono é uma espécie de enciclopédia viva da São Francisco dos velhos tempos. A Argosy Book Shop (a livraria de Liebel), portanto, é também uma versão modernizada dos gabinetes de curiosidades, funcionando como um espaço complementar ao escritório de Elster.

$\mathrm{Na}$ medida em que a história narrada por Liebel vai ficando mais e mais sombria, o cenário, como que contaminado pelo tom soturno do relato, escurece paulatinamente. $\mathrm{O}$ espaço vai ficando ensombrecido e os rostos vão sumindo, num efeito de (des)iluminação tão sutil quanto eficaz. "Os homens, naquela época, podiam fazer esse tipo de coisa", constata Liebel ao terminar de contar a história, referindo-se à crueldade com que Carlotta foi descartada por seu amante e proibida de ver a filha. Esse poder unilateral dos homens, que causa resignação em Liebel e encantamento nostálgico em Gavin, já aparecia como um dos grandes temas dos gabinetes de curiosidades do Renascimento, que celebravam "um mundo de homens", um mundo em que a liberdade era um privilégio masculino. Naquela câmara secreta em que indivíduos de imenso poder e invejável cultura se arrogavam a capacidade de reordenar o mundo "numa mise en scène que mistura miniaturização e totalização", o papel 
reservado à mulher era o da "figura alegórica da musa". ${ }^{270}$ Para o homem do Renascimento, a beleza feminina é uma duplicidade da qual se deve desconfiar; a mulher é associada ao pecado e à curiosidade, uma "mulher-armadilha" cuja beleza "é apenas superficial". ${ }^{271} \mathrm{O}$ mundo corpóreo é eterna fonte de sedução e engano. Tal desconfiança faz surgir, em contraponto, um elogio do diáfano e uma exaltação da mulher que se sacrifica para preservar a virtude. O sacrifício feminino constitui um tema honroso na pintura maneirista, que transforma em musas as grandes mulheres suicidas da História (Lucrécia, por exemplo, a lendária romana que se matou após ter sido violada).

Para Michèle Perrot, o Renascimento sela a ruína das mulheres. Os tratados de família, os livros de civilidade, os compêndios medicais insistem sobre sua fragilidade e sobre o dever dos homens de protegê-las contra sua fraqueza, dirigindo-as com uma mão doce, mas firme. [...] O Renascimento defende a beleza feminina, que o neoplatonismo humanista conduz aos píncaros como valor imutável de distinção social. [...] $\mathrm{O}$ gabinete enciclopédico será por excelência o território onde o homem se livrará [se débarrassera] da mulher, para em seguida dignificá-la pela imagem. ${ }^{272}$

A elucubração acima pode ser transposta ipsis litteris para o contexto de Vertigo. No “território emancipado" de Gavin, em seu escritório-gabinete, ele monta uma imagem que ao mesmo tempo enaltece e diminui, mitifica e fragiliza a mulher. Madeleine, cuja beleza se adequa a todo um repertório de códigos de distinção social, é descrita como um mistério (para os homens) e um perigo (para si mesma), devendo ser vigiada e "corrigida" ao longo de um trajeto que culminará em seu "sacrifício". Embora ela seja o grande assunto do encontro, o grande tema da conversa, seu modo de comparecimento na cena do escritório é indireto, por alusão e invocação imaginária, o que contribui para que sua figura se invista de expectativas mistificadoras. Quando ela for mostrada na cena seguinte, já será na forma de ícone, de musa: o retrato feminino que virá completar a coleção de quadros de Gavin Elster. Pois a Madeleine vista por Scottie no restaurante Ernie's nada mais é que um dos muitos quadros de Gavin com a temática "São Francisco do século XIX". Um quadro especial, o destaque da coleção, mas ainda assim uma imagem no meio de outras imagens. O cenário hiperestilizado no qual ela é introduzida é mais um dos espaços-relicários contidos no filme; um cenário requintado, clássico, com um luxo anacrônico, enfeitado com objetos que bem poderiam estar expostos numa galeria de arte, num museu ou quem sabe até num santuário. $\mathrm{O}$ plano que inicia a

\footnotetext{
${ }^{270}$ C. Davenne, op. cit., p. 14 .

${ }^{271}$ Ibid., p. 55.

${ }^{272}$ Ibid., p. 59.
} 
sequência do Ernie's é filmado do lado de fora e mostra a porta do restaurante chique, que é ornada por um vitral à maneira de uma igreja ou de uma capela gótica, "anunciando religiosamente o que está prestes a acontecer: a adoração de um ícone". ${ }^{273}$

A cena do Ernie's fecha a visita guiada que Gavin oferece a Scottie. Tal qual a imagem da Virgem nos gabinetes de colecionadores, a imagem de Madeleine é a última peça a chegar, o último troféu a ser exibido por Gavin, o arremate de sua coleção de curiosidades e belezas. Ela exige, portanto, um trabalho de contextualização, de encaixe, de adequação num sistema de imagens ou num discurso iconográfico. Não por acaso, conforme já demonstramos, a sequência do Ernie's comporta todo um trabalho de demarcação sistemática dos dispositivos de enquadramento. O problema do encaixe da star feminina na narrativa de Vertigo é mais ou menos comparável ao da adaptação do ícone religioso no espaço de uma coleção de pinturas. E se o "quadro" de Madeleine que Gavin apresenta não é o original, mas uma cópia, isso em nada o afasta da lógica dos gabinetes, muito pelo contrário: os donos dos gabinetes de curiosidades usavam às vezes falsificações e contrafações para forjar um discurso de completude, ou até mesmo para avaliar os conhecimentos dos visitantes. O desejo de totalidade e exaustividade e a obsessão pela posse das imagens, assim como a disputa de saberes e expertise, prevaleciam sobre a "fetichização da autenticidade" (valor que só seria resgatado pela burguesia numa época posterior). "Havia dois tipos de falsificações: as que os mercadores pouco escrupulosos faziam passar por verdadeiras e as cópias utilizadas pelos curiosos para dar à sua coleção a completude que eles almejavam. [...] O falso serve à idealidade da coleção, à sua coerência e completude". ${ }^{274}$ A estética clássica se organizara em torno da ideia de verdade mimética. Autorizando a entrada da cópia, os gabinetes subvertem o sistema da representação clássica. Isso se repete em Vertigo: o ritual de entrada em cena de Madeleine (ou melhor, de sua cópia) sacramenta o advento inexorável de uma imagem que implica a morte do sistema no seio do qual ela continua, todavia, a se mover.

Enquanto Scottie se embriaga com sua primeira visão de Madeleine - ignorando (total falta de expertise!) que ela seja uma falsificação -, novas analogias entre as imagens de Hitchcock e os quadros de gabinetes vão surgindo e criando uma série de "coincidências fatais" (para empregar o título de uma célebre exposição realizada em 2000-2001, que abordou justamente as relações de Hitchcock com as artes plásticas ${ }^{275}$ ):

\footnotetext{
${ }^{273}$ F. Niney, op. cit., p. 53.

${ }^{274}$ C. Davenne, op. cit., p. 244.

275 Cf. Guy Cogeval e Dominique Païni (orgs.), Hitchcock et l'Art: Coïncidences fatales, Paris: Centre Pompidou/Mazzotta, 2001.
} 

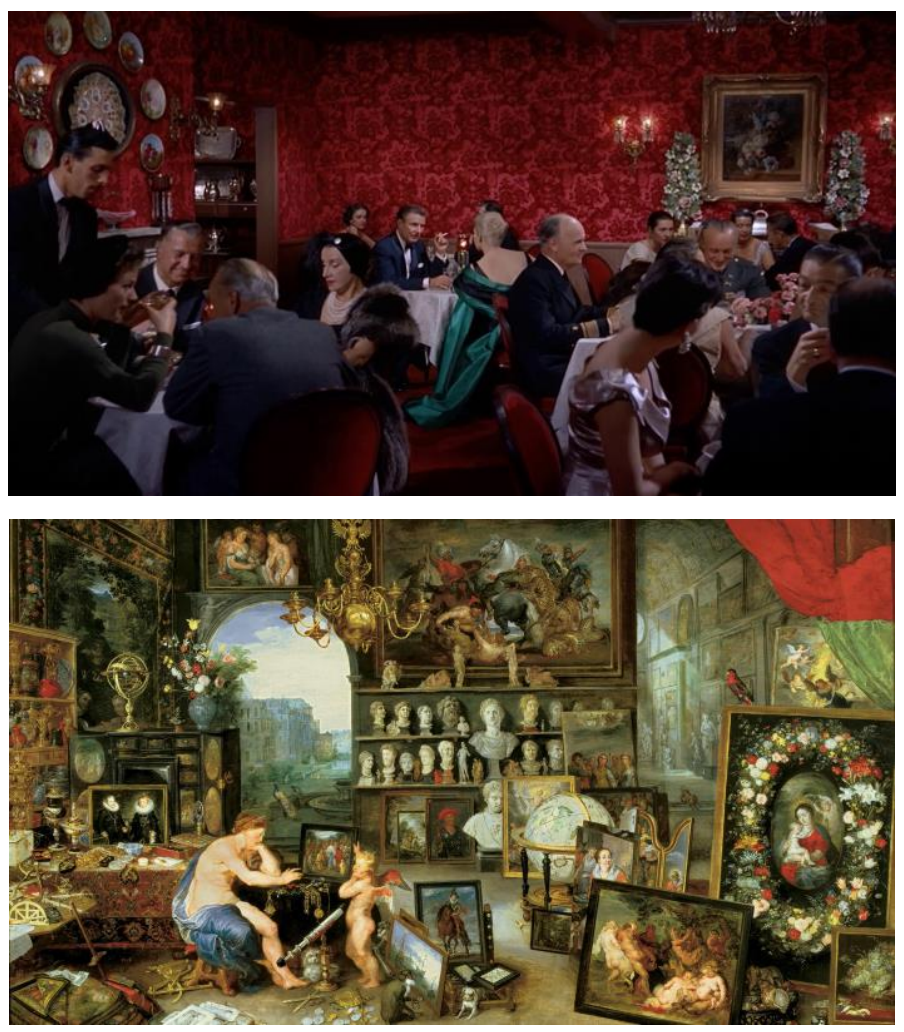

Peter Paul Rubens e Jan Brueghel, A Visão, 1617
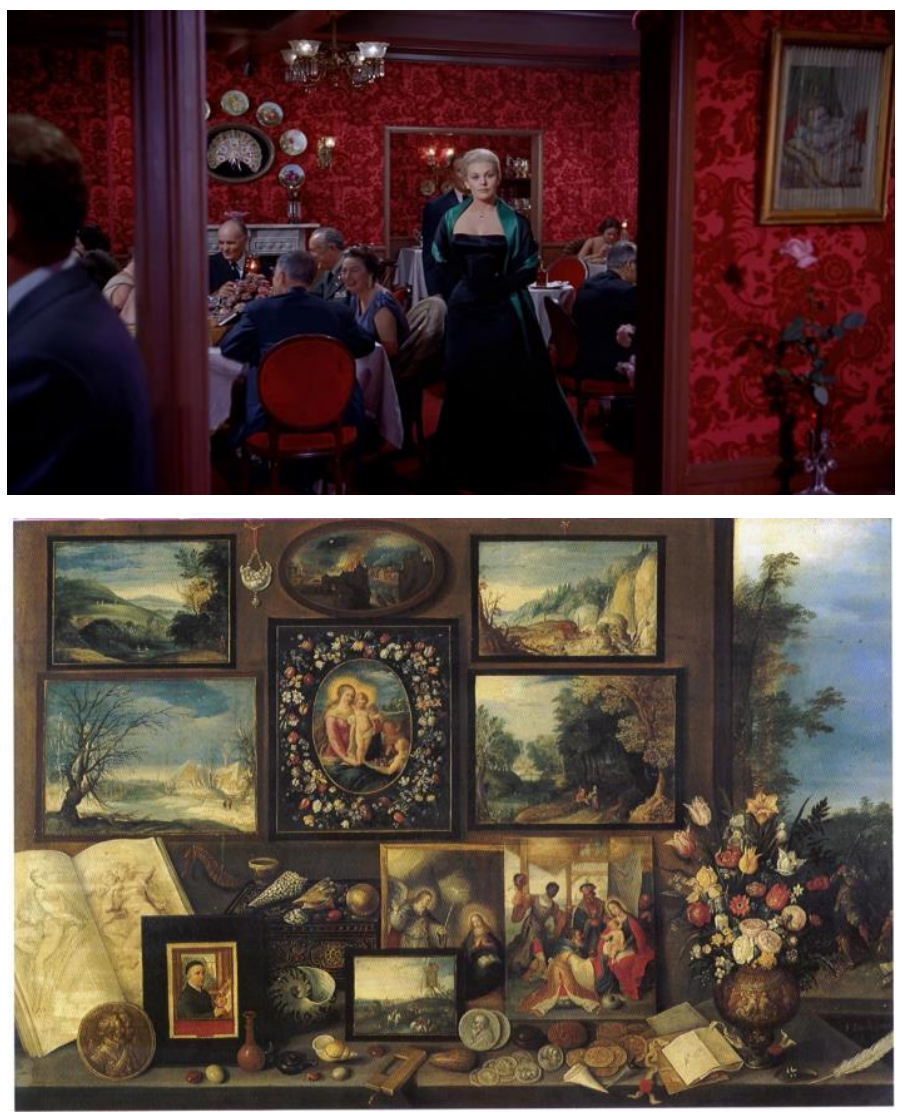

Frans Francken II, Eine Kunstkammer, 1619 
Além das questões mais gerais (os arranjos composicionais, a saturação visual dos ambientes), a aproximação das imagens ressalta alguns detalhes bastante curiosos, como o vaso de flores que "passa" do quadro de Francken II para um plano de Vertigo, onde reaparece em versão minimalista, ocupando o mesmo quadrante da imagem e funcionando não só como elemento de equilíbrio da composição, mas, sobretudo, como peça de reforço de um discurso sobre o belo produzido pelo quadro em seu conjunto. As flores, assim como os demais detalhes decorativos do ambiente (que são abundantes), participam de um ecossistema plástico que mescla belezas naturais e artificiais, um espaço de maravilhas no qual tanto a imagem da Virgem (no quadro de Francken II) quanto a de Madeleine (no filme de Hitchcock) são valorizadas pelo entorno: os arredores da imagem formam o encantamento periférico de uma composição que inevitavelmente dirige o olhar para sua atração principal, a figura feminina em destaque no centro da imagem, frisada por sobre-enquadramentos. $\mathrm{O}$ formato oval do quadro situado acima da imagem da Virgem na pintura de Francken II também terá seu correspondente no plano de Hitchcock: à esquerda de Madeleine, na parede ao fundo, vê-se um quadro de mesmo formato (ou sou eu que já me deixei contagiar pelo "demônio da analogia" 276 que rondava os gabinetes de curiosidades?). É como se os motivos plásticos da pintura de Francken II pegassem uma passarela secreta e fossem parar no filme de Hitchcock, o mesmo ocorrendo com a guirlanda que ornamenta a imagem da Madona no quadro de Rubens e Brueghel, e que reaparece no Ernie's em posição similar (também na lateral direita do quadro), dando ênfase a uma pintura exposta na parede, uma natureza morta que consiste basicamente num vaso de flores (mais um). Como nos gabinetes de curiosidades, o espaço do Ernie's em si já é uma imagem (o que suas paredes cobertas por um tecido carmesim não nos deixam esquecer); uma imagem na qual outras imagens vêm se incrustar.

A comparação desta cena com o quadro $A$ Visão merece ser explorada um pouco mais detidamente. Resultado da bem-sucedida colaboração entre Rubens e Jan Brueghel, A Visão faz parte de um conjunto de pinturas com representações alegóricas dos sentidos (visão, audição, olfato, paladar, tato). Em todos os cinco quadros que compõem a série (pertencente ao Museu do Prado), um mesmo esquema se repete: auxiliada por cupidos, a musa alegórica realiza alguma ação ligada ao sentido ali representado; à volta dela, o espaço é totalmente povoado por uma diversidade de objetos implicados no tema. Os atrativos dos quadros são de ordem tanto estética quanto intelectual, já que oferecem ao olhar curioso e investigativo uma enormidade de conjecturas.

\footnotetext{
${ }^{276}$ Cf. P. Mauriès, Cabinets de curiosités, p. 35.
} 
$\mathrm{Na}$ alegoria da visão, a musa contempla um quadro que lhe é mostrado pelo cupido. Ao que tudo indica, trata-se de uma pintura representando a cura do cego por Jesus ${ }^{277}$, episódio bíblico diretamente associado à visão. No espaço do gabinete que serve de palco a esta alegoria, em meio a quadros, esculturas e outros objetos relacionados ao tema, acham-se também dezenas de instrumentos ópticos usados na astronomia, com destaque maior para o telescópio posicionado no chão, aos pés da musa, preenchendo o espaço entre ela e o cupido. A coabitação do espaço pictórico por instrumentos científicos e obras de arte demonstra o desejo de Rubens e Brueghel de assegurar o parentesco entre a pintura e a ciência (evidente no contexto da pintura flamenga daquele momento, mas já presente anteriormente, por exemplo, em Leonardo da Vinci). Executada com rigor e disciplina comparáveis aos das ciências naturais, a pintura do século XVII se assume como uma forma de abordagem científica do real. Descrever a natureza, escrutá-la em toda sua diversidade e complexidade, apreendê-la nos mínimos detalhes, distinguir minuciosamente os relevos e as texturas das superfícies visíveis: tudo isso faz parte tanto do sistema pictórico de um Pieter Claesz ou de um Emanuel de Witte quanto dos grandes projetos hermenêuticos que lhe são contemporâneos, tal como a catalogação científica das diferentes espécies de plantas e animais, submetidas a todo um processo de ordenação e classificação do mundo visível. É neste campo epistêmico que a alegoria da visão pintada por Rubens e Brueghel é gerada. $\mathrm{O}$ quadro enfatiza "a importância da visão e da representação visual na ciência do norte da Europa no século XVII", isto é, “o caráter especificamente visual da investigação científica" realizada em tal conjuntura. ${ }^{278}$

Se Hitchcock, conscientemente ou não, chega a soluções visuais que se aproximam desta pintura, isso não deve causar tanto espanto: Vertigo parte justamente daquela confiança depositada na visão pelo homem racional, para mostrar, três séculos depois de Jan Brueghel (que pintou ainda um quadro intitulado A Óptica, exposto no Museu do Louvre), seu completo colapso na sociedade do simulacro. A história de Scottie é a do fracasso da visão enquanto forma de conhecimento sensível do real. No universo de Vertigo, ela só conduz à ilusão. Os autores de $A$ Visão, na verdade, já indicavam esse perigo: na porção esquerda do quadro, há uma abertura na parede, dando vista para uma paisagem externa (com uma fonte, pássaros, um parque, um castelo, o céu com algumas nuvens etc.). Ou será uma paisagem pintada, uma janela ilusória? Como não poderia deixar de ser, a reflexão de Rubens/Brueghel sobre a visão inclui esse elemento inquietante relacionado aos enganos do olhar e à dúvida

\footnotetext{
${ }^{277}$ Cf. María Dolores Jiménez-Blanco (org.), O Guia do Prado, Madri, Museo Nacional del Prado, 2012, p. 350.
}

${ }^{278}$ D. Arasse, Le Détail, p. 188. 
quanto à natureza real ou fantasiosa do que é visto. No século XVII, esse impasse talvez pudesse ser solucionado pelo olho do intelecto, pela verificação cuidadosa das aparências visíveis através do espírito inquisitivo da razão. Detendo-se sobre a imagem, analisando-a com o amparo das leis da óptica e do raciocínio lógico, perceber-se-ia a verdadeira situação de cada signo visual. Em Vertigo, contudo, essas ferramentas não são mais suficientes, e o mistério fundamental da imagem vence a capacidade do olho de decifrá-la.

O que resta, então? Resta a imagem, e nada além da imagem: Vertigo apresenta "uma hipótese de nascimento da imagem em si mesma, ou ainda de nascimento da própria noção de imagem: exatamente aquele instante para além do inteligível em que um corpo se transforma em seu simulacro inerte, um cadáver". ${ }^{279}$ A vertigem abordada pelo filme seria, em última análise, a paralisação do entendimento, a perda de chão do sujeito do olhar diante da aparição desse fenômeno que ele desconhece, essa imagem cuja única verdade é sua opacidade e seu silêncio. Madeleine é tão somente o evento, o acontecimento da imagem, a entrada no mundo das formas de uma pura ideia visual. E Judy refeita como Madeleine é a reprise desse acontecimento, sua reescrita maneirista.

Vertigo encena o aparecimento da imagem como imagem, algo cuja consequência inevitável é o retorno da opacidade que a linguagem "transparente" cunhada pelo sistema clássico de representação havia habilmente contornado. É como se o olho se aproximasse demasiadamente de um quadro de Rembrandt ou de Velásquez, transgredindo a "boa distância" recomendada para a sua apreciação e preferindo ficar, digamos, a um palmo da tela: a figura é dissolvida no caos, a ilusão de profundidade e tridimensionalidade se desfaz; o que surge em resposta é a materialidade do suporte da pintura, a superfície plana coberta por uma matéria colorida, a marca do pincel, o resquício do trabalho gerador da imagem, em suma, a pintura como pintura, revelada em sua intimidade. ${ }^{280} \mathrm{O}$ quadro-janela, imagem transparente, troca-se pelo quadro-pintura, matéria opaca. O sentido da representação clássica é subvertido, desviado pela constatação de sua evidência última, a saber, a sua condição material de representação. É isso o que acontece quando Scottie repara que Judy está usando o colar de Carlotta, percebendo, pela atenção incisiva aplicada ao detalhe, um significado novo que redimensiona a compreensão do "quadro", um distúrbio local, um pormenor cuja aparição inopinada transtorna a visão e faz o dispositivo da representação bascular. Scottie se aproximou demais do retrato de Madeleine que ele mesmo acabara de copiar e reconstruir; ele

\footnotetext{
${ }^{279}$ Didier Semin, “Ce que j'aurais fait si j'avais repêché Kim Novak inconsciente dans la baie de San Francisco”, in Cinéma, n. 5, Paris, Éditions Léo Scheer, 2003, p. 7.

${ }^{280}$ Cf. D. Arasse, Le Détail, pp. 268-280.
} 
encostou o nariz na tinta ainda fresca, transgrediu o "ponto de distância", elemento essencial ao funcionamento da ficção clássica. Ao ter a chance de interagir fisicamente com o objeto de seu encanto e adoração, ao estabelecer uma relação de intimidade com a imagem e fuçar o segredo do seu modo de produção, Scottie descobre, em contrapartida, a desconcertante platitude dessa imagem, de cuja origem duvidosa ele começa também a se dar conta, reconhecendo enfim a falsificação que tomara por obra autêntica. É uma dupla frustração, portanto: a do Scottie "espectador comum", antes fascinado, mas agora vendo aflorar a incômoda consciência de que tudo é uma questão de representação, e de que a única coisa que a imagem de Judy-Madeleine tem a mostrar é o próprio fato de que ela é uma imagem (a fascinação icônica cede lugar à opacidade reflexiva), e a frustração do Scottie "aspirante a connoisseur", que se percebe enganado por um falsificador. Daí em diante, tudo desaba. A única salvação de Scottie - e de Judy - teria sido ele aceitar a imagem como imagem (falsa, autêntica, pouco importa). Mas ele a recusa, abrindo caminho para a tragédia que desmonta, num só golpe, a imagem clássica e seu espectador. 


\section{III.}

\section{A cena escondida}

\section{Figuras numa paisagem}

Vimos que Janela indiscreta e - mais enfaticamente - Vertigo encenam o limiar da representação clássica, seu ponto de basculamento, o momento de inflexão a partir do qual a imagem, não mais se apresentando unicamente como objeto de percepção e prazer visual, emerge em sua dimensão reflexiva, afirmando-se como espaço de investigação teórica.

Se há um filme que claramente dá sequência a essa reflexão sobre a imagem, retomando as interrogações hitchcockianas sobre a relação entre pulsão de saber e prazer escópico para situá-las num novo contexto, este filme é Blow up - Depois daquele beijo (Blow up, 1966), de Michelangelo Antonioni.

A trama do filme, grosso modo, pode ser assim resumida: num singelo passeio a um parque, um fotógrafo capta com sua lente voyeurística o idílio romântico de um casal; ao revelar as fotos, ele percebe que algo de estranho se passa, o olhar da mulher indica alguma coisa escondida na imagem; ampliando e reampliando as imagens, o fotógrafo acaba descobrindo o detalhe criminoso que a paisagem camuflava. Ele percebe a "mancha" que ressignifica a situação registrada pela câmera. A banalidade é subvertida.

As relações deste filme com Janela indiscreta são muitas. A começar pela profissão do protagonista: Thomas (David Hemmings), a exemplo de Jeff, é fotógrafo. Ele divide seu tempo entre o fotorrealismo (começa o filme saindo de um dormitório público, onde se fez passar por desabrigado para registrar com mais naturalidade e realismo a situação local) e a fotografia de moda. ${ }^{1}$ A tensão que, em Janela indiscreta, estava expressa no casal

\footnotetext{
${ }^{1}$ A fotografia estava no epicentro da ebulição cultural britânica dos anos 1960. Em Londres (a "Swinging London" cuja efervescência Antonioni captou em todas as cores), a figura do fotógrafo vinha sendo valorizada de forma inédita. As principais revistas inglesas de atualidades, seguindo a tendência das americanas Life e Esquire, adotavam um visual cada vez mais sofisticado, e abrigavam em suas páginas um número cada vez maior de imagens, com um espaço significativo dedicado a fotos de cunho artístico e não apenas jornalístico ou publicitário. Uma das consequências foi a promoção dos fotógrafos, bem como de algumas de suas modelos
} 
Jeff/aventura/fotojornalismo-Lisa/conforto/moda, em Blow up está concentrada numa só personagem. De um lado, uma função de flagrar o real, mostrar o mundo em sua sujeira cotidiana, registrar os bas-fonds londrinos imiscuindo-se neles. Do outro, as imagens límpidas da publicidade, concebidas em ambiente asséptico, sobre as paredes brancas do estúdio, com modelos que posam para a câmera. Ambas são formas de intervenção artística no mundo, não há dúvida, mas as fotografias que Thomas faz fora do estúdio têm uma disposição - ao menos em tese - de deixar falar a linguagem inalterada do real, enquanto as fotos publicitárias já são um embelezamento cosmético, uma maquiagem proposital da realidade. Ao se fechar no estúdio, ele almeja corresponder a um resultado pré-planejado, encontrar a imagem que já de início espera encontrar. Ao sair para as ruas, ele se abre à possibilidade do imprevisto, submete-se à dimensão incontrolável da realidade exterior, ainda que permaneça latente uma vontade de dobrar as aparências a seu olhar de artista: “Thomas não almeja unicamente ilustrar o mundo, documentá-lo, mas criar um outro, autônomo e independente, um mundo que, mesmo sem se desligar do mundo real, corresponderia a seu universo mental". ${ }^{2}$

Na primeira cena em que Thomas é filmado trabalhando em seu estúdio, ele faz uma sessão de fotos com a top model alemã Veruschka, que Antonioni decidiu incluir no filme depois de vê-la posar para o fotógrafo David Montgomery. Como relata Philippe Garner, "Veruschka já estava explorando a atividade de modelo como um meio de expressão e invenção, afirmando-se como uma artista de performance". ${ }^{3}$ A sessão de fotos com ela em Blow up segue um crescendo de intensidade e intimidade corporal, terminando por se assemelhar a uma cena de sexo. Os corpos do fotógrafo e da modelo dialogam voluptuosamente. Alguns ângulos buscados por Thomas obrigam-no a assumir com a modelo formas de interação que parecem posições sexuais, tendo a câmera como substituto fálico, e exclamando frases que a circunstância tinge com o duplo sentido de encorajamento profissional e estimulação sexual. A cena explicita o vínculo que a profissão de Thomas estabelece entre imagem e erotismo. Num plano mais geral, trata-se de assimilar no filme a cumplicidade entre o desejo sexual e a pulsão escópica. Numa cena mais adiante, Thomas faz

\footnotetext{
mais recorrentes, ao posto de celebridades. Houve uma glamourização da profissão do fotógrafo, em consonância com o lugar de honra que a fotografia passara a ocupar na vida cultural e nos hábitos de consumo dos londrinos. Nomes como David Bailey, John Cowan, David Hurn e Don McCullin (Antonioni convidou este último para fazer as fotos que aparecem no filme como sendo as de Thomas), que se dividiam entre o universo da moda, a reportagem documental e projetos pessoais esteticamente ambiciosos, entraram assim para a lista das grandes personalidades do momento, figurando em colunas sociais e sendo foco constante da mídia. Antonioni se inspirou neles para compor o protagonista de Blow up. Cf. Philippe Garner, "Fleeting images: photographers, models and the media - London, 1966", in GARNER, P. e MELLOR, David Alan, Antonioni's Blow-up, Göttingen: Steidl, 2010, pp. 106-121.

${ }^{2}$ Thierry Roche, Blow up: un regard anthropologique, Paris, Yellow Now, 2010, p. 58.

${ }^{3}$ P. Garner, Antonioni's Blow-up, op. cit., p. 120.
} 
um ménage à trois com duas jovens modelos em busca de ascensão profissional. Tal cena se mistura às sequências de ampliação e investigação das imagens do parque (o ménage é praticamente uma pausa recreativa entre o primeiro tempo da análise das fotos e o segundo), como a garantir a conversibilidade entre as energias libidinais e hermenêuticas: o sexo e o "estudo" das fotografias se revezam, uma atividade preparando o corpo para a outra.

A sessão de fotos com a modelo alemã representa uma transição entre o trabalho documental realista no abrigo público e a sessão seguinte à dela, que será mais francamente artificial e posada. Com Veruschka, Thomas ainda está à procura de uma verdade, de uma autenticidade que surge do corpo a corpo do fotógrafo com a modelo, cujas poses não necessariamente obedecem ao repertório já codificado pela indústria da moda. A sessão acaba sendo um tour de force em que, inevitavelmente, afloram questões pessoais e afetivas entre os dois (o diálogo deles antes de começar o trabalho indica uma ligação que extrapola o profissional, e que está abalada por eventos recentes que desconhecemos).

O plano em que Veruschka é introduzida no filme retoma parcialmente o dispositivo do plano-espelho da loja de flores de Vertigo. A modelo aparece para o espectador refletida num vidro, depois que Thomas cruza a porta do estúdio e a encontra aguardando por ele, sentada no chão. Assim como Hitchcock, Antonioni substituiu o campo-contracampo por um dispositivo óptico que chama atenção para o próprio trabalho do quadro, sua composição meditada, pensada - o plano se destaca da cadeia narrativa e se torna uma digressão reflexiva.

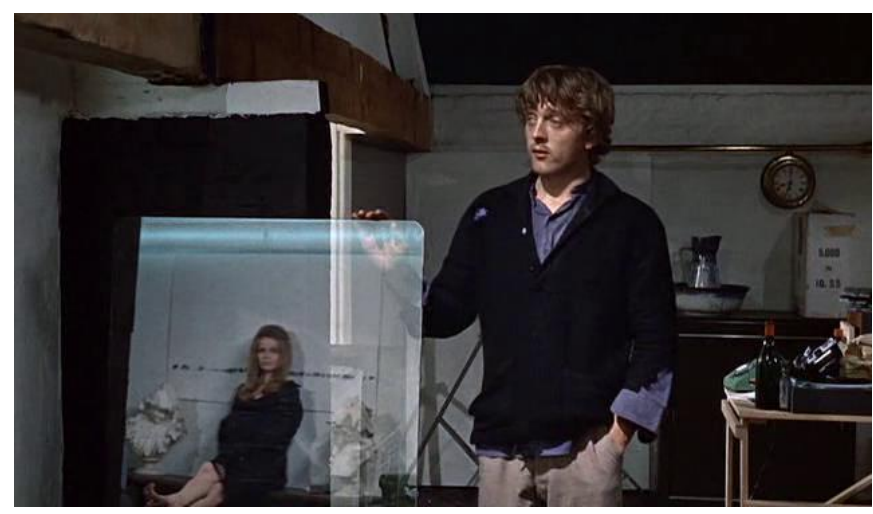

Thomas e a modelo trocam olhares, o que não acontecia entre Scottie e Madeleine no plano-espelho de Vertigo. Ao contrário do espaço colorido e elegante, do esplendor floral que emoldurava Madeleine, o espaço ao redor de Veruschka (isto é, o estúdio de Thomas) é filmado praticamente em preto e branco: um espaço esvaziado, neutralizado, sem cor nem glamour (estes só existirão como simulacro, como beleza artificial das imagens lá fabricadas). 
Veruschka já está de certa forma enquadrada e "fotografada": sua imagem se acha perfeitamente decupada no espaço e duplicada numa superfície que recebe a ação da luz. $\mathrm{O}$ formato quadrado do vidro também já prefigura o devir-foto da modelo. No entanto, se ela mudar de posição, a imagem já será outra, ou até mesmo sumirá. Para fixá-la, para ter sua aparência capturada não apenas como imagem, mas como objeto visual, será preciso acorrer à fotografia - a imagem especular, o puro reflexo, não basta.

Thomas acaba de voltar do dormitório público onde passou a noite trabalhando. Ele ainda veste a roupa surrada e rasgada que usou para se disfarçar de morador de rua, e seu rosto expressa o cansaço de uma noite mal dormida. Mas ele fará as fotos com Veruschka imediatamente, sem descanso. Depois, emenda em mais uma exaustiva sessão de fotos, com cinco outras modelos. Seu fastio e estresse são visíveis. Quando chegar ao parque, Thomas já terá passado as últimas 24 horas fotografando, num regime de trabalho nonstop. As fotos do casal no parque serão feitas, portanto, num estado de fadiga ocular, num ponto de exaustão em que o olho começa a ver menos e mais ao mesmo tempo: certas coisas, certas figuras desaparecem, passam despercebidas para o olhar esgotado, que, em compensação, torna-se sensível a outros elementos antes tratados como insignificantes. É nesse estado fronteiriço da visão que surgem os eventos surpreendentes de Blow up.

Quatro visitas de Thomas ao parque em que fotografa a situação suspeita pontuam o filme. Na primeira visita, sua atenção é atraída pela cena edênica que observa: um homem e uma mulher interagem próximos a uma árvore, rodeados pelo verde da natureza. Adão e Eva no paraíso, minutos antes de cometer o pecado original - como nos filmes de Hitchcock, em que há sempre uma cena como essa (o homem, a mulher e o "paraíso" pronto para ser conspurcado por eles e pela própria câmera, cuja simples presença é perversora):

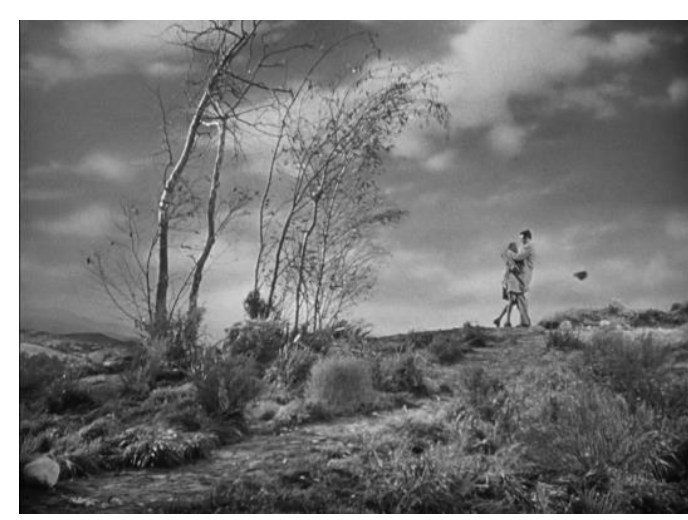

Suspeita, Hitchcock, 1941

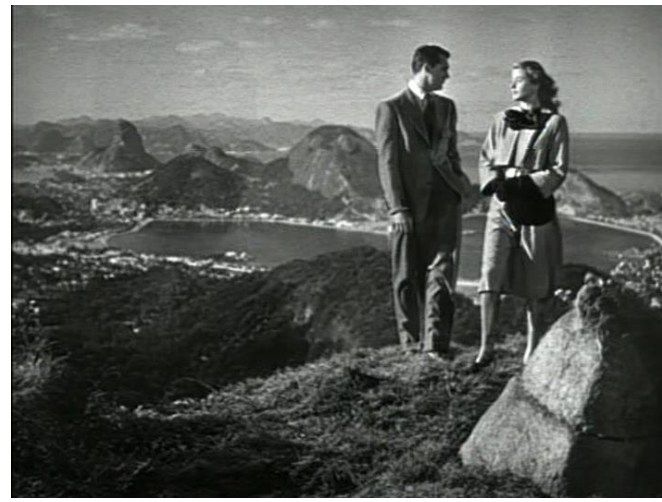

Interlúdio, Hitchcock, 1946 


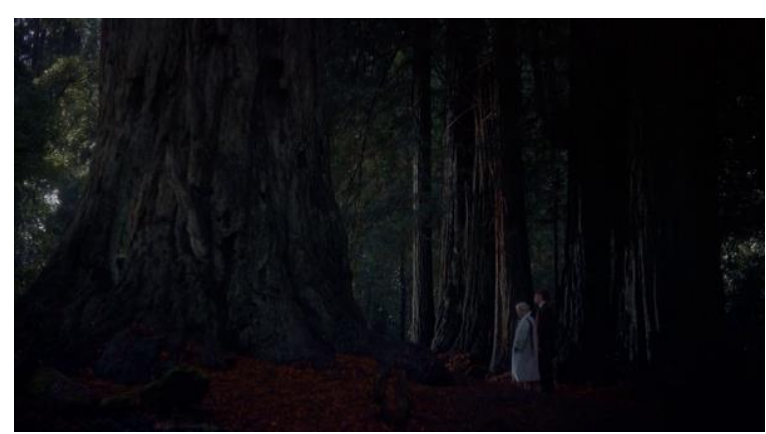

Vertigo, Hitchcock, 1958

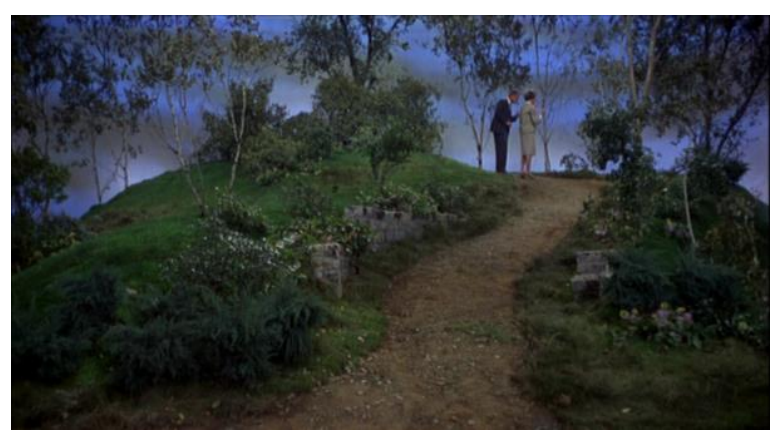

Cortina rasgada, Hitchcock, 1966

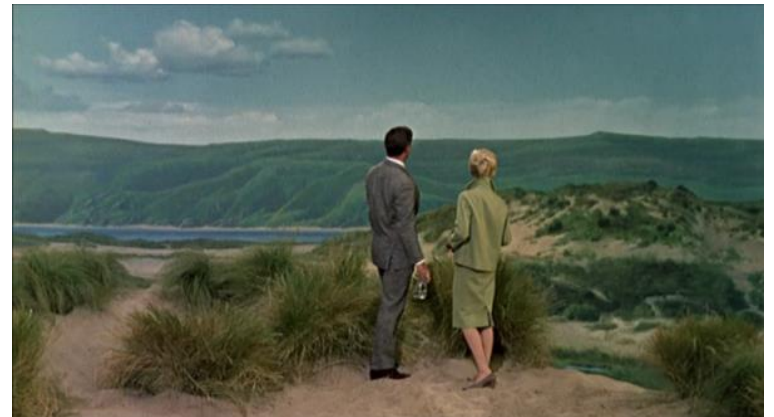

Os pássaros, Hitchcock, 1963

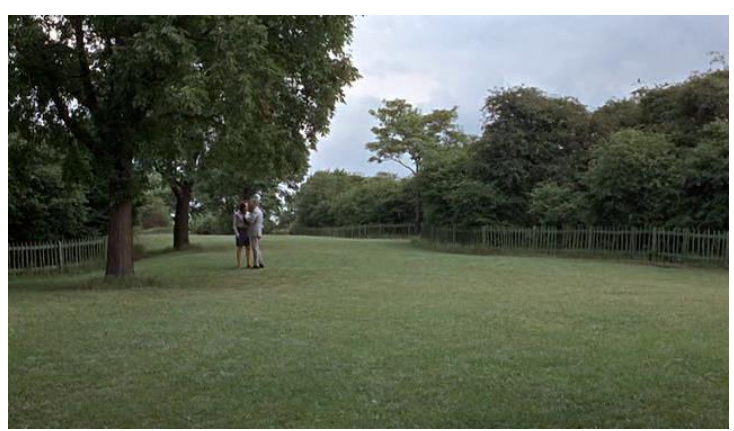

Blow up, Antonioni, 1966

O casal que namora no parque em Blow up não está a sós: um olhar se soma à cena, o olhar do fotógrafo que os observa, que duplica tanto o olhar do diretor como o do espectador. Esse múltiplo encaixe de olhares é o suficiente para que a cena deixe de ser pacífica, reconfortante, e se torne tensa, misteriosa, perversa. O registro fica expulso assim do "Éden cinematográfico onde a angústia com a montagem do olhar ainda era desconhecida".

Mas a inocência se perde antes mesmo dessa intrusão de um terceiro elemento, dessa inclusão na cena de um sujeito cuja função é olhar, observar, espiar; ela se desfaz tão logo se atente para o aspecto obsceno do próprio registro, o que vale também para os filmes de Hitchcock: "Por que a escolha desta cena? Por que este recorte, este enquadramento, este olhar? Desde que intervenham essas questões, tudo muda. A inocência original é suspeita, ela já é perdida". 5

Thomas, ao fotografar o casal no parque - essa área verde em plena selva de tijolo e concreto, elipse no seio do espaço urbano, lugar de passeio e repouso frugal, mas também de encontros clandestinos e crimes sem explicação -, pensa estar apenas presenciando o encontro plácido de duas pessoas numa manhã de sábado. Ou sua curiosidade já é movida por alguma desconfiança, mesmo que passageira? A cena, de longe, parece romântica: o homem abraça a mulher como se tivesse nela seu único porto seguro. A mulher, no entanto, ao se perceber

\footnotetext{
${ }^{4}$ P. Bonitzer, Le champ aveugle, op. cit., p. 47.

${ }^{5}$ Ibid., p. 51.
} 
fotografada por Thomas, corre ao encontro dele e pede para ficar com o filme da máquina. Sua preocupação com as fotos excede o comum e sugere uma situação delicada, suspeita.

O que, afinal, as fotos contêm? A sequência em que Thomas as revela em seu laboratório é uma descrição minuciosa, quase documental, do processo fotográfico. Antonioni solicita muita atenção ao processo, como se aquela lenta alquimia, aquele detalhado ritual estivesse dando vida a um acontecimento, fazendo emergir das trevas um evento que a fotografia salvou da invisibilidade. Prontas as imagens, Thomas coloca uma ampliação ao lado da outra e começa a analisar os trajetos dos olhares - começa a fazer montagem, por assim dizer. O filme encadeia uma sucessão de fotos, com Thomas remontando em sua cabeça a cena testemunhada, concatenando ideias. O som do vento nas folhas retorna, como a nos transportar de volta ao local onde foram registradas as imagens. É a segunda visita ao parque - visita imaginária, que ocorre na mente do fotógrafo enquanto ele reconstitui os acontecimentos.

Depois de fazer as fotos no parque, Thomas havia encontrado seu editor para uma reunião num restaurante. Bastante empolgado com as fotografias, ele assim as descrevera para o editor: "It's very... peaceful, very still". Os dois adjetivos utilizados por Thomas contrastam violentamente com o que ele vai descobrir ao analisar as fotos: um assassinato se desenrolando sob a aparente tranquilidade do encontro no parque. A emulsão química e a ampliação óptica irão desvelar um evento que originalmente não estava na mira do fotógrafo, mas que sua câmera captou mesmo assim.

A figuração do crime, em Blow Up, é função daquilo a que Walter Benjamin chamava o "inconsciente fotográfico":

\begin{abstract}
A natureza que fala à câmera não é a mesma que fala ao olhar; é outra, especialmente porque substitui a um espaço trabalhado conscientemente pelo homem, um espaço que ele percorre inconscientemente. [...] Só a fotografia revela esse inconsciente ótico, como só a psicanálise revela o inconsciente pulsional. $^{6}$
\end{abstract}

A fotografia, diz Raúl Ruiz, torna "grandes e formuláveis" as coisas minúsculas que escapam ao planejamento do artista. Em virtude da natureza mecânica/inconsciente do registro, a informação guardada na fotografia é "impura", pois vem contaminada pelas “centelhas de acaso" que a câmera não consegue evitar. Uma nuvem de poeira, de elementos insignificantes, se infiltra na imagem e ultrapassa a forma desejada: "A distração que

\footnotetext{
${ }^{6}$ Walter Benjamin, "Pequena história da fotografia", in Obras escolhidas, vol. 1: Magia e técnica, arte e política. $3^{a}$ ed., São Paulo: Brasiliense, 1987, p. 94-95.
} 
caracteriza os sistemas de reprodução mecânica torna impossível manter fronteiras estritas e afastar signos externos". ${ }^{7}$ Nessa perspectiva, o que influi decisivamente no registro é menos a precisão, a perícia do fotógrafo, do que a absoluta indiferença do aparelho. Por não obedecer estritamente às intenções do artista, a imagem fotográfica retém aspectos do mundo que o olhar já havia descartado, ou não havia notado, e que ressurgem no momento da revelaçãoampliação. A ficção de Blow up se constrói em torno dessas irrupções do "inconsciente fotográfico".

Em Janela indiscreta, a reflexão sobre o real, a verdade e as aparências estava concentrada no ato da visão. Em Blow up, ela se desloca para a etapa de revelação fotoquímica. "Passamos do olhar, em Hitchcock, à ampliação, em Antonioni, ou seja, do humano ao tecnológico". ${ }^{8}$ Antonioni nos situa numa era em que o homem só consegue ver através da imagem. O crime em Janela indiscreta era percebido pela junção de informações recebidas no próprio ato de olhar (mesmo que este fosse mediado por ferramentas como binóculos e lentes teleobjetivas), ao passo que em Blow up o crime só aparece na ampliação da foto, só aparece na imagem, cuja inscrição está condicionada ao aparato técnico que a preside. Desde a captação até a revelação/ampliação, as diversas etapas da produção das fotos do parque passam por toda uma variedade de máquinas e instrumentos ópticos:
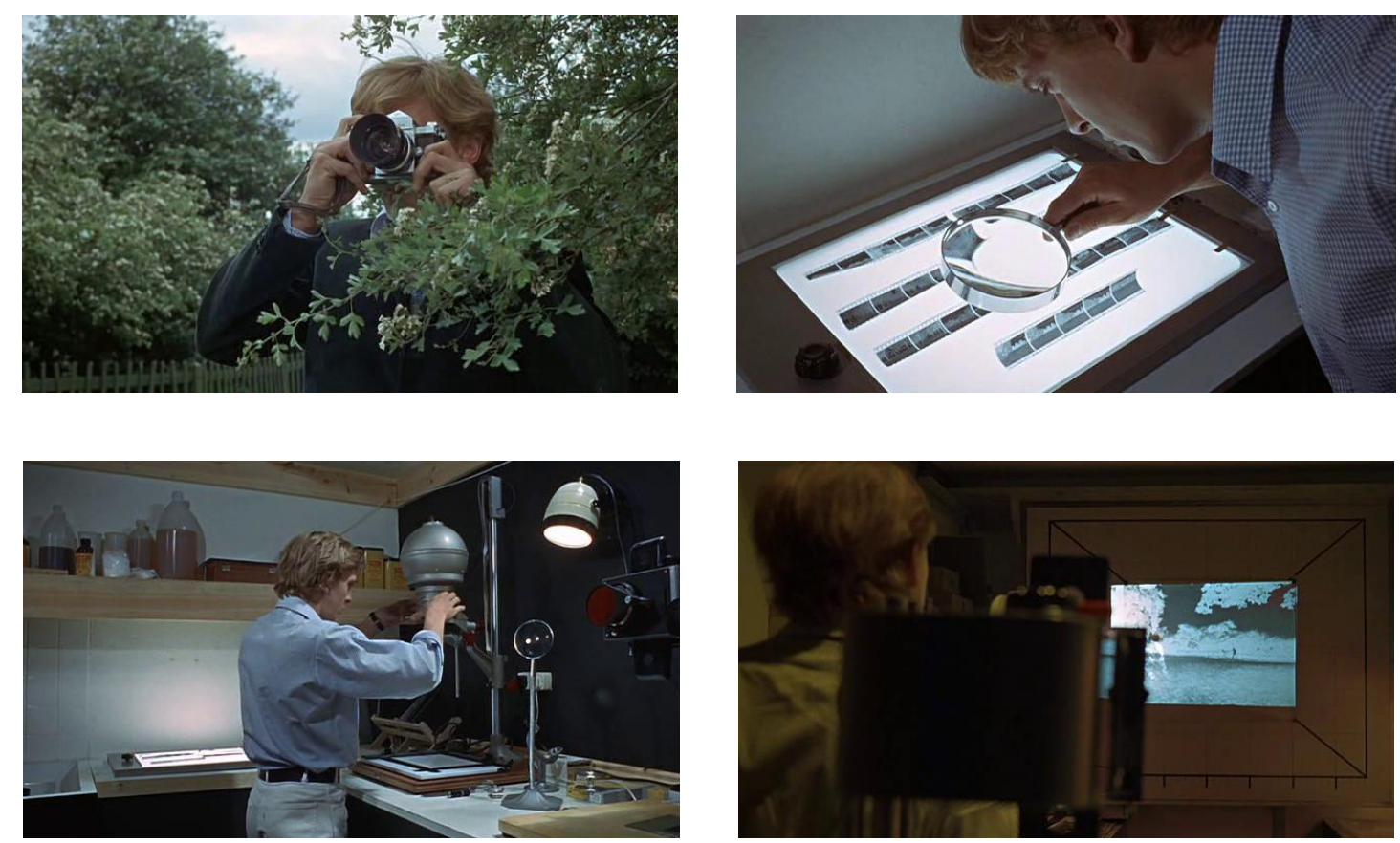

\footnotetext{
${ }^{7}$ Raúl Ruiz, Poetics of cinema, Paris: Éditions Dis Voir, 2005, p. 33.

${ }^{8}$ René Predal, Michelangelo Antonioni ou la vigilance du désir, Paris: Les Éditions du Cerf, 1991, p. 120.
} 
É precisamente essa "maquinização da figuração", ou essa "dissolução do Sujeito na e pela representação maquínica"9 , o que está na base da revolução que a fotografia proporciona na história das tecnologias de imagem. Diferentemente dos dispositivos ópticos do Renascimento (a tavoletta, a camara obscura etc.) - que ajudavam os artistas a sistematizar o espaço e aperfeiçoar a figuração mimética da realidade percebida pelo olho, mas não eram “operadores de inscrição", pois a imagem continuava sendo produzida pelas mãos do pintor ou do desenhista -, a máquina, no processo fotográfico, não se limita a organizar e estruturar a visão: ela inscreve a imagem propriamente dita, "por meio das reações fotossensíveis de certos materiais que registram por si mesmos as aparências visíveis geradas pela radiação luminosa". ${ }^{10}$

Para André Bazin, a originalidade da fotografia em relação às outras artes reside justamente nessa "objetividade essencial", que em última análise deriva de seu "poder irracional", de sua "mecânica impassível". Ao reproduzir mecanicamente o real, a câmera “despoja o objeto de hábitos e preconceitos, de toda a ganga espiritual com que a minha percepção o revestia", tornando-o "virgem à minha atenção e, afinal, ao meu amor". ${ }^{11}$ Se a pintura substitui o modelo por uma forma idealizada, a fotografia limita-se a gravar no material sensível "um registro das impressões do objeto por intermédio da luz", dando uma imagem do mundo sobre a qual não pesa a liberdade de interpretação do artista.

A "gênese automática" da fotografia, a ideia de que ela "se faz sozinha", de que ultrapassa a intencionalidade humana e registra aspectos do mundo não necessariamente visados pelo fotógrafo, tal ideia possui, nas teorias que destacam a indexalidade da imagem fotográfica, um desdobramento de ordem ontológico-fenomenológica: a fotografia vale menos como reprodução fiel das aparências do que como testemunho concreto de algo que "foi", ou seja, em fotografia, o índice prevalece sobre o ícone, o caráter de vestígio (guardar o traço material da situação luminosa de um corpo em determinado instante e lugar) prevalece sobre o critério mimético - "o poder de autenticação sobrepõe-se ao poder de representação"12, como escreve Roland Barthes (que, não por acaso, cita Blow up como protótipo da angústia policial, da vertigem entre a certeza e o esquecimento das coisas provocada pela fotografia).

Barthes afirma que dois elementos fundamentam seu interesse pela fotografia: em primeiro lugar, “o studium, que não quer dizer, pelo menos de imediato, 'estudo', mas a aplicação a uma coisa, o gosto por alguém, uma espécie de investimento geral, ardoroso, é

\footnotetext{
${ }^{9}$ Philippe Dubois, Cinema, vídeo, Godard, São Paulo: Cosac Naify, 2004, p. 42.

${ }^{10}$ Ibid., p. 38.

${ }^{11}$ André Bazin, O cinema - Ensaios, São Paulo: Brasiliense, 1991, p. 22.

${ }^{12}$ Roland Barthes, A câmara clara, Rio de Janeiro: Nova Fronteira, 1984, p. 132.
} 
verdade, mas sem acuidade particular". ${ }^{13} \mathrm{O}$ segundo elemento é o que ele designa como punctum, "pequeno buraco, pequena mancha, pequeno corte" que se destaca da imagem, "fere" o olhar, modifica o regime de atenção do observador e cria uma abertura, uma brecha, uma via de acesso a um extracampo, a alguma coisa que está na imagem sem necessariamente se mostrar.

E não seria uma passagem do studium ao punctum o que a cena das ampliações em Blow up demonstra? De uma atitude vaga e flutuante, o olhar do fotógrafo se transfaz num investimento obcecado. Antonioni retoma, em parte, a dinâmica de funcionamento do plano hitchcockiano (da paisagem à mancha, do olho que vê ao olho que mira), mas o local em que esse exercício do olhar se dá - e tal mudança é deveras importante - é agora a superfície de uma fotografia: a câmera de Hitchcock percorria o espaço físico do cenário, a de Antonioni procura se "aprofundar" - por meio de avanços e recuos, idas e vindas descontínuas promovidas pela laboriosa decupagem da cena das ampliações - no espaço virtual cujo volume a fotografia dá a imaginar. O protagonista de Blow up experimenta uma verdadeira vertigem da imagem, "uma imersão prolongada do olhar no espaço fotográfico". ${ }^{14}$

O que motiva Thomas a perscrutar as imagens à procura de um signo suscetível de lhe dar uma chave de compreensão é "a ideia de que talvez haja na foto um detalhe, um elemento registrado apesar dele, que a mulher sabe que existe. Sua enquete começa como um desafio intelectual cujo único objetivo é o prazer ligado ao suporte de expressão que ele utiliza: a fotografia como revelador para além do olhar humano". ${ }^{15}$ Por saber que a fotografia traz um "certificado de presença", uma "emanação do real passado"16, e por estar convencido de que se acha diante de um mistério, Thomas se sente impelido a ampliar a foto para vê-la melhor:

\begin{abstract}
A Fotografia justifica esse desejo, mesmo que não o satisfaça: só posso ter a esperança louca de descobrir a verdade porque o noema da Foto é precisamente isso foi e porque vivo na ilusão de que basta limpar a superfície da imagem para ter acesso ao que há por trás: escrutar quer dizer virar a foto, entrar na profundidade do papel, atingir sua face inversa (o que está oculto é, para nós, ocidentais, mais "verdadeiro" do que o que está visível). ${ }^{17}$
\end{abstract}

Há uma síndrome do segredo perpassando o enredo de Blow up - uma síndrome desencadeada pelas próprias virtudes do aparato fotográfico:

\footnotetext{
${ }^{13}$ Ibid., p. 45.

${ }^{14}$ T. Roche, Blow up: un regard anthropologique, op. cit., p. 83.

${ }^{15}$ Ibid., p. 79.

${ }^{16} \mathrm{R}$. Barthes, A câmara clara, p. 132.

${ }^{17}$ Ibid., p. 148.
} 
O que nosso olhar não nos fez compreender, a foto, por um desvio e uma manipulação, vai nos ajudar a descobrir. Assim, a imagem não teria a vocação de restituir fielmente o verdadeiro, mas de produzir uma ficção [...] da qual a verdade emerge por um caminho alternativo. Ver o que o olho não pode ver, não por utilizar uma tecnologia que dá acesso ao infinitesimal, mas simplesmente por enquadrar o real de tal maneira que ele se oferece a nós sob uma nova luz. ${ }^{18}$

O poder da fotografia de revelar aspectos latentes das coisas se deve, portanto, não apenas à "verdade mecânica" do registro, à infiltração na imagem de um real inopinado, mas também ao fato de que o recorte do enquadramento gera uma potência de focalização, uma concentração do olhar num determinado fragmento do mundo visível. Graças à limitação estratégica operada pelo quadro, a foto isola do fluxo das aparências sensíveis uma série de elementos que, embolados no tecido indiferenciado do mundo fenomênico, não teríamos como perceber. Tudo é questão de "descontextualizar para analisar"19, tirar o fenômeno do seu contexto natural para observá-lo em laboratório. Enquanto Thomas analisa os acontecimentos do parque, "o que ele olha não é mais a cena, mas a fotografia representando a cena. Thomas, ao olhar as fotos, olha o que já olhou; ele está num trabalho de ajustamento da memória do olho e da atualidade do visível", ${ }^{20}$

A fotografia implica necessariamente uma dupla distância: distância espacial, já que a foto torna presente um objeto ausente (o "aqui" do signo jamais se confunde ao "ali" do referente $\left.^{21}\right)$; e distância temporal, pois toda foto mostra sempre o passado, mesmo que seja um passado muito próximo:

Todos sabem de fato que o que nos é dado a ver na imagem remete a uma realidade não apenas exterior, mas igualmente (e sobretudo) anterior. E essa distância temporal, que torna a fotografia uma representação sempre atrasada, adiada, [...] corresponde ao processo técnico da revelação, que é necessariamente inscrito na duração, com suas fases sucessivas obrigatórias, indo da imagem latente à imagem revelada e depois à imagem fixada. ${ }^{22}$

A espera da revelação é a fase da dúvida, do suspense. É o momento em que a imagem, "ainda virtual, fantasma de imagem, não cessa de correr todos os riscos, todos os sonhos". ${ }^{23}$ Antes de aparecer fixada, a foto flutua entre o real e o imaginário. E quando a

\footnotetext{
${ }^{18}$ T. Roche, Blow up: un regard anthropologique, op. cit., pp. 82-83.

${ }^{19}$ Ibid., p. 83.

${ }^{20}$ Ibid., p. 85.

${ }^{21}$ Cf. P. Dubois, $O$ ato fotográfico, p. 88.

${ }^{22}$ Ibid., p. 89.

${ }^{23}$ Ibid., p. 313.
} 
imagem finalmente surge, as dúvidas que suscitou naquele período de latência não desaparecem, pelo contrário: acentuam-se. O que vejo é o que esperava (re)ver ou já algo diferente? Entre a imagem captada e a imagem revelada, introduziu-se um hiato, uma fenda, uma lacuna que o sujeito, enquanto aguardava pelo processo de revelação, foi ocupando com a memória, o engano, a ansiedade, a imaginação, o esquecimento. Quando a fotografia fica pronta, ela já não pode ser contemplada apenas como o registro objetivo de um evento passado; ela inclui também os fantasmas que a mente alimentou na fase de espera. É a própria noção de objetividade e indexalidade da imagem fotográfica que se vê estremecida: "Ali onde o índice vinha marcar um efeito de certeza, de plenitude, de convergência, o princípio de distância vem marcar um efeito de abalo, de defasagem, de vazio". ${ }^{24}$ Philippe Dubois ressalta que "essa distância que vem fazer a relação estabelecida da imagem com o mundo tremer" é central em Blow up: "O tema do filme é a impossibilidade de fazer o real coincidir com a sua representação a posteriori, justamente porque entre os dois, na distância, algo aconteceu - que não é apenas do tempo". ${ }^{25}$

Tudo se dá, portanto, nesse intervalo que separa - espacial e temporalmente - a foto do objeto/ser/evento fotografado. Em outras palavras, o fundamental do filme está na imagem intermediária, na imagem latente, que não é nem o "real", aquilo que foi testemunhado in loco, nem o "imaginário", aquilo que derivou do processo fotográfico. É o que fica perdido entre os dois. Talvez não perdido, mas suspenso, tencionado, esticado (como um fio). Se a imagem fotográfica é o traço, o índice, a marca deixada pela passagem de uma força, a imagem latente só pode ser o que vem antes disso, ou seja, ela é a própria passagem da força. Não se trata ainda da figura, mas de uma tensão rumo à figura - uma espécie de "latência figurável". 26

Na sequência das ampliações, Thomas pendura as fotos uma ao lado da outra, para tentar entender o sentido do olhar inquieto da mulher. Mas a imagem que poderia revelar a razão dessa inquietação (uma imagem que mostrasse o que ela estava vendo naquele momento, e que a perturbava) não está ali, ou melhor, está, mas ainda em latência. O fotógrafo precisa então precipitar a aparição dessa imagem. Ele precisa fazêe-la surgir.

Como a restituir um vazio originário, Antonioni coloca em relevo nesta cena não somente as fotografias, mas também os hiatos, os intervalos entre elas. Ele sublinha as falhas, as ausências que fendem o esboço de fotonovela que Thomas compõe com as imagens feitas

\footnotetext{
${ }^{24}$ Ibid., p. 91.

${ }^{25}$ Ibid., p. 92.

${ }^{26}$ L. Marin, De la représentation, op. cit., p. 66.
} 
no parque. A mise en scène de Antonioni dá uma forma cinematográfica às lacunas entre as imagens, por meio de panorâmicas que vão de uma ampliação à outra: para chegar à imagem seguinte, a câmera precisa passar pelo vazio, pelo pedaço de muro que as separa; desse modo, o diretor filma o intervalo. As panorâmicas ora perfazem um trajeto linear, saltando de imagem em imagem ordenadamente, ora descrevem um ziguezague, indo e voltando repetidas vezes entre duas fotos - vaivém angustiado de um olhar que tenta achar o ponto cego e prover a imagem com o sentido que ela insiste em esconder. Enquanto a câmera alterna entre as duas imagens, o zoom vai se aproximando delas, como se Thomas de fato mergulhasse no espaço fotográfico ou estivesse "aprisionado numa espiral vertiginosa". ${ }^{27}$ Ao longo da cena, o fotógrafo não consegue parar quieto: observa, recorta, faz novas ampliações e em seguida as amplia ainda mais, vai de um lado para o outro, suado, excitado.

Eis esse sujeito em sua corrida louca entre dois mundos que não se adaptam, em sua compulsão em atravessar nos dois sentidos a inelutável distância fotográfica, ei-lo perdido nas aparências, preso no jogo dos fantasmas, das ficções, das miragens, caindo cada vez mais na fratura que acreditava estar preenchendo - escavando seu próprio túmulo. ${ }^{28}$

O "efeito Blow-up da fotografia", segundo Dubois, reside no "fato de a revelação revelar algo além do que a latência nos deixava acreditar", o que "induz inelutavelmente o sujeito ao movimento, ao deslocamento, à travessia". ${ }^{29} \mathrm{O}$ ziguezague do fotógrafo, seu ir e vir incessante - revelando, ampliando, comparando, analisando e recomeçando tudo de novo -, representa o comportamento taquipsíquico do sujeito afetado pela sobrecarga de investimento característica da imagem latente: na falta de uma figura estável à qual se ater, o olhar se vê obrigado a percorrer as linhas de força (é o que a câmera de Antonioni faz, seguindo os trajetos de olhares de uma foto à outra, ou de um ponto a outro dentro de uma mesma foto), a transitar apressadamente pela esfera dessa imagem ainda em estado de figurabilidade, em tensão. O observador descobre, no processo, que é preciso colocar-se nas imagens. "O visível não é uma superfície”, diz A. Minazzoli: "ele faz superfície, e só podemos percorrê-lo se também o atravessarmos, se penetrarmos nele, se sondarmos sua profundidade, guiados pelas associações de imagens que tecem sua trama - sombras e reflexos, manchas ganhando forma e se metamorfoseando, imprevisíveis". ${ }^{30}$

\footnotetext{
${ }^{27}$ P. Dubois, $O$ ato fotográfico, p. 175.

${ }^{28}$ Ibid., p. 92.

${ }^{29}$ Ibid., p. 175.

${ }^{30}$ A. Minazzoli, La première ombre, op. cit., p. 173.
} 
O que Thomas investiga, na verdade, não é o que as imagens escondem, mas o que elas dizem na sua evidência fenomenal mesma. Não se trata de investigar o que está velado, mas justamente o que as fotos mostram, isto é, o que foi revelado. O que quer dizer aquela expressão no rosto, aquele olhar inquieto? E aquela mancha no fundo do quadro? O ponto de partida, desse modo, é o enigma, e não o mistério: “O enigma [...] não é o que está escondido, mas o que salta aos nossos olhos; ele se posta diante de nós, intrigante, [...] e imediatamente nos desafia a adivinhá-lo". ${ }^{31}$ Em Blow up, a evidência do crime já está na foto, mas ainda é preciso fazê-la aparecer para o olho, o que implica um trabalho de decupagem e focalização. Thomas tem de passar do ver, que é um olhar mais amplo e difuso, "mais passivo, involuntário e global", ao enxergar, que é "mais voluntário e refletido, mais intencional e focalizado": "ver é um estado (quase permanente), e enxergar, uma atividade (pontual)". 32

O cenário em que Thomas dispõe as fotografias e as analisa é o oposto dos gabinetes de pinturas que vimos no capítulo anterior: lá, não havia paredes brancas nem intervalo entre as imagens, que se acavalavam provocando uma experiência de saturação óptica; aqui, as paredes são de um branco impecável, e as brechas entre as fotos inscrevem no sintagma visual composto por Thomas a presença/ausência fantasmática das partes que faltam no seu quebracabeça. As lacunas parecem realçar o caráter incompleto da narrativa, sua abertura:

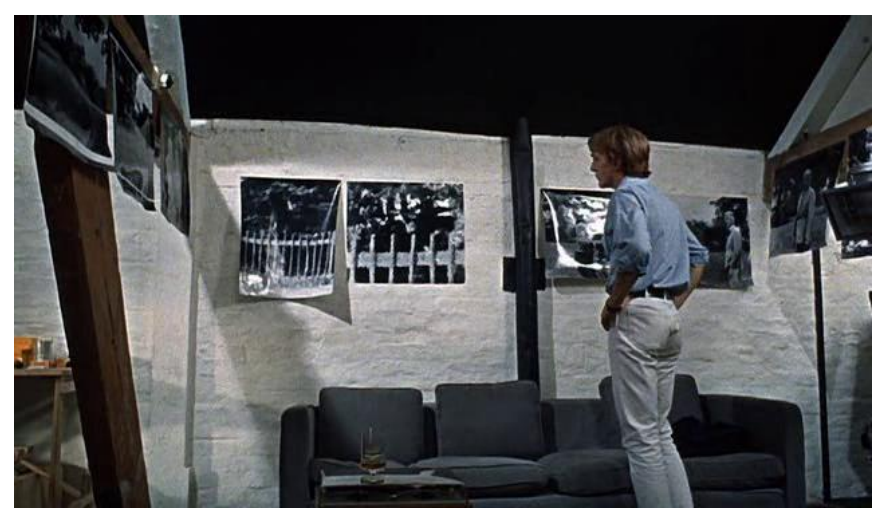

O mural de Thomas, de certo modo, é uma espacialização do processo de montagem. É como se o fotógrafo tivesse diante dele os planos ainda não montados de um filme dispostos no mesmo espaço que ele ocupa com seu corpo - e lhe coubesse agora encontrar os raccords, as conexões (evidentes ou secretas, fluidas ou dissonantes, harmoniosas ou conflitivas) entre as imagens, o sistema de ligações que confere a elas um sentido somente obtido no conjunto. Não à toa, assim que Thomas começa enfim a entender o que aconteceu,

\footnotetext{
${ }^{31}$ F. Niney, Le subjectif de l'objetif, op. cit., p. 114.

${ }^{32}$ Ibid., p. 67.
} 
ou começa tão simplesmente a criar sentido para as fotos, Antonioni, em vez de transitar pelas imagens mediante movimentos de câmera, prefere recorrer à montagem, cortando de uma fotografia para a outra e apresentando-as na ordem que Thomas acaba de estabelecer mentalmente. É durante esta espécie de exibição de slides que se ouve novamente o som do vento nas folhas, como a indicar que o fotógrafo de fato (re)montou a cena vista no parque.

David Alan Mellor nota que, do ponto de vista de uma simples inclusão em algum gênero, Blow up seria, ao menos num primeiro momento, uma típica narrativa de crime e mistério na melhor tradição britânica; uma história de detetive baseada nas velhas lições do empirismo, que repousam sobre uma aguda observação dos detalhes. Mas o desenrolar do filme demonstra algo diferente: Thomas representa um narrador modernista deparado com "uma crise de interpretação". ${ }^{33}$ As provas do crime estão escondidas nos interstícios de uma imagem que, à medida que é ampliada e esticada, acelera um processo de desintegração figurativa.

No começo do filme, Thomas encontra um amigo pintor que está trabalhando numa tela abstrata. O pintor explica seu processo: "Não significa nada enquanto estou pintando, apenas uns borrões. Depois, consigo achar alguma coisa que serve de referência, como esta perna. Então tudo começa a se encaixar, a fazer sentido. É como achar uma pista num romance policial". A cena é particularmente elucidativa, pois expõe e esclarece um percurso da abstração à figuração - que o filme fará, primeiramente em sentido oposto, dinamitando a figura e reencontrando uma espécie de visibilidade anterior, originária, e depois naquele sentido sugerido pelo pintor, redescobrindo a figura a partir de uma "pista" encontrada em meio a uma caótica paisagem de pontos e manchas. Thomas vai selecionando partes das fotografias e ampliando, penetrando cada vez mais fundo tanto no acontecimento registrado pela câmera quanto na matéria constitutiva da imagem. Dos planos abertos, onde o que ele tem diante dos olhos nada mais é que um motivo pictórico clássico - paisagem com figuras -, Thomas vai passando aos planos fechados, onde as formas perdem os contornos legíveis e os grãos crescem devorando o conteúdo figurativo da imagem. A sequência demonstra que a própria fotografia comporta, em seu interior, uma tendência de desfiguração da representação, como se estivesse atravessada por forças de "desanalogização". ${ }^{34}$ As últimas ampliações de Thomas se assemelham ao expressionismo abstrato. É justamente aí, nesse limite, "espécie de

\footnotetext{
${ }^{33}$ D. A. Mellor, "Fragments of an unknowable whole: Michelangelo Antonioni's incorporation of contemporary visualities", in GARNER, P. e MELLOR, D. A., Antonioni's Blow-up, op. cit., pp. 132-133.

${ }^{34}$ P. Dubois, Cinema, vídeo, Godard, p. 55.
} 
visão abissal de um mundo constituído por pontos aglutinados numa ordem aleatória"35, que os detalhes que antes se dissimulavam no fundo da paisagem aparecem agora em primeiro plano e se impõem como a evidência da morte ocorrida no parque. Com a imagem esgarçada ao máximo, surgem a arma do assassino numa foto e o corpo da vítima em outra, o grau de nitidez da figura sendo bem maior no primeiro caso que no segundo - o cadáver, diferentemente da mão segurando a arma, surge menos como uma imagem acabada e inequívoca do que como uma mancha; menos uma figura do que uma potência de figura, ou ainda, menos uma reprodução mimética do que um traço, um vestígio.
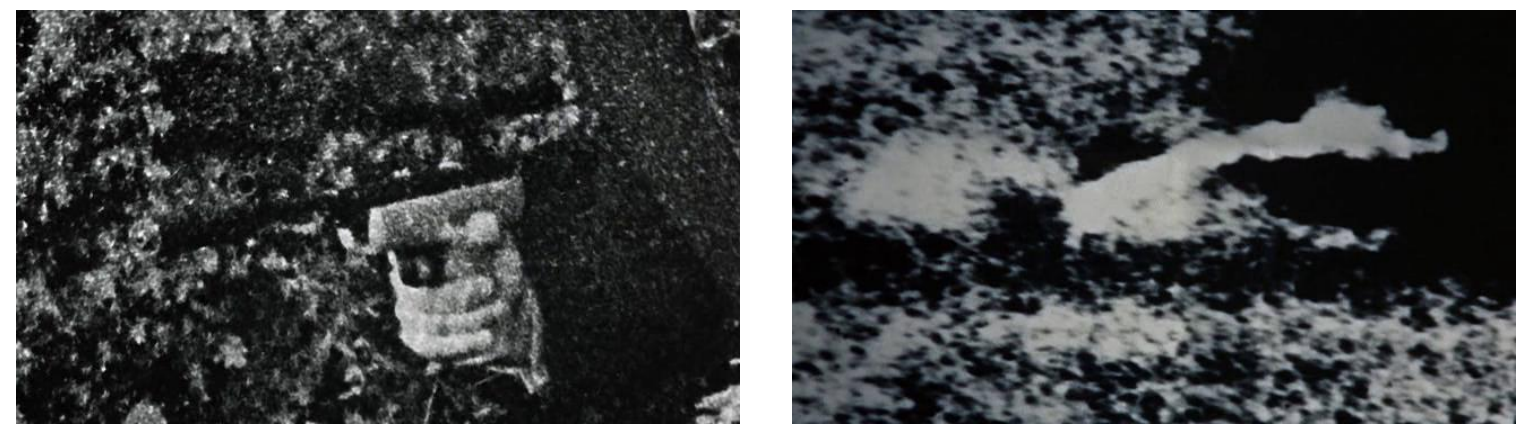

A fotografia de Thomas, agora, conecta-se com a pintura de seu amigo. Foi preciso mergulhar na matéria, implodir o espaço sistemático desenvolvido desde o Renascimento, para só então - estando em fase com um novo tipo de visão plástica - encontrar alguma pista, alguma nesga de sentido. Os corpos figurados na foto precisaram ser dissolvidos para que, já no limiar da abstração, naquele ponto em que a materialidade própria da imagem - sublinhada e fermentada - havia destruído a legibilidade, outros corpos, antes "invisíveis", pudessem ser encontrados.

Durante a preparação de Blow up, como D. A. Mellor aponta, Antonioni imergiu na cultura visual britânica que fervilhava nos anos 1960. Além de conhecer de perto o universo dos fotógrafos, ele estabeleceu contato com as obras de artistas plásticos como Richard Hamilton e Ian Stephenson. Hamilton vinha trabalhando, na primeira metade da década, justamente com os processos de reprodução fotográfica. Em Whitley Bay, de 1965, ele usa como suporte de sua pintura a cópia fotográfica de um detalhe destacado de um cartão postal e ampliado até que se obtivesse uma imagem em que, junto ao aparecimento dos grãos e cristais que são a própria matéria da imagem fotográfica, surgissem figuras residuais, aspectos do mundo que estavam silenciados no fundo da imagem, mas que agora emergem como num

\footnotetext{
${ }^{35}$ T. Roche, Blow up: un regard anthropologique, op. cit., p. 84.
} 
processo de desrecalcamento do inconsciente óptico daquela foto pertencente ao imaginário popular (esse lado ready made não seria incorporado por Antonioni, já que, no filme, Thomas usa uma fotografia de autoria própria - de resto, o significado da ampliação é o mesmo). A "granulação visual" observada nesse trabalho de Hamilton também pode ser encontrada nas pinturas de Stephenson - a quem foram encomendadas as telas que aparecem no filme como sendo de autoria do pintor amigo de Thomas $^{36}$-, que consistem em imagens formadas basicamente por pontos e manchas, como se ele atingisse a escala micromolecular do universo visível. Ainda que extremamente abstratas, as telas de Stephenson usadas no filme conservam um fantasma de figuração, uma figura latente ou potencial. Afinal, como diria Rohmer: "Na abstração, existe ainda a memória da figuração". ${ }^{37}$

Outro aspecto determinante para a concepção de Blow up foi o clima de paranoia e vigilância que, àquela altura, já era parte integrante da consciência visual de uma época marcada, entre outras coisas, pela Guerra Fria e a cada vez mais sofisticada indústria da espionagem. Em paralelo às temáticas de complô e conspiração política então em voga, havia também a constatação de que a imagem havia colonizado as diversas esferas da vida cotidiana (uma generalização/banalização da dimensão estética do cotidiano, um mundo transformado em mera imagem de si próprio) e de que em todo lugar havia uma câmera (profissional ou amadora) apta a flagrar alguma coisa. Nada mais escapava à imagem.

Um evento em particular confirmaria tudo isso: o assassinato de John F. Kennedy em Dallas, em 22 de novembro de 1963, que um cinegrafista amador, Abraham Zapruder, filmou em Super-8, registrando o momento exato em que o presidente foi atingido pelos tiros, evento traumático divisor de águas na história moderna norte-americana. O “filme Zapruder" se tornaria não apenas uma peça-chave na investigação do assassinato, mas um reservatório de pesadelos e choques visuais que assombrariam o imaginário coletivo a partir de então. ${ }^{38}$

Pouco depois do assassinato, a revista Life publicou fotogramas extraídos de momentos decisivos do filme Zapruder, fornecendo um material que rapidamente se tornaria objeto de escrutínio e especulação, nutrindo toda sorte de teoria conspiratória. Outra imagem que ficaria célebre, incrementando o acervo de documentos fotográficos do caso Kennedy, é a Polaroid feita por Mary Moorman, que testemunhou o crime de um lugar muito próximo de onde o carro do presidente passava na hora em que ocorreram os disparos. A foto de Moorman, captada uma fração de segundo após o tiro fatal (o que atingiu a cabeça de

\footnotetext{
${ }^{36}$ Ver D. A. Mellor, Antonioni’s Blow-up, op. cit., p. 126.

${ }^{37}$ Philippe Fauvel e Noël Herpe, "Le souvenir de la figuration", entrevista com Éric Rohmer em Positif, n. 590, abril de 2010, p. 107.

${ }^{38}$ Cf. Jean-Baptiste Thoret, 26 secondes: L’Amérique éclaboussée, Pertuis: Rouge Profond, 2003.
} 
Kennedy), mostraria algo suspeito na vegetação ao fundo, um vulto que poderia sugerir um atirador escondido atrás de uma cerca (exatamente como em Blow up).

Em 1966, a revista Life retorna às imagens do filme Zapruder, desta vez numa perspectiva analítica, que coloca em dúvida as conclusões divulgadas pelo dossiê da comissão que investigou o assassinato (o título da matéria é "A matter of reasonable doubt"39). É o começo de uma era de contestação da versão oficial sobre o evento.

Embora as fotos obtidas a partir da filmagem de Zapruder tenham começado a circular logo em seguida à tragédia de Dallas, o filme em si - os 26 segundos de imagem em movimento que mostram o carro de Kennedy desfilando pela rua, até culminar com os tiros e a aterrorizante imagem da cabeça do presidente explodindo sob o impacto da bala - ficaria retido nos arquivos do FBI, sendo censurado e ocultado pelo governo. O filme só vazaria dos arquivos federais no final da década de 1960, quando cópias clandestinas, feitas em 16mm, seriam comercializadas no mesmo nicho underground em que se podiam encontrar filmes pornográficos ou de violência extrema. Agora em movimento, reinscritas na duração do acontecimento, as imagens do assassinato de Kennedy reacendem a obsessão dos buffs (como foram apelidados os detetives de imagem amadores que se debruçavam sobre o registro no intuito de desvendar o mistério do assassinato). Após ver e rever milhares de vezes o filme Zapruder, os buffs são tomados por uma vertigem de interpretação que os leva a enxergar um complô se dissimulando em cada um dos inúmeros detalhes aparentemente insignificantes da cena do assassinato. Uma das conclusões a que os buffs chegam é a de que o filme foi manipulado e adulterado: houve colagem, trucagem, inversão na ordem de algumas imagens e, sobretudo, deleção de fotogramas situados em momentos cruciais do filme. Em suma, há imagens faltando. Qualquer inferência, qualquer teoria extraída do filme será, portanto, necessariamente inconclusiva, insuficiente, fendida pelas ausências, os elos perdidos, as imagens suprimidas, aquelas que poderiam, talvez, dar uma explicação à história.

O protagonista de Blow up, ao analisar obsessivamente as fotografias do parque, comporta-se como um desses detetives de imagem. A narrativa visual que ele investiga, assim como a versão do filme Zapruder que chega aos buffs, contém saltos, elipses, lacunas que acusam a ausência de imagens-chave. Além disso, a realidade registrada nas fotos de Thomas não se dá a ver de forma transparente: as imagens do parque colocam o fotógrafo diante da obtusidade do mundo, da sua ambiguidade opaca - donde o impulso de penetrar nelas, de tentar vencer essa opacidade e preencher as lacunas.

\footnotetext{
${ }^{39}$ Cf. D. A. Mellor, Antonioni's Blow-up, op. cit., p. 133.
} 
O vazio sempre estruturou os planos de Antonioni. Vazio do espaço, vazio entre os seres. Em Blow up, ele acentua esse outro vazio: o que se impõe entre as imagens. A trama investigativa de Blow up - evasiva, insólita, próxima da abstração - deriva de "uma forma de narrativa fragmentária, em que a atividade do intervalo se tornou essencial". ${ }^{40}$ Antonioni filma os interstícios entre o ver e o não ver. A saga de seu protagonista pode ser resumida como a busca pela cena "escondida", pela imagem que falta para completar um mosaico que pouco a pouco se desprende da realidade para assumir a forma de uma paisagem mental. Uma vez que a cena não está exatamente no quadro, no campo, mas no entre-imagens, na elipse, no intervalo ("o crime se situa entre duas fotos" ${ }^{41}$ ), vê-la não é mais uma questão puramente de óptica, mas de interpretação semiológica. (Curioso notar que a voga da ficção paranoica no cinema coincide historicamente com o momento em que a linguística, a semiótica e suas variantes dominam os saberes, funcionando como mediadores teóricos para praticamente todas as áreas de produção de conhecimento. Há todo um campo a se explorar nesse sentido, associando as máquinas interpretativas elaboradas nos filmes de espionagem e conspiração política abundantes nas décadas de 1960/70 com as próprias construções intelectuais que se observam na semiologia, na linguística, no estruturalismo etc.)

Se Blow up pode ser visto como uma espécie de filme-tese do cinema moderno, é porque cristaliza um sentimento já pregnante desde o pós-Segunda Guerra, mas acentuado com a turbulenta chegada dos anos 1960: a constatação de que a imagem não pode mais se fingir transparente, unívoca, imediatamente legível; ela deve colocar uma questão, tornar-se o próprio assunto a ser explorado pelos filmes. "Tudo se passa então como se as coisas, a realidade e a crença que elas implicam tivessem sido subitamente evacuadas em proveito de uma interrogação sobre a imagem, sobre as 'relações de produção' da imagem”. ${ }^{2}$ O cinema, ou melhor, as artes visuais em geral, assim como as demais imagens (científicas, jornalísticas, publicitárias etc.), não dão a ver o mundo inocentemente: cada qual a seu modo, elas formam uma linguagem carregada de sentido e intenção (mas perpassada também por forças desconhecidas, inconscientes, inarticuladas), ideologicamente comprometida, historicamente determinada, tencionada pelas energias da sociedade e suas neuroses coletivas. Para compreendê-la, não basta ver: é preciso analisar, desconstruir, escrutar a superfície das imagens à procura dos sintomas que elas entregam tanto quanto mascaram. Blow up é o ponto

\footnotetext{
${ }^{40}$ T. Roche, Blow up: un regard anthropologique, op. cit., p. 117.

${ }^{41}$ Ibid., p. 120.

${ }^{42}$ P. Bonitzer, Le champ aveugle, op. cit., p. 130.
} 
fulcral dessa autoconsciência moderna, na medida em que desloca o problema do enigmadelito para o enigma-imagem, a trama policial se trocando por uma análise do próprio suporte fílmico.

Análise que só se completa com as duas últimas idas de Thomas ao parque. A mais breve dessas idas ocorre à noite, numa atmosfera muito próxima dos filmes de terror. O lugar está escuro e deserto. Thomas se encaminha para a moita atrás da qual, na fotografia, enxergou o cadáver. E, de fato, o cadáver lá se encontra: um corpo plastificado, artificial, mais parecendo uma escultura hiper-realista do que um corpo de verdade. Thomas observa o cadáver por um tempo e depois se retira.

Na manhã seguinte, tendo sobrevivido a uma agitada noitada, ele retorna ao parque. Agora, contudo, ele não encontra mais o cadáver: este simplesmente desapareceu sem deixar rastro. Desolado, Thomas caminha pelo extenso gramado e resolve assistir à performance de uma trupe de mímicos que já tinha aparecido em outros momentos do filme. Eles fingem jogar tênis numa quadra situada dentro das imediações do parque. De repente, um dos mímicos dá uma raquetada muito forte, e a bola imaginária cai fora da quadra, perdendo-se no gramado. A câmera acompanha o trajeto da "bola" num travelling que parece realmente acreditar na existência de um objeto ali enquadrado. Os mímicos olham para Thomas, sugerindo que ele vá atrás da bola. Após certa hesitação, ele vai, apanha a bola imaginária e a arremessa de volta para a quadra.

Por meio desse gesto, um gesto real na realidade mas sem referente material, Thomas articula, pensa e propõe uma relação possível entre ficção e realidade, mas igualmente entre fotografia e cinema: a bola invisível não é fotografável, mas o gesto é filmável. De certa maneira, Antonioni mostra a diferença [écart] entre a foto e o cinema insistindo sobre a especificidade do segundo, sua capacidade de captar e restituir o movimento. ${ }^{43}$

Esse paragone, essa comparação entre fotografia e cinema já fora iniciada na cena anterior, quando, diante da constatação do sumiço do cadáver, Antonioni apontara sua câmera para a árvore acima da cabeça de Thomas e filmara o vento nas folhas por alguns segundos, tempo suficiente para nos fazer prestar especial atenção, a partir de então, ao fato de que todas as árvores do parque nessa cena estão balançadas por um forte vento, como se quisessem nos reafirmar uma velha verdade sobre o cinema: "por mais imóvel que seja a imagem cinematográfica, ela é atravessada - habitada? - por algo que a fotografia não capta: o ar. Insondável, impalpável certamente - a menos que se observe o eventual estremecimento de

\footnotetext{
${ }^{43}$ T. Roche, op. cit., p. 57.
} 
uma folha numa árvore -, mas presente, definitivamente presente". ${ }^{44} \mathrm{O}$ vento possui uma interessante parceria com a imagem cinematográfica, cujo corolário não cabe aqui explorar a fundo, mas apenas mencionar. Mais que qualquer outro elemento filmável, o vento é aquilo que injeta na imagem de cinema o movimento, não o movimento deste ou daquele corpo, mas o movimento do mundo, o deslocamento incessante de todas as suas partes. $\mathrm{O}$ vento deixa claro que a sensação ou impressão de movimento no cinema não é simplesmente questão de apreender (ou simular) o deslocamento aparente dos corpos: há algo na imagem cinematográfica que ultrapassa a antiga questão (já encontrada na pintura, na escultura, na fotografia) da figuração ou da representação do movimento; há uma pulsação inquieta, uma atividade do próprio espaço, da própria luz, uma vibração generalizada. É a imagem em si que se acha em movimento. Uma granulação perpassa o campo, uma poeira de luz carregada pelo vento, que permite ao cinema tornar expressivo o ar, o vazio que preenche os intervalos entre os corpos. Muito já se falou sobre a reação de Méliès ao assistir a uma das primeiras vistas de Lumière (Le repas de bébé): ele ignorou o teatrinho burguês que se desenvolvia no primeiro plano (um casal alimentando seu bebê) e ficou siderado com o que acontecia no fundo da imagem, isto é, as folhas das árvores se mexendo ao sabor do vento. Tal interesse pelo “insignificante” é plenamente justificável: mais que o conteúdo principal da vista (o almoço do bebê), o vento nas folhas - acontecimento sutil, suplementar, coadjuvante, mas decisivo aos olhos de Méliès - era o aspecto da imagem de Lumière que realmente abria o olhar para uma nova percepção do mundo fenomênico. Algumas boas décadas depois, Antonioni ratifica essa evidência do cinema, tão óbvia quanto apaixonante: as folhas se mexem.

Blow up termina, portanto, com o protagonista - após ter percorrido diversas especulações e caminhos interpretativos - constatando o vazio, a ausência de prova, a falência de sua empreitada investigativa. Em Janela indiscreta, a "febre interpretativa" da personagem ainda recebia algum tipo de recompensa (Jeff tinha, no final, a confirmação de que o crime realmente ocorrera). Essa recompensa se perderá em Blow up: as ampliações e os negativos do fotógrafo somem, o corpo do homem assassinado some, não resta nada como prova material do crime flagrado na imagem. Restaura-se o vazio que existia na cena originalmente, ou seja, a insignificância primeira da imagem do casal no parque. O ponto de fuga da

\footnotetext{
${ }^{44}$ Ibid., p. 122.
} 
vertigem especulativa do olhar é o Nada - como um retorno ao puro branco do papel fotográfico que, conforme visto na demorada cena da revelação das fotos, antecedera a imagem que ali se formaria. A garantia de real, encarnada na presença do corpo no local do crime, se desfaz da noite para o dia; real e imaginário se confundem, fato e engano se apagam reciprocamente. Thomas deverá se confrontar com a perda da imagem e do sentido. Experiência exigente para um homem que vive da fabricação de imagens, ou seja, que passa o tempo combatendo o inacabamento do mundo, sua falta de sentido, preenchendo com imagens - construções subjetivas de mundos significantes - o vazio e a incoerência inerentes à vida. O que Antonioni lhe propõe, opostamente, é a suspensão do sentido, o oximoro da "presença do vazio".

O olhar de James Stewart, em Janela indiscreta, conduzia o espectador na busca de um segredo, estimulando e alimentando seu “desejo de ver mais, de ver por trás, de ver através". 45 A cenografia maquinada por Hitchcock favorecia tal dinâmica: janelas, cortinas, paredes, portas que se abrem e se fecham, mostram e escondem (mas escondem o quê?). Dessa tensão entre a descoberta e seu adiamento, entre a visibilidade e sua obstrução, entre a revelação do mistério e sua negação, entre o ver e o acreditar ter visto, nascia o suspense, sempre na fronteira - permeável - da imagem mental (intuída) com a realidade material (percebida). Hitchcock já colocava o olhar em dúvida: há mesmo um segredo ou tudo está à vista e qualquer coisa a mais terá sido invenção sem propósito? Tão logo se faça essa pergunta, o terror se instala, porque o suspense, no fim das contas, não é o medo do que quer que possa existir para lá das aparências, mas sim a angústia perante a possibilidade de que não haja nada. Isso equivaleria a constatar um mundo opaco e completamente alheio aos nossos desejos de visão. Um mundo assustador porque monótono e sem resposta (a platitude causa horror). Em Blow up, Antonioni dá o passo seguinte e mostra uma realidade que não pode ser aprofundada, escavada, penetrada; ele frustra o prazer voyeurístico da procura pelo "segredo atrás da porta". Mesmo após a descoberta de um possível crime revelado na imagem (no "fundo" da imagem, para ser mais preciso - mas o fundo da imagem não é senão uma ilusão óptica produzida numa superfície bidimensional), a intriga não se desenvolve, o mistério não se desenlaça; a sensação de vazio perdura. Ao contrário de Jeff, Thomas fracassa na tentativa de descortinar o que há por trás da camada mais aparente da realidade. O que ele tem diante de si é uma fotografia, uma imagem, e uma imagem é uma imagem - nada mais, nada menos. Barthes: "não posso aprofundar, penetrar a Fotografia. Posso apenas varrê-la com o olhar,

\footnotetext{
${ }^{45}$ S. Daney, A rampa, op. cit., p. 229.
} 
como uma superfície imóvel. A Fotografia é chã, em todos os sentidos da palavra". ${ }^{46}$ De tanto arranhar as fotografias com os olhos, Thomas havia chegado a acreditar que podia transpassálas, furá-las para ver através delas. Ele obteve lá sua recompensa durante um breve momento. Mas logo a perdeu.

Um elemento tão banal quanto crucial no filme é a hélice de avião que Thomas cisma em comprar num antiquário: objeto que, deslocado de seu lugar e de seu uso habituais, perde a função e a utilidade, passando a mobilizar o olhar de maneira diferente, reconfigurando-se para o mundo, estetizando-se, existindo como forma e não apenas como apetrecho. Fora do contexto do avião, a hélice perde seu sentido, sua finalidade, mas ganha um design até então despercebido enquanto tal. "Para que serve?", pergunta a mulher que ele fotografou no parque, que foi até seu estúdio para tentar pegar os negativos. "Para nada, é bonito", responde Thomas. "Se eu tivesse um salão enorme assim, ia usá-la como ventilador de teto", ela diz. "Talvez eu ponha aqui, como escultura", ele diverge, preferindo encarar a hélice como "um objeto perfeitamente inútil que nem sequer serve como ventilador, mas que permite descrever círculos ao redor de um centro vazio"47 (impossível não associar essa hélice à espiral de Vertigo). A despeito do caráter aparentemente gratuito de sua presença, a hélice funciona, na verdade, como metonímia do estado de transição do mundo captado por Antonioni; ela atesta uma situação de deslocamento, tanto no sentido duchampiano (a operação conceitual de “desenquadrar" o objeto, de tirá-lo do seu espaço habitual, de fazer o utensílio aparecer como signo pelo simples gesto de transladá-lo e expô-lo) quanto no sentido mais literal de movimentação no espaço. As coisas não estão mais no lugar onde estavam. Antes que o fotógrafo possa fixar alguma coisa na gelatina sensível, essa coisa já se foi e deu lugar a outra.

O filme aborda a dificuldade do artista de reter algum traço de uma realidade que se move profusamente à sua volta. O olhar fixo, tão eficaz em Hitchcock, já não tem mais utilidade aqui: é preciso um olhar móvel, apto a acompanhar a não-permanência dos corpos, a volubilidade dos eventos, o estatuto provisório dos seres e das coisas. E também o sujeito centralizado, focado, que goza de um ponto de vista único (parcial porém privilegiado, a exemplo da janela de Jeff), já não consegue mais impor ordem e sentido à realidade fragmentária. Blow up é de certo modo o fracasso do voyeur e o esgotamento da dramaturgia do olhar fixo. Quase dez anos depois, em Profissão: repórter (Professione: reporter, 1975), Antonioni filmará um plano que ilustra bem essa constatação: num bar de beira de estrada,

\footnotetext{
${ }^{46}$ Barthes, op. cit., p. 156.

${ }^{47}$ Domènec Font, Michelangelo Antonioni, Madrid, Cátedra, 2003, p. 188.
} 
Jack Nicholson e Maria Schneider descansam em meio à fuga, e a câmera, em vez de se concentrar neles, faz rápidas panorâmicas de um lado para o outro tentando apreender o movimento dos carros que passam na estrada atrás das personagens. Fascinado pelo deslocamento, tragado pelo movimento incessante do mundo, e sem compreender qual é seu foco ou seu objetivo, o olhar perde o centro, rechaça a fixidez e renuncia ao "enxergar nítido". A ambiguidade prevalece - a mesma ambiguidade de que o espectador havia sido poupado pela decupagem hitchcockiana e sua famosa manipulação da atenção, e que agora é reintroduzida na estrutura da imagem.

Embora não se diga seu nome em momento algum do filme, o fotógrafo de Blow up é designado no roteiro e nas anotações de Antonioni como Thomas (nome pelo qual venho me referindo a ele). Não se trata, com certeza, de uma escolha inocente.

O nome faz alusão a São Tomé, ou São Tomás (Saint Thomas, em inglês), o incrédulo, cuja história concerne o ponto central da fé cristã. Ao ouvir outros discípulos dizerem ter visto o Enseigneur, São Tomé reage incrédulo e reivindica provas sensíveis, mensuráveis, palpáveis, visíveis/tangíveis, do corpo ressuscitado do Cristo. Ele só acreditará na Ressurreição depois de tocar a ferida do Cristo, num episódio bíblico bastante conhecido.

Em Blow up, como observa Jean-François Robic, é somente a partir do momento em que encosta o dedo na imagem, em que a toca com o indicador, "que Thomas começa a compreender, ou ao menos a acreditar, que alguma coisa se esconde em suas fotos, algo que ele não viu. Ora, esse gesto, nós o conhecemos: ele pertence à nossa cultura ocidental e à iconografia cristã. É um gesto relativo justamente à crença... e a São Tomé!". ${ }^{8}$

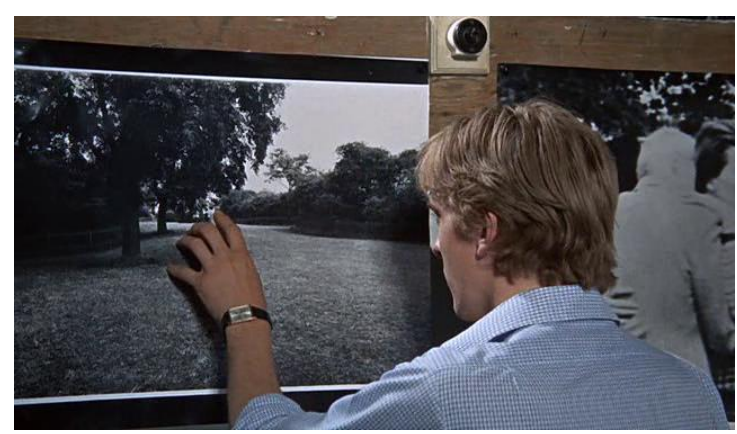

\footnotetext{
${ }^{48}$ J.-F. Robic, Blowup: une seconde vue, Paris: L'Harmattan, 2012, p. 328.
} 
Antonioni filmará novamente - na visita noturna ao parque - essa "conjunção do olhar e do tocar (modo háptico)"49, essa ação emblemática do toque como verificação, como confirmação do teor de verdade daquilo que se apresenta ao olhar:

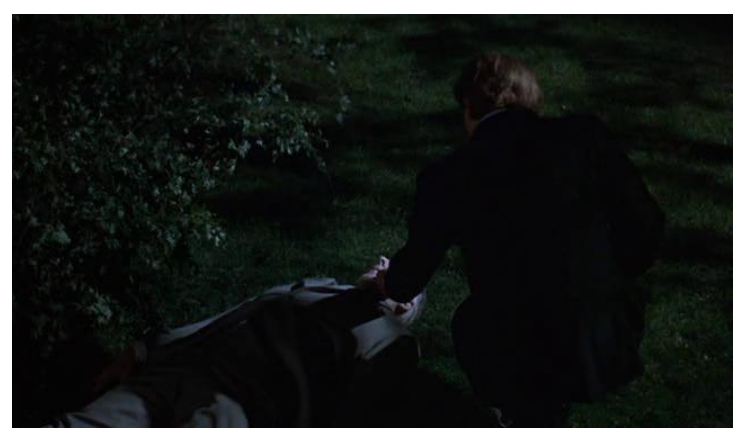

Se Thomas toca o cadáver, é para "se assegurar mais realmente de sua descoberta [...] usando outro sentido que não a visão". ${ }^{50}$ Assim como São Tomé, portanto, ele exige uma "evidência indexal", noturna no parque revela uma confiança limitada na visão, uma assunção de que a percepção visual é falível, propícia ao engano. Daí a necessidade de complementá-la com o toque: “Como se, no fim das contas, o fotógrafo, cuja profissão se baseia na visão, na apreensão do mundo pelo visível, recorresse in fine ao tato, o sentido mais concreto, mas nem por isso isento de ilusão". 52

Ainda que consiga uma prova tangível da presença do cadáver, Thomas vê tudo mudar novamente pela manhã, quando, conforme já dito, volta ao parque e não mais encontra o corpo visto e tocado na noite anterior. Só lhe resta, então, a verdade invisível e impalpável do jogo dos mímicos. Um circuito se fecha entre a desaparição do cadáver e a "aparição" da bola de tênis. O sumiço do cadáver não significa o fim de uma verdade - pelo contrário: o chão vazio, o pedaço de grama em que outrora jazia o corpo do homem de terno cinza, e que agora se afirma como suporte não mais de uma presença, mas do acontecimento de uma ausência, enfim, esse cenário de desaparição designa uma verdade que não pode ser tocada nem vista, mas que nem por isso é menos verdadeira, o que nos reporta novamente ao fundo metafísico/cristão das especulações de Antonioni. Relembremos que a história de São Tomé evocada pelo filme questiona, em sua própria premissa, a lógica da fé cristã na Ressurreição. Como explica Jean-Yves Leloup, a Ressurreição "não se impõe nem aos sentidos, nem à

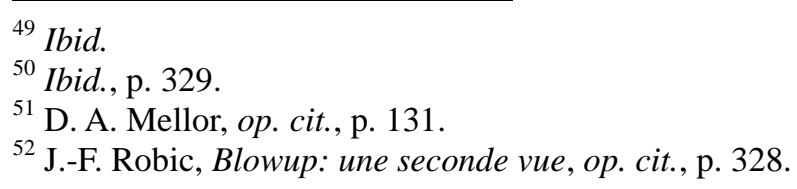


razão: não é da ordem da evidência, mas da fé, que consiste na adesão do coração e da inteligência a uma Realidade que transcende o que pode ser objetivado". 53 Crer na Ressurreição não é acreditar num retorno à vida, mas enxergar a presença do Cristo na sua ausência mesma. A verdade do corpo ressuscitado é sua subtração, sua retirada. ${ }^{54} \mathrm{O}$ signo da Ressurreição é o túmulo vazio, e a verdadeira fé consiste em respeitar esse vazio, conforme consta no ícone das mirróforas:

[...] as mulheres irão debruçar-se sobre o túmulo e não encontrarão o corpo que pensavam descobrir. Somente repousa no túmulo, dobrado e arrumado, o pano que envolvia Cristo e do qual nos fala o texto evangélico. Esse pano seria o sudário de Turim, como pensa um número crescente de cientistas e fiéis? [...] O ícone se situa, portanto, entre o "vazio escancarado" do túmulo e a "prova evidente" do sudário, entre a espiritualidade evanescente e o materialismo explicativo. ${ }^{55}$

Ora, em Blow up, igualmente, ao "vazio escancarado" do corpo desaparecido corresponde uma "prova evidente", a fotografia. Como disse Barthes, "a Fotografia tem alguma coisa a ver com a ressurreição: não se pode dizer dela o que diziam os bizantinos da imagem do Cristo impregnada no Sudário de Turim, isto é, que ela não era feita por mão de homem, acheiropoietos?"56 O Santo Sudário, "essa mortalha que teria revestido o corpo mártir do Cristo agonizante e teria conservado sua marca", funciona, de fato, como o "protótipo quase mítico da fotografia". 57 Trata-se de uma superfície que guardou, por contato direto com o corpo do Cristo, o vestígio, a marca de sua passagem no mundo; uma imagem que se formou por si mesma, por impressão ou impregnação (como a fotografia), e não por traços desenhados pela mão de alguém. O Sudário seria, assim, a primeira "fotografia" (e já a primeira fotografia de crime!). ${ }^{58}$

Não é difícil imaginar o valor que tal relíquia possui aos olhos dos fiéis. E, no entanto, quem se aproxima do Sudário vê nada mais que um pedaço de pano manchado: "não há nada a ver, ou quase nada. No máximo, algumas manchas disformes, pouco perceptíveis. Nenhuma imagem. Mas essa decepção, essa perturbação diante da invisibilidade inicial já coloca a máquina em movimento". 59 Justamente por se tratar de uma trama de vestígios pouco esclarecedores, de um agregado de "manchas disformes, pouco perceptíveis", o Sudário

\footnotetext{
${ }^{53}$ J.-Y. Leloup, $O$ ícone: uma escola do olhar, São Paulo: Editora Unesp, 2006, p. 86.

${ }^{54}$ Cf. Jean-Luc Nancy. Noli me tangere. Madri: Trotta, 2006.

${ }^{55}$ Leloup, op. cit., p. 78.

${ }^{56}$ R. Barthes, A câmara clara, p. 124.

${ }^{57}$ P. Dubois, $O$ ato fotográfico, pp. 223-224.

${ }^{58}$ Ibid., p. 223.

${ }^{59}$ Ibid., p. 224.
} 
potencializa a vontade de ver e, por conseguinte, de crer no que é visto. O olho se sente impelido a buscar a imagem santa nas marcas imprecisas da mortalha. A imagem do Sudário não é uma imagem que toma forma espontaneamente; uma longa espera e uma atenta observação precedem sua gênese e sua emergência. Ela se impõe ao olhar menos pelo modo da impressão do que do surgimento, da aparição do invisível. De tanto procurar, o olho encontra. Para ver a imagem do Cristo impregnada no pano é necessário, antes de tudo, desejar ver: "trata-se de fazer aparecer algo nesse quase nada, de transformar o arquipélago de manchas em forma, em figura, em corpo. A história do Sudário nesse sentido é exatamente a história de um advento ao olhar pela força de ver". ${ }^{60}$ É a história da visão - e da fé - como um processo ativo, e não uma contemplação passiva.

O protagonista de Blow up, qual um fiel perante o Sudário, também precisa transformar em corpo, em figura, um "arquipélago de manchas": confrontado à turvação figurativa de suas últimas ampliações, ele precisa achar uma ilha de legibilidade num mar de abstração.

Perto do final do filme, depois que descobre que seu estúdio foi saqueado e todos os documentos fotográficos e os negativos desapareceram, Thomas percebe que a única ampliação que os assaltantes não acharam necessário levar foi justamente aquela em que ele isolou e estirou a mancha delatora, o detalhe que representa o cadáver camuflado na paisagem. Separada do seu contexto, porém, essa imagem não passa de um retângulo composto de pontos brancos e pretos, uma imagem abstrata que, como dirá Patricia, a mulher que vive com seu amigo pintor, "parece uma das pinturas de Bill". Essa imagem abstrata, indiscernível, ilegível, embora emane fisicamente da realidade, embora siga a lógica da fotografia como vestígio, como rastro do "isso foi”, já não está ligada ao real senão por um fio muito tênue; imagem dúbia, ao mesmo tempo visão alucinatória, porque cortada da cadeia em que poderia fazer sentido, e traço indiciário, porque oriunda de uma impressão do real na matéria sensível. O filme se coloca num interstício que é a própria condição da fotografia e, mais ainda, do cinema, esse "composto inextricável de imagens brutas e de formas mentais", essa fenda entre a "febre de realidade e a fantasmagoria". ${ }^{61}$

A dúvida de Thomas expõe o conflito do homem racional que suspeita da validade dos fenômenos que ultrapassam a razão, mas que, por fim, depois de ver suas certezas e referências se evanescerem, acaba aquiescendo - como fica claro na cena final em que Thomas entra no jogo dos clowns e arremessa a bola de tênis imaginária - à "aceitação do

\footnotetext{
${ }^{60}$ Ibid.

${ }^{61}$ D. Font, op. cit., p. 195.
} 
vazio", que Jacques Rancière aponta como a verdadeira vertigem provocada pela investigação óptica: "por trás da lógica policial e aristotélica da revelação da verdade que dissipa as aparências há a lógica niilista da ilusão, que é a própria verdade da vida" ${ }^{62}$

\section{Vertigem do detalhe}

Antes de ir ao parque, Thomas havia entrado numa loja de antiguidades (onde ele voltaria mais tarde para comprar a hélice de avião) e havia sido abordado por um velho rabugento, que perguntara o que ele estava procurando. "Quadros", ele respondeu. Que tipo de quadros? "Paisagens."

Por mais anódina que pareça, essa cena já insinua o tipo de atitude do olhar - errática, oscilante, descentrada - que levará o fotógrafo a se aventurar pelo parque e a descobrir o casal enigmático. O gênero pictórico pelo qual Thomas se demonstra interessado - a pintura de paisagem - sugere um prazer visual ligado justamente à falta de meta predeterminada: trata-se de uma pintura que convida o olhar a vagabundear pelo espaço plástico da tela, a deslocar-se de um ponto a outro, a oscilar entre o detalhe e o conjunto, entre a vista de longe e a vista de perto. Toda pintura permite que o olho passeie livremente pelo quadro (daí o tempo de fruição de uma pintura variar de um observador para outro, não sendo construído senão no próprio ato da percepção). O que a pintura de paisagem faz nada mais é que acentuar essa característica: "A pintura de paisagem é um lugar privilegiado para o exercício desse olhar que escande temporalmente a superfície do quadro ao percorrê-la". ${ }^{63}$ Ela é uma imagem que solicita, de início, o mesmo modo de visionamento em ziguezague, a mesma perda de fixidez e de centro constatada nas cenas em que Thomas analisa suas ampliações. Ao induzir o olhar a não fixar seu alvo imediatamente, estimulando-o a explorar antes a pluralidade das formas e viajar pela multiplicidade dos detalhes, a pintura de paisagem autoriza o interesse do observador por todo e qualquer pormenor do quadro.

Vez ou outra, pode acontecer de um desses pormenores "fazer ruído", saltar aos olhos como o signo de uma ligeira discrepância ou de um segundo grau de leitura que o conjunto da representação dissimulava, ou melhor, reservava para os olhares mais atentos e questionadores. Em seu estudo sobre os diferentes estatutos do detalhe em pintura, Daniel Arasse fala das surpresas e estranhezas que a observação minuciosa dos pormenores de um

\footnotetext{
${ }^{62}$ J. Rancière, As distâncias do cinema, p. 35.

${ }^{63}$ D. Arasse, Le Détail, p. 248.
} 
quadro pode revelar. Aproximar o olho da pintura pode fazer ressair o detalhe que ressignifica o discurso do quadro tal como ele era percebido enquanto se respeitava a "boa distância". "Bastante diferente do olhar lançado de longe, o olhar colocado de perto é aquele que, segundo Klee, 'pasta' [broute] a superfície, faz aflorar o sentimento de uma intimidade, quer seja a intimidade do quadro, do pintor ou do próprio ato da pintura." ${ }^{\text {, }} \mathrm{O}$ detalhe que eventualmente sobressai da pintura assim examinada pode tanto trabalhar em harmonia com o conjunto, contribuindo humildemente para a mensagem global da obra, quanto desafiar essa mensagem, perturbá-la, oferecer-lhe resistência e deslocar seu sentido: neste caso, o detalhe intervém na percepção do quadro "como um momento fulgurante que provoca um suspense do olhar e de sua errância, uma estase ou um êxtase" ${ }^{\text {65 }}$, momento de parada do olhar e arrebatamento.

É o que acontece em Blow up quando Thomas capta numa das fotografias do casal no parque um detalhe que destoa do resto da paisagem/imagem. Esse detalhe alimenta dúvidas, gera interrogações, dispara conjecturas. Quando dá por si, o fotógrafo já está capturado na vertigem do detalhe.

O detalhe que faz ruído, em Blow up, é um depósito residual de matéria imagética, um detrito figurativo que acena para o fotógrafo lá do fundo nebuloso em que havia sido deixado num primeiro momento. Esse detalhe é a tal mancha que se destaca da paisagem (para lembrar o que Bonitzer dizia sobre a fagulha de ativação do suspense hitchcockiano), ou o pequeno traço que fere o olhar (se quisermos revisitar o conceito barthesiano de punctum). Há um plano do filme em que Thomas dá forma visível a essa experiência do corte perceptivo causado pelo detalhe fulgurante: ele contorna com um lápis o foco de mistério que pescou na imagem, isola da fotografia a mancha, o detalhe que causa um distúrbio visual no quadro:

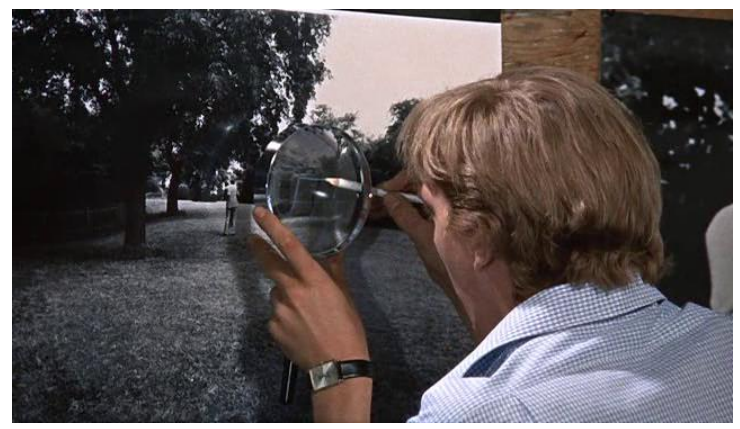

\footnotetext{
${ }^{64}$ Ibid., p. 7.

${ }^{65}$ Ibid., p. 244.
} 
A paisagem tranquila e organizada do parque - grama aparada, plantas protegidas por cercas, trilhas pavimentadas - é tudo o que restou de natureza no mundo essencialmente urbano de Blow up. Uma natureza desenhada, enquadrada, dirigida pelo homem. Uma paisagem cenográfica, beleza de fundo na qual vêm se inscrever, de forma um tanto indiferente, as narrativas humanas.

A princípio, a natureza aí representada é a mesma das pinturas clássicas, ou seja, uma natureza "organizada na ordem calma e imóvel de uma composição centralizada". ${ }^{66}$ Situada em segundo plano, colocada literalmente em perspectiva, ela se apresenta simbolicamente distanciada das personagens, como um mundo à parte. Mas eis que, depois da revelação das fotografias, a paisagem demonstra ter algo mais a dizer. Ampliada e vista através da lupa, a vegetação do parque - aquela paisagem ordenada, emoldurada, calada no fundo da cena revela-se carregada de figuras enigmáticas, de ameaças silenciosas: no registro fílmico, "a Natureza, diversas vezes aprisionada como efígie pelas artes da paisagem, retorna como o espectro de nosso inconsciente fotográfico". ${ }^{67}$ As manchas que surgem por entre os arbustos, e que pouco a pouco se afiguram como corpos, são como um "resto espectral" da paisagem, ou como ruínas de representações anteriores, fragmentos deteriorados descobertos após a escavação de um sítio arqueológico que ficara esquecido por um longo tempo. A atividade de Thomas, que, encontrando na imagem 'uma superfície 'mágica' em que ressurgem diversas camadas de figuração" ${ }^{\prime 68}$, submete-a a uma série de prospecções e sondagens em busca de suas "significações recalcadas, crípticas, arcaicas"69 , tal atividade não deixa de se assemelhar ao trabalho do arqueólogo (ainda que, conforme já dissemos anteriormente, a fotografia seja apenas uma imagem plana sem real profundidade - a operação que ela autoriza está mais para uma varredura de superfície).

Ou ao trabalho do psicanalista: o vulto na moita pode ser também o fantasma psíquico do próprio fotógrafo, seu duplo - ou, para usar um vocabulário mais adequado ao tema do filme, sua figura em negativo. Não por acaso, num dos planos em que Thomas é filmado fotografando o casal, ele está exatamente no mesmo cenário e na mesma posição em que o atirador aparecerá na imagem ampliada. A única diferença é que, em vez de uma pistola, ele maneja uma câmera fotográfica (a qual não deixa de ser uma arma, ou ao menos de ter com esta uma série de pontos em comum).

\footnotetext{
${ }^{66}$ Maurizia Natali, L'Image-paysage: iconologie et cinéma, Saint-Denis: Presses Universitaires de Vincennes, 1996, p. 68.

${ }^{67}$ Ibid., p. 75.

${ }^{68}$ Ibid., p. 73.

${ }^{69}$ Ibid., p. 70
} 

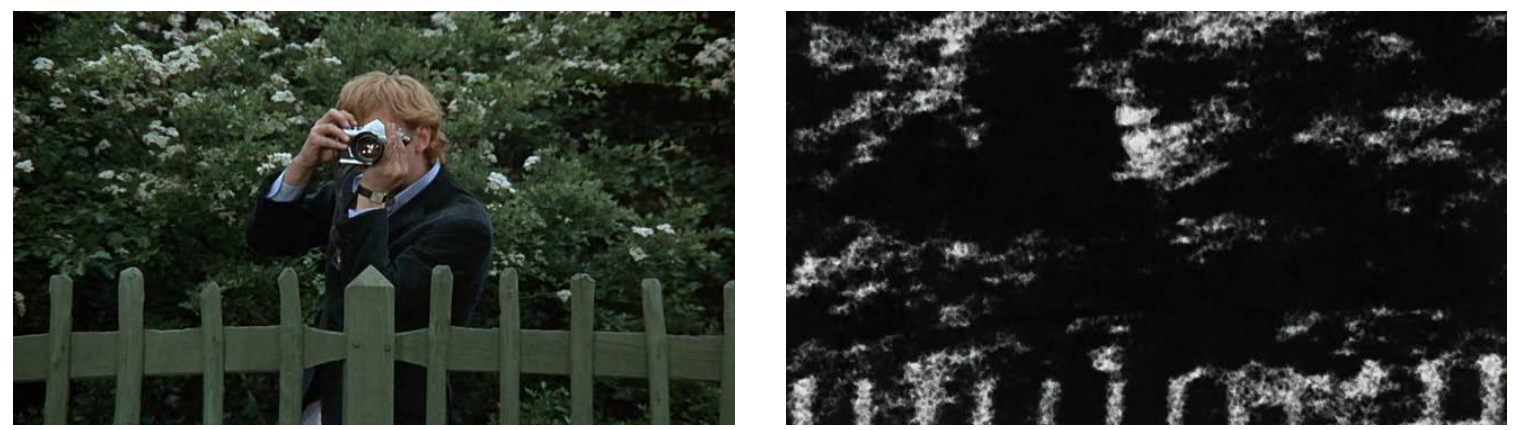

Nessa aparição do detalhe inquietante da foto - esse detalhe intrusivo que desponta como um resto de figura que sobreviveu a um prolongado mergulho no informe -, há algo do conto A obra-prima desconhecida, de Balzac, que aborda os limites da pintura fornecendo uma verdadeira reflexão filosófica sobre a função representacional da arte. O conto narra uma visita fictícia do jovem Poussin, acompanhado de outro pintor (Porbus), ao mestre ancião Frenhofer, que há anos se dedica obstinadamente à feitura de um retrato que represente uma figura feminina com perfeição e vivacidade. Oferecendo sua esposa como modelo, Poussin vai à casa de Frenhofer, ansioso para vê-lo terminar o tão aguardado retrato. Mas, quando é finalmente apresentado ao quadro, ele afirma nada ver "senão cores confusamente amontoadas e contidas por uma infinidade de linhas bizarras que formam um muro de pintura”. Nenhuma forma discernível, nenhuma figura, somente uma superfície coberta de tinta, uma parede de cor.

Aproximando-se do quadro, contudo, uma surpresa: num canto de tela, insinua-se a ponta de um pé nu saindo "daquele caos de cores, de tons, de nuanças indecisas, espécie de névoa sem forma”. Aquele pedaço de pé aparece ali como um fragmento que escapou de "uma lenta e progressiva destruição", ou "como um torso de alguma Vênus de mármore de Paros que surgiria dentre os escombros de uma cidade incendiada”, escreve Balzac. Um caco de figura, um último achado figurativo no meio de um caos visual. É a definição mesma do fulgor e daquilo que Didi-Huberman denomina, no livro em que se debruça sobre o conto de Balzac, o "encontro traumático do detalhe". ${ }^{70}$

Poussin e Porbus descobrem no pé nu, por um momento, a delícia da pintura "viva" (Balzac dá suficiente destaque à nudez erotizada do pé, que claramente se apresenta como um fetiche). Mas o efeito do detalhe não dura senão um segundo: a beleza gerada por seu fulgor “desaparece no mesmo instante sob o 'muro de pintura', que é muro $d a$ pintura". ${ }^{71}$ Aporia do detalhe: "Se você olha somente o quadro como um quadro, isto é, de muito longe, você perde

\footnotetext{
${ }^{70}$ G. Didi-Huberman, A pintura encarnada, op. cit., p. 79.

${ }^{71}$ Ibid., p. 79.
} 
o fulgor do quadro, perde pois o quadro [...]. Mas se você mergulhar no fulgor do detalhe, sua 'vida', você perde o quadro, porque perdeu o todo do quadro [...]". 72 Situado ao longe, portanto, o olho negligencia a palpitação da pele no corpo representado, a vibração do espetáculo pictórico propriamente dito (a carnação da pintura); perto demais, porém, ele não vê senão o "inferno figural", a trama de pigmentos, a mancha amorfa: o figurativo sucumbe ao pictórico. A dialética da obra-prima de Frenhofer consiste em apresentar "a pintura, opaca substância, como obstáculo ao enunciado representativo do quadro - do qual a pintura, opaca substância, é, porém, o veículo único". 73

O protagonista de Blow up é exposto a uma dialética semelhante. O detalhe fotográfico por ele destacado e ampliado - aquela quina de figura que, tal como o pé no quadro de Frenhofer, emerge das cinzas de um desastre visual - é menos um ícone, signo representativo, do que um simples rastro luminoso, marca-índice de um trabalho formador de imagem. $\mathrm{O}$ parentesco de Thomas com o jovem Poussin retratado em A obra-prima desconhecida reside, sobretudo, na experiência inaudita, desconcertante, de uma imagem que foi submetida a uma "redução fenomenológica", como bem definiu Alain Bonfand (comparando, justamente, o filme de Antonioni ao conto de Balzac $^{74}$ ). Se, por um lado, a ampliação extrema anuvia o efeito mimético da foto, por outro, ela põe em relevo o traço do trabalho físico da matéria que constitui essa foto. Isolado do quadro e de sua lógica representativa, o detalhe mostra "a matéria da imagem em gestação", como se ela não estivesse ainda metamorfoseada naquilo que pretende representar, sendo apenas uma figura embrionária, uma imagem em potencial. $\mathrm{O}$ detalhe hipertrofiado instaura, assim, uma opacidade aparentemente incontornável, uma suspensão da representação ou "uma falha em seu dispositivo de transparência"75; a imagem perde suas capacidades figurativas, ou ainda, ela volta a ser um embrião de si mesma, uma forma deixada em estado de formação. Pelo obstáculo que oferece à sua identificação como signo transitivo (um signo que representaria alguma coisa), o detalhe fermentado pela ampliação fotográfica perturba a legibilidade da imagem e engendra um paradoxo da visibilidade: o olho não consegue identificar aquilo que, todavia, nunca esteve tão visível. Será preciso persistir nesse caminho, estirar a imagem um pouco mais, empurrá-la justo ao limite, para que, esgotada a resistência da matéria (toda matéria resiste de alguma maneira à forma), o detalhe se reconcilie com a representação figurativa, volte a ter relação com um referente.

\footnotetext{
${ }^{72}$ Ibid., p. 101.

${ }^{73}$ Ibid., p. 114.

${ }^{74}$ Cf. A. Bonfand, Le cinéma de Michelangelo Antonioni, Paris: Images Modernes, 2003, pp. 33-34.

${ }^{75}$ D. Arasse, Le Détail, p. 280.
} 
Mas esse detalhe que salta aos olhos, fulgurante, revelador, esse detalhe sempre existiu como tal? Ou foi o observador que assim o fez? Segundo Arasse, "um detalhe pode ser 'inventado' - no sentido arqueológico do termo - pelo desejo daquele que o olha". ${ }^{76}$ Em se tratando da fotografia e do cinema, o detalhe inventado, projetado na imagem pelo desejo do observador, é um evento ainda mais perturbador do que na pintura, pois coloca em dúvida a crença que acompanha o regime fotográfico da imagem, a certeza de que o que ela mostra esteve diante de uma câmera em algum momento e, portanto, preexiste ao espectador - e até mesmo ao artista - independentemente dos seus desejos, lapsos ou alucinações.

Além de Blow up, outros filmes construíram seus dispositivos em torno justamente de uma provocação (não confundir com desmistificação) ou de uma colocação à prova dessa suposta objetividade fílmica que foi o apanágio de algumas das mais importantes teorias da imagem fotográfica. Podemos citar como exemplos Hapax Legomena I: Nostalgia (1971), de Hollis Frampton, e As fotos de Alix (Les Photos d'Alix, 1980), derradeiro filme de Jean Eustache, curta-metragem de cerca de vinte minutos rodado para a série televisiva Contes modernes e composto por um diálogo entre a fotógrafa Alix Cléo-Roubaud e o jovem Boris Eustache (filho do diretor), a quem ela mostra e comenta algumas de suas fotos. Tanto o filme de Frampton como o de Eustache se constituem, grosso modo, da exposição sequencial de fotografias que são comentadas por aqueles que as fizeram, e ambos operam uma defasagem entre o comentário e a imagem (o que é ouvido não bate com o que é visto). Em Nostalgia, a discrepância entre som e imagem é sistematizada pelo dispositivo de Frampton: o comentário em off diz respeito não à imagem que o espectador está vendo, mas àquela que surgirá logo em seguida, e assim sucessivamente, de modo que o comentário da primeira foto nunca será ouvido e a última das treze imagens nunca será vista. Em As fotos de Alix, as regras do jogo não são tão claras, o dispositivo é mais sutil: as descrições das primeiras fotografias são perfeitamente congruentes com as imagens, e é somente com o desenrolar do filme, a partir da quinta ou sexta foto (são dezenove, no total), que as imagens que vemos e os comentários que ouvimos começam a não coincidir. O indício da desregulação, na verdade, é dado bem cedo, já na terceira imagem, quando Boris toma por um quadro a figura de um homem captado no limite direito de uma das fotos de Alix, que explica para ele que se trata de uma pessoa real que estava presente no momento em que ela fez a fotografia. E mais: ele não só não é um quadro como não estava nu, ao contrário do que a fotografia sugere. O visível, portanto - ao menos o visível isolado da percepção sensorial global e reificado na superfície da foto -, é

\footnotetext{
${ }^{76}$ Ibid., p. 7.
} 
desde o início apresentado como lugar da indeterminação e do engano. O resultado é a desestabilização do espectador, "que se vê privado de sua parte de certeza" situar no território incerto em que o filme o instala. A crença na imagem dá lugar a um não reconhecimento visual, a uma perda de familiaridade com o visível; o espectador não sabe mais se deve confiar ou não na sua visão (no que pesa o caráter confusamente abstrato de muitas das fotografias de Alix, que se prestam à ambiguidade: elas tanto podem ser o que o comentário afirma quanto podem estar completamente desvinculadas dele).

Num primeiro momento, tentamos instintivamente acreditar que o que vemos casa com o que ouvimos, e chegamos a forçar a barra para que esse casamento aconteça, concordando em ver coisas (ditas por Alix) que, no fundo, não vemos. Demora um pouco até que aceitemos o divórcio entre o sonoro e o visual. O que equivale a dizer que embarcamos numa alucinação momentânea, deixando de enxergar com clareza, procurando nas imagens as pistas falsas entregues pelo áudio, desejando ver o que a narração descreve - o invisível. Contribui para isso a maliciosa costura narrativa de Jean Eustache, que, por diversas vezes, faz coincidir alguns aspectos comentados por Alix (uma mancha, um clarão, um contorno na borda do quadro, um reflexo no espelho) com elementos que efetivamente aparecem na foto mostrada para o espectador. Em seguida, porém, ela começa a descrever uma figura, um corpo, um espaço que definitivamente não vemos na foto. E então a incerteza retorna reduplicada. A montagem, portanto, não junta fotografias e comentários tomando o cuidado somente de dissociá-los: há todo um meticuloso trabalho de (des)ajuste entre as fotos e as partes do diálogo que as acompanham, num jogo que acusa uma decalagem ao mesmo tempo em que sugere uma conexão possível. Quanto à verdadeira imagem resultante dessa ambígua dessincronia, só a vemos em pensamento. O filme nos coloca em algum lugar entre a imagem mental e a evidência material da fotografia, que se desprende parcialmente da realidade à qual deveria estar ligada, supunha-se, por um pacto ontológico. Toda vez que Alix aponta na fotografia um detalhe que não vemos, é como se uma imagem virtual tentasse se infiltrar na imagem atual. E a recíproca é verdadeira: o vazio que ela indica, lá onde o que percebemos são corpos, imediatamente faz desses corpos espectros, fantasmas intrusos, seres que lutam contra a desaparição.

Uma das primeiras fotografias mostradas no filme se chama "Vertigo", como Boris Eustache observa. "Sim, esta foto se chama "Vertigo", Alix confirma, acrescentando em seguida: "Mas, na verdade, ela se chama assim por razões anedóticas. Eu vi Vertigo depois de

\footnotetext{
${ }^{77}$ Stéphane Bouquet, "Le doute surexposé", in Cahiers du cinéma, n. 523 (suplemento "Spécial Jean Eustache"), abril de 1998, p. 16.
} 
ter feito a fotografia, na mesma tarde. Não há muita relação, salvo o fato de que eu sofria de uma vertigem bastante aguda enquanto fazia esta foto. Eu havia bebido muito... esta garrafa [ela aponta para a garrafa na foto] está quase vazia”.

A foto de Alix pode não ter muito a ver com o filme de Hitchcock do qual pegou emprestado o nome. Mas Eustache - que, como conta Jean-Noël Picq, às vezes era atacado de uma "crise de monomania hitchcockiana" e podia alugar o ouvido de alguém para narrar Vertigo plano por plano, imagem por imagem, comentando cada detalhe, e levando o dobro do tempo que o próprio filme tinha ${ }^{78}$ - talvez aproveite a referência a Vertigo trazida pelo título da foto para já dar uma pista do que acontecerá adiante: a desarticulação do raccord subjetivo, a perda de conexão entre o campo e o contracampo, que, no filme de Eustache, ocorre pela decalagem entre o comentário sobre as fotos e a visão destas, ao passo que em Hitchcock tratava-se de um desligamento entre o olhar de Scottie e o mundo sensível (que ele havia impregnado com o fantasma de Madeleine).

Alix diz que a fotografia "Vertigo" possui uma história "estranha", uma história “muito peculiar". Boris pede que ela conte tal história. Ela começa: "É uma história bem obscena. Eu estava numa situação embaraçosa com um amigo. Eu estava acendendo um cigarro e ele me disse: 'Você vai acender um cigarro neste momento, nesta circunstância, como uma puta de Amsterdam?'. E eu disse: 'Sim, por que não? E não apenas vou acender um cigarro como vou tirar uma foto. E então eu tirei a fotografia'”. É somente quando Alix termina esta última frase que Eustache finalmente corta para o primeiro plano da foto (até então, a câmera enquadrava as personagens conversando sobre ela, que já aparecia sobre a mesa, mas ainda não a víamos em detalhe):

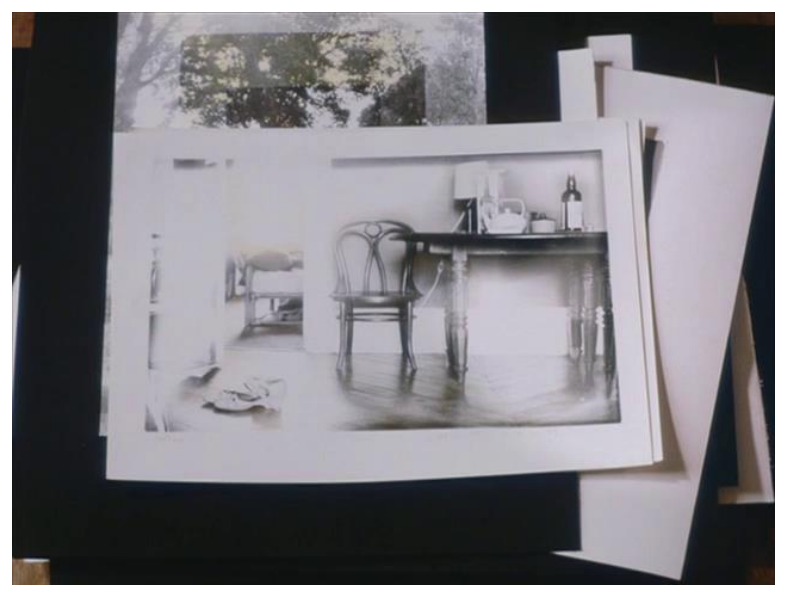

\footnotetext{
${ }^{78}$ Cf. Emmanuel Burdeau e Thierry Lounas, "Le monologue infini”, entrevista com Jean-Nöel Picq, Cahiers $d u$ cinéma, n. 523 (suplemento "Spécial Jean Eustache”), p. 25.
} 
Segundo Alix, fazia muito calor naquele dia, o que ela tentou representar por "uma espécie de coloração desajeitada", que ela aponta na parte mais superexposta da imagem (comentário e foto, neste início de filme, ainda casam). Aquela parte da imagem se encontra velada, tanto no sentido fotográfico (do filme hiperexposto, estragado pelo excesso de luz) quanto no simbólico (da realidade encoberta, escondida por um véu). Talvez seja um efeito produzido no próprio ato da tomada de vista, talvez fabricado posteriormente, no laboratório (muitas das fotos de Alix, como ela mesma explica, são parcial ou totalmente póstrabalhadas). Esse branco estourado, essa infiltração de luz pode estar ali para mascarar alguma coisa, para apagar parte da informação impressa na fotografia. Por pudor, por prudência. Ou tão somente para brincar com a curiosidade do espectador, jogar com sua atração instintiva pelo que está escondido. Mas a questão é: se Alix não tivesse dito que a foto havia sido concebida em circunstâncias "obscenas", veríamos nela alguma obscenidade? Desconfiaríamos que suas áreas de opacidade, de tapume luminoso, escondem algo? Ou deixaríamos a imagem descansar em sua aparente inocência? Onde está, afinal, o obsceno?

"Uma fotografia pode ser pessoalmente pornográfica e, ao mesmo tempo, publicamente decente", afirma Alix, como um último comentário a respeito dessa foto. Em outras palavras, ela não acredita que a obscenidade de uma fotografia esteja na imagem, mas no ponto de vista sobre ela. É a ideia de que "nada é obsceno em si", e de que o objeto obsceno, "elaborado ao mesmo tempo no plano do psiquismo individual e das representações coletivas"79 , não é um evento exterior, mas interior à subjetividade do observador. Ele é "algo que inquieta e se desnuda ao mesmo tempo, algo que só se identifica após certo esforço". 80

$\mathrm{Na}$ foto de Alix, o obsceno é associado ao domínio da sexualidade. Embora tal associação seja a mais comum, é preciso notar que a categoria do obsceno não se restringe à representação do sexo, podendo fazer referência também à morte, à violência, às fobias, aos estados-limite do corpo. ${ }^{81}$ Tampouco se pode tomar o obsceno como sinônimo de pornográfico (outro curto-circuito usual, que cria uma série de confusões de sentido): o espetáculo pornográfico se exibe frontalmente, francamente, mostra de imediato um conteúdo explícito que o espectador quer ver (o espectador que consome a pornografia não é pego de surpresa, não é escandalizado), ao passo que o obsceno está mais ligado ao surgimento inesperado de uma "inquietante estranheza", à aparição de "algo que normalmente deveria estar escondido, mas que se revela de modo brutal, provocando um choque naquele que o

\footnotetext{
79 Julie Amiot-Guillouet, "Obscène/pudeur, masculin/féminin: les termes d'un débat visuel et discursif au cinéma”, in SEGUIN, Jean-Claude (org.), L'obscène, Lyon: Le Grimh-LCE-Grimia, 2006, p. 123.

${ }^{80}$ Ibid., p. 122.

${ }^{81}$ Sem falar nas obscenidades de ordem política, social, ética... O assunto mereceria uma tese à parte.
} 
presencia”. ${ }^{82}$ Esse choque não reside na descoberta de algo novo, mas, ao contrário, na "revelação de um saber relativamente antigo, que o sujeito havia "recalcado". ${ }^{83} \mathrm{O}$ elemento obsceno surge inopinadamente para provocar um incômodo, um desconforto psicológico. Aqui chegamos à definição de obsceno que mais nos interessa (e que é, certamente, a que melhor condiz com as ampliações de Blow up): o obsceno como a reserva de inconsciente óptico, o depósito de conteúdos figurativos recalcados que toda imagem possui, e cuja irrupção se dá a partir do momento em que um evento perceptivo - a mancha, o detalhe que faz ruído (o efeito do detalhe comporta, de fato, o que Arasse designa como "uma inominável obscenidade" ${ }^{\nexists 4}$ ) - retira-os dessa zona obscura e os traz à superfície. O obsceno seria, assim, o "surgimento abrupto de algo que vem romper o curso normal da representação". ${ }^{85}$ Algo que não está na parte evidente da imagem, mas no seu inconsciente óptico. Como a obscenidade invisível (mas presente) na fotografia de Alix.

Essa foto possui com o quadro As pantufas, de Samuel van Hoogstraten, um parentesco que vale a pena explorar (entre outras coisas, porque nos ajudará a desenvolver as questões que serão abordadas em seguida). A tela, conservada no Museu do Louvre, apresenta uma vista de interior de um típico lar holandês do século XVII:

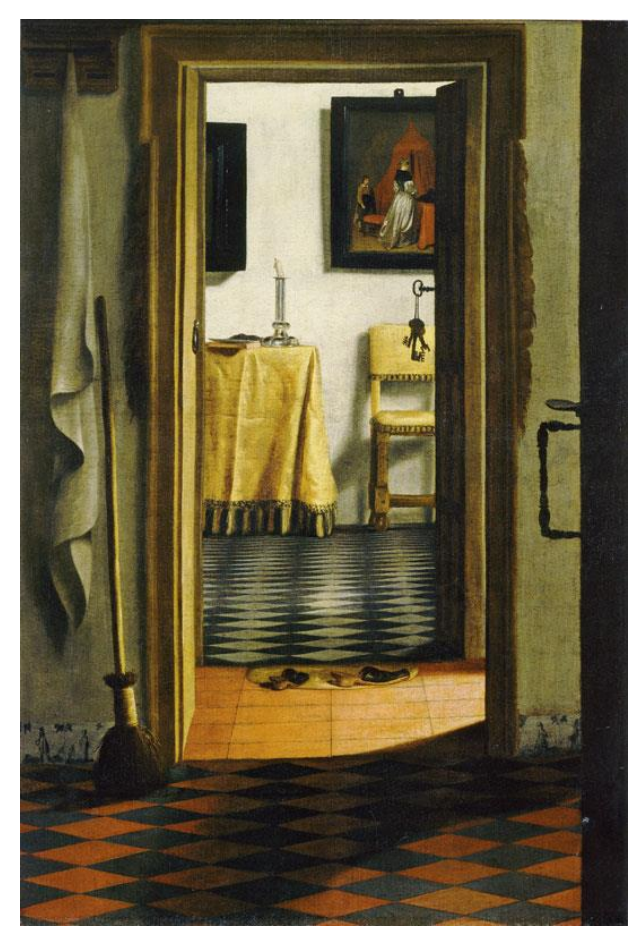

Hoogstraten, As pantufas, c.1654-62

\footnotetext{
${ }^{82}$ J. Amiot-Guillouet, art. cit., p. 123.

${ }^{83}$ Ibid.

${ }^{84}$ D. Arasse, Le Détail, p. 256.

${ }^{85}$ J. Amiot-Guillouet, art. cit., p. 127.
} 
Alguns dos objetos vistos na fotografia se reencontram no quadro (com as devidas variações, naturalmente), a exemplo do par de pantufas largado no chão, próximo a uma das portas, um pouco como o par de calçados femininos na foto de Alix. Mas o que conecta o quadro e a fotografia, de fato, mais do que as coincidências visuais, é a maneira como ambos colocam em cena não exatamente um acontecimento ou uma figura retratável, mas antes o desejo (logo, a falta), o impulso, o afeto, o efeito, a ideia mesma que motivou a imagem.

A primeira coisa que chama atenção na pintura de Hoogstraten é o fato de que ela não possui "personagens" (sua única presença humana consiste nas figuras pintadas no quadro dentro do quadro - reprodução de uma obra de Gerard Terborch - pendurado na parede ao fundo); ela não descreve nenhuma ação, não contém uma "cena" - ou, se a contém, não a vemos diretamente, mas através de um enredo cifrado, narrado tão somente pelos objetos, os quais, sabiamente disseminados no cenário, ganham destaque sobrecomum: o molho de chaves pendendo da fechadura de uma das portas, a vassoura encostada à parede, o livro fechado sobre a mesa ao fundo, o castiçal com a vela apagada, o quadro acima da cadeira... Para não falar, obviamente, nas pantufas (que estão posicionadas justamente na área mais iluminada do cenário).

A ausência de cena ou de assunto cria um elemento perturbador no quadro. De imediato, somos levados a nos perguntar: por que esse interior, essa casa, essas pantufas? Por que dar atenção a esse espaço vazio? Por que esse cômodo e não outro? Ao fazer essas perguntas, o espectador já está absorvido na vertigem do quadro, intrigado com o mistério das ausências que o estruturam. Para além da riqueza formal, da construção geométrica do espaço, o interesse central de As pantufas reside em sua própria concepção de olhar. Trata-se de uma pintura que possui como tema seu próprio ponto de vista, o ângulo de visão, o enfoque, a presença sensível de um olhar. O "assunto" do quadro é a atividade desse olhar. Hoogstraten impede que o observador contemple passivamente a pintura: o olhar não consegue escapar a uma inquietação diante do vazio preenchido do quadro.

O elemento obsceno admitido por Alix em sua foto também está presente no quadro de Hoogstraten, por caminhos parecidos-mas-diferentes. A cadeira, a mesa, o quadro dentro do quadro e mais um ou outro objeto só são mostrados parcialmente. A pintura em si é uma vista parcial, que se quer limitada, gerando o natural desejo de ver não apenas o que a imagem mostra, mas, sobretudo, o que ela esconde. Instaura-se um suspense, uma tensão que lança o desejo para além dos limites do que a imagem dá a ver. Hoogstraten dramatiza o fora de quadro (mas a pintura, ao contrário do cinema, não conta com a participação dinâmica desse espaço off). O pintor trabalha, assim, com a estrutura parcial do erotismo, encerrando o espaço 
no rigoroso dispositivo composicional do quadro e, dialeticamente, abrindo a imaginação para um "extracampo", para uma cena escondida ou proibida. Daniel Arasse afirma, aliás, que o quadro de Hoogstraten deveria se chamar não As pantufas, mas As chaves, uma vez que estas indicariam melhor a ideia que preside ao dispositivo do quadro, a saber, a estimulação da pulsão escópica e do voyeurismo (pôr o olho no buraco da fechadura...). ${ }^{86}$

Essa face voyeurista da arte de Hoogstraten se comprova com igual ou maior clareza nas suas famosas "caixas de perspectiva". Dentre os poucos exemplares remanescentes, achase um peepshow concebido por ele na segunda metade da década de 1650 e atualmente exposto na National Gallery de Londres. Trata-se de uma caixa retangular cujas faces interiores representam um espaço doméstico. Três das quatro paredes internas estão pintadas mais ou menos no mesmo estilo visto em As pantufas. O teto e o assoalho também estão pintados, dando a ilusão de uma casa em miniatura. Uma das paredes é inexistente, permitindo a entrada da luz proveniente de alguma fonte luminosa externa. $\mathrm{O}$ conjunto forma uma espécie de cubo cênico. Em cada um dos dois flancos laterais, há uma pequena abertura para o observador colocar o olho e ter a visão do interior da casa. Pelo ângulo de visão proporcionado nessa abertura, as distorções perspectivas e as anamorfoses percebidas através da vista frontal (isto é, olhando a casa do lugar onde não há parede) se convertem num certo efeito de tridimensionalidade.

Os experimentos de Hoogstraten com a perspectiva constituem uma parte crucial de sua obra. No volumoso tratado artístico que ele escreveu no final da vida, o pintor holandês "considera a perspectiva como uma técnica de composição, um procedimento que permite seduzir o olhar e conduzi-lo pela superfície do quadro". ${ }^{87}$ Boa parte de suas pinturas se dedica à experimentação de um sistema de construção perspectiva que, embora desenvolvido de acordo com as regras gerais da ciência pictórica, foi retrabalhado com uma forte dose de invenção pessoal.

Em As pantufas, o efeito perspectivo é sublinhado pela variação que o desenho quadriculado do piso sofre - tornando-se cada vez mais oblíquo à medida que se afasta do primeiro plano em direção ao fundo -, bem como pelo sutil jogo alternante de luz e sombra e pela apresentação sistemática de portas que se abrem umas sobre as outras formando uma série de reemolduramentos do quadro. A entrada do olhar no campo da composição é facilitada pela sucessão de portas abertas, que acentuam a ilusão tridimensional do espaço. $\mathrm{O}$

\footnotetext{
${ }^{86}$ Cf. D. Arasse, Le Détail, p. 222.

${ }^{87}$ Jan Blanc, Peindre et penser la peinture au XVIIe siècle: La théorie de l'art de Samuel van Hoogstraten, Berna: Peter Lang, 2008, p. 73.
} 
efeito de profundidade assim reforçado permite a Hoogstraten "guiar a percepção do espectador fazendo-o penetrar, de modo fictício, no espaço do quadro". ${ }^{88}$ O observador "é convidado a contemplar, por [essa] série de portas abertas, um puro exercício da visão, da pintura e da visão da pintura". ${ }^{89}$ Hoogstraten representa a própria "operatividade da imagem, seu campo de ação, sua margem de movimento, o espaço em que se desenvolvem suas virtualidades". 90

O quadro parece ser inteiramente construído em função de sua percepção. Ele enforma uma mise en scène da percepção visual. Segundo Jan Blanc, "Hoogstraten faz da composição uma instância de organização e de ordenação da superfície pictural, [...] cujo principal objetivo é exercer uma influência ou uma ação mais ou menos direta sobre a percepção e o comportamento do espectador que a contempla". ${ }^{91}$

Há outros quadros de Hoogstraten que operam na mesma lógica, como, por exemplo, Vista de um corredor, pintado em 1662:

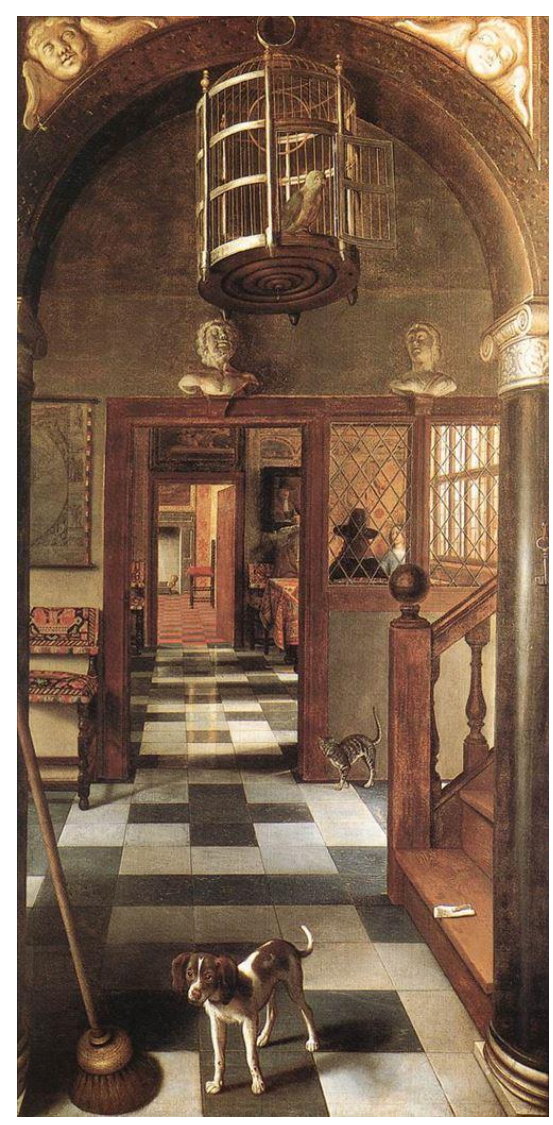

Hoogstraten, Vista de um corredor, 1662

\footnotetext{
${ }^{88}$ Ibid., p. 75.

${ }^{89}$ D. Arasse, Le Détail, pp. 220-222.

${ }^{90}$ A. Minazzoli, La première ombre, op. cit., p. 83.

${ }^{91}$ J. Blanc, op. cit., pp. 283-284.
} 
Assim como em As pantufas, o que se tem aqui é uma espécie de corredor de reverberação para o olhar. Com o acréscimo de que a construção perspectiva é agora ainda mais acentuada que no quadro anterior. A ausência quase total de figuras que bloqueiem o caminho ou prendam a atenção facilita a circulação do olhar ao longo do eixo de profundidade. Se, em As pantufas, era importante que o olhar se detivesse nos objetos, que fosse percorrendo um a um na medida em que se aprofundasse no espaço, até chegar àquele quadro dentro do quadro que era a própria figuração da mise en abyme do pensamento pictórico de Hoogstraten, em Vista de um corredor, diferentemente, o que está em jogo, acima de tudo, é a pura travessia do espaço perspectivo. Hoogstraten depura a mise en scène do olhar através de portas, janelas etc. (o doorkijkje, motivo composicional bastante comum na idade de ouro da pintura holandesa), chegando a "uma solução centrada inteiramente no jogo dos espaços. Ele se lança ao problema do interior puro como encadeamento interminável de vãos, signo de uma pesquisa paralela àquela que conduzirá às suas célebres caixas de perspectiva". ${ }^{92}$

Janelas e portas têm a propriedade de recortar o espaço visível, de enquadrá-lo espontaneamente. Por isso mesmo, são constantemente assimiladas nas artes visuais como estruturas de composição, não raro com a função de inscrever na imagem uma reflexão sobre o dispositivo do quadro. Mas a porta se diferencia da janela enquanto forma de decupagem "natural" do mundo visível e de comunicação entre dois espaços. Se a janela é uma abertura a ser atravessada (ao menos em tese) somente pelo olhar, estando desde sempre ligada ao visual, à visão, e constituindo em si mesma uma metáfora do quadro, a porta, por sua vez, já possui um estatuto diferente: ela não remete necessariamente ao visual, seu papel primordial sendo o de permitir a passagem de um lugar para o outro, a entrada/saída em/de um espaço.

Mas se a janela implica, estruturalmente, o olhar do interior para o exterior (por conseguinte, da cultura para a natureza), a porta pode, também ela, ser objeto de um investimento visual, só que em sentido inverso. [...] É o olhar voltado para o interior que a define. E mais ainda: não é o simples olhar do exterior para o interior (o qual permanece, é claro, uma possibilidade) que lhe confere verdadeiramente suas conotações características, mas o olhar de um interior para um outro interior. [...] Ela representa um corte menos distanciador que a janela, a qual separa cultura e natureza. A porta não é senão um hiato no seio do mundo da cultura. ${ }^{93}$

\footnotetext{
${ }^{92}$ V. I. Stoichita, L'instauration du tableau, p. 77.

${ }^{93}$ Ibid., p. 71.
} 
A porta se constitui, assim, como um motivo de predileção das vistas de interiores. Mais ainda: "ela se torna, no século XVII, um topos utilizado como método de autodefinição da pintura de interior". ${ }^{94}$ A vista através da porta se equipara então à da janela - e até mesmo a supera - como forma de designação da pintura e do seu sistema perspectivo, algo de que os quadros de Hoogstraten aqui comentados são um ótimo exemplo. Em As pantufas, o substrato metapictural do doorkijkje não poderia se expressar de forma mais evidente: é toda a superfície da imagem pictórica que se apresenta como o vão de uma porta; o quadro em sua totalidade nada mais é que a vista exata que se tem através de uma porta aberta, o que a própria imagem deixa claro ao figurar em sua margem direita a maçaneta e parte da porta. $\mathrm{O}$ que o doorkijkje de Hoogstraten tematiza é a própria contemplação do quadro como proposta de abertura de um campo perceptivo.

A travessia óptica do espaço, o transporte do olhar ao longo de uma extensão determinada, vetor fundamental das pinturas de Hoogstraten que acabamos de analisar, é também o parti pris de Wavelength (1966-67), de Michael Snow, filme que, grosso modo (sem levar em conta algumas nuanças que serão abordadas mais adiante), consiste num longo e lentíssimo zoom de mais de quarenta minutos, partindo da tomada geral de um espaço (um loft) até chegar a um detalhe contido nesse espaço (uma fotografia colada na parede situada no outro extremo do apartamento). A pista sonora é composta por ruídos de ambiente, sons sincronizados (a exemplo das falas durante os parcos e breves "eventos humanos" que ocorrem no filme) e, mais marcadamente, por uma onda sonora gerada por sintetizador, que começa com oito minutos de filme e vai até o fim num crescendo constante, do mais grave ao mais agudo, na mesma medida em que a visão migra do plano geral ao primeiro plano. Snow dilata ao máximo o tempo de deslizamento do olhar - um olhar sem corpo, que não pertence a nenhum sujeito em particular - pelo espaço fílmico (esse espaço a meio caminho entre realidade e ilusão, apreensão objetiva e construção imaginária). Ele testa empiricamente, com as ferramentas específicas do cinema, o trajeto visual que Hoogstraten já induzira por meios pictóricos. A vertigem do detalhe, o mergulho do olhar na direção de um pormenor do quadro, assume agora uma forma que demanda o agenciamento não só do espaço como também do tempo, da duração.

\footnotetext{
${ }^{94}$ Ibid., p. 75.
} 
A primeira tomada do filme é um plano geral do ambiente: vemos o teto, o chão, parte das paredes laterais e toda a parede de frente com suas quatro janelas longilíneas. Poucos móveis e objetos se acham no cenário. Dentre eles, na porção central da parede de frente, destaca-se uma cadeira amarela (também havia uma em As pantufas...).

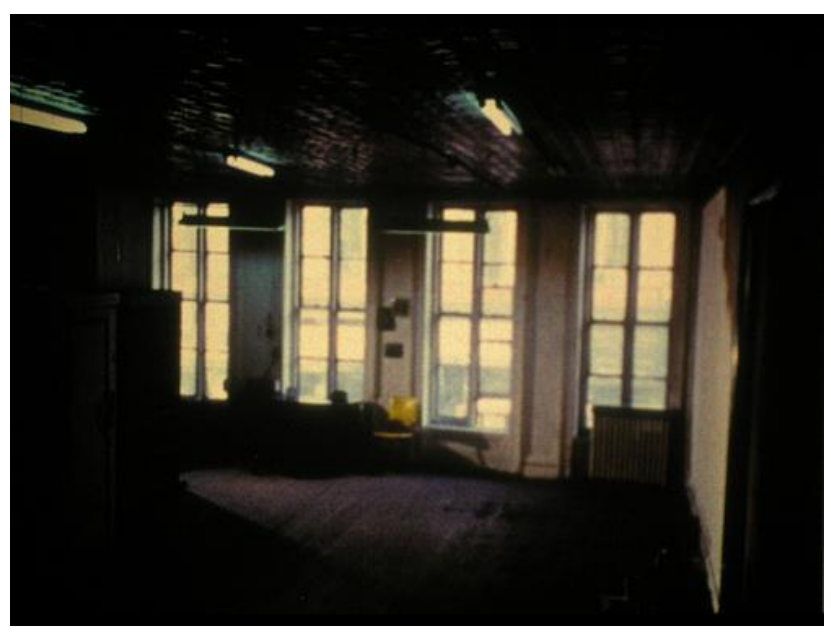

A câmera, nesse primeiro momento, está bem elevada em relação ao chão, e o ponto de vista não é frontal, mas oblíquo, pois situado à direita do eixo central do espaço. Esse ângulo cria uma grande tensão entre as linhas de força do quadro. De certo modo, o espaço se acha reduzido à sua estrutura tectônica, ao seu esqueleto geométrico. Apresentando a imagem inicialmente como uma espécie de caixa, de cubo, Snow parece dizer: eis uma unidade elementar de cinema, um plano, um bloco de espaço-tempo, e agora vamos atravessá-lo de um lado a outro.

Acima da cadeira, na parede, estão afixadas três fotos. Num primeiro momento, à distância, são apenas três pequenos retângulos indistintos. Somente com a aproximação do zoom elas se mostrarão com maior clareza. Uma delas - aquela em que a câmera se concentrará aos poucos, como se a tivesse mirado como alvo, ou como se estivesse atraída por ela como um pedaço de metal por um ímã - é uma fotografia de ondas do mar, sobre a qual o filme se concluirá, preenchendo toda a tela com a imagem fixa das ondas, que lá será mantida por um bom tempo antes do desfoque final. Ao cabo da intensa aventura perceptiva que nos leva às ondas, a eventual impressão de vê-las se movendo, apesar da fixidez da foto, é um efeito colateral perfeitamente compreensível, e provavelmente previsto por Snow.

Ora, no travelling óptico que compõe Wavelength, é como se Michael Snow chegasse a uma representação fílmica do olhar que explora as caixas perspectivas de Hoogstraten. O plano inicial do filme, aliás, dá uma visão bastante similar àquela oferecida pelos pontos de 
mira do peepshow conservado na National Gallery: o que se tem aí é o interior de uma habitação transformado numa espécie de câmara óptica, um cubo perspectivo que convida o olhar a explorá-lo, a viajar por seu espaço puramente visual, a descer até os seus detalhes, seus pormenores, suas imagens dentro da imagem. As figuras furtivas que vemos nos quadros de Hoogstraten - como o cachorro, o gato e as duas presenças humanas longínquas e imprecisas mostradas em Vista de um corredor - tornam-se, em Wavelength, eventos ou aparições transitórias que se sucedem no tempo: pessoas vêm e vão, acontecimentos (incluindo a morte de um homem, cuja causa se dá no fora de campo) se inscrevem no espaço "cênico" (se é que o termo se aplica ao filme), mas nada se fixa no mesmo lugar ou no mesmo estado; os seres e os eventos passam pelo filme, ou melhor, o filme passa por eles, já que a câmera continua seu movimento óptico impassivelmente, indiferente aos acontecimentos. O cinema, arte do espaço, mas também da duração, se afirma como superfície de passagem, de escoamento permanente.

Aproximar Wavelength da pintura de Hoogstraten não é tão arbitrário quanto parece: numa carta endereçada a Jonas Mekas e P. Adams Sitney (publicada na revista Film Culture), Snow citou Vermeer como uma inspiração para o filme, o que mostra que, de alguma forma, ele tinha de fato a pintura de interior holandesa do século XVII em mente. ${ }^{95}$ Assim como os quadros de Hoogstraten são meditações sobre os componentes estruturais da pintura de interior, o filme de Snow constitui em si mesmo uma teoria sobre os meios e os materiais que estruturam a apreensão do espaço e a percepção cinematográfica do tempo. O próprio Snow escreveu que o que pretendia com Wavelength não era menos que "uma declaração definitiva sobre o espaço-tempo fílmico em estado puro". ${ }^{96}$ Foi nesse sentido que Sitney considerou Wavelength a suprema realização do cinema estrutural no que este tem de eminentemente metafílmico; o filme seria, segundo ele, "uma experiência continuamente mutante de ilusão e anti-ilusão cinematográfica". ${ }^{97}$ Dominique Noguez afirma algo parecido, observando no filme "uma tensão dialética entre a ilusão realista de profundidade e a superfície colorida em duas dimensões que a torna possível", o que revelaria "uma vontade de dar a ver a própria materialidade do filme". ${ }^{98}$ Com efeito, o percurso de Wavelength é uma espécie de redução do cinema à realidade última de seu suporte, uma jornada rumo ao que o objeto-filme é

\footnotetext{
${ }^{95}$ Cf. P. Adams Sitney, Visionary Film: The American Avant-garde 1943-1978, 2a. ed., Nova York: Oxford University Press, 1979, p. 380. Ver também Regina Cornwell, Snow Seen: The Films and Photographs of Michael Snow, Toronto: PMA Books, 1980, pp. 77-78.

${ }^{96}$ M. Snow, "Notes sur Wavelength pour le Festival du Film expérimental de Knokke-le-Zoute (1968)", in Des écrits: 1958-2001, Paris: Centre Pompidou, 2002, p. 28.

${ }^{97}$ P. A. Sitney, Visionary Film, p. 378.

${ }^{98}$ D. Noguez, "Sur la longueur d'onde de Michael Snow", in SAYAG, Alain (org.), Michael Snow, Paris: Centre Georges Pompidou, 1978, p. 17.
} 
materialmente: imagens planas e fixas, fotografias - se bem que a experiência da projeção o negue sob a ilusão de volume e profundidade e a percepção contínua do movimento. Em Wavelength, como diz Alain Fleischer, assistimos à imagem em movimento se esforçar para se reduzir à imagem fixa, "com a qual ela gostaria de se confundir, [...] inelutavelmente seduzida, como numa vertigem suicida mais forte que tudo". ${ }^{99}$ O que há, portanto, é uma ativação da dialética entre o filme como objeto, o rolo de película, imenso enfileiramento de fotos estáticas, e o filme como experiência, aquilo que é percebido pelo espectador durante o tempo da projeção.

Idealmente, ou conceitualmente, Wavelength consta de um movimento fluido, contínuo, ininterrupto, que atravessa o espaço como se ignorasse as constrições materiais do meio físico, quase como um movimento mental. Na prática, porém, o espectador facilmente percebe que o filme é constituído não só por esse movimento constante e uniforme, mas por uma série de descontinuidades e heterogeneidades. O zoom é interrompido e retomado subrepticiamente, e sua progressão não é perfeitamente estável, mas afetada por "uma leve gagueira visual". ${ }^{100}$ Ainda que avance em linha reta, a câmera não desce até a foto num só impulso: ela vai camada por camada, desfolhando o espaço visível cadenciadamente. O filme tampouco dispõe de um bloco temporal monolítico, pois é feito de múltiplos registros acoplados de modo a forjar a continuidade do movimento. "Snow, como o Warhol de Sleep, finge dar a duração real, sem elipse, quando fabrica, na verdade, um tempo sintético obtido pela montagem". ${ }^{101}$

Essas "imperfeições", antes de serem escamoteadas, são assumidas e intensificadas por Snow, que deixa à mostra os pontos de amarração do material filmado. Vemos, assim, em paralelo aos "defeitos" sutis (discretas variações de eixo, ligeiros recuos ou avanços na passagem de um pedaço de registro a outro), rupturas assaz exclamativas: passagens bruscas do dia para a noite e vice-versa, manipulações deliberadas da imagem, trechos em negativo, sobreimpressões, sub ou superexposições, mudanças abruptas de cor por conta do uso de filtros etc. O filme faz questão de admitir a defasagem entre o pensamento organizador da obra e a realidade técnica de sua execução. E, no entanto, sua ideia-motriz é tão poderosa, sua estrutura conceitual é tão presente, que nada a atrapalha no fim das contas: "O filme estica um fio e o espectador, com o olhar focado nesse fio, qual um funâmbulo, nada vê além disso, e

\footnotetext{
${ }^{99}$ A. Fleischer, "La cinémachine de Micheal Snow", in Hubert Damisch et alii, Michael Snow: Panoramique, Bruxelas: Cinémathèque Royale de Belgique, 1999, p. 38.

${ }^{100}$ Annette Michelson, "Toward Snow", in P. A. Sitney (org.), The Avant-Garde Film: A Reader of Theory and Criticism, Nova York: New York University Press, 1978, p. 174.

${ }^{101}$ D. Noguez, art. cit., p. 17.
} 
atravessa assim o espaço puro de uma ideia, indiferente ao caos do mundo real, que a ideia não organiza senão imperfeitamente". ${ }^{102}$ Os distúrbios da viagem, tanto os acidentais quanto os propositais, são reabsorvidos num fluxo de continuidade ideal, que segue esse fio imaterial e invisível, essa linha pontilhada imaginária que conduz o olhar até a fotografia na parede, a fotografia das ondas, imagem final que, durante o tempo em que ocupa toda a tela, abre um novo espaço dentro do espaço já esgotado pela câmera. A foto prolonga virtualmente (ao infinito?) o campo do olhar, convidando o pensamento a inventar formas a partir da imagem das ondas (um pouco como quem adivinha a figura nas nuvens ou tenta enxergar o desenho no tapete). Terminado o movimento da câmera, continua o da mente.

Snow, em Wavelength, nada faz senão traçar uma linha, o mais curto caminho entre um ponto e outro (ainda que essa linha seja percorrida num movimento ondulatório). "A linha une dois pontos. O ponto é um instante, e são dois instantes que definem a linha em seu começo e em seu fim". ${ }^{103}$ Se a linha conjuga dois instantes, ela é uma "quantidade de tempo". "A mão que segue e fixa uma linha apreende o tempo e lhe dá forma [...]". ${ }^{104}$ Isso vale também para o olho que segue e apreende visualmente uma linha (real ou imaginária). $\mathrm{O}$ trajeto óptico de Snow, portanto, indo de um ponto a outro daquele loft, equivale ao traçado de uma linha e, consequentemente, à apreensão de uma determinada extensão do tempo. Como assinalou Annette Michelson, Snow "redefine o espaço como sendo o que Klee já defendia: essencialmente "uma noção temporal". ${ }^{105} \mathrm{Na}$ medida em que "a linha se torna a consciência de um espaço de tempo", ela traduz também "a dimensão de uma ideia projetada no e com o tempo"106: quem liga dois pontos já está seguindo uma linha de pensamento ou construindo o fio de um raciocínio. O movimento da câmera de Snow, sua lenta caminhada por dentro do loft, pode ser então equiparado ao "movimento da consciência". ${ }^{107}$

Nesse sentido, o filme se assemelha a um processo de organização mental ou perceptiva cujo sistema delineia a estrutura básica da atenção: selecionando um ponto de interesse dentro de um campo visual mais vasto e nele se concentrando com mais e mais intensidade, ofuscando e excluindo aos poucos as partes que ficam na periferia do objeto focalizado, Michael Snow estaria nos convidando a avaliar o espectro de intensidade da nossa atenção. Em Suspensões da percepção, Jonathan Crary demonstrou que a questão da manutenção da atenção já havia se tornado, no último quartel do século XIX, um dos grandes

\footnotetext{
${ }^{102}$ A. Fleischer, art. cit., p. 36.

${ }_{104}^{103}$ Manlio Brusatin, Histoire de la ligne, Paris: Flammarion, 2013, p. 19.

104 Ibid., p. 85.

${ }^{105}$ A. Michelson, art. cit., p. 176.

${ }^{106}$ M. Brusatin, op. cit., p. 85.

107 A. Michelson, art. cit., p. 175.
} 
problemas da modernidade. Dentre as muitas questões - de ordem neurofisiológica, sociológica, psicanalítica, filosófica etc. - que então surgiram, achava-se o problema, ainda atualíssimo, de como manter um "estado de atenção" dentro do regime de sobrecarga sensorial que marca a vida moderna. Snow talvez esteja partindo de questionamento similar: sua insistência em manter-se focado no mesmo objeto, concentrado no mesmo movimento, no mesmo ritmo, durante os 45 minutos de Wavelength, enfrentando todas as forças de dispersão, variação e descontinuidade que encontra pelo caminho, pode ser uma reação paroxística à cultura moderna de saturação e "distração". Mas já nas décadas de 1880 e 1890 sabia-se que a atenção era incompatível "com qualquer modelo de olhar estético prolongado. A atenção sempre trouxe consigo as condições de sua própria desintegração, era atormentada pela possibilidade de seu próprio excesso - que todos tão bem conhecemos sempre que tentamos ver ou ouvir alguma coisa durante muito tempo". ${ }^{108}$ Contrariando uma tradição crítica que remonta, entre outros, a Walter Benjamin, Crary defende que atenção e distração não formam polos opostos, mas existem em "um continuum no qual as duas fluem incessantemente de uma para a outra" (p. 75). Em meio à crise epistemológica generalizada do final do século XIX, a atenção teria deixado de estar relacionada à noção de estabilidade perceptiva para ser reconhecida como um processo dinâmico, que não se dá de forma homogênea, mas por uma constante variação de intensidades: "a atenção passou do modelo clássico de estabilização mental da percepção dentro de um molde fixo para um continuum de variação, uma modulação temporal, repetidas vezes descrita como de caráter rítmico ou ondulante" (p. 90). Esta definição moderna de uma percepção instável, modulável e ondulante é bastante apropriada a Wavelength, que seria como que a demonstração cinematográfica de quão precário e problemático é o processo de síntese do campo perceptivo, dividido entre a atenção fixa, o olhar contínuo, e a autoimposição de uma visão fragmentada, disruptiva e mutável.

Wavelength tem um quê de experimento científico, de verificação empírica das possibilidades de um dispositivo (bem como de suas limitações). "Para Michael Snow, o cinema é uma máquina, mas não uma máquina de filmar imagens ou narrativas preparadas para ela: é antes uma máquina que bate o terreno, que abre o caminho para o olhar, ou seja, que dá ao olhar um poder de transformação [bouleversement] do visível". ${ }^{109}$

Essa máquina, no caso de Wavelength, pega emprestado o movimento-padrão da engrenagem hitchcockiana: do plano geral ao plano-detalhe. Utilizamos como exemplo desse

\footnotetext{
108 J. Crary, Suspensões da percepção: atenção, espetáculo e cultura moderna, trad. Tina Montenegro, São Paulo: Cosac Naify, 2013, p. 71.

${ }^{109}$ A. Fleischer, art. cit., p. 38.
} 
movimento, no início do primeiro capítulo, o plano da chave em Interlúdio, e vale agora complementá-lo com outros exemplos igualmente significativos, começando pela cena de Jovem e inocente (Young and Innocent, 1937) em que a heroína, afoita para inocentar seu companheiro (tomado como falso culpado de um assassinato), vai ao hotel em que ela sabe que se encontra o verdadeiro criminoso, que poderá ser reconhecido por conta de um inconfundível tique nervoso nos olhos. Assim que ela chega ao hotel, a grua realiza um movimento parecido com o de Interlúdio: partindo de um grande plano geral do hall de entrada, passa para o salão de baile, onde vários casais dançam animados pela música tocada por uma orquestra que, pouco a pouco, torna-se o foco de interesse da câmera. O quadro vai lentamente se fechando sobre a orquestra posicionada ao fundo do salão, até isolar apenas o baterista, chegando cada vez mais perto de seu rosto (que está pintado, mascarado) e, em seguida, concentrando-se nos olhos, onde, por fim, manifesta-se o tique nervoso (o traço delator, que revelará a identidade do assassino a despeito do seu disfarce). É como se a câmera tivesse saído em busca do segredo que Hitchcock queria compartilhar com a plateia (o assassino é o baterista da banda).

Mais ilustrativa ainda é a abertura de Frenesi (Frenzy, 1972), uma tomada aérea de Londres com a câmera percorrendo o rio Tâmisa, quase uma apresentação turística da cidade - um plano-cartão postal. Mas, quando a câmera desce e encontra o prefeito fazendo um discurso sobre a despoluição das águas, alguém avista o corpo nu de uma mulher morta boiando no rio. A aparição do cadáver acusa a parte sórdida da realidade, que a imagem oficial da cidade omitia (essa cena tem a mesma lógica do trabalho conceitual de Richard Hamilton em Whitley Bay: corromper a imagem do cartão postal para fazê-la revelar as sujeiras que a vista de longe mascarava).

Se Michael Snow reemprega em Wavelength a estrutura típica do plano hitchcockiano - "esse fechamento progressivo do campo perceptivo, essa concentração da câmera num objeto preciso" $" 110$, ele o faz de acordo com uma premissa ao mesmo tempo visual-estética e intelectual-teórica, que termina por evidenciar aquilo que Hitchcock ainda empacotava como parte do espetáculo: o arbitrário da forma. Embora já subordinasse a mise en scène a um "postulado formal", a uma ideia visual de base, Hitchcock ainda a justificava em termos de narrativa e construção dramática: o mergulho da câmera no espaço cênico, seu movimento do plano de conjunto ao primeiro plano, por mais extravagante e arbitrário que pudesse parecer, estava totalmente integrado a um programa ficcional. Em Wavelength, esse movimento é

${ }^{110}$ D. Noguez, art. cit., p. 17. 
preservado apenas como esquema, desenho, forma de estruturação do campo visual. De certo modo, é como se Snow submetesse o plano da chave de Interlúdio (ou o do baterista de Jovem e inocente) a uma extrema ralentação, fazendo o trajeto durar quarenta e cinco minutos e não quarenta segundos. Nessa velocidade infinitesimal, o movimento perde parte de sua precisão e agudeza, de sua fluidez; amplificam-se as perturbações, as claudicâncias do foco, os microestremecimentos da câmera. Ainda que os caminhos sejam outros, a lógica de fundo não é tão distinta daquela de Blow up. Lá, o fotógrafo ampliava os pormenores da imagem para enxergá-los mais de perto, desencadeando um processo em que a perda de precisão analógica da foto, sua progressiva deformação, era compensada pela revelação de aspectos materiais e figurais antes imperceptíveis. Aqui, a aproximação do olhar em direção ao detalhe constitui-se de maneira diferente, como deslocamento no espaço, travessia de um ponto a outro - o que Snow "amplia" não é o tamanho da imagem, e sim a duração, a extensão temporal desse deslocamento -, mas, entre o ponto de largada e o enquadramento final, exploram-se, como em Blow up, as forças de figuração intrínsecas ao material fílmico, desvelando as nuanças que o plano magistral de Hitchcock ignorava em seu movimento ansioso. O que era um convite à pronta hipervisibilidade em Hitchcock torna-se uma maratona da percepção em Snow. De Hitchcock a Wavelength, o percurso do olhar é mantido, mas o espetáculo da mobilidade do olho cinematográfico se desdobra num problema perceptivo e epistemológico. 


\section{IV.}

\section{O museu imaginário}

\section{A imagem anterior}

Vertigo e Blow up, os dois filmes que guiam a nossa investigação, têm em comum o fato de suas narrativas gravitarem em torno de uma imagem que o protagonista deve “estudar". Em Vertigo, essa imagem é o retrato de Carlotta, imagem fascinante que contamina a realidade e nela se reduplica. Em Blow up, trata-se de uma fotografia que, uma vez analisada e dissecada, revela uma nova imagem dentro da imagem, ou melhor, uma nova camada de significação: Antonioni abre uma "ferida hermenêutica"1 na imagem, que absorve o protagonista num trabalho obstinado de interpretação e análise.

Esse trabalho será retomado em 1975 por Dario Argento, que dará ao ator de Blow up, David Hemmings, uma nova imagem para decifrar. O filme em questão é Prelúdio para matar (Profondo rosso), em que Hemmings é Marc Daly, pianista de jazz que, ao ver uma mulher sendo assassinada, vai ao seu socorro, mas já a encontra sem vida. Na cena seguinte, enquanto relata o que viu para um policial, Marc afirma que o local do crime não está mais do mesmo jeito, há algo faltando. Após matutar, ele conclui que sumiu um quadro, uma das várias pinturas existentes no apartamento. Convencido de que esse quadro contém uma pista importante, Marc começa uma investigação por conta própria.

Para descobrir o mistério do quadro desaparecido, ele precisará antes imergir num mundo-pintura, num universo em que tudo é forma, cor, estilo, composição. Sua investigação deverá se provar, acima de tudo, um aprendizado estético.

A praça em que Marc encontra seu amigo Carlo, ainda no começo, já demonstra com nitidez o fato de que ele está inserido num mundo transformado em cenário pictórico: espaço imponente obtido por uma mescla de Edward Hopper (o "Blue Bar" é uma explícita citação a Nighthawks) e De Chirico (como comprova a arquitetura da praça - suas arcadas e colunas em

\footnotetext{
${ }^{1}$ Emmanuel Siety, Fictions d'images, Presses Universitaires de Rennes, 2009, p. 67.
} 
estilo clássico, suas esculturas monumentais dividindo espaço com signos modernos -, bem como as sombras proeminentes, a perspectiva esmagadora convergindo para um ponto de fuga situado no solo, o cenário semideserto, as incongruências espaciais, a atmosfera surrealista):
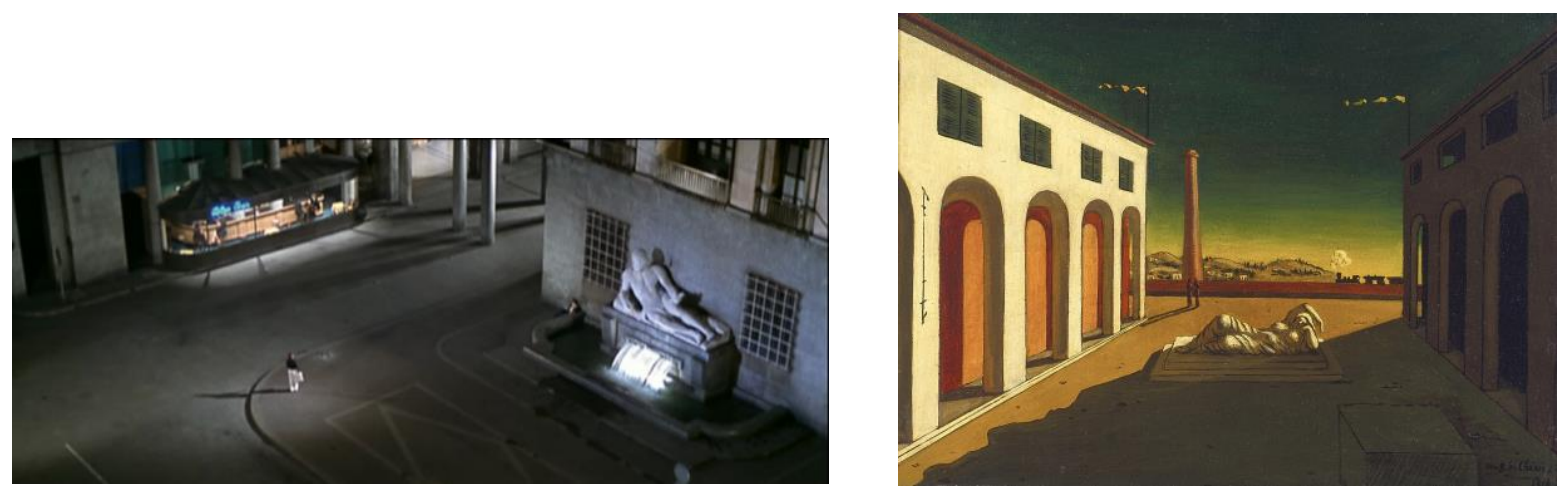

Giorgio de Chirico, Melancholia, 1916
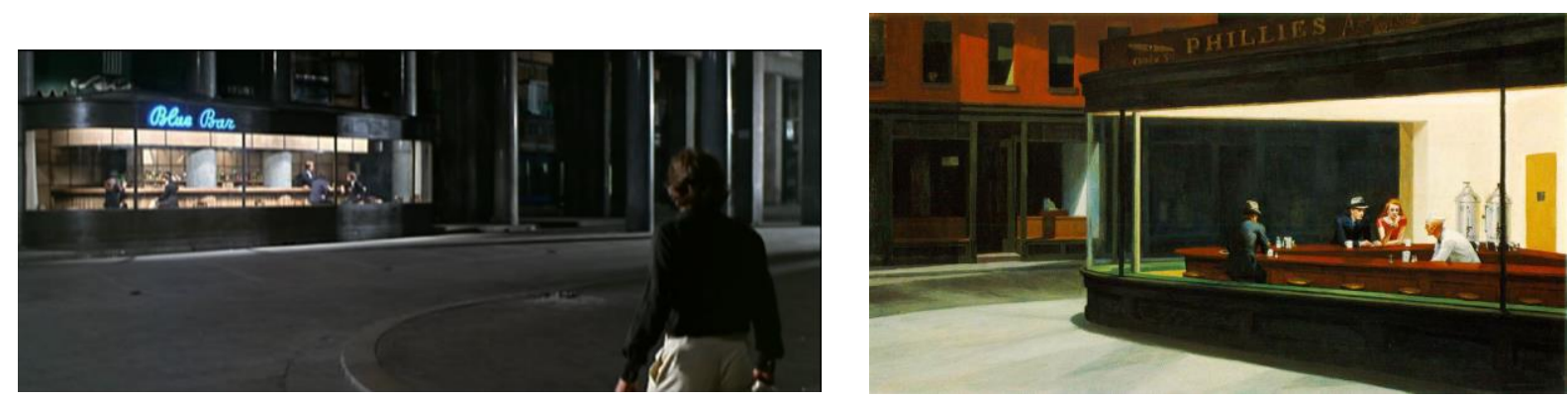

Edward Hopper, Nighthawks, 1942

É nesta praça que Marc ouve o grito feminino que anuncia o crime. Ele olha para um prédio próximo à praça e, numa das janelas, vê a mulher sendo esfaqueada. Sobe afobado a escadaria do prédio. Depois de atravessar o interior do apartamento, que mais se assemelha a uma galeria de arte, ele encontra o corpo da vítima cravado no vidro da janela, como uma espécie de escultura cuja morbidez já fora prefigurada pelos rostos expressionistas nas pinturas pelas quais passara anteriormente (Argento segue nessa cena uma tendência do giallo de estetizar a morte violenta e fazer do cadáver uma obra de arte, uma composição escultural que vem coroar o tour de force operístico da sequência de assassinato).

Em Blow up, o fotógrafo visitava e revisitava o parque em que ocorreu o crime. Em Prelúdio para matar, o lugar visitado por David Hemmings ao longo de sua investigação será uma mansão abandonada. A vítima do assassinato testemunhado por Marc, a renomada parapsicóloga Helga Hullman, havia mencionado essa mansão numa palestra no início do filme. Depois, num livro sobre um faits divers macabro (cuja autora será também 
assassinada), o protagonista descobre que lá viveu uma criança que sempre cantarolava uma mesma música infantil e, em seguida, chorava e gritava assustada (a tal música é ouvida toda vez que o assassino entra em ação). Dentro da casa, Marc olha cada cômodo, escadaria, cada detalhe e ornamento barroco da antiga mansão, como quem redescobre a locação abandonada de um filme de Riccardo Freda. A cena culmina no momento em que ele percebe na parede de um dos cômodos um detalhe intrigante: duas pequenas falhas no reboco da parede dão a ver que há alguma coisa escondida, alguma imagem encoberta pelo cimento. Marc imediatamente se põe a raspar a parede:

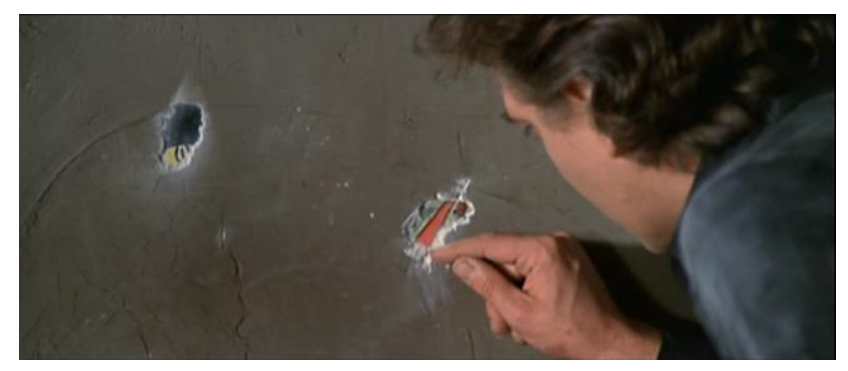

O gesto de Marc, descascando o cimento com a ponta do dedo, relembra o do fotógrafo de Blow up, que também colocara o dedo indicador na imagem como se quisesse apurar a visão por meio do toque. Argento transforma em ação o que, no gesto de Hemmings em Blow up, era apenas intenção: raspar a imagem, desfazer sua primeira camada opaca para enxergar o que há por trás. Mais uma vez, é tudo questão de um detalhe cuja irrupção obriga o olhar a retornar à imagem, a enxergá-la de novo, a desconfiar da primeira impressão e a reinterpretar o que foi visto antes.

Aos poucos, à medida que Marc esfarela o cimento, surge um desenho infantil um tanto aterrorizante: uma criança segura uma faca ensanguentada ao lado de um homem assassinado (essa criança, Marc descobrirá mais tarde, é Carlo, seu amigo depressivo e alcoólatra). O pianista pensa ter encontrado aí a imagem-chave da investigação. Mas, depois que ele se retira da casa, a câmera se aproxima em travelling do desenho na parede, como a pedir que olhemos mais de perto, ou como a se preparar para nos contar um segredo. Quando a câmera termina o movimento, um pedaço do reboco da parede cede e despenca, revelando uma parte do desenho não descoberta por Marc. Surge uma terceira personagem no desenho, uma mulher, a verdadeira autora do crime ali representado. Não tendo visto a imagem inteira, Marc se iludiu com uma falsa revelação. Algo semelhante acontecera em Blow up, entre a primeira e a segunda etapa das ampliações. Thomas, a princípio, pensara ter evitado um assassinato (ao chamar a atenção do casal com seu olhar intruso, ele teria dispersado a cena, 
impedindo a morte do homem), mas, depois que ele retorna às imagens, um novo elemento indica a consumação do crime: uma mancha atrás da moita, não vista anteriormente, representa o cadáver do homem de terno, que foi morto enquanto Thomas discutia com a mulher e explicava que só mais tarde lhe daria os negativos (ou seja, ele não só não evitou o crime como, no fim das contas, facilitou, já que o atirador aproveitara justamente o momento em que o homem de terno ficara sozinho para efetuar o disparo e esconder o corpo). Uma imagem nunca mostra tudo de uma só vez. Há sempre algo por descobrir, algo que permaneceu nas bordas ou no fundo. É preciso desconfiar sempre das imagens, voltar a elas, arriscar um novo ponto de vista - "síndrome Blow up" que retorna em Prelúdio para matar.

$\mathrm{Na}$ segunda vez em que vai à misteriosa mansão, Marc compara a fachada da casa com uma antiga foto que arrancou de um livro. Ele nota que uma das janelas vistas na foto desapareceu. Munido de uma picareta, Marc arrebenta a parede no local onde havia a janela e descobre que há um cômodo escondido na casa, murado de todos os lados. Ele ilumina o interior do cômodo com uma lanterna, encontrando lá o cadáver do homem que aparece sendo assassinado no desenho (ou seja, o pai de Carlo). Debaixo de teias de aranha e crostas de poeira, a cena do crime permanece de alguma forma preservada e mumificada dentro desse cômodo, como uma peça de museu de cera, ou como um dos quartos de O segredo da porta fechada (Secret beyond the door, 1947), de Fritz Lang, paradigmático thriller psicanalítico em que a personagem de Michael Redgrave possui um estranho hobby: colecionar cômodos que reproduzem nos mínimos detalhes os cenários onde ocorreram crimes famosos (um dos quartos, porém, não pode ser mostrado: sua porta vive trancada...).

Se Thomas, em Blow up, esbarrava na bidimensionalidade da fotografia, na sua realidade chã, Marc, por sua vez, está diante de uma imagem "atravessável”. Seu desejo de volume e profundidade é satisfeito. A imagem não mais se restringe a uma superfície impenetrável que não admite profundidade senão ilusória: ela se torna "uma parede transponível, um limiar”, como escreveu Jean-Baptiste Thoret. “A passagem para o outro lado da imagem contesta assim a platitude da experiência e revela a profundidade ausente e fantasmatizada no filme de Antonioni. 'E se Thomas pudesse penetrar no interior de sua foto?' é a questão delirante colocada a Blow up por Prelúdio para matar". ${ }^{2}$

O trabalho de David Hemmings em Blow up, conforme analisamos, era comparável ao de um arqueólogo que escavava a imagem à procura dos seus significados soterrados e esquecidos. Em Prelúdio para matar, a comparação é ainda mais pertinente. Marc visita um

\footnotetext{
${ }^{2}$ J.-B. Thoret, Dario Argento: Magicien de la peur, Paris: Éditions Cahiers du cinéma, 2008, p. 81.
} 
sítio em ruínas e invade uma cripta que guarda a imagem residual de uma história anterior. As imagens se apresentam, nesse filme, como uma matéria arqueológica, uma crosta estratificada que é preciso escavar, raspar, desbridar. Argento faz uma arqueologia do visível, uma busca pelas formas remanescentes, pelas imagens mais antigas, que subjazem às atuais. "As imagens são uma matéria como outra qualquer", diz Hervé Aubron: "elas se sedimentam por estratos sucessivos, encobrem o mundo e aí se aglomeram". ${ }^{3}$ Num mundo saturado de signos visuais das mais diferentes procedências, onde as imagens se superpõem e formam uma crosta que impede o olhar de atingir o que há na origem (a imagem primeira? o real? o mundo "verdadeiro"?), enfim, nesse mundo filmado por Argento, como reordenar a experiência visual, como reaprender a ver senão por meio de "um trabalho de escavação: sondar, cavar, revolver os estratos imagéticos, misturar, peneirar esse estrume, cortá-lo por dentro e, eventualmente, discernir uma linha, uma fenda, até mesmo uma imagem"? 4

Em sua análise do filme, Thoret dá especial atenção ao plano em que a câmera, posicionada dentro do cômodo secreto, enquadra Marc de frente, a quebrar o muro como se transpassasse a própria tela do cinema, desobstruindo a visão do espectador para fazê-lo acessar esse axioma que estrutura a obra de Argento: "uma imagem sempre esconde outra imagem". 5

O cadáver encontrado por Marc no cômodo secreto depois que ele põe o muro abaixo remete imediatamente ao cadáver de Mrs. Bates em Psicose, filme-matriz de toda uma vertente do thriller de horror da qual o giallo, gênero que Argento conduz ao máximo de elaboração em Prelúdio para matar, é a variação italiana (com as devidas anamorfoses, hipérboles, reinvenções, deslocamentos). Esse cadáver é o antepassado artístico que Argento não conseguiu enterrar, e que tencionou seu filme internamente, devorou-o por dentro, até arrebentar a parede que o continha e vir à tona.

Marc, tal um arqueólogo da história do cinema, portanto, encontra as ruínas e os restos mortais de uma imagem anterior. "O cadáver iluminado pela lanterna se imbui de múltiplas significações: cadáver de uma memória cinematográfica e pictural asfixiante [encombrante], cadáver de Blow up, cadáver de Mrs. Bates, cadáver, enfim, de uma profundidade denegada". ${ }^{6}$ A filmagem frontal, que mostra Marc quebrando o muro como se destruísse a própria superfície da imagem cinematográfica, tem por efeito a interpelação violenta do

\footnotetext{
${ }^{3}$ H. Aubron, "À rebours", in (org.), Projections baroques (edição especial da revista Vertigo), Paris, outubro de 2000, pp. 9-10.

${ }^{4}$ Ibid., p. 10.

${ }_{6}^{5}$ J.-B. Thoret, Dario Argento: Magicien de la peur, p. 25.

${ }^{6}$ Ibid., p. 83.
} 
espectador, cuja pulsão escópica, na mesma medida em que é atendida, vira-se contra ele, porquanto descamba na visão dessa imagem irrefutável, imagem concreta, demasiado concreta, do cadáver, do corpo putrefato - a imagem da morte, a única realidade inexorável à qual todos se encaminham. Essa cena é um autêntico memento mori, e o plano que apanha Marc contemplando de frente o cadáver através da abertura na parede é um dispositivo-limite, pois figura um homem olhando a imagem que ele próprio terá depois de morrer.

Essa acumulação de cadáveres e de fantasmas, segundo Thoret, revela um cinema sem exterioridade, sem fora de campo possível: tudo - incluindo os dejetos, os restos, o lixo - se acumula dentro do plano, até o ponto do transbordamento: "a questão não é mais saber nem especular sobre o que se situa fora do campo, mas sobre o que, no interior deste, faz mistério (Blow up). Donde essa sensação de uma ausência de gravidade da imagem, que conduz o espectador a se focalizar em vários centros de interesse". ${ }^{7} \mathrm{O}$ espaço ficcional se assemelha então a um studiolo: lugar exíguo e amontoado, espaço de acumulação, de dobras infinitas, de sobrecarga de imagens múltiplas, como se todo o universo estivesse "contido numa gota d'água". ${ }^{8}$ Não é mais questão de imaginar e desejar aquilo que ficou no campo cego, no fora de campo, mas sim de procurar, na imagem mesma, o que ela esconde ou mascara, o que seus signos em excesso articulam secretamente, o que faz pressão sob a superfície das aparências visíveis, em suma, tudo aquilo que, dissimulado nas regiões mais nebulosas do campo, aguarda o momento certo para irromper e desviar radicalmente o curso da representação.

A resolução da intriga de Prelúdio para matar vai justamente nesse sentido. Marc retorna ao apartamento em que Helga Hullman foi assassinada. Ele tenta se lembrar do que viu, refazendo mentalmente o momento em que entrou no apartamento pela primeira vez e atravessou o corredor de quadros. Seu intuito é identificar o que, no cenário presente, diverge da imagem original. É como se ele efetuasse uma análise comparativa entre a imagem que tem diante dos olhos e a imagem anterior, mental (guardada na memória, mas sem boa resolução), tentando assinalar a diferença, o elemento que uma imagem possui e a outra não. Quando seu olhar cruza com um espelho, cuja moldura é do mesmo formato oblongo dos quadros pendurados pelo corredor, Marc começa a entender o que aconteceu. Vendo seu próprio rosto refletido no espelho, ele percebe enfim o equívoco: ele havia visto o rosto da assassina naquele mesmo espelho, mas o confundira com as figuras perturbadoras - dignas das Pinturas negras do último Goya - de um quadro que o espelho também refletia (como um flashback irá elucidar). A imagem especular, ao achatá-los numa mesma superfície reflexiva,

\footnotetext{
${ }^{7}$ Ibid., p. 136.

${ }^{8}$ Ibid., p. 135.
} 
tornara indiscerníveis os rostos pintados e o rosto real da assassina, cuja maquiagem grotescamente exagerada contribuíra para aclimatá-lo melhor no universo expressionista do quadro. Argento baseou o enigma desencadeador da trama nessa qualidade potencialmente traiçoeira do espelho, o qual, multiplicando de maneira artificial as perspectivas de um espaço interior, pode ser cúmplice de dispositivos intrincados, de armadilhas para o olho.

O mistério do quadro desaparecido, então, nada mais era que uma charada óptica. Para decifrá-la, Marc, como bom analista de imagens, precisou de duas ações complementares: um segundo visionamento da cena (após já ter enriquecido sua investigação com uma série de outras descobertas) e uma mudança de ponto de vista. Seu retorno ao apartamento de Helga Hullman é uma espécie de revisão crítica: ele desfaz o engano inicial, que decorria de uma má interpretação de imagem.

Em Prelúdio para matar, portanto, Argento se provou um cineasta-arqueólogo, alguém que, plenamente consciente da história das formas em que seu filme se inscreve, investiga o passado das imagens, persegue sua origem perdida, revisita certas obras matriciais (Psicose, Blow up, O segredo da porta fechada) acionando uma operação de escavação e de exumação das imagens de que sua memória não consegue se livrar.

No ano seguinte, em Trágica obsessão (Obsession, 1976), Brian De Palma também embarca numa expedição arqueológica, numa viagem rumo à origem histórica (ou mítica?) do seu cinema; ele concebe o filme inteiro, em cada traço, em cada nuança, como a reinterpretação subjetiva de um filme anterior, que ele toma como modelo e ponto de partida.

Aprofundando o diálogo do diretor com o cinema de Hitchcock, já esboçado em seus filmes anteriores, Trágica obsessão se assume abertamente como uma releitura de Vertigo, uma variação em torno dos seus motivos centrais. De Palma age aqui como um exegeta de Hitchcock que, em vez de expor suas teorias e análises em tratados conceituais ou ensaios escritos, transforma-as em ideias visuais, em ideias filmadas.

O filme começa em 1959 (como se De Palma voltasse no tempo e situasse a narrativa numa época em que ele ainda estava sob o impacto de sua primeira visão de Vertigo, ocorrida no ano anterior). Michael Courtland (Cliff Robertson) comemora seu décimo aniversário de casamento com Elizabeth (Geneviève Bujold), com quem tem uma filha de nove anos, Amy. A felicidade do casal parece inabalável. Terminada a festa, porém, um evento vem destruir essa vida familiar aparentemente perfeita: a esposa e a filha de Michael são sequestradas. A ação dele, orientada pela polícia, será desastrosa, e resultará na morte de Elizabeth e Amy num acidente de carro durante a perseguição aos sequestradores. 
Passados dezesseis anos, Michael, que é um próspero construtor civil empenhado em reformular a paisagem urbana de Nova Orleans preservando os "grandes valores do antigo Sul" [sic], acompanha seu sócio Bob numa viagem a Florença, a cidade italiana que é quase sinônimo do Renascimento e do ponto de virada da história artística ocidental. Visitando a basílica de San Miniato al Monte, a mesma igreja onde conheceu Elizabeth muitos anos antes, Michael avista uma moça que, para sua total estupefação, é a sósia de sua falecida esposa. Com visível emoção, ele contempla a bela jovem enquanto ela trabalha na restauração de um afresco pré-renascentista. Michael retorna no dia seguinte, vê a moça novamente, espera ela sair da igreja, persegue-a pelas ruas e pontes antigas de Florença. Ele vai à igreja uma terceira vez, e pede que Bob o acompanhe. Ao vê-la, este exclama incrédulo: "É idêntica!".

Michael não retornará com Bob para Nova Orleans, decidindo ficar mais uns dias em Florença. Numa nova ida à igreja, ele trava contato com a sósia de Elizabeth: ela se chama Sandra Portinari, ex-secretária bilíngue e atual estudante de história da arte que se ofereceu como voluntária no projeto de restauração de um afresco (representando a Virgem) pintado por Bernardo Daddi em 1328. Sandra explica para Michael que a umidade danificou parte do afresco, revelando, nas áreas em que houve infiltração, uma outra imagem da Virgem, uma imagem anterior, mais antiga. Os restauradores ficaram num impasse: "Deveriam eles remover e destruir uma grande pintura de Daddi para descobrir o que parece ser apenas um primeiro esboço ainda cru? Ou deveriam restaurar o afresco como tal, mas permanecer sem saber ao certo o que jaz sob ele? O que você faria?", Sandra pergunta a Michael após a explicação. Ele afirma que ficaria com a imagem mais recente, pois "a beleza deve ser preservada". "Ótimo. Foi o que os especialistas decidiram fazer", ela aprova.

De Palma cria, nessa cena, um espelhamento entre Sandra e a imagem-palimpsesto da Virgem. Se, na porção mais deteriorada do afresco, é possível ver um pedaço do rosto da Madona anterior à de Bernardo Daddi (a Madona à qual ele sobrepôs sua pintura), em Sandra, analogamente, os traços de Elizabeth sobrevivem, pedem passagem através dela.

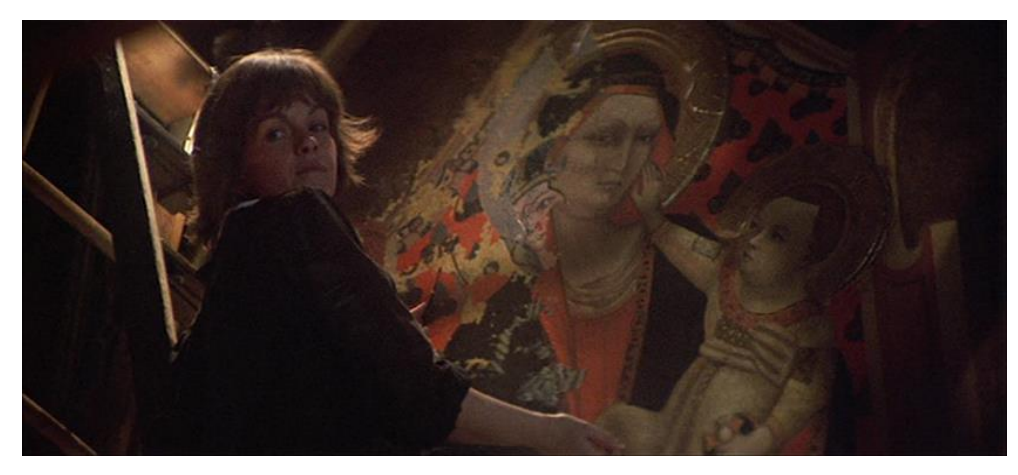


Assim como em Argento, portanto, a aparição de uma imagem, em De Palma, revela sob ela a existência de outra imagem, que lhe é anterior. Mas, enquanto Argento não se furta a raspar a imagem atual, a destruir a superfície do visível para investigar o mistério da imagem subjacente, De Palma prescreve o exato oposto: preservemos a imagem já conhecida e a admiremos por ela mesma; aceitemos que a visão de uma imagem implica o sacrifício parcial ou total de uma outra.

Ao longo desse diálogo sobre a restauração da pintura, De Palma coloca as cartas sobre a mesa: ele está refazendo uma imagem original, sem ocultar que constrói seu filme sobre os resquícios de uma obra anterior, de uma imagem-matriz. A forma correta (ou recomendada) de ver Trágica obsessão é situando-o num espaço relacional, num constante diálogo interfílmico com seu antecessor, ou seja, com Vertigo. É preciso, a cada momento, comparar os dois filmes, cotejá-los. Um espectador que não tenha visto Vertigo pode perfeitamente se envolver com a trama e entender Trágica obsessão. Mas há toda uma reserva de significados e efeitos que está guardada somente para o espectador iniciado. O sentido pleno da obra, sua verdadeira razão de ser só se mostra àqueles que conhecem (e bem) o filme de Hitchcock. De Palma se inscreve, assim, na lógica de uma época culturalmente tardia. Certas imagens (maneiristas? modernas?) só podem ser inteiramente compreendidas se o espectador já tiver visto as imagens que vieram antes, que as precederam historicamente; seus dispositivos estéticos só se abrem por inteiro àqueles que já adquiriram uma determinada bagagem iconológica. De Palma e Paul Schrader (que escreveu o roteiro) pensaram desde o princípio um filme que se assumisse transtornado, assombrado pela beleza inesquecível de Vertigo (o primeiro título do projeto era Déjà vu); um filme que permitisse ao espectador perceber - entre um e outro detalhe plástico ou narrativo retrabalhado por eles - as reminiscências da obra-prima de Hitchcock.

À semelhança do que Scottie fizera com Judy em Vertigo, Michael Courtland, ao descobrir Sandra, tentará remodelá-la à imagem de Elizabeth e transformá-la num duplo de substituição da mulher morta. O périplo de Courtland, como afirma Luc Lagier, reflete o percurso artístico de De Palma. Cada qual a seu modo, ambos estão diante de um impasse: “Courtland é confrontado ao luto e De Palma a uma perfeição cinematográfica insuperável e quase mítica - aquela da personagem de Madeleine em Vertigo. Para De Palma, Hitchcock levou a arte cinematográfica aos mais altos cimos. Como ultrapassar essa perfeição?”.

\footnotetext{
${ }^{9}$ L. Lagier, Les mille yeux de Brian De Palma, Paris: Cahiers du Cinéma, 2008, p. 51.
} 
Talvez Hitchcock representasse para De Palma, em 1975, o que Rafael deve ter representado para Pontormo em 1520: uma inspiração e uma assombração. A ambientação em Florença favorece essa ligação do filme com a história da pintura: De Palma se coloca mais ou menos na mesma situação enfrentada pelos primeiros pintores maneiristas (Pontormo, Rosso Fiorentino, Parmigianino, Bronzino, Beccafumi), que enxergavam no estilo de mestres como Rafael e Michelangelo o apogeu insuperável de um ciclo de evolução das formas artísticas que se havia iniciado com as realizações do Quattrocento. Espelhando um pouco do contexto do maneirismo florentino do século XVI, a geração de Brian De Palma começa a filmar num momento em que a forma clássica, lapidada ao longo de meio século de cinema, parece exaurida. Como emblema disso, os antigos mestres do cinema hollywoodiano desaparecem, se aposentam ou são simplesmente ignorados pela indústria. A nova geração, então, resolve apropriar-se do passado clássico para dilatar, distorcer, deformar seus códigos e suas figuras típicas, explodir seu sistema de representação numa estética moderna marcada pela exacerbação da forma, pelo excesso de estilo, pela ênfase na violência e no erotismo.

Os filmes dessa geração, que constitui a chamada Nova Hollywood, atestam a sobrevivência mítica de um modelo numa época que já não o comporta mais, que já perdeu o seu segredo. Expulso da realidade, esse modelo se refugia no mito.

Mas a idade de ouro dos estúdios hollywoodianos não é alvo somente de culto e de fetichismo nostálgico por parte dos diretores que despontam no final dos anos 1960: ela é submetida também a uma releitura crítica. Egressos das universidades, os cineastas da Nova Hollywood tomam os grandes clássicos do cinema como verdadeiros objetos de análise. Se o cinema clássico americano está morto, resta-lhes dissecá-lo.

"Nesse sentido, a escolha de Brian De Palma, concentrando-se principalmente em Vertigo e Psicose, se revela particularmente judiciosa". ${ }^{10}$ De fato, tanto em Vertigo como em Psicose, os dois filmes a que De Palma retornará com mais insistência, propondo inúmeras variações de suas cenas magistrais (a cena do chuveiro de Psicose, a cena do museu de Vertigo), o que está em jogo é “a questão do luto e da recriação e conservação de uma forma já morta", em narrativas cujas personagens "mantêm uma relação conflituosa com a morte e a decomposição. [...] Buscando negar o esvaecimento das formas passadas, eles mergulham numa démarche mórbida fundada na contestação do tempo". " Basta pensar em Madeleine e sua fascinação por Carlotta, ou em Scottie e sua recriação de Madeleine, ou em Norman Bates e o corpo mumificado de sua mãe.

\footnotetext{
${ }^{10} \mathrm{Ibid} .$, p. 47.

${ }^{11}$ Ibid.
} 
Em Trágica obsessão, De Palma, tal como seu protagonista, sai "em busca do tempo perdido para recriar uma imagem morta". ${ }^{12}$ Optando por situar boa parte de sua reelaboração de Vertigo em Florença, e fazendo dessa cidade-museu, berço do Renascimento, o lugar de um encontro quase transcendental (o encontro de Courtland com o duplo fantasmático de sua esposa, ao som de um coral que confere à cena um ar de liturgia - brilhante contribuição de Bernard Herrmann, nesta que é a última trilha sonora assinada por ele antes de morrer), De Palma se comporta ao mesmo tempo como um cinéfilo e um historiador da arte. Assim como Courtland vai a Florença reencontrar - entre os templos e museus de uma época artística gloriosa, mas já esvaída - a imagem originária de seu amor por Elizabeth, que ele lá conheceu em 1948, De Palma “vai” a Vertigo reencontrar a cena traumática originária de seu amor pelo cinema, revisitando a imagem de um passado cinematográfico igualmente glorioso e morto. A Florença por ele filmada se apresenta então como "um imenso mausoléu povoado por figuras defuntas, e essas figuras são tanto as obras de arte como as personagens". ${ }^{13}$ Michael vaga pela cidade com o olhar afundado no passado e na tristeza da perda. Ele tem um olho na Florença de 1975 (Sandra, o presente) e outro na de 1948 (Elizabeth, o passado), da mesma forma que De Palma tem um olho na Nova Hollywood e outro na era clássica do cinema dos estúdios (de que Vertigo seria a quintessência). Cada imagem do filme exprime uma crise temporal: há uma decalagem entre o olhar do protagonista e o mundo por ele olhado, que reverbera diegeticamente a decalagem que está na origem do próprio filme. Todos os planos de Trágica obsessão expressam um investimento fantasmático numa imagem do passado, imagem mítica a ser recriada e desviada.

Um procedimento comum numa obra de releitura é a dilatação desmesurada de um motivo secundário, ou a supervalorização de um elemento que, na obra original, era apenas um detalhe. É assim que De Palma destaca um pormenor de Vertigo - a saber, o brilho nos olhos lacrimejantes de James Stewart no momento em que ele vê Madeleine retornando do mundo dos mortos no quarto do Empire Hotel - e o amplifica de tal maneira que esse brilho deixa de ser um efeito isolado e passa a dar o tom de todo o filme. Em praticamente todas as cenas de Trágica obsessão, Cliff Robertson está com aquela mesma expressão no olhar. A emoção incontida que, por sua própria intensidade transbordante, estava restrita, em Vertigo, a um único momento de clímax romântico, expande-se à escala de um filme inteiro. Todas as

\footnotetext{
${ }^{12}$ Ibid., p. 55.

13 Jean-Marie Samocki, "De l'origine du maniérisme au maniérisme de l'origine?", in Campan e Menegaldo (orgs.), Du maniérisme au cinéma, op. cit., p. 153.
} 
imagens de Trágica obsessão se deixam inundar por esse excesso, que sai, não obstante, do registro dramático para servir a uma premissa formalista e até mesmo abstrata.

Seguindo esse mesmo princípio de generalização/amplificação de um efeito que no filme original era usado apenas pontualmente, De Palma filma todos os planos de Trágica obsessão com o filtro difusor que Hitchcock reservara para momentos muito específicos de Vertigo (a exemplo da cena da visita à lápide de Carlotta, que é filmada com o mesmo tipo de filtro que será empregado sistematicamente por De Palma). Como resultado, o filme em sua totalidade ganha o aspecto de uma lembrança ou de um sonho; as imagens ficam impregnadas por uma falsa névoa que, além de sugerir uma visão mágica, descolada da realidade, suaviza os contornos, valoriza o potencial fotogênico dos rostos e intensifica o aproveitamento plástico da atmosfera.

Uma vez que Trágica obsessão dá prosseguimento à problemática hitchcockiana da relação espectador-imagem, as cenas em que De Palma se concentra sobre a imagem e o olhar a ela dedicado - e nas quais reconstitui, por tabela, o seu próprio encontro com Vertigo acabam sendo as mais reveladoras do filme. Além dos já citados momentos em que Michael observa Sandra na igreja - explicitando a dimensão religiosa da adoração do ícone feminino (já presente em Vertigo, mas mantida no subtexto) -, a sequência mais interessante, desse ponto de vista, é aquela em que Geneviève Bujold contempla um retrato de Elizabeth exposto na sala de estar da casa de Michael. De Palma retoma, no plano que introduz a cena, quase a mesma disposição do plano geral que inicia a sequência do museu em Vertigo:
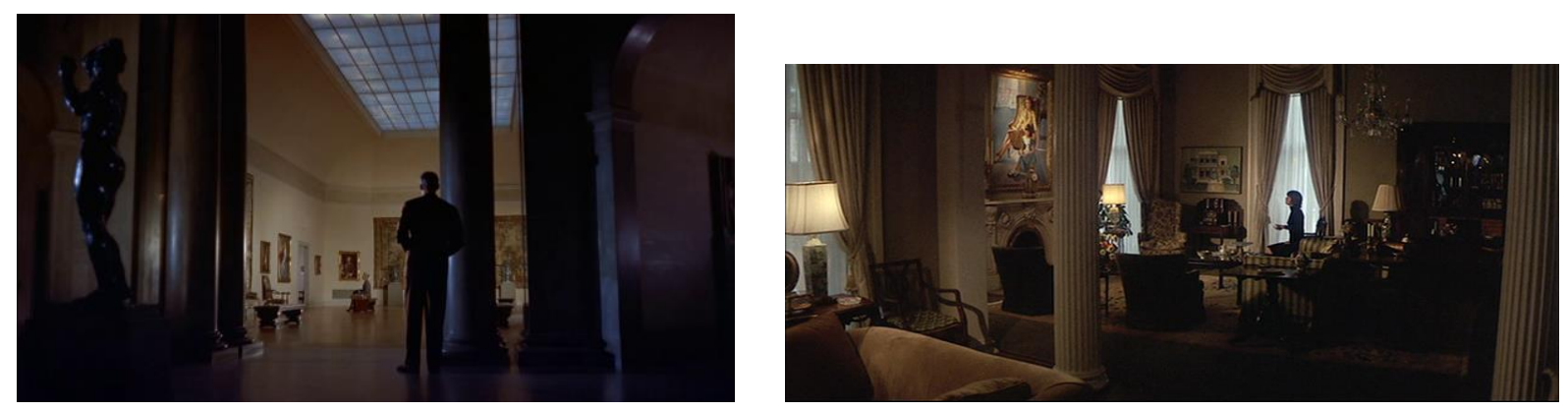

Tal como Madeleine no museu, Sandra é vista sentada, de perfil, hipnotizada pela pintura, rodeada por um ambiente luxuoso, num espaço delimitado por colunas. Mas De Palma, no decorrer da cena, irá transgredir a decupagem de Hitchcock: enquanto este só mostrava Madeleine de perfil e de costas, De Palma, depois de passar por essas etapas, acrescentará à cena um plano do rosto de Sandra, captando sua reação ao quadro. O espelhamento entre Sandra e Elizabeth atinge aí seu momento culminante. 

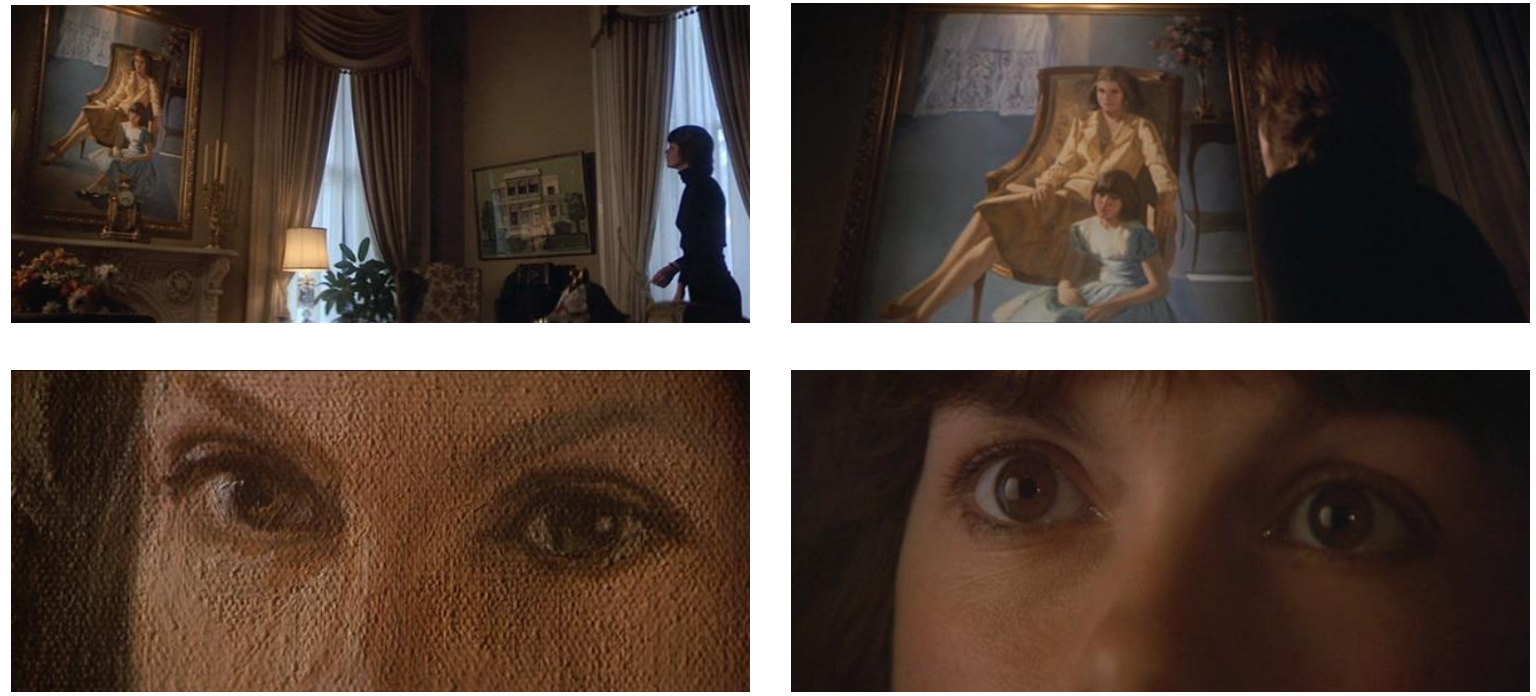

O retrato, portanto, não aparece mais num museu, e sim no espaço doméstico, o que certamente diz algo sobre o filme: De Palma está tentando trazer a imagem que o assombra para uma relação mais íntima, familiar. Mas algo da distância e da monumentalidade dessa imagem lá permanece, irredutível. Embora tente desmistificar a obra que está a "imitar", aproximando-se o máximo possível do coração secreto de Vertigo, De Palma não consegue esquecer o choque de tê-lo visto um dia numa tela gigante, sob os poderes deslumbrantes do VistaVision. ${ }^{14}$ Talvez seja isso o que o brilho nos olhos arregalados de Sandra representa.

\section{A contaminação pela imagem}

Florença, a cidade escolhida por De Palma para colocar em relevo o discurso metaartístico presente em Trágica obsessão, será também o palco da primeira parte de Síndrome mortal (La Sindrome di Stendhal, 1996), de Dario Argento.

A síndrome do título se refere a uma emoção demasiado forte provocada pelas obras de arte em determinados sujeitos hipersensíveis. A afecção se manifesta, por exemplo, quando o espectador de um quadro é invadido por uma sobrecarga de sensações tão intensa que, psiquicamente exaurido, ele desfalece. A psicanalista que definiu o quadro clínico da

\footnotetext{
${ }^{14}$ Processo de imagem usado pela Paramount em algumas produções dos anos 1950 (Vertigo foi uma delas). A peculiaridade do VistaVision consistia em fotografar a imagem num fotograma duplicado, com o filme correndo na horizontal, numa câmera especialmente projetada para isso. Por conta da maior área de negativo ocupada por cada frame, ganhava-se muito em definição e qualidade de imagem. Mas gastava-se o dobro da quantidade de negativo que o processo convencional empregava, e a câmera, por sua vez, pesava toneladas. Esses empecilhos, somados à descoberta de tecnologias menos custosas, fizeram com que o VistaVision fosse abandonado no final da década.
} 
síndrome, Graziella Magherini, tem seu livro citado pelo psiquiatra que cuida de Anna Manni (Asia Argento), a protagonista do filme. Anna sofre uma crise enquanto visita a Galleria degli Ufizzi, o principal museu de Florença, que conta com a mais extraordinária coleção de pinturas renascentistas. Logo que ela entra no museu, a câmera inicia uma série de travellings que a montagem picota alternando entre o olhar embasbacado de Anna e as pinturas e esculturas que se enfileiram pelos corredores. A câmera desliza pelo espaço, passa de uma sala para outra, aponta para o teto e gira vertiginosamente ao mostrar um afresco em contraplongée. Os cortes da montagem não interrompem a fluidez, pelo contrário: favorecem a experiência de movimento e passagem e intensificam o caráter imersivo da cena, inserindo na cadeia de planos a visão subjetiva de Anna, que "entra" cada vez mais nas pinturas. É o exato oposto dos longos planos rigorosamente fixos e frontais de Jean-Marie Straub e Danièle Huillet em Uma visita ao Louvre (Une visite au Louvre), de 2004: para Dario Argento, o espaço do museu solicita o deslocamento constante do observador, a mobilidade inquieta do olhar, como se todo quadro contivesse um movimento potencial à espera de ser ativado ou guardasse um efeito de anamorfose que só pode ser percebido se experimentados vários ângulos de visão, incluindo os mais obtusos e incomuns. Mesmo quando a câmera de Argento se detém sobre um quadro, a contemplação estática é rapidamente desvirtuada por um zoom ou uma panorâmica que recolocam a pintura em movimento e carregam o olhar para dentro de um espaço dominado pelas cores e as formas pictóricas. O museu é apresentado como um "caleidoscópio quase delirante, [...] um labirinto cultural". ${ }^{15}$

Na Florença de Trágica obsessão havia apenas uma imagem, uma única imagem que Michael perseguia como um maníaco; na de Síndrome mortal, há imagens demais, "e esse excesso é patológico", como afirma Jean-Marie Samocki num artigo em que compara os dois filmes. ${ }^{16}$ As imagens proliferam-se, avolumam-se ao redor de Anna e parecem querer devorála como plantas carnívoras, para incorporá-la à matéria plástica das pinturas. O som participa da confusão alucinatória que suga Anna para dentro do espaço pictural: diante de um quadro de Uccello, ela ouve os sons da batalha ali representada, os cavalos relinchando, os ruídos secos das flechas cortando o ar, os gritos de dor dos homens atingidos pelas lanças inimigas, tudo isso se misturando ao burburinho dos turistas que lotam o museu. Depois, Anna escuta o som do vento que é soprado por Zéfiro nos longos cabelos da Vênus de Botticelli. A câmera segue o trajeto do vento com uma panorâmica, endossando o desejo de movimento já figurado na pintura. A mesma sensação de movimento se propaga para outro célebre quadro de

\footnotetext{
15 Ibid., p. 158.

${ }^{16}$ Ibid., p. 152.
} 
Botticelli, A Primavera, que Anna observa num misto de assombro e deslumbramento. "As pinturas... elas pareciam estar flutuando", Anna dirá ao psiquiatra mais tarde. As pinturas vistas por ela no museu dos Uffizi, portanto, mostram-se vivas: dançam, vibram, flutuam no espaço, produzem sons.

É interessante que Dario Argento, nesse processo de emprestar movimento cinematográfico às imagens pictóricas ${ }^{17}$, passe justamente pelos dois quadros de Botticelli $(O$ nascimento de Vênus e A Primavera) que são analisados por Aby Warburg no famoso estudo em que ele identifica nessas pinturas não as figuras em repouso, estáveis, estáticas, que outros historiadores da arte (Winckelmann, Wölfflin) atribuíam ao estilo renascentista, mas exatamente o contrário, isto é, a representação intensa dos movimentos externos dos corpos e dos seus acessórios (vestes, cabeleiras). Warburg enxerga nos quadros de Botticelli personagens animadas de movimento sensual e voluptuoso, vestes agitadas pelo vento que revoluteia nos tecidos e nos cabelos, massas ondulantes, formas transitórias dignas das Metamorfoses de Ovídio. Ele procura demonstrar como a influência da arte antiga na pintura renascentista consiste, antes de tudo, no "tratamento dos acessórios animados" e na "mobilidade externa das figuras". ${ }^{18}$ Cotejando os quadros de Botticelli "com as correspondentes ideias da literatura poética e das teorias estéticas da época”, Warburg conclui que o conhecimento que então se tinha dos Antigos, ou melhor, "o que da Antiguidade 'interessava' aos artistas do século XV"19, era menos um repertório de posturas serenas do que uma forma de expressão do movimento que vai de par com um resgate do erotismo embutido nos antigos dramas mitológicos. ${ }^{20}$

Philippe-Alain Michaud interpreta assim as descrições de Warburg: “A figura não surge como uma entidade estável, mas parece nascer de um jogo de forças contraditórias que se encontram no limite externo do envoltório do corpo, para retomar os termos de Aristóteles, e não na automanifestação de sua presença imóvel". ${ }^{21}$ Nos contornos dançantes, na vibração das figuras dos quadros e desenhos analisados por Warburg, reproduz-se "menos a figura constituída do que a própria realidade da figuração, [...] o trabalho secreto da visibilidade". ${ }^{22}$ O que está em jogo é "representar a energia em ato", e se o artista do Renascimento revisita a

\footnotetext{
${ }^{17}$ A contaminação entre cinema e pintura começa já na sequência dos créditos iniciais, que mostra uma série de quadros de artistas e épocas diversos (de Caravaggio a Van Gogh, de El Greco a Monet, de Turner a Pollock...) desfilando verticalmente na parte direita da tela, como se fossem os fotogramas de um filme que está sendo projetado.

${ }_{18}^{18}$ A. Warburg, O Nascimento de Vénus e A Primavera de Sandro Botticelli, Lisboa: KKYM, 2012, p. 31.

${ }^{19}$ Ibid., p. 7.

${ }^{20}$ Ibid., pp. 59-60.

${ }^{21}$ P.-A. Michaud, Aby Warburg e a imagem em movimento, Rio de Janeiro: Contraponto, 2013, p. 77.

${ }^{22}$ Ibid., pp. 78-79.
} 
mitologia antiga, ele a encara menos como "conteúdo discursivo" do que como "pretexto para enunciar os movimentos de que uma figura é capaz". ${ }^{23} \mathrm{Um}$ dos pontos cruciais das reflexões de Warburg consistiria na noção de que o movimento, para vir à tona, exige a participação ativa do espectador. Numa série de anotações anteriores ao trabalho sobre Botticelli, Warburg já indicava, conforme demonstra Michaud, o papel ativo do olhar na impressão de movimento experimentada diante dos quadros: "Warburg chegou a propor que, por um exercício particular da atenção, o espectador podia substituir a causa externa que imprimia movimento às figuras". ${ }^{24}$ A importância de tal proposição não deve ser subestimada: o movimento é aí colocado como produto não da "disposição das figuras no espaço, mas da concatenação das imagens que desfilam no pensamento de quem olha"; trata-se, portanto, de uma ativação da imagem pelo olhar e pelo pensamento. "A partir de então, o movimento já não é o do objeto olhado, mas o do sujeito que olha. Não decorre mais da contemplação, mas da ação. O espectador deixa a recepção passiva para intervir na representação, reformulando a questão do movimento num novo grau de interioridade". ${ }^{25}$

Vale assinalar que o movimento de que fala Warburg não é da mesma ordem das ilusões cinéticas provocadas, por exemplo, pelas figuras da $O p$ art: nestas, a impressão de movimento é causada pela interação de padrões geométricos e elementos gráficos que perturbam o sistema sensorial humano e estimulam respostas involuntárias dos olhos e das partes cerebrais envolvidas na percepção visual. Nos quadros de Botticelli, diferentemente, o movimento das figuras depende de um fator psicológico, de um investimento afetivo e intelectivo do espectador, que põe a imaginação para trabalhar. Não se trata de uma ilusão de óptica, mas de uma realidade psíquica produzida pelas forças do imaginário.

Ora, no cinema, a ilusão de movimento - ou o atravessamento da imagem por essa pulsão de movimento perseguida desde os pintores da Renascença - exerce um impacto direto sobre a percepção, o que lhe confere uma força de "empatia" (para continuar falando em termos warburguianos) ainda maior que aquela testemunhada na pintura figurativa. Segundo Edgar Morin, o movimento, fator determinante na impressão de realidade própria da imagem cinematográfica, seria a pedra de toque da percepção objetiva responsável por estimular a participação afetiva do espectador. O movimento acentua a objetividade fílmica, a qual, por sua vez, acentua o encanto da imagem, seu coeficiente de fascinação. Somando-se ao poder de

\footnotetext{
${ }^{23}$ Ibid., p. 84.

${ }^{24}$ Ibid., p. 87.

${ }^{25}$ Ibid., p. 88 .
} 
convencimento da reprodução fotográfica das aparências, o movimento completa a "realidade corporal" da imagem: "As formas fornecem a sua armação objetiva ao movimento, e o movimento dá corpo às formas". ${ }^{26} \mathrm{O}$ movimento constitui, nessa lógica, o mais forte índice de realidade da imagem cinematográfica: "Há de fato uma lei geral da psicologia conforme a qual o movimento, desde que percebido, é em geral percebido como real, diferentemente de muitas outras estruturas visuais como o volume, que pode muito bem ser percebido como irreal mesmo quando percebido (é o que se dá com os desenhos em perspectiva)". ${ }^{27}$ Contudo, uma vez que a experiência do cinema é produto de uma dialética entre a "verdade objetiva" da imagem e a "participação subjetiva" do espectador, o movimento aqui em jogo não pode ser entendido apenas como o movimento exterior, aquele dos corpos móveis e do dinamismo imanente ao mundo filmado: ele deve ser entendido também como uma construção ativa por parte do espectador, "uma atividade afetiva, perceptiva e intelectiva". ${ }^{28}$

É neste ponto que Anna Manni, Warburg e o cinema se encontram para alinhar forças: a protagonista de Síndrome mortal - apanhada no vórtice desse psiquismo dinâmico que é o fundamento tanto da estética warburguiana como da experiência cinematográfica - coloca a pintura em movimento por intermédio do olhar e, é claro, da ação do pensamento; ela transforma as imagens sensíveis em imagens mentais, dando origem a um novo domínio visual que "emana de um fundo alucinatório" e implica "uma figuração do psiquismo e da interioridade" 29 de tal modo que não se possa distinguir o subjetivo do objetivo. ${ }^{30}$

Já demonstramos, no segundo capítulo, que a contemplação de uma pintura acompanhada ou não de um comentário sobre ela - é muitas vezes empregada num filme como pretexto para uma glosa sobre a relação do espectador com a imagem cinematográfica.

\footnotetext{
${ }^{26}$ E. Morin, O cinema ou o homem imaginário, Lisboa: Moraes Editores, 1980, p. 108.

${ }^{27}$ Christian Metz, A significação no cinema, $2^{\mathrm{a}}$ ed., São Paulo: Perspectiva, 1977, p. 21.

${ }^{28}$ Ibid., p. 25.

${ }^{29}$ J.-M. Samocki, art. cit., p. 157.

${ }^{30}$ Em rigor, não há em nossa vida psíquica separação original entre percepção objetiva e representação subjetiva, como Freud apontou: “[...] todas as representações mentais [Vorstellungen] se originaram de percepções e de fato elas são repetições [Wiederholung] destas últimas. [...] Assim, a oposição entre o subjetivo e o objetivo não existe desde o início. Ela somente se estabelece pelo fato de que o pensar possui a capacidade de novamente presentificar, através da reprodução no imaginar [Vorstellung], algo que já foi uma vez percebido, isto é, pode-se imaginar o objeto sem que ele precise estar presente no mundo externo" (Sigmund Freud, Escritos sobre a Psicologia do Inconsciente, volume 3: 1923-1940, Rio de Janeiro: Imago, 2007, p. 149). Sem temer um barbarismo conceitual, podemos dizer que o cinema, mesmo se o considerarmos em seu gesto mais elementar - o da captação/restituição, isto é, filmagem de um evento e projeção para uma plateia, não levando em conta efeitos de montagem e de amarração discursiva -, desfaz essa dualidade, ou pelo menos enfraquece seu sentido: na filmagem, com as escolhas aí implicadas (o ângulo da tomada de vista, a movimentação ou fixação da câmera, a composição do quadro etc.), a realidade dita objetiva já está sendo transmutada numa forma de representação. Um filme resulta de uma dialética entre um "projeto subjetivo" e "as formas constantes da percepção objetiva"; tanto para o realizador como para o espectador, o cinema é um processo, como diz Morin, "duplamente virado para a objetivação e para a subjetivação" ( $O$ cinema ou homem imaginário, op. cit., p. 111).
} 
Em Síndrome mortal, não é diferente: se Dario Argento dialoga com a pintura, é para refletir, concomitante e principalmente, sobre a situação espectatorial vivida no cinema. $\mathrm{O}$ que são esses "quadros que parecem flutuar" descritos por Anna, o que são essas pinturas que parecem estar vivas senão uma metáfora do próprio cinema? O excesso de que a personagem de Asia Argento sofre advém não somente da percepção sensorial, mas, sobretudo, da exacerbação de uma consciência projetiva que o cinema tem por hábito intensificar, entre outras coisas, através da ilusão do movimento.

No clímax da sequência do museu, após desmaiar perante o quadro A queda de Ícaro, de Pieter Brueghel ${ }^{31}$ (que mostra a personagem mitológica se afogando), Anna se transporta mentalmente para dentro da pintura, mergulhando nas águas do mar e atingindo o fundo, onde encontra um enorme peixe monstruoso e o beija na boca, numa distorção em chave grotesca da parcela libidinosa do seu envolvimento excessivo com as obras de arte. A entrada de Anna no espaço da pintura é figurada por uma fusão entre o quadro de Brueghel e uma imagem gerada por computador, que faz a "câmera" sobrevoar a superfície do mar e depois submergir. Dario Argento radicaliza o dispositivo hitchcockiano de hipnose/absorção da personagem feminina pela pintura: o quadro se revela uma máquina pulsional, quiçá "um ser vivo, uma matéria sensual" ${ }^{32}$ que envolve, desnorteia e até mesmo engole a personagem - e a vertigem, mais do que nunca, é uma vertigem de imagem. Anna realiza o sonho (já convertido em pesadelo) do fotógrafo de Blow up: entrar na imagem, nadar em sua substância, explorá-la com todo o corpo.

A psicanálise clássica, como aponta Gaston Bachelard (aludindo, inclusive, ao mito de Ícaro), associa o "sonho de voo" aos desejos voluptuosos e a "queda imaginária" aos medos primitivos $^{33}$ - simbolizações que certamente podem ser identificadas nessa cena de Síndrome mortal. Mas, em se tratando de Dario Argento, a passagem do voo ao mergulho, da leveza ao peso, do ar ao mar, não pode deixar de ser associada também a uma poética dos elementos que é uma constante em seu cinema, e na qual a água, como Thoret bem especificou, desempenha o papel de "substância-mãe". ${ }^{34}$ Nos filmes de Argento, a água é a matéria-prima dos pesadelos: ela evoca a ideia de uma infiltração e de uma circulação generalizada dos entes maléficos (sejam eles de origem real ou fantasiosa). Assim sendo, a maior parte das cenas em

\footnotetext{
${ }^{31} \mathrm{O}$ quadro de Brueghel, na verdade, encontra-se em Bruxelas, da mesma forma que A batalha de San Romano, de Uccello, visto em cena anterior, está conservado na National Gallery de Londres. Ou seja: o museu visitado por Anna é menos a Galeria dos Uffizi do que o museu imaginário de Dario Argento, onde originais e cópias, quadros locais e transplantes arbitrários são misturados num mesmo espaço, sem traço distintivo - afinal de contas, depois de filmados e reduplicados pela câmera de cinema, todos se tornam, de algum modo, reproduções.

${ }^{32}$ J.-M. Samocki, art. cit., p. 158.

${ }^{33}$ Cf. $O$ ar e os sonhos: ensaio sobre a imaginação do movimento, $2^{\mathrm{a}}$ ed., São Paulo: Martins Fontes, 2001.

${ }^{34}$ J.-B. Thoret, Dario Argento: Magicien de la peur, p. 68.
} 
que Anna tem um episódio da síndrome inclui de alguma maneira "o elemento aquático"35, que representa a fluidez e a transparência do Mal. Em uma dessas cenas, que acontece não mais no museu, e sim num prédio da polícia, Anna invade uma pintura de paisagem que tem como atrativo principal uma queda d'água:
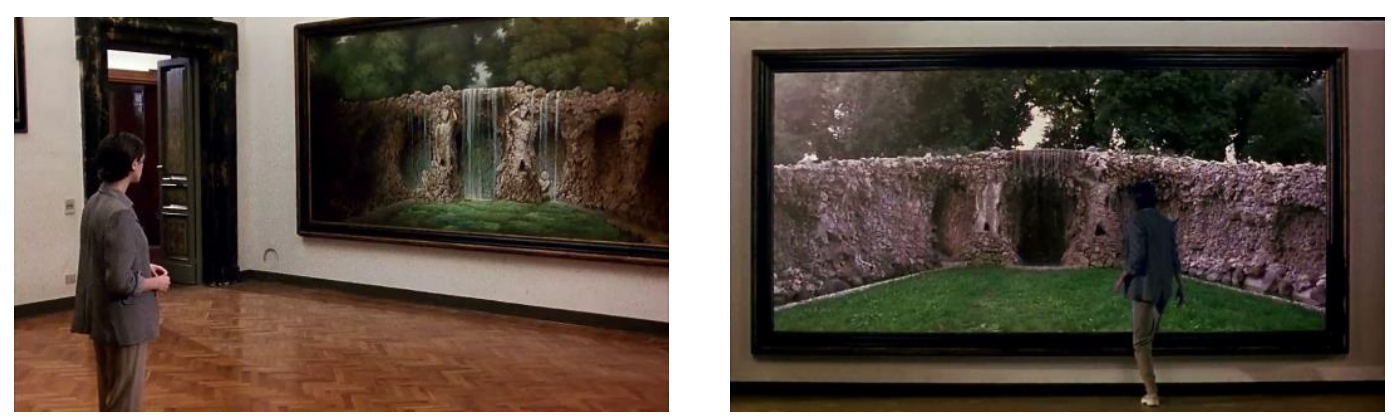

No momento em que Anna penetra na pintura, o quadro hiper-realista se troca por uma imagem da mesma paisagem, mas desta vez filmada e não mais pintada. Com isso, Argento transforma uma imagem que deseja e figura o movimento (a pictórica) em uma imagem que tão simplesmente é movimento (a cinematográfica). Ele explicita também uma concepção da imagem como limiar, como linha divisória entre dois espaços, dois regimes, dois mundos. A imagem não é mais uma mera superfície mimética que oferece ao espectador um mundo semelhante ao seu: ela é a fronteira fluida e instável que separa dois territórios regulados por leis distintas.

Anna não se transporta para o mundo da pintura de forma brusca, mas gradativamente. O primeiro estágio de sua incorporação à imagem é a aparição do seu reflexo no vidro protetor do quadro A Primavera, ainda na cena do museu. $\mathrm{O}$ rosto de Anna se funde à pintura, antecipando sua posterior imersão na imagem. Como a querer tocar seu próprio reflexo, ela levará o dedo ao quadro, disparando o alarme de segurança do museu.
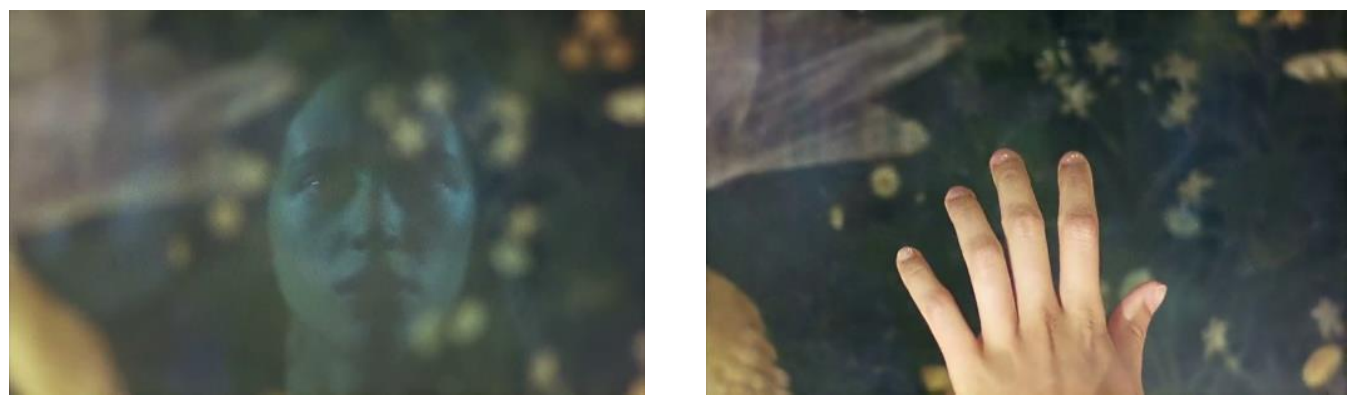

${ }^{35}$ Ibid., p. 69. 
Mais uma vez, vemos a personagem aquiescer a esse gesto de tocar a imagem, de senti-la com a mão, como Thomas fizera em Blow up e Marc repetira em Prelúdio para matar.

O reflexo do rosto de Anna no quadro de Botticelli é só a primeira de uma série de imagens especulares que ilustram, por etapas, o conflito de identidade que afeta a personagem. Detetive à procura de um assassino-estuprador em série, Anna irá se tornar, ela própria, uma das vítimas dele, assumindo, em seguida, a identidade do seu algoz, num processo de transferência de personalidade cujas sucessivas fases são descritas por diferentes imagens da protagonista em frente ao espelho. ${ }^{36}$ Numa dessas imagens, ela observa uma cicatriz em seu rosto, herança do episódio traumático:

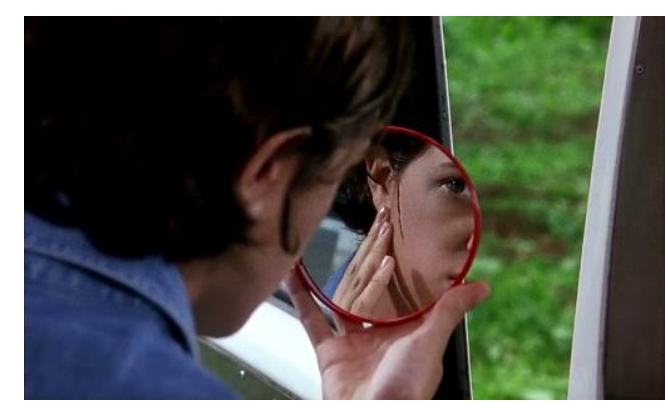

A cicatriz exterioriza, na verdade, um corte bem mais profundo, uma ferida psíquica que piora com o tempo. A cena narcísica foi fraturada: olhando-se no espelho, o sujeito não mais se reconhece por inteiro. Na etapa seguinte, Anna põe uma peruca loira, da cor do cabelo do assassino psicótico, como se, na incapacidade de exorcizar o demônio que a atormenta, ela resolvesse igualar-se a ele. Da imagem como processo de identificação, passamos à imagem como fator de contaminação, o que um plano rodado na saída do museu já prefigurava ao sobrepor o semblante do assassino ao da protagonista:

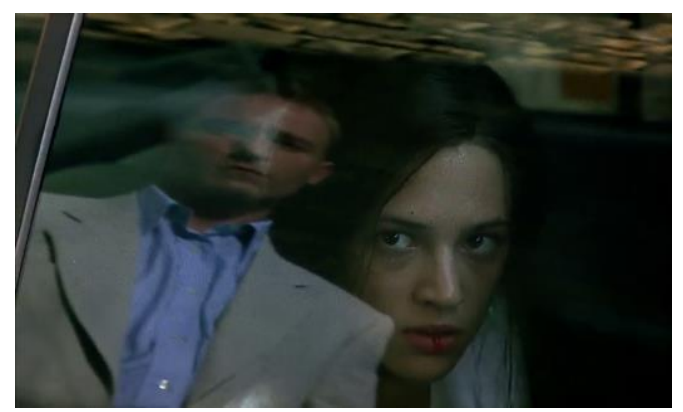

\footnotetext{
${ }^{36}$ Para uma análise mais detida da recorrência da imagem especular em Síndrome mortal, ver Frédéric Astruc, "Le miroir aux abysses", in Cinergon, n 19-20, 2010, pp. 198-211.
} 
O rosto do psicopata, refletido no vidro do carro, ligeiramente anamorfizado, encarna uma ameaça que é tanto externa quanto interna. Esse plano ameaçador confirma a vulnerabilidade de Anna às imagens exteriores e sela seu contágio psicopatológico com o assassino.

Outra contaminação pela imagem, tendo o museu como espaço-chave, ocorre em Vestida para matar (Dressed to kill, 1980), em que De Palma prolonga e refina sua empreitada de reescrita do suspense hitchcockiano. Desta vez, ele não recria inteiramente a estrutura narrativa de um filme (como era o caso em Trágica obsessão, praticamente todo construído em cima do roteiro de Vertigo), optando, antes, pela hipertrofia fetichista de algumas cenas tomadas isoladamente, e decalcadas de filmes diferentes (Vertigo e Psicose, sobretudo), o que dá ao filme um aspecto menos coeso e até mesmo esquizofrênico, quase uma junção arbitrária de sequências individuais, uma sucessão de performances de mise en scène virtuosísticas articuladas entre si por pretextos narrativos que obedecem menos a uma lógica romanesca de narração do que a um princípio formal de comunicação interna das imagens.

Como em Psicose, a personagem que protagoniza as primeiras cenas de Vestida para matar será assassinada com pouco mais de meia-hora de filme, levando a narrativa a sofrer uma radical mudança de ponto de vista. Essa personagem é Kate Miller (Angie Dickinson), dona de casa insatisfeita com o casamento. Numa sessão de análise, Kate conta para o seu psicanalista, o Dr. Robert Elliott (Michael Caine), que está frustrada sexualmente, pois o marido não a satisfaz na cama. Depois da consulta, ela vai ao Metropolitan Museum, onde flerta com um desconhecido. Os dois acabam passando a tarde juntos no apartamento dele. Enquanto se apronta para ir embora, aparentemente realizada em seu desejo, Kate resolve deixar um bilhete para o amante. Entretanto, ela descobre numa gaveta o resultado de um exame informando que o homem com que acaba de transar é portador de uma doença venérea. Ela sai transtornada do apartamento. Pega o elevador, mas, ao chegar ao térreo, percebe que esqueceu a aliança de casamento e decide voltar. Quando a porta do elevador se abre, Kate é assassinada por uma mulher (ou um homem travestido de mulher?) portando uma navalha. Liz Blake (Nancy Allen), uma jovem prostituta de luxo, chega ao elevador e vê, além do corpo ensanguentado de Kate, o reflexo do(a) assassino(a) no espelho. Liz foge apavorada. 
Ela ficará amiga do filho de Kate após conhecê-lo na delegacia, e ambos se tornarão os novos protagonistas do filme, conduzindo uma investigação paralela à da polícia.

A cena que nos concerne aqui é a do museu, que começa com Kate contemplando um retrato feminino. $\mathrm{O}$ enquadramento inicial e a postura corporal de Angie Dickinson remontam a um dos principais planos da cena que mostra Madeleine vendo o retrato de Carlotta em Vertigo. Fica claro, assim, que De Palma fará uma variação em torno da cena preexistente.
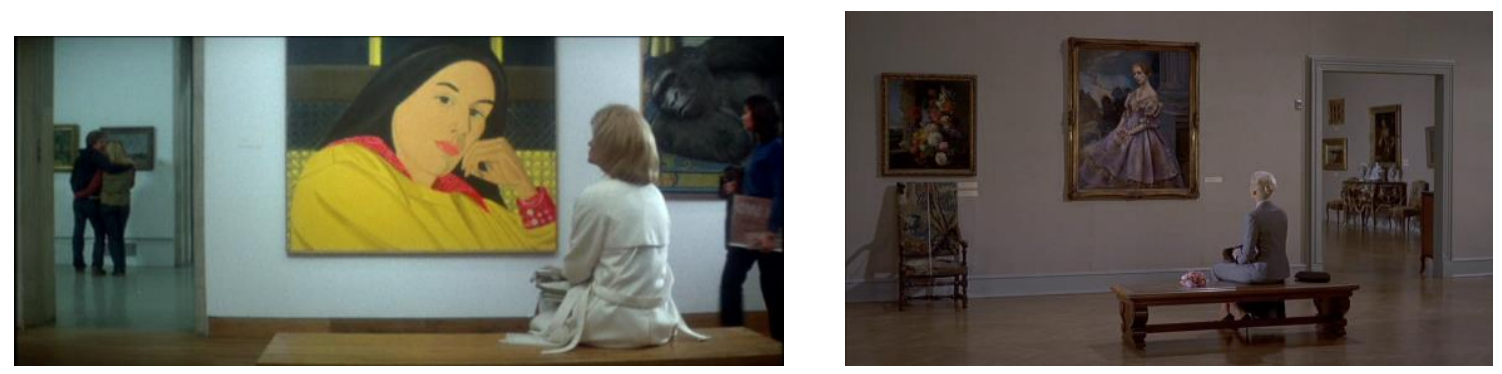

O comportamento de Kate, contrariamente ao de Madeleine, é dispersivo; ela não está hipnotizada pelo quadro como a personagem de Kim Novak estava no filme de Hitchcock. Kate divide sua atenção entre a pintura, algumas anotações banais que faz em sua agenda, o jovem casal de namorados na sala ao lado, uma criancinha asiática que se perde dos pais etc. O olhar compenetrado de Madeleine se troca por uma atenção frouxa, volúvel.

Outra mudança diz respeito ao ponto de vista: a decupagem faz o espectador compartilhar do olhar de Kate, ao passo que a cena de Vertigo era filmada da perspectiva de Scottie. Na cena do museu de Vestida para matar, em vez de enquadrar a personagem apenas de costas e de perfil, De Palma filma também seu rosto: a câmera se aproxima dela com um travelling que a circunda, até que um corte nos joga para um primeiro plano enquadrando-a de frente. Daí em diante, a decupagem contará com vários planos rodados do ponto de vista de Kate, ou seja, planos que mostram o que ela vê, "como se a cena original de Vertigo fosse agora percebida por Madeleine e não mais por Scottie". 37

A cena de Vertigo era propositalmente "frustrante": ela mostrava pouco, ou não mostrava o suficiente, e por isso provocava um desejo de ver mais, de ver por outro ângulo, por outro viés. Em Vestida para matar, De Palma infringe essas leis de contenção visual e procura completar as partes que "faltavam" na cena:

\footnotetext{
${ }^{37}$ L. Lagier, Les mille yeux de Brian De Palma, op. cit., p. 61.
} 
A imagem hitchcockiana é assim contestada e transformada. Aproximandose de sua personagem, De Palma responde à frustração da imagem inicial. [...] o cineasta fantasia aquilo que estava anteriormente ausente; ele propõe o contracampo da imagem de Vertigo. A fixidez e o ponto de vista único de Hitchcock são para De Palma elementos que se deve retrabalhar a fim de preencher a falta sentida na cena original. [...] Madeleine é sistematicamente vista de longe? De Palma se aproxima de Kate Miller. Madeleine é sempre vista de costas, por um ângulo de visão imutável? Brian De Palma filma sua personagem de frente e propõe a intervenção da montagem. ${ }^{38}$

Imiscuindo-se no olhar e no pensamento de Kate Miller (em alguns momentos, a tela se divide em duas permitindo que visualizemos, ao lado do rosto de Kate, suas imagens mentais, como a lembrança da luva que ela deixou cair, objeto-fetiche que funciona como pivô da cena), De Palma humaniza o ícone feminino e o despe de sua "aura fantasmática", desmistifica-o: a mise en scène de De Palma "nega o mistério de Madeleine. Lá onde esta parecia intocável e inacessível, Kate Miller parece abordável e vulnerável”. 39

Depois que o homem desconhecido senta ao lado de Kate e eles trocam olhares, começa um jogo de esconde-esconde por dentro do espaço labiríntico do museu, aqui caracterizado como uma dessas "arenas sociais" que, surgidas com a modernidade, introduziram na vida cotidiana a prática de "um consumo visual ambulante" motivador de novos "encontros e itinerários libidinais". ${ }^{40}$ Destaquei, na análise de Vertigo, a aparência asséptica e solene do museu filmado por Hitchcock, em contraste com o erotismo latente na relação de Scottie com Madeleine e mesmo na relação de ambos com o retrato de Carlotta. Em Vestida para matar, De Palma tira esse erotismo das entrelinhas e o traz para a dianteira da cena: o museu que ele filma é um espaço de flerte, namoro, encontros, uma experiência essencialmente libidinosa. O desejo sexual transbordante de Kate Miller ressoa não só no comportamento de alguns visitantes do museu (o rapaz que insiste em descer a mão até o traseiro da namorada, o homem que tenta passar uma cantada numa moça) como também nas obras (o olhar sedutor da figura feminina no retrato, os corpos nus da pintura pendurada na parede oposta). A cena de museu de Vestida para matar se assume, portanto, como uma cena erótica. De Palma escancara o que no filme de Hitchcock estava subentendido. O projeto estético de uma releitura, muitas vezes, é justamente o de preencher as lacunas da obra original, mostrar aquilo que ficara apenas sugerido em razão de uma censura ou por conta de uma simples questão de convenção. Com frequência, a tarefa da imagem de segundo grau é ativar as virtualidades da imagem preexistente (a cena do assassinato no elevador segue essa

\footnotetext{
${ }^{38}$ Ibid., p. 60.

${ }^{39}$ Ibid., p. 61.

${ }^{40}$ J. Crary, Suspensões da percepção, p. 146.
} 
mesma lógica: a dilaceração do corpo, a imagem da navalha ferindo a carne, é incluída dentro do plano, e não mais elidida pelos cortes da montagem como era na cena do chuveiro em Psicose, na qual Hitchcock agredia o "corpo do filme", dilacerando a montagem para não ter de dilacerar o corpo nu da atriz).

Conforme vimos, a cena de Trágica obsessão que remetia à cena do museu de Vertigo - ou seja, aquela cena em que Sandra contemplava o retrato de Elizabeth exposto na sala de estar da casa de Michael - mantinha uma reverência, uma distância, um respeito com relação à obra original. Em Vestida para matar, De Palma muda de atitude: seu intuito agora é transgredir, violar as regras, invadir a mise en scène de Hitchcock e subvertê-la.

Com aquele travelling para frente [no início da cena], De Palma parece mergulhar na imagem de Vertigo. Ele atravessa o espelho, penetra no interior da imagem original e se introduz simbolicamente na cena de Hitchcock. [...] Em Trágica obsessão, De Palma descrevia a principal vertigem do cinéfilo, uma vertigem temporal que reside no desejo de rever várias vezes o mesmo filme para tentar reencontrar a emoção original. Nessa cena de museu de Vestida para matar, De Palma descreve a segunda vertigem do cinéfilo, uma vertigem, desta vez, espacial, que conta com o poder de atração da imagem cinematográfica e com essa vontade irreprimível, essa fantasia que consiste em querer mergulhar [na imagem] para fazer um tour do outro lado. ${ }^{41}$

Assim como Síndrome mortal, portanto, Vestida para matar coloca em cena essa perigosa travessia da "fronteira" da imagem, essa viagem para o "outro lado". Tanto Argento como De Palma recriam, de forma exorbitante, a sequência do museu de Vertigo. Em ambos, o museu aparece como espaço caleidoscópico que estimula uma bulimia visual, um excesso de imagens em que o olhar forçosamente se perde. A diferença é que De Palma, à exceção do retrato feminino e do quadro hiper-realista de um gorila, dá pouca atenção às pinturas, que são filmadas de relance, literalmente en passant, enquanto Argento se detém sobre elas, escolhe a dedo os quadros que quer detalhar e citar, dialoga especificamente com as formas e os temas lá representados. Argento filma, de fato, as pinturas, ao passo que De Palma está "atraído pelo espaço do museu como puro labirinto". 42

Em Síndrome mortal, a personagem feminina não se contenta em somente contemplar os quadros: ela cai dentro de um deles. Dessa queda em águas perigosas (mais perigosas que as águas da Baía de São Francisco, onde Madeleine caíra e fora resgatada por Scottie), Anna

\footnotetext{
${ }^{41}$ L. Lagier, Les mille yeux de Brian De Palma, op. cit., p. 60.

${ }^{42}$ Cf. Stéphane Delorme e Jean-Marie Samocki, "Les maniéristes et la question du genre", entrevista com JeanFrançois Rauger em Au hasard Balthazar, n 2, maio de 1997, p. 31.
} 
Manni sai contaminada. O primeiro sintoma é um corte no lábio (ela bate com a boca na quina de uma mesa enquanto desmaia), lesão corporal que precede e anuncia o posterior distúrbio psíquico.

Já em Vestida para matar, quem realiza a travessia para o outro lado do espelho não é a personagem, mas o próprio diretor: o filme como um todo é um mergulho nas imagens de Hitchcock, uma exploração de cada ângulo, de cada detalhe deixado em suspenso. De Palma desmembra os esquemas espaciais e figurativos das cenas de Hitchcock de que se apropria. Isso se estabelece com maior nitidez na forma como ele refaz insistentemente não a cena do museu de Vertigo, mas a cena do chuveiro de Psicose. Há pelo menos três reprises da cena em Vestida para matar: o prólogo (que consiste num sonho erótico de Kate, filmado às raias da pornografia, e logo transformado em pesadelo violento), o assassinato no elevador (espaço exíguo cujo formato é o mesmo de um boxe de banheiro, e cuja porta tem a mesma função cênica da cortina do chuveiro de Psicose) e o epílogo (mais um pesadelo, agora vivido por Liz). Trata-se de espremer as imagens hitchcokianas e tirar delas toda a energia erótica, toda a violência pulsional, todos os conteúdos figurativos e psíquicos que ficaram recalcados, em suma, refilmar a cena-chave de Psicose de forma ainda mais perversa e violenta que Hitchcock.

Na cena do elevador, que é a mais complexa das três releituras da cena do chuveiro, a intrusão de uma terceira personagem além do assassino e da vítima é a contribuição fundamental de De Palma. Liz se soma ao dispositivo escópico da cena participando como testemunha. Sem chegar a entrar no elevador, vendo tudo de fora, ela se comporta como um espectador paralisado diante da imagem que vê na tela. Mas De Palma não quer manter esse espectador na posição apenas do voyeur: "Ele quer que ele participe, que ele entre na ação, que ele se molhe". ${ }^{43}$ Por isso, quando Kate estica a mão em suplício na direção de Liz, pedindo ajuda (ou convidando-a a participar da cena), Liz oferece sua mão em socorro, mesmo sob o risco de levar uma navalhada. Mas antes que as mãos possam se tocar, a porta do elevador se fecha. E um pouco antes que a porta se feche, a navalha do assassino cai no chão, bem no limite entre o elevador e o corredor do prédio (dir-se-ia entre o campo e o fora de campo), e Liz não hesita em apanhá-la. Testemunha ocular da cena do crime, ela agora carrega consigo um vestígio concreto dessa cena. Liz não apenas assistiu ao crime, mas participou dele ao ficar com a arma (de certo modo, trata-se de um comentário sobre a fantasia mor do fetichismo cinéfilo: guardar um pedaço da imagem, um objeto icônico que

\footnotetext{
${ }^{43}$ S. Delorme e Sylvie Encrevé, "La main ”, in Au hasard Balthazar, n” 2, maio de 1997, p. 26.
} 
sirva como signo substitutivo do filme). Em outras palavras, Liz contaminou-se com a cena, infectou-se com a substância da imagem (que o sangue na navalha representa). A dinâmica da contaminação e do contágio, que já havia marcado presença na cena anterior (como De Palma fez questão de enfatizar por meio do já mencionado exame médico que indica a doença sexualmente transmissível do parceiro de Kate), prova-se crucial para a lógica de construção do filme. A contaminação pela imagem, em Vestida para matar, é tão irremediável quanto aquela sofrida por Anna Manni em Síndrome mortal. Por mais diferentes que sejam as respostas de cada diretor, as perguntas que Argento e De Palma formulam a partir de Vertigo são as mesmas: e se o contato intenso com a imagem, a exemplo da relação de Madeleine com o retrato de Carlotta, implicasse realmente uma transformação da personalidade? E se a imagem, catalisadora de pulsões, agisse no espectador de maneira irreversível? E se houvesse de fato um vaso comunicante entre o mundo da imagem e o do espectador? Levantar essas questões já é admitir que o legado hitchcockiano consiste não apenas na mestria de uma forma narrativa do suspense, mas também numa reflexão sobre a imagem e os poderes, prazeres e perigos que ela engendra.

\section{O eterno retorno}

Extrapolando as premissas da cena do museu de Vertigo, Dario Argento criou a ficção de Síndrome mortal com base na ideia, tão mirabolante quanto fecunda, de entrar na pintura, de explorá-la como quem visita um espaço e não somente como quem examina visualmente uma superfície imagética. Em A hipótese do quadro roubado (L'Hypothèse du tableau volé, 1978), Raúl Ruiz desenvolve essa ideia por outro caminho, encenando a vertigem espacial da pintura-transposta-para-o-cinema mediante a técnica do tableau vivant, que consiste em fazer uma composição pictural ser encarnada por modelos vivos.

A vertigem filmada por Ruiz, na verdade, já se manifesta na contemplação de imagens pintadas, antes mesmo de aparecerem os primeiros tableaux vivants: logo no início do filme, a câmera percorre com um travelling lateral o gabinete em que se acha uma coleção de pinturas; num dado momento, uma das pinturas, filmada de frente, passa a ocupar toda a tela; a câmera parece ter se detido nessa imagem; lenta e sutilmente, porém, o quadro começa a mudar de figura, como se sofresse uma anamorfose; a imagem roda lateralmente, e somos inelutavelmente tomados pelo efeito vertiginoso de tal manobra, até percebermos que é a câmera que está se inclinando, saindo da pintura e indo para outra parte do gabinete. 

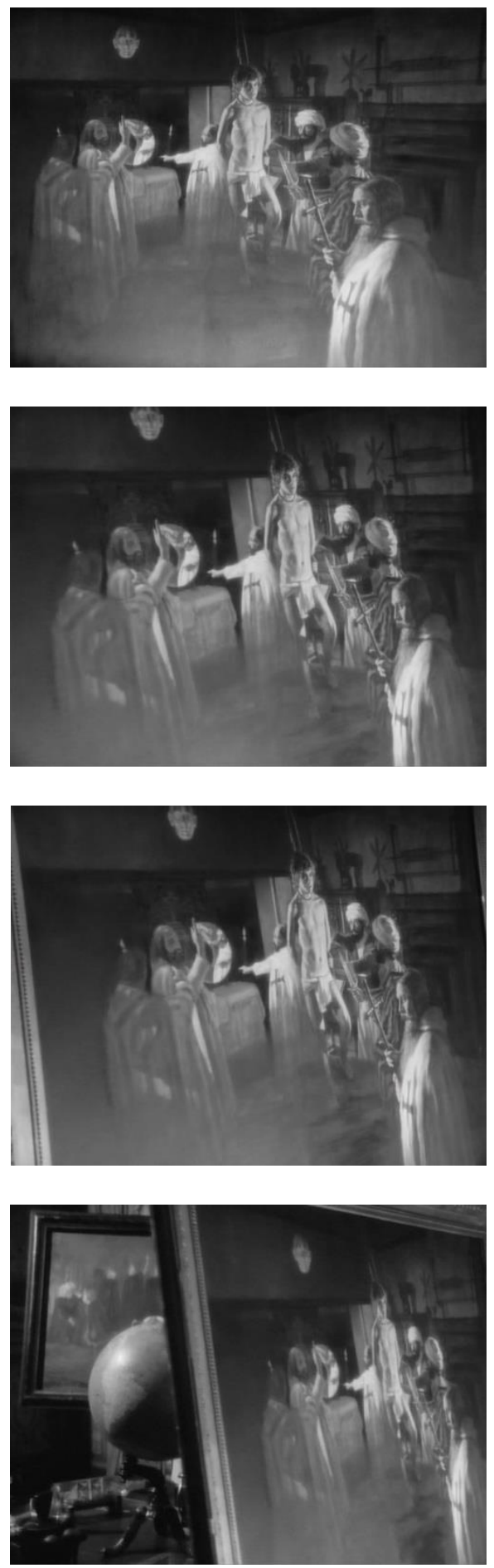

O simples deslocamento axial da câmera, em pleno travelling, confunde a natureza estática e bidimensional da pintura e cria um efeito plástico novo, que desnorteia momentaneamente a percepção. Esse plano questiona a relação entre pintura e cinema exprimindo ao mesmo tempo uma contradição e um encontro, uma disputa e uma cumplicidade. 
Amante dos jogos de anamorfose e de espelho, de distorção, reflexão e refração do visível, Ruiz se empenha em destituir o significante cinematográfico de qualquer pressuposto de transparência, objetividade ou imediaticidade. Para Ruiz, uma imagem nada mais é que a imagem de outra imagem, ou seja, toda imagem é mediada e codificada de alguma maneira, e o cinema não escapa a essa precondição. ${ }^{44}$ Nesse sentido, os tableaux vivants caem no cinema de Ruiz como uma luva, na medida em que se apresentam e se definem como imagem de uma imagem, representação de uma representação. Originalmente ligados às liturgias medievais, os tableaux vivants ficaram muito populares entre a segunda metade do século XVIII e o começo do século XIX, sendo a atração de salões mundanos, festas privadas, feiras e até mesmo palcos teatrais, já que "inúmeras peças de teatro faziam sua ação culminar na imobilização dos atores na disposição exata de pinturas célebres". ${ }^{45} \mathrm{Em}$ diversos de seus filmes, mas especialmente em A hipótese do quadro roubado, Ruiz emprega o tableau vivant como forma de salientar o aspecto antinatural e codificado da imagem. O próprio processo de significação se torna um ato em exposição, uma exibição virtuosa e artificiosa da retórica visual e sonora que estrutura a narrativa fílmica, a qual, deste modo, fica desprovida de sua suposta "inocência", ou do "mito desesperado de algum adamismo icônico". 46 O cinema, segundo Ruiz, não restitui às coisas seu sentido natural, sua presença "pura": ele é um espetáculo subjetivo que complica ainda mais nossa já problemática percepção do mundo.

Inspirado em um ensaio de Pierre Klossowski, A hipótese do quadro roubado se apresenta como um passeio da câmera de Ruiz por dentro de uma mansão em cujos jardins, cômodos e áreas secretas se acham reconstituídos, sob o modo de tableaux vivants, os quadros de um pintor, Tonnerre, que no final do século XIX foi alvo de grande escândalo. A visita é guiada por um erudito colecionador de arte e por uma voz off com a qual ele às vezes dialoga. Conforme explica o colecionador, a obra de Tonnerre que originou o escândalo consiste numa série de sete pinturas que estão conectadas por um fio secreto. Refazendo esse fio, é possível desvendar o motivo obscuro pelo qual os quadros geraram polêmica em sua época.

A hipótese de que uma mesma narrativa perpassa todos os quadros vêm da constatação do colecionador de que um dos quadros apresenta personagens num porão onde o sol penetra por duas claraboias opostas, o que sugeriria um universo com dóis sóis. Por uma passagem secreta, ele sai do gabinete e começa o tour pelos tableaux vivants, demonstrando que um dos

\footnotetext{
${ }^{44}$ Cf. Ruiz, Poetics of cinema, op. cit., p. 53.

${ }^{45}$ Valentine Robert, “Le tableau vivant chez Raoul Ruiz: l'extension de la perception”, in Décadrages, n. 15, outono de 2009, p. 38.

${ }^{46}$ Metz, A significação no cinema, op. cit., p. 184.
} 
dois raios solares se deve, na verdade, à reflexão do sol sobre o espelho segurado por uma Diana caçadora, personagem de outro tableau vivant, que se acha no jardim contíguo à mansão. O colecionador "tira daí argumentos para postular a primeira de suas hipóteses, a existência de uma ligação secreta entre todos os quadros". ${ }^{47}$

Porém, um dos quadros está faltando, o "quadro roubado". Logo, a cadeia está interrompida, esburacada, o nexo está quebrado. A montagem, a passagem de uma imagem à outra, acusa então uma falha, um hiato, um plano de ligação a menos. Assim, o filme coloca em evidência o fato de que "o espaço cinematográfico comporta vazios que são sistematicamente recalcados, "suturados"” pela montagem, pela organização significante do material filmado. ${ }^{48}$ Esse vazio, aqui, fica escancarado, pois efetivamente não pode ser recoberto, uma vez que a cadeia sofre uma interrupção. Se todos os quadros se conectam entre si, a ausência de um deles gera uma situação equiparável a um campo-contracampo em que um dos termos fosse subitamente suprimido, implicando um "campo cego", conforme a expressão de Bonitzer. ${ }^{49}$

O colecionador não se furta a visitar essa cena ausente e a estabelecer seu lugar na série (ela seria a quarta pintura das sete, ou seja, se situaria exatamente no meio da narrativa). O quadro roubado é representado por um cômodo vazio, desertado pelas figuras humanas. Uma vez que o colecionador nunca viu a pintura original, ele pode tão só imaginá-la. $O$ espaço vazio que substitui o quadro roubado é um desafio lançado à imaginação e à especulação, um espaço devotado aos investimentos fantasmáticos de toda ordem.

Ao mostrar o tableau vivant seguinte, que representa o quadro recusado pelo Salão de 1887 e desencadeador do escândalo, o colecionador se interroga: "Será que essa cena familiar aparentemente banal é realmente inocente? Podemos assegurar que ela está totalmente isenta de certos aspectos obscuros? Quem sabe se essa cena não nos revela aspectos inéditos do escândalo, imediatamente acessíveis para o espectador iniciado?”. O colecionador afirma que há algo de inquietante nessa cena da vida cotidiana, como se alguém, alguma das personagens do quadro tivesse acabado de cometer um "ato repreensível”. A partir de então, tudo parece corrompido (afinal de contas, uma imagem só é inocente até que se comece a interpretá-la). $\mathrm{O}$ colecionador busca a resposta num romance que, a seu ver, foi a fonte de inspiração do quadro. Procurando na narrativa de um texto literário a explicação da pintura e o significado de seu trabalho plástico, ele age como um iconólogo da linhagem panofskyana, isto é, um

\footnotetext{
${ }^{47}$ P. Bonitzer, Le champ aveugle, op. cit., p. 79.

${ }^{48}$ Ibid., p. 73.

${ }^{49}$ Ibid.
} 
historiador da arte para quem o sentido das obras de arte visuais reside, antes de tudo, nos textos que forneceram seus temas, motivos e conceitos. ${ }^{50}$

Mas Ruiz conta ainda com outra ferramenta de investigação: recriando as pinturas com os recursos da mise en scène cinematográfica, ele pode "decupar" os tableaux vivants; sua câmera invade as pinturas, aproxima-se das personagens, filma-as por novos ângulos e pontos de vista, ou seja, mostra-as de uma forma que difere daquela que consta no quadro original. Ruiz utiliza o tableau vivant como um dispositivo de mise en scène que permite uma "experimentação do ponto de vista". ${ }^{51}$ Trocando a platitude da imagem pintada por uma cenografia tridimensional, e libertando o observador da unidade imutável do ponto de vista pictórico, o tableau vivant traz a possibilidade de percorrer a cena, de descobrir os ângulos mortos, os pontos cegos, aqueles que na superfície bidimensional não podem ser acessados. $\mathrm{O}$ estatismo das poses é compensado pela mobilidade e a multiplicidade dos pontos de vista. $\mathrm{O}$ próprio colecionador entra nas pinturas e deambula entre os modelos. Ele chega a acender a luz para desfazer o claro-escuro de um dos quadros, tornando a iluminação homogênea e permitindo que se enxerguem melhor os detalhes e os gestos.

Em Blow up, o fotógrafo bem que gostaria de poder dar a volta nos "modelos" e ver a cena por outro ângulo, para tentar entendê-la melhor. Mas ele esbarrava na platitude da fotografia, no seu espaço achatado em duas dimensões. Em A hipótese do quadro roubado, Ruiz resolve esse problema transpondo as pinturas para o espaço tridimensional, o que lhe permite entrar nelas e variar o ponto de vista. No entanto, a série de quadros interrompida, esburacada em seu centro pela falta de uma das pinturas, remete ao mural de fotografias de Thomas em Blow up, também ele assombrado por imagens ausentes, hiatos. Ambos, o colecionador do filme de Ruiz e o fotógrafo do filme de Antonioni, estão condenados, em última instância, à eterna suposição e à dúvida.

\footnotetext{
${ }^{50}$ A interpretação dos quadros por parte do colecionador vai longe, e não é o caso aqui de colocá-la em pauta. Bonitzer faz um bom resumo das teses propostas pela personagem de Ruiz: "O filme, sob o pretexto da elucidação e da investigação, acrescenta por capricho obscuridades às obscuridades. A intriga se embaralha, as personagens se multiplicam, trata-se de um complô, de uma vasta conspiração da qual o pintor Tonnerre teria feito parte, enfim, uma espécie de franco-maçonaria oriunda da Ordem dos Templários e comungante em uma cerimônia secreta que teria sido, propriamente, o objeto do escândalo que o colecionador pretende elucidar: os quadros seriam uma alusão a essa cerimônia, implicando personagens do regime; depois, o colecionador descobre que os quadros - mas eles mudaram de natureza no curso da investigação - eram a própria 'cerimônia': eles celebram, pelo menos, como acabamos sabendo, o culto do 'Baphomet', demônio andrógino outrora adorado pelos Templários. O escândalo seria, em resumo, um tipo de missa negra à maneira de Huysmans. Mas o colecionador não se detém aí; uma vez acumuladas todas as hipóteses, e todas elas permanecem em suspenso em consequência do 'quadro roubado' (tudo o que resta de inexplicável provém da hipótese do quadro roubado), o colecionador é conduzido a uma vasta divagação que o leva a supor que o próprio culto do Baphomet seria, em si mesmo, apenas uma ressurgência do de Mitra, que é celebrado pelo conjunto das nações do mundo e que consiste em nada menos que 'a aniquilação geral'”' (Le champ aveugle, op. cit., pp. 76-77).

${ }^{51}$ V. Robert, art. cit., p. 40.
} 
Se grande parte dos filmes aqui analisados são ficções que brotam da contemplação de uma imagem ou de um conjunto de imagens, A hipótese do quadro roubado traz a peculiaridade de se debruçar sobre imagens de um tipo muito especial: imagens que são reproduções vivas de quadros pictóricos, colocando em jogo a própria natureza da representação cinematográfica e da percepção espectatorial:

O cinema é tomado, assim, como um espaço de falsos semblantes, de ilusões de óptica [trompe-l'oeil] de todos os gêneros. A cegueira do público em relação às molas secretas da maquinaria se torna o pretexto de um jogo, não somente com a perspectiva, como pode ser o caso na pintura, mas com todo o espaço do cinema, inclusive o espaço sonoro, inclusive o espaço off, o fora de campo onde se originam todos os equívocos, todas as inquietudes, todos os desejos que o cinema anima. ${ }^{52}$

À medida que dispõe a pintura no espaço, o tableau vivant engendra uma temporalidade paradoxal, habita uma dobra do tempo, pois se reconecta com o que estava na origem do quadro que ele está a reproduzir: a tensão física que os modelos do tableau vivant têm de suportar é a mesma tensão sentida pelos modelos que posaram para o pintor. Os modelos do tableau vivant empreendem um esforço enorme para manter a pose, mas é inevitável que eles se mexam em alguns momentos, mesmo que minimamente. Uma tensão atravessa o campo, uma luta silenciosa entre a imobilidade e o movimento. Os corpos ficam suspensos entre dois estados, dois instantes. A intensidade retesada nas poses dos modelos originais, as tensões de superfície congeladas pela pintura retornam agora nos modelos do tableau vivant. "Os primeiros modelos são, num certo sentido, reencarnados no tableau vivant, ou pelo menos é a tensão que se acha aí reencarnada. Em tais gestos reencarnados, alguns filósofos como Nietzsche e Klossowski viram uma ilustração, talvez até mesmo uma prova, do eterno retorno". 53

Ora, tal ilustração do eterno retorno já podia ser vista em Vertigo. Madeleine não é também uma espécie de tableau vivant, uma reprodução viva do retrato de Carlotta? Sentada no museu, contemplando a pintura, Madeleine não está posando para Scottie e restituindo, com a devida variação de contexto, a atitude corporal de Carlotta posando para o pintor? Imitando a pintura, Madeleine reencarna o modelo vivo que a pintura imitou. $\mathrm{O}$ círculo se fecha, ou melhor, a espiral entra em movimento. O devir-retrato da personagem de Kim Novak, além de levá-la a comportar-se como manequim e "embaralhar a linha de separação

\footnotetext{
${ }^{52}$ P. Bonitzer, op. cit., pp. 79-80.

${ }^{53}$ R. Ruiz apud V. Robert, art. cit., p. 40.
} 
entre o animado e o inanimado",54, evoca também essa ideia tão cara à filosofia nietzschiana, o eterno retorno, que está implícito na mise en scène do tableau vivant.

\footnotetext{
${ }^{54}$ P. Bonitzer, op. cit., p. 79.
} 


\section{V. \\ Da paranoia à pornografia}

\section{A lógica do complô}

Cenas como aquela de Blow up em que o protagonista analisa com lupa suas ampliações fotográficas se tornariam recorrentes no cinema dos anos 1960 e 1970 (as fotos sendo eventualmente substituídas por gravuras, filmes, livros, notícias de jornal ou outro tipo de documento). Tais cenas ilustram com precisão um período marcado por uma série de filmes que contestam o princípio de transparência sobre o qual se erguera o cinema clássico. O que está em crise, de modo amplo, é toda uma "ideologia do visível que supõe a adequação perfeita entre a percepção dos fenômenos e sua compreensão".

Além da influência exercida por alguns filmes em particular (Vertigo e Blow up à frente dos demais), há um variado conjunto de fatores envolvido nessa recorrência de narrativas em que a interpretação e reinterpretação obsedantes de uma determinada imagem acabam por acusar os limites da percepção e do olhar e por colocar em xeque o paradigma clássico da visão. Há de se destacar, dentre tais fatores, alguns eventos político-midiáticos que abalaram a posição do espectador e trouxeram à tona a questão da credibilidade das imagens (podemos encará-las como um testemunho fiel dos fatos ou teriam elas sido manipuladas antes de vir a público?). Já mencionei, no terceiro capítulo, o papel fundamental que as imagens do assassinato de JFK tiveram na reconfiguração dos padrões visuais da contemporaneidade. No livro 26 secondes: L’Amérique éclaboussée, J.-B. Thoret vai mais longe e articula a tese de que o filme de Abraham Zapruder - o cinegrafista amador que registrou em Super-8 a tragédia de Dallas - representou o corte epistemológico decisivo, o marco histórico do início de uma nova era no que tange a fabricação e a recepção das imagens. O simples fato de um pequeno filme amador ser o registro cabal de tamanha catástrofe já seria suficiente para torná-lo um documento histórico sem precedentes. Mas o

\footnotetext{
${ }^{1}$ J.-B. Thoret, 26 secondes: L'Amérique éclaboussée, p. 39.
} 
legado do filme de Zapruder vai além e diz respeito, sobretudo, à conflagração de um delírio interpretativo sem fim, de uma procura inesgotável pelos signos de uma espécie de realidade secundária (uma conspiração) que só se revelaria aos que se arriscassem a interpretar os pontos obscuros das imagens. O filme de Zapruder pedia uma investigação, uma montagem discursiva capaz de suprir suas ausências, de fazer surgir todas as respostas ocultadas no fora de campo (essa "zona letal" de onde vêm os tiros). Diante disso, a visão "tornou-se uma operação de análise, um pequeno exercício semiológico que submete as imagens ao teste da decodificação e da interpretação". ${ }^{2}$

Entretanto, esse filme de apenas vinte e seis segundos, mesmo depois de dissecado como nenhum outro filme jamais fora, de escrutado fotograma por fotograma, de ampliado e congelado para análise, não foi capaz de fornecer a resposta buscada por aqueles que se debruçaram obstinadamente sobre ele. As tentativas de se aproximar do acontecimento mediante a exegese de seu registro fílmico desembocaram em teses que, apesar das engenhosas deduções que propunham, não conseguiam dissipar a opacidade do evento tal como este aparecia no filme de Zapruder. A filmagem do assassinato de JFK resistia a toda tentativa de desvelamento; ela mostrava tudo, mas não explicava nada, e configurava-se, assim, como um "texto" inconcluso, um objeto aberto à pluralidade contraditória das inúmeras interpretações a que dava origem.

Não se pode ver essa pequena fita de vinte e seis segundos sem cair na vertigem da decifração e ficar dividido entre o valor documental daquilo que ela mostra e a ficção de sua trucagem. Para muitos, esse verdadeiro/falso plano-sequência contribuiu para o fim da inocência do olhar e a dúvida que iria planar sobre as imagens a partir de então. Ver a fita de Zapruder é ser levado, quase sem querer, a encarar o filme como um emaranhado de signos e a supervalorizar cada mínimo detalhe. ${ }^{3}$

De acordo com Thoret, o filme de Zapruder "pode retrospectivamente ser considerado uma das cenas primitivas do cinema americano pós-63". ${ }^{4} \mathrm{O}$ autor elenca uma série de motivos e tropos que, reaparecendo e variando de filme em filme, fazem parte do que ele designa como a "configuração Zapruder": o complô e o assassinato político, o found footage ou o filme amador como chave da investigação, o quadro cinematográfico como campo de mira, o horror gore da cabeça explodindo sob o impacto do tiro etc. Um gênero em particular, a ficção paranoica, sobretudo em sua variante mais revisitada pelo "cinema americano pós-63",

\footnotetext{
${ }^{2}$ Ibid., p. 40.

${ }^{3}$ Ibid., pp. 41-42.

${ }^{4}$ Ibid., p. 71.
} 
isto é, o thriller de conspiração política, reúne uma parte considerável desses motivos. Tratase de um gênero situado na extremidade do olhar problematizado por Hitchcock (em quase todos os seus filmes) e por Antonioni (em Blow up): aquele olhar que tenta despir as aparências, arrancar os véus da realidade cotidiana, como se houvesse significados profundos escondidos nas casualidades.

Frequentemente, o herói do filme de conspiração tem de enfrentar o obstáculo da incredulidade dos outros. Num primeiro momento, ninguém lhe dá ouvidos. Ele é o homem que sabe demais: passa por insano num universo de sã ignorância. O paranoico vê sempre por baixo das aparências os indícios de alguma outra coisa que não é evidente. Ele é o indivíduo que se faz perguntas o tempo todo, e que rebate tais perguntas com novas indagações, numa espiral infinita. "Para ler tanto o mundo quanto os textos de modo suspeito, é preciso elaborar algum tipo de método obsessivo". Assim, o paranoico leva às últimas consequências a prática da interpretação suspeita, remontando a um critério interpretativo ao qual Umberto Eco chama "semiótica hermética", que pautou toda uma tradição do pensamento ocidental, e "cuja sobrevivência pode ser rastreada ao longo dos séculos". 6

A interpretação paranoica estaria ligada, em primeiro lugar, à "superestimação da importância das pistas": "Antes de tudo, um excesso de perguntas leva a superestimar a importância das coincidências explicáveis de outras formas. O hermetismo da Renascença procurava 'sinais', isto é, pistas visíveis que revelassem relações ocultas". 7 O paranoico, assim como o pensador hermético, está em busca de uma verdade que imagina existir, mas cujo significado ainda lhe escapa. Uma vez que acredita estar diante de uma revelação sem precedentes, de uma verdade ainda inalcançada, ele tende a enxergar tudo como um conjunto de códigos, signos, hieróglifos, mensagens seladas, um mundo-esfinge pedindo para ser decifrado. Esse conhecimento secreto se opõe à compreensão superficial e postula que a verdade reside no que não é dito ou no que é dito de forma obscura, devendo ser compreendida "além ou sob a superfície de um texto". 8

As relações dedutivas labirínticas propostas pelo jogo interpretativo da semiótica hermética ressurgem com força na pós-modernidade, seja na crítica desconstrucionista, seja no thriller paranoico hollywoodiano dos anos 1970. Os filmes de complô e paranoia que pulularam naquela década estão impregnados da sensação de que tudo conspira, de que todos os detalhes da realidade circundante são signos de uma trama maquinada em sigilo, e que se

\footnotetext{
${ }^{5}$ Umberto Eco, Interpretação e superinterpretação, $2^{\mathrm{a}}$ ed., São Paulo: Martins Fontes, 2005, p. 57.

${ }^{6}$ Ibid., p. 53.

${ }^{7}$ Ibid., p. 59.

${ }^{8}$ Ibid., p. 35.
} 
espalha como uma teia enredando as personagens. São reincidentes, nesses filmes, as arquiteturas opressoras à maneira de Welles ou, com frequência ainda maior, os grandes espaços modernos esquadrinhados por geometrias rigorosas, onde os corpos aparecem minúsculos, como insetos aprisionados numa teia de aranha. Exemplos de tais enquadramentos podem ser encontrados em dois dos melhores filmes que exploraram a temática do complô na década de 1970, A trama (The Parallax View), de Alan J. Pakula, e A conversação (The conversation), de Francis Ford Coppola, ambos de 1974.

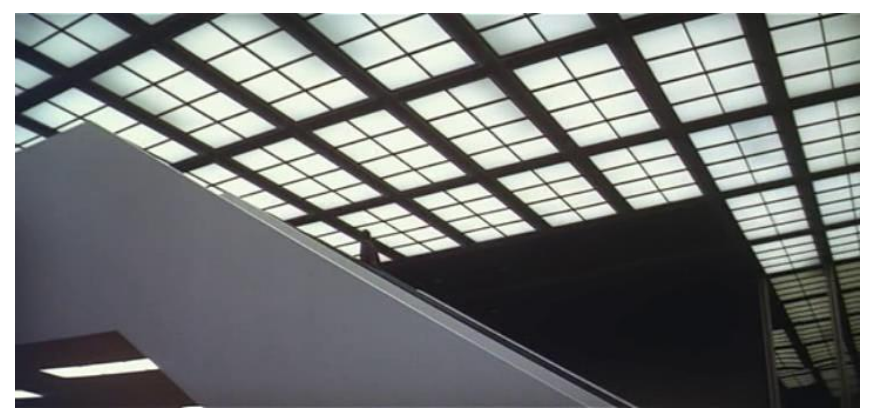

A trama (A. J. Pakula)

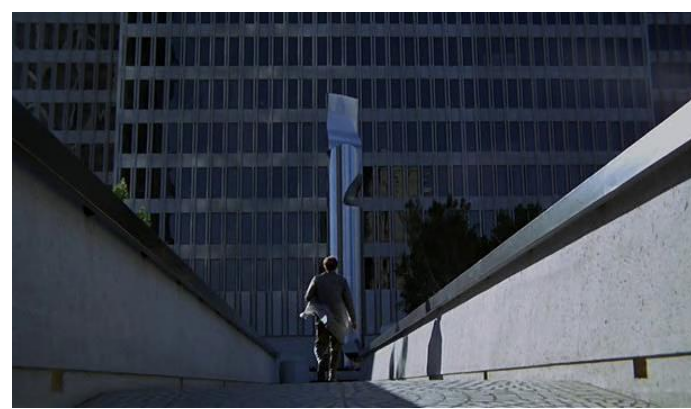

A conversação (F. F. Coppola)

Essa subdivisão geométrica do espaço confere ao universo dos filmes um aspecto ao mesmo tempo encarcerador e abstrato. O espaço se mostra preordenado por uma espécie de grelha ou de planilha, fazendo eco às redes de interconexões secretas, ao sistema reticular subjacente ao território visível. Se o elemento humano aparece oprimido ou perdido dentro dessa estrutura espacial, é porque de fato não é mais um homem (ou um grupo de homens) quem está no controle: o poder se espalhou por redes difusas, formando um sistema cujas diversas partes se acham interligadas por dispositivos tecnológicos que operam de modo tão eficaz quanto obscuro. Esse "poder oculto" não só se difunde pelas redes de telecomunicação e de trocas de informação como às vezes se confunde a elas. Desfaz-se "a dialética centro/periferia", que pressupunha "a existência de um poder centralizado e humano ao qual se poderia ascender por movimentos concêntricos. [...] O poder, outrora detido nas mãos de um grupo identificável ou de um único homem (o presidente, por exemplo), é dissolvido no interior de gigantescas networks". ${ }^{9}$ Em tal contexto, o complô não é mais obra de uma única mente perversa, mas de todo um sistema corrompido; "o complô se torna intransitivo, pois a identidade das entidades que compõem a rede importa menos que o mecanismo da conspiração". ${ }^{10} \mathrm{O}$ gênio maligno à moda languiana (Dr. Mabuse) ou hitchcockiana (Gavin

\footnotetext{
${ }^{9}$ J.-B. Thoret, 26 secondes: L'Amérique éclaboussée, p. 155.

${ }^{10}$ Ibid., p. 165.
} 
Elster) é trocado pela hipótese da rede: um mal sistêmico e de "geometria variável", "uma estrutura instável em perpétua metamorfose". ${ }^{11}$ Assim, no final dos anos 1960, a cartografia da ficção norte-americana muda "de uma concepção centrada e limitada do mundo para essa concepção multipolar própria da rede". ${ }^{12}$ As oposições binárias do cinema hollywoodiano clássico cedem lugar a um princípio de indiscernibilidade: civilização e barbárie, Bem e Mal, centro e periferia, establishment e contracultura se interpenetram e se confundem. À mitologia da expansão da fronteira e da conquista do espaço, crucial para o cinema americano clássico (principalmente no western, mas não só), substitui-se o realismo desencantado das grandes cidades contemporâneas, selvas de pedra atravessadas por vias e linhas entrecruzadas, onde o sentido de comunidade se trocou pela batalha do indivíduo contra o sistema (político, corporativo, midiático, militar...).

Se a paranoia se prova o combustível essencial dessa nova cartografia reticular, é justamente porque o pensamento paranoide, com a sofisticação do seu jogo hermenêutico, com a sua capacidade extraordinária de fazer conexões e encontrar analogias, é o único pensamento apto a restabelecer a coerência do sistema, a ligar e suturar os elementos disjuntos que constituem a rede. A teoria do complô se tornaria, desse modo, "o grande pensamento estruturante" 13 do cinema americano dos anos 1970.

Há ainda um outro elemento que esses filmes colocam constantemente em pauta: o ponto de vista, o lugar de onde se percebe uma imagem ou se interpreta um signo. Não são apenas as imagens que mentem; não são apenas os meios de comunicação que falseiam a realidade: nosso aparelho perceptivo também comete enganos. Dependendo da posição do observador, um evento pode dar vazão a diferentes interpretações, com conclusões díspares.

O plano inicial de A trama expõe essa questão com bastante clareza. A câmera enquadra um totem indígena que se destaca do azul intenso do céu. Por alguns segundos, tudo o que vemos é o totem sobre o fundo azul celeste. Até que um travelling para a esquerda, combinado com panorâmica, desloca o ponto de vista de maneira que possamos ver surgir, por trás do totem, o Space Needle, marco arquitetônico da cidade de Seattle. Uma interessante inversão se observa nesse plano: o totem indígena é quem encobre, a princípio, a construção moderna, e não o contrário, ou seja, o monumento que simboliza a população indígena massacrada para que fosse erguida a civilização cujo triunfo é ostentado pela torre - é trazido a primeiro plano, invertendo a lógica do recalque, que consiste em apagar do espaço social os

\footnotetext{
${ }^{11}$ Ibid.

${ }^{12}$ Ibid., p. 169.

${ }^{13}$ Ibid., p. 170.
} 
signos que acusem o etnocídio que marcou a conquista desse espaço. Antes do movimento da câmera, era o passado que encobria o presente, como a fazer um apelo de memória histórica, já situando o filme sob o signo de uma violência originária, fundadora. Após a mudança de eixo, o objeto se vê duplicado; a imagem se transforma num jogo de antíteses: atrás da escultura arcaica, cujos relevos talhados perfazem figuras antropomorfizadas, desponta o edifício high-tech, com sua escala sobre-humana e sua arquitetura futurista.
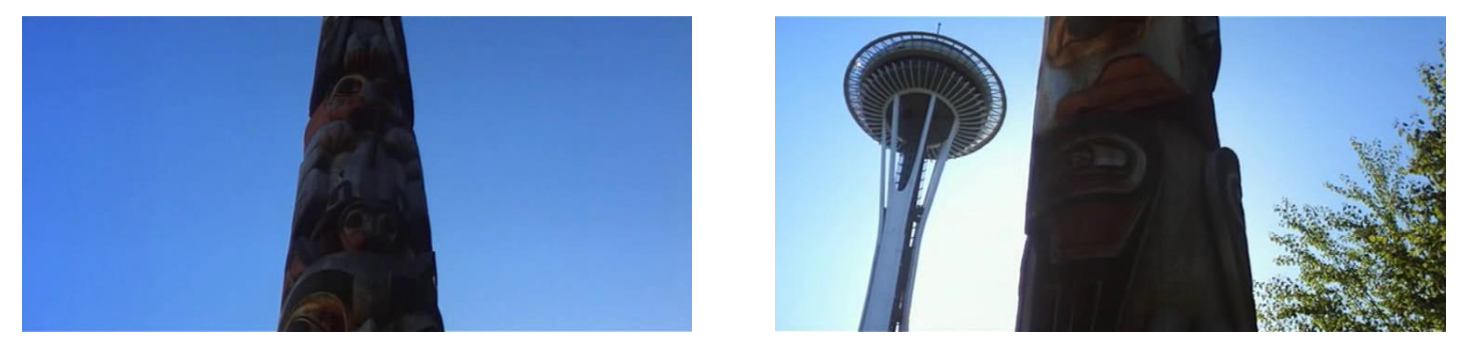

No alto daquela torre, um senador que pretende se candidatar à presidência será assassinado enquanto faz um discurso. Três anos depois do assassinato, o jornalista Joseph Frady (Warren Beatty) investiga o caso, motivado pelas sucessivas mortes (sempre em situações suspeitas) de várias testemunhas do acontecimento. Não tarda até que a investigação coloque a vida do próprio jornalista em perigo. Pakula exercita aqui a estrutura do filmedossiê, na qual mais tarde se tornaria um especialista, dirigindo filmes como Todos os homens do presidente (All the president's men, 1976) e O Dossiê Pelicano (The Pelican Brief, 1993). O diferencial de A trama, como seu título original já antecipa ("The Parallax View"), reside num "problema estritamente óptico": Pakula enfatiza "as relações conflituosas da visibilidade e do real" 14 , demonstrando como uma simples mudança de ponto de vista pode redimensionar completamente a compreensão de um fato. A "visão em paralaxe" do título ganha uma explanação já naquele plano de abertura do filme: a mudança do eixo óptico indica a diferença aparente surgida da observação de um mesmo objeto a partir de dois pontos de vista distintos. Entre o visível e o real, entre o objeto e sua representação, há sempre uma defasagem e uma incerteza que o intelecto não compensa senão parcialmente. É nessa dúvida, nessa fenda entre a realidade e a percepção, nesse intervalo entre o que uma imagem mostra e o que ela só mostrará depois (ou manterá escondido), enfim, é exatamente aí nessa zona de tensão entre dois pontos de vista possíveis sobre um mesmo evento que se infiltram todas as suspeitas e especulações que alimentam a "histeria hermenêutica" do paranoico. Em última análise, como disse Thoret, o impasse gerado por essa relatividade do ponto de vista, ou por essa quebra da

\footnotetext{
${ }^{14}$ Ibid., p. 120.
} 
confiança na realidade aparente, conduz à "entropia interpretativa" 15 , cabendo ao olhar, no fim das contas, fabricar sua própria visão da realidade, sintetizar o campo perceptual em que ela se dá, mesmo que ela só faça sentido dentro da lógica do complô, que deve ser entendida aqui menos como o padrão de engrenagem narrativa de um gênero cinematográfico do que como uma forma de interpretação do mundo. ${ }^{16}$

A reflexão sobre o ponto de vista e a questão da falibilidade da percepção também estão presentes de maneira determinante em A conversação, cujo plano de abertura, a exemplo daquele de A trama, já é a proposição de um programa interpretativo intrincado, o qual se complicará ainda mais com o decorrer do filme. A câmera começa mostrando um grande plano geral da Union Square, no centro de São Francisco, onde circula uma enorme quantidade de gente. A praça é vista de longe e do alto. Aos poucos, a imagem se desloca em zoom. Do plano aberto, vai passando a uma escala mais fechada. Os sons e ruídos que vêm da praça (as canções tocadas pelos músicos de rua, o burburinho das conversas, os passos na calçada, os latidos dos cães que passeiam com seus donos), a princípio longínquos, vão aumentando de volume em sincronia com o afunilamento do zoom. Como Michael Snow fizera em Wavelength, Coppola reemprega a estrutura do plano-olhar hitchcockiano, mas com um acréscimo: o fechamento progressivo do campo visual é acompanhado por um movimento de aproximação do ponto de escuta, ou seja, trata-se não apenas de um zoom óptico como também de um zoom sonoro. Afinal de contas, o mote da cena é a gravação de uma conversa. Em dois prédios próximos, conforme o espectador ficará sabendo posteriormente, técnicos de som apontam microfones de altíssimo alcance na direção do alvo da gravação, isto é, um casal que deambula pela praça. Um terceiro homem da equipe de som encontra-se lá embaixo, onde procura ficar perto do casal para captar a conversa com o microfone que carrega disfarçado. Sendo assim, a pista sonora correspondente a esse primeiro plano do filme é composta de uma soma de registros captados a partir de posições diferentes - ao contrário da imagem, que consiste numa única tomada feita de um só local (se bem que o enquadramento varie por conta do zoom e de panorâmicas). No desenrolar daquele plano-sequência, portanto, Coppola convida o espectador a penetrar na imagem pelo espaço sonoro, questionando e estratificando a unidade do ponto de vista por intermédio da multiplicidade do ponto de escuta.

$\mathrm{Na}$ medida em que o movimento óptico nos aproxima da praça, a câmera parece se interessar pelas atitudes de um mímico que imita as pessoas. O mímico vai para perto de um

\footnotetext{
${ }^{15}$ Ibid., p. 133.

${ }^{16}$ Ibid., p. 138.
} 
homem de sobreveste cinza, que bebe café ao lado de uma árvore enfeitada para o natal. Percebendo-se imitado, o homem começa a andar para se desmarcar do mímico, que ainda o persegue por alguns metros, tal uma sombra, até desistir dele. A câmera permanece focalizando o homem de cinza enquanto ele se distancia. Esse homem é Harry Caul (Gene Hackman), um brilhante engenheiro de som, ex-agente da CIA que agora trabalha em sua própria firma particular (a personagem de Hackman é inspirada em Hal Lipset - creditado no filme como "consultor" -, o encarregado de analisar o conteúdo das escutas na investigação do escândalo de Watergate). Harry foi contratado por um megaempresário que quer registrar a conversa de sua esposa adúltera com o amante. Quando a câmera se imiscui pela primeira vez entre os transeuntes da praça, diversos fragmentos de diálogos aleatórios preenchem a pista sonora antes que se consiga escutar a conversa do casal, a qual se mistura a uma massa caótica de ruídos. O diálogo é perturbado às vezes por algumas falhas e interferências na captação do som, o que demonstra que ouvimos o casal através do ponto de escuta dos técnicos (mais precisamente, da central de som, localizada num furgão estacionado do outro lado da rua). "O diálogo que Harry Caul e sua equipe tentam captar é incerto, impreciso, incompreensível. Ele oscila entre o audível e o inaudível, forma um fluxo modulável, marcado por pequenos segmentos, por fragmentos capturados no voo". ${ }^{17}$ O casal, já desconfiando de que está sendo vigiado, anda em círculos, pois assim minimiza as chances de alguém gravar sua conversa. Mas Harry contorna essa dificuldade por meio da tecnologia e da sagacidade. "Seria legal saber sobre o que eles estão conversando", diz o assistente de Harry. "Não ligo a mínima para o que eles estão falando. Tudo o que eu quero é um bom material de gravação [a nice fat recording]", Harry responde com um mau humor que voltará em outras cenas do filme - ele só tem ouvidos para a qualidade técnica da gravação.

O material captado nessa cena será levado para o estúdio de Harry, onde ele limpa, filtra, equaliza, retrabalha o som do diálogo para entregá-lo a quem encomendou o serviço. Quando vai realizar a entrega, contudo, descobre que o empresário não se encontra no escritório. Harry se recusa a deixar a fita magnética com o assistente do empresário, que o adverte a não se meter na história daquela gravação. Intrigado por essa advertência, Harry leva a fita de volta para o estúdio e começa a analisá-la com mais atenção. Ele nota que uma das falas do homem permanece encoberta pelas impurezas sonoras, abafada por distúrbios de gravação e ruídos de ambiente, além do batuque africano de um conjunto de músicos. Com o auxílio de seu moderno equipamento, consegue isolar a faixa que contém o registro da fala do

\footnotetext{
${ }^{17}$ Iannis Katsahnias, Francis Ford Coppola. Paris: Éditions de l'Étoile/Cahiers du cinéma, 1997, p. 143.
} 
homem: "Ele nos mataria se tivesse a oportunidade [He'd kill us if he got the chance]". A partir daí, Harry se convence de que aqueles nacos de diálogo enunciam, em sua própria forma banal e desconexa, um segredo revestido de fatalidade, que põe em risco a vida do casal. É o início de sua odisseia no inesgotável mundo da paranoia. O que antes era uma sucessão nebulosa de palavras quaisquer, sem nenhum significado digno de maior atenção, reagrupa-se agora em torno de um possível drama latente: a conversação dispersiva e vazia pode ser uma narrativa de suspense disfarçada como diálogo superficial. Estariam o homem e a mulher falando em códigos? Se, num primeiro momento, o interesse de Harry naquela gravação era apenas técnico/profissional, depois que o tema "morte" entra no diálogo, ele se envolve moral e emocionalmente. O projeto existencial de Harry era evacuar da sua vida todo e qualquer fator humano, investir na execução técnica do seu trabalho e não se envolver demais com as pessoas. Mas a descoberta que faz (ou pensa fazer) o desvia desse projeto. Harry "contrai o pior dos vírus: a curiosidade". ${ }^{18}$ Ele aciona a engrenagem hermenêutica que o levará à angústia e ao desespero. Seu papel na "rede" era o de funcionar como simples via de passagem e filtragem (tecnológica, e não ideológica) da informação. Agora, porém, ele se vê em posse de uma informação que não consegue - ou não pode - passar adiante. Ou seja, ele se vê em posse de um segredo. "O que é um segredo senão uma informação que possuímos e os outros não?"19 Uma vez que a informação é retida, que não é transmitida a um destinatário, ela fica sendo remoída ciclicamente. Harry mergulha no conteúdo da conversação, ouve a fita dezenas de vezes, reinterpreta cada palavra, isola cada sinal, em suma, faz com uma gravação sonora aquilo que o protagonista de Blow up havia feito com uma fotografia, ou seja, uma varredura minuciosa. Coppola estabelece uma correspondência direta com o filme de Antonioni. Embora tenham em mãos materiais distintos, os protagonistas de A conversação e Blow up se encontram, no fundo, na mesma situação: eles manipulam, espremem, torcem um registro documental da realidade (sonoro num caso, fotográfico no outro) até conseguir extrair dele uma ficção, um segredo, uma trama que em ambos os filmes se prova uma história de assassinato e complô.

Como acontecera com o fotógrafo de Blow up, Harry esbarra num engano. Ao ouvir a frase em que surge o assunto do assassinato, ele põe a ênfase na palavra errada. Harry entende: "Ele nos mataria se tivesse a oportunidade [He'd kill us if he got the chance]". Mas o correto seria ouvir: "Ele nos mataria se tivesse a oportunidade [He'd kill $\underline{\text { us }}$ if he got the chance]". Esse simples deslocamento da entonação muda absolutamente tudo: o homem não

\footnotetext{
${ }^{18}$ J.-B. Thoret, 26 secondes: L'Amérique éclaboussée, p. 160.

${ }^{19}$ Ibid.
} 
está tentando dizer para a amante que o marido dela planeja matá-los, e sim que eles estão certos em agir antes dele, em se antecipar. Em outras palavras, ele está ratificando algum plano de matar o marido dela antes que este tenha a oportunidade de fazer o mesmo contra eles. Portanto, se havia um complô em andamento, era para assassinar o empresário e não o casal. Quando Harry percebe seu engano, já é tarde.

Mais uma vez, o trabalho de Harry o põe em contato com a morte. No passado (um passado que ele prefere esquecer), três pessoas foram mortas por causa do conteúdo de uma de suas gravações. Ele carrega o peso dessa culpa. Por conta de seu trabalho, baseado na tecnologia de ponta em matéria de som, ele parece não conseguir escapar a uma associação indesejada com a morte. Isso demonstra uma visão negativa da tecnologia: "tal como encarada pelos filmes de complô dos anos setenta, [a tecnologia] não serve mais ao indivíduo, mas o instrumentaliza". ${ }^{20}$ Ela é vista com desconfiança pelo cinema americano daquele período, que estabelece "uma límpida equivalência entre a tecnologia e a morte". ${ }^{21} \mathrm{Em} A$ conversação, esse vínculo letal do homem com os aparatos tecnológicos aparece já nos primeiros minutos de filme: no alto de um prédio, tal um atirador de elite, o técnico de som aponta seu equipamento na direção do casal, que é visto por ele através de um dispositivo óptico exatamente igual à mira de uma arma de precisão. A associação entre vigilância, tecnologia e morte não poderia ser mais explícita:
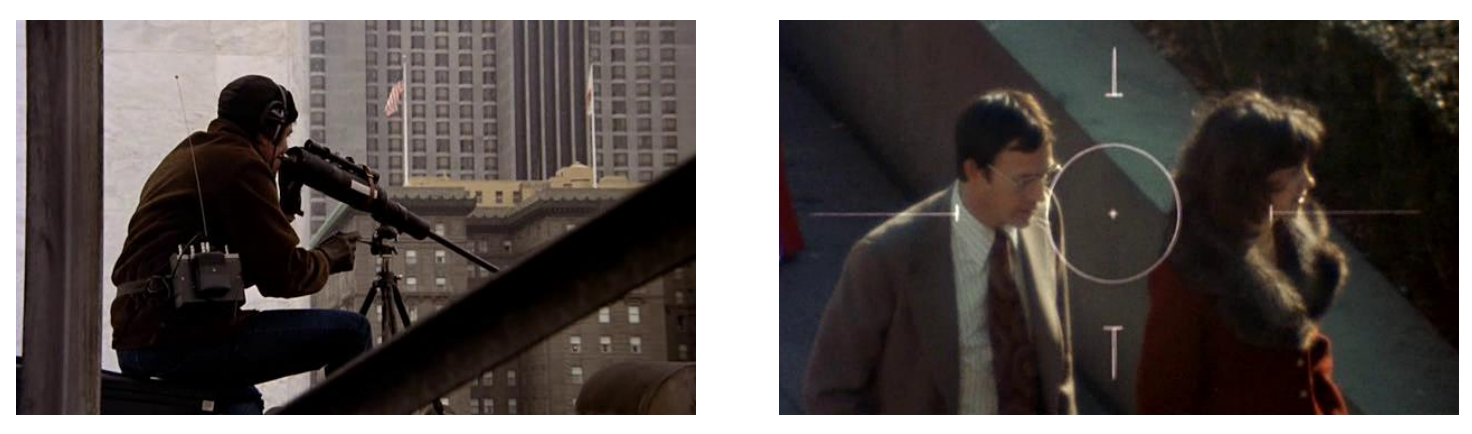

A morte acompanha a personagem de Gene Hackman desde a infância, antes mesmo de seu envolvimento com o mundo da tecnologia. Na cena em que Harry tem um sonho, ele encontra a moça da gravação numa paisagem com neblina e conta para ela um trauma de infância: quando tinha cinco anos, seu pai o apresentou a um amigo; sem mais nem menos, Harry deu um soco com todas as forças na barriga do homem, que morreria um ano depois. $\mathrm{Na}$ cabeça dele, aqueles dois fatos estariam inexoravelmente conectados, numa relação de

\footnotetext{
${ }^{20}$ Ibid., p. 155.

${ }^{21}$ Ibid., p. 154.
} 
causa-efeito que, embora possa ser vista como improvável ou até mesmo absurda por um adulto, na mente de uma criança soa perfeitamente plausível. Toda vez que seu trabalho coloca em risco a vida de alguém, é como se ele visse aquele trauma e aquela culpa retornarem, reafirmando sua inevitabilidade.

$\mathrm{Na}$ cena mais significativa do filme, Harry vai ao quarto de hotel em que o crime supostamente teria ocorrido. Ele revista o espaço, procurando por indícios do crime, ou melhor, querendo não achar tais indícios, para poder acreditar que tudo é uma ilusão, que nenhum mal aconteceu. Ele entra no banheiro da suíte, que está limpo e higienizado, de uma brancura quase impecável. A cena alude a Psicose: é como se Harry visitasse o banheiro do Bates Motel logo depois de Norman tê-lo limpado sem deixar nenhum rastro do assassinato de Marion Crane. Harry fecha uma torneira da qual a água ainda gotejava. Em seguida, leva a mão ao ralo da banheira, constatando que está molhado. Mas não há nada ali que acuse um assassinato. Quando já se prepara para ir embora, resolve checar o vaso sanitário. Ao apertar a descarga, vê surgir do fundo da privada uma mancha de sangue. Sob o olhar aterrorizado de Harry, a mancha cresce, vem à tona; o sangue transborda da privada, como um mal subterrâneo que agora aflora e contamina todo o espaço. É o retorno do recalcado, ou ainda, a irrupção do obsceno, para voltarmos àquela definição da obscenidade ${ }^{22}$ como o ressurgimento indiscreto de uma cena traumática, de um saber antigo, de uma imagem incômoda ou até mesmo repulsiva, que a consciência lutava para manter distante. Os dejetos, os excrementos que a descarga manda para um espaço off - para o fora de campo - retornam e se impõem por todo o campo. Há um conjunto de elementos que aí regressam: a memória cinéfila de uma cena hitchcockiana incontornável enquanto referência; a consciência histórica de duas décadas assombradas (assassinatos de JFK, Robert Kennedy e Martin Luther King, Guerra do Vietnã, Watergate); as lembranças traumáticas de Harry. Coppola articula, assim, o trauma coletivo (os crimes políticos) à psicologia individual (o invencível sentimento de culpa que remonta à infância de Harry Caul). A cena do banheiro apenas condensa, e aprimora em termos de efeitos visuais, a lógica que está na base do filme, e que já era trabalhada desde o primeiro plano: aproximando-se de uma cena aparentemente anódina, de um quadro aparentemente inofensivo, percebe-se o elemento destoante que aponta para uma outra realidade, a qual possui significado radicalmente diferente.

${ }^{22}$ Ver capítulo 3, pp. 188-189. 
Brian De Palma, para quem as imagens da morte de Kennedy constituíram um ponto de partida tão determinante quanto os filmes de Hitchcock, também fez um thriller de complô político em que o protagonista é um especialista em som. O filme em questão é Um tiro na noite (Blow out, 1981), e seu herói é Jack Terry (John Travolta), o encarregado dos efeitos sonoros de uma produtora de filmes de terror vagabundos sediada na Philadelphia. Enquanto grava sons noturnos numa ponte, Jack registra, por acaso, um acidente de carro. Depois de ver o carro perder a direção e cair no rio que corre sob a ponte, ele nada até lá e salva a moça que encontrou ainda viva. No hospital, descobre que o homem que conduzia o carro, e que morreu no acidente, era o governador, futuro candidato à presidência. Um agente do governo se aproxima de Jack e tenta convencê-lo a manter sigilo quanto à existência da garota no carro. $\mathrm{O}$ agente afirma que quer proteger a família do político de prováveis constrangimentos. Jack resiste, mas acaba concordando em manter silêncio. Em seguida, vai visitar a moça em outra ala do hospital. Ela se chama Sally e, como Jack descobrirá mais tarde, é uma call-girl, uma garota de programa de luxo.

Na noite do acidente, Sally (que é interpretada por Nancy Allen) pede que Jack a tire do hospital e a leve para algum lugar que não seja sua casa. Eles vão para um motel. Sally cai rapidamente no sono, e Jack decide ouvir o material sonoro que captou. De Palma reconstitui, então, a cena em que o rapaz registrou, nesta ordem, os sons do vento noturno nas árvores, de um casal namorando, de um sapo coaxando, de uma breve série de cliques não identificáveis (eles vêm da máquina fotográfica de outro homem que só aparecerá mais tarde no filme, e que, como também só saberemos depois, está escondido debaixo da ponte), de uma coruja e, finalmente, do carro derrapando e caindo no rio. A mestria de De Palma consiste em inverter a estratégia de filmagem da sequência em que o acidente apareceu pela primeira vez. Lá, a cena era toda filmada de um ponto de vista objetivo, exterior a Jack. Na cena do motel, quando ele ouve a gravação e refaz os eventos mentalmente, a sequência é refilmada do seu ponto de vista subjetivo. A câmera faz ressurgirem, um a um, os autores (o sapo, a coruja, o casal etc.) dos sons ouvidos por Jack (e pelo espectador, que compartilha seus pontos de vista e de escuta). Com um lápis, Jack simula os movimentos que executava com o microfone direcional na hora da gravação. Assistimos, portanto, a uma nova versão da cena, agora com alguns acréscimos, algumas contribuições pessoais de Jack, que não deixa de fora nenhum dos detalhes que seu ouvido apurado consegue identificar. É assim que ele chega à conclusão de que, antes do carro derrapar, há o barulho de um tiro e de um pneu estourando. Logo, se há um tiro, trata-se de um atentado e não de um acidente. 
No mais importante momento da cena, De Palma justapõe ao rosto de Jack a imagem fabricada mentalmente - do tiro sendo disparado por alguém escondido na vegetação da beira da estrada e do pneu do carro furando. Essa trucagem "reúne dois regimes de imagem distintos, um regime objetivo (o rosto de Jack) e um regime subjetivo (as imagens que ele rememora)" ${ }^{, 23}$, condensando a ideia de uma realidade dividida entre captação e fabricação.
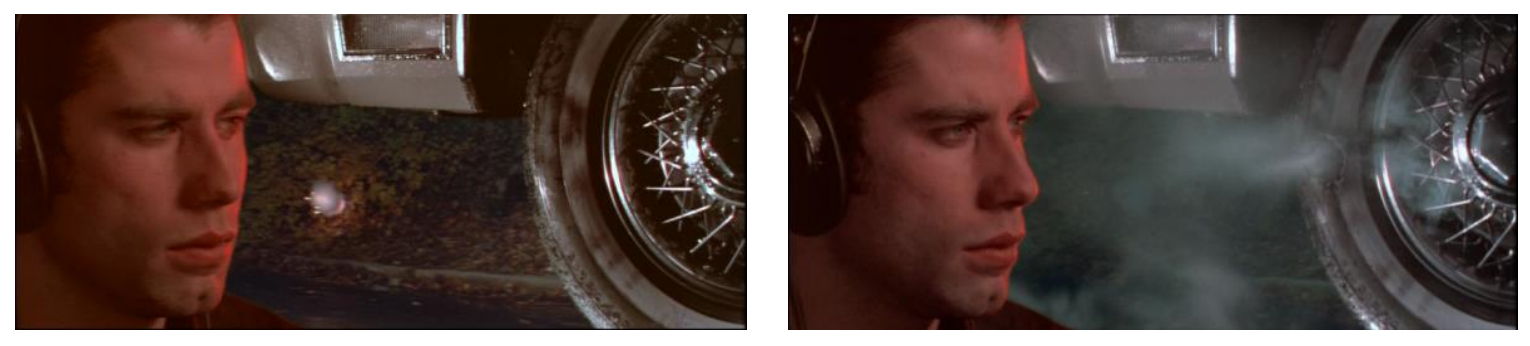

O título original de Um tiro na noite ("Blow out") já o apresenta abertamente como uma releitura de Blow up. Jack Terry, como Thomas em Blow up, registra acidentalmente um crime, e só se dá conta de que o registrou quando revisita o material, que neste caso não é uma fotografia, mas uma gravação sonora. Se Thomas precisava refazer mentalmente o som enquanto contemplava as imagens, Jack tem de refazer mentalmente as imagens enquanto ouve o som. Evidentemente, De Palma remete também ao filme A conversação, do qual é admirador confesso. Segundo Luc Lagier, os três filmes, Blow up, A conversação e Um tiro na noite, "poderiam constituir uma trilogia sobre a percepção e a compreensão a posteriori de um evento através de meios tecnológicos cada vez mais sofisticados". 24 Os filmes, feitos consecutivamente nas décadas de 1960, 70 e 80, falam de uma realidade inacessível, invisível à primeira vista; uma realidade à qual só se pode chegar posteriormente, com a ajuda de materiais registrados em imagem e/ou som. A quantidade de aparatos, dispositivos e suportes que são necessários para se chegar à informação desejada vai se multiplicando de um filme para o outro, o que demonstra que a mediação da percepção pela tecnologia vai se tornando mais complexa de uma década para a outra. Em Um tiro na noite, Jack não só aparece constantemente rodeado de máquinas de imagem ou de som como também manipula incisivamente os materiais, as fitas, os aparelhos etc. Como Lagier observou, a relação de Jack Terry com os materiais cinematográficos é tátil, física, íntima, o que se deve, é claro, ao fato de a personagem pertencer ao mundo do cinema profissional. Isso permite a De Palma enfatizar o caráter cinematograficamente construído da interpretação do complô. Para

\footnotetext{
${ }^{23}$ J.-B. Thoret, 26 secondes: L'Amérique éclaboussée, p. 107.

${ }^{24}$ L. Lagier, Les mille yeux de Brian De Palma, op. cit., p. 95.
} 
entender o que "realmente" aconteceu no acidente, Jack submete seu registro a uma série de manipulações e, no fim, o que sobra não é mais a realidade, mas uma reconstrução ficcional. "Em Um tiro na noite, De Palma mostra que todo elemento sacado do real, reconsiderado em outro contexto, se transforma". ${ }^{25}$

Um fator vem contribuir para o desejo de complô de Jack Terry: poucos dias depois da morte do governador, a revista News Today publica imagens captadas por Manny Karp (Dennis Franz), um fotógrafo que também testemunhou o acidente (De Palma alude aqui, obviamente, às fotos que a Life magazine publicou depois da morte de Kennedy). As imagens reconstituem o acidente passo a passo. Trancado no laboratório de animação de sua produtora, Jack recorta as imagens da revista e fotografa uma por uma, para depois colocá-las em sequência e construir um filme, o qual tentará sincronizar com o som que captou. Se houver como localizar, na imagem, algo que corresponda visualmente ao barulho do tiro que ele ouve na gravação sonora, Jack terá a prova de que o acidente, na verdade, foi um crime provocado por um fator externo. De Palma obtém, desta maneira, a síntese dos dois filmes precedentes: “À personagem de Blow up falta a dimensão sonora; à de $A$ conversação falta a imagem. Jack Terry, por sua vez, pode desfrutar das dimensões sonora e visual". ${ }^{26}$ Ele realiza o sonho dos buffs que se debruçavam sobre o filme de Zapruder (que não tinha som): completar a imagem com o registro sonoro do acontecimento, para saber quantos disparos foram feitos e em que instantes exatos.

Enquanto realiza seu trabalho de montagem, Jack marca com um X o ponto em que há o barulho do tiro na fita de som. Depois verifica que esse $\mathrm{X}$ corresponde exatamente ao momento em que, no filme montado com as imagens da revista, surge um ponto branco na parte inferior esquerda do quadro, sugerindo o disparo de uma arma de fogo. Ele aponta com o dedo indicador o lugar onde aparece a pequena mancha, o pequeno distúrbio, o detalhe que casa com o som do tiro, em suma, o sinal de que algo literalmente faz ruído na imagem.
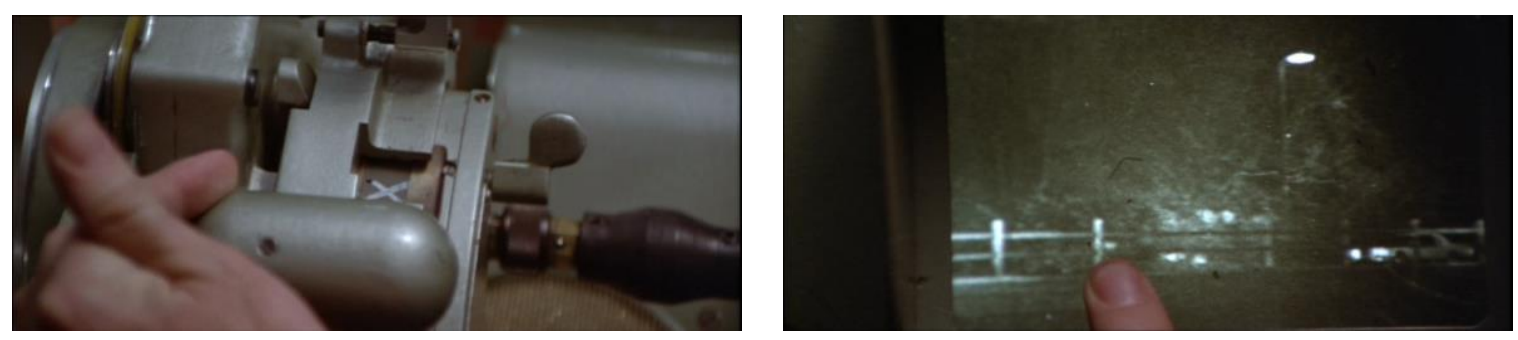

\footnotetext{
${ }^{25}$ Ibid., p. 102.

${ }^{26}$ Ibid., p. 95.
} 
Aquele pontinho branco é o suficiente para que Jack tenha certeza de que sua tese está correta. Como em Blow up, uma mancha na paisagem é tudo de que o herói precisa para se persuadir da existência de uma anomalia que a imagem teria registrado. $\mathrm{O}$ tiro, tanto em sua representação sonora como na visual, é a fagulha desencadeadora, o clique que transforma o cotidiano tedioso e solitário do protagonista num suspense policial intrigante.

As imagens em preto e branco do filminho fabricado por Jack "são um pouco turvas", como Sally dirá depois de vê-lo. A montagem dá saltos bruscos em alguns momentos. A luz é inconstante, há estouros luminosos, variações de intensidade, fantasmas. A imagem, fortemente granulada, às vezes parece riscada, arranhada, como a combinar esteticamente com os scratches produzidos por Jack nos momentos em que mexe e remexe na pista sonora. $\mathrm{Na}$ medida em que ele avança e recua incessantemente a imagem, o movimento recomposto na fotomontagem deixa de ser linear para se tornar um vai e vem insistente (o carro mergulha no rio e retorna à estrada repetidas vezes). Os ruídos da película arrastando nas peças dos aparelhos usados por Jack para o visionamento das imagens criam a sensação de que ela está sendo desgastada, queimada (como o pneu que vai perdendo a borracha na derrapagem). É como se ele esfregasse o filme, enfraquecesse suas resistências por exaustão mecânica, até fazer o sintoma latente se manifestar. O pontinho branco que corresponde ao barulho do tiro surge, assim, como resultado de um processo de análise intensiva da imagem. Ao arrastar seu filme para lá e para cá, Jack acaba liberando as forças da noite, as presenças obscuras que dão à realidade sua camada de pesadelo. ${ }^{27}$

Com a ajuda de Sally, Jack acaba conseguindo o filme original de Manny Karp (as fotos publicadas na revista News Today eram fotogramas extraídos da filmagem do acidente

\footnotetext{
${ }^{27}$ Guardadas as devidas proporções, o princípio da exegese fílmica colocada em prática por Jack Terry prefigura os filmes experimentais realizados com material de found footage por Martin Arnold. Em Pièce touchée (1989) e Passage à l'acte (1993), por exemplo, o realizador austríaco seleciona pequenos trechos de filmes hollywoodianos clássicos e, duplicando e reduplicando frames do material original, monta um filme com inúmeras idas e vindas, avanços e recuos, inversões e reversões, uma experiência alucinatória de repetição compulsiva. As iminências de movimento, o abrir e fechar de portas, o apagar e acender de luzes, os gestos corporais que se repetem freneticamente contribuem para ativar as forças dormentes, potencializar o erotismo, fazer falar o inconsciente pulsional do filme clássico de onde saíram as imagens. Pela repetição insistente, gestos inocentes se transfazem em movimentos sexuais, ao passo que um copo sendo colocado sobre a mesa ou uma porta sendo aberta podem se tornar atos de extrema violência. $O$ filme original é friccionado de tal modo que acaba por gerar uma nova energia, uma nova força de significação que provoca a liberação das tensões antes retidas nas entrelinhas das singelas cenas domésticas pinçadas por Arnold (uma refeição em família, um homem chegando em casa e beijando a esposa que o aguardava). Em Pièce touchée, o diálogo da cena original não é aproveitado, e Arnold se concentra basicamente na matéria visual, chegando a efeitos estroboscópicos vertiginosos na parte final do curta-metragem. Já em Passage à l'acte, além da gagueira visual gerada pela repetição dos frames, há um vigoroso trabalho com o som do diálogo da cena original (extraída de $O$ sol é para todos, de 1962, com Gregory Peck), que se transforma numa cacofonia de sílabas e ruídos manipulados como numa discotecagem de hip-hop, lembrando o trabalho de Jack com o som do acidente registrado por ele em $\mathrm{Um}$ tiro na noite.
} 
feita por ele). Jack sincroniza o seu material sonoro com o filme de Karp e obtém uma espécie de versão aperfeiçoada do filme Zapruder. A versão anterior, feita com as imagens da revista, carecia de fluidez e clareza; esta agora tem o efeito de realismo necessário para convencer como prova documental de um acontecimento. "Ninguém vai acreditar. Vão dizer que eu fabriquei isso no laboratório, e o pior é que eles estarão certos", Jack havia afirmado a respeito da primeira versão. Com a nova versão, feita com as imagens do filme de Manny Karp - a cores e em movimento fluido, sem trepidações -, ele reage de forma diferente: “Fantástico! Perfeito!”. Ele agora tem a certeza de que encontrou a combinação ideal entre som e imagem, de que passou do experimento ao documento, do artificial ao verossímil. "O objetivo de Jack Terry consiste em propor um filme-testemunho melhorado, graças a seu conhecimento da técnica cinematográfica. [...] Terry fabrica aquilo que o documento Zapruder não podia ser: um filme-testemunho perfeito". ${ }^{28}$

Embora pareça ter a faca e o queijo na mão, Jack não sairá vitorioso dessa aventura. Uma das cenas mais emblemáticas de Um tiro na noite é o plano-sequência em que a câmera fica girando em $360^{\circ}$ enquanto ele vai colocando uma fita após a outra para rodar, percebendo que o conteúdo de todas elas foi apagado. Enquanto as fitas de som rodam no vazio, a câmera gira num movimento circular sem fim, configurando ao mesmo tempo a vertigem da paranoia e o resultado inócuo da empreitada de investigação. Da mesma forma que a personagem de David Hemmings em Blow up chega um belo dia em seu estúdio e constata que todos os seus negativos e ampliações foram roubados, Jack descobre que alguém apagou todas as suas fitas.

Essa luta contra o vazio é o grande traço em comum dos heróis de Blow up, A conversação e Um tiro na noite. O final do filme de Coppola é talvez o mais significativo dos três: depois de ter descoberto que interpretara erroneamente a gravação sonora, Harry Caul recebe uma ameaçadora ligação anônima avisando que uma escuta foi implantada em seu apartamento. Ele imediatamente começa a desmontar todos os objetos, a tirar todos os papéis de parede, a fuxicar prováveis esconderijos do dispositivo de escuta. Ele revira o apartamento à procura de um instrumento de vigilância que, se existe ou não, pouco importa, pois o que está em jogo é um sentimento paranoico já subjetivado por ele. A paranoia, doravante, deixa de ser um estado perceptivo anômalo para se tornar uma das condições da subjetividade contemporânea.

\footnotetext{
${ }^{28}$ Ibid., p. 98.
} 


\section{Peep art}

$\mathrm{Na}$ abertura de Um tiro na noite, assistimos a uma cena de um típico slasher film dos anos $1980 .^{29}$ A cena - que pertence a um filme dentro do filme, em cuja finalização Jack Terry está trabalhando - é filmada com uma câmera subjetiva que representa o ponto de vista do assassino enquanto ele persegue suas vítimas (adolescentes nuas ou seminuas que festejam, fazem sexo ou simplesmente perambulam pelo alojamento feminino de uma universidade). Essa câmera que faz o espectador partilhar a perspectiva visual do serial killer durante longas e elaboradas sequências de perseguição e morte já havia se consolidado como um dos clichês estilísticos do gênero. No final dessa cena de Um tiro na noite, o assassino chega ao banheiro do alojamento e abre a cortina do chuveiro, onde encontra sua vítima - uma jovem nua, é claro - tomando banho (enésima variação de De Palma em torno da cena-chave de Psicose). Ela dá um grito tão desafinado que leva Jack à risada. Ele assiste à cena ao lado do diretor do filme, que pede que ele arrume um novo grito para dublar o original, pois a voz da atriz está deixando ridículo o desfecho da cena. O percurso do filme está aí determinado: encontrar o grito certo, o som que poderá conferir àquela imagem a carga dramática adequada.

Esse grito será dado por Sally no clímax final, no momento em que ela for assassinada por se envolver com o crime político investigado por Jack com a sua ajuda. O filme termina como começou: Jack assiste àquela mesma cena do slasher film vista no início. Mas, desta vez, o grito fake da atriz foi dublado pelo grito verdadeiro de Sally. A investigação do complô político produziu o som que finalmente combinaria com aquela imagem de nudez e violência: ao colar o grito de Sally sobre a imagem de um slasher erótico, Jack sela "a fusão última entre a enquete política, o gore e o sexo". ${ }^{30}$

A ligação da política com a representação obscena do sexo já dera as caras anteriormente, quando Jack descobrira que Sally realizava, em conchavo com Manny Karp, alguns serviços sujos que consistiam em fazer fotografias de políticos e de outras personalidades públicas flagrados em situações embaraçosas (leia-se: na cama com Sally), para depois chantageá-los e extorqui-los. O próprio filme de Karp, em que ele registrou o acidente de carro que matou o governador, havia sido encontrado por Sally em meio a fotos

\footnotetext{
${ }^{29}$ O slasher é um subgênero do terror com narrativas regadas a muito sexo e violência gráfica, nas quais invariavelmente um serial killer persegue e mata um grupo de pessoas - na maior parte dos casos, adolescentes. Halloween (John Carpenter, 1978), Sexta-feira 13 (Friday the 13th, Sean S. Cunningham, 1980), O trem do terror (Terror train, Roger Spottiswoode, 1980), A morte convida para dançar (Prom night, Paul Lynch, 1980) e Areia sangrenta (Blood beach, Jeffrey Bloom, 1980) são alguns dos clássicos do gênero, cujo precursor histórico pode ser identificado em Bay of blood (1971), de Mario Bava. No momento em que De Palma realizou Um tiro na noite, o ciclo do slasher estava no auge.

${ }^{30}$ J.-B. Thoret, 26 secondes: L'Amérique éclaboussée, p. 114.
} 
comprometedoras e fitas pornográficas espalhadas pela quitinete bagunçada onde o fotógrafo morava. De Palma inscreve a temática da paranoia e do complô, portanto, numa trama em que imagens cobiçadas por razões políticas vão parar no mesmo circuito em que imagens pornográficas são fabricadas e vendidas.

Ora, nada mais lógico: se uma das consequências extremas do olhar obcecado tematizado por Hitchcock e Antonioni - e desdobrado por De Palma - é a ficção paranoica, seu outro ponto limítrofe é a pornografia. Tanto a superinterpretação do paranoico como a curiosidade insaciável do consumidor de material pornográfico derivam de um mesmo desejo de levar o visível até suas últimas fronteiras, de vencer seus últimos bloqueios, de fazê-lo confessar sua "verdade" final, para além da qual não há mais nada para ver ou saber.

A paranoia e a pornografia são duas manifestações diferentes de um mesmo desejo de tornar tudo visível e de ter acesso ao "grande segredo". Não à toa, uma estreita relação estabeleceu-se, no final dos anos 1960, entre o gosto pela paranoia e a crescente indústria de imagens pornográficas. Um mesmo "princípio de visibilidade maximal"31 conduz tanto a produção de imagens hard-core no cinema pornô como a exegese dos documentos fotográficos e cinematográficos do caso Kennedy, notadamente do filme de Zapruder, cujas imagens, lado a lado com as do gore e do pornô, situam-se na extremidade do visível.

Como afirma Thoret, a circulação numa mesma rede das imagens do assassinato de Kennedy, das teorias de complô político e dos filmes pornográficos não é mera coincidência conjuntural:

Ela demonstra uma relação mais profunda entre a atitude do analista (expert ou simples cinéfilo) face ao filme de Abraham Zapruder (e de todos os documentos fotográficos ligados ao assassinato) e a do fã de cinema hardcore. Com efeito, ambos trabalham no interior de uma mesma ideologia do visível que impõe como condição ao conhecimento de seu objeto (a verdade sobre o assassinato/ a verdade do sexo) um princípio de exaustividade e de microvisão: tudo mostrar e tudo ver, no mínimo detalhe. Exaustividade do corpo feminino até a visão do sexo em primeiro plano, exaustividade de cada um dos fotogramas de Zapruder por ampliações sucessivas e leituras feitas à lupa do mais ínfimo de seus detalhes. ${ }^{32}$

$\mathrm{O}$ diretor que mais insiste sobre esse ponto de encontro entre as interpretações paranoicas suscitadas pelo caso Kennedy e a disseminação da pornografia é o próprio Brian De Palma, que sempre incluiu a exegese do filme de Zapruder na mesma economia de

\footnotetext{
${ }^{31}$ Ibid., p. 112.

${ }^{32}$ Ibid., pp. 115-116.
} 
imagens do hard-core: "Em Saudações [Greetings, 1968], assim como em Um tiro na noite, De Palma estabelece uma ligação quase consanguínea entre a enquete sobre o assassinato político (de Kennedy e de um senador) e o hardcore". ${ }^{33}$

Saudações mostra com clareza a imbricação do mundo da pornografia com o dos amantes das teorias de complô. Lloyd Clay (Gerrit Graham), um dos três protagonistas do filme, é totalmente obcecado pelo assassinato de JFK. Ele passa os dias a "tentar demonstrar a falsificação das provas oficiais e lançar luz sobre os mecanismos de um vasto complô".34 Perto dos vinte minutos de filme, ele conversa com um homem sentado num banco de uma praça pública, que lhe explica como funciona o "falso cartão postal" que fez para uma revista de arte. A obra consiste numa série de ampliações fotográficas obtidas a partir de um cartão postal que mostra uma praia lotada de gente. As imagens estão dispostas numa tira de papel dobrada em forma de sanfona; quando esticada, ela se assemelha a um pedaço de película cinematográfica, cada ampliação valendo como um fotograma. À medida que a imagem é ampliada, ela revela informações visuais novas, que não se conseguia ver no cartão postal original; mas, em contrapartida, ela perde nitidez, fica mais abstrata, resume-se a manchas e formas indefinidas:
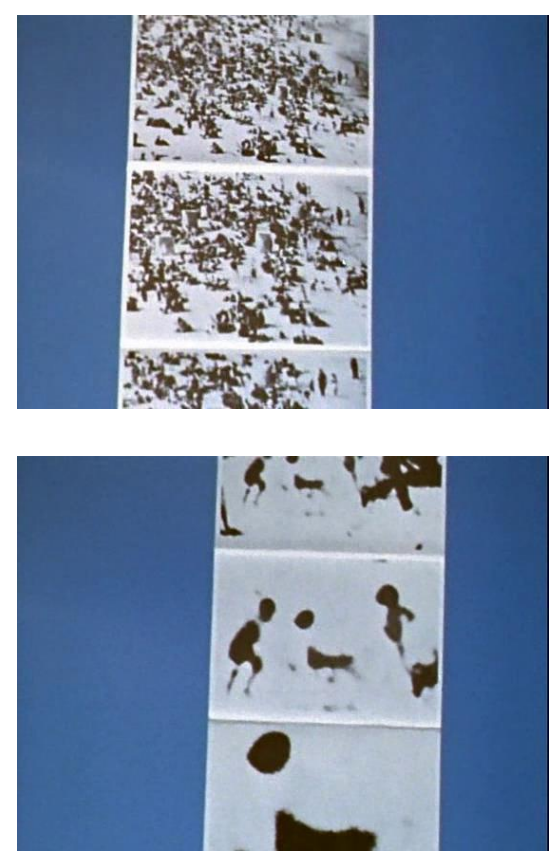

"É como aquele filme Blow up", Lloyd diz ao artista. "Sim, já me disseram isso. Mas eu fiz esse trabalho 18 meses antes do filme", explica o artista, que fez também algumas

\footnotetext{
${ }^{33}$ Ibid., p. 114.

${ }^{34}$ Ibid., p. 86.
} 
pinturas com base na mesma ideia. Ora, esse homem com quem Lloyd conversa é o artista plástico Richard Hamilton, sobre o qual já falamos anteriormente, quando inserimos Blow up no contexto das artes visuais britânicas da primeira metade da década de $1960 .{ }^{35}$ O diálogo de Hamilton com Lloyd Clay em Saudações resume a lógica da teoria conspiratória: quanto mais perto se chega da imagem, quanto mais informações são obtidas, menos se enxerga efetivamente. A imagem fica menos indicativa e mais sugestiva, como atesta a interpretação feita por Hamilton em cima das fotos do cartão postal, estabelecendo novas associações entre elementos que, vistos de longe, não pareciam ter qualquer relação um com o outro. A partir de um determinado momento, tudo pode significar tudo, já que, objetivamente, nada significa nada. A realidade se transforma, escapa de si mesma para se refugiar na ficção e na abstração. É o que acontece também com as teorias criadas pelos buffs: "o desejo de complô termina por fazer surgir uma outra realidade no interior da qual ele se realiza". ${ }^{36}$

Depois do encontro com Hamilton, Lloyd leva para o laboratório fotográfico de uma amiga uma foto tirada no dia do assassinato de Kennedy segundos depois dos tiros. Ele mostra a ela que todas as pessoas da foto estão correndo na direção do que ele acredita ser um homem de blusa branca portando uma arma e escondido atrás de uma árvore. Sua amiga afirma que é apenas uma "mancha branca que se pode ver através da árvore". Lloyd, entretanto, está bastante certo de que se trata de um dos autores dos disparos que puseram fim à vida de Kennedy. Ele quer que ela amplie o detalhe da foto para poder mostrar para todo o mundo o homem de branco segurando a arma do crime. "Você não vai conseguir ver nada além de grãos do tamanho de bolas de golfe", ela o desencoraja. E continua: "Eu vi Blow up, eu sei como isso termina: você não conseguirá ver nada”. Mas a jovem aquiesce à insistência de Lloyd, que, enquanto ela prepara as ampliações, analisa mais uma vez a foto, num plano que remete diretamente a algumas cenas de Blow up:

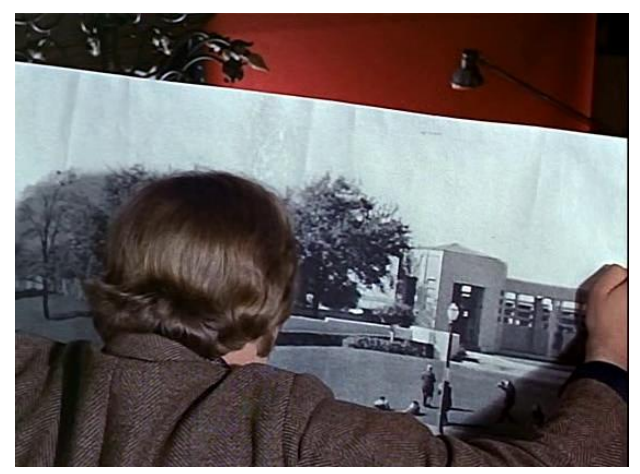

\footnotetext{
${ }^{35}$ Ver capítulo 3, pp. 168-169.

${ }^{36}$ J.-B. Thoret, 26 secondes: L'Amérique éclaboussée, p. 90.
} 
Se Blow up foi um filme ainda mais influente para a onda de ficção paranoica dos anos 1960 e 1970 do que outras obras que abordavam muito mais de frente a questão do complô e da conspiração política ${ }^{37}$, isso só pôde acontecer por Antonioni ter percebido que o centro nevrálgico da questão não era mais o evento em si (o assassinato, o complô), mas o frisson, o delírio interpretativo desencadeado pelas parcas imagens captadas de tal evento. A possibilidade de encontrar nas imagens, por mais escassas, opacas e inconclusivas que elas fossem, a chave do enigma, a explicação do caso, seria uma das grandes obsessões dos anos seguintes. O centro de gravidade, o nó do problema havia se deslocado da realidade para a imagem. Localizando a raiz da problemática diretamente na imagem, ou melhor, na percepção e na análise da imagem, Blow up cristalizou um sentimento que estava disperso no ar depois do assassinato de JFK e da repercussão que suas imagens tiveram. E o filme ainda demonstrava qual era o único aprendizado que ficava da história: a fragilidade da realidade, por um lado, e a potência performativa da imagem, por outro.

De Palma, que muito cedo assimilou a lição de Antonioni, já a põe em prática nessa cena de Saudações em que Lloyd, falando diretamente para a câmera, segura a foto que pediu que fosse ampliada e diz que nela se pode ver com clareza o homem armado com um rifle próximo à árvore. A câmera fecha o zoom no detalhe que ele indica. "Veja!", Lloyd exclama exaltado. E o que vemos? Uma mancha, uma imagem esgarçada e sem definição, composta de grãos e tachas disformes.
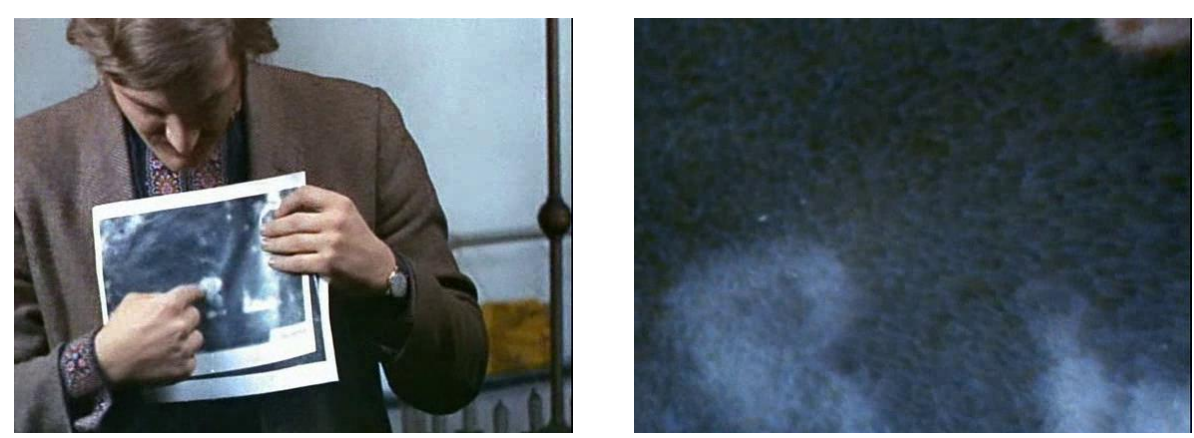

Um conflito se cria entre a indexalidade da imagem fotográfica, que Lloyd representa gestualmente, colocando o dedo indicador no ponto preciso que quer destacar da foto, e a falta de resolução lá observada depois da aproximação do zoom, que acaba enfraquecendo o efeito analógico e cortando os fios que ligam a imagem ao seu referente real. Mas, ainda que o

\footnotetext{
${ }^{37}$ Como, por exemplo, Sob o domínio do mal (The Manchurian Candidate, 1962), de John Frankenheimer, que, de forma premonitória, um ano antes da morte de JFK, contava a história de um ex-combatente que sofria uma lavagem cerebral para assassinar um político durante um comício.
} 
detalhe ressaltado por Lloyd não nos pareça mais que um acidente óptico dificilmente interpretável em termos objetivos, aos olhos dele está tudo ali: aquela imagem confusa, precária, carente de legibilidade, é a prova cabal do complô por trás do assassinato de JFK.

Conforme essa cena de Saudações demonstra (com distanciamento crítico e cômico), a dissecção das imagens do caso Kennedy desemboca num paradoxo do visível:

Por conta de estar aumentado e privado de seu contexto [...], o detalhe termina por não mais remeter senão a si mesmo. [...] A interpretação descamba, de fato, no delírio, pois o detalhe só fará sentido às custas de conexões novas e forçosamente subjetivas que recriam relações artificiais entre signos que, tomados isoladamente, nada significam. ${ }^{38}$

O que aconteceu com a foto de Lloyd é o mesmo que acontecia com os fotogramas do filme de Zapruder recortados e ampliados pelos buffs: eles perdiam a nitidez (como em Blow up) e eram deslocados de seu espaço de referência (o que havia no restante do quadro? e nos outros fotogramas?), neutralizando o elemento que supostamente deveriam revelar. "Tudo mostrar mas nada ver: a aporia hermenêutica suscitada pelo filme de Zapruder faz eco a uma crise do visível". ${ }^{39}$ Lloyd encarna essa crise, que afeta a sociedade norte-americana nos anos 1960 e coloca em jogo o regime de crença no visível que, no passado, dera às imagens o poder de esclarecer a realidade. "Ao regime do visível se substituiu então um regime do segredo, e toda imagem (ficcional, documental, televisiva, fotográfica...) tornou-se suspeita de mascarar uma outra realidade. A visão cedeu lugar à exegese, e a crença ao ceticismo." ${ }^{40}$ Como em Intriga internacional, de Hitchcock, o mundo visto por Lloyd é um infinito quadro de signos e mensagens secretas, um texto hermético que deve ser interpretado com todas as ferramentas semiológicas disponíveis. Isso o leva "a substituir à realidade objetiva [...] uma realidade deformada por seu desejo de complô". ${ }^{41}$

Há uma cena em que Lloyd tenta localizar, usando o corpo nu de sua parceira sexual como substituto do cadáver de Kennedy, os pontos de entrada e saída das balas que atingiram o presidente. Lloyd procura provar as incoerências do relatório oficial, a falta de nexo das teorias apresentadas pelo comitê que investigou o crime. A cena começa com um planodetalhe de uma edição de 1967 da revista Film Comment, que aborda justamente a polêmica em torno das imagens do caso Kennedy. Em seguida, um zoom para trás abre o quadro e

\footnotetext{
${ }^{38}$ J.-B. Thoret, 26 secondes: L'Amérique éclaboussée, p. 116.

${ }^{39}$ Ibid., p. 117.

${ }^{40}$ Ibid., p. 39.

${ }^{41}$ Ibid., p. 90.
} 
revela que a revista serve de tapa-sexo para a amante de Lloyd, que está nua e adormecida. Ao lado dela, na cama, acha-se a edição de 25 de novembro de 1966 da revista Life, com a reportagem "A matter of reasonable doubt", que expõe as contradições da tese oficial sobre o assassinato de JFK.
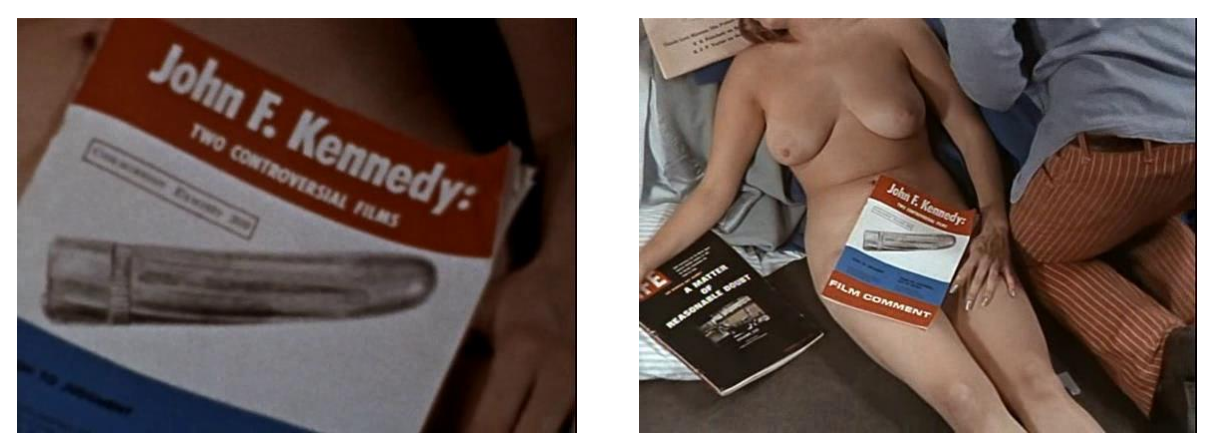

A mulher dorme. Lloyd, ao contrário, está excitado e ofegante. Ele transpira, fala atropeladamente, entra em êxtase quando descobre que as descrições do relatório oficial não batem com o que acaba de verificar. O prazer que o fortalecimento da teoria do complô provoca nele é comparável à satisfação do desejo sexual.

A imagem da mulher com o sexo tapado pela revista (que exibe na capa a figura fálica de um projétil igual aos que atingiram JFK) estabelece uma equivalência direta entre o enigma político e o enigma ligado ao desejo feminino. De Palma associa inequivocamente a revelação da verdade sobre o assassinato de Kennedy com o desnudamento da mulher, "metáfora da Verdade". ${ }^{2}$ Como Yann Lardeau relembra em seu fundamental artigo sobre cinema e pornografia, "a mulher nua sempre foi, em nossa sociedade, a representação alegórica da Verdade (sabemos também que, para Freud, a vontade de saber se manifesta com a descoberta, pela criança, dos 'mistérios' da sexualidade)". ${ }^{43}$ Donde se pode concluir que a revista com a imagem fálica na capa, encobrindo o órgão genital da mulher, recalca a diferença sexual a que Freud atribui a origem do medo masculino da castração. O típico herói masculino do cinema moderno é um indivíduo neurótico (como Lloyd), e uma das razões de sua neurose, segundo Jean-François Rauger, é "a impossibilidade para o homem de conhecer e compreender a verdade do gozo feminino". ${ }^{4}$ Nessa perspectiva, De Palma estaria associando, em Saudações, o inalcançável do desejo feminino ao inexplicável do caso Kennedy, que os teóricos do complô buscam cercar e desvendar de todas as formas.

\footnotetext{
${ }^{42}$ Ibid., p. 116.

${ }^{43}$ Yann Lardeau, "Le sexe froid", in Cahiers du cinéma, n 289, junho de 1978, p. 49.

${ }^{44}$ J.-F. Rauger, "La mise en scène de l'acte sexuel: focalisation/fuckalization", in AUMONT, Jacques (org.), La mise en scène, Bruxelas: De Boeck Université, 2000, p. 272.
} 
Em outra cena importante, Jon Rubin (Robert De Niro) lê trechos de um livro que traça o perfil psicológico e descreve o comportamento típico de um voyeur. Em seguida, ele reencontra a loira cleptomaníaca por quem ficara interessado depois de tê-la visto roubando livros (Marnie?). Ele explica para ela o conceito de um "projeto" em que está trabalhando. "Você já ouviu falar em Pop art, certo? Então, eu chamo o que eu faço de Peep art". No jogo de palavras de Rubin, o voyeurismo é apresentado como uma forma de arte conceitual contemporânea (uma mistura de Janela indiscreta com Andy Warhol). "Eu estudo pessoas", diz Rubin. Por isso observou a loira cleptomaníaca na livraria: ele está sempre atento ao comportamento das pessoas, sobretudo em seus "momentos privados". Vê-la roubando aqueles livros foi, para ele, como flagrar a beleza de um momento privado. Rubin fala da instalação que pretende expor no Whitney Museum: um filme em 8mm será projetado de maneira que o feixe de luz do projetor atravesse um retângulo vítreo no qual está pintada a fachada de um edifício; do outro lado, o espectador colocará o olho num telescópio; ele verá o filme projetado, que consistirá numa mulher chegando em casa e tirando a roupa; o filme estará enquadrado numa das janelas do edifício pintado no vidro, e assim o espectador se colocará na situação de um voyeur que assiste a uma vizinha fazendo um strip-tease (como veremos adiante, o dispositivo óptico da instalação de Rubin será retomado por De Palma em Dublê de corpo).

Rubin convida a moça para atuar no filme que será projetado na instalação. A sequência seguinte já mostra as filmagens. O enquadramento nos coloca no ponto de vista que o espectador da instalação terá, e ouvimos a voz de De Niro ordenando que a mulher entre em quadro, sente na cama, faça expressão de cansada, comece a tirar a roupa etc. Rubin pede que ela faça tudo com naturalidade. Mas ela, que havia dito já ter alguma experiência como atriz, não consegue se furtar a superdramatizar cada mínimo gesto. O simples ato de tirar a blusa ou de bocejar adquire a grandiloquência de um monólogo shakespeariano. Rubin fica um pouco irritado, mas continua rodando o filme e tentando fazê-la tirar a roupa, que é o essencial para ele no fim das contas.

Da filmagem de Rubin, corta para um plano em que imagens documentais rodadas no Vietnã são projetadas ao lado de um homem que explica como se deram algumas ações militares comandadas por ele. O recado não poderia ser mais direto: De Palma curto-circuita a obscenidade pornográfica do filme de Rubin com a obscenidade política da Guerra do Vietnã. E ele retoma essa estratégia de ligação direta no final do filme, na cena em que Rubin participa de uma reportagem feita por um canal de televisão no front de batalha (pois, apesar dos esforços de se passar por um fanático direitista para não ser convocado pelo exército, ele 
acaba agradando os militares que o avaliam e é mandado para a guerra): Rubin encontra uma jovem vietnamita e, com o fuzil apontado para ela, começa a ordenar que tire a roupa e atue para a câmera, da mesma forma que fizera com a loira cleptomaníaca. Até as indicações que dá são as mesmas (“Não olhe para a câmera! Aja com naturalidade!”). Para não deixar dúvida de tal paralelismo, De Palma recupera alguns inserts do pornô amador e clandestino de Rubin e os intercala com a imagem da vietnamita representando a mesma cena (uma mulher que tira a roupa e se prepara para dormir). O circuito se fecha. ${ }^{45}$

\section{A visão em excesso}

Cabe aqui um breve recuo teórico a fim de circunscrever com mais precisão a relação entre cinema e pornografia, já que ela estará presente nos filmes de que nos ocuparemos no segmento posterior, os quais, embora não sejam filmes pornográficos, dialogam fortemente com esse universo num momento (os anos 1980) em que era grande a polêmica em torno dele.

O consumo compulsivo de imagens de sexo explícito (assim como a busca paranoica pela resolução do enigma do caso Kennedy ou de qualquer outra conspiração política) constitui um olhar ávido por conhecimento e em estado de superexcitação. Historicamente, esse olhar se enquadra naquilo que Jean-Louis Comolli denominou um "frenesi do visível", expressão pela qual ele define um contexto cultural surgido na segunda metade do século XIX, época de "multiplicação social das imagens" (maior produção e circulação de jornais ilustrados, gravuras, caricaturas, fotos etc.) e de uma "expansão do campo do visível" impulsionada, entre outras coisas, pela proliferação de instrumentos ópticos. ${ }^{46}$

Linda Williams, em seu livro indispensável sobre o pornô hard-core, retoma a expressão de Comolli e esclarece que "esse frenesi, embora possa soar extremo, não é uma aberração nem um excesso, mas antes a consequência lógica de uma variedade de discursos da sexualidade que convergem na produção de certas tecnologias do visível". ${ }^{47} \mathrm{O}$ cinema pornográfico estaria, assim, na extremidade de uma cultura visual cujas formas artísticas e

\footnotetext{
${ }^{45}$ Não será um acaso o fato de que os dois únicos filmes de guerra que Brian De Palma irá dirigir mais tarde, Pecados de guerra (Casualties of war, 1989) e Guerra sem cortes (Redacted, 2007), reforçarão essa visão da guerra como algo imoral, e contarão exatamente a mesma história: a do estupro coletivo de uma adolescente (vietnamita no filme de 1989, iraquiana no de 2007) por um grupo de soldados americanos.

${ }^{46}$ Cf. J.-L. Comolli, "Machines of the visible", in Teresa De Lauretis e Stephen Heath (orgs.), The Cinematic Apparatus, Nova York: St. Martin's Press, 1980, pp. 122-123.

${ }^{47}$ L. Williams, Hard core: power, pleasure, and the frenzy of the visible. Los Angeles: University of California Press, 1989, p. 36.
} 
tecnológicas se desenvolveram, ao longo da história, motivadas principalmente pelo interesse e pelo prazer de olhar o corpo humano em movimento. Porque está obcecado com a verificação óptica dos seus conhecimentos (e porque admite suas limitações perceptuais), o homem da segunda metade do século XIX inventa máquinas para complementar a visão e, em muitos casos, corrigi-la ou aprimorá-la. Muitas dessas máquinas seriam rapidamente assimiladas como forma de espetáculo e prazer visual, como é o caso do cinema.

$\mathrm{Na}$ ocasião do seu surgimento, o cinema engrossou um discurso - que a cronofotografia já despertara antes dele - calcado na ideia de que o olho mecânico da câmera enxerga com mais precisão do que o olho humano: “o prazer cinemático da ilusão do corpo em movimento emergiu, em parte, como um subproduto da busca pelas 'verdades' inicialmente invisíveis desse movimento". ${ }^{4}$

Deste modo, o cinema participou de um conjunto de tecnologias que, originalmente engajadas na exploração científica do movimento, tornariam a imagem do corpo mecanicamente reproduzível e analisável. Do zoopraxiscópio de Muybridge ao cinematógrafo dos Lumière, é interessante observar que "os mesmos princípios de repetição mecânica que tornaram possível a produção industrial tinham agora tornado o movimento mais visível". 49

Essa utilização do aparato cinematográfico a serviço da aquisição de maiores conhecimentos sobre o corpo humano não demoraria a alcançar o domínio em que a curiosidade sobre o corpo, a repetição mecânica do movimento e a ativação do prazer escópico se entrelaçam e se potencializam, isto é, o sexo. A pulsão epistemológica que alimenta o "frenesi do visível” logo penderia para este que, como disse Bazin, é o "tropismo o mais eficaz" $" 50$, originando as primeiras fitas dedicadas ao "estudo" do ato sexual. Um dos caminhos de evolução das técnicas de visualização cinematográficas se dá claramente no sentido de suprir o desejo de ver partes ou ações do corpo - e, sobretudo, do corpo da mulher (voltaremos a isso) - antes escondidas. O estímulo que leva o homem à produção de filmes pornográficos tem algo a ver com a pulsão de conhecimento que o conduz à microscopia e à radiografia: um desnudamento do corpo sem precedentes, uma nova exploração visual da paisagem corpórea, incentivada por aparatos ópticos que extrapolam o alcance da visão natural. "É esse fundamento científico do cinema o que as tecnologias sexuais do pornô restituem". ${ }^{51}$ Com a pornografia, o cinema "reencontra uma de suas vocações primitivas: a

\footnotetext{
${ }^{48}$ Ibid., p. 39.

${ }^{49}$ Ibid., p. 38.

${ }^{50}$ A. Bazin, “À margem de 'O erotismo no cinema”, in

${ }^{51}$ Y. Lardeau, art. cit., p. 58. O cinema-Ensaios, op. cit., p. 226.
} 
análise dos corpos em movimento, a decomposição científica do gesto". 52 Ciência e espetáculo aí se complementam para satisfazer a um princípio de visibilidade máxima:

No hard-core propriamente dito, esse princípio tem operado de diferentes formas em diferentes estágios da história do gênero: privilegiar close-ups de partes do corpo em detrimento de outros planos; superiluminar os órgãos genitais, que são facilmente obscurecidos; selecionar posições sexuais que mostrem o máximo dos corpos e órgãos; e, mais tarde, criar convenções genéricas, como a variedade dos "números" sexuais ou o pênis ejaculando externamente $[\ldots] .{ }^{53}$

L. Williams acredita que o cinema pornô hard-core deriva menos das antigas tradições da arte erótica do que daquilo que Foucault designa como scientia sexualis: "uma hermenêutica do desejo que visa a explorações cada vez mais detalhadas das verdades científicas da sexualidade". ${ }^{54}$ Nessa perspectiva, a pornografia resultaria de "uma 'pulsão de saber' que se dá através de um voyeurismo estruturado como uma urgência cognitiva". 55 Aquele desejo de ver e saber mais sobre o corpo humano e a mecânica de seu movimento, que está na base da própria invenção do cinema, desaguaria eventualmente na pornografia, a qual participaria, à sua revelia ou não, de um sistema mais amplo, de uma estrutura de poder que almeja tornar mensuráveis e controláveis as verdades "confessadas" pelo corpo no momento do prazer. Assim sendo, o que o pornô nos mostra não é somente a performance do ato sexual, mas antes "o dispositivo de sexualidade como campo de saber e de poder". 56 O que preside à concepção e à realização dos filmes pornográficos, como escreveu Y. Lardeau (antecipando alguns pontos que depois seriam retrabalhados e aprofundados por L. Williams, se bem que por outro viés), é “a obsessão pela verdade, por tudo saber, por nada deixar escapar ao conhecimento, por esgotar e saturar o real até seus interstícios; é a vontade de uma vigilância e de um controle permanente e total, um panoptismo de que a câmera, com sua capacidade de reproduzir perfeitamente o real, é o meio técnico pleno". 57

A própria primazia do primeiro plano, do close-up (que é o princípio formal do pornô), atende a uma demanda de conhecimento totalitário: trata-se de "chegar o mais perto possível do sexo, de fornecer dele a imagem mais nítida e mais próxima: a mais precisa. A câmera, através do agenciamento dos enquadramentos, ângulos e enfoques, mostra-nos o sexo do

\footnotetext{
${ }^{52}$ J.-F. Rauger, art. cit., p. 270.

${ }^{53}$ L. Williams, Hard core: power, pleasure, and the frenzy of the visible, op. cit., pp. 48-49.

${ }^{5}$ Ibid., p. 34.

55 Ibid., p. 48.

${ }^{56}$ Y. Lardeau, "Le sexe froid", art. cit., p. 49.

${ }^{57}$ Ibid., p. 50.
} 
homem ou da mulher como ninguém nunca os viu nem os verá, ou ainda, como jamais existiram". 58 O plano-detalhe pornográfico faz um "inventário exaustivo" daquilo que representa; ele quer ser o registro total e sistemático do sexo, visualizá-lo até a saturação.

Estamos aqui, ainda e sempre, no mesmo modelo visual que engloba algumas pesquisas científicas contemporâneas - ou imediatamente anteriores - ao nascimento do cinema: a intensificação da percepção ocular por meio de um instrumento óptico que permite ao sujeito aproximar-se do objeto que quer observar e isolá-lo do restante do espaço visível. O desejo de "aproximação microscópica" lança o espectador numa dimensão monomaníaca da representação: a única coisa que há para ver é o sexo, que se acha ali reduzido à sua própria realidade, focalizado de modo direto e simples, sem tergiversação nem complicação. O sexo, "circunscrito à sua materialidade genital (objetivado)", realçado pelo primeiro plano, exilado do resto do corpo, "pode então circular livremente fora do sujeito - como a mercadoria circula e se troca independentemente dos produtores, ou como o signo linguístico, em sua qualidade de valor, circula independentemente dos locutores". ${ }^{60}$ Encerrado no close-up, o sexo se realiza como espetáculo, mas se esgota como imaginário.

É disso, aliás, que Barthes se queixava com relação à imagem pornográfica, que ele comparou a uma vitrine que só exibe uma única joia: "ela é inteiramente constituída pela apresentação de uma única coisa, o sexo: jamais objeto segundo, intempestivo, que venha ocultar pela metade, retardar ou distrair". ${ }^{61}$ Barthes diferencia a imagem pornô da imagem erótica: esta segunda seria "um pornográfico desviado, fissurado", uma imagem que "não faz do sexo um objeto central: ela pode muito bem não mostrá-lo; ela leva o espectador para fora de seu enquadramento". ${ }^{6}$ Já o excesso do pornô, diferentemente da forma elusiva do erotismo, "absorve o voyeur a ponto de cegá-lo". ${ }^{63}$ Uma certa reserva ou distância, quiçá interdição, se imporia então como condição do erotismo e do próprio prazer voyeurístico. Se a imagem pornográfica, segundo Barthes, é uma imagem monótona, é porque ela que já não tem mais nada a esconder: imagem sem mistério, sem véu, imagem escancarada que neutraliza o voyeurismo, pois o combustível do voyeur era justamente a proibição implícita em seu ato, algo que a transparência corrompida da pornografia, sua predisposição de "tudo mostrar", aniquila.

\footnotetext{
${ }^{58}$ Ibid.

${ }^{59}$ Ibid.

${ }^{60}$ Ibid., p. 51.

${ }^{61}$ R. Barthes, A câmara clara, op. cit., p. 67.

${ }^{62}$ Ibid., pp. 88-89.

${ }^{63}$ Olivier Smolders, apud J.-B. Thoret, 26 secondes: L'Amérique éclaboussée, p. 116.
} 
“O plano pornográfico é inteiramente guiado por uma exigência de visibilidade." 64 Ao contrário do espectador de Blow up, que fica apenas na esperança e na torcida de ver os seios de Vanessa Redgrave, mas é sub-repticiamente frustrado pelo filme, o espectador do pornô tem a garantia e a certeza de que a câmera, mais cedo ou mais tarde, irá driblar o objeto que eventualmente oblitera a visão ou tapa a parte do corpo desejada.
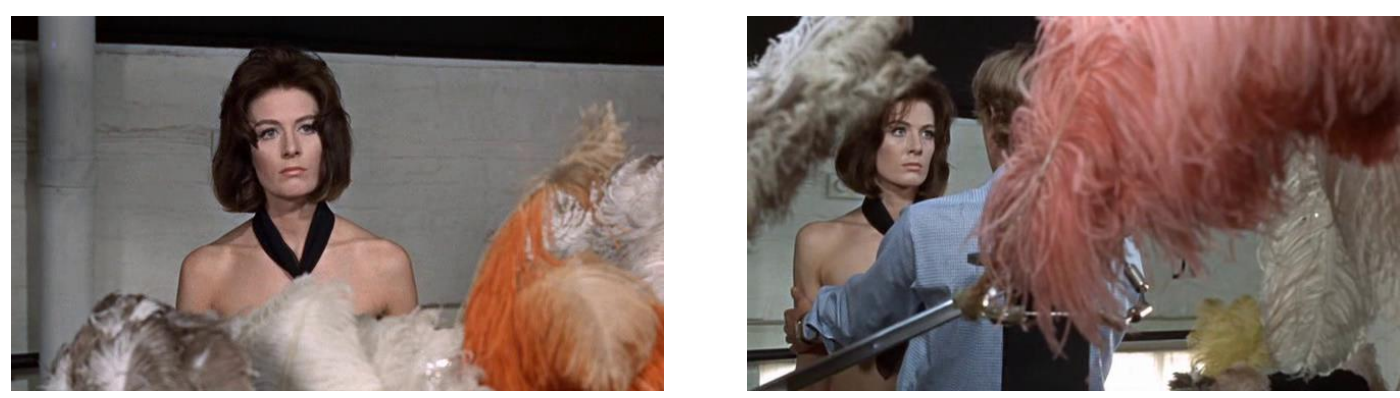

A gag de Antonioni incide precisamente sobre a expectativa de uma visibilidade direta e unívoca, recusada por seu cinema, mas fundamental na pornografia.

Através do "culto do hipervisível", cujo emblema seria a invenção da pussylight, "uma luz especialmente concebida para iluminar o interior do sexo feminino"65, o pornô faz o cinema reencontrar a perversão fetichista das suas origens.

Com a invenção do cinema [...], o fetichismo e o voyeurismo ganham nova importância e normalidade através de sua conexão com a busca positivista pela verdade dos fenômenos visíveis. Eles não mais seriam perversões sexuais relativamente raras, praticadas por certos homens para compensar suas dificuldades na performance sexual. O cinema implantou essas perversões mais firmemente, normalizando-as nos "modos de ver" sociais e tecnológicos. Como resultado, os espectadores gradualmente habituaram-se à ideia de que ver corpos humanos em movimento, nessa forma privilegiada proporcionada pelo cinema, incluiria aqueles prazeres perversos como decorrência natural. ${ }^{66}$

Assim, paralelamente às novas descobertas científicas no campo da óptica e aos novos conhecimentos acerca da estrutura ocular, que levam à invenção de diversas máquinas e próteses de ampliação ou correção da visão, a modernidade desenvolve um gosto crescente pelo voyeurismo e pela perversão escópica.

\footnotetext{
${ }^{64}$ J.-F. Rauger, art. cit., p. 274.

${ }^{65}$ Matthieu Dubost, La tentation pornographique: Réflexions sur la visibilité de l'intime, $2^{\mathrm{a}}$ ed., Paris: Ellipses, 2014, p. 22.

${ }^{66}$ L. Williams, Hard core: power, pleasure, and the frenzy of the visible, op. cit., p. 46.
} 
O cinema, como parte inegável disso tudo, alimenta um desejo moderno de ubiquidade e panoptismo e provê o olhar de uma potência que, no passado, só aparecia em sonho.

No entanto, essa "nova magia do visível",67, à proporção que fascina e deslumbra, inscreve o olho humano na confusão, na dúvida. Ao mesmo tempo em que parece respeitar e até mesmo aperfeiçoar a "visão normal", prometendo uma percepção mais acurada que a do homem, o cinema traz de volta uma série de acidentes e aberrações ópticas que as leis da visão clássica tinham reprimido: o espetáculo da escrita luminosa do movimento propicia certos efeitos - em grande parte, impensados e imprevistos - que questionam, quando não destroem, as normas estabelecidas da figuração analógica e da representação visual. Evidencia-se, assim, a falsa objetividade não só do cinema, mas de todos os dispositivos de captação automática do real, que muitas vezes aumentam a incerteza que supostamente viriam a solucionar. Estimulado pela vontade de ver mais e melhor, de vencer a opacidade do mundo, de inventar artifícios que iluminem os pontos cegos da visão, o homem termina por "criar formas de cegueira ainda mais peculiares". ${ }^{6}$

Um dos filmes mais cultuados de Roger Corman, $O$ homem dos olhos de raio- $X(X$, 1963), aborda justamente essa sede de visão (como sinônimo de conhecimento) que leva o homem a superar suas barreiras ópticas e a se confrontar, no limite, com um novo tipo de cegueira, que se dá pelo excesso de visão, e não por sua falta. O filme conta a história de um médico cientista, o Dr. James Xavier (Ray Milland), que desenvolve um colírio para ter visão de raio-X. No começo, ele se beneficia das vantagens de enxergar além do alcance comum. Mas, com o tempo, os efeitos da droga se acumulam e ele não apenas sofre com as reações fisiológicas adversas como ainda enfrenta as consequências desastrosas de sua curiosidade científica irrefreável.

$\mathrm{Na}$ primeira cena do filme, James é examinado por seu colega oftalmologista. O exame de rotina indica que sua visão continua boa. Mas o colega sabe das pesquisas dele, e o questiona sobre suas motivações. "Eu quero ver!”, ele exclama. "Mas você já enxerga bem”, contesta o oftalmologista. James expõe então suas razões: "O alcance do olho humano é de menos de um décimo do espectro de ondas existentes. $\mathrm{O}$ que poderíamos realmente ver se tivéssemos acesso aos outros 90\%? Somos virtualmente cegos. Todos nós. Sou cego a tudo, exceto a uma décima parte do universo". O que o Dr. James Xavier persegue em suas pesquisas, portanto, é a visão total. Ele quer muito mais que superar as limitações do olho

\footnotetext{
${ }^{67}$ J.-L. Comolli, "Machines of the visible", art. cit., p. 123.

${ }^{68}$ L. Williams, Hard core: power, pleasure, and the frenzy of the visible, op. cit., p. 56.
} 
humano: trata-se de alcançar o horizonte terminal daquele "frenesi do visível" cultivado desde o século XIX.

Na cena seguinte, diante de uma radiografia de tórax, James pede que sua colega Diane (Diana van der Vlis) arrisque um diagnóstico. "Uma lesão próxima ao coração, talvez nos pulmões. Pode ser um carcinoma", ela diz. "Ou um coágulo, ou somente uma mancha na chapa", James retruca, e prossegue: "Pode ser uma diversidade de coisas. Mas o que é isso, realmente? Só um teatro de sombras, um dado visual para ser usado em conjecturas inteligentes". O colírio que está a desenvolver, ele argumenta, seria uma forma de sensibilizar o olho humano para que este veja a radiação, incluindo os raios gama. Com isso, segundo James, uma técnica como a radiografia passaria a fazer parte dos museus da história da medicina, e a própria semiologia médica ficaria obsoleta: em vez de interpretar sinais imprecisos como uma mancha na chapa de raio-X e relacioná-los com os sintomas apresentados pelo paciente, de modo a formar um quadro clínico e deduzir a causa da doença, o médico poderia simplesmente transfixar o corpo do paciente com o olhar, penetrar em sua verdade corpórea mais profunda e descobrir a doença por intermédio de um simples "golpe de vista”, para lembrar a expressão com que Foucault, em $O$ nascimento da clínica, define justamente aquele olhar invasivo e cortante desenvolvido pela medicina moderna desde fins do século XVIII - um olhar que atravessa as formas imediatas do sensível e vai além das superfícies. James afirma que, com a ajuda do colírio, poderá olhar para os corpos dos enfermos como se fossem "janelas abertas". É o que acontece quando um médico do hospital em que trabalha pede que ele olhe uma jovem paciente cardiopata, que sofre de estenose e será operada no dia seguinte. Sob o efeito do colírio, James a examina - somente com a visão, sem sequer tocar na paciente - e discorda do diagnóstico do colega: "Ela não tem estenose, e sim um tumor na aurícula, colado à válvula". O colega se ofende com o tom peremptório da afirmação. Na manhã seguinte, após brigar com o outro cirurgião, James opera a menina com sucesso, provando que ela sofria de um tumor na aurícula, e não de estenose.

Mas, para além dessa aplicabilidade prática das propriedades do colírio, James é movido por um impulso mais primitivo e profundo: a curiosidade. "Por que você quer enxergar mais?", Diane pergunta. "Estou curioso, intensamente curioso", ele responde prontamente. A pulsão de saber se coloca acima da própria utilidade médica da substância. Diane e o colega oftalmologista de James tratam-no como um viciado compulsivo: ele deve ser curado de uma dependência química que o consome. Mas sua droga não é o colírio em si: é o conhecimento. 
O efeito cumulativo da substância vai se tornando um fardo insuportável para James. Num determinado momento, indo de carona no carro conduzido por Diane, ele diz que a cidade que vê se assemelha a um espaço morto, cadavérico, um conjunto de vigas e estruturas, sem qualquer marca de beleza; somente um esqueleto de cidade, "com sua carne dissolvida em um ácido de luz". James assiste a um mundo em que as construções foram reduzidas a vigas, e os corpos, a esqueletos (como uma radiografia em escala universal). As cores da natureza deram lugar a uma mescla estridente de tons acidulados. Nenhum conforto, nenhum descanso para o olho.

$\mathrm{Na}$ primeira vez em que James utiliza o colírio, Roger Corman introduz o procedimento de câmera subjetiva que marcará as cenas em que a droga age com mais intensidade sobre o protagonista. A câmera faz um travelling em volta do rosto de Ray Milland, até enquadrar sua nuca; então, ela avança como se quisesse entrar na mente do cientista. E, de fato, é como se ela entrasse, atravessasse a zona cortical, passasse pelo nervo óptico e chegasse ao globo ocular, numa espécie de viagem ao centro do olho.

A primeira imagem que surge da visão de raio-X de James é instável, intensa e, acima de tudo, alucinatória (para não dizer lisérgica...). O primeiro efeito não é de aumento da precisão e da acuidade, mas de confusão. Em seguida, a visibilidade começa a ressurgir e a se refazer. James se exalta com os efeitos de seu colírio: “É como uma divisão do mundo [It's like a splitting of the world]. Minha visão está fragmentada, e vejo mais luz do que jamais vi. Está cheio de luz!". Um mundo multicolorido, transbordando em energia luminosa, aparece para ele por trás de uma grade quadricular. O campo visual se fragmenta, perde sua unidade, para depois recuperá-la aos poucos. Superada a explosão visual inicial, James começa a enxergar com mais clareza, até perceber que seu olhar está atravessando as superfícies opacas, vendo além do que podem os olhos comuns. Ao mesmo tempo em que se excita com a descoberta, ele pondera: "Por enquanto, eu apenas penetrei a superfície. Meus olhos ainda não estão condicionados... mas já é um começo".

Um aspecto importante da nova visão de James, já destacado nessa cena em que ele experimenta o colírio pela primeira vez, é a instabilidade do campo escópico. Todos os planos-ponto-de-vista que correspondem à visão subjetiva de James mostram um campo de intensidades variáveis, no qual a luz ondula como uma substância química num meio hiperreativo, liberando suas miríades fosforescentes. O poder de radiografar os corpos e as coisas não é constante: ele vai e vem, enfraquece e acentua-se sem regularidade calculável. "Os efeitos do composto ainda são imprevisíveis", James relata já na segunda metade do filme: “Às vezes consigo ver através de paredes e pedras tão facilmente como vejo através do ar. 
Outras vezes, mal posso penetrar a primeira camada da pele humana”. Ao potencializar as capacidades oculares, o colírio acentua também o caráter fundamentalmente instável da percepção visual. Em outras palavras, o composto traz à tona não só as potências latentes, mas também as precariedades da visão, ignoradas pelo olho em suas funções ordinárias.

A princípio, James acredita cegamente no progresso científico representado pela substância que o permite ver em raio-X. Mas o desejo do cientista de tudo enxergar é caracterizado, desde o início, como uma espécie de perversão visual. Assim, apesar de a finalidade primordial do composto por ele inventado ser científica, nada o impede de nutrir alguns prazeres secretos: um dos benefícios do colírio na fase inicial consiste em permitir-lhe ver mulheres nuas, como a recepcionista do hospital - cujos seios, todavia, são tapados por um objeto cênico, num típico exemplo daquele recurso parodiado por Antonioni em Blow up:

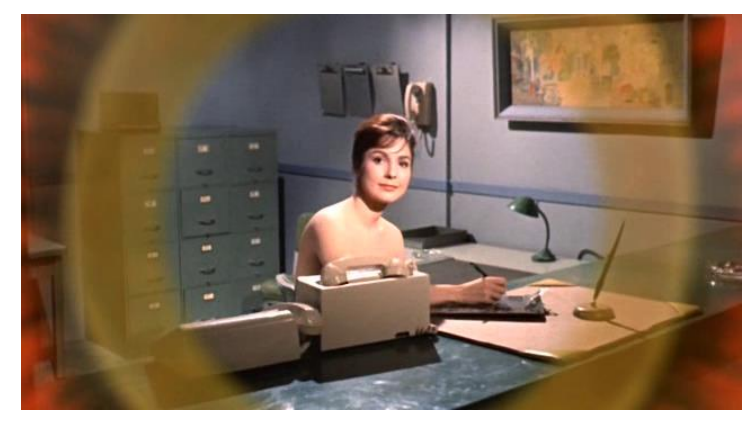

Em outra cena, no meio de uma confraternização com os demais médicos e funcionários do hospital, o efeito do colírio atinge um pico e James passa a ver as pessoas da festa como um bando de corpos nus dançando: o evento social se torna, aos seus olhos, um festival de nudez e erotismo, como se todos se preparassem para uma bacanal. O olhar do cientista perverte a realidade trivial por ele enfocada. Nada demais é mostrado (as partes sexuais dos corpos não aparecem), mas o essencial da cena consiste em apontar o solo comum das imagens científica e pornográfica, mostrando que ambas provêm de uma mesma vontade de saber, de uma mesma ideologia do visível atrelada ao desejo de acessar e dominar os mistérios que desafiam o olhar curioso e investigativo. Tal como acontece em Janela indiscreta, Blow up e Saudações, o filme de Roger Corman indica, à sua maneira, "a 'perversão' subjacente a qualquer busca por fatos, por verdade". ${ }^{6}$

\footnotetext{
${ }^{69}$ J. Crary, Suspensões da percepção, op. cit., p. 147.
} 


\section{A imagem anticlássica}

Larry Cohen e Brian De Palma, diretores com mais coisa em comum do que pode parecer à primeira vista, realizaram, no mesmo ano, filmes que se assemelham não só por serem releituras de Vertigo, mas, sobretudo, por buscarem refletir sobre os limites da representação cinematográfica mediante as imagens da pornografia e da violência. Esses filmes são, respectivamente, Special effects e Dublê de corpo (Body double), ambos de 1984. Se Vertigo, assim como sua reelaboração feita por De Palma em Trágica obsessão, não falava do cinema senão indiretamente, Special effects e Dublê de corpo decidem abolir o simbolismo e trazer a primeiro plano o discurso metacinematográfico implícito no filme de Hitchcock.

Special effects foi baseado num roteiro intitulado "The Cutting Room", escrito por Larry Cohen dezessete anos antes com a esperança de que Hitchcock pudesse dirigi-lo. $\mathrm{Na}$ época, porém, o projeto não foi para frente, e ele só o retomaria em 1984 para realizar um filme de baixo orçamento e com elenco desconhecido, evidenciando sua afinidade com um certo cinema nova-iorquino low-budget e independente, que tem John Cassavetes como referência principal. Performances espontâneas, improvisação, desrespeito às normas técnicas e ao profissionalismo rebuscado dos grandes estúdios são algumas das características desse cinema, que podem ser vistas em Special effects. É claro que Cohen é influenciado também pelo cinema hollywoodiano tradicional, como demonstram as muitas referências a Hitchcock. Mas, por estar trabalhando fora do coração do sistema, ele percebe a inutilidade e até mesmo a impossibilidade de emular o estilo clássico de Hollywood, e se lança a uma démarche mais próxima dos filmes marginais de Andy Warhol (há uma serigrafia de Marilyn Monroe exposta num dos cenários principais de Special effects, como a reivindicar essa filiação) do que do próprio suspense hitchcockiano.

O filme começa com Keefe (Brad Rjin) chegando a Nova York para resgatar sua esposa Mary Jean (Zoe Tamerlis, que no começo dos anos 1990, já assinando como Zoë Lund, faria o roteiro de Vício frenético, de Abel Ferrara) e levá-la de volta para Oklahoma. Keefe encontra Mary Jean, que agora responde pelo nome artístico de Andrea Wilcox, posando para uma sessão de fotos eróticas. Depois de escapar da vida pacata em Oklahoma, Andrea, que tinha o sonho de ser atriz, acabara parando no mundo da pornografia. Enfurecido, Keefe a leva até a casa dela em Manhattan, e lá projeta para ela um filme em $16 \mathrm{~mm}$ com imagens da antiga vida em família ao lado dele e do filho que tiveram juntos. Eles brigam, e Andrea foge de novo do marido para ir ao encontro de Chris Neville (Eric Bogosian), cineasta 
renomado que acaba de amargar um grande fracasso de crítica e público e tem o futuro de sua carreira em Hollywood comprometido.

Neville recebe Andrea em seu apartamento em Greenwich Village, onde ela o encontra assistindo, num equipamento semelhante àquele utilizado por Jack Terry em Um tiro na noite, ao filme do assassinato de Lee Harvey Oswald (o homem que teria matado JFK, de acordo com a investigação oficial). “Jesus! That's real!", Andrea afirma ao ver a imagem de Oswald levando o tiro. "Mas o que faz isso ser real, independentemente de você saber que de fato aconteceu?", Neville questiona. "Essa expressão no rosto. Ninguém conseguiria fingir isso", Andrea responde, referindo-se à reação facial de Oswald ao receber o tiro.

Como o psicopata de A tortura do medo (Peeping Tom, Michael Powell, 1960), Neville se mostra fascinado pela evidência - obscena - da morte captada por uma câmera. Ele se interessa, também, pelo estatuto ambíguo das imagens, pela fronteira tênue entre o real e o artificial, entre o documental e o ficcional. Seu próximo projeto consistirá justamente na tentativa de fazer o real passar por ficção, invertendo o processo da dramaturgia convencional, que busca fazer o ficcional, o artificialmente construído, passar por real. Com isso em mente, ele seduz Andrea e a leva para o seu quarto, pois lá há uma câmera de $16 \mathrm{~mm}$ escondida atrás de um espelho falso. O intuito de Neville é filmar-se transando com Andrea, para obter um pornô caseiro e documental. Por meio desse controverso método de filmagem, ele espera registrar a verdade do corpo no momento do sexo, o prazer não fingido, autêntico. Mas, antes mesmo de começarem a transar, Andrea, que já estava desconfiada da quantidade excessiva de luz que há no quarto, ouve o barulho do motor da câmera e descobre a armadilha de Neville. Ela o insulta e o acusa de impotente. Irritado, Neville a estrangula até a morte. A câmera atrás do espelho registra tudo. Neville agora possui um filme de sua própria autoria no qual se pode ver aquela expressão que, como a própria Andrea havia dito, "ninguém conseguiria fingir" (a expressão da morte verdadeira no rosto de uma pessoa).

O corpo de Andrea é encontrado num carro abandonado junto ao cais. Keefe se torna o principal suspeito. Ele é detido pela polícia, mas Neville se propõe a pagar a fiança e a contratar um bom advogado para defendê-lo, desde que Keefe aceite participar da biografia de Andrea que planeja filmar. O trato é feito. Pensando em usar a filmagem real do assassinato de Andrea como o grand finale, Neville acredita estar a caminho de realizar sua obra-prima.

A atriz que fará Andrea é encontrada quando Keefe topa com Elaine (igualmente interpretada por Zoe Tamerlis), uma sósia de sua esposa morta. O par Elaine/Andrea repete a relação Judy/Madeleine de Vertigo. Com o detalhe de que Elaine está menos para a triste 
plebeia do que para a princesa entediada que ocupa a semana com trabalhos voluntários, eventos sociais e militância feminista, ou seja, ela está menos para Judy do que para a Melanie de Os pássaros.

A questão da modelagem da personagem feminina, que implica uma relação de poder e dominação, é preponderante em Special effects, como já era em Vertigo. Elaine é modelada tanto por Keefe, que quer transformá-la na sua versão particular de Mary Jean - isto é, a boa mãe de família que ela não quis ser -, como por Neville, que a enquadra numa imagem artisticamente concebida (seu filme se chamará "Andrea", e não "Mary Jean", o que demonstra que ele não está interessado na pessoa real, mas na imagem que ela queria construir de si). "Quem sou eu, afinal?", Elaine pergunta em dado momento. "Por que não modelar uma personalidade inteiramente nova? Você tem os perfeitos materiais brutos para isso...", rebate Neville. "E você é o primeiro cara que tenta tirar a minha roupa para moldar minha personalidade", ela ironiza.

Com o papel que cabia a Gavin Elster (o do mestre manipulador) sendo agora atribuído a um cineasta (Neville), Cohen amarra toda a maquinação da trama como uma discussão metafílmica. Neville, manipulador obsessivo, mas fascinado também pelo imprevisto, encarna o conflito eminentemente hitchcockiano entre a vontade de planejamento e controle absolutos e o reconhecimento da força inexorável do acaso. O sistema de filmagem com câmera escondida que ele montou em seu próprio quarto é sintomático: um dispositivo calculado e arquitetado com o objetivo de capturar momentos espontâneos - a dialética entre manipulação e descontrole está aí condensada significativamente. Além disso, Cohen retoma as ideias de Hitchcock acerca da potência letal do cinema, da sua capacidade de precipitar a morte. "Special effects é uma interrogação autorreflexiva sobre o olhar mortífero [murderous gaze] de Hitchcock" ${ }^{70}$ : através da personagem do cineasta, que calha de ser o vilão do filme, Cohen leva adiante as associações hitchcockianas entre a fascinação visual com o corpo feminino e a pulsão de morte, inscrevendo-as em situações ainda mais extremas. O cinema é retratado no filme como um reduto de perversidade e assassinato. Emblematicamente, para matar o técnico de um laboratório de imagem que o estava chantageando, Neville utiliza um pedaço de película cinematográfica, com o qual o estrangula. Mais tarde, Keefe tentará matar Neville com uma tesoura de montador, e o diretor acabará morrendo eletrocutado na piscina do seu apartamento, na qual cairá junto com um refletor de cinema que está com o fio

\footnotetext{
70 Tony Williams, Larry Cohen: The radical allegories of an independent filmmaker, Carolina do Norte: McFarland, 1997, p. 172.
} 
desencapado. Em Special effects, portanto, os materiais e equipamentos cinematográficos são armas letais.

Perguntado por um repórter, no início do filme, sobre qual o cineasta que mais o influenciou, Neville responde que foi Abraham Zapruder. Mais do que uma resposta irreverente, a afirmação de Neville é a carta de intenções do filme. Pois quem é Zapruder? Um cinegrafista amador, responsável por um filme-marco, conforme sabemos - o filme da morte de JFK. Um filme sem montagem, um registro documental contínuo de 26 segundos, feito de uma única tomada capturada de um ângulo que não é o melhor, de um ponto de vista que não é o mais adequado, com uma qualidade técnica que não é a mais admirável. Mas, e isso é o que realmente importa para Neville, trata-se de um filme que imprimiu uma morte chocante, que se deu de uma maneira que ninguém poderia pensar ou prever - o que só torna o registro ainda mais impactante e real (dir-se-ia mais real que a própria realidade). Pois o que está em jogo em Special effects, tal como no filme de Zapruder, não é propriamente a questão da mise en scène, nem mesmo do ponto de vista (o ângulo de tomada, o eixo, a distância entre câmera e objeto etc.), mas tão somente a captação, ou melhor, a impressão, a fixação do acontecimento, o horror presenciado e registrado pelo aparato fílmico. Tudo o que interessa para Neville está na imagem, no campo; basta ver.

Há uma cena em que Neville assiste na moviola ao material que filmou durante o assassinato de Andrea. A câmera de Cohen faz um travelling na direção do monitor, aproximando-se do rosto desesperado da atriz:
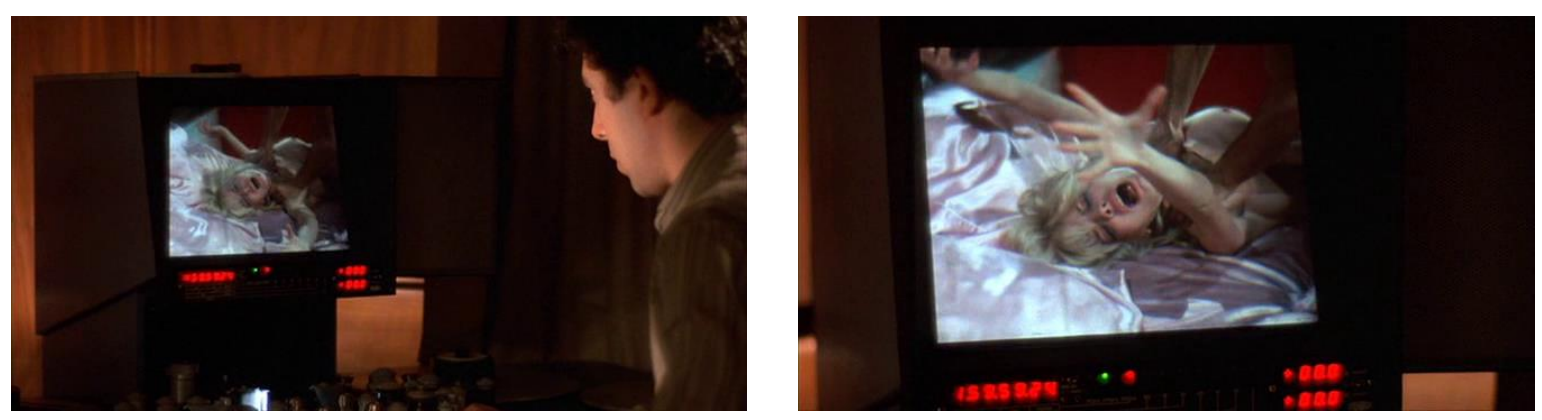

Neville não precisa montar essa imagem com outra, não precisa do efeito Kulechov. Tampouco tem de variar o ponto de vista para revelar algum aspecto novo ou fabricar algum efeito. Seu "efeito especial” consiste na própria realidade gráfica e concreta da expressão agonizante de Andrea, no espasmo instintivo do seu corpo, na forma patética (de pathos) que assume durante a carga de estresse e tensão infligida pelo agressor. A contorção de dor que ela identificara no rosto transfigurado de Lee Harvey Oswald agora se produz em seu próprio 
corpo. O atrativo do filme de Neville reside na força ontológica do registro, na força primitiva do plano cinematográfico, sem recurso às artimanhas da montagem. Elegendo a morte e o sexo como seus objetos, ele nada faz senão sublinhar e radicalizar a "obscenidade ontológica" e intrínseca do cinema. ${ }^{71}$

Como Neville diz ao policial que investiga o assassinato de Andrea, seu "truque" consiste em pegar a realidade e fazê-la parecer fingimento: "Isso também é um efeito especial”. Exilado do sistema de Hollywood, descreditado pela imprensa após seus fracassos recentes, ele se refugia nas margens da indústria cinematográfica, nos porões em que se produzem filmes pornôs, teorias da conspiração e documentários macabros que mostram a morte sem censura e sem trucagem (os chamados snuffs). Ele se vê apto a explorar o horror explícito, deslavado, imoral, que a dramaturgia convencional proíbe, recalca ou embrulha em artifícios retóricos. Neville realiza o filme sobre a vida de Andrea em 16mm, com câmera na mão, em estilo semidocumental, como a querer equalizar essas imagens com os documentos reais que utilizará (o filme familiar de Keefe, o filme da morte de Andrea) e dar ao conjunto um aspecto de filme caseiro: o que vale é a brutalidade, a crueza, o falso amadorismo como marca paradoxal da autenticidade do registro.

Perto do final de Special effects, Keefe destrói acidentalmente o filme da morte de Andrea. Ele queria, na verdade, resgatar o filme familiar, que Neville guardara misturado aos seus outros arquivos. Mas Keefe confundiu as latas e acabou pegando por engano o filme do assassinato. E, ao tentar projetá-lo, antes mesmo que conseguisse ver alguma coisa, provocou um estrago: a película foi mastigada pelo projetor e depois ficou toda embolada. Neville se viu obrigado, então, a refazer a cena. Por isso, ele convida Elaine para o seu apartamento e a seduz, exatamente como fizera com Andrea. A intenção é levá-la para a cama e, filmando tudo com a câmera escondida atrás do falso espelho, estrangulá-la.

Em Vertigo, Scottie tentava refazer Madeleine a partir de Judy; por mais que pudéssemos enxergar em Madeleine uma encarnação da imagem cinematográfica, e em sua reelaboração no corpo de Judy uma espécie de "remake", isso permanecia no plano abstrato da interpretação e da leitura de segundo grau. Já em Special effects, Neville está a lidar, efetivamente, com um filme, com um registro cinematográfico: ele quer refilmar com Elaine a

\footnotetext{
${ }^{71}$ Cf. A. Bazin, "A morte todas as tardes", in I. Xavier (org.), A experiência do cinema, op. cit., pp. 129-134. Reproduzo aqui a parte mais essencial do texto: "Pôde-se ver na primavera de 1949, num cine-jornal, um documento alucinante sobre a repressão anticomunista em Xangai, 'espiões' vermelhos executados a tiros de revólver em praça pública. Ao toque da campainha, a cada sessão, esses homens estavam novamente vivos: o impacto da mesma bala estremecia-lhes a nuca. [...] Espetáculo intolerável, não tanto por seu horror objetivo, mas por seu caráter de obscenidade ontológica. Antes do cinema, conheciam-se apenas a profanação de cadáveres e a violação de sepulturas. Hoje, graças ao filme, pode-se violar e exibir à vontade o único dos nossos bens temporalmente inalienável. Mortos sem réquiem, eternos re-mortos do cinema!” (pp. 133-134)
} 
cena que havia rodado com Andrea. Usando uma mulher que conheceu na rua, Scottie tentava reencontrar o objeto do seu amor perdido e fazer reviver uma mulher morta. Neville, por sua vez, escala uma nova atriz e escolhe uma nova data de filmagem para refazer um filme destruído cuja atriz já está morta: Cohen encena a transformação de Elaine em Andrea como uma operação puramente cinematográfica. Neville não a veste, maquia e dirige "como se estivessem" num set de filmagem: eles estão num set de filmagem.

Em Dublê de corpo, De Palma também leva a narrativa de Vertigo para dentro do universo específico do cinema, como o plano em que aparece o título do filme já deixa claro: temos uma visão panorâmica de uma paisagem do deserto californiano; mas a imagem, a princípio estável, começa a se deformar, e não demora até que descubramos que essa paisagem, na verdade, é um cenário pintado que dois homens transportam pelo estacionamento de um estúdio de cinema. A planície desértica - típica do faroeste, "o cinema americano por excelência" - não passava de um fundo falso para cenas filmadas em estúdio.
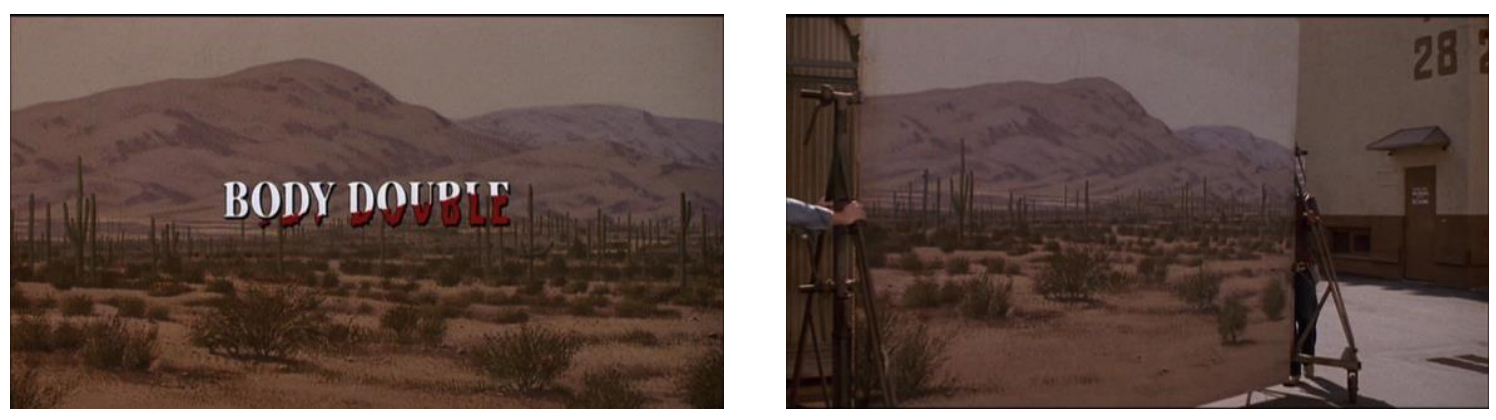

Tal como o primeiro plano de A trama, esse plano de Dublê de corpo apresenta um problema de óptica e alerta para os enganos da percepção visual. De Palma, a exemplo de Pakula, faz a imagem se reconfigurar internamente para revelar um aspecto que antes negligenciávamos. Mas, se Pakula não demarcava sua reflexão como especificamente cinematográfica, De Palma, contrariamente, localiza o efeito óptico por ele abordado como parte do mundo próprio do cinema, desvendando um dos procedimentos mais típicos das técnicas de ilusão cinematográfica. Ele articula, assim, uma questão que está na base mesma do filme: o trompe-l'oeil, o caráter ilusionista da representação mimética, e sua relação com o dispositivo do cinema. 
$\mathrm{Na}$ continuação da sequência de créditos iniciais, uma nova anedota visual é feita: um trailer de cachorro-quente, filmado de perfil, ganha o aspecto de um par de nádegas com um falo penetrando no meio. A conotação sexual é reforçada pela cena protagonizada pelo casal ao lado: o rapaz enfia um cachorro-quente na boca da namorada (num gesto um tanto impositivo, já antecipando discretamente as agressões sexuais que marcam a narrativa). Para reorganizar a percepção e desfazer qualquer eventual engano, a câmera se desloca em travelling até enquadrar de frente o tosquíssimo trailer em forma de hot-dog.
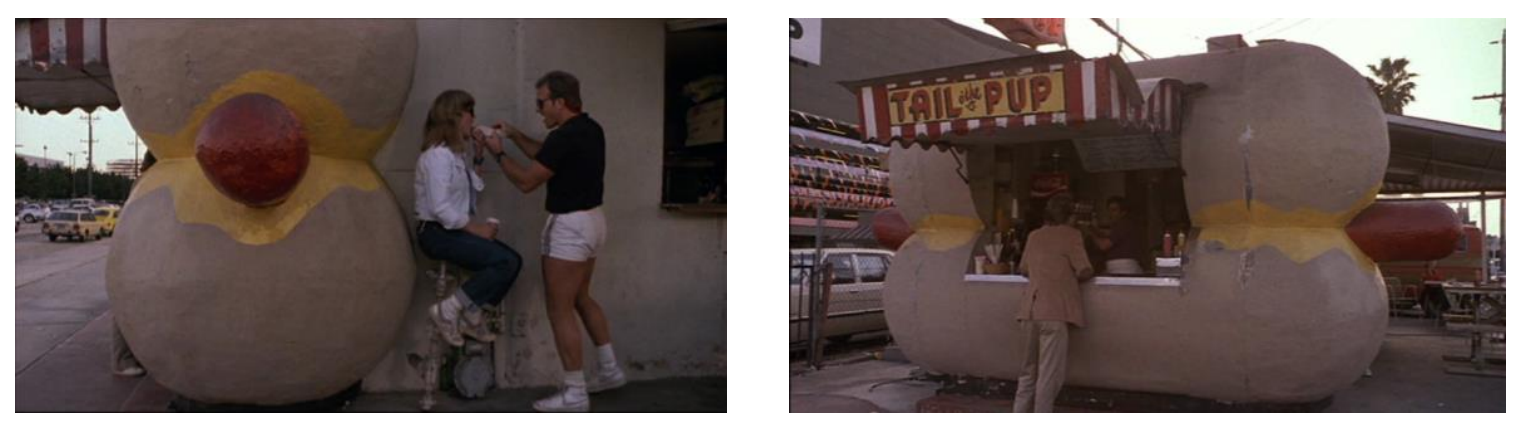

Em Special effects, conforme analisamos há pouco, a questão central residia na força intrínseca do registro, no poder da imagem como impressão do real. Em Dublê de corpo, diversamente, De Palma realoja o problema numa reflexão sobre o ponto de vista e as condições da recepção. Nessa perspectiva adotada por De Palma, a escolha do ponto de vista determina a forma e o efeito da percepção, e a sua variação, mesmo a mais simples, pode ressignificar a imagem inteiramente.

A trama do filme, que se baseia na manipulação visual de uma personagem que se deixa levar por uma ilusão de óptica, mostra exatamente isso. Tal personagem é Jake Scully (Craig Wasson), ator fracassado que atua como vampiro em filmes de terror de quinta categoria. Após ter uma crise claustrofóbica em pleno set de filmagem, ele volta para casa mais cedo e encontra sua mulher transando com outro homem. Resolve sair de casa e, sem ter onde ficar, aceita o convite de Sam Bouchard, colega do curso de teatro que lhe oferece estadia num apartamento modernoso, espécie de torre panóptica com vista privilegiada de Los Angeles. O apartamento conta com todo o luxo e conforto, mas o principal atrativo, como Sam se apressa em mostrar para Jake, é o show gratuito que a vizinha da casa em frente oferece toda noite: ela fica seminua, faz uma dança sensual e se masturba como se estivesse se apresentando no palco de uma boate erótica. Um telescópio estrategicamente direcionado para o quarto da vizinha exibicionista dá a Jake uma boa visão do espetáculo. E ele não se furta ao papel de voyeur, acompanhando, por duas noites seguidas, o pequeno show de strip-tease. 

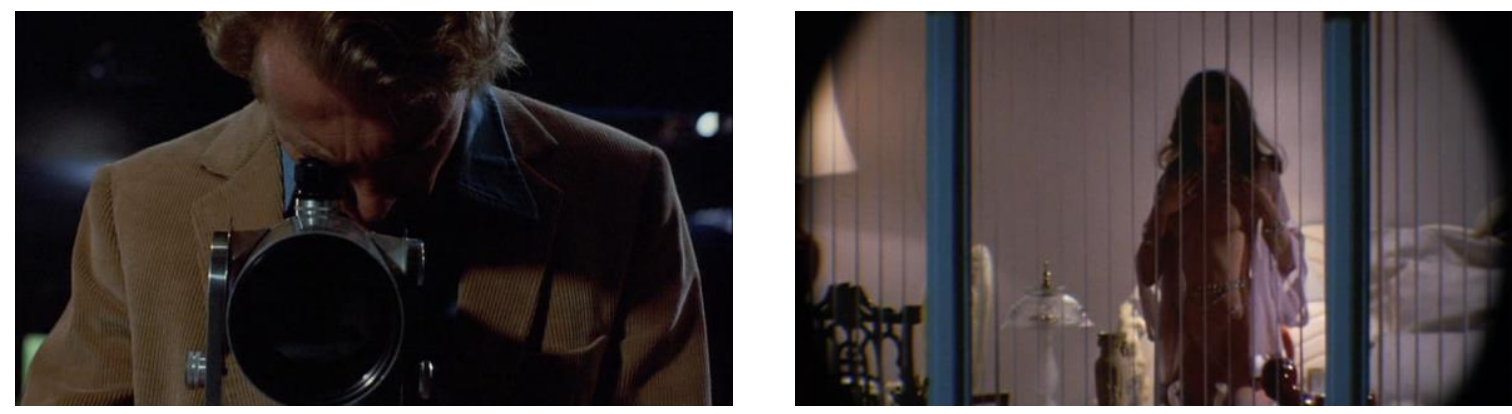

O dispositivo evoca, evidentemente, Janela indiscreta - ainda mais porque a mulher é vista sendo agredida por um homem misterioso, como acontecia com a Sra. Thorwald no filme de Hitchcock. Estruturalmente falando, contudo, o modelo principal do filme não é Janela indiscreta, mas Vertigo. À semelhança de Scottie, Jake é vítima de uma armadilha óptica: a dança erótica da vizinha é um espetáculo armado por Sam para manter Jake atento ao que está acontecendo na mansão em frente. O intuito de Sam é colocá-lo na posição de testemunha. E o plano funciona: numa noite, Jake observa pelo telescópio que há um homem de feições indígenas - e com o rosto deformado, o que lhe confere um ar assustador rondando a casa da vizinha. No dia seguinte, ele a vê saindo de carro e o índio a perseguindo num jipe. Ele resolve protegê-la, indo atrás dos dois em seu carro. Ocorre uma longa e intrincada sequência inspirada nas perseguições de Scottie a Madeleine. Depois de passar por um shopping, a mulher vai para um motel à beira da praia, onde Jake a vê caminhando pela areia, com o índio se aproximando dela. Ele vai ao socorro da moça, que tem sua bolsa roubada pelo índio. Jake corre atrás dele, e a perseguição culmina num túnel que liga duas partes diferentes da praia. Por sofrer de claustrofobia, o protagonista não consegue seguir adiante. Ele assiste ao índio esvaziando a bolsa da mulher no chão e pegando um cartão, mas deixando o resto. Com muito esforço, Jake se esgueira por dentro do túnel e resgata os pertences da moça, que depois aparece e, percebendo que ele está ofegante, com expressão agoniada, ajuda-o a sair de lá. Ela se chama Gloria Revelle (interpretada por Deborah Shelton, que integrava o elenco de Dallas). Depois de um diálogo hesitante, eles se olham fixamente e, por magia repentina, entregam-se a um beijo caloroso. Mas ela interrompe o beijo e se retira dali apressada, sem dar muita explicação.

À noite, de volta à posição de voyeur, Jake assiste a Gloria Revelle chegando em casa e sendo violentada pelo índio (o cartão magnético que este roubara da bolsa dela abria a porta da mansão). Jake corre até lá, mas não consegue impedir que ela seja hediondamente assassinada. Interrogado pela polícia, ele conta o que viu: o índio de aparência estranha invadiu a casa e matou Gloria. 
Dias depois, deprimido, rodeado pela bagunça que deixou se acumular no apartamento, Jake assiste na televisão ao anúncio publicitário de um filme pornô intitulado Holly Does Hollywood, estrelado por Holly Body (Melanie Griffith ${ }^{72}$ ), star da indústria pornográfica. Ela dança nua, e Jake reconhece em seus movimentos exatamente a mesma coreografia que era feita pela vizinha. Ele corre para uma locadora de vídeo, aluga o filme e, após vê-lo, convence-se de que era realmente Holly quem dançava para ele toda noite.

Com o intuito de conhecer Holly e descobrir qual é sua conexão com o assassinato de Gloria, Jake comparece a um teste de elenco para um filme pornográfico em que ela será a protagonista. Depois de contracenar com Holly, ele visita seu camarim e a convida para jantar. Daí em diante, é questão de pouco tempo até que a intriga seja desvendada: a mulher que ele via dançando era Holly, e não Gloria; Sam, na verdade, era o marido da milionária, e havia planejado matá-la para ficar com a herança; Jake, como testemunha ocular de que o crime fora executado por um índio estranho que entrou para roubar as joias e o dinheiro de Gloria, isentaria o marido de qualquer suspeita; mas o tal índio, no fim das contas, era Sam disfarçado com uma máscara de látex igual às que são usadas nos filmes de terror em que o próprio Jake atuava. Em resumo: Sam montou uma farsa digna de filme B e escolheu o mau ator de que precisava para o papel principal. O claustrofóbico Jake, que começara o filme sendo dispensado de um set de filmagem (tal como Scottie fora dispensado da polícia após a crise de acrofobia), regride, a princípio, ao lugar do espectador, limitando-se a assistir ao show de Holly. Com o desenrolar da trama, no entanto, ele tem a oportunidade de voltar à ação. "Como Scottie em Vertigo, Scully passa do estatuto de espectador ao de ator e mergulha progressivamente na ficção inventada por Sam Bouchard."73

Judy e Madeleine, em Vertigo, eram interpretadas pela mesma Kim Novak. Em Special effects, Elaine e Andrea também eram interpretadas pela mesma atriz, Zoe Tamerlis. Em Dublê de corpo, Brian De Palma modifica o esquema: Holly e Gloria correspondem a duas atrizes diferentes, Melanie Griffith e Deborah Shelton. Do seu ponto de vista, Jake assume que a mulher que faz a dança erótica é Gloria, ignorando que se trata de uma atriz pornô contratada exclusivamente para aquele número. Se, em Vertigo, Scottie pensava que havia duas mulheres (Judy e Madeleine), quando na verdade só havia uma (Judy), em Dublê de corpo, inversamente, Jake acha que só há uma mulher (Gloria), mas na verdade há duas

\footnotetext{
${ }^{72}$ Filha de Tippi Hedren (atriz protagonista de Os pássaros e Marnie), o que permite a De Palma ratificar uma filiação física e genética com o cinema de Hitchcock e, ao mesmo tempo, afirmar, em paralelo a uma certa decadência, uma liberação sexual da personagem feminina hitchcockiana (já que a ninfomaníaca Holly representa tudo o que a frígida Marnie não podia ou não conseguia ser).

${ }^{73}$ L. Lagier, Les mille yeux de Brian De Palma, op. cit., p. 72.
} 
(Gloria e Holly). A confusão vem do fato de que Jake não pode ver de um lugar mais próximo, nem por outro ângulo, o que acontece na casa da vizinha. $\mathrm{O}$ rosto dela não pode ser identificado com nitidez, ainda mais com a penumbra do quarto. No fundo, a maquinação de Sam Bouchard se inspira num artifício comum no cinema, já anunciado pelo título do filme: substituir a atriz por uma dublê para filmar as cenas de nudez. Nas cenas em que Gloria dirige o carro e vai ao shopping, é ela própria quem atua. Já nas cenas em que ela dança e se masturba, é Holly Body quem entra em ação. Para Jake, entretanto, trata-se sempre da mesma mulher. A cena de créditos finais é uma espécie de explicação didática de como funciona o procedimento: de volta ao elenco do filme de terror de que fora expulso, Jake participa de uma cena em que o vampiro interpretado por ele ataca uma moça que está tomando banho; os planos em que aparecem os rostos são filmados com a atriz principal, enquadrada apenas do ombro para cima; já nos momentos em que devem ser mostradas as mãos do vampiro acariciando os seios da moça, a atriz é substituída pela dublê. Com o filme montado, o espectador assumirá que o rosto visto no plano A e os seios vistos no plano B pertencem ao mesmo corpo, quando, na verdade, são partes estanques que formam um corpo imaginário, que só existe no mundo artificial e mentiroso urdido pela montagem cinematográfica.

De Palma inscreve no filme "o discurso sobre a implicação do sujeito no dispositivo da representação". ${ }^{74}$ Como o detetive que investiga a morte de Gloria Revelle afirma para Jake, o crime só aconteceu porque ele estava lá como testemunha/voyeur. E é a pura verdade: Sam só podia executar seu plano caso conseguisse alguém para ficar de testemunha. Tendo em vista o discurso reflexivo de Dublê de corpo, isso significa que os planos de um filme, e as imagens em geral, são pensados e produzidos em razão do contexto de sua recepção, ou seja, levando em conta o sujeito que verá tais imagens e onde/quando/como as verá. As imagens que Jake vê pelo telescópio só fazem sentido porque existe o seu olhar contemplando a cena e, mais ainda, suturando o corpo de Holly ao rosto de Gloria.

Dublê de corpo começa e termina num set de filmagem. No começo, Jake fica travado dentro do caixão, sofrendo de claustrofobia, e não consegue completar a cena. No final, ele está de volta ao estúdio de filmagem, encarnando novamente aquele mesmo vampiro, o que demonstra que foi reincorporado ao elenco daquela produção. O percurso narrativo de Dublê de corpo pode ser resumido, então, como o esforço de Jake para conseguir voltar ao mundo do cinema. O primeiro passo é redescobrir o fascínio da imagem cinematográfica, regredindo

\footnotetext{
${ }^{74}$ A. Ledoux, L'ombre d'un doute, op. cit., p. 37.
} 
ao estágio inicial, ou seja, à posição de espectador. Gloria Revelle, a princípio, é nada mais que uma imagem: ela representa o mundo do qual Jake foi afastado, o mundo do cinema que ele agora deve observar à distância e através de um aparato óptico. Ele só conseguirá voltar a esse mundo depois que conhecer Holly e se imiscuir no universo da pornografia. É como se ele tivesse sido forçado a viver um breve exílio à margem do sistema, antes de regressar e dar continuidade à sua carreira em Hollywood (uma Hollywood lado B, mas ainda assim Hollywood). Se Jake retorna aos estúdios, portanto, é pela porta dos fundos, aqui representada pela indústria do cinema pornô.

A cena que simboliza o esforço de Jake para voltar ao mundo do cinema é a da travessia do túnel, depois da perseguição ao índio na praia, que termina quando o herói depara com o túnel e não consegue mais prosseguir. Seu rosto se enche de suor, tal qual o de Scottie paralisado no meio da escadaria que o levaria à torre da igreja no final da primeira parte de Vertigo. Para figurar o mal-estar da sua personagem, Hitchcock recorrera ao famoso efeito visual que combinava zoom e travelling em direções opostas. De Palma, por sua vez, opera um nauseante vai e vem da lente zoom e balança a câmera diagonalmente.
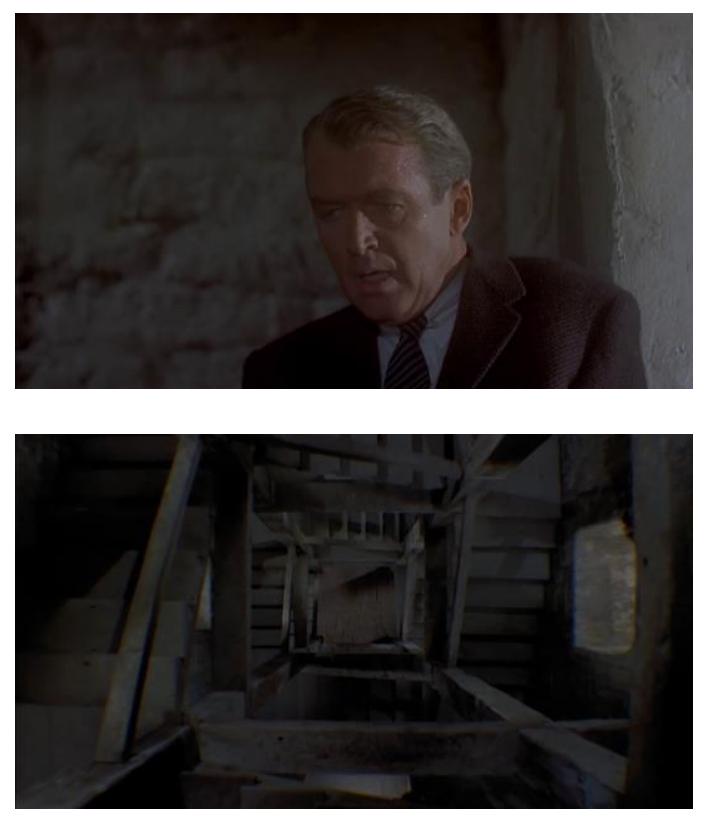

Vertigo
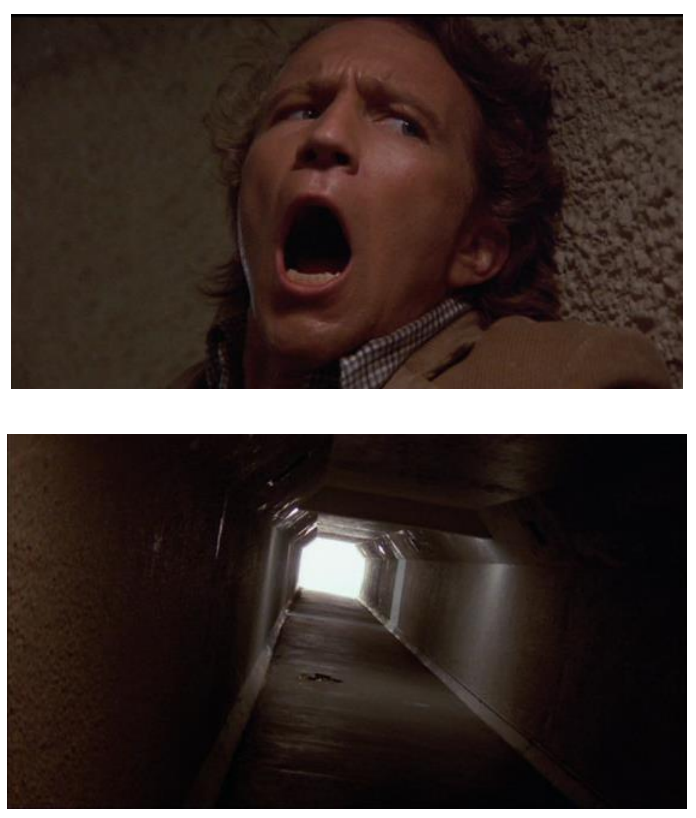

Dublê de corpo

Em Vertigo, Scottie possuía medo de altura; Gavin Elster utilizava isso a seu favor, pois sabia que Scottie jamais chegaria ao topo da torre da igreja, e permaneceria numa posição de onde o assassinato de Madeleine pareceria um suicídio (sem contar que ele nunca saberia que a mulher que viu cair não era a mesma que havia seguido). A estratégia de Elster, 
assim como a de Sam Bouchard em Dublê de corpo, inclui "um efeito de montagem manipulador que explora a tendência do espectador a introduzir continuidade entre dois planos (o corpo que sobe ao alto da torre e o corpo que cai em Hitchcock; o corpo que dança próximo à janela e o corpo que sai da casa em De Palma)". ${ }^{75}$ Uma interpretação psicanalítica tende a ver, por trás desse esquema, uma metáfora da impotência sexual: Scottie não consegue chegar ao topo da torre, ou seja, não consegue ter uma ereção, e perde a mulher de que gosta, fracassando sexualmente. Em Dublê de corpo, Jake não tem acrofobia, mas claustrofobia; sua crise se dá quando ele fica paralisado diante do túnel. A variação proposta por De Palma é interessante: não é mais uma torre, e sim um túnel, o que assusta o protagonista. Ora, se a torre era um representante simbólico do pênis, o túnel está mais para o canal vaginal. O que apavora Jake, portanto, é a visão do sexo feminino. A metáfora sexual se desloca do órgão genital masculino para o feminino: é o corpo da mulher, seu mistério, sua diferença, o que agora está em jogo.

Não se pode esquecer que o fracasso profissional de Jake no começo do filme (ele não conseguiu fazer a cena porque se sentiu claustrofóbico dentro do caixão do vampiro) foi logo em seguida complementado pelo fracasso conjugal (ao voltar para casa, flagrou sua mulher na cama com outro homem). Para ele, então, superar a claustrofobia será também uma prova de recuperação no plano sexual. Não à toa, depois que ele é ajudado por Gloria a sair do túnel, há uma ardente cena de beijo, como se vencer a claustrofobia significasse poder voltar a se relacionar com uma mulher. De Palma retoma, nessa cena, o plano circular do beijo de Scottie e Judy no Empire Hotel, com direito a back projection e tudo o mais. Mas o diretor de Dublê de corpo conscientemente vulgariza o beijo romântico de Vertigo, como a demarcar um novo contexto da imagem, bem distante de todo o brilho do antigo classicismo hollywoodiano.
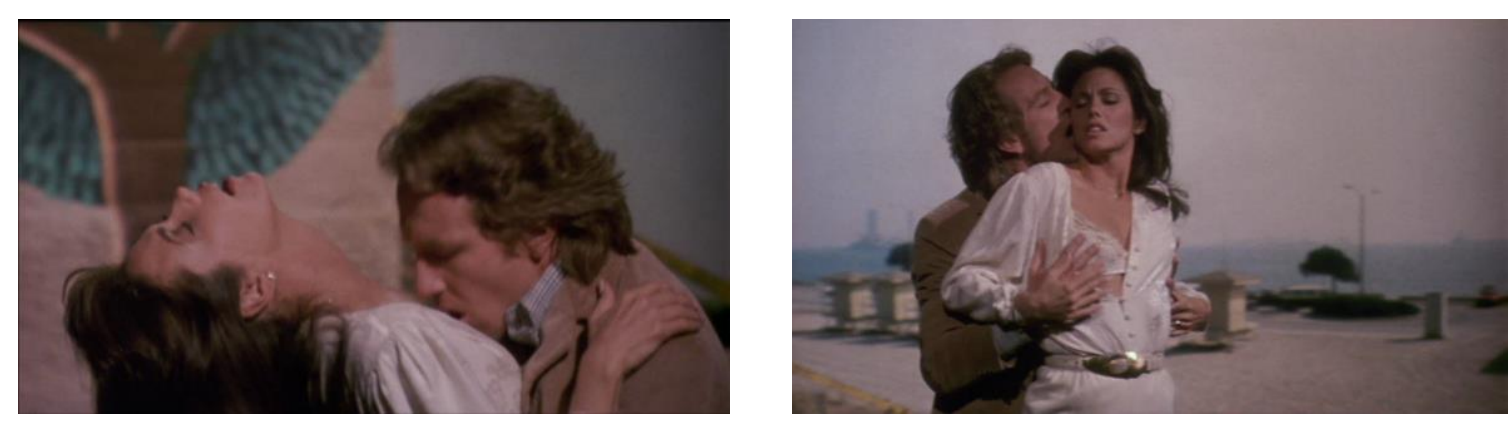

O enlace amoroso é aqui encenado como um clímax romântico totalmente forçado, que irrompe com a gratuidade de um clichê publicitário. O beijo apaixonado de Scottie em

\footnotetext{
${ }^{75}$ Ibid., p. 38.
} 
Judy, que condensava a ideia de um tempo que retorna, é trocado por uma excitação libidinal passageira. Embora comece em clima de fantasia romântica (corroborado pela emotividade inundante da trilha sonora), o beijo de Jake em Gloria rapidamente abafa o lirismo em proveito da carga puramente erótica da interação dos corpos. "Não há mais amor, mas um erotismo tristemente pornográfico."76 A própria magia do truque visual que fazia os amantes girarem e o cenário se metamorfosear esvazia-se num efeito tão delirante quanto aleatório.

O que nos diz esse filme? Que o mundo das imagens desrealizadas, falseadas, interesseiras, que visam somente a produzir dinheiro, rebaixa os homens e os reduz à impotência. Que Hollywood, que já soube sublimar os mais loucos sonhos, agora os degrada. Que suas imagens foram confiscadas pelas intenções mercantis da publicidade. Em suma, que esse cinema canceriza o imaginário coletivo - e, portanto, o individual - e o leva a se decompor. ${ }^{77}$

A substituição efetuada na narrativa - primeiramente nos momentos em que Holly se passa por Gloria para fazer o show de strip-tease, e depois quando a segunda morre e sobra apenas a star pornô - significa algo mais que um mero jogo de duplos: "O corpo sexualizado de Holly, puro fantasma de vulgaridade, suplanta o corpo aristocrático de Gloria, personalizado por seu rosto e sua elegância. Dramática e visualmente, o primeiro recobre, elimina, assassina o segundo". ${ }^{78}$ De Palma expõe assim o devir pornográfico da indústria cinematográfica e da sociedade como um todo. Ele filma, talvez, o que Rauger denominou "o tempo pós-pornográfico", ou seja, um tempo marcado por "uma impregnação difusa e generalizada do gesto erótico", a ponto de a realidade no conjunto tornar-se palco de um "investimento libidinal total”, transfazendo-se numa "gigantesca zona erógena". 79

Para compreender de que modo De Palma ilustra essa mudança de paradigma, basta continuar a comparar Dublê de corpo com seu ancestral hitchcockiano. Por exemplo: em Vertigo, Madeleine, depois de comprar flores, vai a um museu, onde contempla o retrato de Carlotta; em Dublê de corpo, Gloria vai a um shopping, onde entra numa loja de lingerie e compra uma calcinha. Enquanto experimenta a calcinha no provador, ela é observada por Jake, cuja postura voyeurística reconstitui de modo abertamente obsceno - tanto que a vendedora chama o segurança do shopping para removê-lo de lá - a situação disfarçada e secreta de Scottie espiando Madeleine na loja de flores. Do museu ao shopping, do buquê de

\footnotetext{
${ }^{76}$ La DVDéothèque de Jean Douchet, Paris: Cahiers du cinéma, 2006, p. 24.

${ }^{77}$ Ibid.

${ }^{78}$ Ibid., p. 23.

${ }^{79}$ J.-F. Rauger, art. cit., p. 277.
} 
flores à calcinha, da espionagem escondida à perversão escancarada, há nitidamente um movimento de erotização e vulgarização do enredo de Vertigo.

Dentro dessa mesma lógica, a mulher que o herói masculino persegue e contempla em Dublê de corpo não é mais a heroína psicologicamente atormentada, assombrada pelos fantasmas da História, dividida entre dois mundos, mas simplesmente a burguesa mal amada, consumista, cujo único mistério consiste em dançar nua em frente à janela e se masturbar sempre com hora marcada.

Como em Hitchcock, a imagem se revela enganosa e a mulher desejada se revela diferente do que se acreditava, mas o que importa aqui é que um número de strip-tease substitui a história de Carlotta, que o equivalente de Judy é uma atriz pornô, e que a galeria de museu se faz galeria comercial: se Dublê de corpo é ainda a narrativa de uma mistificação, a imagem fascinante tornou-se débil e parece preocupada somente com seu consumo. ${ }^{80}$

Esse rebaixamento deliberado dos motivos narrativos e formais de Vertigo também se confirma na trilha sonora de Dublê de corpo: o tema romântico-wagneriano de Bernard Herrmann se troca pela música "parodicamente lasciva e sensual" ${ }^{\prime 1}$ de Pino Donaggio, com destaque para o tema musical das cenas de strip-tease, que consiste numa variação satírica do que pode haver de mais artificial em termos de música sexy. Aliás, a primeira cena em que Jake vê a vizinha se dá ao som dessa música que embala o strip-tease. Ou seja, em Dublê de corpo, o equivalente da deslumbrante aparição de Madeleine no restaurante Ernie's é uma cena erótica digna das madrugadas da TV a cabo. Se Hitchcock filmara a entrada em cena de Kim Novak em Vertigo com o máximo de requinte e exuberância, lançando mão de estratégias composicionais e códigos figurativos da mais elevada pintura renascentista, e chegando a dialogar com a forma de representação dos ícones religiosos, De Palma, em Dublê de corpo, introduz a musa feminina por meio de uma cena de strip-tease que poderia muito bem ter sido tirada de um filme de sexploitation feito diretamente para vídeo.

No entanto, essa diferença de tom não deve esconder o diálogo teórico implícito que se instaura entre o filme de Hitchcock e o de De Palma. Pois, a despeito de uma oposição de registros, essas duas cenas têm exatamente a mesma função: instalar [mettre en place] uma manipulação pela fascinação que uma imagem exerce. [...] A aparição do corpo da personagem em sua versão icônica (Vertigo) ou crua (Dublê de corpo) vale por todo discurso, e talvez até funcione como um imperativo. ${ }^{82}$

\footnotetext{
${ }^{80}$ A. Ledoux, L'ombre d'un doute, op. cit., p. 39.

${ }^{81}$ Ibid., p. 112.

${ }^{82}$ Ibid.
} 
O ápice desse diálogo teórico que De Palma estabelece com Vertigo ocorre num dos planos da sequência da filmagem do pornô em que Jake e Holly contracenam, sequência esta que funciona quase de forma heterogênea na narrativa do filme, sendo praticamente o enxerto de um clipe da música "Relax", de Frankie Goes to Hollywood, que se tornaria um dos maiores sucessos do technopop dos anos 1980.

O plano em questão, o qual, conforme analisaremos daqui a pouco, repete exatamente a mesma estrutura de composição do plano-espelho de Vertigo, é precedido por um outro plano também merecedor de nossa atenção, pois igualmente fundado nas potências plásticas e psicológicas da imagem especular. Esse plano mostra Jake diante de um espelho no qual consegue ver refletida a imagem de Holly Body dançando seminua em outra parte do cenário (que é o banheiro feminino de uma boate noturna, ou seja, um espaço interditado aos homens). Por meio desse prolongamento cenográfico propiciado pela imagem no espelho, De Palma convida o olhar do espectador a se perder num espaço visualmente poluído, confuso, concebido como reino do reflexo e do duplo - um mundo em que "o objetivo a atingir não é mais a realidade, mas a imagem, e somente a imagem". 83

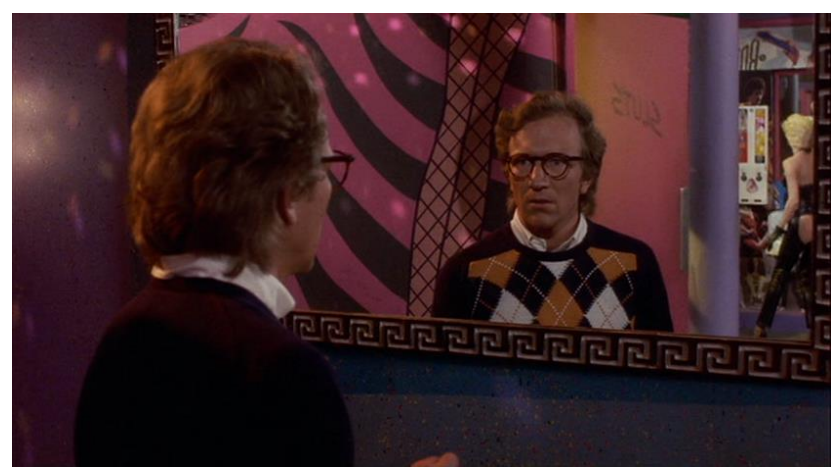

Na primeira vez em que Jake a viu, Holly era uma imagem televisiva. Agora, ela é uma imagem no espelho. No momento seguinte, se conseguir transgredir a fronteira que os separa e atravessar a porta que dá para o outro cenário (o banheiro feminino), Jake poderá ver Holly em carne e osso. Há, portanto, uma progressão da visão, numa escala que vai do mais distante - o tele-visual - ao mais próximo (o corpo presente), ou do conhecimento visual ao “conhecimento carnal” (para usar a célebre expressão pela qual a Bíblia designa o coito).

Todavia, o que Jake irá alcançar, caso ultrapasse o limite imposto pela porta, é um corpo que já vestiu uma espécie de pele de imagem. E mais: porquanto ele enxerga o seu alvo, Holly, como imagem refletida numa superfície retangular que evoca a própria tela em que o

\footnotetext{
${ }^{83}$ J. Achemchame, "Essence du cinéma en miroir: regarder le désir en face”, art. cit., p. 35.
} 
filme é exibido, o significado de atravessar aquela porta, para Jake, é o de penetrar na imagem, transgredir a posição de espectador para reassumir a de ator. Toda a segunda parte de Dublê de corpo, no fundo, pode ser vista como uma travessia do espelho. Com o adendo de que o que se acha do outro lado do espelho, ou do outro lado do cenário, não é mais o mundo encantado da ficção cinematográfica, a dimensão abstrata e mágica do cinema, mas exatamente o oposto: o mundo concreto dos cenários, dos instrumentos técnicos, da equipe de filmagem, em suma, o espaço desencantado em que se dá a fabricação dos filmes. O jogo de palavras do nome artístico da personagem de Melanie Griffith - Holly Body, "corpo santo", ou "sagrado", mas que de santo ou sagrado não tem nada - já indica ironicamente o processo de dessacralização (de Hollywood, de Vertigo) a que De Palma se dedica em Dublê de corpo.

Tudo isso se cristaliza no plano em que Jake, introduzindo-se pela porta entreaberta do banheiro, observa Holly em sua dança provocativa. "Eu gosto de olhar”, ele fala para a atriz, paralisado à soleira da porta, sem saber ainda se deve cruzar ou não aquela fronteira. É neste momento que De Palma revisita o plano-espelho da loja de flores de Vertigo para propor-lhe uma nova versão. O trabalho de reconstrução dos signos figurativos realizado por De Palma é tão detalhista, seu movimento de aproximação-oposição em relação ao plano de Hitchcock é tão precisamente calculado que, para analisá-lo a contento, faz-se necessário retomar a imagem de Vertigo e justapô-la à de Dublê de corpo:
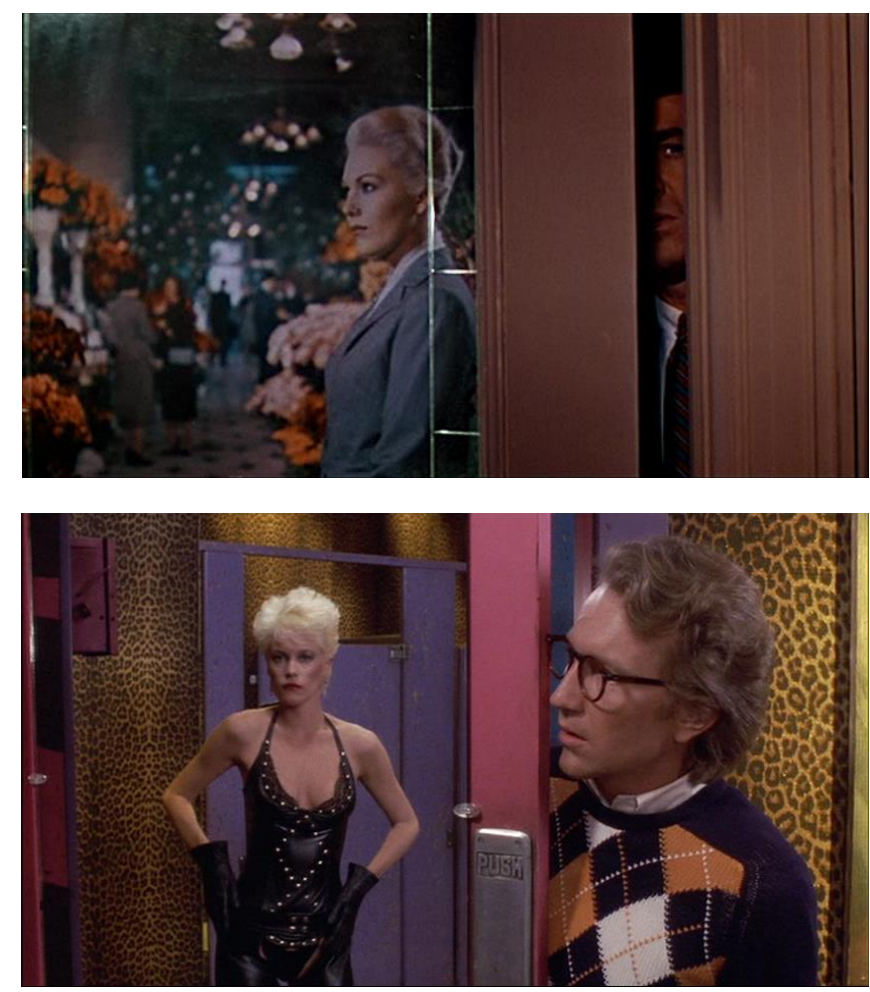
O plano-espelho se revela, em Dublê de corpo, uma verdadeira máquina hermenêutica, um dispositivo intelectual concebido como meio de reflexão meta-estética. De certa maneira, De Palma "desnuda" o plano de Vertigo (que já foi longamente analisado no segundo capítulo $^{84}$ ), filma o reverso vulgar e obsceno da imagem elegante e límpida de Hitchcock. É como se ele virasse a página para mostrar o que se esconde atrás da cena clássica, a saber, o fantasma pornográfico que a assombra, e que ela recalca de todas as formas que pode. Assim, a figura contida e aristocrática de Madeleine, em seu sóbrio tailleur cinza, é substituída pelo corpo exibicionista e hipersexualizado de Holly, que aparece vestida com um figurino de couro à moda sadomasoquista. O perfil, forma de visualização parcial e enigmática, cindida entre a presença e a ausência, cede lugar ao plano frontal, que se exibe e se impõe como espetáculo autossuficiente, sem deixar nada para a imaginação (o fetiche, a fantasia, a tara, a depravação, tudo já está à mostra, tudo já está inscrito no corpo). De evanescente e distante, a imagem da personagem feminina se torna palpável e oferecida - o que se reflete na própria duração do plano, curtíssima em Vertigo, relativamente longa em Dublê de corpo. O ambiente requintado da loja de flores se troca pelo cenário kitsch de um filme pornô (com direito a papel de parede imitando pele de onça!), e as cores agradáveis ao olhar são substituídas por uma mistura enjoativa de rosa, lilás e amarelo vivo, uma histeria cromática. O voyeur, por sua vez, não está mais escondido: ele se faz ver. O esquema dos olhares se inverte: em Vertigo, era o olhar de Scottie que cruzava com o do espectador, enquanto Madeleine tinha o olhar perdido no fora de campo; em Dublê de corpo, o olhar que interpela o do espectador não é mais o do voyeur, mas o da própria personagem feminina, que afronta a câmera e até mesmo dirige-lhe palavras de excitação e provocação erótica - destinadas a Jake, mas, por conta do reflexo no espelho, redirecionadas para o espectador, que é chamado a participar da cena, como a formar com a dupla de atores uma espécie de ménage à trois.

Em Trágica obsessão, De Palma tirava o chapéu para o mestre e expunha toda sua admiração por Vertigo num thriller romântico que era uma variação respeitosa do filme de Hitchcock. Uma década depois, a atitude já é outra: Dublê de corpo se assume como um sacrilégio, uma agressão iconoclasta, um gesto ousado de afrontamento e desmistificação. De Palma opera uma "dessublimação da tradição clássica" ${ }^{85}$ Ele conscientemente "enfeia" a imagem matricial transpondo-a para o universo do filme pornô e do terror B. ${ }^{86}$ Como disse Aurélie Ledoux, "a imagem de Dublê de corpo é uma imagem antifotogênica, ou seja, ela não

\footnotetext{
${ }^{84}$ Ver pp. $46-53$.

${ }^{85}$ A. Ledoux, L'ombre d'un doute, op. cit., p. 116.

${ }^{86}$ Cf. L. Lagier, Les mille yeux de Brian De Palma, op. cit., p. 74.
} 
sublima o voyeurismo em fantasia cinematográfica (como no cinema clássico), mas o entrega como tal" ${ }^{87}$ Se Dublê de corpo pode ser considerado o ponto de ebulição do maneirismo depalmiano, é porque esbanja uma atitude anticlássica que podemos identificar, sem exagerar na analogia, como algo correlato ao que Walter Friedländer, em seu ensaio sobre a corrente maneirista da pintura italiana do século XVI (publicado pela primeira vez em 1925, e um verdadeiro divisor de águas), aponta como o aspecto determinante da nova sensibilidade artística surgida em Florença por volta de $1520{ }^{88}$ Ao falar do espaço irreal criado pelo subjetivismo óptico de um "novo estilo rítmico anticlássico", Friedländer nos faz pensar na forma como De Palma, levando adiante a instabilidade visual plantada por Hitchcock em Vertigo, desloca seus dispositivos plásticos para um universo inteiramente abstrato e organiza tudo - os enquadramentos, os movimentos, os tempos dos planos e das sequências - segundo um senso estético dos ritmos e dos contrastes.

Claro está que Dublê de corpo, assim como Special effects, não é um filme pornô. De Palma não mostra cenas de sexo explícito ou atos sexuais não simulados. Diferentemente dos diretores de cinema hard-core, ele não está interessado em filmar o sexo acontecendo "para valer”. As poucas cenas de sexo de Dublê de corpo, para dizer a verdade, são filmadas e interpretadas de forma marcadamente estilizada e fantasiosa, deixando bem evidente que não são situações reais, nem mesmo verossímeis. Se há um diálogo com a imagem pornográfica, este se dá por um filtro artístico-intelectual assaz enfático. A incursão pelo universo da pornografia se apresenta, em Dublê de corpo, como uma forma de conduzir o sistema de representação do cinema clássico hollywoodiano às suas margens, aos seus limites, às suas fronteiras estéticas e morais. Trata-se, antes de tudo, de reinterpretar criticamente a imagem clássica confrontando-a com uma outra forma de expressão - aqui representada pelo tratamento pornográfico da imagem e do corpo - na qual tudo o que o classicismo mantinha sob o signo do mistério e do fantasma, a exemplo da sexualidade feminina, fura essa tela de fumaça e ressurge com uma nova identidade, oposta à anterior. A um cinema que só pode mostrar certas coisas, e que só pode mostrá-las de uma certa forma, De Palma opõe um outro cinema, de "mau gosto", que pode mostrar não importa o quê, não importa como. Dessa confrontação - entre o "bom" e o "mau" cinema, entre a imagem elusiva do classicismo e a imagem abusiva do filme de horror moderno e da pornografia - nasce o diálogo intertextual que enforma as imagens de Dublê de corpo.

\footnotetext{
${ }^{87}$ A. Ledoux, L'ombre d'un doute, op. cit., p. 116.

${ }^{88}$ Cf. W. Friedländer, Maniérisme et antimaniérisme dans la peinture italienne, Paris: Gallimard, 1991.
} 
Em Vertigo, Hitchcock deixara claro que a mise en scène do corpo feminino no cinema hollywoodiano é uma performance mistificadora, que se pode desconstruir através de uma tomada de consciência sobre seus modos de produção e codificação. Promovendo uma subversão paródica de Vertigo, Dublê de corpo extrapola essa crítica a ponto de negá-la, e o filme se oferece como uma leitura irônica de si mesmo.

Se o paradoxo de Vertigo (que é o que faz dele, a um só tempo, o último filme clássico e o primeiro filme moderno norte-americano) "consiste em colocar em cena seus próprios mecanismos sem que eles deixem, contudo, de ser eficazes", ${ }^{89}$ o mesmo já não pode ser dito de Dublê de corpo, pois aqui os mecanismos deixam de ser eficazes. Prova disso é que, no plano-espelho que estamos a analisar, depois que Holly e Jake saem de quadro, a câmera continua na mesma posição e apreende seu próprio reflexo no espelho, assim como o de parte da equipe de filmagem, desrespeitando uma das regras formais do cinema clássico: a de excluir do sistema espacial da ficção esse "quinto segmento" do fora de campo ${ }^{90}$, o espaço da câmera e de quem está atrás dela, espaço secreto da criação cinematográfica (o lugar de “enunciação", diriam os semiólogos), cuja invisibilidade se impunha como uma das condições de funcionamento da dramaturgia clássica. Em Dublê de corpo, o "descuido" que permite à câmera entrar em quadro é uma falha programada, um erro consentido. Por meio desse plano literalmente autorreflexivo, De Palma recorre à estratégia anti-ilusionista mais direta do cinema, ou seja, aquela que consiste em inscrever na imagem o próprio ato da sua fabricação, em tornar visível o aparato fílmico e o contexto profissional, sem glamour, que preside à ilusão cinematográfica. ${ }^{91}$

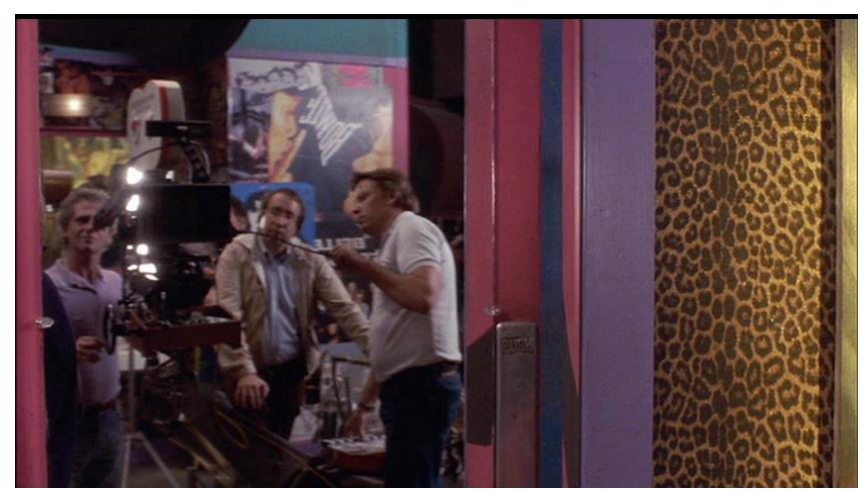

\footnotetext{
${ }^{89}$ A. Ledoux, L'ombre d'un doute, op. cit., p. 114.

${ }^{90}$ Cf. Noel Burch, Práxis do cinema, São Paulo: Perspectiva, 1992, p. 37.

${ }^{91}$ Ver J. Achemchame, "Essence du cinéma en miroir: regarder le désir en face", art. cit., pp. 34-36. Tal artigo, já citado anteriormente, também se dedica à análise comparativa entre o plano-espelho de Vertigo e sua reconstrução por De Palma em Dublê de corpo, embora não tão detidamente como faço aqui. O autor ainda analisa a reaparição desse mesmo motivo composicional em O jogador (The Player, 1991), de Robert Altman, filme que, ao contrário de Dublê de corpo, não se encaixa em minhas prioridades.
} 
Em Hitchcock, o espelho acolhia o ícone feminino, que resplandecia em toda sua beleza e mistério. Em De Palma, o espelho abriga primeiramente a imagem "suja" e pervertida de Holly e, em seguida, a imagem ainda mais desmistificadora da equipe de filmagem e do olho artificial da câmera. A eficácia dramática do espetáculo é parcialmente sacrificada em benefício do distanciamento e do metadiscurso. É quase como se o diretor quisesse destruir por dentro a ficção hitchcockiana, implodi-la para depois impor a sua forma sobre a do mestre.

Com seu ar de pastiche trivial, Dublê de corpo pretende, na verdade, instalar-se no interior das imagens de Hitchcock, explorar os seus avessos e alterar sua direção. [...] [O filme de De Palma] realiza de algum modo o que Rivette outrora dizia da crítica: a melhor análise de um filme só pode ser um outro filme - ou para dizer como Proust: o pastiche depalmiano, manifesto apócrifo e comentário incestuoso, é uma forma de "crítica em ação". ${ }^{92}$

Dublê de corpo se afigura, assim, como uma "imitação analítica" de Vertigo, uma "empreitada de transposição e exegese do material hitchcockiano" ${ }^{33}$, como afirma JeanPhilippe Trias, que compara o trabalho de "montagem das citações" operado por De Palma já que o diretor "compila em uma só imagem, em uma só figura, ou em uma só cena", elementos derivados de cenas ou de filmes distintos, numa espécie de bricolagem dos significantes hitchcockianos - ao trabalho do sonho tal como descrito por Freud:

O texto do sonho se constitui efetivamente, segundo Freud, por um trabalho de condensação e de deslocamento das ideias latentes ou das lembranças escondidas [enfouis], trabalho de transposição, de deformação, de "interversão", de fissão e de fusão dos significantes, ao qual procede também a reprise depalmiana. ${ }^{94}$

A ambição de Dublê de corpo é a de fazer as conexões que Vertigo deixou no ar, investigar suas elipses, abrir o seu "campo de latência", como se o segredo da obra hitchcockiana residisse numa cartografia criativa traçável ao se ligar os pontos de uma cena a outra e de um filme a outro, inventando novos raccords e trajetos visuais dentro do universo de Hitchcock, do qual De Palma fornece, assim, sua interpretação pessoal, num gesto ao mesmo tempo crítico e lúdico.

\footnotetext{
${ }^{92}$ Jean-Philippe Trias, "Doublure \#1: le rêve du modèle", in Cinergon, n. 16, 2003, p. 116.

${ }^{93}$ Ibid., p. 120.

${ }^{94}$ Ibid., pp. 132-133.
} 
Num texto que já se tornou referência obrigatória quando o assunto é a análise de uma imagem por outra imagem, Nicole Brenez enquadra o trabalho de De Palma a partir dos tropos hitchcockianos no que ela chama de "estudo visual", isto é, "um encontro frontal, um face a face entre uma imagem já feita e um projeto figurativo que se consagra a observá-la [:] um estudo da imagem pelos meios da própria imagem". ${ }^{95}$ De acordo com Brenez, que analisa as diversas reprises depalmianas da sequência do chuveiro de Psicose, "De Palma estuda a imagem de cinema em sua dimensão mais abstrata e específica, ou seja, a dimensão do montável: suas ligações, seus encadeamentos, a volumetria mental que propriamente lhe pertence". ${ }^{96}$ Entre a obra original e a reprise, então, cria-se uma intensa circulação de signos de toda ordem (visuais, sonoros, corporais, verbais, gestuais, textuais...), pois De Palma não reemprega apenas cenas e roteiros de Hitchcock, mas também técnicas narrativas, parâmetros estilísticos, situações visuais, raccords, partituras, gestos, leitmotiven etc. Trata-se de uma reinvenção estética da imagem matricial, de uma reinterpretação num registro totalmente diferente, e não de um mero efeito de citação. O grande mérito dessa noção de "estudo visual", quando aplicada ao cinema de Brian De Palma, é sublinhar a verdadeira potência analítica embutida em sua deformação deliberada das imagens de Hitchcock.

Havíamos visto que Vertigo, sem precisar se negar como espetáculo, continha um dispositivo crítico que estabelecia um corte, uma sutil perturbação na linguagem romanesca hollywoodiana, o suficiente para colocar em crise a lógica da transparência representativa do cinema clássico e expor em alto relevo o oculocentrismo de sua estrutura, sobretudo no que toca os modos de espetacularização da sua principal figura icônica, a estrela feminina.

Vertigo se baseava definitivamente na aura do corpo de Kim Novak e na sua transformação demiúrgica por Hitchcock: por isso, ele é um filme que conta a história de um certo cinema, aquele da era clássica e da criação das stars hollywoodianas. Inversamente, Dublê de corpo não nos fala mais dos olhares do espectador para um ícone artificial mas fascinante, e sim da fabricação e do consumo de imagens reduplicáveis. ${ }^{97}$

Dublê de corpo engendra, portanto, uma nova relação com o corpo da vedeta, que tem sua aura negada e se torna "uma matéria fílmica como outra qualquer". ${ }^{98}$ A cena em que isso

\footnotetext{
${ }^{95} \mathrm{~N}$. Brenez, "Puissances d'une forme cinématographique: l'étude visuelle (d'Al Razutis à Brian De Palma)", in AUMONT, Jacques (org.), Pour un cinéma comparé: Influences et répétitions, Paris: Cinémathèque Française, 1996, p. 347.

${ }^{96}$ Ibid., p. 366.

${ }^{97}$ A. Ledoux, L'ombre d'un doute, op. cit., p. 118.

${ }^{98}$ Ibid.
} 
vem à tona é a da morte de Gloria Revelle, que Stephen Prince classificou como "a mais horripilante sequência de carnificina sexual num filme mainstream da década [de 1980]".99 Gloria é massacrada com uma máquina furadeira cuja broca é de tamanho escandalosamente desproporcional. Embora haja uma justificativa diegética (a furadeira estava sendo usada pelo índio para arrombar o cofre da casa de Gloria), a única explicação para a escolha desse extravagante instrumento como arma do crime é o repertório de choques visuais e hipérboles gráficas que ele propicia (além, é claro, do seu significado fálico evidente). A estratégia adotada por De Palma nesta cena é diametralmente oposta à de Hitchcock em Vertigo:

[...] a morte de Gloria Revelle é amplificada de forma quase paródica e se transforma num cúmulo de violência, ao passo que a morte de Madeleine em Vertigo se distinguia, ao contrário, por uma mise en scène particularmente elusiva. Hitchcock significava a morte de seu ícone sem filmá-la realmente, a fim de preservar sua aura fantasmática. De Palma, por sua vez, não hesita em destripar o corpo de uma Gloria Revelle que agoniza num banho de sangue. ${ }^{100}$

O desfecho da cena é ainda mais revelador: depois de perfurado e destroçado pelo índio, o corpo de Gloria Revelle, longe de qualquer sublimação possível, aparece como um cadáver num saco plástico. Se Madeleine, em diversas passagens de Vertigo, sugeria uma existência fantasmática, Gloria, ao contrário, termina por se provar carnal e perecível.
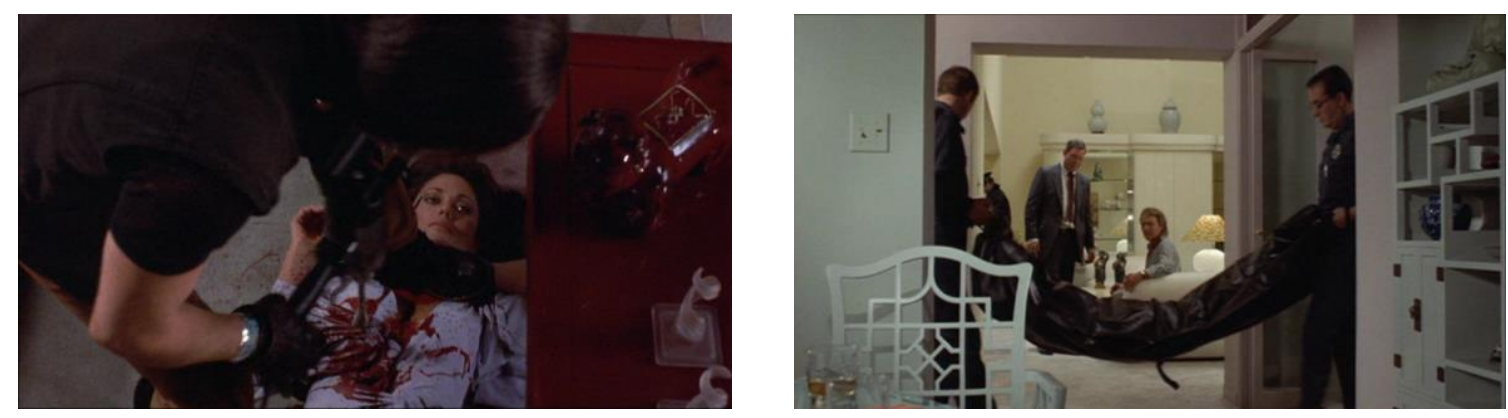

Através de Gloria Revelle, Dublê de corpo dá realidade material e corpórea a uma personagem, a da esposa verdadeira, que praticamente não aparecia no filme de Hitchcock: a mulher de Gavin Elster em Vertigo, a Madeleine efetiva ou original (e não a imitação encarnada por Judy), era um modelo-fantasma, que só tinha uma "existência nominal" "101, sua

99 “... the decade's ghastliest sequence of sexual slaughter in a mainstream film”. S. Prince, A New Pot of Gold: Hollywood under the electronic rainbow, 1980-1989, Los Angeles: University of California Press, 2002, p. 353.

${ }^{100}$ L. Lagier, op. cit., p. 74.

101 J.-P. Trias, art. cit., p. 121. 
única aparição no filme se resumindo a três ou quatro míseros planos distanciados e fugidios que mostravam ela despencando do campanário da igreja e depois já estatelada. Ao conferir uma existência material ao modelo e lhe garantir um lugar efetivo na ficção, o que De Palma intenciona, contudo, é tão somente destruí-lo: a única forma de aniquilar o fantasma original é emprestando-lhe um corpo, da mesma maneira que a única forma de perpetuá-lo é mantê-lo no plano da imagem ideal e inalcançável, que pode ser eternamente relançada por sucessivas tentativas de elaboração secundária. Em Trágica obsessão, De Palma ainda cultuava o fantasma; em Dublê de corpo, ele julga por bem enterrá-lo.

A violência paroxística da cena da morte de Gloria, ainda mais porque considerada à luz de suas conotações sexuais inegáveis, rendeu algumas reações veementes por parte da crítica feminista. ${ }^{102}$ De Palma já fora alvo de fortes acusações de misoginia à época de Vestida para matar, que fez considerável sucesso em seu lançamento comercial, chamando atenção, sobretudo, por conta das cenas que combinavam sexo e violência. Para as feministas que se opuseram contra o filme, a cena do assassinato de Kate Miller no elevador, depois de esta ter descoberto que adquirira uma doença venérea, aparecia como o perfeito exemplo do gesto punitivo da sociedade machista perante a manifestação da busca por prazer sexual da mulher. Com Dublê de corpo, as críticas voltaram com força ainda maior. Não bastasse a sanguinolenta cena do assassinato de Gloria, o filme ainda se embrenhava pelo universo da indústria pornográfica, que, aos olhos de muitas feministas, era o epítome de todos os valores sociais que elas mais combatiam:

Para as feministas radicais americanas, a pornografia seria condenável não porque ela provoca uma excitação sexual ou porque é obscena, mas porque ela é, na sua própria essência, um ato de violência contra as mulheres: uma representação e uma institucionalização de sua subordinação sexual e política. ${ }^{103^{3}}$

A pornografia, nessa visão - que recebeu suas principais contribuições intelectuais de scholars feministas como Andrea Dworkin e Catharine MacKinnon -, desumanizava a mulher e a transformava em objeto sexual para a câmera e, por conseguinte, para o espectador masculino. "Entendida nesses termos, a pornografia tratava as mulheres como coisas e, ao fazê-lo, ajudava a sustentar uma atmosfera cultural propícia à violência misógina". ${ }^{104}$

\footnotetext{
${ }^{102}$ Ver, a respeito disso, o balanço histórico de S. Prince em A New Pot of Gold, op. cit., p. 353.

${ }^{103}$ Julien Servois, Le cinéma pornographique, Paris: Vrin, 2009, p. 22.

${ }^{104}$ S. Prince, A New Pot of Gold, op. cit., p. 357.
} 
Flertando com a pornografia, portanto, De Palma automaticamente angariava a ira das ativistas feministas. Também nisso, ele seguiu os passos de Hitchcock, verdadeiro objeto de paixão (e ódio) dos estudos de cinema feministas, sobretudo aqueles que, mesclando o instrumental teórico da semiologia, da psicanálise freudo-lacaniana e do marxismo althusseriano, dedicaram-se à releitura crítica do cinema hollywoodiano clássico (Laura Mulvey, Pam Cook, Mary Ann Doane e Tania Modleski são só algumas das teóricas que consagraram estudos decisivos ao cineasta ${ }^{105}$ ). Mas a ofensiva contra De Palma, ao contrário dessa profícua onda de análises feministas da obra de Hitchcock, tinha um caráter mais estratégico do que intelectual, e refletia um fenômeno social maior, ligado ao ataque - que crescera e ganhara força política ${ }^{106}$ - à cultura da pornografia. "A violência gráfica de cunho sexual em filmes de grande público e a crescente prevalência de materiais pornográficos na sociedade passaram a ser encaradas como sintomas complementares de um mesmo problema, o qual consistia nas expressões de misoginia na cultura visual contemporânea."

O objeto que tanto escandalizou na cena da morte de Gloria Revelle, isto é, a furadeira com a enorme broca, não foi, na verdade, uma invenção de Brian De Palma. Essa arma tão peculiar já podia ser vista em The Slumber Party Massacre, um slasher movie feito em 1982 (dois anos antes de Dublê de corpo, portanto) com produção de Roger Corman. O filme, que não é dos mais conhecidos da época áurea do slasher, mostra um grupo de meninas adolescentes se reunindo para uma festa do pijama na casa de uma delas. O que as jovens estudantes ignoram é que um assassino psicopata escapou do asilo psiquiátrico em que estava preso e voltou à cidade para matar todo adolescente que encontrar pelo caminho, de preferência os mais lascivos. E sua arma, encontrada "ao acaso", será uma máquina furadeira com broca gigante exatamente igual àquela que aparecerá em Dublê de corpo.

A hipótese mais provável não é a de uma simples coincidência: De Palma parece realmente ter tirado a ideia da broca de Slumber Party Massacre, o que certos planos do seu filme comprovam, retomando de forma muito semelhante algumas ideias visuais do filme de 1982, especialmente os enquadramentos que exploram as evidentes conotações fálicas do instrumento:

\footnotetext{
${ }^{105}$ Subscrevo o que disse Ginette Vincendeau: "Ainda que esses estudos (por conta de sua base psicanalítica) tendam às vezes a uma análise abstrata das categorias 'mulher' e 'Hitchcock', não é exagerado dizer que eles mudaram fundamentalmente o lugar desse realizador na história do cinema" (cf. "Lectures féministes", in CinémAction, n. 60, 1991, p. 123).

${ }^{106}$ Ensejando, inclusive, uma coalisão das feministas com a direita conservadora religiosa, uma das alianças políticas mais bizarras da década de 1980 .

${ }^{107}$ S. Prince, A New Pot of Gold, op. cit., p. 356.
} 

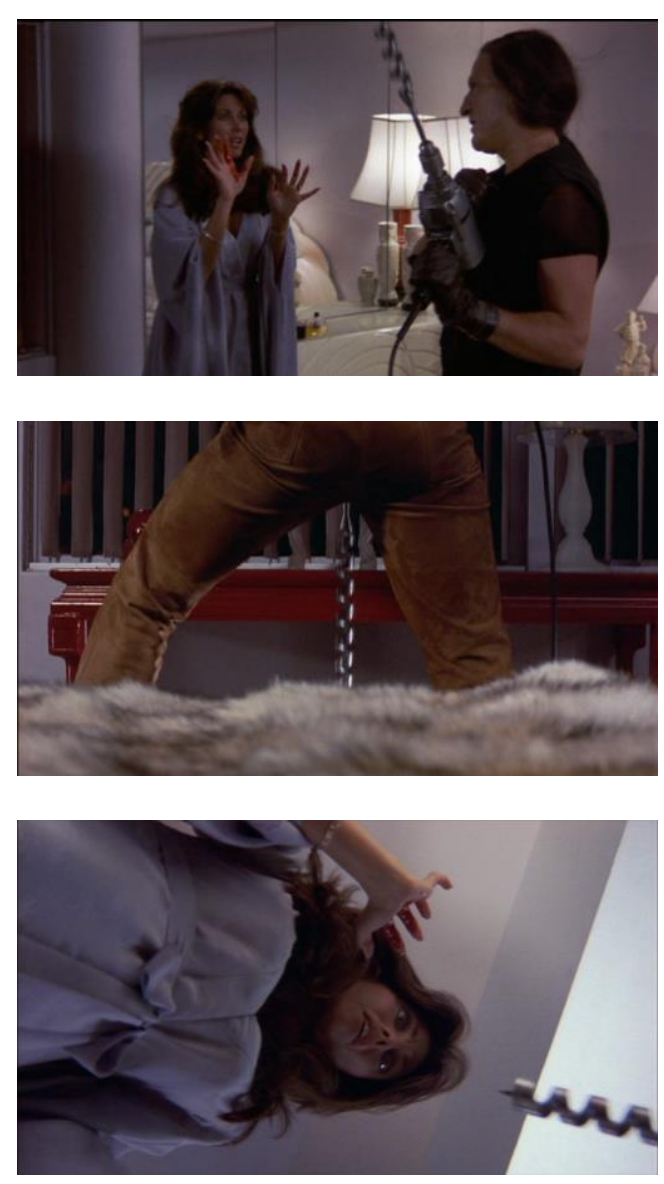

Dublê de corpo
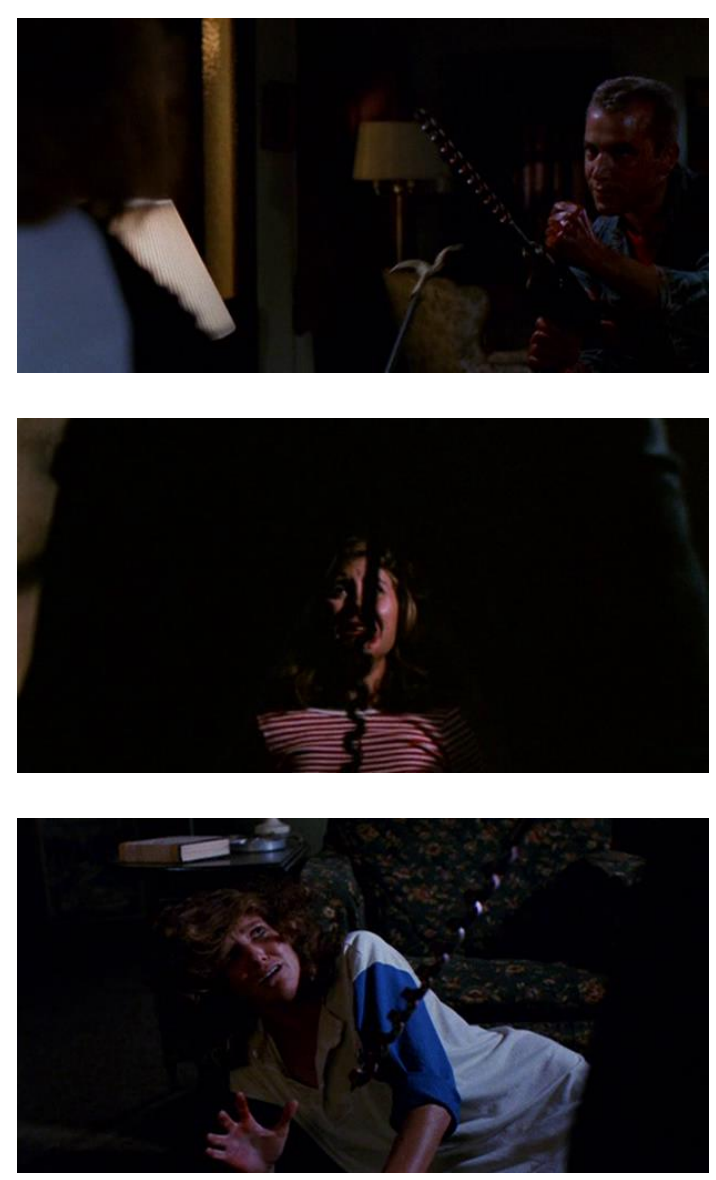

The Slumber Party Massacre

Como escreveu J. A. Kerswell, “The Slumber Party Massacre era atípico em muitos sentidos - e quase parecia um pastiche do slasher." ${ }^{108}$ Dirigido por uma mulher (Amy Holden Jones) e roteirizado por uma conhecida ativista feminista (Rita Mae Brown), o filme pode muito bem ser lido como um slasher feminista que se apropria dos clichês e convenções do gênero apenas para subvertê-los infiltrando-se no seu próprio sistema. Assim, o filme atrairia o público que usualmente se interessa pelo slasher e, no entanto, daria a ele uma variante em que não é mais o ponto de vista masculino que prevalece, e sim o feminino. Com efeito, os significados desta ordem são suficientemente claros no filme, cujo clímax é uma luta entre o assassino com sua broca e a heroína com um facão. No auge do duelo, ela consegue partir a broca dele ao meio, gerando o óbvio duplo sentido de castração de uma masculinidade que se manifestara de forma violenta. Mas as cenas de mulheres revidando as agressões dos seus algozes não eram novas no slasher: na verdade, elas tinham se tornado uma presença obrigatória desde o duelo antológico entre Jamie Lee Curtis e Michael Myers no final de Halloween. Por outro lado, em The Slumber Party Massacre, das nove personagens que são

\footnotetext{
${ }^{108}$ J. A. Kerswell, The slasher movie book, Chicago Review Press, 2012, p. 128.
} 
mortas, seis são homens. Num slasher comum, a maioria das vítimas são mulheres, e as cenas de suas mortes costumam ser muito mais dilatadas e elaboradas que as dos homens, que tendem a ser mais elípticas e simplórias. No filme de Amy Holden Jones, é precisamente o contrário: as cenas de assassinato mais demoradas e estilizadas graficamente são aquelas em que a vítima é um homem. Numa dessas cenas, a montagem cria um paralelismo entre os golpes fatais que um rapaz recebe e as facadas que são dadas em uma mulher num filme de terror a que a heroína está assistindo na televisão naquele mesmo momento. Por conta dos gritos da mulher no filme, a jovem não pode ouvir os pedidos de socorro do rapaz, que é massacrado na calçada em frente à residência dela. Jones devolve aos homens, num jogo de montagem perfeitamente consciente de sua ironia (já que o grito do rapaz é encoberto justamente pelo grito de uma mulher que está sendo morta num slasher típico), o sadismo estético que geralmente é visto nas cenas de assassinato das personagens femininas do slasher. ${ }^{109}$

Como a jogar de forma ambígua com as expectativas do público masculino, o filme conta com um número de cenas de nudez feminina acima da média, mesmo se comparado com outros exemplares deste subgênero cujo lema é "tits and a scream". Ainda que a diretora garanta que rodou tais cenas a contragosto, por exigência do produtor Roger Corman, o fato é que elas estão lá desde os primeiros minutos do filme, como comprova um despudorado travelling lateral durante a ducha coletiva no vestiário feminino de uma high school, com a câmera passando de uma personagem à outra e percorrendo de cima a baixo seus corpos nus enquanto elas tomam banho. A cena é tão escancaradamente exploitation que acabamos por nos perguntar se ela realmente não estaria ali na condição de comentário reflexivo sobre a forma misógina e semipornográfica com que a câmera trata as mulheres nesse gênero de filmes.

Mais tarde, dois rapazes que querem entrar de penetra na festa do pijama - para a qual só foram convidadas mulheres - observam pela janela, eufóricos, o momento em que as meninas trocam de roupa tranquilamente, sem saber que estão sendo bisbilhotadas.

A cena, de fato, não foge muito do protocolo habitual do slasher erótico. Mas é preciso notar que esses dois rapazes sofrerão as duas mortes mais grotescas de Slumber Party Massacre. O voyeurismo masculino, portanto, é severamente punido no filme - o que não impediu que este fosse abordado, de maneira geral, menos como uma sátira de cunho

\footnotetext{
${ }^{109}$ Como demonstra seu enredo mais recorrente (um grupo de jovens sai para acampar, festejar e fazer sexo e é depois "punido" por um psicopata que os persegue e mata um a um), o slasher é provavelmente o gênero popular que deu contornos mais evidentes ao fantasma neoconservador de uma sociedade que ainda nem tinha terminado de digerir a revolução sexual da década anterior.
} 
reflexivo/crítico do que como um slasher genérico que acaba aquiescendo aos valores falocêntricos dominantes. ${ }^{110}$

Nesse sentido, os filmes, vídeos e performances realizados por pornógrafas feministas como Candida Royalle e Annie Sprinkle seriam mais bem sucedidos que o slasher de Amy Jones e Rita Mae Brown em conseguir se infiltrar num gênero dominado por códigos sexistas e invertê-los estrategicamente. O surgimento mais recente do "post-porn", assim como da queer theory e das práticas culturais que a acompanham, viria a contestar a militância antipornográfica coordenada por parte do movimento feminista dos anos 1980 (até porque, no afã de denunciar a ideologia subjacente à pornografia, ou seja, o modelo do homem como dominador e da mulher como dominada, as feministas radicais norte-americanas acabavam por se embrenhar num discurso não isento de propostas normativas e de patrulhamentos das práticas sexuais). Reflexo direto das querelas internas do feminismo, o movimento post-porn deixaria de enxergar na pornografia tão somente uma forma de ilustração da dominação masculina e das injustiças sexistas, passando a vislumbrar um modelo de contra-produção em que o pornô - devidamente reprogramado, isto é, recusado em seus códigos representativos tradicionais e reempregado à contracorrente - aparece como forma válida de combate à estrutura falocêntrica opressora e, sobretudo, como via de expressão e de liberação do corpo feminino e de outros corpos (transexuais, transformistas) que se constituem numa militância performática destinada a retirar o corpo de um condicionamento genital-biológico e abri-lo a uma experiência que se daria fora de um código de masculinidade/feminilidade já sedimentado na cultura mainstream. Há toda uma produção contemporânea (de textos, manifestos, performances, filmes) empenhada em pensar a sexualidade fora de uma "matriz heteronormativa" e desvinculada do quadro teórico freudiano da diferença sexual como origem do fetichismo. Mas aí já começa uma outra história, que foge completamente ao escopo deste trabalho.

\section{O orgasmo feminino}

Nos anos 1980, como acabamos de ver, o debate em torno da representação da violência contra a mulher no cinema hollywoodiano esteve em alta, movimentado pela emergência de uma grande quantidade de pesquisadoras e críticas feministas oriundas dos

\footnotetext{
${ }^{110}$ Ver Carol J. Clover, "Her Body, Himself: Gender in the Slasher Films", in GRANT, Barry Keith (org.), The Dread of Difference: Gender and the Horror Film, Austin: University of Texas Press, 1996.
} 
círculos universitários norte-americanos. Em razão dos controversos thrillers hitchcockianos que então rodou (Vestida para matar e Dublê de corpo), Brian De Palma esteve em muitos momentos no centro da polêmica, que seria reaquecida no início da década seguinte por conta de uma proliferação de filmes que adaptavam para o contexto da América pós-feminista dos anos 1990 a figura da femme fatale egressa do cinema noir clássico. "Catalisado pelo sucesso de Atração fatal [Fatal Attraction, Adrian Lyne, 1989], notório manifesto antifeminista", nas palavras de Julianne Pidduck, esse ciclo de filmes floresceu e encadeou uma série de narrativas que "transformam em estereótipos negativos mulheres que têm uma personalidade muito forte e uma sexualidade sem complexo". ${ }^{111}$ De Mulher solteira procura (Single White Female, Barbet Schroeder) a Relação indecente (Poison Ivy, Katt Shea Ruben), passando por A mão que balança o berço (The Hand that Rocks the Craddle, Curtis Hanson) e Desejos (Final Analysis, Phil Joanou ${ }^{112}$ ), o ano de 1992 foi particularmente marcado por filmes em que a mulher de comportamento liberal e independente era retratada como neurótica, psicopata, deprimida, perigosa ou tudo somado. Segundo Pidduck, esses filmes "têm uma função ideológica claramente definida": proteger o núcleo familiar tradicional do perigo representado pela ascensão da mulher liberal e independente, desligada do casamento e da maternidade, e por isso punida em narrativas cujos desfechos a encaminham para a quarentena ou a morte. ${ }^{113}$ Essa guinada reacionária estaria inserida num quadro histórico marcado pelo forte incômodo de uma parcela mais conservadora dos homens - a qual retornara em grande número na paisagem política dos anos 1980 - diante das conquistas feministas que vieram com as revoluções sexuais e comportamentais iniciadas no final da década de 1960. "No film noir tradicional, a femme fatale é frequentemente associada a um mal-estar profundo suscitado pela confusão de papeis entre o homem e a mulher numa sociedade em época de guerra ou de pós-guerra". ${ }^{114}$ No neo-noir dos anos 1990, a "ameaça" que pesa sobre os homens já é outra, e diz respeito à emancipação da mulher na sociedade contemporânea.

\footnotetext{
${ }^{111}$ J. Pidduck, "La femme fatale hollywoodienne des années 90: Basic instinct, un cas de figure", in Vertigo, $\mathrm{n}^{\circ}$ 14 (dossiê "Féminin/masculin"), janeiro de 1996, p. 127.

112 Desejos é uma readaptação de Vertigo não totalmente desprovida de interesse. O filme começa afirmando o poder da psicanálise através da personagem de Richard Gere, psicanalista que, durante uma sessão de julgamento num tribunal, é tratado como autoridade incontestável. Mas, daí em diante, tudo o que se vê é uma queda contínua e irreversível do protagonista masculino, que carrega consigo a credibilidade da psicanálise. $\mathrm{O}$ enredo de Vertigo é retorcido por Phil Joanou de modo a colocar a mulher no controle absoluto da situação e, principalmente, a contestar essa autoridade psicanalítica que havia sido a moldura de tantas ficções hollywoodianas desde os anos 1940, sobretudo aquelas com que o filme dialoga (noir, woman's picture).

${ }^{113}$ Pidduck, art. cit., pp. 127-128.

${ }^{114}$ Ibid., p. 127.
} 
Dentre os filmes que compuseram esse ciclo de neo-noir do começo dos anos 1990, o mais ambíguo, complexo e interessante, sem sombra de dúvida, é Instinto selvagem (Basic instinct, 1992), de Paul Verhoeven, cuja matriz indisfarçada é Vertigo, como comprova a intriga ambientada em São Francisco e centrada nas perseguições de um detetive a uma loira pela qual está obcecado (este é, todavia, apenas o traço geral de um diálogo estético que vai bem além do mero remake de roteiro).

O filme começa com uma cena de sexo. A princípio, trata-se de uma cena de sexo como outra qualquer, talvez um pouco mais ousada que de costume, mas ainda assim uma encenação do ato sexual enquadrada dentro dos parâmetros "realistas" que o cinema mainstream já aprendera a assimilar desde os anos 1970. O bônus só virá depois, com o clímax da relação sexual e a irrupção da violência. No momento em que isso ocorre, a mulher está posicionada sobre o homem, e este se acha com as mãos atadas à cabeceira da cama. $\mathrm{O}$ controle da situação, portanto, é dela. A cena segue um crescendo de tensão erótica, tendo como ápice o orgasmo da mulher. É então que, em meio às convulsões de prazer, ela pega um picador de gelo debaixo das cobertas e começa a atacar o amante. Os movimentos das estocadas se somam aos espasmos orgásticos, ao passo que os gemidos de prazer se trocam por gritos de dor e urros raivosos. Ao lado da mesa de cabeceira, a estatueta de um dragão estilizado faz eco à violência flamejante da loira assassina.
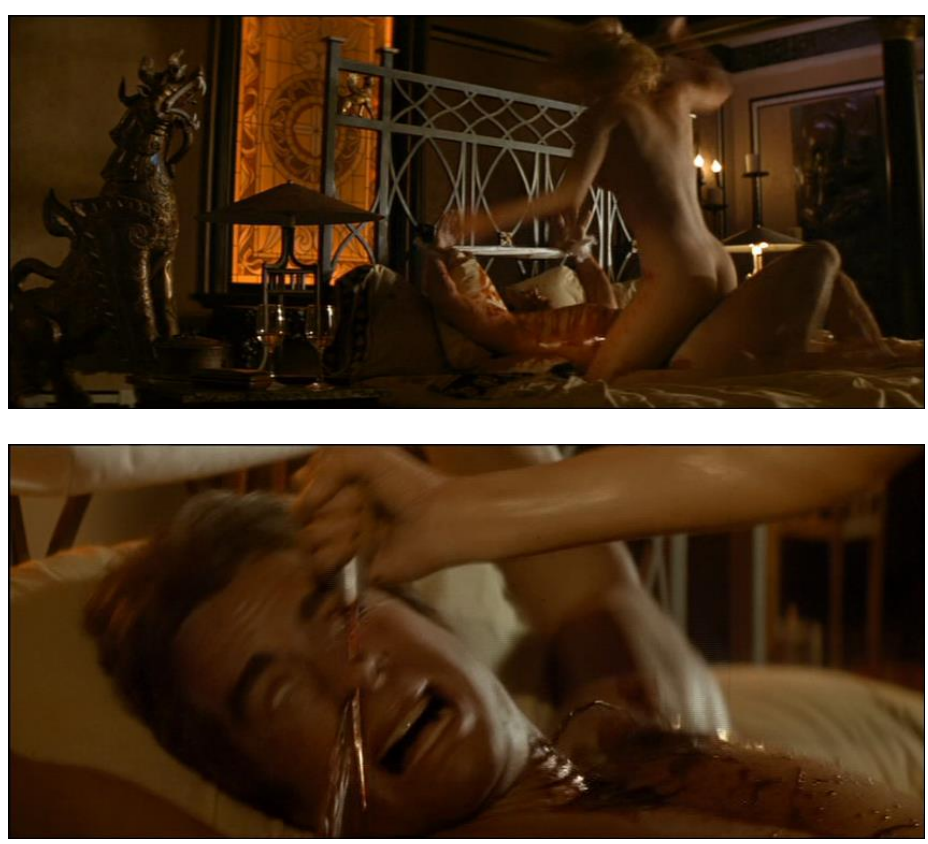

Esta cena de abertura de Instinto selvagem dispõe de uma combinação de erotismo e violência gráfica ainda mais exclamativa que a dos filmes de Brian De Palma. A diferença é 
que, desta vez, a vítima é um homem, e a assassina é uma mulher cujo rosto não aparece, pois permanece ora tapado pelo cabelo, ora fora de quadro, gerando uma indeterminação quanto à sua identidade, algo que será essencial para a manutenção do clima de suspense e ficará sem esclarecimento mesmo após o final.

A principal suspeita do crime será a namorada do homem assassinado, Catherine Trammel (Sharon Stone), uma mulher de charme, beleza e frieza notáveis. Formada em psicologia, escritora de romances policiais, bissexual, viúva de um lutador de boxe, Catherine é uma loira rica, intrigante e - novidade em relação às femmes fatales que vieram antes dela intelectual. Nick Curran (Michael Douglas), o detetive encarregado de investigar o assassinato, se envolverá com ela, dando início a um relacionamento perigoso e imprevisível.

No decorrer da investigação, Nick descobre que o modus operandi do crime havia sido descrito, anos antes, num dos best-sellers de Trammel, o que serve tanto para incriminá-la como para absolvê-la, já que ela pode usar - e, de fato, acaba usando - o livro como álibi ("Vocês acham que eu seria estúpida o suficiente para matar um homem exatamente da forma como havia descrito no meu livro?", ela pergunta aos policiais durante um interrogatório).

O filme possui uma trama assaz complicada e sinuosa, que não cabe aqui esmiuçar. Concentremo-nos apenas nos aspectos que participam de maneira mais direta da forma como Verhoeven responde às eternas questões colocadas por Vertigo. Começando pela cena em que ele desmembra o plano-espelho de Vertigo num campo-contracampo entre o olhar de Nick e o espetáculo a ele oferecido por Catherine, que troca de roupa no closet de sua casa de praia:
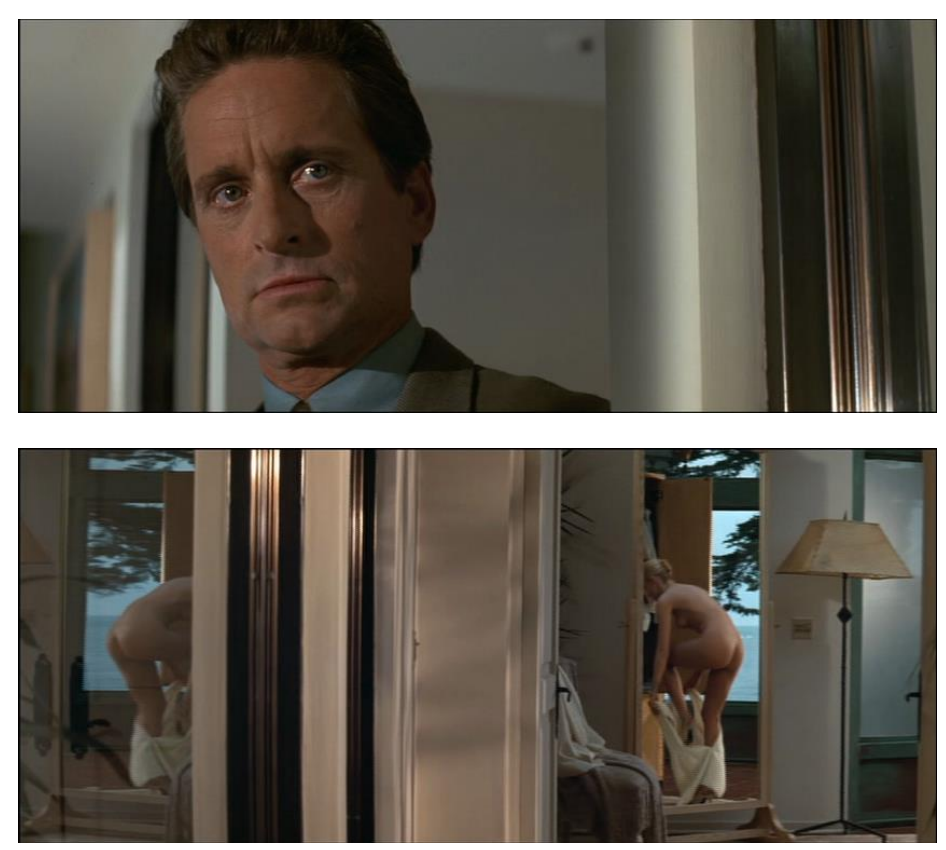
A decupagem da cena obedece à estrutura convencional do plano-ponto-de-vista: há um plano do olhar de Nick e o plano seguinte mostra o que ele está olhando (no caso, Catherine nua). Com isso, o enquadramento do plano-espelho exclui a figura do detetive, que foi deslocada para outro plano. O que se tem agora é uma imagem duplicada da femme fatale, com a devida inversão que é própria da imagem especular, anunciando que "Instinto selvagem será um filme sobre a reversibilidade dos signos, a confusão e a reflexividade". ${ }^{115}$ Essa duplicação/inversão da imagem da femme fatale condena à especulação infinita a investigação de Nick, a qual entra em curto-circuito com o romance que Catherine está escrevendo, e do qual ele participa como fonte de inspiração para uma personagem. Usando Nick como objeto de pesquisa para seu próximo livro, e fazendo da realidade um mero reflexo do que já consta em seus romances, é como se Catherine se apoderasse da própria intriga do filme.

O campo-contracampo da cena do closet separa, por um lado, mas unifica, por outro, os espaços visuais ocupados por Nick e Catherine. Verhoeven aí formula não só o espelhamento que se criará entre as duas personagens como também a oposição que o filme promoverá entre o mundo previamente organizado e hierarquizado da enquete policial, personificado pelo cartesianismo tatibitate do detetive, e o universo sem amarras da criação literária, encarnado pela inteligência provocativa da escritora.

A primeira imagem de Instinto selvagem já havia figurado a quebra da unidade do ponto de vista masculino sobre a mulher: na superfície fragmentada de um prisma (espécie de espelho cubista), refletira-se a imagem difusa de um corpo feminino decomposto em diferentes ângulos. Verhoeven apresentara seu filme, assim, como "um Vertigo que teria trocado o motivo da espiral pelo do cubismo". ${ }^{116}$ De fato, um retrato feminino pintado por Pablo Picasso apareceria mais tarde exposto numa das paredes da casa de Catherine, como a indicar de onde saiu o conceito visual do filme.

A lógica de desnudamento do plano-espelho de Vertigo, já mencionada na análise de Dublê de corpo, atinge aqui a literalidade. Se o plano de Hitchcock era um dispositivo erótico disfarçado, o de Verhoeven o é de forma assumida. Em Vertigo, a nudez de Madeleine era objeto de elipse: depois de ser salva do afagamento, ela já aparece na casa de Scottie vestida com um robe emprestado por ele; um plano da área de serviço mostra as peças da roupa que ela antes usava secando no varal, verdadeira imagem de substituição para o corpo nu de Kim Novak. Já em Instinto selvagem, o corpo nu de Sharon Stone é entregue de forma direta, sem recurso alusivo - é um a priori do filme.

\footnotetext{
${ }^{115}$ Olivier Marie, "L'indistinct manifeste", in Éclipses, no 42, 2008, p. 71.

${ }^{116}$ Ibid., p. 70.
} 
Truffaut, assim como Godard, havia observado que Madeleine não usava sutiã. Ora, Catherine, como a cena do closet demonstra, não usa sutiã nem calcinha. Para ir à delegacia prestar depoimento, ela simplesmente veste um tubinho branco, sem nenhuma roupa de baixo, dando ensejo ao plano mais famoso do filme, aquela inesquecível descruzada de pernas de Catherine durante a cena antológica do seu interrogatório. Por um breve momento, o sexo da escritora fica à mostra, deixando os policiais boquiabertos e desconcertados. A nudez de Madeleine em Vertigo permanecia na esfera da fantasia, do desejo irrealizado, do fantasma; a de Catherine em Instinto selvagem faz parte da realidade frontal e corpórea filmada por Verhoeven. A personagem de Sharon Stone não tem nada a esconder, e aí reside sua grande opacidade. Submetida ao detector de mentiras, ela se safa. Mas, num diálogo com Nick, ela diz que a máquina pode ser enganada. Tudo nela está exposto, tudo dela está à mostra - e, no entanto, tudo permanece indecifrável; a hipervisibilidade funciona como um novo tipo de máscara. A melhor forma de se esconder, para Catherine, é se mostrar. O véu, a aura fantasmática que cobria a femme fatale clássica desapareceu, mas deixou em seu lugar um corpo tão em evidência que já não se sabe mais o que ele é. "Classicamente, a femme fatale se define como uma personagem de duas faces. Um polo angelical se opõe ao polo demoníaco e manipulador, um se apagando ao longo da ficção para deixar que o outro apareça. Figura da duplicidade, a femme fatale só revela seu ser profundo por um processo gradual". ${ }^{117}$ Em Instinto selvagem, porém, os dois lados permanecem indiscerníveis: "Catherine multiplica os elementos que desfazem a unidade". ${ }^{118}$ Esfinge moderna, ela desafia o entendimento dos homens, faz deles meros peões tontos no seu tabuleiro de xadrez. Impossível encurralá-la e forçá-la a confessar sua verdade, como se fazia com a femme fatale no film noir clássico. Aqui, Catherine se mantém inabalável como enigma.

A impossibilidade de determinar a identidade da assassina coloca Nick em estado de paranoia. E isso perdura até os instantes finais. No último plano do filme, a câmera realiza um tilt para baixo da cama em que Nick e Catherine estão juntos, focalizando um picador de gelo em plano-detalhe, signo do possível destino que aguarda o herói. “Até as suas últimas imagens, Instinto selvagem sublinha a vulnerabilidade física e sexual e a autoridade moral declinante do protagonista masculino". ${ }^{119}$ Ciente do seu poder sexual e ligada a outras mulheres por laços afetivos enigmáticos, Catherine tem todos os ingredientes para provocar paranoia e ansiedade nos homens. Suas melhores amigas são mulheres que já assassinaram

\footnotetext{
${ }^{117}$ Ibid., p. 74.

${ }^{118}$ Ibid.

${ }^{119}$ Pidduck, art. cit., p. 128.
} 
maridos, amantes, irmãos etc. É nesse universo povoado por loiras atraentes, sexualmente ambíguas e predadoras de homens que o filme se instala.

Uma vez que as personagens femininas de Instinto selvagem, todas elas lésbicas, bissexuais ou pelo menos já tendo experimentado relações com outras mulheres (como é o caso de Beth, a psicóloga e amante ocasional de Nick), são retratadas como homicidas em potencial, o filme não passou em branco para a comunidade gay, que protestou contra ele na época de sua estreia nos cinemas. As feministas também ergueram a voz, mas nem sempre para condená-lo. A fascinação de J. Pidduck com Instinto selvagem, apesar de todas as suas reservas, é um exemplo perfeito do tipo de reação ambivalente que o filme provocou. A crítica reconhece que, embora se trate de "uma obra infinitamente misógina", há momentos em que "as questões de gênero e de poder são colocadas de modo bastante produtivo [...], oferecendo uma crítica bastante irônica e até mesmo involuntária dos valores familiares, das relações entre sexos e da autoridade masculina". ${ }^{120}$ Pidduck segue aí uma vertente importante dos estudos feministas de cinema que, em vez de buscar num gênero como o film noir apenas a cristalização das estruturas opressivas do patriarcado, procura destacar também o potencial liberador de heroínas que não estão encerradas no quadro familiar, chamando a atenção para “o fato de que os excessos narrativos e estilísticos do gênero podem ser vistos como a expressão de contradições no coração da ideologia patriarcal que os filmes são incapazes de resolver, apresentando assim uma autocrítica involuntária de seu próprio projeto ideológico". ${ }^{121}$ A reciclagem da figura da femme fatale na cultura popular dos anos 1990, como Pidduck percebe, não deixa de expressar um profundo abalo no inconsciente coletivo provocado pela revolução feminista. "Ainda que ela não revele nada de real no que concerne a experiência de base da mulher norte-americana, a impossível figura da mulher violenta veicula uma carga afetiva e fantástica, um excesso discursivo que pode ser, no fim das contas, bastante estimulante para o discurso feminista". ${ }^{122} \mathrm{Um}$ filme como Instinto selvagem proporcionaria, segundo a pesquisadora, uma inversão dos papeis, uma transformação radical da "persistente convenção cultural" segundo a qual a mulher é sempre retratada como vítima da violência. Pidduck termina o texto admitindo que Catherine Trammel/Sharon Stone, com sua verve, sua sexualidade desenfreada, sua capacidade de enfrentar e desconcertar uma sala repleta de policiais durões, sem falar na habilidade com que maneja o já lendário picador de

\footnotetext{
${ }^{120}$ Ibid., p. 129.

${ }^{121}$ G. Vincendeau, "Lectures féministes", art. cit., p. 124.

122 J. Pidduck, art. cit, p. 129.
} 
gelo (signo da castração), provoca na espectadora feminista momentos do mais intenso e supremo guilty pleasure. ${ }^{123}$

Um aspecto crucial do filme é a maneira como ele transforma o suspense psicológico e de acento metafísico de Hitchcock num thriller composto basicamente de sensações corporais, que solicitam os sentidos de forma mais "primitiva". Enquanto as perseguições de Scottie a Madeleine criavam uma sideração, uma lenta experiência da duração e do olhar, a cena de perseguição de Instinto selvagem é pura adrenalina: Catherine sai ultrapassando todo mundo em seu veloz carro esporte e Nick tenta manter-se na sua cola, até que, numa das ultrapassagens perigosas, ele quase bate de frente com um caminhão.

Se, em Vertigo, a conexão entre Scottie e Madeleine se exprimia por uma relação transcendente que evocava o conhecimento platônico da Ideia, em Instinto selvagem, ao contrário, a ligação entre Nick e Catherine se pauta numa relação imediata, num magnetismo de corpos e mentes conectados por ferormônios e forças químicas de atração. Por conseguinte, a identificação do espectador com as personagens não se dá mais por nuanças psicológicas, mas por emoções fortes ligadas à carne e aos sentidos primários, às pulsões de sexo e de violência, aos baixos instintos.

Não por acaso, as cenas de sexo, que inexistiam em Vertigo (pois Hitchcock mantinha nas elipses os momentos em que, como se pode presumir, Scottie e Madeleine fazem sexo), têm uma importância capital em Instinto selvagem (e não me refiro somente à bilheteria alcançada pelo filme). Ao mesmo tempo em que representa o ato sexual em toda sua transpiração e corporeidade, Verhoeven desloca o polo do prazer para o lado feminino, fazendo da representação do orgasmo da mulher o momento culminante e privilegiado das cenas (com exceção da transa afobada de Nick com Beth, em que ele descarrega com brutalidade - beirando o estupro - as tensões libidinais acumuladas ao longo do dia). Embora as cenas de sexo do filme correspondam a uma técnica de prazer essencialmente masculina, seguindo o "modelo hidráulico do orgasmo como tensão crescente que desemboca num alívio explosivo" $" 124$, há de se reconhecer que o clímax da grande transa do filme (ou seja, a primeira transa entre Nick e Catherine) é a ação da mulher - posicionada por cima do homem - numa escalada de prazer que termina de forma apoteótica, fazendo jus ao restante da performance espetacular do casal.

\footnotetext{
${ }^{123}$ Ibid.

${ }^{124}$ L. Williams, Screening Sex: Une histoire de la sexualité sur les écrans américains, Paris: Capricci, 2014, p. 119.
} 
Em seu filme seguinte, Showgirls (1995), a obra-prima mais maldita dos anos 1990 (e talvez o mais belo suicídio artístico da história recente de Hollywood ${ }^{125}$ ), Verhoeven filmaria uma outra cena de orgasmo feminino em chave ainda mais hiperbólica. Trata-se da cena em que Nomi (Elizabeth Berkley), que foi para Las Vegas tentar carreira como dançarina, transa com o dono de uma rica casa de shows na piscina da mansão em que ele mora. A piscina é rodeada de palmeiras de néon e possui uma queda d'água artificial: estamos no paraíso do simulacro e da cafonice. Quando Nomi chega ao orgasmo, ela pende o tronco e a cabeça para trás e balança o corpo freneticamente, com a água da cachoeira artificial caindo sobre ela. É um espetáculo no limite do exagero e do atletismo sexual. Já não se trata de sexo, mas de "hipersexo". ${ }^{126}$ Nomi repete com o parceiro os mesmos movimentos que já havia executado numa cena anterior, quando fizera uma lap dance para ele. O sexo verdadeiro e o sexo simulado, portanto, se equivalem. Ela fingiu prazer nas duas ocasiões? ${ }^{127}$ Ou gozou de verdade tanto durante a performance na boate de strip-tease quanto na cena íntima na piscina? Ou não faz sentido diferenciar uma situação da outra, já que, no coração da sociedade do espetáculo, a vida é uma performance permanente e não há fronteira entre o real e sua simulação?

O fato é que, tanto na cena do orgasmo de Catherine em Instinto selvagem como nesta do orgasmo de Nomi em Showgirls, Verhoeven enfatiza, reforça, sublinha essa cena recalcada pela sociedade patriarcal e, por extensão, pelo cinema hollywoodiano clássico: o gozo feminino, o grande outro de um modelo sexual androcêntrico. O diretor conscientemente promove uma perda da aura, uma quebra do encanto da antiga star feminina, para que possa emergir toda uma potência corporal que, anestesiada pelo código performativo da Hollywood clássica, retorna agora nas explosões somáticas de Catherine e, principalmente, de Nomi.

Não que as mulheres da Antiga Hollywood estivessem desprovidas de erotismo, muito pelo contrário: isso era uma das exigências do espetáculo, e foram muitas as estrelas que não raro contrastando com outra atriz que representasse a imagem da mulher comportada, sem sal ou até mesmo frígida - praticamente impuseram aos filmes uma carga erótica inescapável, como foi o caso de Marlene Dietrich, Rita Hayworth, Cyd Charisse, Kim Novak, Gloria Grahame e, naturalmente, Marylin Monroe. Além disso, não podemos negligenciar que a era

\footnotetext{
${ }^{125}$ Depois do extraordinário sucesso de Instinto selvagem, Verhoeven tinha carta branca de todos os estúdios para fazer o que quisesse. Optou por fazer um virulento retrato da América contemporânea e uma demolição impiedosa dos mitos que o cinema hollywoodiano ajudara a construir. O resultado, em termos de bilheteria e de repercussão na imprensa especializada, foi um fracasso retumbante.

${ }^{126}$ J.-F. Rauger, "La mise en scène de l'acte sexuel: focalisation/fuckalization", art. cit., p. 277.

127 Afinal, como Meg Ryan demonstrou muito bem numa cena clássica de Harry \& Sally - Feitos um para o outro (When Harry met Sally, Rob Reiner, 1989), "as mulheres podem simular os orgasmos mais espetaculares" sem que os homens percebam que se trata de fingimento (cf. L. Williams, Screening Sex, op. cit., p. 91).
} 
clássica já continha também uma crítica interna do patriarcalismo puritano que ditava suas normas. Os melodramas de Douglas Sirk, alguns filmes de Fritz Lang (Os corruptos [The Big Heat, 1953], Só a mulher peca [Clash by Night, 1952]) e de Vincente Minnelli (Paixões sem freios [The Cobweb, 1955], Deus sabe quanto amei [Some came running, 1958]), para não falar dos próprios filmes de Hitchcock, são só alguns dos exemplos de obras que exprimiam uma clara consciência crítica a respeito da submissão da mulher, no modelo patriarcal, a uma idealização, a uma imagem preconcebida pelo homem, e que a sufocava.

Mas, no fim das contas, essa imagem sobrevivia aos filmes, e a estrela feminina permanecia envolta numa redoma de cristal. A diferença, em Verhoeven, está justamente aí: suas heroínas destroem os moldes de maneira irreversível. Elas impõem no centro da imagem não apenas seus magníficos corpos, mas, sobretudo, os fluidos e desejos carnais que eles implicam, e que não podem ser sublimados numa relação amorosa idealizada. É sexo o que elas querem, e não o ideal romântico nutrido pelo passado de Hollywood, aquele ideal que enterrava o prazer sexual feminino sob a imagem de uma vida matrimonial tão honrada quanto insossa.

Como se sabe, o sexo, de forma geral, fosse ele abordado do ponto de vista da mulher ou do homem, constituiu a grande ausência estruturante do cinema clássico hollywoodiano. Proibido de ser filmado pelo código de censura, ele tornou-se onipresente, ainda que sempre de forma simbólica ou metafórica.

\begin{abstract}
Antes da legalização da pornografia cinematográfica (definamo-la pelos filmes que mostram atos sexuais não simulados), os atos sexuais visivelmente admissíveis eram limitados e codificados. A representação do coito ou de qualquer outra prática periférica implicando a visão de certas zonas erógenas do corpo (o sexo, as nádegas, os seios) é então construída através da utilização de uma máquina retórica complexa, que faz apelo à elipse, ao fora de campo e, sobretudo, ao símbolo, na forma de metáforas ou de sinédoques (mostrar um detalhe que deve significar o todo) que encerram a significação de uma ação que não pode ser mostrada. ${ }^{128}$
\end{abstract}

Num livro que trata dos modos de aparição e recepção das cenas de sexo no cinema norte-americano - desde as formas indiretas de aludir ao sexo na Antiga Hollywood até as formas modernas e naturalistas de encená-lo, passando pela fase de transição em que os filmes falam sem pudor de sexo mas ainda não ousam mostrá-lo efetivamente -, L. Williams dedica um capítulo aos orgasmos protagonizados por Jane Fonda em três filmes diferentes realizados

${ }^{128}$ J.-F. Rauger, art. cit., p. 266. 
entre 1968 e 1978. Primeiramente, ela analisa o registro camp de Barbarella (Roger Vadim, 1968), em que, num mundo futuro dessexuado, uma máquina supostamente de tortura leva a personagem de Jane Fonda a ter orgasmos múltiplos. O rosto da atriz, entregue a uma expressão que tanto pode significar o prazer extremo como o sofrimento, teria sido, segundo Williams, a primeira imagem do orgasmo feminino a aparecer nas telas americanas. ${ }^{129}$ Depois, em Klute (A. J. Pakula, 1971), Fonda interpreta Bree Daniels, uma garota de programa de luxo que, como diz Williams, é uma complexificação da imagem da "femme fatale de hábitos levianos, encarnação clássica do mal". ${ }^{130} \mathrm{Na}$ cena de sexo entre Bree e o policial com quem ela se envolve, o filme evita as convenções que normalmente eram empregadas (música edulcorante, abstração dos corpos por enquadramentos muito aproximados, elementos cenográficos que servem como tapume etc.) e dá uma imagem mais fiel à realidade física daquela relação, pautada num diálogo corporal tenso e mudo. Por fim, em Amargo regresso (Coming Home, Hal Ashby, 1978), Sally, a tímida personagem de Fonda, chega ao primeiro orgasmo de sua vida ao se relacionar com um homem que ficara paraplégico na Guerra do Vietnã: o modelo de uma virilidade masculina representada pelo falo e a ereção é totalmente posto de lado para representar o gozo feminino a partir de uma relação sem penetração vaginal, sem participação ativa do órgão sexual do homem (Sally atinge o orgasmo via sexo oral).

É evidente que três cenas protagonizadas por uma mesma atriz ao longo de dez anos não bastam para mudar definitivamente a forma de representação do sexo em Hollywood, mas é inegável que as cenas com Jane Fonda destacadas e analisadas por Linda Williams foram historicamente influentes e "cruciais para o conhecimento cinematográfico do sexo nos anos 1970 "131, sobretudo porque trouxeram à tona esse ponto cego da scientia sexualis, que é o orgasmo feminino. Em seu livro anterior, já citado aqui, Williams abordara a dificuldade dos filmes hard-core em figurar o conhecimento visual do prazer das mulheres. Enquanto o prazer sexual masculino torna-se exteriormente visível por meio da ereção e da ejaculação - o que originou a mais longeva e persistente tradição do pornô hard-core, isto é, o "money shot" (o plano que mostra o pênis ejaculando) -, o prazer da mulher já é mais secreto e invisível. Se o homem, no cinema pornô, desde o pioneiro Garganta profunda (Deep Throat, Gerard Damiano, 1972), sempre goza fora, é para que a câmera possa registrar essa verdade incontestável do orgasmo, que, no caso do homem, seria expressa pela ejaculação:

\footnotetext{
${ }^{129}$ L. Williams, Screening Sex, op. cit., p. 109.

${ }^{130}$ Ibid., pp. 111-112.

${ }^{131}$ Ibid., p. 124.
} 
A ejaculação visível é a prova indiscutível e quase jurídica da autenticidade das ações filmadas. [...] Como disse Alain Bergala durante uma conferência sobre a montagem, a ejaculação visível é um plano de autenticação, conforme o princípio caro a André Bazin do advento no quadro de um evento puro, não fabricado por um efeito de montagem. ${ }^{132}$

Essa meta última do hard-core - a de registrar um gozo que não é trucado, simulado, mas sim uma confissão involuntária do corpo no momento em que atinge o paroxismo do prazer - encontra na mulher, entretanto, um ponto de opacidade que desafia e perturba o discurso pornográfico da hipervisibilidade, já que o aumento do detalhe, no caso do orgasmo feminino, "apenas chama a atenção para a impossibilidade de representar o clímax tal como experimentado nas 'maravilhas do mundo invisível"', e o orgasmo que é mostrado (ou melhor, que não é mostrado) acaba funcionando, na verdade, como "uma nova figura de ausência". ${ }^{133}$ L. Williams demonstrou que, desde os estudos fotográficos de Charcot sobre o corpo convulsivo de mulheres histéricas até as técnicas mais invasivas do cinema hard-core, o corpo feminino vem sendo tratado pelo homem moderno como objeto de investigação e de reelaboração fetichista. "De Charcot a Muybridge, de Freud a Edison, e desses teóricos e tecnicistas do prazer ao cinema hard-core, a cada nova formulação, a scientia sexualis procede pela solicitação de maiores confissões dos segredos escondidos do prazer feminino". ${ }^{134}$ Pode-se deduzir que a angústia originária dessa vontade de saber é a constatação de que, ao contrário do corpo do homem, o da mulher não dá uma prova visível e indiscutível da autenticidade do seu prazer. ${ }^{135}$

Tudo isso para dizer, voltando a Instinto selvagem e Showgirls, que Verhoeven fez eclodir, por uma exorbitância carnavalesca, o prazer sexual da mulher, geralmente acondicionado pelo cinema mainstream em cenas posadas e românticas, quando não simplesmente ignorado. Enquanto o valor da cena do orgasmo de Jane Fonda em Amargo

\footnotetext{
${ }^{132}$ J.-F. Rauger, art. cit., p. 271.

${ }^{133}$ L. Williams, Hard core: power, pleasure, and the frenzy of the visible, op. cit., p. 119.

${ }^{134}$ Ibid., pp. 52-53.

${ }^{135}$ Contudo, uma das modas recentes do pornô consiste justamente em mostrar o jato ejaculatório feminino, que se manifesta em algumas mulheres, e que algumas delas atestam que pode ser atingido mediante exercício e prática. Mas aí também o corpo feminino é novamente fonte de mistério, pois, diversamente da substância ejaculada pelo homem, que todos sabem o que é (sêmen) e qual sua função (reprodução), o líquido ejaculado pela mulher não tem uma constituição química óbvia e tampouco uma função biológica evidente, sendo motivo de muita controvérsia entre ginecologistas, sexólogos, psicanalistas etc. Há quem diga que é um mito, há quem assevere que é uma incontinência urinária provocada pelas contrações do orgasmo. O certo é que, diante de mais esse "mistério" do corpo feminino, a reação é a mesma de sempre, ou seja, a de tentar investigar e entender esse obscuro objeto do desejo para poder enquadrá-lo num discurso médico-científico e neutralizar sua eventual ameaça.
} 
regresso, que fez dela um caso de exceção e um marco histórico, estava em seu caráter realista, delicado, sério, se não didático, o das cenas filmadas por Verhoeven reside na transgressão - desta vez pela hipérbole - dos critérios dramatúrgicos da encenação do sexo no cinema comercial. Se há algo de pornográfico em Instinto selvagem e Showgirls, mesmo que não sejam filmes com atos sexuais efetivos ou detalhes explícitos da penetração, da felação etc., essa pornografia consiste no próprio transbordamento barroco dos movimentos eróticos do corpo, na demonstração eloquente e performática do prazer, na exteriorização radical (na pele, no rosto, na explosão muscular, no suor) das intensidades libidinais do corpo feminino, que o cinema de grande público - por compromissos com a censura, a seriedade ou simplesmente o "bom gosto" - tradicionalmente inibe ou maquia. Verhoeven começa os filmes apontando o lugar da mulher no imaginário hollywoodiano como ícone, somente para depois transformá-la em corpo, carne, glândulas, máquina de prazer e violência - e isso, em

Hollywood, mesmo na Hollywood dos anos 1990, pode soar obsceno. É claro que o próprio excesso de estilização das cenas de orgasmo feminino em Instinto selvagem e Showgirls acusa a externalidade do olhar masculino que as dirige e filma. Mas há nesses corpos devoradores de Catherine e Nomi, nessas imagens onívoras, indomáveis, plenas de energia sexual e de impulsos castradores e homicidas, enfim, há nelas uma força de representação cinematográfica da mulher, para dizer o mínimo, bem distante da ideia de submissão ou de opressão inelutável.

\section{O outro lado de Madeleine}

O destino quis que Estrada perdida (Lost Highway, 1997), de David Lynch, chegasse aos cinemas no mesmo ano em que era lançada uma versão inteiramente restaurada de Vertigo em 70mm e som estereofônico DTS (fruto da famosa empreitada de restauração de 1996, realizada por Robert Harris e Jim Katz para a Universal). O espelhamento entre os dois filmes, que já seria evidente, ficou ainda mais perceptível, como muitos críticos destacaram.

Thierry Jousse, em seu artigo seminal sobre Estrada perdida, não titubeou em apontar Vertigo como a matriz principal do filme, observando, porém, que Lynch inverte os arquétipos femininos de Hitchcock e apresenta a morena como frígida e a loira como explosiva. Sem negar a influência de Vertigo, Lynch já disse em entrevista que seu Hitchcock preferido, todavia, é Janela indiscreta, pois este apresenta um mundo ficcional fechado sobre 
si mesmo, algo que muito o atrai. ${ }^{136}$ De fato, se juntarmos a estruturação temporal de Vertigo, sua trajetória circular feita de repetições e dualidades, com o funcionamento espacial em circuito fechado de Janela indiscreta, teremos a experiência de Estrada perdida, que Jousse muito bem definiu como um "filme-instalação" 137 , isto é, um filme que envolve o espectador em sua ambiência para fazê-lo sentir-se em meio às imagens, e não em face delas. A narrativa de Estrada perdida transita por dentro de câmaras de isolamento sensorial que potencializam os fluxos de percepção do espectador, a quem é proposta menos uma história a ser seguida do que uma atmosfera de sensações acústicas e visuais de grande poder de imantação e impregnação. O dispositivo decerto funciona, pois as imagens e os sons do filme agem na mente de forma prolongada e intensa (como uma droga psicotrópica de efeito duradouro).

Como Vertigo, Estrada perdida se divide em duas partes. Na primeira, vemos o casal formado por Fred Madison (Bill Pullman) e Renee (Patricia Arquette, de cabelo preto) em cenas domésticas marcadas por silêncio, tédio e frieza. Um ar pesado preenche a distância entre os dois. A casa de design moderno, com seu interior minimalista e clean, abriga uma atmosfera depressiva, acentuada pela nítida tristeza conjugal de Fred e Renne. Uma cena de sexo mostra uma Renee desinteressada, com o pensamento alhures, e um Fred derrotado, desconfiado, que tenta interpretar os gestos automáticos e desafetados da esposa (sobretudo os leves tapinhas que ela dá em suas costas para reconfortá-lo de uma impotência ou de uma performance ruim). À noite, no clube noturno em que trabalha como músico, Fred parece purgar todas as suas angústias no free jazz agudo e desesperado que sai de seu saxofone.

No dia seguinte, pela manhã, Renne encontra na entrada da casa um pacote com uma fita de videocassete. Eles assistem ao vídeo, que mostra a fachada da própria residência deles. Numa outra manhã, uma nova fita chega. Desta vez, a câmera percorre o interior da casa até entrar no quarto de Fred e Renee e mostrá-los dormindo. Renee, amedrontada, chama a polícia, que, representada por dois detetives que parecem egressos de Twin Peaks, faz perguntas e investiga os possíveis pontos vulneráveis da casa. Depois, o casal Madison vai a uma festa na mansão modernosa de Andy, amigo de Renee de quem Fred tem ciúmes. Renee flerta com outros homens, Fred se dirige ao bar. Um homem misterioso, vestido de preto, "encarnação da morte, do diabo e de tantas outras figuras alegóricas virtuais"138, surge na festa e se aproxima de Fred. "Já nos vimos antes”, ele diz. Fred não entende. "Na sua casa,

\footnotetext{
${ }^{136}$ D. Lynch apud J. Achemchame, Entre l'oeil et la réalité: le lieu du cinéma (Mulholland Drive de David Lynch), Paris: Publibook, 2010, p. 231.

${ }^{137}$ T. Jousse, "Lost Highway, l'isolation sensorielle selon Lynch", in Cahiers du cinéma, n. 511, março de 1997, p. 59.

${ }^{138}$ Véronique Campan, "Le principe d'anamorphose", in CAMPAN, Véronique e MENEGALDO, Gilles (orgs.), Du maniérisme au cinéma, op. cit., p. 41.
} 
não se lembra? Na verdade, estou lá agora mesmo." O homem puxa um telefone celular e pede que Fred ligue para sua casa. E, de fato, quem atende ao telefone da casa de Fred, numa duplicação que perturba qualquer compreensão lógica, é o homem misterioso, o mesmo que está agora na sua frente. Depois de uma risada demoníaca, o homem se retira e vai embora.

Mais tarde, uma nova fita chega à casa de Fred. O que ela mostra, para o seu total horror, é uma carnificina perpetrada ali mesmo: Renee foi morta e dilacerada, e o único suspeito, o único culpado é o próprio Fred, que será condenado à cadeira elétrica. No corredor da morte, preso em sua cela, ele sofre de terríveis dores de cabeça, que o levam a ter alucinações e visões inexplicáveis. Um belo dia, o carcereiro que faz a ronda matinal não consegue acreditar no que vê: na cela de Fred, que sumiu, encontra-se agora um outro homem, mais jovem e completamente diferente. Ele se chama Pete Dayton (Balthazar Getty), um rapaz de família humilde, que trabalha como mecânico de automóveis. A polícia não tem outra opção além de soltar o rapaz, mantendo-o, porém, sob a vigilância de dois agentes. Pete volta à rotina: retoma o namoro morno com uma jovem da sua idade e volta a trabalhar numa oficina, na qual Mr. Eddy, um violento mafioso local, confia-lhe com exclusividade o motor de sua Mercedes. As coisas saem do eixo quando Mr. Eddy aparece na oficina acompanhado da namorada, a bela e fogosa Alice (Patricia Arquette novamente, mas agora com cabelo loiro ${ }^{139}$ ), que, numa entrada em cena radiante, troca olhares com Pete e, à noite, retorna sozinha para seduzi-lo. Começa um romance tórrido entre os dois. Mr. Eddy descobre e, num telefonema em que se acha acompanhado do homem misterioso de preto (o que falara com Fred na festa), ameaça Pete de morte. Ele e Alicia planejam fugir para bem longe. Uma vez que precisam de dinheiro, ela arma uma cilada para Andy, que é realizador de filmes pornográficos dos quais ela já foi atriz (o que deixa Pete bastante enciumado). Alice irá seduzir Andy enquanto Pete invade a casa e rouba as joias e o dinheiro, que ela sabe onde o pornógrafo guarda. Depois de entrar na casa de Andy e matá-lo acidentalmente, Pete foge com Alice, que o leva para o meio do deserto, onde fazem amor sob o céu noturno, iluminados apenas pelos faróis do carro. No auge do prazer, Pete diz para Alice: "Eu quero você". Ao que ela responde pausada e enfaticamente: "Você nunca me terá [You will never have me]", e se retira para dentro de um casebre de madeira construído sobre pilotis. Quando Pete se levanta, é Fred quem vemos, como se a metamorfose se tivesse desfeito. Ele entra no bangalô, mas não encontra Alice, e sim o homem misterioso, que porta uma câmera de vídeo. Fred foge dali e vai a um hotel de beira de estrada, onde encontra Mr. Eddy e Renee (de volta

\footnotetext{
${ }^{139}$ Tal como Hitchcock fizera em Vertigo, Lynch utiliza em Estrada perdida a mudança da cor do cabelo como signo da dualidade feminina: loira e morena constituem assim as duas faces de uma mesma mulher.
} 
do mundo dos mortos?) hospedados no mesmo quarto. Ele deixa Renee fugir, mas mata Mr. Eddy com a ajuda do homem misterioso - este, contudo, some de um instante para outro (ele era uma invenção da cabeça de Fred? Sua metade obscura?).

Fred se torna um fugitivo da polícia. Ao volante do carro, numa estrada que corta o deserto, perseguido por várias viaturas, ele sofre repentinas convulsões que deformam seu rosto. O último plano do filme será igual ao primeiro: as marcas divisórias da estrada, iluminadas pelo farol do carro em movimento, e ao redor a escuridão.

Recapitular as sequências principais de Estrada perdida - ainda mais do jeito que fiz acima, suprimindo uma série de detalhes importantes - de nada adianta para a constituição de um fio narrativo coerente, pelo simples fato de que este não existe. ${ }^{140}$ Lynch fermenta o mistério, distribui pelo caminho uma multiplicidade de pistas, signos, traços, indícios. Tudo leva a crer que há um grande segredo ou uma grande conspiração aguardando para serem revelados. Mas a essa inflação de signos e pistas não corresponderá uma proporcional disponibilidade de elementos ligantes, e muitas informações permanecerão soltas. Não há raccord suficiente para todas as imagens, que, libertas das regras de continuidade tradicionais, relampejam na tela com a força imediata da pura imagem-intensidade. O que Lynch constrói, no fim das contas, é "um sentimento de relatividade absoluta, em que nenhuma identidade estável subsiste, e em que tudo é apanhado no movimento de um devir ilimitado". 141 "Em Estrada perdida, o complô é sem fim, sem fundo, o inimigo está no interior do país ou do cérebro, e as significações deliram". ${ }^{142}$

Essa estética de Estrada perdida pode ser abordada à luz da definição de Fredric Jameson para a esquizofrenia, que ele considera um dos traços determinantes da estética da pós-modernidade. O autor - que chegou a escrever sobre David Lynch à época de Veludo azul (Blue Velvet, 1986) - define a esquizofrenia, a partir de Lacan, como sendo "a ruptura na cadeia dos significantes, isto é, as séries sintagmáticas encadeadas de significantes que constituem um enunciado ou um significado". ${ }^{143}$ Quando a relação interna dos significantes se rompe, quando se quebram as cadeias da significação, o que temos é a experiência das "materialidades significantes pairando livremente", desgarradas de uma sequência coerente e, por isso mesmo, "resplandecendo de energia alucinatória". Com a desarticulação da linguagem, a continuidade temporal se troca por uma soma de puros presentes não

\footnotetext{
${ }^{140}$ Essa impossibilidade de reduzir o filme a uma sequência lógica de acontecimentos, como já se sabe, retornaria de forma ainda mais desnorteante em Cidade dos sonhos (Mulholland Drive, 2001).

${ }^{141}$ V. Campan, art cit., p. 39.

${ }^{142}$ T. Jousse, art. cit., p. 57.

${ }^{143}$ F. Jameson, "A lógica cultural do capitalismo tardio". In: capitalismo tardio. São Paulo: Ática, 1997, p. 53. . Pós-modernismo - A lógica cultural do
} 
relacionados no tempo. A fragmentação do tempo em uma série de presentes perpétuos tem como resultado "uma intensificação libidinal ou alucinógena" de nossa percepção comum: “assim isolado, o presente repentinamente invade o sujeito com uma vivacidade indescritível, uma materialidade da percepção verdadeiramente esmagadora, que dramatiza, efetivamente, o poder do significante material - ou melhor, literal - quando isolado". ${ }^{144}$ A sensação do tempo em Estrada perdida ("um tempo espacializado", como disse T. Jousse ${ }^{145}$ ), com seu presente desconexo, sem lógica subordinativa com o passado ou prospectiva com o futuro, gerando um efeito narcótico pela repetição alucinatória do presente, acha-se perfeitamente contemplada nessa descrição de Jameson do estado esquizofrênico que marca a experiência pós-moderna. O filme propõe uma "fuga psicogênica" ${ }^{146}$, um trajeto esquizoide que se afasta da realidade para percorrer as dobras internas da mente, onde predominam projeções fantasmáticas.

Poderíamos nos lançar a diversas hipóteses interpretativas sobre Estrada perdida, uma mais entusiasmante que a outra; todas fariam sentido e nenhuma explicaria nada. Mas nosso intuito definitivamente não é este. O grande interesse do filme, do nosso ponto de vista, está na maneira como Lynch desdobra o motivo do duplo, principalmente em relação à figura feminina.

Antes de tudo, é preciso observar que o filme internaliza a poética do duplo em sua própria estrutura: "Tudo é duplo em Estrada perdida - as personagens, as situações, os objetos - e cada elemento só pode ser percebido em função de uma rede de correspondências própria ao filme". ${ }^{147}$ Partindo dessa premissa de uma duplicidade generalizada das coisas e dos seres, Lynch dará vazão àquele que talvez fosse o grande desejo latente no cinema de Hitchcock: filmar a face escondida (da mulher, da realidade, do universo). ${ }^{148}$

Todo visível contém seu duplo, e todo duplo acusa um grau de desconhecimento por parte do sujeito que se põe a vê-lo, que deve se confrontar com a impossibilidade de apreender o visível em todas as suas faces simultaneamente - uma face (ou mais de uma) vai sempre permanecer escondida. Mas, no filme de Lynch, como assinala Guy Astic, a existência de uma face escondida "significa menos a ideia de um sentido esquivo, de um enigma a resolver, do que o mistério do figural". ${ }^{149}$ A face escondida atualiza na imagem lynchiana a

\footnotetext{
144 Ibid., p. 54.

${ }^{145}$ T. Jousse, art. cit., p. 58.

${ }^{146}$ Cf. Guy Astic, Le purgatoire des sens: Lost Highway de David Lynch, Pertuis: Rouge Profond, 2004, p. 92.

${ }^{147}$ T. Jousse, art. cit., p. 58.

${ }^{148}$ Além dos desdobramentos psicológicos e estéticos, a empreitada tem também um lado místico e esotérico que Lynch de maneira alguma despreza.

${ }^{149}$ G. Astic, Le purgatoire des sens, op. cit., p. 42.
} 
evidência de uma opacidade, de um não fechamento da figura, de uma incompletude cuja função é gerar um trabalho de figurabilidade infinitamente recomeçável.

Se o motivo do duplo invade praticamente todas as imagens de Estrada perdida, ele traz na bagagem a dimensão metapsíquica que Hitchcock já lhe havia emprestado - e que este herdara, por sua vez, do romantismo e do expressionismo alemão. O tema se desenvolvera primeiramente na literatura, sobretudo no século XIX, quando se impôs graças às obras de Poe, Stevenson, Maupassant, Tieck, Hoffmann. "A figura do duplo na literatura está intimamente ligada ao campo de pesquisa predileto dos românticos: o 'lado noturno' do ego, que eles aceitam como uma parte integrante da personalidade, ao invés de reprimi-lo e condená-lo como um reduto de 'doença"”. ${ }^{150}$ No cinema, arte cujo próprio procedimento de formação de imagem consiste em fabricar duplos das pessoas, das coisas e da realidade de modo geral, o tema iria se aclimatar com facilidade, reinventando-se com a ajuda das potências visuais do meio, sua habilidade em comunicar-se com o mundo das sombras e dos fantasmas do subconsciente.

No cinema alemão do período silencioso, vários filmes importaram da literatura a temática do duplo e a incrementaram com os artifícios do cinema. Um desses filmes nos interessa em particular: Fantasma (Phantom, 1922), de F.W. Murnau, que certamente faz parte da árvore genealógica de Vertigo. A trama desenvolvida por Murnau, embora siga muito mais os protocolos da morality play e das narrativas clássicas de arrependimento e regeneração, tem seu ponto de partida no motivo do Doppelgänger, e mais especificamente no retorno fantasmático de um rosto feminino que obceca o protagonista. Tudo começa quando ele é atropelado por uma carruagem conduzida por uma linda jovem, pertencente à família mais rica da região. Ela mesma o socorre, e ele, acordando do susto como quem retorna de um sonho, fica obcecado com a imagem daquela moça bela e inacessível. Ele passa os dias a tentar reencontrá-la, sem sucesso. Tempos depois, conhece uma dançarina de cabaré que é idêntica à sua musa. Como uma versão embrionária da femme fatale concupiscente e corruptora de almas que despontaria no cinema noir americano dos anos 1940, ela o levará a cometer atos moralmente reprováveis para satisfazer aos seus caprichos. Está colocada aí a dualidade que será readaptada por Hitchcock em Vertigo e por Lynch em Estrada perdida: uma mesma figura feminina se mostrando em duas faces opostas, a nobre e a vulgar, a santa e a puta, a dama respeitável e a vigarista inexpiável. Enquanto Hitchcock sutiliza o modelo de Murnau, Lynch o radicaliza, fazendo a outra face da personagem feminina se revelar nas

150 Bettina Rosenbladt, "Doubles and doubts: the German connection", in ALLEN, Richard e ISHIIGONZÁLES, Sam (orgs.), Hitchcock: Past and Future, Londres: Routledge, 2004, p. 58. 
circunstâncias mais sórdidas. Sendo assim, a jornada de Fred e Pete em Estrada perdida desemboca numa descoberta traumática da face escondida da mulher que amam, da vida secreta que ela leva sem a aprovação deles. A cena que melhor representa isso é aquela em que Pete chega à casa de Andy e vê um filme pornográfico estrelado por Alice. O filme está sendo projetado num telão de forma aparentemente gratuita, sem nenhum espectador, como se a própria Alice o tivesse colocado lá à espera de Pete (que ela sabia que apareceria para roubar o dinheiro de Andy, conforme tinham planejado). Ela queria que ele visse esse seu outro lado, que soubesse do que ela é capaz, que experimentasse essa inquietante estranheza de vê-la numa situação que a transforma numa imagem obscena e perturbadora.

A vertigem amorosa, em Estrada perdida, descamba nas visões mais desagradáveis, nas projeções (no duplo sentido cinematográfico e psíquico) mais delirantes. A imagem pornográfica, aí temperada por horror, violência, sadomasoquismo, sangue - ou seja, anexada ao repertório de um snuff movie -, surge como a figuração de um mal-estar, como a confirmação da suspeita de que havia, na pessoa amada, um lado escabroso que, uma vez descoberto, faria tudo desmoronar.

A pornografia snuff representa também esse momento em que o filme chega ao fundo do pesadelo, ao porão onde o imaginário americano - que Lynch explora como um reservatório inesgotável de formas, ícones, clichês - esconde suas perversões mais aberrantes, seus complôs mais escandalosos. A narrativa conflui para o excesso pornográfico num movimento que parece inexorável; o snuff movie surge como um ponto de culminância e, ao mesmo tempo, de desrealização de todo esse imaginário, que é extravasado numa pletora de sensações extremas ativadas por imagens eróticas que depois são substituídas por imagens grotescas e, por fim, abjetas.
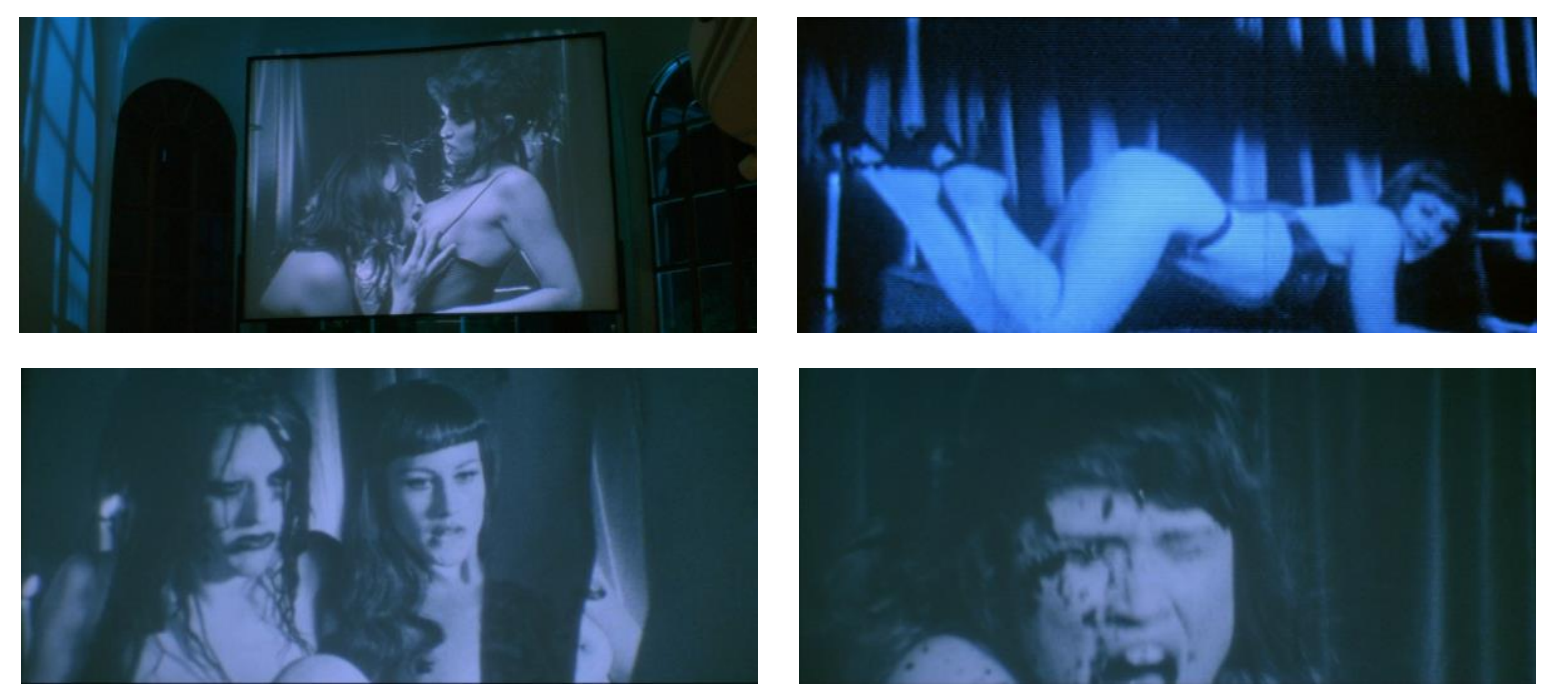
A outra face de Renee/Alice se revela, portanto, num contexto em que é a realidade como um todo que se mostra bifacial, dividida entre o pesadelo (a parte 1 do filme) e o pesadelo dentro do pesadelo (a parte 2).

Em Veludo azul, Lynch já havia representado uma realidade parecida. Lá, o filme opunha a um lado florido, solar - e de uma normalidade que, de tão normal, tornava-se estranha -, um outro lado noturno e sombrio, havendo, é claro, uma interpenetração desses dois mundos. As primeiras imagens do filme mostram um subúrbio americano tão típico que pitoresco, com suas casas de grama bem aparada, seus jardins protegidos por cercas, suas flores e passarinhos coloridos, seus bombeiros simpáticos e prestativos, suas senhoras risonhas que acenam para quem passa na rua. Mas, num desses jardins bem cuidados, um homem que aparava a grama do seu quintal tem um ataque cardíaco e desaba no chão. Seu filho, sabendo do ocorrido, volta à cidade para visitá-lo no hospital e acompanhar sua recuperação. Logo que chega, o rapaz encontra uma orelha apodrecendo na grama de um terreno baldio, com formigas já passeando por cima dela. É a mesma lógica do cadáver encontrado por uma criança no início de $O$ terceiro tiro, de Hitchcock: no bosque ao lado do pequeno vilarejo em que o filme se passa, um menino encontra o corpo de um homem morto, e este corpo funciona como o elemento que macula a imagem de paraíso terrestre que aquela paisagem idílica poderia representar, ainda mais estando embelezada pela variação outonal das cores da exuberante folhagem de suas árvores. Lynch repete esse mesmo princípio, ou seja, oferece primeiramente um quadro de beleza e inocência (mesmo que sejam uma beleza e uma inocência um tanto plastificadas, falsas) e depois insere uma mancha que suja esse quadro - e o ressignifica - apontando a existência de um mal escondido nesses jardins talhados à imagem da América "pura" e "feliz" dos anos 1950. Mas a forma de apresentação desse detalhe revelador, em Lynch, é mais violenta e aterrorizante: não se trata de um cadáver, e sim de uma orelha arrancada de um corpo e invadida por insetos, o que torna a descoberta ainda mais misteriosa e inquietante, e indica um mal ainda mais ameaçador e agressivo.

Jeffrey (Kyle MacLachlan), o rapaz que encontrou a orelha na grama, começa a investigar o caso movido por uma curiosidade comparável à de seu quase xará Jefferies, o protagonista de Janela indiscreta. Se este, conforme vimos no primeiro capítulo, podia contar com a ajuda da namorada (a personagem de Grace Kelly), o herói de Veludo azul, por sua vez, contará com a cumplicidade de Sandy (Laura Dern), a filha adolescente do delegado da pequena cidade de Lumberton. Embora personifique a imagem positiva da pureza, Sandy não esconde certo tormento; algo nela indica uma inocência já corrompida. Na sua entrada em 
cena, Lynch revisita a mise en scène da reaparição de Madeleine na segunda parte de Vertigo, quando Scottie a vê saindo do banheiro do Empire Hotel; ele reemprega o movimento de aproximação da atriz, sua lenta progressão do fundo da imagem para a superfície, bem como sua passagem de um regime de visibilidade para outro.
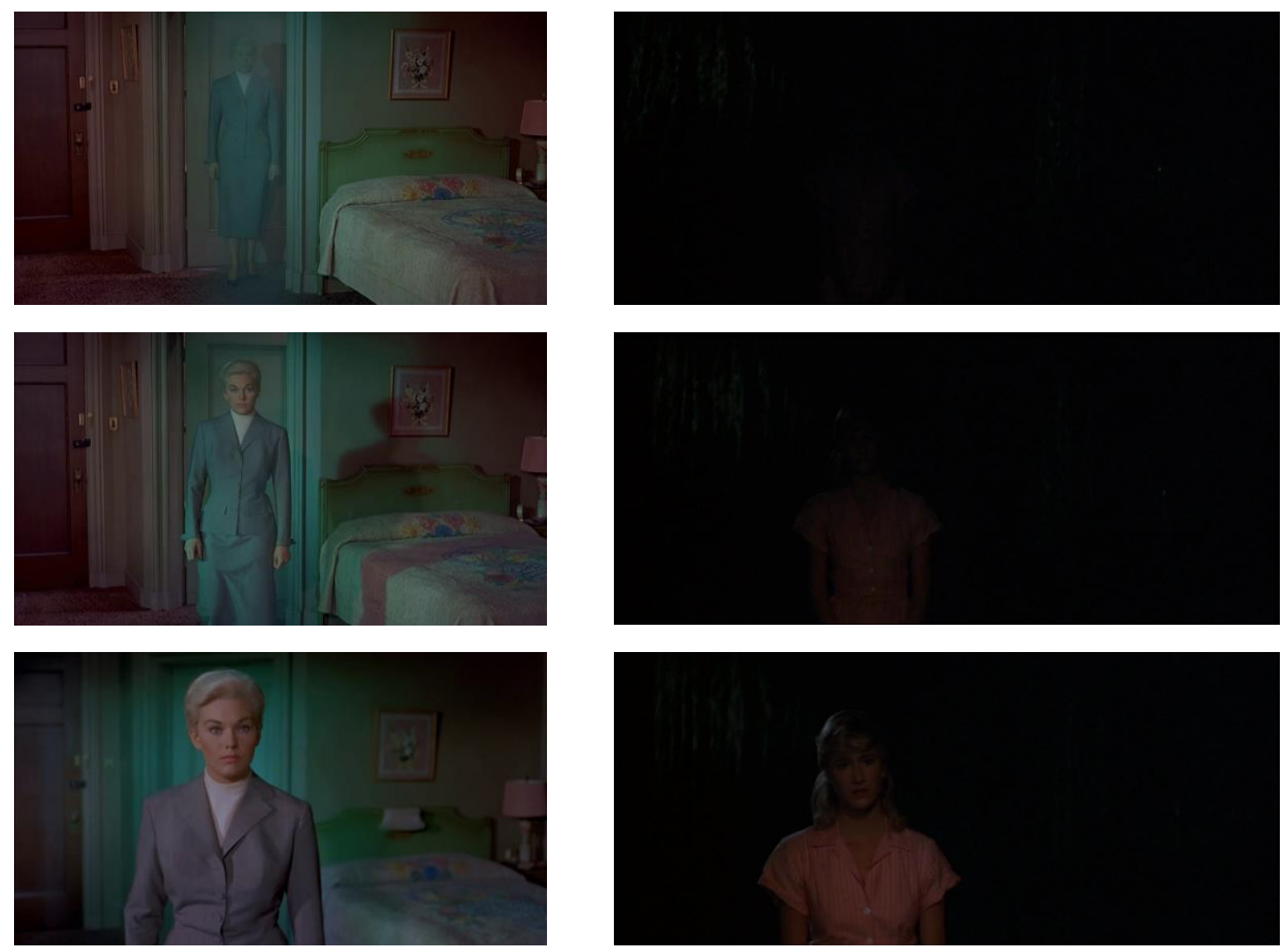

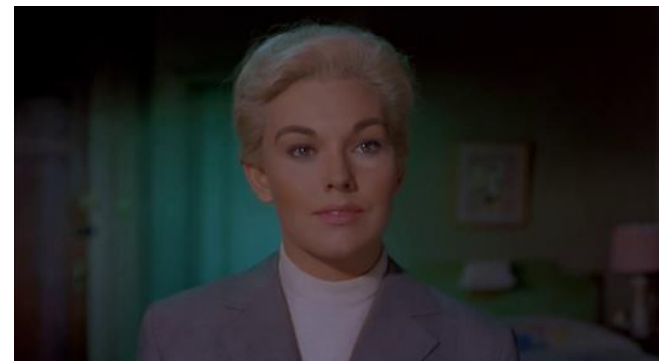

Vertigo

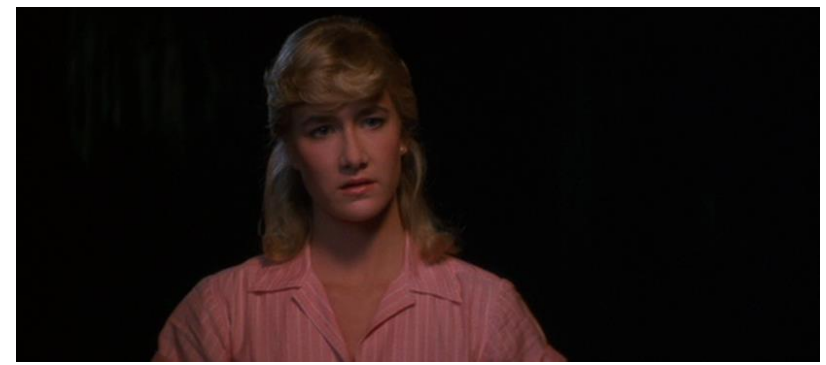

Veludo azul

Em Vertigo, a imagem de Madeleine transita de um estado espectral, holográfico, para uma forma mais tangível e corpórea, como se o fantasma se materializasse para a câmera. Em Veludo azul, Sandy sai de uma área de sombra e caminha em direção à luz, tornando-se visível à medida que se aproxima da câmera; ela é tão somente uma pessoa que estava numa zona escura, onde não podia ser vista, e deslocou-se para uma zona mais clara, onde pode ser 
vista. No entanto, muito embora disponha de maior realismo fotográfico, a aparição de Sandy é tão "sobrenatural" quanto a de Madeleine: ela brota das trevas como um anjo luminoso que de lá se libertou para vir ao encontro de Jeffrey. A cena é um misto de surpresa e estranhamento: da escuridão que o cinema usualmente reserva aos demônios da noite, surge, desta vez, um rosto doce e delicado.

Em Estrada perdida, Lynch revisita novamente a cena da reaparição de Madeleine. Agora, contudo, ele faz a figura feminina retornar ao estado fantasmático de que Hitchcock partira na cena do Empire Hotel.
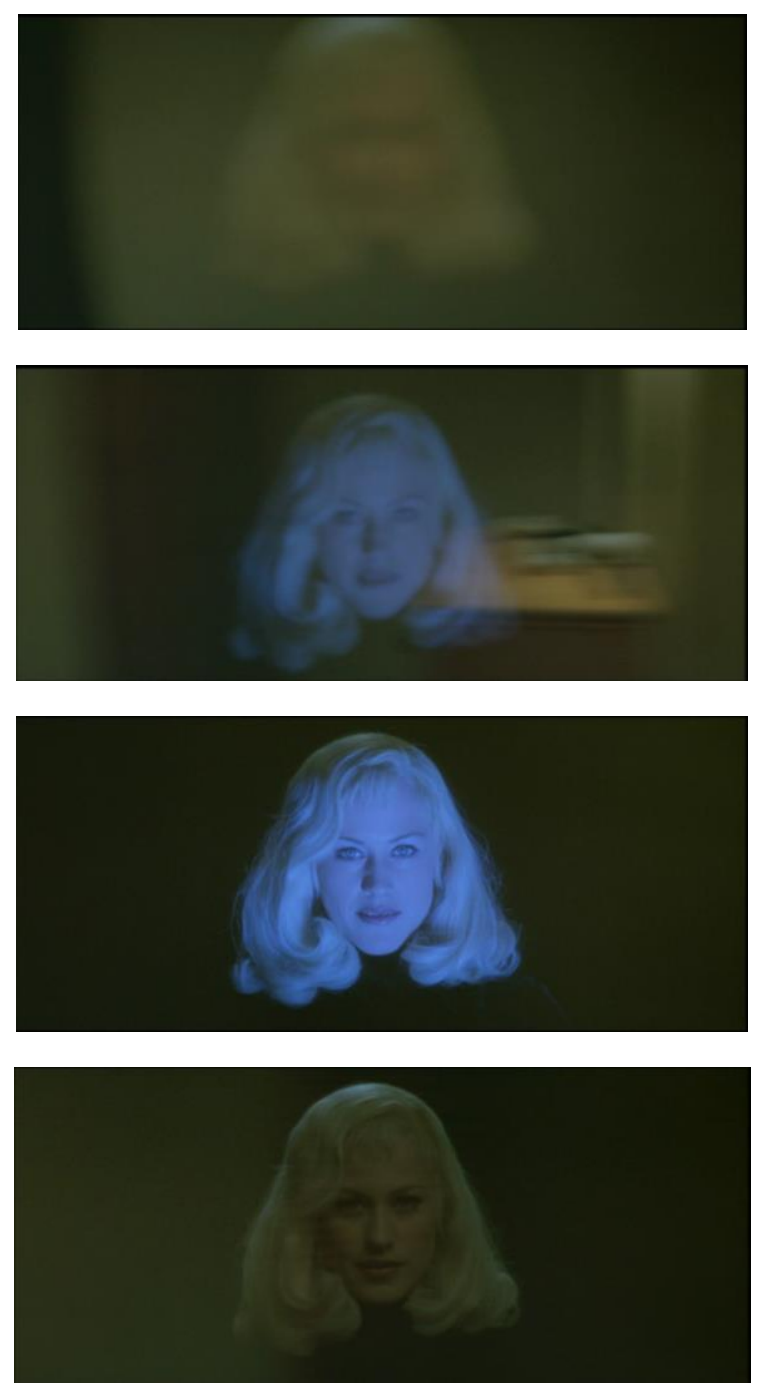

O rosto de Alice aparece para Pete - em meio a uma crise de dor de cabeça e alucinação - como uma pura efígie luminosa, uma máscara espectral flutuando no vazio. Ela está sobreimpressa num plano em que a câmera gira pela sala de estar da casa de Pete, um plano subjetivo que representa a vertigem que ele sente naquele momento. $O$ fundo da 
imagem mostra o giro de $360^{\circ}$ pelo espaço enquanto a figura de Alice, a princípio embaçada e turva, vai ganhando nitidez e presença. Lynch junta numa mesma imagem, portanto, o plano da reaparição de Madeleine com o plano circular do beijo entre ela e Scottie, no qual o fundo do cenário também é submetido a um movimento rotatório. Lynch incrusta a figura de um plano (o fantasma de Madeleine se aproximando) no fundo do outro (o espaço rodando), numa bela montagem plástica de duas diferentes ideias visuais decalcadas de Vertigo.

A Madeleine lynchiana, como demonstra a cena analisada acima, é uma imagem que não se pode coagular nem reter - uma identidade em fluxo. Na cena em que Alice faz amor com Pete no meio do deserto (ao som da versão etérea feita pela banda This Mortal Coil para a música "Song to the Siren", de Tim Buckley), com o farol do carro incidindo sobre seus corpos e transformando-os em esculturas de luz, um pouco antes do momento em que Alice irá sumir do filme tão somente ao cruzar um limite do fora de quadro, ela aparece em sua tradução mais plena: uma pura energia fluorescente, uma figura voluptuosa e radiante que, ao atingir o máximo de sua incandescência, prepara-se para desaparecer (um fantasma?).

\section{7. "Shot missing"}

No mesmo ano de Estrada perdida, surgiria outro filme que também revisitaria a cena da reaparição de Madeleine no Empire Hotel, fornecendo a esse momento-chave de Vertigo aquela que talvez seja a sua mais nebulosa e intrincada releitura: Blackout - Sentiu minha falta? (The Blackout, 1997), de Abel Ferrara.

Dennis Hopper, nesse filme, embora não seja o protagonista, interpreta uma personagem fundamental: um cineasta histriônico e obsessivo que tenta realizar - em vídeo um remake erótico do Nana de Christian-Jaque (1955). Mickey (a personagem de Hopper) insufla no set uma tensão permanente, uma atmosfera inundada por sua exaltação dionisíaca, sua pulsão criativa furiosa, intensa, desmesurada. Ele filma com várias câmeras ao mesmo tempo, cobrindo - no sentido televisivo, ou até mesmo da vídeo-vigilância - praticamente todo o espaço de um estúdio/boate em que dezenas de mulheres seminuas dançam sob os holofotes delirantes de uma ambiência onde os excessos são celebrados e canalizados para as imagens do filme (o de Ferrara e o de Mickey, o filme e o filme dentro do filme).

A estrela desse remake de Nana é a atriz e top model francesa Annie (Béatrice Dalle), namorada de Matty (Matthew Modine), um ator de cinema que, como se diz em todo lugar em 
que ele chega, está vivendo o auge da carreira - ele é o nome da vez em Hollywood. Mas o auge, enquanto ponto mais alto de uma trajetória, é também o prenúncio da queda: a partir de então, só se pode descer. E é o que acontecerá com Matty: um declínio vertiginoso.

Os filmes de Ferrara, sobretudo os que ele realizou de Blackout em diante, colocam-se quase sempre num estado limítrofe, numa experiência do delírio, da loucura, da histeria, do êxtase (religioso, dionisíaco, estético-barroco, apocalíptico). Em tal circunstância, o homem se mantém ligado à realidade por não mais que um fiapo de consciência. E a imagem de cinema, para Ferrara, ocupa justamente esse interstício, essa fenda entre a realidade e o fantasma. Daí uma construção visual central em sua obra, e abundante em Blackout: a sobreimpressão, a fusão entre duas ou mais imagens, a visão fronteiriça que embaralha percepção objetiva e construção subjetiva, visão sensível e visão mental, lucidez e loucura.

Esse estado limítrofe, em Blackout, é dado pela droga, pelo álcool, mas também pelo cotidiano alucinante das celebridades, que habitam uma realidade paralela, um lugar fora do mundo. No começo do filme, Matty chega a Miami, para se juntar à sua namorada, e é como se transitasse por um mundo-imagem, uma paisagem em back projection. O que Ferrara flagra nesse filme - entre desfiles de moda, quartos de hotel, festas, porres, brigas de casal, brigas de set de filmagem, céus crepusculares que mais parecem painéis publicitários - é um mundo coberto por imagens, monitores e telas. Já não é questão de estetização do cotidiano, de reificação do mundo social por seu superpovoamento com formas visuais e espaciais: a questão agora é de convivência, coabitação, troca de energia afetiva com as imagens que estão por toda parte (como no plano em que Matty encosta o rosto num monitor que exibe a imagem de Annie). A grande "novidade" que Ferrara incorpora em suas ficções a partir de Blackout é precisamente essa constatação da onipresença da imagem e, por conseguinte, da infinidade de texturas, reflexos, impressões visuais, afetos psíquicos, enfim, o caos sensorial e psicológico que aí se instala. Imagens fílmicas, imagens de vídeo, imagens subjetivas, flashbacks mentais de Matty: tudo isso é processado e centrifugado numa montagem que acompanha o estado mental do protagonista.

Alcoólatra e viciado em drogas pesadas, Matty passa toda a primeira metade do filme sob o efeito de substâncias. Annie, insatisfeita com o relacionamento, conta que fez um aborto. Eles brigam violentamente, ela o abandona. Matty, que a ama de uma forma exasperada, doentia, passa a noite em claro (bebendo, se drogando). No dia seguinte, ainda bastante alterado, ele vai a uma lanchonete onde é atendido por uma bela e jovem garçonete cujo nome, como se lê em seu crachá, também é Annie. Matty a convida para passar o dia ao lado dele, e ela aceita. Eles vão ao estúdio de Mickey, que aproveita para filmar, com Matty e 
a garçonete (rebatizada de Annie 2), a cena que falta ao remake de Nana. Mickey pede que Annie 2 vá ao camarim e coloque uma peruca curta, para ficar mais parecida com Annie 1. No momento em que ela retorna do camarim, Matty tira os olhos do monitor (em que apreciava imagens de Annie 1) e se fixa em Annie 2. Em pleno delírio, ele pensa que ela é Annie 1, e que esta teria voltado para ficar com ele. Matty vai em direção a Annie 2 e a abraça emocionado. Aqui já não é Nana que Ferrara refilma, mas Vertigo. Ele refaz o clímax romântico do filme, a cena em que Madeleine retorna do banheiro (onde preparava, justamente, o cabelo) e Scottie a toma em seus braços:
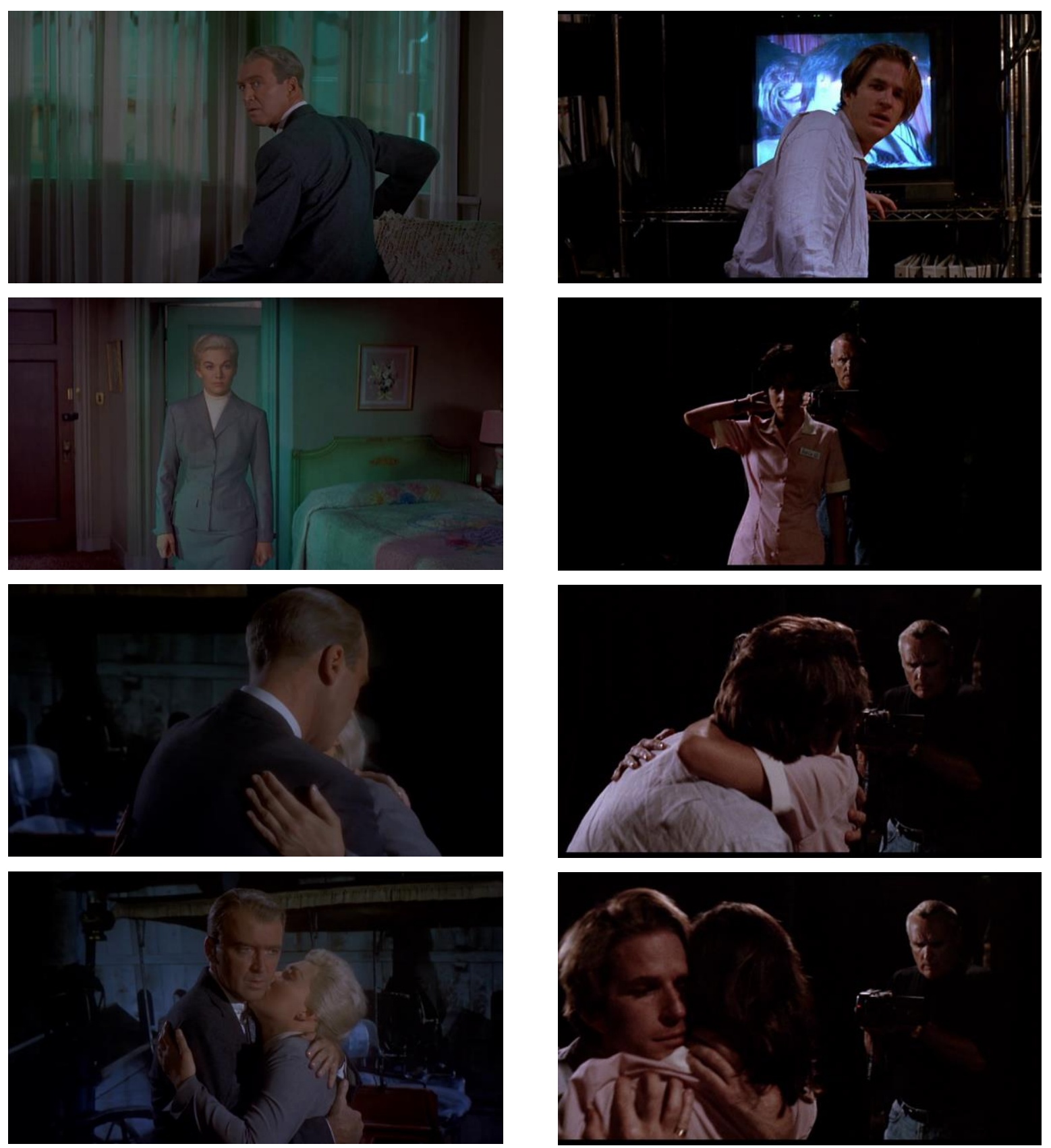

Vertigo

Blackout 
Em Vertigo, o delírio de Scottie é figurado pela mudança do pano de fundo da cena: o quarto de hotel se troca pelo estábulo da missão espanhola, lugar em que Scottie havia dado o último beijo em Madeleine antes de ela correr para a torre da igreja e de lá despencar. A vertigem amorosa o faz voltar no tempo e se imaginar novamente nos braços de Madeleine, como se ela não tivesse morrido, ou como se o destino tivesse sido revertido.

Em Blackout, Matty também pensa reencontrar sua amada. Embora não conte com plataforma giratória, back projection ou qualquer outro efeito cênico sofisticado, o dispositivo visual dessa cena é ainda mais complexo que o da original. A cena é feita com duas câmeras na mão, ambas focadas no abraço entre Matty e a garçonete. A câmera 1 (a de cinema) enquadra, além do casal se abraçando, a presença de Mickey segurando a câmera 2 (a de vídeo), que capta esse mesmo abraço, mas pelo ângulo diametralmente oposto. Ferrara duplica, portanto, não apenas a figura feminina (Annie 1 e Annie 2, a primeira aparecendo num monitor de vídeo e a segunda presente corporalmente - mas, na imaginação perturbada de Matty, ambas se fundem numa só), mas também o aparato de captação (câmera 1 e câmera 2) e a própria imagem do filme, já que se obtém um duplo registro, feito de dois pontos de vista diferentes, com duas texturas diferentes (cinema e vídeo). Na montagem, Ferrara alterna entre os dois pontos de vista, indo da câmera 2 à câmera 1 , do vídeo ao cinema e vice-versa.

Atrás do casal, na imagem fornecida pela câmera 1, não há um cenário mutante, não há back projection, mas antes a figura controladora do diretor de cinema, que, parcialmente dissimulado na escuridão daquele canto do estúdio, dirige a cena de perto, operando a câmera e dando instruções para os atores. Mickey é o gênio manipulador, o Gavin Elster de Blackout, que doravante sai da posição do criador invisível e inatingível para entrar numa relação de corpo a corpo com suas criaturas. O fundo da imagem deixa de ser uma superfície de projeção (psíquica, fílmica) para se tornar um espaço de personificação do autor-cineasta, que se coloca no limite entre a encenação supercontrolada e superdramatizada e o registro passivo das intensidades transbordantes dos atores.

Depois do abraço, as tensões progridem, as emoções se embolam, com Matty cada vez mais confuso e imprevisível. Começam a surgir inserts de outras cenas do remake de Nana, imagens picantes de Annie 1 se relacionando com mulheres. De repente, há um apagão, um "blackout" (um desmaio de Matty?), e a tela fica, por alguns segundos, como uma televisão fora do ar. A cena foi interrompida.

Em seguida, elipse: um ano e meio se passaram. Matty frequentou um programa de reabilitação e está sóbrio há um ano. Ele agora vive em Nova York com outra mulher, Susan (Claudia Schiffer, top model na vida real, artista plástica no filme), que é o oposto de Annie: 
loira, comportada, caseira, não bebe, não usa drogas. "Ela é como uma loja de comida saudável”, diz Matty durante uma sessão de terapia gravada em vídeo.

A vida de Matty parece ter entrado nos eixos. Mas, abrindo-se para o seu terapeuta, ou abrindo-se para si mesmo nos sonhos, ele demonstra que ainda não superou a perda de Annie. Ele traz também alguns pensamentos atormentados, um sentimento de culpa muito forte, que não sabe de onde vem. Matty vive tendo pesadelos em que se imagina estrangulando Annie até a morte. Alguns flashes às vezes se somam a esses pesadelos (um corpo sendo jogado num terreno baldio, por exemplo). Ele sente que alguma coisa sinistra se esconde no fundo de sua memória ou jaz bloqueada no subconsciente.

A fixação por Annie persiste. Aproveitando que Susan sairá para uma viagem a trabalho durante três dias, ele decide ir a Miami atrás de Annie. Como Scottie depois que sai da clínica psiquiátrica, ele vaga pelo passado em busca de um rosto desaparecido. Mickey o ajuda a reencontrar Annie. Mas quando ela chega ao hotel, encontra Matty completamente bêbado e drogado. Voltar a Miami foi voltar também ao vício, foi descer de novo ao inferno. Pensando poder recuperar Annie, tudo o que Matty consegue é perdê-la mais uma vez: depois de encontrá-lo naquele estado, ela sai e o deixa sozinho no hotel, não sem antes insultá-lo e acusá-lo de patético.

Num lampejo de lucidez, Matty começa a juntar as peças daquela noite turbulenta em que, um ano e meio antes, chegou ao estúdio de Mickey acompanhado de Annie 2, a garçonete que acabara de conhecer. Matty vai ao encontro de Mickey, que lhe mostra a fita onde ficou gravada a cena que Matty apagou da memória (como se apaga uma fita de vídeo), a cena em que ele contracenou com Annie 2. No começo de Blackout, na mesa de edição de Mickey, um monitor mostrava o filme de Christian-Jaque à esquerda e, ao seu lado, via-se que o plano equivalente àquele em que Nana era estrangulada pelo amante no filme original ainda estava em falta no remake. Mas agora a imagem ausente foi achada: ela consiste em Matty estrangulando Annie 2 (pensando que ela era Annie 1), dando a Mickey, com toda a verdade e a intensidade que o diretor não conseguira encontrar antes, a exata cena de que precisava.
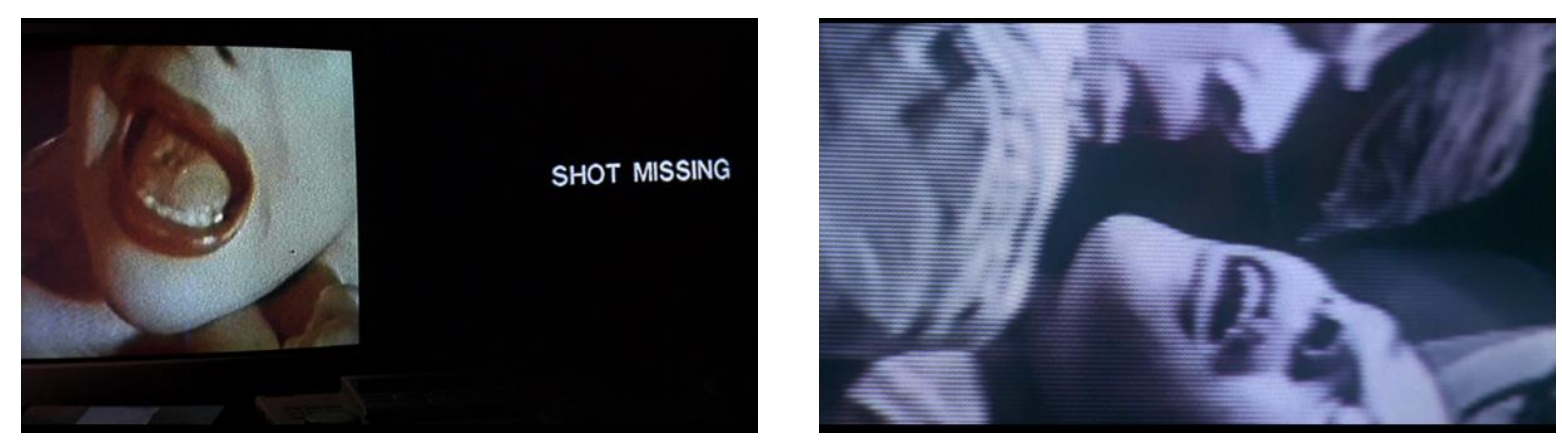
A crueldade das relações sociais é mais enfatizada em Blackout do que em Vertigo: Annie 2, a garçonete de origem pobre, a jovem trabalhadora e sonhadora, a Judy de Blackout, vítima do poder dos homens ricos, é eliminada e extirpada da sociedade como uma peça descartável, de quem ninguém sentirá falta. O último plano do filme é bastante forte nesse sentido: o fantasma de Annie 2 aparece e pergunta a Matty: "sentiu a minha falta?".

Depois que descobre o que aconteceu, que sabe que é um assassino, Matty entra em desespero. Ele vai para a praia em frente ao hotel, onde encontra Susan, que foi a Miami para tentar ajudá-lo. Mas ele a rechaça e a empurra na areia, gritando que não a ama e que ela não o conhece de verdade. Ele corre para o mar, entra na água, começa a nadar e a se distanciar da praia. A visibilidade é ruim, a noite impede que se veja para onde ele está indo. Ele nada para o meio do oceano, para o vazio, para a escuridão. Até se afogar e se diluir nas trevas. Que Deus tenha piedade. 


\section{VI.}

\section{A imagem-fantasma}

\section{Ruínas circulares}

Não ser um homem, ser a projeção do sonho de outro homem, que humilhação incomparável, que vertigem!

(Jorge Luis Borges, "As ruínas circulares"1)

No documentário Dans le labyrinthe de Marienbad, Luc Lagier sugere que, contra todas as expectativas, a referência cinematográfica principal de $O$ ano passado em Marienbad (L'année dernière à Marienbad, 1961) talvez seja Intriga internacional, de Hitchcock, realizado somente dois anos antes do filme de Alain Resnais. ${ }^{2}$ Comparando os dois filmes, o crítico aponta, em ambos, a história de um homem perdido em espaços labirínticos compostos por formas geométricas que disfarçam sua estrutura ordenada e uniforme sob a diversidade e a profusão das aparências visíveis; um "mundo de puros simulacros", narrativa abstrata feita apenas de linhas e trajetórias. Para o azar dos heróis desses filmes, eles experimentam um sentimento verdadeiro, a paixão genuína por uma mulher, num universo de autômatos sem vida e sem interioridade. Como viver esse sentimento, como impô-lo a uma estátua? Interessa aos diretores menos a psicologia das personagens, a parte sentimental do drama, do que o trabalho com a estrutura narrativa e a invenção de uma nova forma de construção espaçotemporal no cinema. Em $O$ ano passado em Marienbad, segundo Lagier, Resnais teria chegado a um resultado francamente hitchcockiano: fazer o espectador reagir emocionalmente não ao tema e às personagens, mas ao cinema em estado puro.

Mas por que Intriga internacional e não Vertigo? De fato, a comparação de Lagier é pertinente, e nos convence de uma conexão entre Intriga internacional e Marienbad.

\footnotetext{
${ }^{1}$ Ficções; tradução Davi Arrigucci Jr.; São Paulo: Companhia das Letras, 2007, p. 52.

${ }^{2} \mathrm{O}$ documentário vem de extra no DVD de $O$ ano passado em Marienbad lançado pela distribuidora francesa StudioCanal em 2009.
} 
Contudo, é igualmente certo que Vertigo não pode ficar de fora da equação. Superficialmente, podemos aproximar os filmes pelo tema: o homem que reencontra no hotel de Marienbad a mulher que conhecera no ano anterior, embora ela agora negue ser a mesma pessoa, tem lá seu parentesco com Scottie, que reencontra no hotel Empire a mulher por quem se apaixonou num passado recente. Ambos terão de modelar essa mulher reencontrada no presente para fazê-la aceitar, aos poucos, o papel da mulher conhecida no passado. No entanto, o diálogo mais interessante que se estabelece entre os filmes se dá em outro nível: Marienbad assimilou a espiral de Vertigo em sua própria estrutura temporal e narrativa. Com suas repetições, variações, dobras e bifurcações, o filme incorpora a ideia - que já era comum na literatura da época, nouveau roman incluso - de um tempo circular, labiríntico, uma espiral do tempo que embaralha a ruminação do passado e a captação do presente imediato.

Resnais e Alain Robbe-Grillet (autor do roteiro, e grande nome do nouveau roman) nunca citaram, a respeito de $O$ ano passado em Marienbad, a influência de Hitchcock. Em compensação, com cerca de dez minutos de filme, uma foto de Hitchcock em escala natural aparece ao lado de um elevador, como uma silhueta dissimulada no canto direito da imagem:

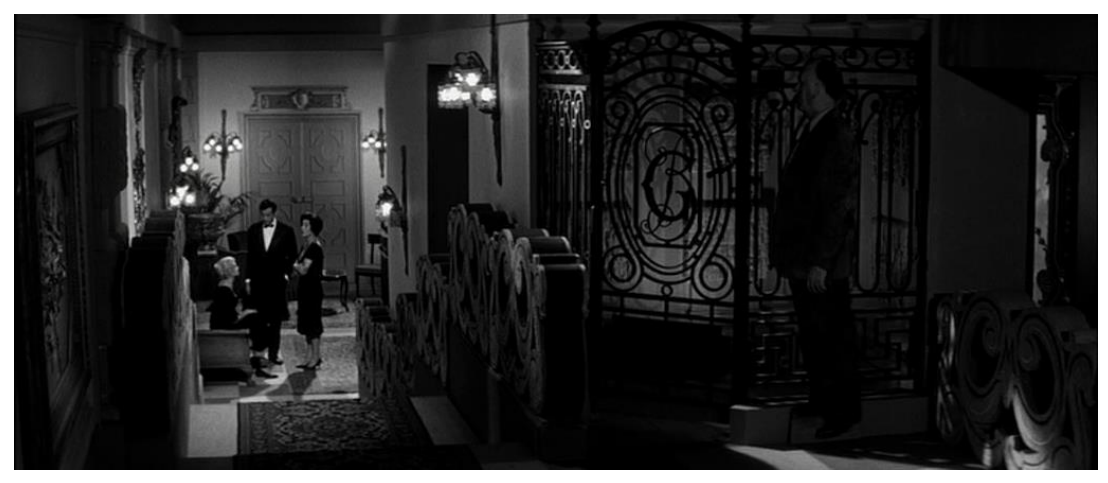

Essa imagem de Hitchcock pode muito bem passar despercebida, ou ser tomada por mais um dos corpos estatuificados que surgem ao longo do filme. Uma vez reconhecida, entretanto, ela inscreve no filme a marca indelével do diretor de Vertigo. "A sombra de Hitchcock plana sobre o labirinto de Marienbad”, afirma Lagier com razão.

Rodado nos castelos de Schleissheim (para as cenas exteriores) e de Nymphenburg e Amalienburg (para interiores), verdadeiras maravilhas arquitetônicas do rococó bávaro do século XVIII, o filme de Resnais é um dédalo de espelhos, corredores, quadros, situações, encontros que se repetem e se confundem. A arquitetura dessas locações - que, na diegese, formam um único lugar imaginário, um hotel luxuoso - constitui um labirinto que será corroborado pela montagem, a qual, por um astucioso jogo de falsos raccords, promove 
novos ligamentos e desligamentos dos espaços e das ações. A câmera constantemente faz e refaz o mesmo travelling, o mesmo enquadramento, mas com alguma variação (onde antes havia um espelho agora pode haver um quadro, por exemplo). Estamos aprisionados num mesmo espaço e num mesmo instante infinitos, explorando todas as possibilidades contidas nessa célula de espaço-tempo, todos os seus túneis. O filme é um verdadeiro "jardim de veredas que se bifurcam"; um "invisível labirinto de tempo". ${ }^{3}$ Os travellings de Resnais, abundantes durante todo o filme, avançam com fluidez e elegância por dentro de um espaço saturado de elementos decorativos. A câmera se embriaga com as infinitas ondulações dos ornamentos barrocos, acompanha os relevos das esculturas e das colunas de granito, percorre o espaço como se cinzelasse cristais de tempo. Talvez esse hotel-labirinto, junto ao imenso jardim que o cerca, seja nada mais que uma enorme escultura de tempo, um passado marmorizado, congelado para a contemplação. Só quem não sabe disso é o homem interpretado pelo ator italiano Giorgio Albertazzi, que insiste em interagir afetivamente com as pessoas, ignorando que, tal como as figuras de bronze e de mármore, elas são estátuas, esculturas - o que fica sugerido, sobretudo, naqueles planos em que os hóspedes do hotel estão paralisados no meio de uma ação, estatuificados, formando um grande tableau-vivant.

A cenografia esbanja em espelhos para criar espaços duplicados, imagens dentro de imagens, dispositivos de trompe-l'oeil. Num desses planos de espelho, encontramos mais uma vez o motivo composicional do plano da loja de flores de Vertigo, se bem que com os lados invertidos (homem à esquerda e mulher/espelho à direita):

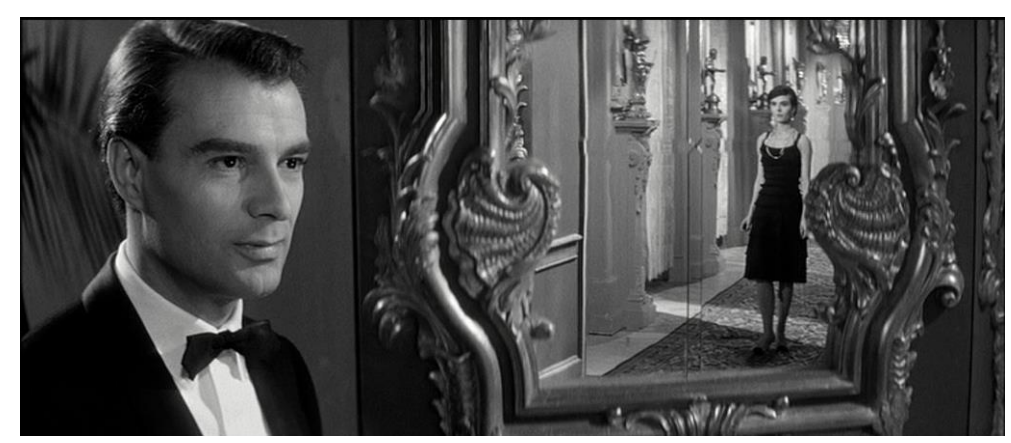

A moldura suntuosa do espelho encerra um espaço visual estilizado, posado, no qual a personagem de Delphine Seyrig não se distingue completamente das esculturas de bronze enfileiradas ao longo do corredor. Ela é mais uma das estátuas desse mundo museificado. O homem que aparece contemplando Seyrig nesse plano é seu suposto amante do passado, que

\footnotetext{
${ }^{3}$ J. L. Borges, “O jardim de veredas que se bifurcam”, in Ficções, op. cit., p. 88.
} 
não cansará de dizer que já a conhece, que já a amou. Ela refuta, nega tê-lo conhecido e amado antes, sequer sabe o que significa o amor. Aos poucos, porém, ela dá sinais de emoção. No final do filme, eles saem juntos do hotel. É novamente a história de Pigmalião: um homem se apaixona pela bela estátua de uma mulher e seu amor lhe insufla vida, transforma-a num corpo de verdade.

Um dos planos mais famosos de $O$ ano passado em Marienbad é aquele grande plano geral do jardim em que Resnais falseia as sombras:

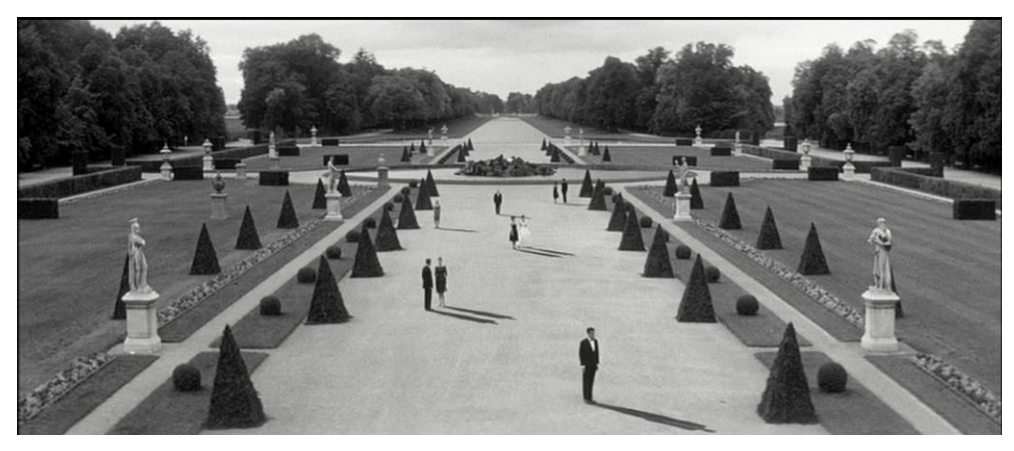

Somente os corpos parados no meio do jardim têm suas sombras esticadas no chão; nenhum dos demais elementos do plano projeta sombra. É como se, para os corpos, o dia estivesse se pondo, e o ângulo de inclinação do sol gerasse aquelas sombras longilíneas, ao passo que as plantas e as esculturas recebem um sol de meio-dia. A sombra perde sua validade como índice (já que não convence mais como emanação física do corpo ao qual se associa) à mesma medida que reforça sua qualidade de signo. Ela é o signo da convergência de séries temporais em que o filme está imerso.

Essa circularidade do tempo vista em $O$ ano passado em Marienbad suscita a ideia de um eterno retorno, de uma ressurgência cíclica de imagens e rostos esquecidos ou, inversamente, aguardados, a exemplo do que ocorre no reencontro do homem X com a mulher A (é assim que eles são designados no roteiro de Robbe-Grillet), que ele aguardou durante todo um ano ("mas um ano não é muito", ela diz). O tempo obedece aí a um movimento de fluxo e refluxo, como um mar que traria de volta coisas levadas pelas águas numa época passada - exatamente como ocorre no início de Venus in furs (1969), de Jess Franco. Neste filme recoberto de erotismo e exotismo, um jovem trompetista chamado Jimmy encontra o corpo nu de uma bela mulher boiando próximo à areia de uma praia em Istambul. O cadáver traz as marcas da violência sofrida pela moça. Ao ver o cadáver, Jimmy imediatamente se lembra do que aconteceu: numa festa em que tocava, ele testemunhou um ritual sádico no 
qual a moça agora morta, que se chamava Wanda Reed, foi violentada e estuprada por dois homens e uma mulher. Encontrada na praia tal a estátua de uma Vênus regurgitada pelos mares da Antiguidade, Wanda Reed anuncia o retorno de seu fantasma, que assombrará não só os responsáveis diretos por sua morte como também Jimmy, a testemunha negligente.

No flashback da festa em que o crime ocorreu, há uma série de planos que mostram os ricos convidados paralisados como estátuas, numa evidente alusão a $O$ ano passado em Marienbad, de que Jess Franco toma emprestados o dédalo temporal e a interseção de imagens mentais e eventos presentes.

A confusão de tempos e espaços começa quando Jimmy, querendo fugir da vida que leva em Istambul, viaja para o Rio de Janeiro bem na época do carnaval. Ele encontra a cidade explodindo em festa e se perde pelos blocos de rua, somando-se à energia coletiva dos foliões. As cenas do carnaval são registros documentais da celebração popular; Jimmy não aparece no meio da multidão, sua participação na folia é somente afirmada por ele em voz off. Um curioso plano exibe a imagem de uma Vênus mitológica afixada a uma alegoria num desfile de escola de samba, fazendo a ponte entre essa realidade documental e o próprio tema ficcional do filme; tudo se mistura num grande magma visual.

Jimmy recupera sua energia e sua criatividade musical no Rio. Mas, para sua infelicidade, ele vê Wanda Reed ressurgir dos mortos durante uma festa à qual fora convidado para tocar. Ela aparece (primeiramente de perfil) numa sala com parede vermelha e repleta de pessoas e quadros. A cena evoca claramente a aparição de Madeleine no Ernie’s.
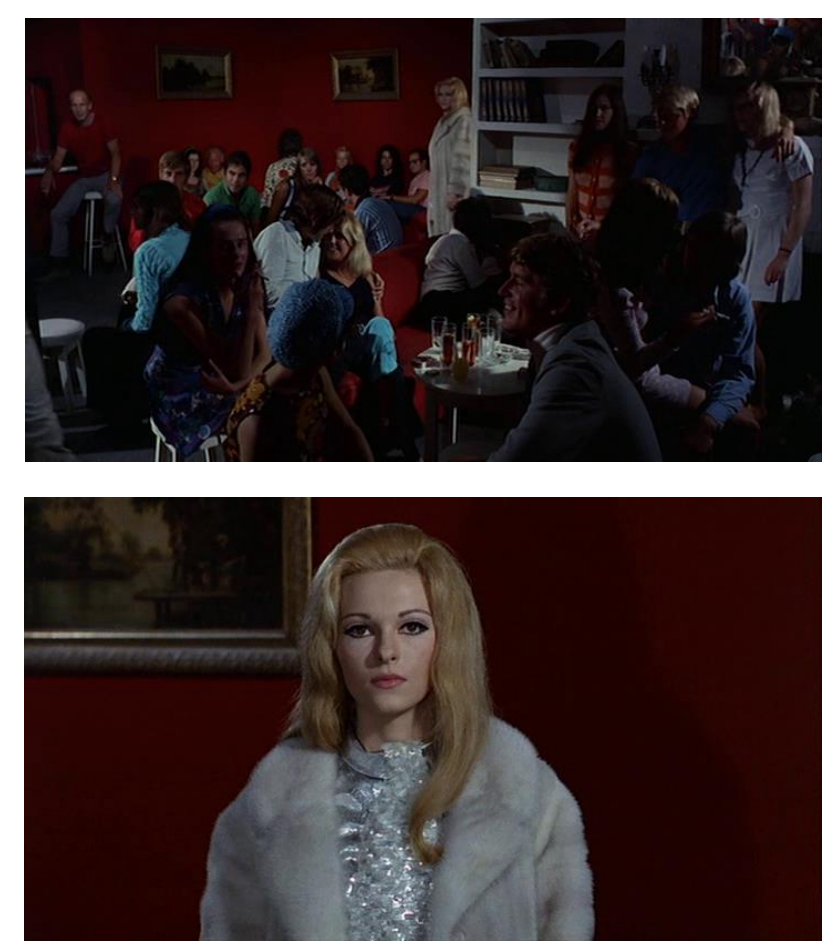
Wanda seduz Jimmy com o olhar. Ela sai da festa e ele vai atrás dela, passando por um pátio interno que guarda semelhanças arquitetônicas com a missão espanhola onde Madeleine é morta em Vertigo. Planos subjetivos de Jimmy demonstram a vertigem provocada nele pela visão de Wanda: a imagem fica turva e instável, como se um líquido de alta viscosidade ondulasse por cima da lente da câmera.
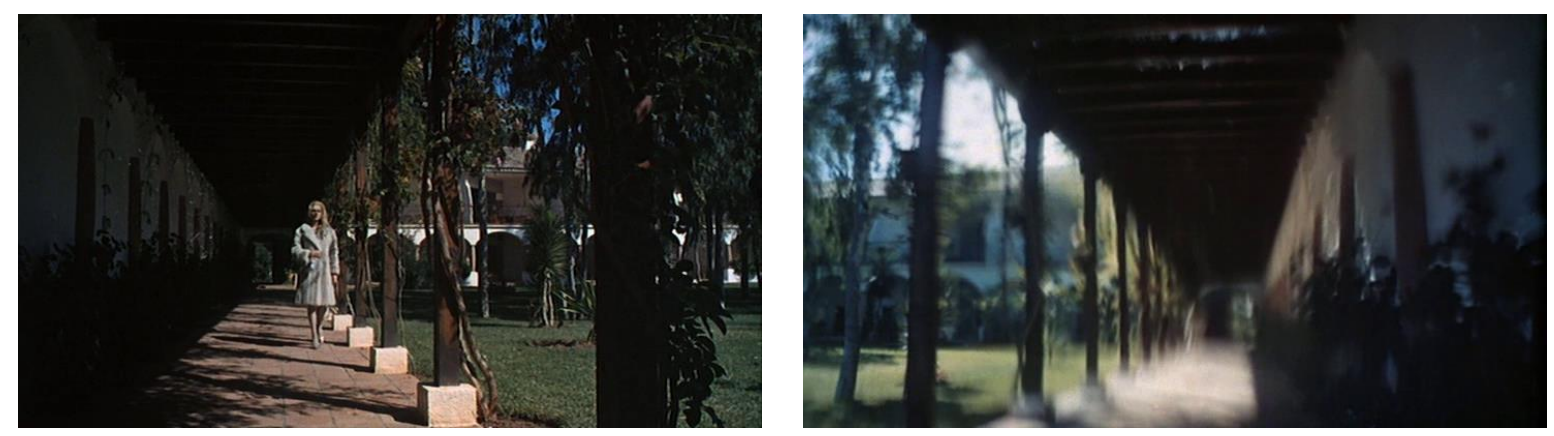

Embora intua que não deve segui-la, Jimmy não consegue resistir, e é arrastado por Wanda para uma outra casa, onde fazem sexo num ambiente ornado por espelhos barrocos e quadros com retratos que os observam:
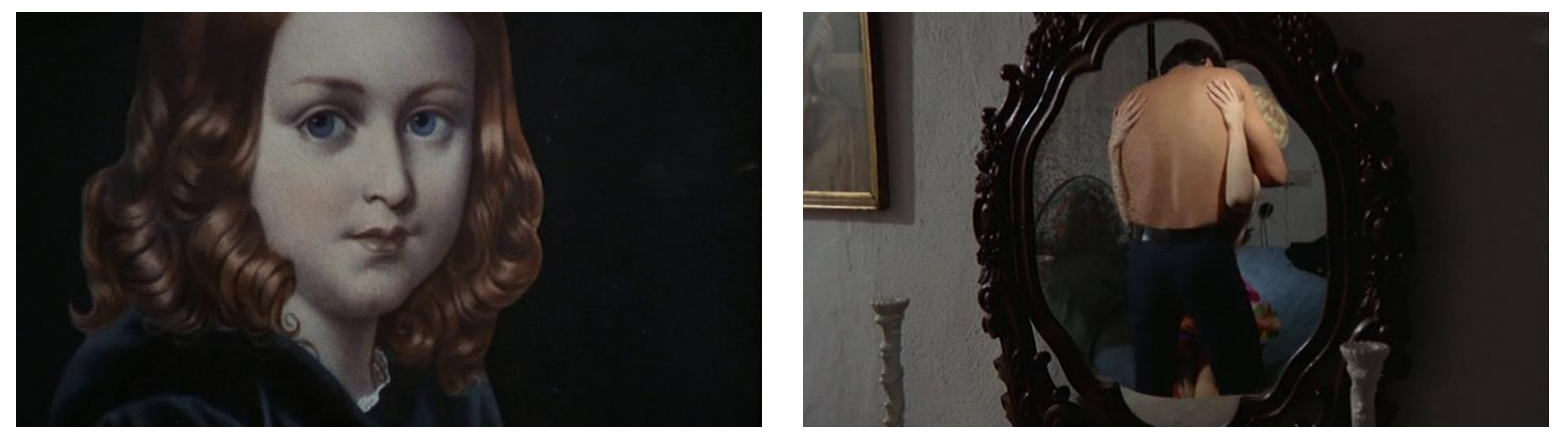

Os elementos visuais e temáticos que conectam Venus in furs a Vertigo são numerosos. Jess Franco, em total coerência com seu universo sempre habitado pelas perversões mais escabrosas, acentua a sugestão de necrofilia que teria ficado implícita em Vertigo (Scottie fazer sexo com a recriação de Madeleine na segunda parte do filme seria o equivalente a possuir uma morta) e que é motivo de controvérsia entre os exegetas do filme. Em Venus in furs, mais do que em Vertigo, a aventura amorosa que Jimmy vive com Wanda tem elementos que de fato sugerem uma fantasia erótica que ele imaginou - e tentou reprimir sem sucesso - depois de ver o cadáver da moça nu e dilacerado na praia. 
Mas o final do filme implica outra interpretação: Jimmy retorna à mesma praia do início e novamente vê um corpo boiando na água. É como um retorno ao ponto inicial, uma volta perfeita no tempo. Chegando lá, no entanto, não é mais o corpo de Wanda o que ele encontra, e sim o cadáver dele próprio, Jimmy, que se horroriza com essa visão antes de compreender que, no fim das contas, é ele mesmo quem está morto. Enquanto ele sonhava a morte de uma pessoa, alguma outra sonhava a sua.

Começando e terminando numa praia, o filme utiliza as ondas do mar e o movimento das marés como metáforas para a dinâmica das influências, das citações, das correntes de imagens que migram de um filme para o outro por um processo de contaminação inerente ao imaginário cinematográfico. À semelhança dos corpos que aparecem na praia, as imagens do passado (de Vertigo, de Marienbad) retornam, refluem na narrativa de Venus in furs.

Algo semelhante acontece em Rio Suzhou (Suzhou he, 2000), de Lou Ye, em que o rio substitui o mar como figura central de uma "poética do elemento líquido" que metaforiza "o jogo de correntes, influências e referências (Vertigo em particular) que irriga o filme de ponta a ponta". ${ }^{4}$ Nos primeiros e nos últimos minutos de filme, Lou Ye usa um procedimento tornado célebre por Prisioneiro do passado (Dark Passage, 1947), de Delmer Daves, em que a personagem de Humphrey Bogart só aparece pela primeira vez com mais de quarenta minutos de filme, depois de ter feito uma cirurgia plástica no rosto. Até então, o espectador via a ação através do olhar dessa personagem invisível: praticamente todos os planos do filme eram filmados com câmera subjetiva situada no ponto de vista de Bogart, de quem ouvíamos a voz em off, a expressar suas falas e pensamentos. ${ }^{5}$

Em Rio Suzhou, Lou Ye não leva tão longe a sistematização da câmera subjetiva, e as implicações de enredo são outras: não se trata de uma personagem que mudará de rosto e por isso deve ter sua face suprimida na primeira parte da narrativa (o que, no contexto da Hollywood clássica, incrementava também a expectativa em torno da aparição da estrela principal do filme), e sim de um narrador-personagem que, embora não adquira uma face visível, faz-se totalmente presente como instância narradora: o manejo da câmera é sublinhado por um comportamento falsamente improvisado e documental, que sugere a ideia de um filme que se faz ali no momento mesmo de sua filmagem, tropeçando em pessoas e acontecimentos que imediatamente se tornam matéria de ficção.

\footnotetext{
${ }^{4}$ Jean-Sébastien Chauvin, "Mécanique des liquides", in Cahiers du Cinéma, n. 550, outubro de 2000, p. 100.

${ }^{5}$ No mesmo ano de Prisioneiro do passado, o ator-diretor Robert Montgomery leva o processo da câmera subjetiva ao extremo em A dama do lago (Lady in the Lake), que é todo filmado a partir do ponto de vista do herói. Mas a generalização do procedimento acaba adquirindo um tom muito mais de paródia do que de experimentação formal.
} 
O narrador-personagem-câmera tem um caso com a jovem Meimei, que trabalha num bar onde faz um show nadando num aquário, vestida como sereia. Ele diz em off que às vezes ela some de sua vida, desaparece por algum tempo, para voltar quando ele menos espera. Numa dessas ausências, o narrador relembra (ou imagina?) uma história de amor. Nessa história - durante a qual o filme deixa de lado a câmera subjetiva que representa o narrador -, Mardar, um jovem motoboy, é contratado para fazer um serviço diferente: levar a adolescente Moudan da casa do pai para a casa da tia. Ele deve fazer esse serviço durante algumas semanas. Mardar e Moudan se apaixonam. Mas não é tão simples: ele está envolvido com a máfia, que o obriga a sequestrar Moudan para exigir do pai dela, um contrabandista de bebida alcoólica, alguma quantia de resgate. Moudan fica profundamente triste ao ser sequestrada pelo próprio rapaz que ama. No dia em que Mardar a levará de volta para o seu pai, ela foge e se joga de uma ponte que atravessa o rio do título, que corta a cidade de Xangai. Antes de se jogar, ela diz para Mardar que um dia voltará como uma sereia.

Depois de passar alguns anos na cadeia, Mardar retorna a Xangai. Ele vai ao bar em que Meimei trabalha como sereia e, ao vê-la, fica impressionado, pois ela é idêntica a Moudan. Mardar voltará diariamente ao bar, e começará um relacionamento com Meimei, sempre cogitando se ela não seria Moudan. Um dia, após buscas incessantes, ele reencontra a verdadeira Moudan numa loja de conveniência. Eles se embebedam e morrem juntos afogados no rio Suzhou. Meimei, comovida com a história, foge deixando um bilhete para seu amante, o narrador-personagem invisível: "se você me ama de verdade, procure por mim!".

Rio Suzhou, como Vertigo, é marcado ao mesmo tempo pela repetição do passado e pela impossibilidade de revivê-lo ou refazê-lo. O que resta então é um fluxo melancólico de afetos e presentes puros, bem no espírito dos filmes de Wong Kar-wai dos anos 1990: trajetos, perambulações, câmeras lentas, letreiros de néon, bebedeiras solitárias, amores perdidos.

Duas cenas tornam o diálogo com Vertigo mais explícito. Na primeira, que remete ao plano-espelho da loja de flores, Mardar observa Meimei trocando de roupa e se preparando para seu espetáculo de sereia:
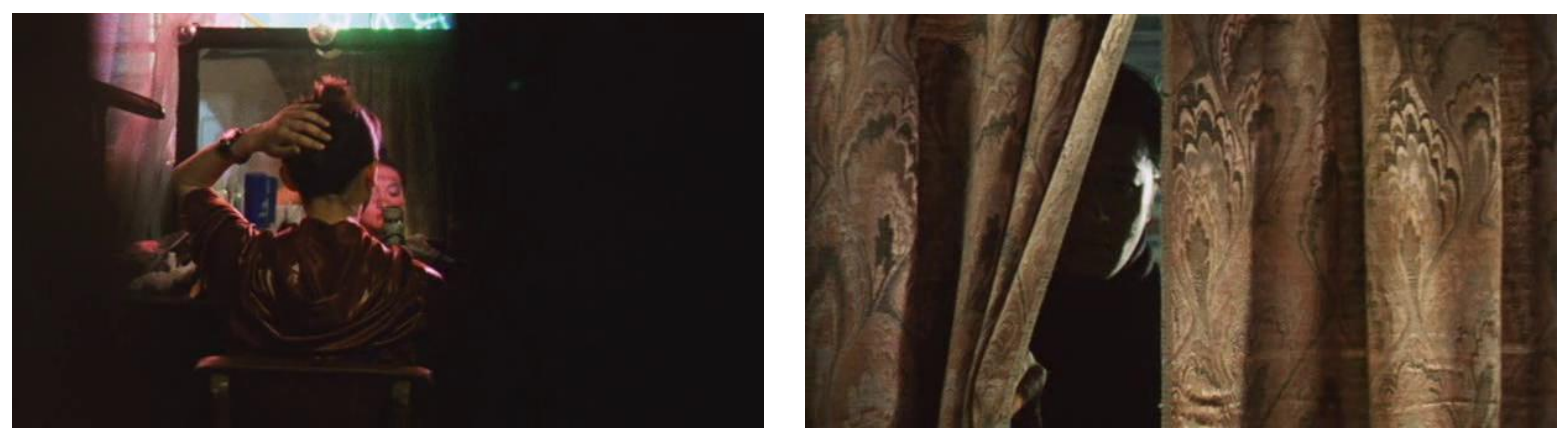
Se a iluminação dessa cena se parece mais com a do Empire Hotel do que com a do florista, não é por acaso: Lou Ye não filma Meimei comprando flores numa loja elegante, mas se transformando em sereia, passando por uma metamorfose, o que, no filme de Hitchcock, acontece no quarto de Judy no hotel modesto em que ela mora. O diretor de Rio Suzhou mistura a situação escópica de uma cena (o observador escondido espiando sua musa na loja de flores) com o padrão de iluminação de outra (a ambiência de néon da cena do ressurgimento de Madeleine no Empire Hotel). A perversão da relação voyeurística, evidentemente, é acentuada de um filme para outro: Mardar vê Meimei trocando de roupa (há um momento em que ela fica apenas de calcinha e sutiã); ele se comporta como o espectador de um peep-show erótico.

A outra cena diretamente extraída de Vertigo ocorre logo depois: Mardar se dirige ao balcão do bar, de onde, tal como Scottie no Ernie's, ele assiste à aparição deslumbrante de Meimei já vestida como sereia e nadando no aquário. A trilha sonora, nesse momento, é uma variação do tema romântico de Vertigo, reforçando a homenagem feita ao filme.

A mesma correnteza que levou Moudan, podemos concluir, trouxe-a de volta na pele da sereia Meimei - do mesmo modo que a experiência do cinema leva embora as imagens que vemos, mas as traz de volta, em curto ou longo prazo, com outro nome e uma aparência mais ou menos modificada. Além de metáfora do tempo e da vida que flui, o rio que dá nome ao filme de Lou Ye é também a figura representativa da memória do cinema e de seu imaginário movediço, do qual o cineasta-cinéfilo resgata algumas imagens presas no fundo e as reatualiza.

Em outras palavras, as imagens do cinema escoam, passam, mas deixam um rastro na memória do espectador, uma impressão que, em alguns casos, é tão intensa que o obriga a recriar essas imagens, a refazê-las à sua maneira.

Não há prova maior disso do que La Jetée (1962), de Chris Marker, que é uma tentativa de recriar Vertigo, de refazê-lo através da memória, como se fosse possível navegar pela "zona" (termo tarkovskiano de nascença - cf. Stalker [1979] - e markeriano por adoção) em que as imagens do filme ficaram depositadas no cérebro. Mas a condição de tal empreitada de "remake" (o próprio Marker se refere - implicitamente - a La Jetée como o "remake [de Vertigo] em Paris", é que, uma vez refeito, o filme seja já outra coisa completamente diferente. Por exemplo: que as cores intensas cedam lugar ao preto e branco; que o tempo cinematográfico vivido como experiência da duração seja ressignificado pelo

\footnotetext{
${ }^{6}$ Ver Chris Marker, “A free replay (notes sur Vertigo)", in Positif, n. 400, junho de 1994, pp. 79-84.
} 
corte temporal do instantâneo fotográfico (que abre a imagem para uma temporalidade nova, que também dura, mas "na imobilidade total, congelada na interminável duração das estátuas", lançada para "o fora de tempo da morte" - lembrando que "as estátuas também morrem", como diz o título de um curta-metragem que Marker e Alain Resnais realizaram em $\left.\operatorname{parceria}^{8}\right)$.

La Jetée, como se sabe, é um curta-metragem de menos de meia-hora realizado com imagens fixas, fotografias "still" em preto e branco, à exceção de pelo menos um plano em movimento, o plano de uma mulher abrindo os olhos (despertando de um sonho?) e piscando (batimento de pálpebra que alude à própria pulsação da imagem cinematográfica, um dos fatores que distinguem esse plano das demais imagens do filme). As fotografias que aparecem em La Jetée, uma vez filmadas e transformadas em fatias de imagem-tempo, passam a ser um objeto híbrido, nem fotografia nem fotograma paralisado, mas antes o que Philippe Dubois denomina um "cinematograma". ${ }^{9}$ Um imóvel movente, um instante que dura.

O corolário dessa peculiaridade formal, que constitui o assunto central de muitas das análises do filme (o "entre-imagens", a fronteira fotografia-cinema etc.), é a intrusão, entre o espectador e a realidade diegética, de uma "camada intermediária", "uma pré-representação fotográfica da realidade de partida". ${ }^{10}$ Tal afastamento faz todo sentido em um filme que é uma reprise de outro filme (uma imagem de imagem, uma representação de segundo grau) e que tem como motor principal a memória: "Instrumento de distanciamento subjetivo, a memória [em Marker] é precisamente o que metamorfoseia o real em imagem". ${ }^{11}$ La Jetée é um filme que se concebe numa certa dialética da memória: uma visão do futuro, mas construída sobre uma lembrança de infância.

A imagem de infância que abre La Jetée é uma cena ocorrida na plataforma de onde as pessoas apreciam as decolagens e aterrissagens dos aviões no aeroporto de Orly. Uma narração em off acompanha as imagens, e nos informa que o menino apoiado na grade do terraço testemunha uma cena obscura, indecifrável para ele: um homem corre na direção de uma mulher, mas tomba no chão antes de conseguir chegar a ela. Essa cena deixa para sempre na mente do menino uma lembrança, um rosto inesquecível: o rosto daquela mulher desconhecida, imagem incompreensível, mas eternamente intensiva. Após esse primeiro conjunto de imagens, o narrador nos diz que Paris (assim como o resto do mundo, presume-

\footnotetext{
${ }^{7}$ P. Dubois, $O$ ato fotográfico, op. cit., p. 168.

${ }^{8}$ Les Statues meurent aussi (1953).

${ }^{9}$ P. Dubois, "La Jetée de Chris Marker ou le cinématogramme de la conscience", in Recherches sur Chris Marker, Paris: Presses Sorbonne Nouvelle, 2002, p. 12.

${ }^{10}$ Ibid., p. 11.

${ }^{11}$ Ibid., p. 14. (org.), Theorème 6:
} 
se) seria destruída pela Terceira Guerra Mundial, que eclodiria pouco tempo depois desse episódio no aeroporto. Na Paris pós-hecatombe, alguns dos sobreviventes vivem nos subterrâneos do Palais de Chaillot (onde já ficou sediada a Cinemateca Francesa). Lá se desenvolvem experimentos de viagem no tempo, com o objetivo de reverter o passado e impedir que a humanidade siga o curso de sua aniquilação. As cobaias das viagens são os prisioneiros de uma espécie de campo de concentração futurista. Durante as sessões, eles são projetados num outro tempo, no qual nascem uma segunda vez, mas já adultos. Nem todos aguentam o choque da experiência. Os inventores do procedimento chegam à conclusão de que os melhores viajantes do tempo são "sujeitos dotados de imagens mentais muito fortes: capazes de imaginar ou de sonhar um outro tempo, eles seriam talvez capazes de lá se reintegrar". A polícia do campo de concentração, que monitora até mesmo os sonhos dos prisioneiros, escolheu um homem dentre milhares de outros, por conta de sua fixação numa imagem do passado. Esse homem é o menino - agora já adulto - visto na plataforma do aeroporto de Orly no início do filme, e a imagem que não lhe abandona os sonhos é a da mulher que lá aguardava por aquele homem que não conseguiria chegar até ela, pois cairia no meio do caminho.

Nas primeiras sessões de transporte no tempo, o homem escolhido não encontra ainda a mulher. "Outras imagens se apresentam, se misturam, num museu que é talvez o da sua memória”, afirma o narrador. Esculturas antigas, com partes faltando ou deterioradas, são algumas dessas imagens que surgem "aleatoriamente": Vênus sem cabeça ou com o rosto desfigurado. Ou à espera de um rosto. Ruínas do passado e do futuro.
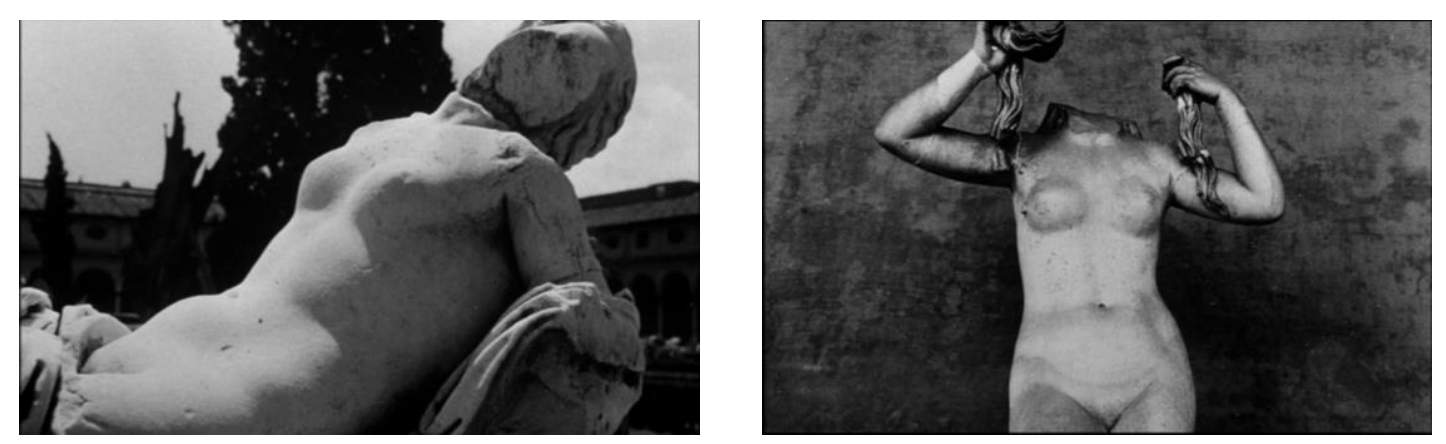

O encontro com a mulher só acontece no trigésimo dia de experimentos. Há, nesse encontro, uma imagem que imita o plano do perfil de Madeleine no momento em que ela cruza com Scottie pela primeira vez no Ernie's. O cabelo da moça está penteado de forma parecida com o da personagem de Kim Novak em Vertigo, e o enquadramento é praticamente o mesmo daquela icônica aparição de Madeleine: 

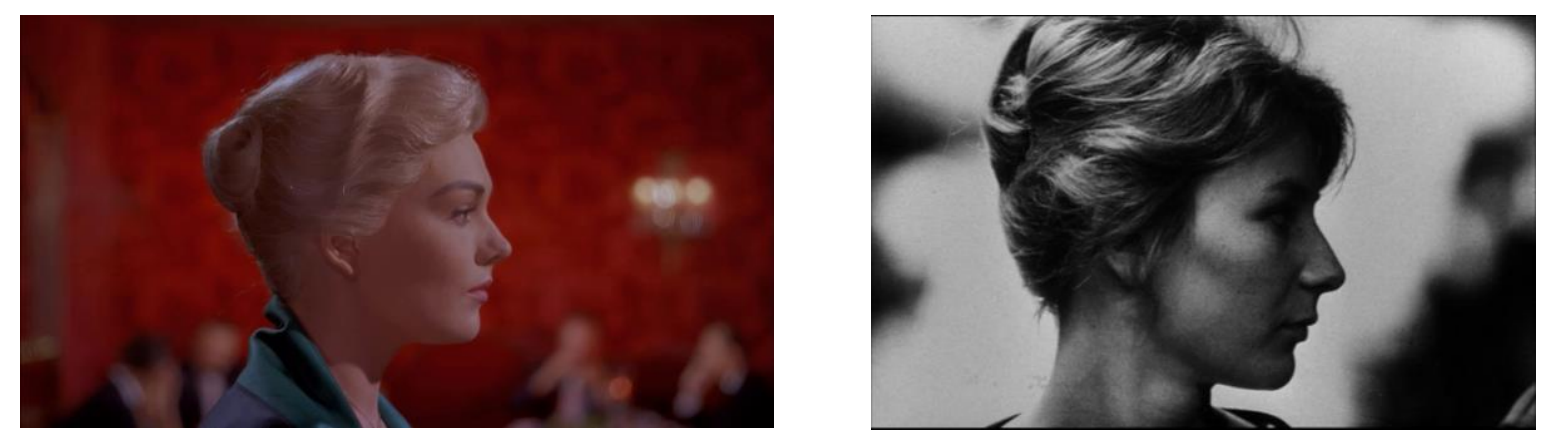

O protagonista de La Jetée inicia com essa mulher uma relação sem passado, sem porvir, puro presente. Ela diz que ele é seu espectro, seu fantasma, que surge e desaparece sem explicação.

Um dia, enquanto passeiam pelo jardim botânico de Paris, eles param diante de um tronco de sequoia. A cena é uma citação da passagem de Scottie e Madeleine pelo parque Muir Woods, onde eles também contemplam o corte transversal de um tronco de sequoia. Em ambos os filmes, as camadas circuncêntricas do tronco estão cobertas de datas históricas que mostram as diversas etapas de formação da árvore milenar. Em Vertigo, Madeleine aponta para o tronco e diz que nasceu e morreu em algum lugar entre 1831 e 1857 (que são, na verdade, as datas de nascimento e morte de Carlotta Valdez). Em La Jetée, o homem não indica um ponto no passado, mas um ponto fora da árvore (fora do tempo?), afirmando que é de lá que ele vem. Antes disso, a mulher pronunciara "um nome estrangeiro" que ele não compreendera. Segundo Frédéric Majour, o próprio Marker iria sugerir, num texto publicado no ano seguinte ao lançamento do filme, que esse nome era o de Hitchcock. ${ }^{12}$

No final do filme, o homem se verá novamente no terraço do aeroporto, o mesmo terraço do início, onde ele procura agora pelo rosto da mulher dos seus sonhos. Ao avistá-la, ele corre em sua direção. Mas percebe, um pouco antes de levar um tiro fatal, que aquele momento era o mesmo que havia testemunhado quando criança, e que só agora pode compreender: a cena que nunca deixara de assombrá-lo era a cena de sua própria morte (Jess Franco reutilizaria essa ideia em Venus in furs).

La Jetée insere seu protagonista numa temporalidade ambígua, um tempo "não somente vivido do interior, mas também apreendido do exterior, com o homem sendo ao mesmo tempo criador dessas imagens que recompõem alguns instantes da sua vida e espectador de seu próprio passado". ${ }^{13}$ Ora, não seria esse herói de La Jetée uma metáfora do espectador de cinema, que assiste a um filme "do exterior", mas projeta-se imaginariamente

\footnotetext{
${ }^{12}$ F. Majour, "On ne vit que deux fois", in Vertigo, n. 46, outono de 2013, p. 25.

${ }^{13}$ Ibid., p. 31.
} 
dentro dele? Não estaria o espectador de cinema sempre apanhado num movimento duplo, percebendo e interpretando as imagens do filme, que lhe são totalmente exteriores, mas investindo nelas as suas próprias imagens interiores? Um filme, ao mesmo tempo em que solicita nossa atenção às imagens atuais que ele projeta na tela, estimula-nos a produzir imagens virtuais que se acoplam às primeiras. A atenção dedicada a um filme "faz também aflorar lembranças, fantasias ou emoções que essas imagens despertam [font remonter] em nós e que não são mais o fruto de uma construção especular, nem mesmo de um processo de interpretação, mas de um movimento de imaginação ou de afecção". ${ }^{14}$

Em La Jetée, Marker - tomado do mesmo impulso criativo que levou Scottie a refazer Madeleine depois de ver Judy - dá forma ao "foto-romance" derivado das imagens mentais que Vertigo lhe despertou. Em última análise, trata-se de um remake não exatamente do filme de Hitchcock, mas do filme-pensamento, do filme-memória que Vertigo imprimiu em Marker. Um remake impossível de Vertigo: seu reflexo especular, ou seja, sua inversão.
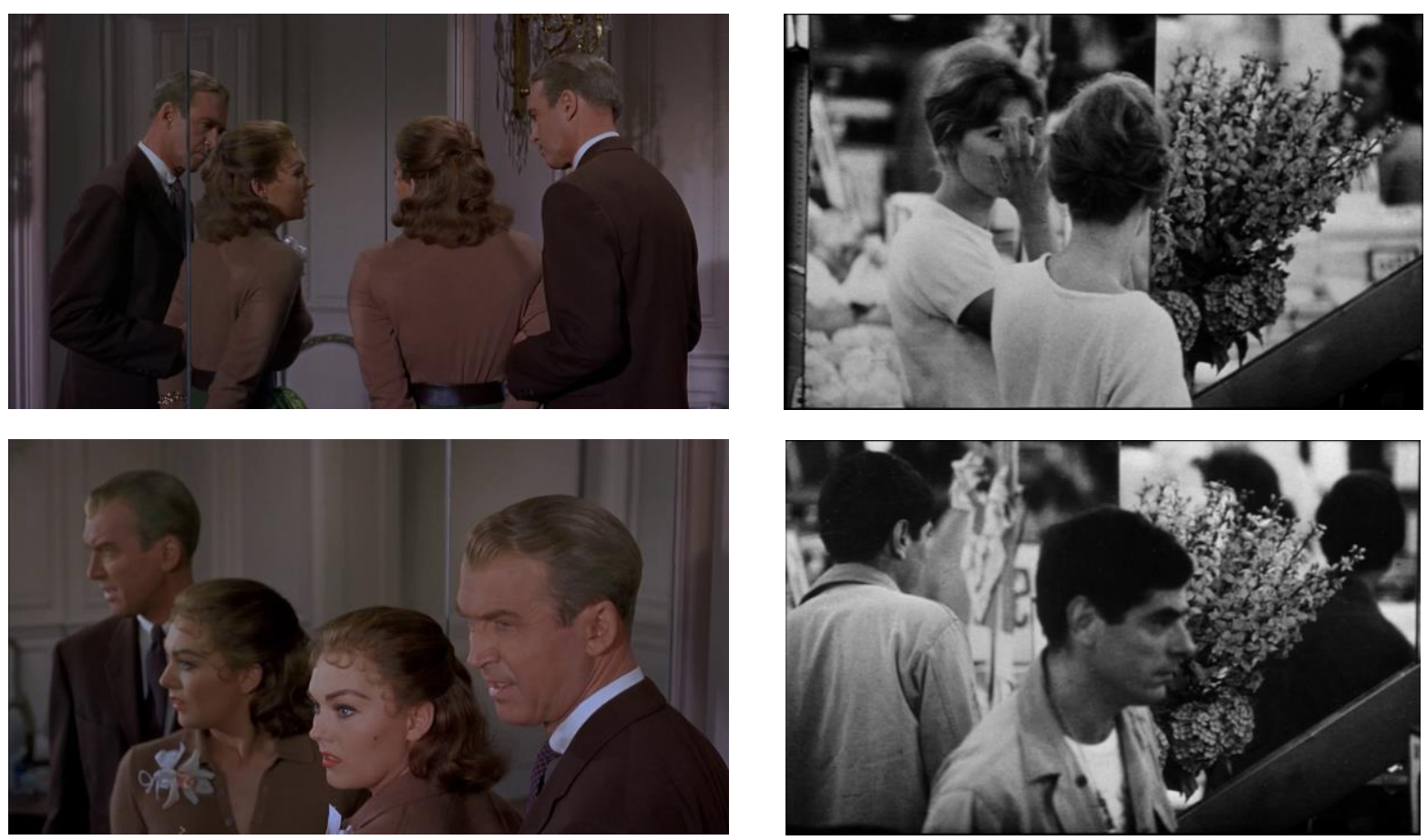

Vertigo

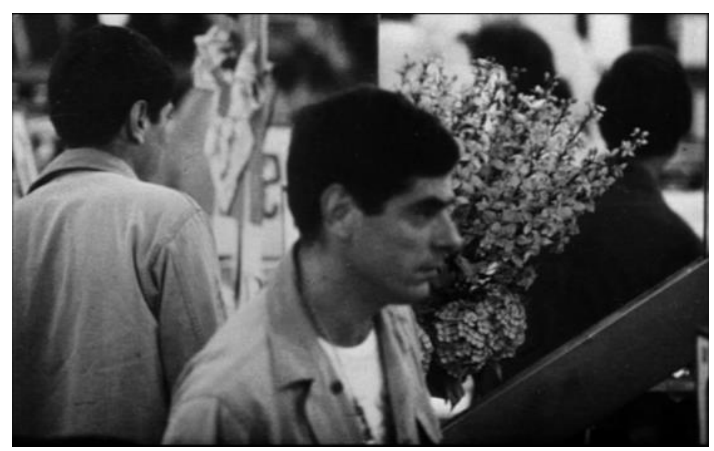

La Jetée

Apesar de todos esses espelhamentos evidentes entre Vertigo e La Jetée, a comparação não foi destacada na época, a não ser pelo próprio Chris Marker. "É preciso dizer que Vertigo não beneficiava ainda da aura que possui hoje em dia". ${ }^{15}$

\footnotetext{
${ }^{14}$ J.-P. Trias, "L’oeil du cinéma", in Cinergon, n. 6/7: "Histoires de l'oeil", 1999, p. 95.

${ }^{15}$ F. Majour, art. cit., p. 25.
} 
Ao lado de Brian De Palma, Marker é o cineasta mais obcecado com Vertigo que já existiu. O filme é um dos seus objetos de fixação, ao qual retorna incansavelmente, como um homem que não consegue se livrar de uma imagem do passado, uma imagem marcante (para usar o jogo de palavras - o trocadilho com o sobrenome do cineasta - que já se tornou lugarcomum nos escritos de seus comentadores). Além de ser a referência central de La Jetée, Vertigo marca presença vinte anos depois em Sans soleil (1982), que lhe dedica algumas divagações. Ele é evocado também em Level 5, de 1997 (embora aí a referência principal seja Laura, de Preminger), e funciona como um dos pontos nodais da complexa teia que constitui o CD-ROM Immemory. Sem falar, é claro, no texto sobre Vertigo que Marker escreveu para a Positif em 1994, do qual uma versão em inglês seria depois disponibilizada na internet, tornando-se facilmente encontrável. Nesse texto, Marker repete muita coisa do que já havia dito em Sans soleil: Vertigo é um filme que soube articular, como nenhum outro, "a memória impossível, a memória louca”. E a vertigem espacial que ele provoca por meio das perseguições em ziguezague e das crises acrofóbicas de Scottie somente mascararia o tema de que realmente trata: a vertigem do tempo, que se manifesta não só na nostalgia de Gavin por uma São Francisco do passado, mas, sobretudo, na utopia de Scottie de consertar a catástrofe causada pelo tempo e ressuscitar um amor perdido, arrancado dele pela morte. A segunda parte do filme seria a tentativa maníaca e insana de negar o efeito do tempo e recriar uma mulher morta. Não podendo aceitar a realidade senão falseando-a, Scottie inventa um duplo de Madeleine "numa outra dimensão do Tempo, uma Zona que seria só dele, e de onde ele poderia decifrar a indecifrável história que havia começado em Golden State, quando ele resgatou Madeleine da Baía de São Francisco, quando ele a salvou da morte, antes de devolvê-la à mesma. Ou foi o inverso?", indaga-se a narradora de Sans soleil durante a sequência de aproximadamente três minutos em que Marker visita as locações de Vertigo em São Francisco e divaga sobre seus significados.

Sans soleil é "narrado" por uma voz feminina. O verbo narrar vem aqui entre aspas porque não se trata, efetivamente, de uma narração, mas antes de uma transmissão oral em tom neutro, desdramatizado - uma pura intermediação discursiva. A narradora (chamemo-la assim por comodidade) lê e comenta as cartas de um cinegrafista húngaro, Sandor Krasna (um heterônimo de Marker). Esse cinegrafista viaja pelo mundo (Japão, Guiné-Bissau, Cabo Verde, Islândia, São Francisco, França) captando imagens sobre as quais depois medita e escreve.

Os planos rodados pelo cinegrafista são ferramentas de memória, material privilegiado no cinema de Marker - que diverge radicalmente, neste ponto, de Jonas Mekas, já que este irá 
sempre preferir a noção de reminiscência ou de lampejo, vislumbre (glimpse), à de memória: a reminiscência tem uma autonomia, uma autossuficiência como fragmento, como vestígio ou impressão conservada de um momento vivido, ao passo que a memória pede um contexto, uma montagem, uma ligação com o antes e o depois, não no sentido cronológico, pois não se trata de restituir a cadeia de eventos, e sim de estabelecer a geografia da memória, de entender como as imagens mentais se aproximam ou se distanciam, que mapa elas formam, que território (imaginário) elas criam (se há um cineasta interessado na memória e em suas tecnologias, esse cineasta é Chris Marker).

Sobre Vertigo, a que Marker/Krasna afirma ter assistido dezenove vezes, a carta lida em Sans soleil adverte: "Tudo parece ser uma questão de perseguição, de enigma, de assassinato, mas, na verdade, é uma questão de poder e liberdade, de melancolia e de deslumbramento [éblouissement]".

A sequência-Vertigo de Sans soleil é ao mesmo tempo uma peregrinação pela cidade de São Francisco e uma visita guiada pela Memória, com toda a sua geografia própria. Quem vai a São Francisco tem a chance de fazer um passeio intitulado "Vertigo tour", uma visita guiada pelos lugares em que foi rodado o filme de Hitchcock. Marker, em Sans soleil, faz o mesmo passeio, a mesma peregrinação, mas tendo como único guia a sua memória e as suas reflexões pessoais sobre o filme. Ele compara imagens de Vertigo com as imagens que filmou vinte e cinco anos depois e constata que alguns lugares foram preservados - o florista, o cemitério, o Ernie's, a missão espanhola (embora a torre da igreja, de onde Madeleine é jogada, seja uma invenção de Hitchcock acrescentada por meio de trucagem) -, ao passo que outros se modificaram ou não existem mais. O hotel McKittrick, por exemplo - a casa em estilo vitoriano onde Madeleine entra e aparece na janela, para depois esvanecer como um fantasma -, foi substituído por uma escola feita de concreto.
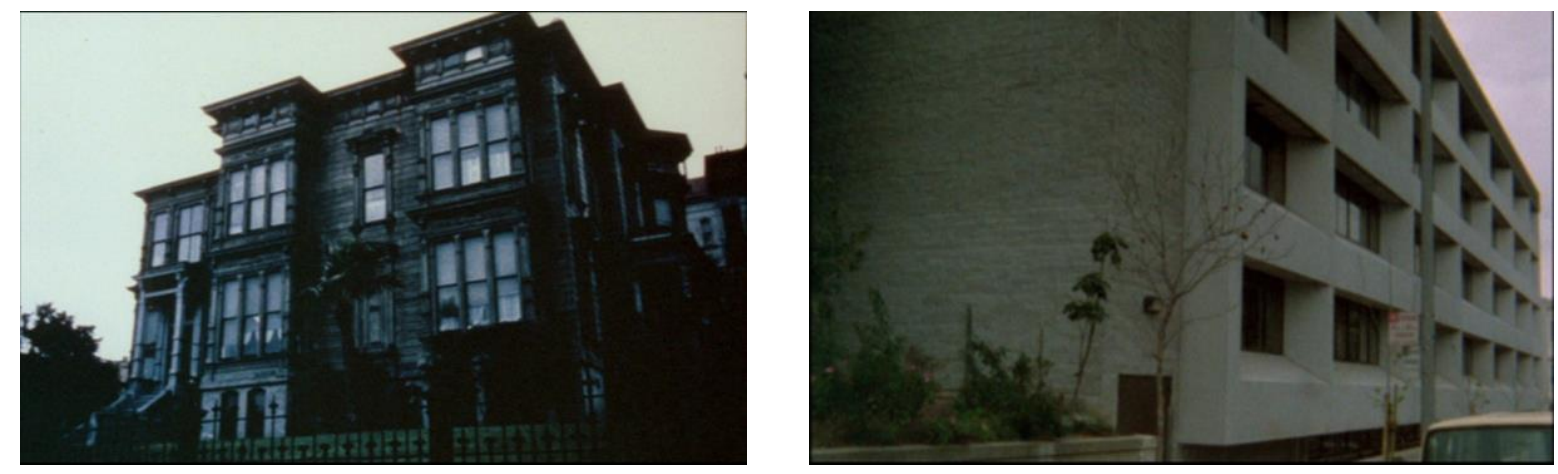
Mostrando um fotograma de Vertigo e comparando-o à imagem atual do lugar, Marker comenta visualmente a própria moral da fábula de Vertigo: a impossibilidade de recriar o passado. Visitar a São Francisco de Vertigo é já encontrar outra cidade. Essa sequência de Sans soleil, ponto fulcral da relação duradoura do seu diretor com o filme-mito hitchcockiano, poderia receber o mesmo título de um dos episódios de L'héritage de la chouette, a série televisiva sobre a Grécia que Marker realizou em 1989: "Nostalgia, ou o retorno impossível”.

\section{2. $\operatorname{Ela}(\mathbf{s})$}

Unas fotos en la ciudad de Sylvia (2007), de José Luis Guerín, é mais um desses retornos impossíveis. Um homem retorna a Estrasburgo à procura da jovem mulher que lá conheceu 22 anos antes. Esse homem é o próprio Guerín, que narra o filme em primeira pessoa, como num diário íntimo. Ele tem apenas três lembranças de Sylvia: ela havia estudado alguns meses em Salamanca; ela adorava a maneira como seu nome soava em espanhol; ela ia começar a trabalhar como enfermeira em Estrasburgo. Partindo dessas únicas três informações, Guerín inicia sua busca obsessiva pela imagem-fantasma de Sylvia, espécie de Madeleine proustiana-hitchcockiana reinventada. Ele começa pelos hospitais, o mais provável lugar de trabalho de Sylvia, mas logo extrapola para outros endereços (museus, praças, ruas, cafés) e para outras cidades europeias onde, assim como em Estrasburgo, o passado histórico e artístico ainda vive e respira (Madri, Lisboa, Florença, Bolonha).

À semelhança de La Jetée (certamente uma das inspirações de Guerín), Unas fotos en la ciudad de Sylvia foi realizado quase que exclusivamente com imagens estáticas em preto e branco (captadas com uma câmera fotográfica e outra digital entre o verão e o outono de 2004). Mas o que chama mais a atenção num primeiro momento é o fato de que o filme não tem som (nem intra nem extradiegético): trata-se de um filme silencioso em sentido estrito, sem diálogos ou vozes (in, off, over...), sem som ambiente, sem efeitos sonoros de qualquer natureza. E, ao contrário do que ocorria com os filmes do passado silencioso do cinema, não se deve acrescentar a Unas fotos nenhum acompanhamento musical. É um filme para ser apenas visto, ou melhor, visto e lido, já que, além das fotografias, algumas informações textuais aparecem na tela, ora impressas nas próprias imagens, ora como cartelas de intertítulos. São anotações pessoais de Guerín, histórias evocadas pelos lugares, aforismos, percepções, observações... Fica evidente no filme, além do pensamento visual de Guerín, um gosto pronunciado pela escrita. O vasto conhecimento literário do cineasta se infiltra nas 
imagens de modo tal que, de repente, a história de Sylvia começa a ecoar as desventuras do jovem Werther de Goethe, ou a paixão de Dante por Beatrice, ou o amor de Petrarca por Laura, sem que saibamos mais o que veio primeiro, a inspiração literária ou a história amorosa do filme. Foi Sylvia quem levou Guerín à cidade que inspirou Werther? Ou foi Werther quem inspirou Guerín a ir à cidade de Sylvia?

Unas fotos foi concebido, a princípio, como um trabalho de pesquisa estética e rascunho fotográfico para um longa-metragem de ficção, Na cidade de Sylvia (de título original bilíngue: En la ciudad de Sylvia/Dans la ville de Sylvia, 2007), que seria realizado logo em seguida. Entretanto, o filme ultrapassa em muito a posição de esboço ou de mero estudo preliminar. Como Miguel Marías bem ressaltou, Unas fotos não é só um storyboard ou um protótipo para outro filme: "é uma combinação - cuidadosamente estruturada e minuciosamente editada - de narrativa e meditação, de relembranças e especulação". ${ }^{16}$

Muitas das fotografias que constituem os "planos" do filme mostram objetos (chaves, mapas, cartões postais, livros, placas com nomes de rua) ou vistas das cidades por onde Guerín passa. Mas o principal elemento de que a câmera se ocupa são rostos femininos (na maior parte das vezes, de mulheres reais, mas ele se interessa também por imagens femininas que aparecem em quadros, esculturas, fotos, painéis publicitários etc.). É como se ele procurasse, em cada rosto feminino fotografado, a reconstrução de um desejo e de uma imagem que emergem do fundo da memória para serem reativados e atualizados pelas realidades transitórias do presente sensível. Raymond Bellour afirma haver no filme "uma reversibilidade constante entre o rosto-corpo feminino e a realidade documental da qual o rosto-corpo surge incessantemente, mas na qual ele igualmente se imiscui e desaparece, num batimento contínuo". ${ }^{17}$ Está aí perfeitamente enunciada a dinâmica do filme: o que Guerín busca, através da reprodução fotográfica das aparências sensíveis, é a extensão de uma imagem mental que a elas se confunde e se mistura. Ao projetar sua própria memória nos rostos e superfícies capturados por sua câmera, ele estabelece uma ductilidade entre a visão interior e a realidade exterior. $\mathrm{O}$ aspecto interessante, e que definitivamente afasta Guerín de uma enésima variação da eterna busca pela "imagem ideal", é o fato de que ele coloca os conteúdos mentais à prova da realidade percebida, e não o contrário. Assim, a narrativa visual de Unas fotos en la ciudad de Sylvia "oscila entre a ideia absoluta de um rosto-imagem e sua disseminação através da variedade infinita das aparências que podem encarná-lo, e isso graças

\footnotetext{
16 M. Marías, "Something really new: Starting over", in Undercurrent, n. 1, abril de 2006. Disponível em: http://www.fipresci.org/undercurrent/issue_0106/guerin_marias.htm.

${ }^{17}$ R. Bellour, "Sylvia quitte ou double", in Trafic, n. 86, verão de 2013, p. 53.
} 
à capacidade do aparelho fotográfico de multiplicá-las e à capacidade da máquina-cinema de associá-las no tempo". ${ }^{18}$

Em vários momentos, o filme elege uma das muitas mulheres pelas quais a câmera se deixa atrair e a persegue durante um longo trajeto. Ela sai de um café, anda pela rua (sempre fotografada de costas, e numa escala que varia do plano americano ao plano geral), dobra esquinas, muda de calçada, despista a câmera de Guerín.
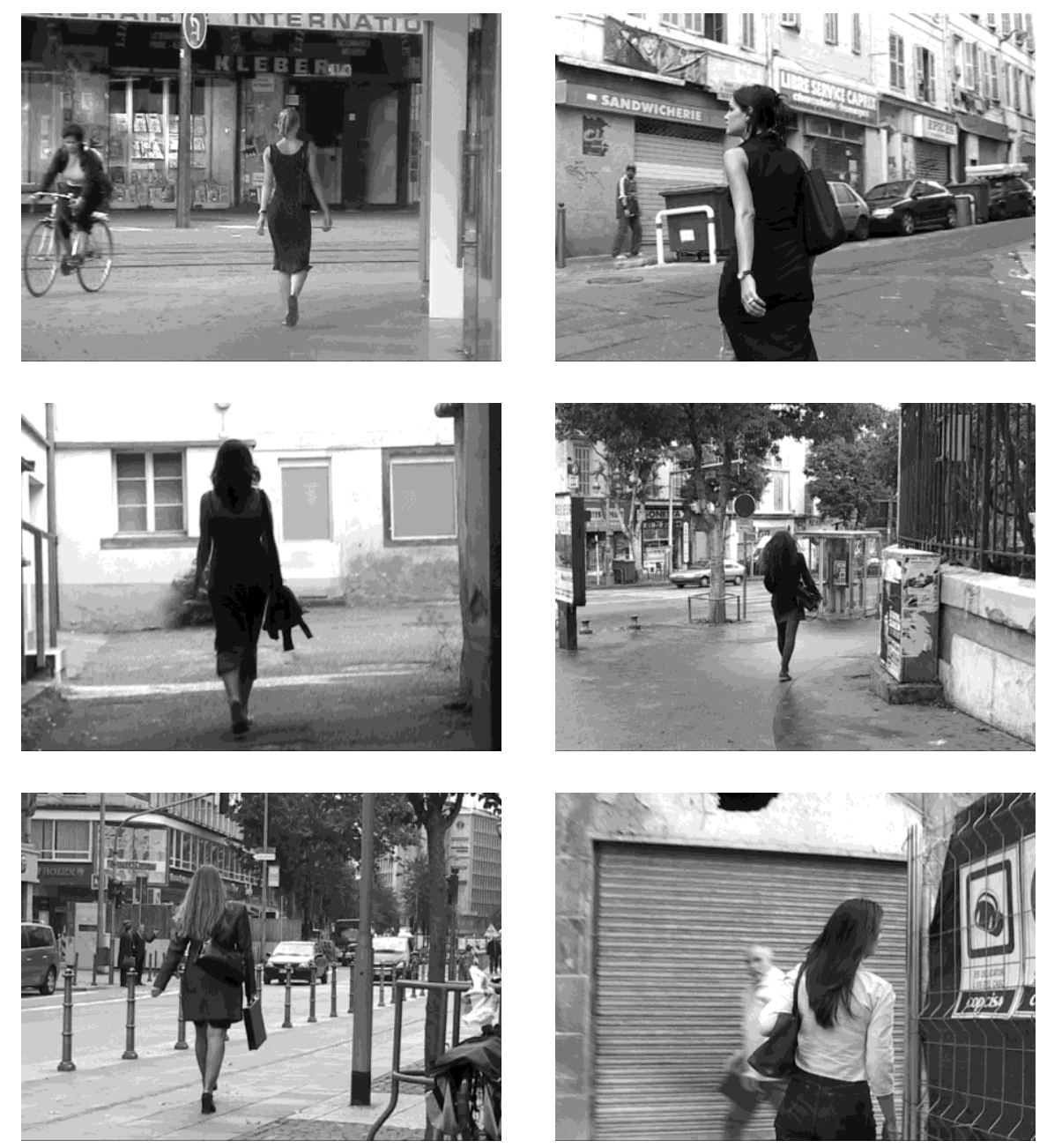

A perseguição montada a partir de imagens que mostram o perseguido pelo ângulo de visão do perseguidor - ou a presa tal como é percebida do ponto de vista do predador constitui um modo de focalização que põe em jogo uma questão fundamental da representação cinematográfica, que é a modulação da distância entre o ponto do olhar e o objeto visado por ele. A cena de perseguição com câmera subjetiva dramatiza essa distância, dinamiza esse intervalo espacial em que o olhar e seu objeto medem forças e variam posições.

\footnotetext{
${ }^{18}$ Ibid., p. 54.
} 
Se, ao longo das perseguições de Unas fotos, as mulheres são mostradas sempre de costas, é porque a "supremacia do olhar masculino" se acha desde o início perturbada e contrariada por uma resistência, por uma opacidade que a figura feminina oferece à câmera, o que torna o campo visual, de saída, problemático. Sylvia é um enigma e nada mudará isso. "Filmar de costas", diz Marie Anne Guerin, "é uma das formas de anunciar a duplicidade, a perturbação e o inacessível de uma personagem, de colocar em cena um segredo ou aquilo que pode ser o objeto de uma revelação. De costas, o ator é um bloco de silêncio, uma figura solitária que preserva seu próprio espaço". ${ }^{19}$ Comentando a relação do olhar masculino com as personagens femininas de Vertigo, Psicose e Marnie, a pesquisadora conclui: "Quanto mais elas são visíveis, quanto mais as vemos, mais as enxergamos como inapreensíveis, como aquilo que certamente nos escapará e nos enganará: no cinema de Alfred Hitchcock, olhar é às vezes perder de vista" (ibid.). A mesmíssima coisa pode ser dita de Unas fotos en la ciudad de Sylvia, em que uma das imagens mais recorrentes é justamente a de uma mulher - que foi perseguida por toda parte pela câmera de Guerín - fazendo um desvio e escapando do olhar do seu stalker:
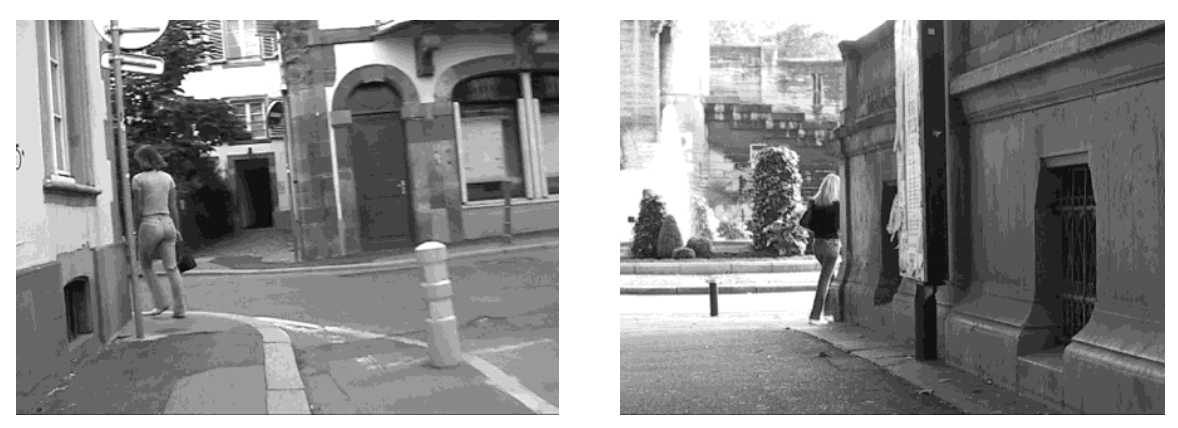

O cineasta fotografa o exato momento em que ela dobra a esquina para abandonar o seu campo de visão (talvez para sempre). Ele obtém assim uma figura no limiar da visibilidade, prestes a ser perdida de vista, ainda que possa reaparecer mais tarde (somente para escapar da sua visão novamente). Eis uma definiçao possível da imagem-fantasma: uma imagem que retorna, que insiste em permanecer, mas que desaparece toda vez que alguém tenta se aproximar dela.

"A arte de gravar um rosto", lê-se numa das cartelas do filme. Em seguida, aparecem fotos - feitas no interior de um museu - que justapõem o rosto de um visitante do museu a um

\footnotetext{
${ }^{19}$ M. A. Guerin, Le récit de cinéma, Paris: Cahiers du Cinéma, col. "Les petits cahiers”, 2003, p. 52.
} 
rosto figurado num quadro atrás dele. Logo depois, vem uma série de fotos enquadradas de modo que a cabeça do visitante ocupe exatamente o lugar do rosto representado no quadro.
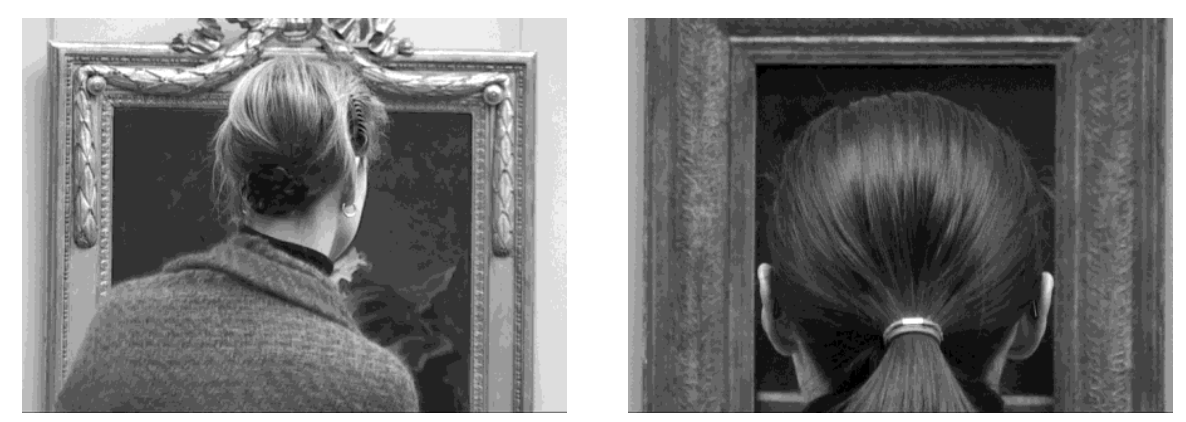

Guerín reconhece que seu filme, de alguma forma, deriva dessa arte de gravar um rosto - a arte do retrato. Mas um retrato de dorso: é a nuca das pessoas o que ele enquadra na moldura que reaproveita dos retratos do museu. $\mathrm{O}$ rosto ainda não apareceu, deve ser procurado (ou inventado). Afinal, é para sair em busca de um rosto apagado pelo tempo que Guerín está realizando esse filme.

Após a cena do museu, o cineasta se interessa pelo trabalho de artistas de rua que fazem retratos e caricaturas e cobram - uma placa nos informa - de 10 a 30 euros, dependendo da qualidade que o cliente deseja (o retrato "rápido" leva 18 minutos para ficar pronto e custa 15 euros; o "normal" demora 30 minutos e custa 30 euros; a caricatura sai a 10 euros). Guerín capta o momento em que o lápis retoca um traço do desenho já quase pronto (não sabemos quanto tempo o artista levou para cada um dos retratos).
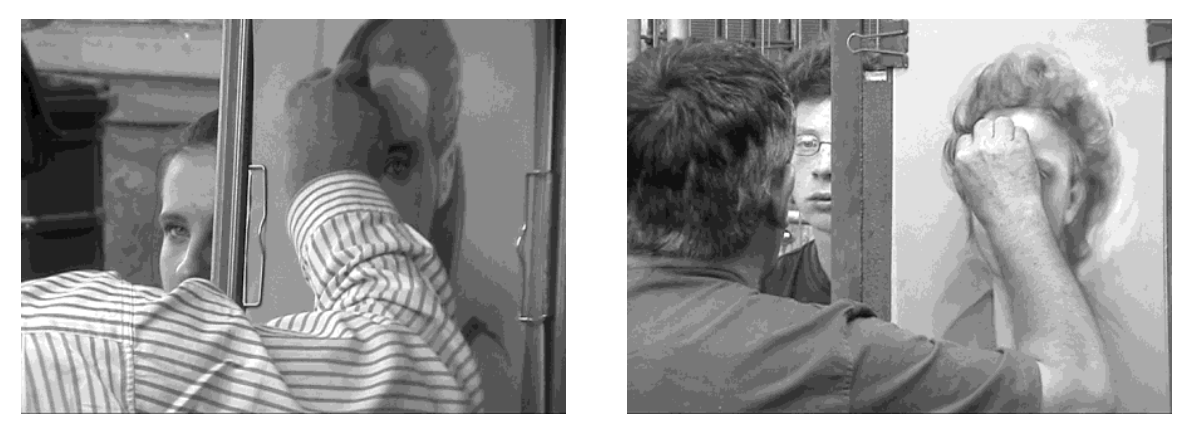

A primeira função do retrato é ser uma ferramenta de identificação, um meio de reconhecimento, oferecer uma imagem semelhante. Mas isso não impede o retrato de aproximar o modelo de uma imagem idealizada: "o ato de reconhecer não é incompatível com uma necessidade de idealização que tende a dar à pessoa representada uma imagem 
harmoniosa temperando o realismo implicado pela identificação". ${ }^{20}$ Daí se origina um dos grandes questionamentos que perpassam a teoria do retrato:

O retrato é cópia virtuosa, e portanto enganadora [trompeuse], do modelo? Ou obra de um poder criador que é capaz de se desprender do real para corrigi-lo e torná-lo conforme à sua visão ideal? Como pano de fundo, é o problema das relações entre a Ideia e a Forma que aparece, tal como ele é evocado por Sêneca, e que é subjacente a todos os discursos sobre o retrato, de Alberti a Diderot. ${ }^{21}$

Essa discussão sobre o retrato e sua teoria se faz presente de forma indireta em Unas fotos. Guerín a evoca através da história amorosa de Petrarca: apaixonado por Laura, que já era uma mulher casada, o poeta extravasou esse amor platônico nos sonetos que compõem sua conhecida obra poética, Il Canzoniere. Em dois sonetos que podem ser datados de 1336, Petrarca fala do retrato de Laura executado pelo pintor Simone Martini a pedido do próprio poeta. Refletindo sobre a beleza da Laura vista no retrato, Petrarca se interroga sobre o poder e a força que um retrato pode ter. "Esses versos célebres representam a condensação de uma teoria do retrato, a primeira na tradição ocidental, cuja interpretação permanece difícil e conflituosa". ${ }^{22}$ Adaptando ideias de autores antigos por intermédio de um filtro cristão, Petrarca afirma que Simone Martini

teve o privilégio de contemplar a imagem divina de Laura, essa imagem primeira que reside no pensamento do Deus criador e que é infinitamente mais bela que sua encarnação terrestre. O retrato de Laura testemunha dessa imagem ideal que o pintor não poderia ter concebido olhando para a Laura real e viva, cujo "corpo joga um véu sobre a alma". Ele surge precisamente dessa oposição entre alma, a ideia original e pura, e velo, o véu, o mundo das aparências, que ofusca o verdadeiro conhecimento. A imagem oferecida pelo retrato é uma reminiscência do mundo das ideias puras. Esse retrato é fundamentalmente ambíguo: realizado no mundo das aparências, portanto da imperfeição, ele remete à perfeição tal como ela pode ser percebida em Deus; ele não é fundado numa semelhança com uma pessoa viva, mas na identidade dessa pessoa com o pensamento do seu criador. [...] Impregnado pelo pensamento de Santo Agostinho, Petrarca inventa, antes mesmo de o retrato ter se tornado um gênero em pleno exercício na história da pintura, o retrato ideal, o retrato da alma, não no sentido que o século XVII dará a essa expressão para designar a vida interior, mas no sentido do ser essencial, tal como ele existe na Ideia criadora divina, antes mesmo de sua encarnação num corpo que, a um só tempo, a revela e a dissimula. ${ }^{23}$

\footnotetext{
${ }^{20}$ E. Pommier, Théories du portrait, op. cit., p. 24.

${ }^{21}$ Ibid., p. 27.

${ }^{22}$ Ibid., p. 35.

${ }^{23}$ Ibid., pp. 36-37.
} 
Em seu platonismo cristão, Petrarca encara o retrato como uma imitação não da Laura de carne e osso, mas da sua ideia, do pensamento sublime, do alto concetto que permanece ao mesmo tempo escondido e manifesto na sua aparência corpórea.

Talvez Guerín se apegue à história de Petrarca justamente porque a Sylvia que ele procura é também uma ideia. Eis a razão pela qual ele insiste em tentar enxergá-la através dos rostos de mulheres jovens, ignorando a influência que o tempo teria tido sobre ela no decorrer dos vinte e dois anos passados. Que efeito o tempo pode ter sobre uma ideia sempiterna?

Mas a "ideia”, segundo Jean-Luc Nancy, "não é uma noção nem um conceito; ela é a forma visível (idea pertence ao léxico grego da visão) daquilo que não é dado de antemão como aparência". ${ }^{24}$ A ideia, a forma essencial, ou a "imagem em seu valor verdadeiro", não se apresenta como uma propriedade ontológica imutável, e sim como um "sentido existencial da passagem de um sujeito que nunca se instala, mas que passa e, ao passar, faz signo". ${ }^{25} \mathrm{~A}$ imagem ideal, em vez de simplesmente restituir a aparência de uma identidade pressuposta, precisa vir à superfície, avançar de algum lugar: ela é movimento. "A identificação não pode ser nem posta nem pressuposta, nem mesmo deduzida ou concluída: ela permanece distante, flutuante, ao mesmo tempo partilhada e fugidia". ${ }^{26}$ Se Unas fotos tem algo a ver com o retrato, é pelo viés do que Nancy designa, a respeito das reinvenções desse gênero na arte contemporânea, como "outro retrato", um retrato cuja missão não é mais "representar o irrepresentável do rosto", mas "testemunhar a passagem, o esvanecimento, a incerteza de uma figura $[\ldots .]. " .{ }^{27}$ Guerín, no fim das contas, se aproxima muito mais desta outra noção de retrato ou de representação de um ser amado do que daquela fornecida pela história de Petrarca citada no filme.

Em determinado momento, o filme relembra também a história de Dante com sua amada Beatrice: numa igreja em Florença, uma mulher desconhecida senta na fileira entre Dante e Beatrice, bloqueando a visão do poeta, impedindo-o de ver o objeto de sua admiração. Mas, ainda que Dante não tenha acesso visual a Beatrice, ele continua a vê-la através do rosto da outra mulher. O amor o provê de um novo tipo de visão, que lhe permite ver a pessoa amada com a vantagem de não mais incomodá-la com seu olhar (pois o olhar do desejo não é inofensivo: ele despe e devora seu alvo).

\footnotetext{
${ }^{24}$ J.-L. Nancy, L'Autre Portrait, op. cit., p. 87.

${ }^{25}$ Ibid., p. 93.

${ }^{26}$ Ibid., pp. 93-94.

${ }^{27}$ Ibid., p. 96.
} 
Essa história, que, de certa forma, resume o projeto de Guerín (ver Sylvia através dos rostos de outras mulheres), é lembrada também por De Palma em Trágica obsessão. Sandra a conta para Michael na parte do filme que se passa em Florença. Ela chega a encenar a história, usando sua bolsa como signo de substituição de Beatrice e posando, ela própria, como a mulher desconhecida que se colocaria entre o olhar de Dante - personificado por Michael - e sua amada. Ora, a cena nada mais é que um esclarecimento interno da própria história que Sandra e Michael estão vivendo: olhando para Sandra, Michael visa, na verdade, a imagem de Elizabeth, sua esposa morta; ele vê um rosto através de outro.

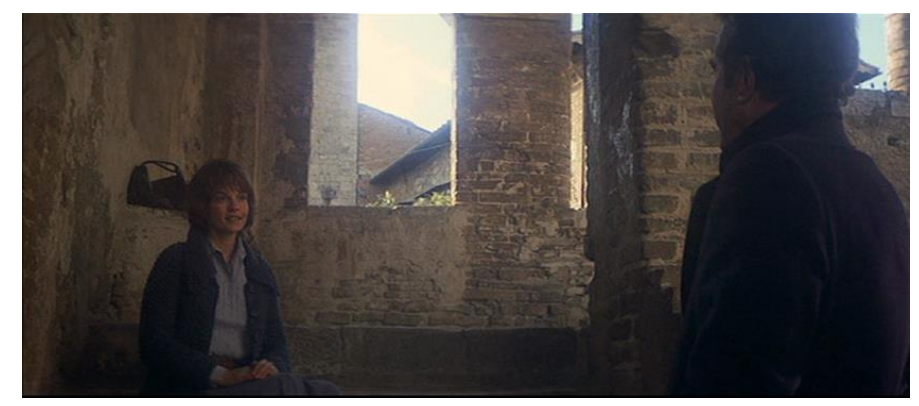

O dispositivo sintetiza o próprio filme: um olhar fixado numa imagem atrás da qual se acha outra imagem, anterior - como já havia sido demonstrado na cena da igreja em que Sandra explica para Michael a história do afresco em que ela está trabalhando. Se retomarmos um detalhe daquele afresco, que é como a metonímia do filme, notaremos certa semelhança com uma das imagens usadas por Guerín em Unas fotos en la ciudad de Sylvia:

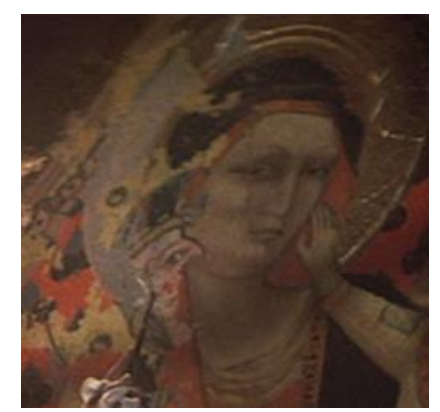

Trágica obsessão, de Brian De Palma (pormenor do afresco de Bernardo Daddi)

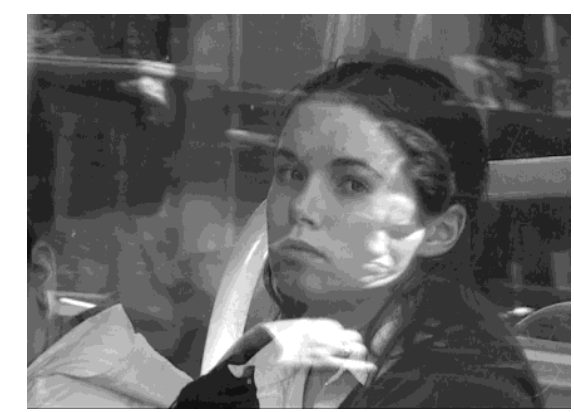

Unas fotos en la ciudad de Sylvia, de J. L. Guerín

Não se trata de uma citação ou de uma reprise figurativa pensada como tal, e sim de uma coincidência - mas uma coincidência que faz todo sentido e tem toda razão de ser, já que ambos os cineastas estão encontrando respostas para a complexidade visual que deriva da necessidade de figurar uma imagem-fantasma, uma imagem do passado que se infiltra nas 
formas do presente e inviabiliza a apresentação direta e imediata de um rosto. De Palma faz tal imagem aflorar de baixo para cima, despontando nas porções estragadas do afresco como um passado que ressurge e rasga a superfície do presente: nessa figura arqueológica de um visível estratificado, acumulado em camadas sobrepostas, havendo a irrupção inesperada de uma das imagens que tinham sido recobertas, está implícita uma ligação com o modelo psicanalítico do retorno do recalcado. Guerín, diferentemente, recorre a uma espécie de sobreimpressão: o rosto refletido no vidro se imprime sobre o outro rosto que está atrás dele, e a fusão daí resultante confere à imagem a sensação de algo fugidio, esvoaçante, pois o reflexo especular traz em si o caráter transitório e instável de seu modo de aparição, ao contrário da pintura encontrada sob o afresco, que afirma uma força de permanência, de preservação, de enfrentamento do tempo. De um lado, em Trágica obsessão, a pulsão conservadora da imagem-fantasma, sua extraordinária insistência de não ser superada; do outro lado, em Unas fotos, a tendência oposta mas complementar: o aspecto evanescente da imagem-fantasma, sua fugacidade, a impossibilidade de apreendê-la em uma forma estável.

Guerín utiliza várias outras imagens como essa - imagens que figuram um rosto feminino por trás de um vidro no qual se refletem outros rostos, outras imagens, outros semblantes capturados em trânsito, gerando uma tensão entre a fixação desse rosto e a profusão de eventos transitórios que o carregam em sua passagem:

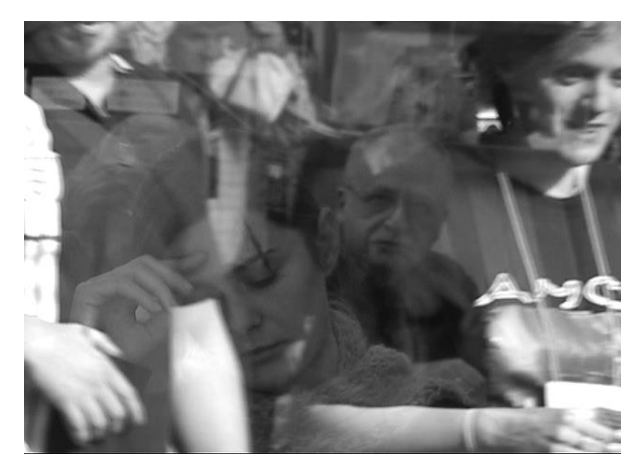

Essas imagens são também uma expressão da lacuna criada pelo tempo e preenchida pela memória: os reflexos no vidro funcionam como uma metáfora de todos os anos - e, por conseguinte, de todos os rostos - que passaram diante dos olhos de Guerín desde que ele conheceu Sylvia e nunca mais a reviu. Se ela reaparecer, agora, será por trás dessa membrana temporal em que diversas outras pessoas e diversos outros eventos foram deixando sua impressão ao longo dos 22 anos que separam Guerín do seu primeiro encontro com Sylvia. Ao inscrever a figura feminina nesses quadros superpovoados de outros semblantes, ele 
afirma a impossibilidade de abstraí-la de toda uma matéria visual múltipla que, embora seja um aspecto inerente à realidade, envolve também um trabalho cumulativo da memória, que coleciona fantasmas à medida que o tempo passa.

Há nessas imagens um curioso retorno do efeito-palimpsesto dos primeiros processos fotográficos. No tempo do daguerreótipo, as placas revestidas com gelatina sensível, que serviam de suporte para os clichês, eram reutilizadas diversas vezes: "Se não fossem bem lavadas, essas placas podiam conservar traços de imagens anteriores, que apareciam na nova tiragem em sobreimpressão". ${ }^{28}$ Mesmo que não passasse de um acidente técnico, esse traço fotográfico de uma imagem anterior reforçava as crenças - bastante em voga em meados do século XIX - nos fantasmas, espíritos e em toda sorte de aparição espectral ou fenômeno visual de fronteira. Por conta desse erro de manipulação, a imagem fotográfica se tornava "um espaço de comunicação com os mortos". ${ }^{29}$ Algo dessa imagem-fantasma do daguerreótipo retorna nas fotos em que Guerín sobrepõe ao rosto de uma pessoa uma variedade de outros rostos que, refletidos no vidro, aparecem como imagens ultrafinas, sem corpo, formas fantasmais. Mas aqui a sobreimpressão não nasce de um acidente fotográfico, e sim de um efeito de composição com fins expressivos calculados.

Outras fotos do filme já serão significativamente diferentes: elas não aproveitarão o vidro como superfície reflexiva, mas antes como obstáculo que refrata e desfoca o rosto fotografado, como se o narrador estivesse vendo Sylvia pelo prisma arranhado e manchado da sua memória.

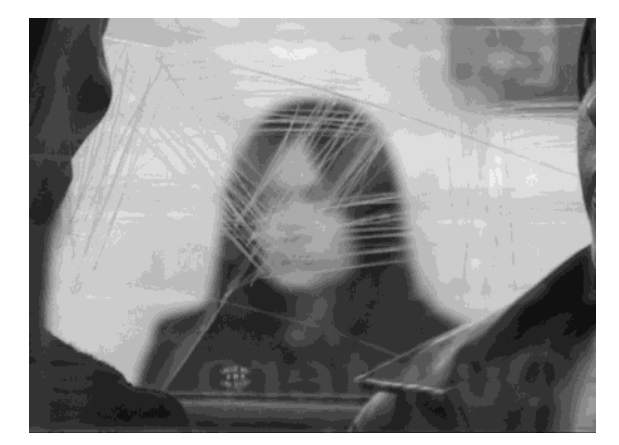

Ainda mais evocativa é a foto que mostra o rosto de uma mulher por trás de um trem que está passando à sua frente. A moça se acha parada na plataforma, mas o trem está em movimento, o que cria um efeito interessante pelo contraste entre o corpo estático e os corpos

\footnotetext{
${ }^{28}$ Sébastien Rongier, "L'ange de la photographie ou la possibilité du fantôme dans L'Étrange affaire Angélica", in Cahier des ailes du désir, n. 22, março de 2014, p. 12.

${ }^{29}$ Ibid., p. 13.
} 
e objetos que passam em alta velocidade sem dar tempo suficiente para que a câmera apreenda sua imagem de forma legível - eles deixam para trás apenas um traço, um rastro, um atestado visual de sua passagem.

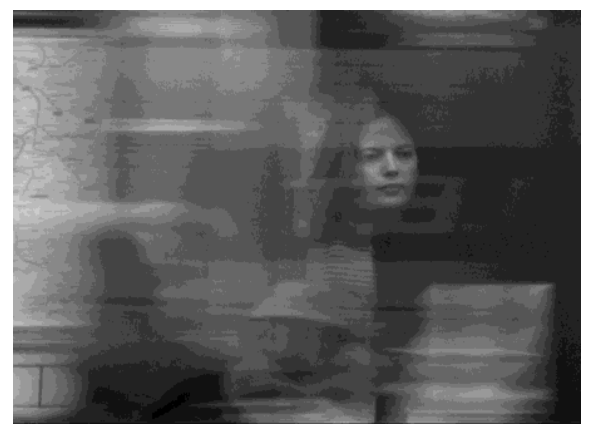

A imagem evoca o próprio trabalho da memória, seu esforço para reter um rosto, para destacá-lo do fluxo irrefreável do tempo. Esse esforço é também aquele empreendido pela fotografia e pelo cinema, que estão aqui inseparavelmente imbricados nessa mescla de fixidez e movimento.

Uma imagem como essa demonstra o total domínio de Guerín dos materiais que utiliza, como Bellour destaca em seu texto:

Rodando tanto com uma pequena câmera digital como com um aparelho fotográfico, [Guerín] conseguiu contaminar reciprocamente o que obteve das duas máquinas, de modo que os instantes descontínuos coletados de suas capturas de vídeo adquirem, um a um, certo valor fotográfico por se encontrarem misturados a fotos montadas segundo um ritmo mais ou menos acelerado, ambos se associando para produzir, num só corpo de imagens, uma ilusão regrada de intermitências fotogramáticas. ${ }^{30}$

O que Guerín fornece, nesse filme que se define a priori como uma mera coleção pessoal de fotografias montadas em certa ordem, é, na verdade, todo um modelo experimental que nos permite pensar as potencialidades do cinema não só como campo de intensificação do mundo percebido, mas também como ferramenta de especulação filosófica e de montagem significante dos pensamentos e das experiências subjetivas.

Miguel Marías compara o trabalho de Guerín com o dos pioneiros da fotografia em movimento (Étienne Marey, Eadweard Muybridge) e afirma que o cineasta catalão “encontrou novamente a verdadeira essência do cinema, seu segredo esquecido, invisível ou ignorado: o fato de que não há imagens realmente em movimento, mas apenas stills, uma série

\footnotetext{
${ }^{30}$ R. Bellour, "Sylvia quitte ou double", art. cit., p. 55.
} 
de fotografias cuja sucessão cria a ilusão de movimento". 31 É verdade que o filme remete aos dispositivos pré-cinematográficos do final do século XIX, mas é principalmente a noção mais tardia (anos 1920, Jean Epstein) do cinema como forma de pensar, como nova etapa da inteligência, o que Guerín recupera em Unas fotos.

A última imagem de Unas fotos é a única autêntica imagem-em-movimento do filme, ou o seu único "plano cinematográfico" propriamente dito: um plano - feito com câmera digital - que dura cerca de 5 segundos e mostra uma moça parada na plataforma do metrô, com o trem passando à frente dela. Há uma intermitência no registro, um batimento gerado pela passagem do trem. A imagem oscila entre esconder e mostrar o rosto da moça, mas o faz numa velocidade tal que o que se percebe é tão somente um efeito de palpitação da imagem desse rosto, emulando, de certa forma, a rápida mecânica de aberturas e fechamentos repetitivos do obturador da câmera de cinema.

Esse plano prefigura um dos principais achados visuais de Na cidade de Sylvia, que é justamente o efeito-cinema dos planos em que os tramways que cortam as ruas do centro histórico de Estrasburgo passam entre o protagonista e a personagem feminina que ele segue pelas vias labirínticas da cidade. Então, do ponto de vista dele, que será também o do espectador ao longo da maioria dos planos do filme, o que se vê é um efeito similar ao que já se testemunhava na última imagem de Unas fotos: a figura feminina refratada e difratada pela palpitação tremeluzente gerada pela passagem do tramway. Submetidos às variações de luz do espaço exterior, os vidros das janelas do tram ora funcionam como meio transparente, ora como meio reflexivo, isto é, ora dão acesso aos rostos que estão do outro lado, ora refletem os rostos que estão do lado de cá da plataforma ou da rua, criando uma indecisão óptica, uma vacilação das aparências em total acordo com a temática do filme: "Deslizamentos, batimentos, enquadramentos, sobre-enquadramentos, reflexos, espelhamentos, visões fluidas: a imagem se duplica e se reduplica incessantemente através das passagens do tram, acumulando-se em camadas para reencontrar suas simples transparência e perdê-la de novo". 32

As primeiras imagens de Na cidade de Sylvia já são ambíguas e sugestivas, jogam com reflexos, sombras e aparições incertas. São planos noturnos em que se veem pedaços do teto, das paredes e de alguns dos objetos de um quarto de hotel, cuja penumbra é esporadicamente invadida pelos faróis dos carros que passam na rua. Talvez seja o ponto de vista de alguém

\footnotetext{
${ }^{31}$ M. Marías, "Something really new: Starting over", art. cit.

${ }^{32}$ R. Bellour, "Sylvia quitte ou double", art. cit., p. 56.
} 
deitado na cama sem conseguir dormir. Na cena seguinte, já pela manhã, um jovem de feições afiladas (Xavier Lafitte, cujo rosto tem algo de uma beleza clássico-renascentista), sentado na cama desse mesmo quarto de hotel, com um caderno e um lápis à mão, parece meditar ou ruminar alguma ideia. O lápis permanece em suspenso acima do caderno aberto sobre a cama, como que à espera da iluminação mental que vai desencadear o primeiro traço de um desenho ou a primeira frase de um texto. O rapaz fica assim por cerca de dois minutos, até que, de um ímpeto, desanda a escrever e/ou a desenhar algo a que a câmera não nos dará ainda acesso. Estará ele tentando reter algum rosto, alguma imagem, alguma coisa vista em sonho?

Sequência seguinte: ele sai do hotel e vai a um café, onde derruba por acidente a bebida que a garçonete lhe trouxe. Corta para outra série de planos noturnos do quarto do hotel (mais uma noite de insônia?). Pela manhã, ele volta ao mesmo café do dia anterior. Sentado a uma das mesas, observa as demais pessoas que lá se encontram, desenhando algumas delas em seu caderno. Seu foco flutua entre as muitas mulheres presentes. Ele desenha os gestos, as poses, os traços, as posturas das mulheres. De repente, o rosto de uma moça chama sua atenção de maneira especial. Ela tem um caderno e uma caneta na mão e, como ele na manhã anterior, parece se esforçar para lembrar ou pensar alguma coisa que pretende anotar ou desenhar. Passados alguns segundos, ela recolhe suas coisas e sai do café. Ele vai atrás dela.

Depois de perseguir a linda jovem por tudo quanto é canto da cidade, ele pega o mesmo tram que ela e finalmente se aproxima. "Sylvie?", ele a interpela. A moça não parece entender do que se trata. O rapaz afirma que eles se conheceram seis anos antes, no bar Les Aviateurs, que fica atrás da catedral de Estrasburgo. "Não se lembra?", ele pergunta. Não, ela não se lembra, e tampouco se chama Sylvie: ele se enganou. "Você não é Sylvie? Que desastre...”, ele diz com expressão de quem realmente acaba de viver uma tragédia. A mulher que não é Sylvie (ou que é, mas fingiu não ser) desce do tram, e ele a vê se distanciar pela rua, dobrar uma esquina e desaparecer. Resta então a cidade, o cenário, o espaço, e outros rostos femininos que também não são o de Sylvie (mas poderiam ser...); resta o movimento do tram, dos carros, das bicicletas, das pessoas a pé, das árvores balançadas pelo vento, em suma, o "fluxo de vida" de que Guerín já falava numa das cartelas de intertítulos de Unas fotos ("Quando a figura desaparece, um cenário aparece... um fluxo de vida que evoca a desaparecida"), e que ele agora filma como se imitasse as vistas concebidas por Lumière nas esquinas movimentadas de Paris, Lyon, Londres, Berlim etc. 
O filme compõe um duplo movimento de fechamento e abertura do campo perceptivo, tendo como pivô a cena do encontro no tram.

Retrocedendo à cena em que o rapaz desenha mulheres no café, podemos identificar o primeiro gesto, o de fechamento do campo. A princípio, o protagonista divide sua atenção entre todas as mulheres que estão à sua volta. Ele faz e refaz seus croquis, estuda as poses, reelabora os traços. Num dos desenhos (cuja figura se assemelha à garçonete do café), ele acrescenta uma palavra: "ela". Mais adiante, ele colocará no plural a legenda desse mesmo desenho: "elas". Essa pluralidade, porém, dará lugar a uma fascinação exclusiva, obsessiva, tão logo ele aviste a moça que confunde com Sylvie (ou Sylvia, como o duplo título original do filme mantém tanto em espanhol como em francês). A partir de então, só um rosto lhe interessará, que não é necessariamente o rosto dessa mulher que avistou, mas talvez um rosto contido em sua imaginação e contemplado pelo olho interior do espírito; um rosto que ele projeta na figura feminina que, dentre aquelas que a realidade lhe ofereceu, é a mais próxima de tal imagem mental.

Os primeiros planos que mostram a suposta Sylvia reutilizam - mais ou menos com a mesma função e significado - aquela forma de composição já presente em Unas fotos: o rosto da mulher escolhida para encarnar Sylvia é filmado por trás de um vidro em que se refletem outros rostos:

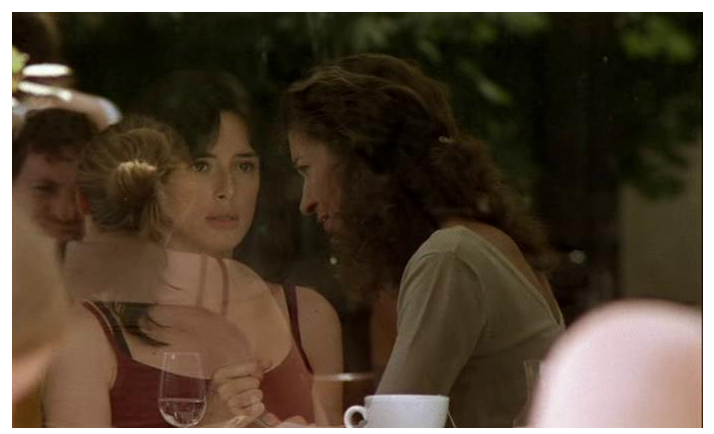

Depois que Sylvia deixa o café e o rapaz vai atrás dela, tem início a infindável cena de perseguição, que dura cerca de vinte minutos, contando a partir do momento em que ele levanta da mesa do café para segui-la e terminando no momento em que fala com ela dentro do tramway. Respondendo por 1/6 da duração total do filme, essa sequência se destaca não só pela dilatação temporal, mas, sobretudo, pela magnífica construção sonora. Quando eles percorrem becos e vias estreitas, pouco movimentadas, é basicamente o som dos seus passos o que ouvimos, a cidade tendo se reduzido a um murmúrio distante. Mas quando eles ganham as ruas mais cheias e barulhentas, o volume do som ambiente cresce ao redor do campo e 
engole os passos de Sylvia numa atmosfera sonora composta por inúmeras conversas alheias e ruídos urbanos de toda natureza possível, acavalados numa simultaneidade que, apesar de tudo, jamais descamba na cacofonia. À concentração absoluta da ação do protagonista, que se mantém atrelado à perseguição a Sylvia, contrapõe-se uma ampla disponibilidade do olhar e do ouvido, que se abrem totalmente à realidade circundante.

Tal inflação da percepção periférica demonstra o desejo de Guerín de imergir nas impressões ópticas e sonoras que despontam da travessia daqueles espaços, de realçar as texturas da realidade material, de tornar sensível de alguma maneira a presença concreta dos corpos nos lugares e as sensações que estes despertam nos primeiros. Deste modo, Guerín inscreve a perseguição num regime de olhar diferente daquele constatado em Vertigo. Lá, a cidade de São Francisco era um cenário quase abstrato, um espaço icônico no qual a narrativa traçava seus arabescos. Nas cenas de perseguição, a cidade era uma imagem previamente filmada e anexada ao campo pela técnica de back projection: o que aparecia no vidro traseiro do carro de Scottie não era o espaço real percorrido por ele, mas a projeção de uma imagem pré-fabricada. A despeito da mestria com que era executado, o artifício criava um hiato, uma perceptível defasagem entre figura e fundo. Em Na cidade de Sylvia, esse intervalo é desfeito, e a figura se funde ao espaço. Mais ainda: é a experiência do espaço que faz a figura; o rosto procurado só pode aparecer do movimento mesmo de atravessar esse espaço. A figura brota do próprio fluxo de vida da cidade, do qual se destaca e no qual se diluirá novamente por um constante movimento de passagem. Guerín introduz no dispositivo de perseguição herdado de Hitchcock esse elemento inteiramente novo: uma realidade "documental" que acompanha a figura e é dela indissociável. O interesse de Guerín se divide entre filmar a mulher perseguida pela câmera, a forma feminina sensual e bela, e, paralelamente, filmar a cidade, o espaço vital em que múltiplas experiências se comunicam e se desenvolvem. O espaço fílmico assim construído é ocupado então por dois tipos de trajetória: há a trajetória desenhada pela perseguição, que se dá em linha reta - ou inicialmente em linha reta, já que a mulher perseguida, a certa altura, começa a andar em círculos e ziguezagues para tentar despistar o stalker -, e há o conjunto de trajetórias que se entrecruzam e se entrechocam no espaço, correspondendo ao somatório desordenado das vivências simultâneas da cidade. Talvez possamos dizer que, de Vertigo a $\mathrm{Na}$ cidade de Sylvia, vai-se do idealismo platônico à fenomenologia existencial: a experiência cinemática de deslizamento do olhar pelo espaço sai de um modelo ideal-espiritual para ser realocada na espessura corpórea da atividade perceptiva, fazendo aflorar o lado mais sensorial - e menos refletido - de uma experiência que nasce do contato do corpo (em toda a sua superfície) com o mundo. 
Mas o passeio por essa fenomenologia sensualista não deve nos cegar para a reflexão profundamente intelectualizada - que o filme propõe sobre a imaginação artística e a relação que esta mantém com conceitos estéticos maiúsculos (a Ideia, a Forma, o Belo).

A melhor maneira de entender como essa discussão se apresenta é relembrar a atividade a que Xavier Lafitte se dedica durante boa parte do filme: o desenho. "O desenho é a abertura da forma", escreveu J.-L. Nancy na primeira frase de um ensaio em que elogia o caráter inacabado do desenho, sua abertura, seu valor dinâmico e enérgico. ${ }^{33}$ "O desenho é a forma não dada, não disponível, não formada. Ele é, portanto, o dom, a invenção, o surgimento ou o nascimento da forma." 34 O desenho é a ideia, a forma verdadeira da coisa, não porque revela a sua essência ou o seu absoluto, mas porque materializa - no próprio traço, no próprio gesto que o inventa - o pensamento formador da coisa. Ele é um ato de designação, uma força formadora. "Forma formans mais do que forma formata." $35 \mathrm{O}$ desenho implica uma compulsão e uma insatisfação: um elã irresistível de repetição, de reformação e transformação, e uma tendência inexorável à não satisfação do desejo que o estimula (por isso a tensão do desenho nunca se esgota).

O protagonista de Na cidade de Sylvia, ao se dedicar ao desenho, jamais ultrapassa o estágio do Entwurf, do esboço, do pro-jeto, do primeiro jato, da primeira forma dada ao desenho. $\mathrm{O}$ esboço, enquanto primeiro jato da forma, constitui uma imagem supercarregada de forças, que drena o máximo de energia das pulsões acumuladas antes da descarga propiciada pelo ato designador. Ele imprime a rapidez e a vibração do gesto. Ele é o desenho que não se satisfaz senão no próprio movimento, na expansão do traço - e no seu recomeço perpétuo.

Essa noção de desenho, no que ela implica de abertura, de inacabamento, de contemplação ativa, repercute no próprio trabalho plástico de Guerín, que incorpora na forma do filme o traçado dinâmico do desenho. Perseguida de rosto em rosto e de esboço em esboço, Sylvia permanece uma imagem inalcançada, pois o que interessa no fim das contas é o vetor, a aventura da linha, o trajeto do pensamento e seu desejo de ganhar uma forma visível: tudo isso que o desenho representa e que Guerín transpõe para o filme através, principalmente, das passagens do tram, que trazem e carregam de volta o rosto de Sylvia, reflexo fugidio a aparecer e desaparecer alternadamente nessa espécie de "tela em movimento" constituída pela superfície desse meio de transporte quase onipresente no filme.

\footnotetext{
${ }^{33}$ Le Plaisir au dessin, Paris: Éditions Galilée, 2009, p. 9.

34 Ibid., p. 11.

35 Ibid., p. 31.
} 
A última vez que Sylvia é vista pelo herói é justamente num plano em que ela aparece dentro do tram, o qual se põe em movimento e a leva embora. Mais uma vez, a figura some e o que emerge de sua ausência é aquele fluxo de vida, aquele escoamento de durações, aquela eterna circulação de corpos que pode ou não trazer a desaparecida de volta em seu movimento incessante. A montagem cria uma analogia entre as passagens do tram no final do filme e as folhas do caderno de desenhos do protagonista sendo mexidas pelo vento (como se alguém o folheasse rapidamente). As figuras desenhadas no caderno se sucedem como num filme de animação, e o que fica dessa passagem não é este ou aquele rosto, esta ou aquela figura, mas a própria imagem-fluxo gerada por esse movimento. A forma recomeça, refaz-se indeterminadamente, e esse (re)fluxo, essa circulação, esse vaivém implica não só a inevitabilidade da desaparição, da fuga, mas também a possibilidade de um retorno.

A questão das formas ressurgentes, das imagens que são esquecidas, negadas, recalcadas, mas que retornam por um processo nem sempre consciente (e talvez aí resida sua grande força), tem um papel fundamental nos filmes de Guerín aqui analisados, que são perpassados pela ideia de uma memória inconsciente das formas visuais. Em Unas fotos en la ciudad de Sylvia, encontramos um perfeito exemplo de como as formas podem retornar e se reatualizar, ou de como elas podem ser virtualmente imbuídas de uma potência de genealogia e memória ${ }^{36}$ : uma das fotos de Guerín, que mostra uma mulher mexendo no cabelo, contém o mesmo gesto, a mesma forma que mais tarde será vista numa escultura antiga fotografada no Museu do Prado. Essas imagens não foram justapostas pela montagem de Guerín, ou seja, estão separadas, situadas bem longe uma da outra na cadeia sintagmática do filme, cabendo ao espectador associá-las mentalmente. Recuperando-as e colocando-as lado a lado, aqui, podemos apreciar o belo díptico que formam:
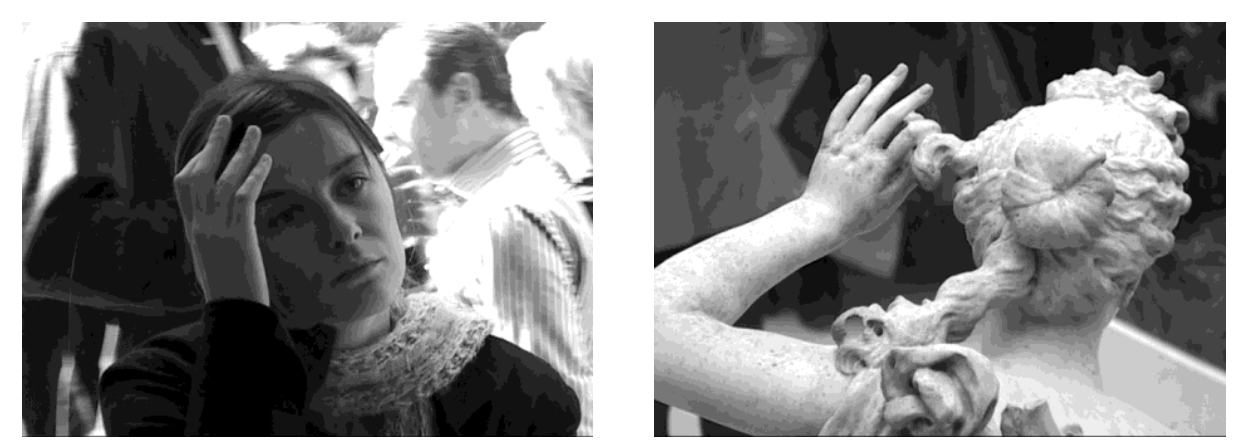

${ }^{36}$ Cf. G. Didi-Huberman, "Revenance d'une forme", in Éditions de Minuit, 1998, pp. 35-46. . Phasmes: Essais sur l'apparition, Paris: Les 
O espelhamento dessas duas imagens atesta a imensa capacidade de migração das formas, o enorme poder que elas possuem de se deslocar, de transitar, de passar de uma imagem para a outra. A forma artística, seja numa fotografia ou numa escultura, revela-se aí a cristalização de uma memória antropológica forjada pela acumulação de gestos que se repetem em diferentes épocas, em diferentes contextos. Assistimos, de certo modo, a uma regurgitação do tempo, que traz de volta os gestos e as formas já figurados no passado da humanidade. Isso se dá por uma espécie de migração subterrânea de energias figurativas que nos obriga a repensar a história das imagens admitindo seus anacronismos, seus processos inconscientes, os pontos em que ela se mostra irredutível à tradição estética. ${ }^{37}$

O mesmo gesto ainda retornará em $\mathrm{Na}$ cidade de Sylvia, no plano em que uma das mulheres observadas no café brinca com o próprio cabelo, enquadrada de costas, tal como a escultura que aparece em Unas fotos:

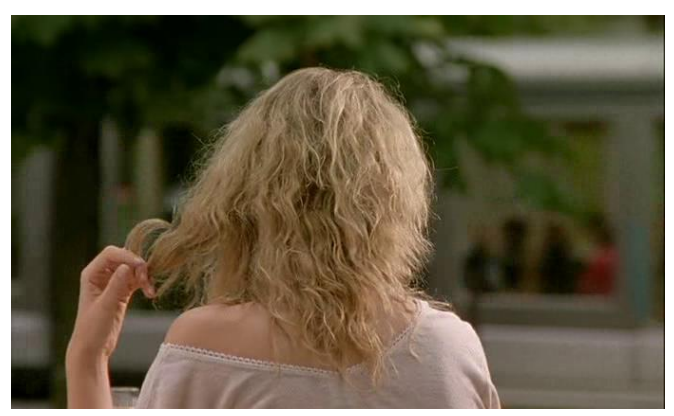

Mas agora se trata de uma imagem já pensada com base no saber iconológico que jaz sob seu dispositivo de figuração: passamos da memória inconsciente das formas à reprise consciente de um motivo artístico.

Ao registrar essas posturas, esses detalhes gestuais, Guerín não está interessado em compor um elenco visual de poses e gestos nem um catálogo de "sintomas". O olhar do seu protagonista, sempre concentrado em algum evento ou em alguém, não esgota o mundo, não o encerra num quadro sistemático. Ele contempla, e a contemplação não consiste em "consumir" o mundo visível, mas em renovar nele "sua fome e sua sede" de visão. ${ }^{38}$

Há um momento em que ele senta no banco de um parque e observa um grupo de meninas se refrescando num rio. A cena evoca os quadros que representam os banhos das ninfas e as sensuais deusas pagãs na pintura mitológica do Renascimento italiano:

\footnotetext{
${ }^{37}$ Ibid., p. 42.

${ }^{38}$ J.-L. Nancy, Le Plaisir au dessin, op. cit., p. 29.
} 

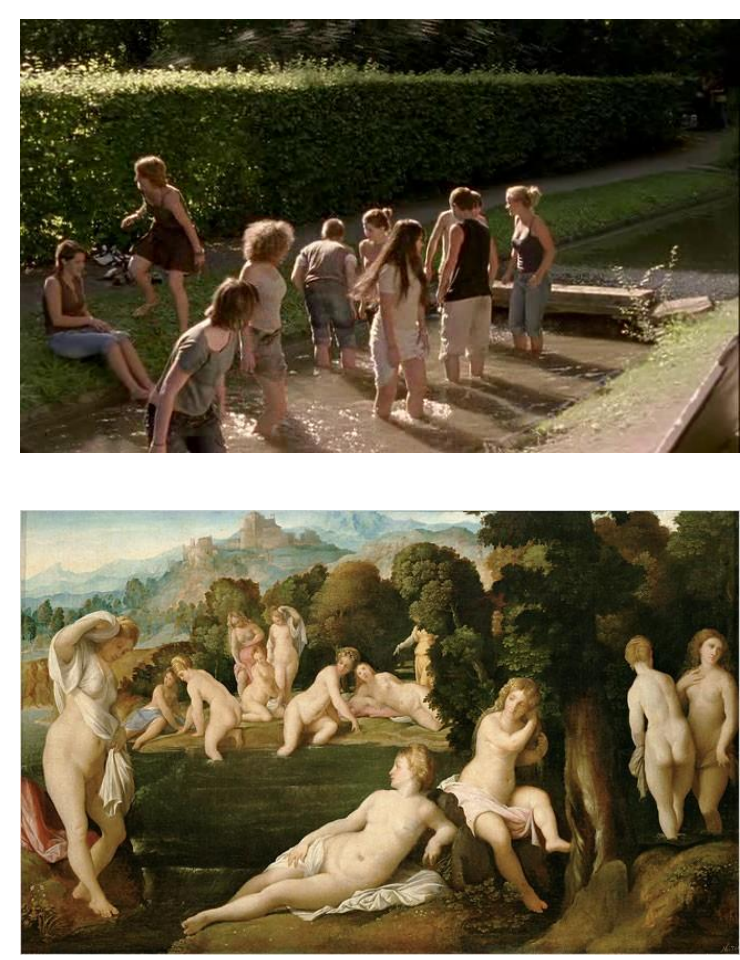

Palma Vecchio, Ninfas no banho, c.1525-28
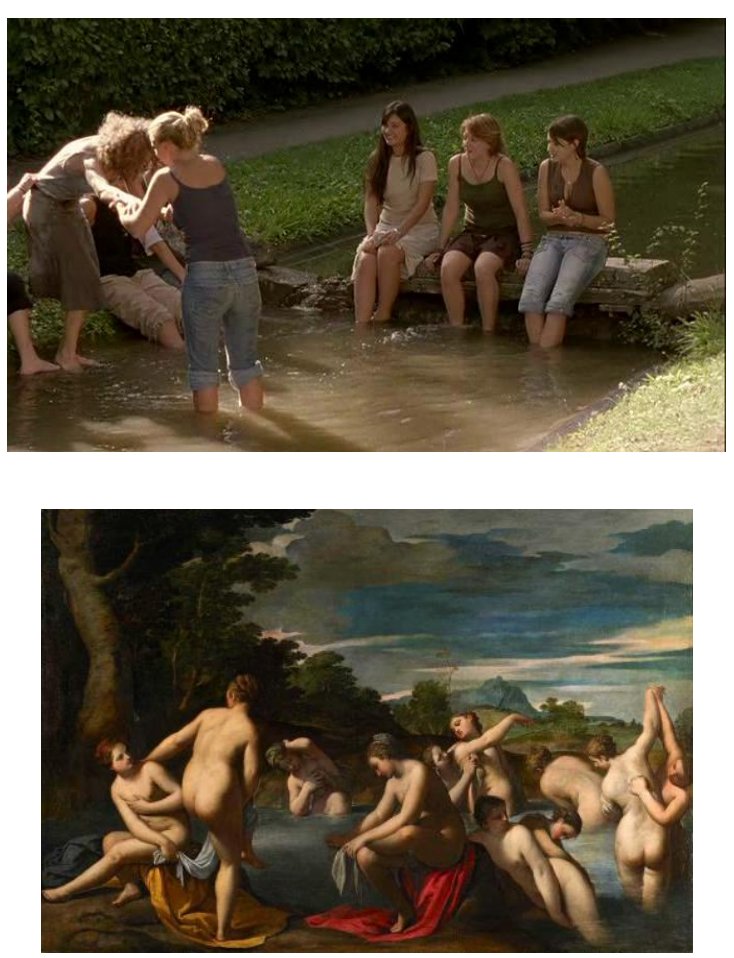

Ippolito Scarsella, Ninfas no banho, c.1600

Não há figura masculina nas imagens acima, que representam um espaço exclusivamente habitado por mulheres. Não há, no caso das pinturas, a presença do voyeur que aparece nas representações de episódios bíblicos ou mitológicos como o de "Susana e os velhos" ou o do caçador que é transformado em cervo por ter espiado Diana e suas ninfas no banho. Esse olhar intruso, se existe, é o do próprio espectador dos quadros.

Já no caso do filme, por conta da montagem e do raccord, que permitem estabelecer uma continuidade entre elementos que estão separados em planos diferentes, esse olhar pode ser incluído na cena e, ao mesmo tempo, manter-se apartado dela. Assim, Xavier Lafitte, mostrado num contraplano, observa as meninas a certa distância. Como o caçador punido por Diana, ele participa da cena como voyeur. Mas a potencial perversidade da situação é atenuada pela postura frugal do observador, seu comportamento plácido, puramente contemplativo.

Guerín filma um mundo em que tudo é olhar, tudo é visão, não no sentido de uma vigilância (não estamos, definitivamente, no registro da paranoia), e sim de uma ocularização generalizada, ou seja, de uma transformação da realidade num imenso campo de atração visual, num espaço perpassado - em todos os seus planos - por raios de visão, por olhares. Um mundo de imagens que olhamos e de imagens que nos olham. 

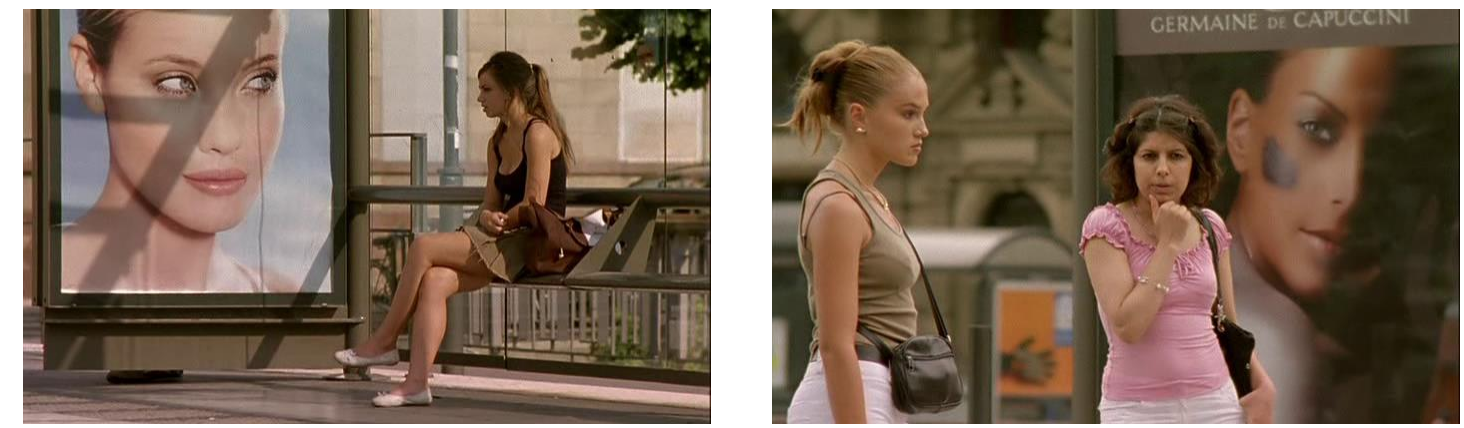

E Guerín inscreve seu mundo-olho numa história que começa muito antes das tecnologias de imagem contemporâneas (cinema, televisão, imagem informática etc.), às quais amiúde se atribui o papel de terem implantado a primazia da visão na vida cotidiana. Ora, existe civilização mais oculocentrista do que a Europa do século XVII, a Europa da pintura perspectivista holandesa, dos tratados conceituais sobre as leis da óptica e os fenômenos da cor e da luz, da Dioptrique (1637) de Descartes, da Ars Magna Lucis et Umbrae (1646) de Athanasius Kircher, das Optical Lectures (1669-1671) de Newton? Já existia aí um movimento que descambaria na febre de visão da contemporaneidade, na sua demanda constante por novas tecnologias produtoras de sensações ópticas e conhecimentos visuais.

É dessa história mais amplamente situada que Guerín se faz herdeiro e continuador, mais do que de uma história recente da proliferação desvairada das imagens. Seu filme é, antes de tudo, sobre o olhar - ou sobre a mobilidade do olhar na modernidade visual, sobre "o olho motor [l'oeil moteur]", título de uma exposição de "arte óptica e cinética" a que o narrador de Unas fotos assiste -, e somente secundariamente sobre a imagem.

Tanto em Unas fotos como em Na cidade de Sylvia, a reflexão de Guerín sobre o olhar é arrematada por meio de uma alusão ao quadro Un bar aux Folies-Bergère (1882), de Manet, obra-prima tardia notabilizada por seu complexo jogo de pontos de vista. Em Unas fotos, a alusão é direta: o quadro é visto e fotografado por Guerín numa exposição de Manet que ocorre no Museu do Prado; mais tarde, uma reprodução da pintura aparece pendurada na parede do quarto do hotel onde o diretor se hospeda. Já em Na cidade de Sylvia a citação é diluída na mise en scène fílmica: o quadro não é mostrado diretamente em nenhum momento; o que há é um plano rodado no bar Les Aviateurs (onde o protagonista teria conhecido Sylvia seis anos antes) que repete os elementos de composição e a mecânica especular do quadro de Manet; trata-se de um plano-tableau, que refaz o dispositivo óptico da pintura por outros meios (cinematográficos). 


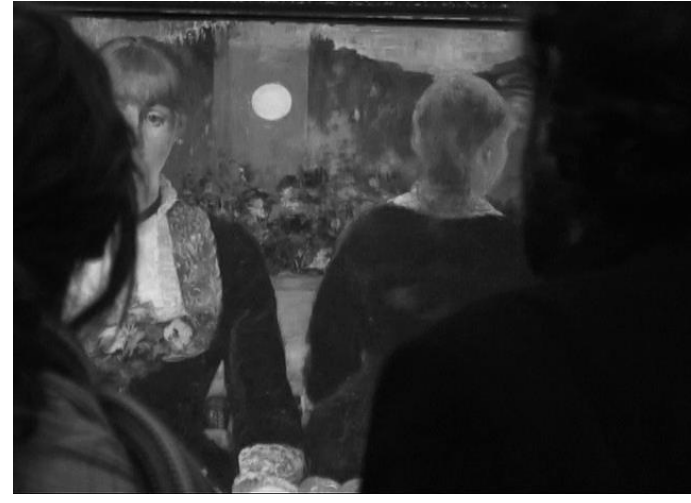

Unas fotos en la ciudad de Sylvia (J. L. Guerín)

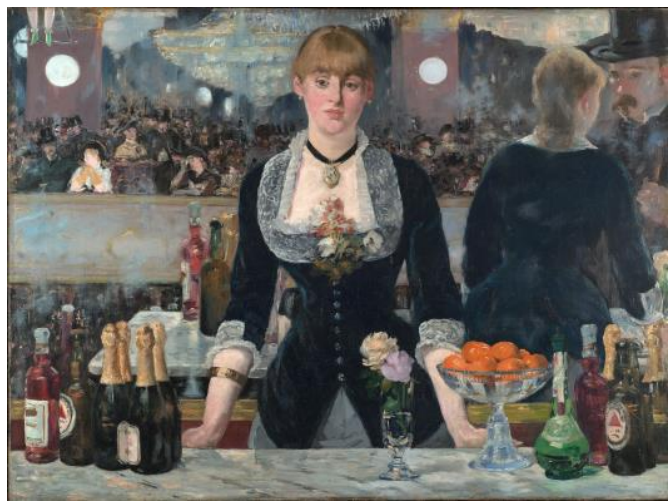

Édouard Manet, Un bar aux Folies-Bergère, 1882

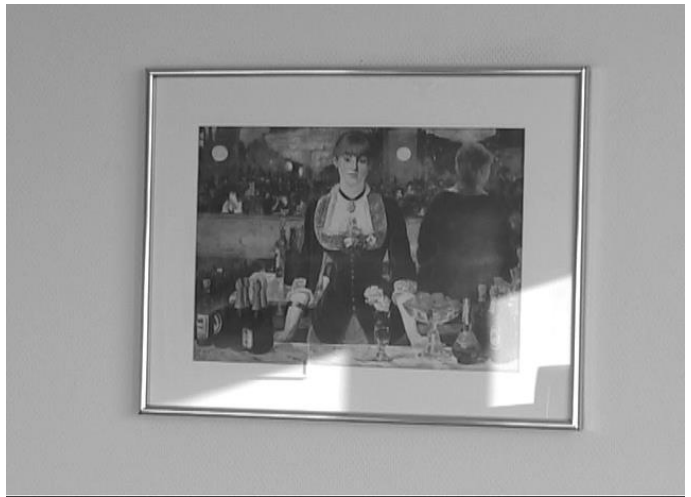

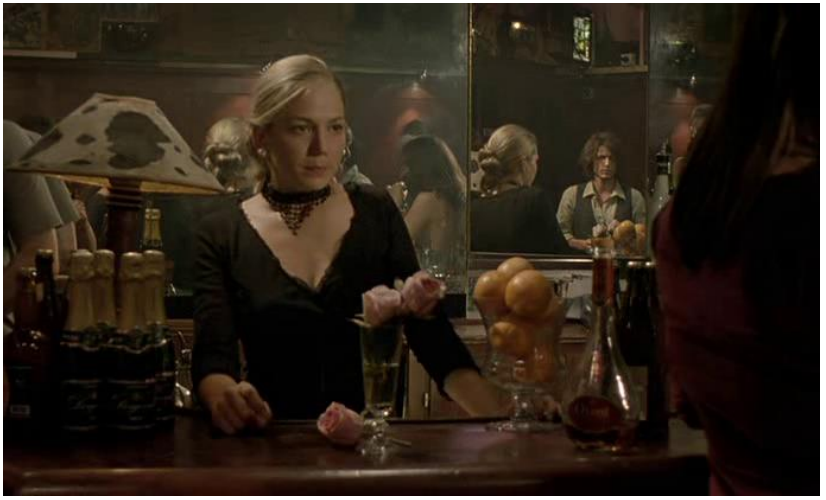

Na cidade de Sylvia (J. L. Guerín)

Três diferentes modos de inscrição de uma pintura no cinema podem ser verificados nessas três diferentes anexações de Un bar aux Folies-Bergère. Em Unas fotos, operam-se duas modalidades de inserção: primeiramente, a pintura é diretamente inscrita na imagem do filme (no momento em que o quadro original é visto no museu); depois, a obra reaparece na forma indireta de uma reprodução, uma cópia, um duplo do objeto artístico original - e desse duplo, o que vemos é um novo duplo, a imagem fotográfica feita por Guerín e exibida no filme (encerrada numa dupla moldura). A citação efetuada em $\mathrm{Na}$ cidade de Sylvia, por sua vez, envolve um efeito de (re)conhecimento em duas camadas: o espectador precisa não apenas conhecer o quadro de Manet, mas reconhecer sua reconstrução fílmica na cena do Les Aviateurs. Esse reconhecimento tem por resultado alertar o espectador para o fato de que "ele está diante de um filme em que a semiosis se dá em diferentes níveis"39: essa citação "escondida" ou disfarçada, esse plano-tableau que finge ser um plano como outro qualquer (e que pode funcionar assim para quem não conhece a pintura ou não reconhece sua recriação dentro desse plano), enfim, esse diálogo com Manet engaja o espectador iniciado e atento

\footnotetext{
${ }^{39}$ J. Aumont, "Introduction", in Les oeuvres d'art dans le cinéma de fiction, op. cit., p. 18.
} 
numa "atividade imprevisível em seus meandros, mas de natureza necessariamente analítica". ${ }^{40} \mathrm{O}$ plano-tableau é uma forma de chamar a atenção para a própria composição do quadro, para o seu arranjo estético, sua organização formal, seu equilíbrio - ou, em outra perspectiva, seu excesso, sua pletora de signos, sua abundância de efeitos decorativos ou estilísticos. Ele é uma maneira de aprofundar a fruição narrativa instaurando uma reflexão sobre os próprios aspectos composicionais e figurativos da imagem. Em outras palavras, o plano cinematográfico que imita uma determinada pintura inscreve no filme uma intenção artística, um gesto de representação consciente. Ele indica "que há algo aí de ordem hermenêutica". ${ }^{41}$ Percebendo os detalhes de Un bar aux Folies-Bergère que se repetem no plano do bar em $\mathrm{Na}$ cidade de Sylvia, avaliando os padrões de composição que são diretamente imitados, bem como aqueles que são modificados ou os detalhes que são acrescidos ou suprimidos, o espectador partilha do pensamento que engendrou a obra à qual assiste. "O filme se constitui então como um imaginário de imaginário que permite todos os jogos de superposição, de folheação e de espelhamento possíveis". ${ }^{4}$

Portanto, as aparições da pintura de Manet em Unas fotos e Na cidade de Sylvia não levam para estes filmes apenas os dados figurativos do quadro, ou sua qualidade genérica de obra de arte: elas colocam em questão, acima de tudo, o dispositivo plástico dessa pintura, bem como sua genealogia e suas significações próprias, que Guerín importa para suas narrativas transcodificando-as (já que ele transfere a imagem pictural para um registro cinematográfico). ${ }^{43}$

Muito da notoriedade do quadro de Manet se deve à disjunção entre o primeiro plano da pintura (que corresponderia à realidade física) e o reflexo no espelho situado no segundo plano, que contém várias duplicações divergentes de coisas representadas no espaço "real". As incongruências de detalhes ou mesmo de aspectos gerais são inúmeras e desafiam o entendimento do quadro enquanto representação de um espaço coerente. "Todas as garrafas da parte esquerda, por exemplo, se encontram deslocadas para a borda oposta do balcão (no balcão real, elas estão bem perto da garçonete, ao passo que no balcão refletido elas estão nitidamente distanciadas da moça)". ${ }^{44}$ E o balcão em si, a julgar por seu reflexo no espelho, parece estar flutuando no ar, pairando sobre a plateia da casa de espetáculos, suspenso num

\footnotetext{
${ }^{40}$ Ibid.

${ }^{41}$ Ibid., p. 22.

${ }^{42}$ P.-H. Frangne, "The willing suspension of disbelief: La fiction cinématographique entre simulacre et simulation", in Les oeuvres d'art dans le cinéma de fiction, op. cit., p. 302.

${ }^{43}$ Cf. Paolo Bertetto, "Les insertions de l'oeuvre d'art dans le film: Un essai de typologie", in Les oeuvres d'art dans le cinéma de fiction, op. cit., pp. 48-49.

${ }^{44}$ Jack Flam, Manet, Un bar aux Folies Bergère ou l'abysse du miroir, Tusson: L'Échoppe, 2005, pp. 10-11.
} 
abismo. Observando outros disparates do gênero, Jack Flam conclui: “A imagem no espelho parece se situar num mundo à parte". ${ }^{45}$ Para o historiador da arte norte-americano, "Un bar aux Folies-Bergère oferece o melhor exemplo de supremacia do mental sobre o visual que se pode encontrar na arte de Manet". ${ }^{46}$ As ambiguidades da organização do espaço estariam, segundo ele, mais pronunciadas do que em qualquer outro quadro anterior de Manet, colocando em xeque a própria noção de realismo. Manet testa os limites do que o espectador da época está apto a tolerar numa representação realista: "Ele ultrapassa nesse quadro os limites do realismo ao desconstruir o espaço pictural naturalista sem derrogar suas convenções e, de certa forma, desconstruindo o próprio realismo". ${ }^{47}$

O reflexo da garçonete é um dos elementos mais problemáticos do quadro. Ele se divorcia do referente não apenas morfologicamente (já que o reflexo mostra uma mulher corpulenta, de porte largo, contrastando com a jovem de cintura fina que está de frente para nós) como também opticamente, pois a imagem refletida foi de tal maneira deslocada para a parte direita do espelho que somente desprezando as leis básicas da representação visual se pode aceitá-la como verossímil. Outro elemento perturbador, talvez o principal, é o fato de que, no espelho, a garçonete troca olhares com um homem que está imediatamente à frente dela. Ora, uma vez que ela olha diretamente para nós, isso deveria significar que o tal homem ocupa exatamente o lugar em que o espectador se posiciona imaginariamente, ou seja, a pintura situaria o espectador no ponto de vista do homem para quem a garçonete está olhando. Mas por que então esse homem, que estaria olhando para a moça num ângulo perpendicular ao plano do quadro, aparece quase de perfil no espelho? A presença desse homem "perturba singularmente nossa percepção do tempo e do espaço. As outras bizarrices do quadro podem se explicar por efeitos de composição, mas a presença mesma dessa personagem é inverossímil o suficiente para exigir uma interpretação simbólica". ${ }^{4}$

Como se vê, o quadro apresenta desvios consideráveis em termos de coerência óptica e construção perspectiva. Uma das formas de enxergar a decalagem entre os corpos e objetos reais e os corpos e objetos no espelho é admitir que, na passagem da realidade ao seu reflexo, há "um deslocamento do próprio olhar". ${ }^{49} \mathrm{O}$ ângulo ocular variou entre a visão frontal da garçonete e a visão oblíqua de sua imagem refletida no espelho. Trata-se de uma "divisão interna da vista"; "é toda a representação, pela dificuldade de discernir a coisa da sua

\footnotetext{
${ }^{45}$ Ibid., p. 11.

${ }^{46}$ Ibid., p. 20.

${ }^{47}$ Ibid., p. 32.

${ }^{48}$ Ibid., p. 29

${ }^{49}$ Marie-Claire Ropars-Wuilleumier, L'Idée d'image, Presses Universitaires de Vincennes, 1995, p. 42.
} 
figuração, que se acha incluída no reflexo e como que devolvida à duplicidade imaginante: esmagada, a profundidade se dá como puro efeito de superfície invertida". 50

Pode-se inferir que esse quadro prefigura "a pretensa multiplicidade de pontos de vista do cubismo", mas Flam acredita que se trata de outra coisa:

O que Manet nos propõe é uma intrusão na psicologia de uma personagem [...]. [A decalagem do quadro] assinala a disparidade entre dois modos de percepção interior e exterior, extremamente difíceis de transpor na pintura tradicional. [...] Uma parte, ao menos, do que vemos no espelho poderia ser compreendida como uma transposição plástica dos pensamentos da garçonete..$^{51}$

Por essa lógica, o reflexo no espelho seria uma junção do imaginário e do visível, da construção mental e da realidade material. O espaço composto por planos discordantes expressaria uma invasão da realidade pela vida interior da garçonete. Seria o reflexo no espelho o lugar de um encontro imaginário entre a mulher e um homem que está na plateia, do outro lado do salão (por exemplo: aquele homem que aparece na parte esquerda do reflexo no espelho, quase no limite do quadro)?

Não é difícil entender as ligações desse quadro com os dois filmes de Guerín aqui em pauta. O encontro com Sylvia, tanto num como noutro filme, também só pode acontecer num espaço imaginário. Talvez, desde a primeira vez em que Guerín a viu, ela sempre tenha sido uma ilusão, uma construção mental, um fantasma que ele persegue inutilmente. Assim como o quadro de Manet, o dístico de Sylvia "deve ser compreendido como uma evocação do desejo em geral, uma tentativa de apreensão dessa coisa impalpável e fugidia, bastante presente e, no entanto, eternamente inapreensível". 52

Numa das fotos da cópia de Un bar aux Folies-Bergère que aparece pendurada no quarto do hotel em Unas fotos en la ciudad de Sylvia, Guerín surge refletido no vidro que protege a imagem, a empunhar a câmera e fazer a fotografia (ele se representa no ato da representação). Intencionalmente ou não, a imagem remete ao plano-espelho de Vertigo. Mas o lugar de Scottie é agora ocupado pelo reflexo narcísico de Guerín; quanto a Madeleine, ela foi substituída pela figura melancólica e introspectiva da mulher da pintura, que, embora nos encare, parece muito mais interessada em sua própria visão interior ou tão somente em algum

\footnotetext{
${ }^{50}$ Ibid., p. 41.

${ }^{51}$ J. Flam, Manet, Un bar aux Folies Bergère ou l'abysse du miroir, op. cit., pp. 26-27.

${ }^{52}$ Ibid., p. 38.
} 
aspecto ausente do quadro, insondável para o espectador. O plano se torna ainda mais insólito que o de Hitchcock: o olhar masculino é desmaterializado, transformado numa projeção fantasmática ou numa espécie de sobreimpressão propiciada pela capacidade reflexiva do vidro. A figura feminina, por sua vez, deixa de ser um reflexo no espelho para ser a personagem de um quadro do século XIX, o que significa que Guerín, à semelhança de Scottie, pode ter se apaixonado, no fim das contas, por uma personagem ficcional, por uma imagem - e mais: uma imagem extraída de um passado que ele não viveu.

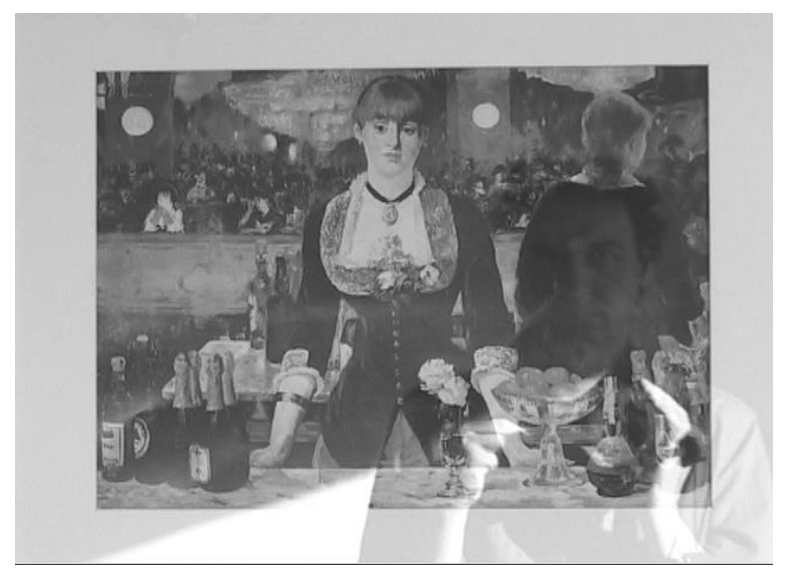

Guerín se inclui na imagem como um reflexo fotografado de frente. No domínio visual que a tradição ocidental consolidou, a imagem especular está associada à identificação do eu, e a aparição frontal, contrariamente à figura de perfil, é uma forma que atenua a alteridade em nome do reconhecimento de si. Essa imagem sugere, portanto, que Guerín talvez não esteja procurando por Sylvia, mas por ele mesmo, ou por uma parte dele que ficou perdida no passado.

Se, em Dublê de corpo (De Palma), Instinto selvagem (Verhoeven) e Rio Suzhou (Lou Ye), a referência ao plano-espelho de Vertigo era deliberadamente pensada como um diálogo intertextual, em Unas fotos, assim como em $O$ ano passado em Marienbad, já não dá para afirmá-lo com tanta certeza, apesar de tudo levar a crer que há também um trabalho consciente de reinterpretação do plano de Hitchcock. Mas o que importa, independentemente da intencionalidade ou não desse diálogo (que a imagem por si só garante), é perceber que há um trajeto de rarefação do expediente figurativo do plano-espelho hitchcockiano: entre De Palma e Guerín, a origem do plano deixou de ser assinalável e ele passou a ser uma imagemfantasma que paira anonimamente sobre a história do cinema. 
Uma última observação: em seu autorretrato disfarçado, não é só o plano-espelho de Vertigo que Guerín evoca, mas também a fotografia Picture for Women, do artista canadense Jeff Wall, feita em 1979 e assumidamente inspirada em Un bar aux Folies-Bergère:

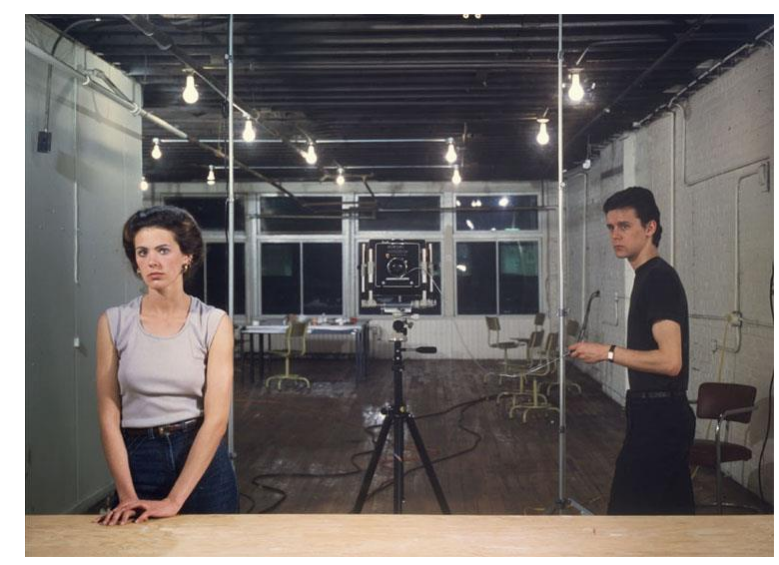

Jeff Wall, Picture for Women, 1979

A fotografia - que repete, em linhas gerais, a estrutura interna da pintura de Manet acha-se dividida em três segmentos precisamente delimitados por duas barras metálicas que percorrem verticalmente o quadro. Cada segmento está ocupado por um corpo diferente, e cada corpo é portador de um determinado olhar. À esquerda, encontra-se o modelo feminino, com as mãos sobre o balcão, imitando a postura e o olhar da barmaid do quadro de Manet. À direita, o fotógrafo (o próprio Wall, que se coloca mais ou menos no lugar do homem misterioso do quadro de Manet), com seu olhar concentrado no modelo. E na porção do meio, a câmera fotográfica, cujo olho mecânico, situado bem no centro geométrico do quadro, mira diretamente o espectador. "O olhar do espectador não está mais dirigido para a ação central da pintura, nem para o corpo de um modelo feminino, mas para o centro de um dispositivo óptico ocupado pela máquina fotográfica". ${ }^{53}$ Se antes o espectador trocava olhares com a figura feminina, agora ele é magnetizado pelo olhar maquínico de uma câmera de fotografia cuja lente constitui o olho da imagem, a abertura pela qual a própria representação nos olha. E se o espelho não mostra nenhuma figura duplicada, é por um motivo simples: não há necessidade de duplicação do visível, de comparação entre um espaço real e seu duplo imaginário, pois agora é toda a representação, a imagem em seu conjunto, que passou para o lado do reflexo, da especulação.

\footnotetext{
${ }^{53}$ Cf. Jean-François Chevrier, Jeff Wall, Paris: Hazan, 2013.
} 


\section{Sombra}

O olhar masculino onipresente nesses dois filmes de Guerín que acabamos de analisar - ou seja, aquele olhar que observa o que as mulheres fazem quando estão entre si, que admira o mundo feminino sem, todavia, conseguir participar dele ou até mesmo compreendê-lo - já havia sido colocado em xeque alguns anos antes (num registro menos solar, e muito mais grave e sombrio) no filme A prisioneira (La captive, 2000), de Chantal Akerman.

Inspirado no quinto volume de Em busca do tempo perdido, a monumental obra romanesca de Marcel Proust, A prisioneira mergulha no ciúme doentio de Simon (Stanislas Merhar), que teme neuroticamente a possibilidade de ser traído por sua companheira Ariane (Sylvie Testud). O filme é uma longa viagem pelas mais sombrias florestas passionais. No caminho, porém, surgem momentos de iluminação, beleza, sensualidade, deleite visual, como se o afeto corrosivo do ciúme intensificasse a percepção estética do mundo. "O veneno da suspeita é uma droga de perfumes, de luzes, de sons", escreveu Philippe Sollers ao relembrar justamente a equação do ciúme em Proust. ${ }^{54}$

Em alguns momentos do romance, longos parágrafos se ocupam da descrição do modo de funcionamento da mente paranoica do ciumento: uma informação, uma palavra, uma frase dita na semana anterior mas só interpretada agora, uma atitude, um olhar, enfim, qualquer coisa serve como fagulha de ativação para as conjecturas que o levam a despencar num poço sem fundo. Uma palavra dita sem muita atenção, sem sentido aparente, uma partícula de linguagem insignificante é tudo de que o ciumento precisa. De uma sílaba ele extrai uma história, uma conspiração, um mundo (o ciúme é uma vertigem do detalhe).

Assistindo ao filme, temos a impressão de que Akerman fez sua câmera entrar num desses túneis, num desses profundos corredores abertos pela suspeita, que dão para labirintos infinitos onde nenhuma paz de espírito é possível. O pensamento de Simon gira sem parar em torno da mesma ideia fixa, da mesma realidade inadmissível, que consiste tão somente na opacidade e no mistério do outro.

Reatando o elo perdido entre Vertigo e Proust (que três anos antes já havia sido explorado por Chris Marker em Immemory), Chantal Akerman dilata ainda mais que Hitchcock as sequências mudas de perseguição e as lentas trajetórias por museus, hotéis, parques e ruas sinuosas. Enquanto Simon procura por Ariane, de carro ou a pé, em diversos endereços de Paris, um clima soturno se instala, uma atmosfera de thriller mental que muitos

\footnotetext{
${ }^{54}$ Portraits de femmes, Paris: Flammarion, 2013, p. 79.
} 
compararam a De olhos bem fechados (Eyes Wide Shut, Stanley Kubrick, 1999). Como representar uma catástrofe íntima? Como filmá-la? Estas parecem ser as perguntas que deram origem ao filme.

Na primeira cena, Simon assiste a imagens em $8 \mathrm{~mm}$ que mostram um grupo de "raparigas em flor" se banhando no mar e brincando com as ondas:
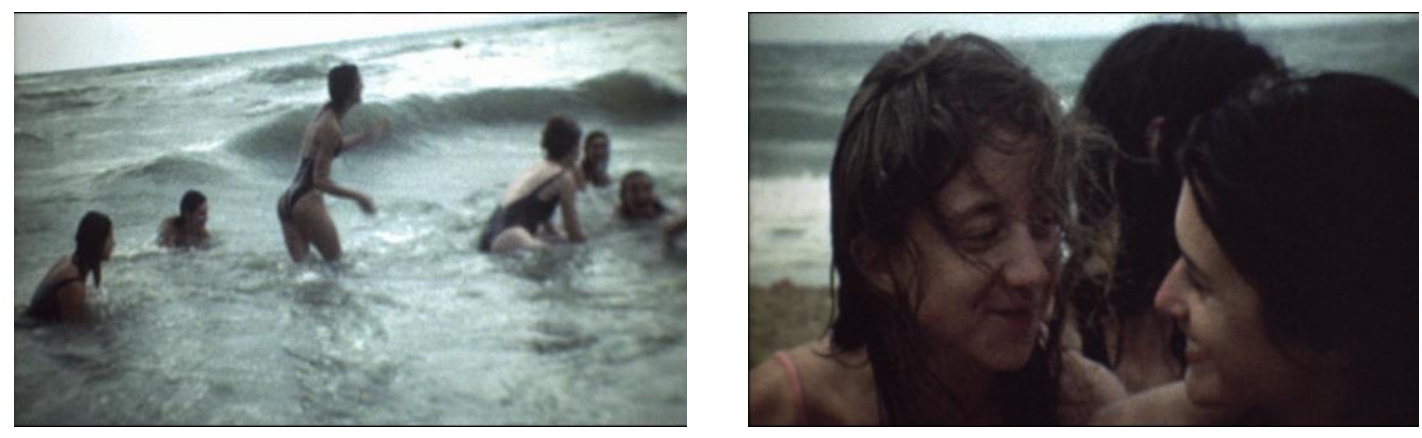

Assim como as meninas filmadas no parque em $\mathrm{Na}$ cidade de Sylvia, elas também lembram as cenas mitológicas das ninfas no banho. Uma troca de sorrisos entre Ariane e Andrée (Olivia Bonamy), sua melhor amiga, demonstra uma cumplicidade, uma ligação secreta que Simon não tem como acessar. Não à toa, elas são observadas por ele de uma posição ainda mais afastada e excluída do que a do observador do filme de Guerín. Se lá o olhar masculino, apesar de distante, achava-se num espaço contíguo ao das mulheres, aqui Simon assiste a um filme projetado numa tela: a separação entre o seu mundo e o das mulheres é afirmada pela própria configuração do dispositivo cinematográfico.

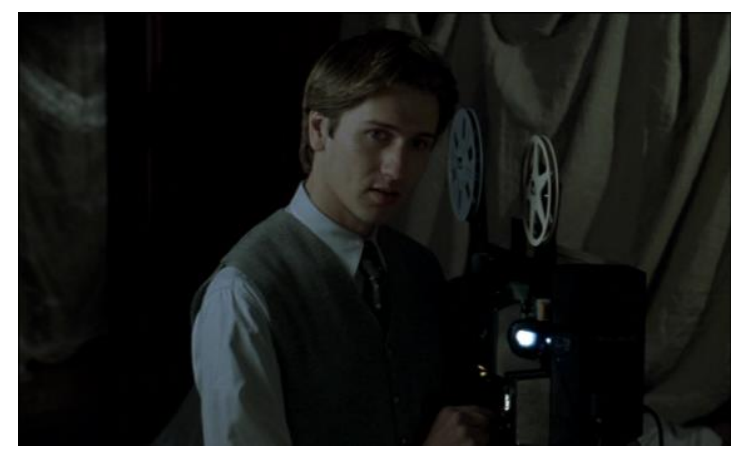

Não sem malícia, Akerman repõe aquela estrutura clássica - denunciada pela teoria feminista - do homem como dono do olhar e da mulher como imagem. Mas a posse, por parte do homem, do aparato óptico do cinema, ou a ocupação por ele do polo ativo do olhar, neste 
caso, apenas reforça sua impotência diante de uma imagem feminina que ele tenta decifrar sem sucesso.

Pouco a pouco, os planos do filme em 8mm se fecham em Ariane. Simon se aproxima da tela e, fazendo sombra à frente do projetor, insere-se na imagem em contraluz. Ele tenta se aproximar daquele mundo feminino, e talvez até se fundir a ele, entrar na tela. Mas o feitiço se volta contra o feiticeiro, e tudo que ele consegue é ratificar sua heterogeneidade, sua estrangeirice no mundo de Ariane, inscrevendo uma área de completa escuridão num plano de luz ao qual definitivamente não pertence. A sombra do rosto de Simon demarca com mais intensidade que nunca o buraco negro no qual sua consciência chafurda a cada vez que percebe em Ariane uma figura de alteridade. Sua distância crescente em relação a ela é representada inequivocamente pela imagem de Ariane se afastando da câmera e correndo na direção do mar (prenúncio do final do filme), tornando-se uma silhueta inapreensível, uma imagem em fuga, para sempre perdida.

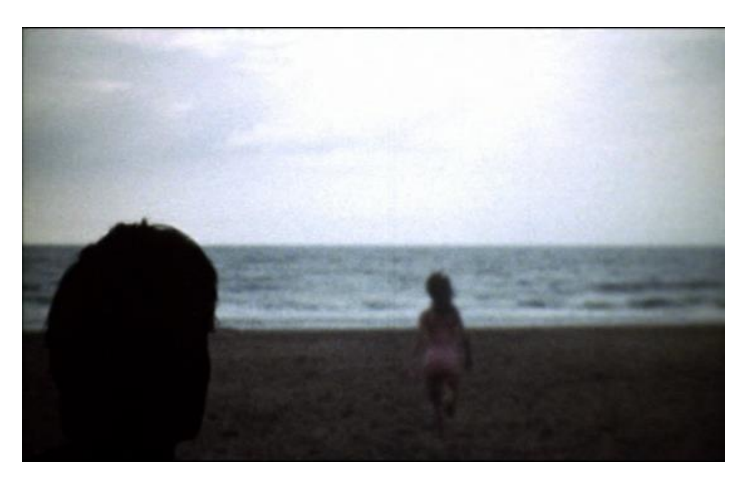

Partindo dessa evidência visível de que a pessoa amada, a despeito de tudo, é e continuará sendo sempre um outro, uma imagem inalcançável, o filme terá como situaçãopadrão as sequências em que Simon segue Ariane e é despistado por ela num labirinto urbano ainda mais fantasmático que a São Francisco de Vertigo. Quanto mais Simon persegue, espiona, interroga e controla a vida de Ariane, menos ele sabe dela, menos ele a tem. Para piorar, surge nele uma forte desconfiança de que ela sente atração por outras mulheres, o que aumenta seu tormento e o conduz a novas e insolúveis dúvidas.

Uma das perseguições leva Simon para dentro do Museu Rodin. Ele segue Ariane a uma distância sempre cautelosa, esgueirando-se por entre as esculturas e pilastras do suntuoso edifício. Não há ninguém no museu além de Simon, Ariane e, posteriormente, Andrée. O silêncio só é contrariado pelos passos de Ariane no assoalho de madeira. 
A deambulação pelas salas do museu se interrompe quando Ariane encontra a escultura La Femme slave (Auguste Rodin, 1906), que consiste no busto de uma mulher emergindo de um bloco de mármore deixado em estado bruto. O penteado da mulher é um coque em espiral que imediatamente ecoa Vertigo. Ariane se deixa hipnotizar pela escultura como Madeleine diante do retrato de Carlotta no filme de Hitchcock. Por meio de um travelling majestoso, a câmera de Chantal Akerman dá a volta na escultura, terminando o movimento num enquadramento que inclui o busto feminino de perfil e Ariane a observá-lo com visível fascínio.
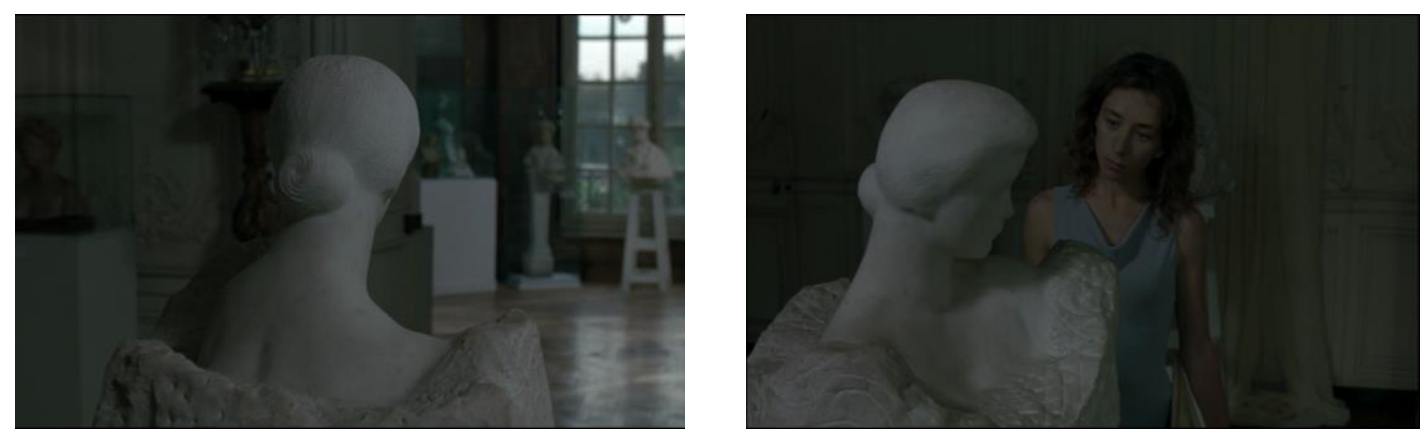

A solenidade, a solidão e o silêncio da cena do museu de Vertigo são recuperados por Akerman, depois das versões caleidoscópicas, erotizantes, superpovoadas, excessivas, de Brian De Palma e Dario Argento em Vestida para matar e Síndrome mortal, respectivamente. Mas, enquanto o retrato de Carlotta em Vertigo se impunha no alto da parede como a imperar sobre o museu e seus visitantes, a escultura vista por Ariane em A prisioneira, diferentemente, é uma forma que tenta se libertar do bloco de pedra, uma figura feminina a despontar do mármore que ainda a mantém prisioneira. Ariane se identifica com essa imagem de uma mulher aprisionada, retida no ato de desabrochar, de elevar-se da matéria informe - uma forma em estado nascente, ao contrário do retrato de Carlotta, obra acabada que lança aos seus espectadores (Madeleine, Scottie) um olhar mortificante.

Se Vertigo retorna com tamanha força em filmes contemporâneos como os de Chantal Akerman e José Luis Guerín, é porque permanece um modelo atual para narrativas que se propõem a confrontar uma imagem da mulher que, moldada por "séculos de obscurantismo" 55 , desaguou na sua idealização poética e mística, na doença romântica e seu corolário: a loucura dos homens. Simon, assim como o rapaz de Na cidade de Sylvia, esbarra

${ }^{55}$ Ibid., p. 115. 
na impossibilidade de encontrar no mundo real a confirmação dessa imagem feminina idealizada. O protagonista de A prisioneira está atrás menos de um ser verdadeiro do que de uma projeção, de um fantasma, como se vê na cena-chave em que ele segue diferentes mulheres achando que elas podem ser Ariane; em determinado momento, a mulher que ele segue está fora de campo, e tudo o que vemos é sua sombra projetada na parede; há então esse significativo plano em que Simon caminha na direção da sombra, até passar por ela, também ele transformado agora numa pura sombra destacada do corpo que a produz - uma simples silhueta imaterial projetada na parede.

Ora, o que a nossa experiência sensível nos ensina é que a sombra "pertence" sempre a algum corpo: se vemos uma sombra, mesmo que ainda não estejamos vendo o seu "dono", sabemos que ele está lá em algum lugar, e sua presença visível é iminente.

No cinema, e isso já desde as primeiras vistas de Lumière, a sombra projetada por um corpo - que não é o único regime de sombra presente no universo, mas "é o primeiro fenômeno a que espontaneamente associamos a sombra" ${ }^{\$ 6}$ - tem sido uma ferramenta figurativa importante, o que se deve, em grande parte, ao caráter dúbio que ela adquire uma vez incorporada à imagem em movimento, onde assume por vezes a aparência de um ente autônomo e dotado de vida. Como os primeiros cineastas - e também os primeiros espectadores - rapidamente perceberam, as sombras vistas no cinema não se reduzem a um fenômeno visual, pois comportam toda uma herança literária e pictórica que repousa sobre a personificação e a animação da sombra. Com relativa frequência, no cinema, a sombra não se contenta em ser "uma pura consequência inerte do jogo da luz, e se põe a desejar uma 'vida' própria". 57

No mais belo plano de A prisioneira, a sombra se mostra um recurso expressivo fabuloso, um verdadeiro atalho para as camadas mais profundas do drama. Trata-se do plano em que Simon e Ariane vêm caminhando por um parque e, a princípio, vemos apenas suas sombras lado a lado, acompanhadas por um travelling lateral. Eles param e as sombras se encostam, provavelmente porque eles se beijam. Durante o beijo, as sombras se fundem numa só figura, apagando a diferença que atormenta Simon: no mundo das sombras, seu corpo e o de Ariane são feitos de uma mesma (anti)matéria, e se misturam de forma homogênea. Substituindo os corpos por suas sombras, Akerman capta deles os pensamentos secretos.

\footnotetext{
${ }^{56}$ J. Aumont, Le montreur d'ombre, op. cit., p. 48.

${ }^{57}$ Ibid.
} 

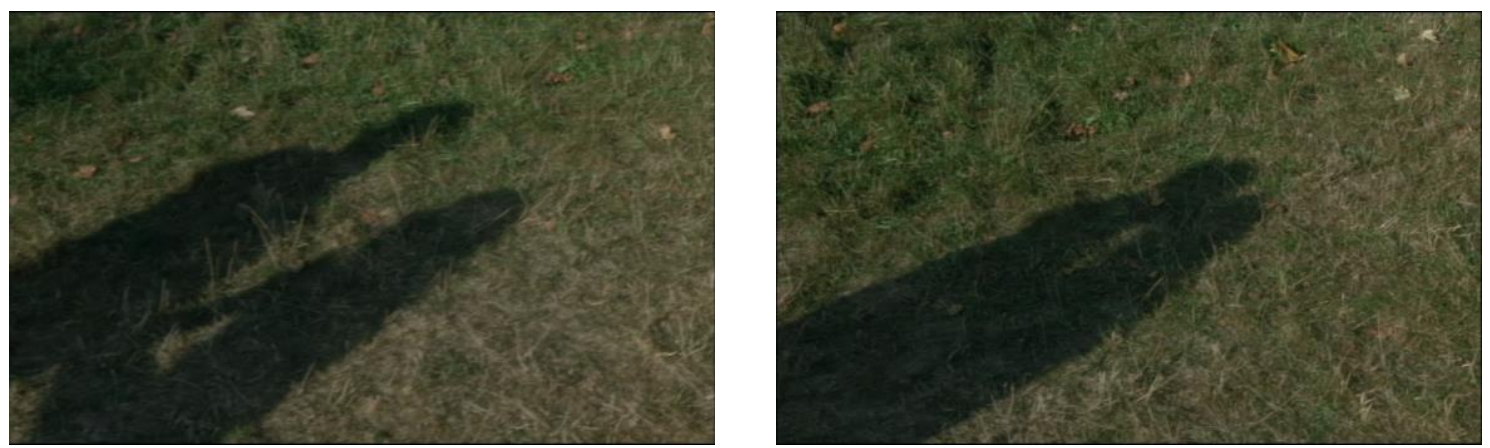

Mas o plano continua e a câmera faz uma panorâmica à esquerda, saindo das sombras para enquadrar os corpos de carne e osso. A ilusão então se desfaz: não há fusão, não há união perfeita, mas sim dois corpos diferentes, heterogêneos, destacados um do outro. A ideia de que dois seres distintos podem se unir no amor e formar apenas um não passa de devaneio romântico. Se há um prisioneiro neste filme, aliás, é Simon, prisioneiro de tal ilusão romântica, desse sonho de união no absoluto de dois seres separados na realidade - uma realidade da qual ele só enxerga as sombras: "Simon ainda não saiu da caverna platônica", afirmou com razão Bernard Benoliel. ${ }^{58}$

Se Chantal Akerman insiste muito menos nos espelhos do que nas sombras em $A$ prisioneira, é em função justamente de uma tradição artística e filosófica alavancada pela célebre alegoria da caverna, na qual, depois de ter descrito o dispositivo princeps de sua teoria do conhecimento (um cenário com homens acorrentados no escuro, de costas para uma fresta por onde passa um feixe de luz, não percebendo o mundo externo senão através de ecos e sombras projetadas na parede), Platão narra o roteiro da libertação do prisioneiro, constituindo um caminho que vai da falsidade à verdade. As sombras (skias), nesse roteiro, formam o primeiro termo, a primeira coisa que o prisioneiro libertado da caverna consegue distinguir. Em seguida, vêm as imagens (eidola) dos homens e de outras coisas refletidas na água, e somente depois surgem as coisas em si mesmas. Na última etapa do conhecimento, após contemplar a luz dos astros e da lua, o homem consegue enxergar o sol, não o seu reflexo na água, mas o sol e seu brilho vistos diretamente: a verdade pura, o extremo oposto da sombra.

De acordo, então, com essa fábula platônica que representa o mito fundador do conhecimento no Ocidente, a sombra é o que pode haver de mais distante em relação à verdade; ela se opõe de maneira absoluta à luz do sol, metáfora do conhecimento verdadeiro. Ela precede até mesmo o reflexo das coisas na água e em outras superfícies especulares, ou

\footnotetext{
${ }^{58}$ Cf. “La Captive: Le temps retrouvé de Chantal Akerman”, Cahiers du cinéma, n. 550, outubro de 2000, p. 17.
} 
seja, o "estágio da sombra" é anterior ao estágio do espelho. ${ }^{59}$ Situando Simon na completa escuridão e reclusão de sua mente, filmando-o como alguém distante da realidade, mas apegado às sombras, Akerman o devolve, portanto, às origens das narrativas de duplicação imaginária do mundo e dos seres. Simon está tão longe da "verdadeira Ariane" quanto lhe é possível, mas muito perto da sua sombra, da sua imagem em negativo.

A partir do mito da caverna, como demonstra Stoichita, a sombra ficará marcada por uma negatividade que a acompanhará ao longo de toda sua carreira na história da representação ocidental. Enquanto signo negativo, "aparência gerada por uma censura à luz" ${ }^{\prime 60}$, ela jamais pode ser tomada como imagem definitiva (e definidora) de algo: o que ela oferece à visão "não é um signo justo, mas um signo mentiroso". ${ }^{61}$ Se a função mimética da sombra, ou seu poder de semelhança, quando ela é comparada a outras formas de imagem, revela-se a mais fraca, sua função mágica, por outro lado, é das mais poderosas, daí ela ser uma ferramenta visual tão efetiva nas obras que lidam com aspectos sobrenaturais ou fantásticos. Tradicionalmente, nas artes visuais, a sombra é ao mesmo tempo um índice da presença física de alguém ou de alguma coisa e uma representação das trevas ou das forças do além: ela indica a existência de um corpo real sem deixar de sugerir a presença inquietante de um alhures, de uma dimensão oculta a literalmente assombrar a realidade física.

Em se tratando de sombras, é difícil não passar sub-repticiamente da metonímia à metáfora: da sombra como índice óptico/físico/material da presença de um corpo que bloqueou a luz à sombra como ser enigmático, atrelado visualmente à obscuridade, dotado de intenções necessariamente sombrias - para não falar na sombra como símbolo abstrato [...]. ${ }^{62}$

No cinema, arte da luz, mas que tem a sombra como condição primordial (basta pensar na própria situação cinematográfica, na sala escura, onde a luz do projetor, para existir, necessita da sombra - não a sombra que aparece como uma figura de contornos nítidos, mas a "sombra ambiente [ombre milieu]"63, que é vivida como uma "qualidade do espaço" em que o espectador se encontra); no cinema, dizíamos, os efeitos de sombra, mesmo os mais simples que se pode imaginar, vêm sempre carregados de grande força visual e simbólica.

\footnotetext{
${ }^{59}$ Cf. Victor I. Stoichita, Brève histoire de l'ombre, Genebra: Droz, 2000, p. 22.

${ }^{60}$ Ibid., p. 25.

${ }^{61}$ J. Aumont, Le montreur d'ombre, op. cit., p. 41.

${ }^{62}$ Ibid., p. 39.

${ }^{63}$ Ibid., p. 11.
} 
Um bom exemplo disso é visto num dos primeiros filmes a se apresentar abertamente como uma variação em torno de Vertigo, o thriller erótico Una sull'altra, realizado pelo cineasta italiano Lucio Fulci em 1969.

Na cena em questão, Jane (Elsa Martinelli), fotógrafa de moda, faz uma sessão de fotos com Monica Weston (Marisa Mell), que é dançarina numa boate noturna de strip-tease. O envolvimento das duas mulheres durante o ensaio fotográfico atinge um clima ambíguo, entre a atração sexual e a cumplicidade artística. Mas esse clima é desfeito quando Jane liga um projetor que lança sobre um telão a fotografia de uma outra dançarina, conhecida como Liz. A imagem que então se forma condensa de maneira interessante a sobreposição de rostos femininos, o jogo de falsas aparências e disfarces que, como paulatinamente se revela, constitui o núcleo da intriga.

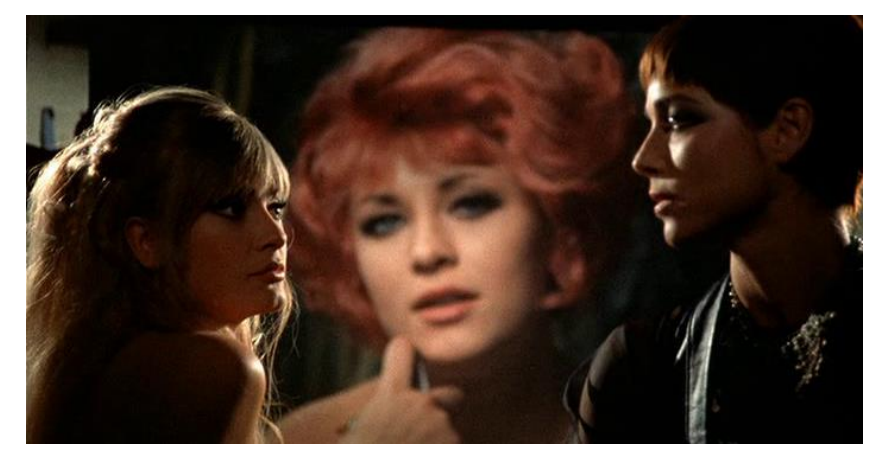

Essa terceira mulher a surgir na cena (como imagem projetada) pode estar envolvida, junto com Monica, no complô que incriminou o amante de Jane, o Dr. George Dumurrier (Jean Sorel), médico renomado, mas conhecido por certo marketing sensacionalista, e agora acusado de ter matado a própria esposa. Ele conheceu Monica, que é um duplo da sua esposa morta, depois de assistir a um número erótico protagonizado por ela num cabaré (o filme faz ressurgir aquela dualidade da figura feminina já apresentada por Murnau em Fantasma, que também possuía uma mulher com essas mesmas duas faces, simultaneamente dama da alta classe e dançarina de cabaré).

George e Jane se empenham em procurar provas que o inocentem, mas o caso só se complica e as pistas da polícia cada vez mais apontam o médico como culpado. Ele será condenado à câmara de gás, antes de descobrir que tudo não passou de um plano de vingança armado pelo irmão invejoso e a esposa insatisfeita, que não havia morrido, e sim continuara viva, mas escondida sob o disfarce de Monica. 
O momento em que Fulci recorre de maneira enfática à sombra é o da aparição inesperada de George na sessão de fotos. Primeiramente, ouve-se sua voz, vinda do fora de campo. Logo em seguida, surge sua sombra de perfil, projetada sobre a imagem de Liz:

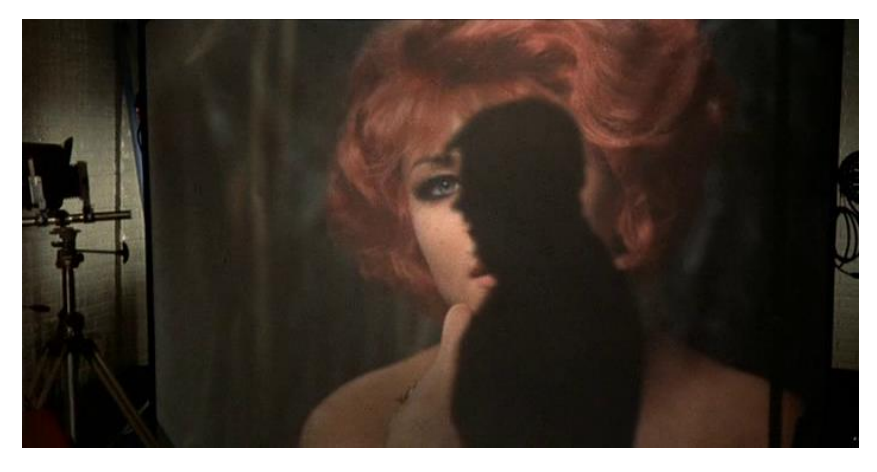

Pouco depois, a câmera recua em travelling e inclui o médico na parte direita do quadro, desta vez apreendido sem mediações ou truques:

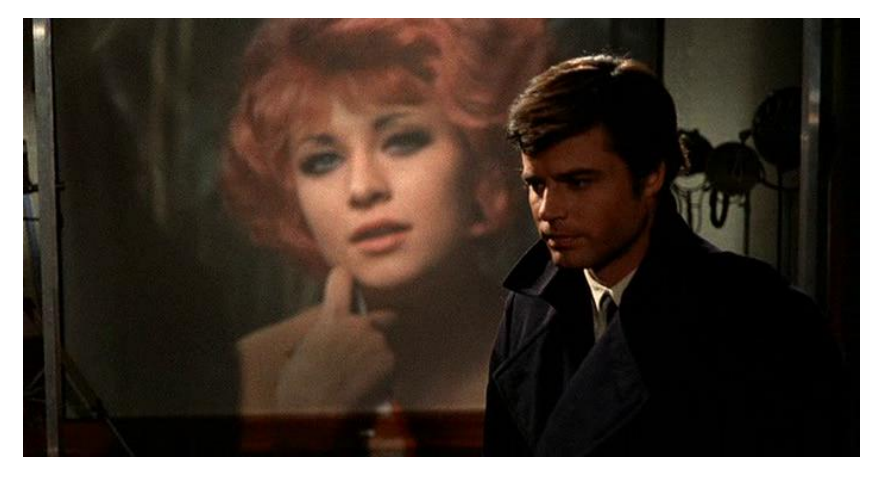

Em não mais que cinco segundos, portanto, Fulci faz uma breve progressão, uma pequena escala crescente de epifenômenos de representação do corpo humano. Ele começa pela voz, que irrompe como um eco proveniente do extracampo, elemento puramente auditivo, sopro imaterial, mas não por isso menos real que os elementos ópticos. Em seguida, surge a sombra (e trata-se da sombra de um perfil, cujos significados para o mito de origem da representação artística ocidental já foram mencionados no segundo capítulo, e voltarão a estar em pauta daqui a pouco), que se projeta sobre uma fotografia (a foto de Liz exibida no telão), fundindo, assim, dois extremos da mimesis: uma forma arcaica de produzir duplos, a sombra, o membro pobre da família dos signos representativos, e uma forma moderna, a fotografia, situada na ponta da história dos meios de reprodução mimética do mundo visível. Depois da voz e da sombra, enfim, aparece o corpo do ator, agora filmado diretamente pela câmera de 
cinema, sem rebatimento como sombra, reflexo especular ou qualquer outra coisa que o valha. Voz, sombra, imagem fotográfica, imagem cinematográfica: a progressão é simples e evidente. Nesse universo de falsos semblantes e armadilhas ópticas, Fulci demonstra que há diferentes gradações, diferentes escalas de semelhança e níveis de ilusão mimética.

Mas a principal função da sombra nessa cena é perturbar a realidade, trazer a ela um eco daquele mundo oculto e enigmático de que falávamos anteriormente, aquele limbo obscuro do qual as sombras funcionam como vasos comunicantes. A sombra de George Dumurrier sobre a foto de Liz indica pelo menos duas coisas: em primeiro lugar, ela prefigura uma descoberta que Jane e George só farão mais tarde, isto é, a descoberta de que Liz foi a mulher que morreu no lugar da esposa do médico, a mulher que ele enterrou achando que era a Sra. Dumurrier (ela foi o cadáver de substituição, por assim dizer); em segundo, a sombra inscreve na imagem a ameaça que pesa sobre a própria personagem de Jean Sorel, ou seja, a ameaça da pena de morte. Nos dois casos, trata-se de figurar, por meio da sombra, uma relação inelutável com a morte, uma cadeia de fatalidade que as personagens não podem contornar ou ignorar. Nos poucos segundos em que é somente uma sombra, George já inicia um processo de transição para “o outro lado". Como Aumont observa, "a palavra 'sombra', já em sua forma latina umbra, tem também essa significação do ser que passou para o outro lado (para o lado da morte) e que doravante só existe de um modo imaterial, ainda que visível". ${ }^{64}$

No mesmo ano de Una sull'altra, outro mestre do cinema popular italiano, Riccardo Freda, realizou A doppia faccia (relançado na França em 1973 com o título Liz et Helen), que possui enormes semelhanças com o filme de Lucio Fulci, o que não surpreende, já que o roteiro foi escrito por ele.

Klaus Kinski interpreta Alexander, um milionário que perde a esposa num acidente de carro. A polícia descobre que o acidente foi fruto de um ato de sabotagem, e Alexander se torna suspeito de ter assassinado a esposa para ficar com a herança. Depois da morte da esposa, Alexander, que sabia que ela era lésbica e tinha uma amante, sai da mansão em que vivia com ela e se instala num hotel. Uma bela noite, ele retorna à mansão, que agora se encontra abandonada e escura. Lá dentro, descobre Christine, uma jovem de 18 anos que invadiu a casa enquanto não havia ninguém. Ela o arrasta para uma festa hippie-psicodélica onde, lá pelas tantas, alguém começa a projetar um filme pornô em que, durante uma cena de lesbianismo, Alexander reconhece numa mulher encapuzada características inconfundíveis de

\footnotetext{
${ }^{64}$ Ibid., p. 42.
} 
sua esposa supostamente morta (uma cicatriz no pescoço e um anel com uma joia em formato de cobra). Para aumentar a estranheza do caso, ele descobre que o filme foi realizado numa data posterior à da morte da esposa. Outros indícios de que ela pode estar viva começarão a surgir, até que, no clímax ambientado numa catedral gótica, o agente que investigava o caso expõe o desenlace: o sogro de Alexander havia planejado a morte da própria filha, para ficar com a parte dela na empresa, e contratara uma sósia da moça para atormentar Alexander e enlouquecê-lo com a hipótese de que ela pudesse estar ainda viva ou seu fantasma rondasse por aí. O intuito era caracterizar Alexander como insano para incentivar a polícia a apertar o cerco sobre ele.

Importante sublinhar que, quinze anos antes de Dublê de corpo, A doppia faccia já encenava aquela situação em que a mulher morta "volta à vida" num filme pornô e é identificada por sinais muito específicos (no filme de De Palma era a forma de dançar, bem como a tatuagem na nádega esquerda da atriz pornô; aqui é a cicatriz no pescoço e o anel). Se o herói de Dublê de corpo pode simplesmente ir a uma locadora de vídeo e alugar o tal filme pornô em que viu sua musa retornar dos mortos, o de A doppia faccia, que vive numa época anterior à liberação da pornografia, tem de recorrer ao mercado clandestino para conseguir o filme em que identificou sua esposa. Vendo-o de novo, ele fica com mais certeza ainda de que a atriz encapuzada é sua mulher.

A cena em que ele assiste novamente ao filme, depois de tê-lo comprado (por uma alta quantia) e levado para casa, lembra o início de A prisioneira. Mas a diferença é que Simon apenas desconfiava de que sua companheira mantivesse relações com outras mulheres, ao passo que Alexander tem certeza, pois flagrou a esposa com a amante em mais de uma ocasião, em cenas que já tinham colocado A doppia faccia num registro totalmente exploitation.

O filme a que a personagem de Klaus Kinski assiste é uma versão pornográfica do “mundo só de mulheres" que Simon contemplava nos seus arquivos em 8mm: a cena inocente das meninas se divertindo na praia se troca aqui pela cena de sexo explícito entre duas mulheres. Tal como Simon fizera, Alexander também se aproxima da tela, interceptando o cone de luz do projetor de modo a ter o contorno de sua silhueta inserido como uma sombra sobre a imagem do filme dentro do filme. A participação da sombra projetada, neste caso, é mais discreta e parece mais fortuita do que no filme de Chantal Akerman, no qual ela integra um programa figurativo muito mais demarcado e deliberado. Mas não deixa de ser interessante sua presença em A doppia faccia, impondo-se na cena praticamente como se 
fosse um acessório obrigatório dessa situação visual que envolve um espectador masculino assistindo à projeção cinematográfica da imagem feminina que o perturba e obceca.

Ao lado de Una sull 'altra, A doppia faccia forma um curioso par: uma dupla de gialli dedicados a reconstruir Vertigo a partir do remanejamento de suas principais peças narrativas. Mas enquanto Fulci ambienta seu filme em São Francisco (uma São Francisco mais moderna e trivial que a de Vertigo), Freda opta por uma Londres perdida entre a era vitoriana, a psicodelia do final dos anos 1960 e o gótico flamejante que marcou seus filmes desse período.

Como se vê, Hollywood não foi o primeiro lugar em que o cinema de Hitchcock seria revisitado, mas sim a Europa, e a Itália em particular, onde os filmes do diretor já começaram a ser citados, imitados e reelaborados desde o começo dos anos 1960, muito antes de Brian De Palma iniciar seu ciclo hitchcockiano com Irmãs diabólicas (Sisters, 1973) e Mel Brooks criar sua paródia-homenagem a Hitchcock com Alta ansiedade (High Anxiety, 1977). Em 1962, Riccardo Freda já realizava o exuberante $O$ diabólico Dr. Hichcock (L'orribile segreto del Dr. Hichcock), que não apenas traz um protagonista cujo nome é Hichcock (Hitchcock menos o “t”) como ainda se inspira em Rebecca e Vertigo para dar um acento necrófilo à vertente gótica do cinema de horror italiano. Nos anos seguintes, Mario Bava inventaria o giallo com dois filmes assumidamente hitchcockianos: o primeiro, Olhos diabólicos, de 1963, já contém uma piscada de olho para Hitchcock no próprio título original (La ragazza che sapeva troppo: "A mulher que sabia demais"); o segundo, Seis mulheres para o assassino (Sei donne per l'assassino, 1964), que é o primeiro giallo propriamente dito (Olhos diabólicos, filmado em preto e branco, ainda carecia do tratamento paroxístico das cores, que seria uma das marcas registradas do gênero), inspira-se nas icônicas sequências de assassinato de Psicose e mostra uma série de cenas de morte que praticamente valem por si mesmas, a intriga pouco coerente sendo um pretexto para que essas mortes possam existir, uma mais elaborada e estilizada que a outra, levando ainda mais longe a audácia visual e a violência do filme de Hitchcock.

$$
* * *
$$

O motivo visual sobre o qual estamos nos detendo há algumas páginas (a sombra projetada de um corpo humano) é o elemento central da conhecida fábula de Plínio sobre a origem da pintura. Conforme já expliquei no segundo capítulo, Plínio atribui a uma jovem de Corinto, na Grécia antiga, o primeiro gesto pictórico ocidental: ela traçou na parede os contornos da sombra do homem que amava, e que estava partindo para longe. Essa narrativa 
fundadora situa o nascimento da pintura "sob o signo de uma ausência/presença (ausência do corpo/presença de sua projeção)", e a "dialética dessa relação pontua a história da arte". ${ }^{65}$

Relendo com atenção a obra de Plínio, Stoichita identifica duas passagens diferentes em que esse mito das origens da representação no Ocidente é evocado: "Na primeira passagem, o autor fala da origem da pintura; na segunda, da origem da escultura. Ao que parece, portanto, é a representação artística em geral que encontra sua origem no estágio primitivo da sombra". ${ }^{66}$ Analisando o texto nas suas entrelinhas, Stoichita chega a uma importante conclusão:

O caráter primordial dessa primeira operação de representação, tal como ela nos é transmitida por Plínio, reside no fato de que a imagem pictural das origens não teria sido o fruto de uma observação direta de um corpo humano e sua representação, mas de uma fixação da projeção desse corpo. A sombra opera uma redução do volume sobre a superfície. Essa primeira operação (fundamental) de transposição e de redução, portanto, é confiada por Plínio à própria natureza. $\mathrm{O}$ artista só intervém num segundo momento. Representação da representação (imagem da sombra), a primeira pintura nada mais é que a cópia de uma cópia. ${ }^{67}$

Em resumo: a primeira imagem pictural não foi produzida com base na realidade ou no "ente verdadeiro", mas já partindo de uma imagem precedente, a sombra no muro, cuja projeção se deu como consequência natural do fenômeno luminoso. Para conceber uma imagem, o artista precisou de um molde figurativo prévio, de uma primeira imagem a ser copiada. Em outras palavras, o que a fábula de Plínio nos conta, mais do que a própria origem mítica da pintura, é o advento do simulacro na arte ocidental.

Acompanhemos mais um pouco o raciocínio de Stoichita:

O primeiro simulacro é criado na ocasião da partida do ser amado. A lenda não nos diz para onde nem por que ele parte, mas menciona somente o fato de que ele deve ir para longe (abeunte illo peregre). A jovem rapariga retém (circumscripsit), com a ajuda da sombra, a imagem do amante que se vai, criando assim uma figura de substituição. Vê-se que o que está em jogo nessa passagem não é pouco: trata-se, com efeito, de uma metafísica da imagem, cuja origem deveria ser buscada numa relação erótica interrompida, na separação, na partida do modelo, donde o caráter de substituto dado à representação. ${ }^{68}$

\footnotetext{
${ }^{65}$ V. I. Stoichita, Brève histoire de l'ombre, op. cit., p. 7.

${ }^{66} \mathrm{Ibid} .$, p. 11

${ }^{67}$ Ibid., p. 12.

${ }^{68}$ Ibid., p. 15.
} 
Esse "primeiro simulacro", então, possui tanto uma função mnemônica quanto uma dimensão erótica: ele é fruto de um gesto amoroso que visa a conservar um traço físico do ser amado e desejado, a fim de torná-lo presente mesmo em sua ausência futura.

Uma bela representação dessa cena originária se acha num quadro exposto num dos museus visitados por Guerín em Unas fotos en la ciudad de Sylvia:

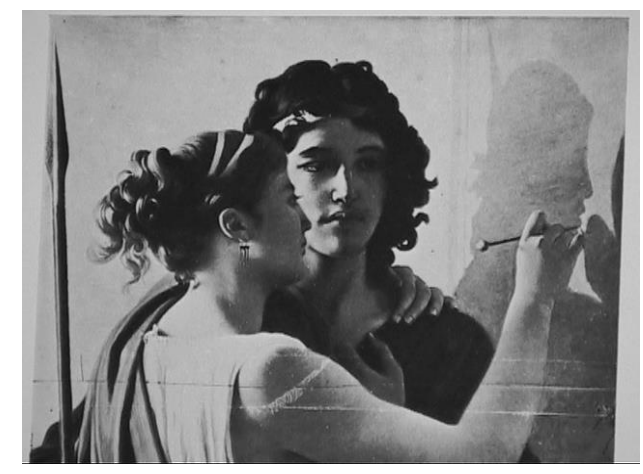

A imagem se encaixa perfeitamente no filme, e até o elucida, na medida em que Guerín também está tentando apreender os contornos de uma pessoa amada (nem que tenha sido um amor de uma só noite), cuja silhueta ele tenta projetar na tela da sua mente. A cada foto, a cada palavra, lembrança ou vivência trazida ao filme, ele acrescenta um novo traço, um novo detalhe do rosto que algum dia esteve diante dele, mas se foi, deixando para trás apenas esse vestígio, essa figura traçada na placa sensível da memória. ${ }^{69}$

Inserindo em Unas fotos en la ciudad de Sylvia, filme quase inteiramente realizado com fotografias, uma imagem que ilustra o mito de origem da representação ocidental tal como este foi narrado por Plínio, Guerín nos incita a pensar a ligação dessa fábula com o próprio dispositivo fotográfico. Dubois discorre sobre essa relação em $O$ ato fotográfico. Ele destaca primeiramente os elementos que o dispositivo da narrativa pliniana tem em comum com a fotografia: a existência de uma superfície de inscrição; o caráter instantâneo do processo de surgimento da sombra (que "ocorre por inteiro de uma só vez sob o impulso luminoso"); a projeção; a "escrita pela luz (foto-grafia)" de uma figura (a sombra do rapaz), "puro índice, que só existe na presença de seu referente", e que deverá ainda "ser duplicada

\footnotetext{
${ }^{69}$ Depois dessa aparição em Unas fotos, a fábula de Plínio ainda ressurge na obra de Guerín numa instalação denominada La Dame de Corinthe, criada no Museu de Arte Contemporânea Esteban Vicente, em Segóvia, e depois recriada no Centro Georges Pompidou, em Paris, no quadro da exposição/retrospectiva "Jonas Mekas/José Luis Guerín. Cinéastes en correspondance", que aconteceu de 30 de novembro de 2012 a 7 de janeiro de 2013.
} 
por um desenho que virá fixá-la por decalque direto". ${ }^{70}$ Indicialidade, planaridade, instantaneidade, duplicação/fixação: de fato, o paradigma da fotografia já se acha prenunciado na história contada por Plínio.

Júlio Bressane parece ter isso em mente quando filma A erva do rato em 2008, pois há um plano do filme que é praticamente uma demonstração do ato fotográfico enquanto reencenação da fábula de Plínio. Trata-se do momento em que, com uma máquina fotográfica, Selton Mello capta diferentes ângulos do rosto de Alessandra Negrini, que tem sua sombra projetada de perfil na parede.

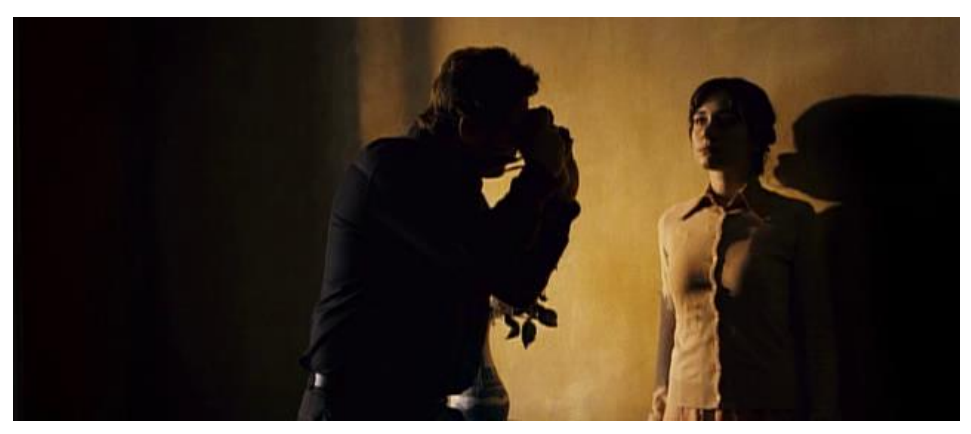

O dispositivo proposto por Plínio sofre variações na sua transposição para o filme. Há, em primeiro lugar, uma troca de papeis entre o homem e a mulher: aqui, em vez de a mulher fixar a imagem do homem, é ele quem fixa a imagem dela. E, para tanto, ele não dispõe de um pedaço de carvão, mas de uma câmera fotográfica.

A pose estática da mulher, seu visível esforço para não se mexer enquanto é feita a fotografia, indica exatamente o que está em jogo: uma fixação, uma petrificação, quiçá uma mortificação, já que seu corpo tem de estancar o movimento da vida para melhor se adaptar ao espaço fotográfico para o qual está sendo enviado. Ela é estatuificada antes de ser fotografada. O que a fotografia fixa, então, não é o corpo, mas esse outro do corpo, esse devir-imagem que ele assume de modo a se preparar para sua representação em retrato (quer dizer, em retração, em retirada ${ }^{71}$ ). Em última instância, o que está em ação é um trabalho de morte, que se dá na passagem do índice ao ícone. O impulso de fixar o rosto de uma pessoa na iminência de partir, ou de fazer o seu retrato - como a jovem de Corinto fez com o namorado, e como a personagem de Selton Mello faz com a de Alessandra Negrini em A erva do rato -, visando a reter alguma coisa, algum traço talvez não de uma presença, mas de uma fuga, de um corpo

\footnotetext{
${ }^{70}$ P. Dubois, $O$ ato fotográfico, op. cit., p. 118.

${ }^{71}$ Ver J.-L. Nancy, L'Autre Portrait, op. cit., p. 15.
} 
em processo de retirada, esse impulso, em suma, abre um diálogo com a morte: fixado "além de sua própria ausência", o referente acaba designado "como inelutavelmente perdido, doravante inacessível como tal para o presente"; ele é remetido "a uma ausência inexorável, ao esquecimento, à carência, à morte". ${ }^{72}$ Afinal de contas, a partida de um ente querido significa, em última análise, seu desaparecimento (no que esta palavra tem de eufemismo para o acontecimento do óbito).

Em A erva do rato, a morte deixa seu carimbo em quase todos os planos. Já começando pela primeira cena do filme, que se passa num cemitério. Selton Mello e Alessandra Negrini, que ainda não se conhecem, estão parados diante de lápides de familiares. Ela sofre uma queda e tem um desmaio. Ele vai ao socorro da moça, e a leva para casa. Coagida a revelar seu passado, ela confessa que esteve na prisão, de onde acaba de sair. Ele oferece a ela estadia em sua casa. Em troca, ela escreverá os textos que ele dita, e cujos temas, de escopo enciclopédico, variam da botânica à mitologia passando pela geografia, a antropologia etc. Aos poucos, ele a convence a posar como modelo para ensaios fotográficos que, ligeiramente pervertidos num primeiro momento, vão se tornando explicitamente eróticos à medida que ele explora o corpo nu da moça por ângulos cada vez mais invasivos, até fotografar seu sexo em primeiríssimo plano.

O momento da revelação dessa fotografia é demorado, vagaroso, filmado num planosequência que preserva toda a duração do processo. A luz vermelha do laboratório dá um aspecto singular à imagem; o protagonista manipula o papel fotográfico, banha-o na solução química; uma mancha começa a aparecer muito lentamente no papel antes em branco; aos poucos, a imagem ganha visibilidade, a figura desponta, até que surge o sexo feminino captado de um ângulo que se reporta ao famoso quadro A origem do mundo, de Gustave Courbet, pintado em 1866.

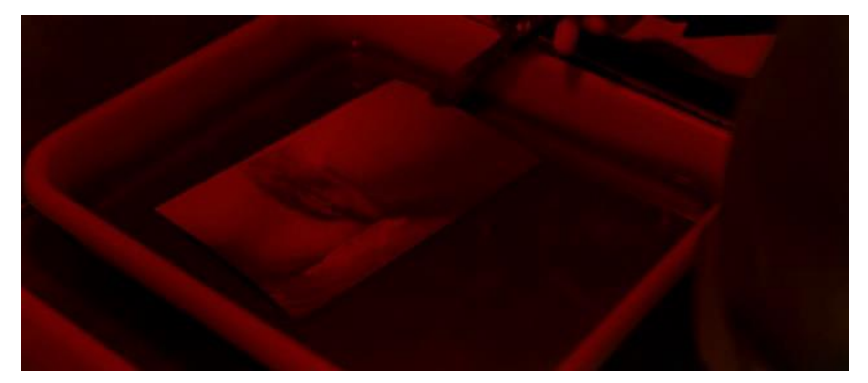

${ }^{72}$ P. Dubois, $O$ ato fotográfico, op. cit., p. 120.

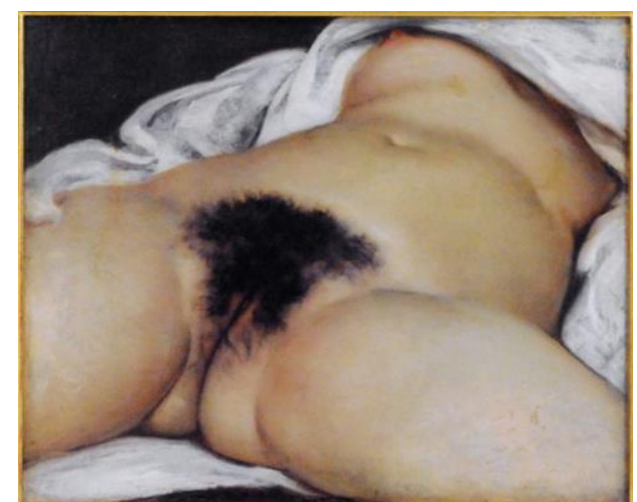

Gustave Courbet, L'Origine du monde, 1866 
A imagem do sexo feminino fotografado e revelado oferece ao protagonista de A erva do rato a mesma "frontalidade siderante" ${ }^{, 73}$ do quadro de Courbet. Não é só o observador que olha para a imagem: a imagem também olha para o observador e o petrifica.

Um plano complementar a esse é aquele de Alessandra Negrini deitada na cama, com o cabelo espalhado no travesseiro de modo a evocar a personagem mitológica da Medusa (a figura feminina com cabeleira de serpentes vivas, que atraía irresistivelmente o olhar dos homens somente para transformar em pedra todos aqueles que a olhassem, até o dia em que Perseu a decapitou com sua espada):

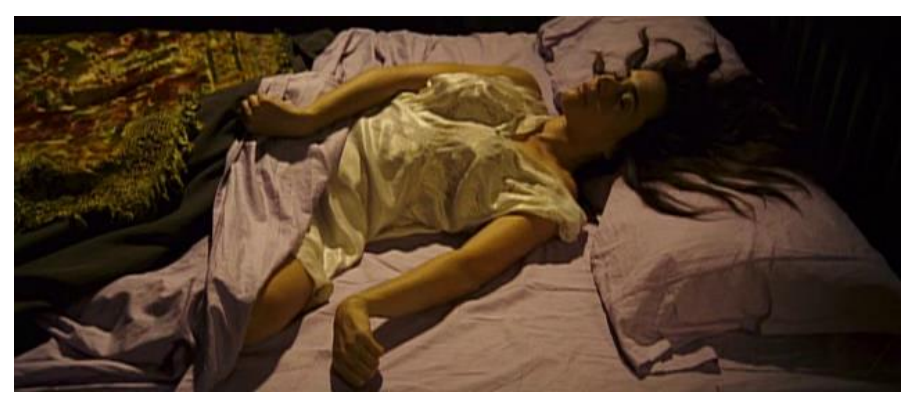

A respeito desse mito, Freud escreveu que a cabeça de Medusa pode ser vista como "um substituto da representação do sexo feminino", definindo a vitória de Perseu sobre a temida Górgona da seguinte forma: "Decapitar = castrar. O medo da Medusa é portanto o medo da castração ligado à visão de algo". 74 "No fundo, quem olha o sexo de uma mulher nua, coxas abertas, está diante da Medusa, da efígie terrível, da cabeleira de serpentes”, diz também Denis Roche. ${ }^{75}$ Ora, o texto de Freud sobre o mito de Medusa pode muito bem ter sido uma das inspirações de Bressane, que associa claramente as ambivalências despertadas por essa figura (repulsão e atração, excitação e medo, ameaça e aparição estupefaciente) ao que a personagem de Selton Mello parece sentir ao revelar a fotografia da vulva da sua companheira.

Essa dimensão erótica da fotografia não é uma questão meramente circunstancial. Comentando a fábula de Plínio, Dubois já chamava a atenção para

a relação da imagem com o desejo e o papel do índice nessa relação. As circunstâncias amorosas nas quais se desenvolve essa história do

\footnotetext{
${ }^{73}$ D. Arasse, Le Détail, op. cit., p. 362.

${ }^{74}$ S. Freud apud P. Dubois, $O$ ato fotográfico, op. cit., p. 153.

${ }^{75}$ Ibid., p. 154.
} 
nascimento da pintura e que a motivam diretamente, evidentemente não são inocentes. Em particular, fica claro que isso indica uma congruência evidente entre desejo e índice. [...] Como eco a essa dimensão desejante da fábula primitiva da sombra pintada, poderíamos evocar tudo o que se refere aos usos sentimentais da fotografia (fotos de amor, fotos de morte, álbuns de família etc. [...] $)^{76}$

Uma vez que a fotografia, assim como a sombra na parede, tem valor de índice, de signo de conexão física, ela serve como "testemunho da presença real do corpo referencial", e pode ser incluída numa economia do desejo que a ausência do corpo desejado teria, a princípio, destruído. "A proximidade física que define o estatuto específico do índice corresponde por inteiro às exigências da relação amorosa". ${ }^{77}$

É levando essa relação ao paroxismo que a personagem de Selton Mello despe e devora com a máquina fotográfica o corpo da mulher. Primeiramente, ele a faz perder o pudor; em seguida, as vestes; por fim, só restará dela o esqueleto - sua carne será consumida pela repetição compulsiva do ato fotográfico, como se este lhe roubasse uma camada a cada novo clique. Impossível não pensar na velha crença, da qual Balzac foi um ilustre partidário, de que a fotografia esgotava o corpo, furtava-lhe as camadas de espectros sobrepostas de que ele era composto. Se o corpo era "apenas um envelope feito unicamente de muitas camadas sucessivas", cada "operação daguerriana”, ou cada fotografia, destacava dele uma dessas "películas infinitesimais" 78 ; pela operação sucessiva, o corpo ia perdendo seus espectros, e o resultado, caso se persistisse nesse processo ad nauseam, seria talvez o que se vê em A erva do rato: a perda total da aparência viva do corpo, do qual só resta o esqueleto, a matéria inorgânica, sua parte morta. E o fotógrafo não desiste diante desse corpo em perda de si mesmo: ele continua fotografando o esqueleto, sem parar, com compulsão ainda maior.

Além dessa dimensão mortífera da fotografia, reencontramos em $A$ erva do rato o motivo central das ficções de retrato de que falamos no segundo capítulo: a relação doentia entre artista e modelo, que culmina na morte deste último como condição para o êxito da obra do primeiro. Trata-se de um esgotamento da vida, que se troca pela sua representação.

Para reforçar o clima mórbido de A erva do rato, Bressane alude a alguns dos motivos pictóricos mais fortemente conectados aos temas que gravitam em torno da morte. A começar pela natureza morta, gênero que ganhou prestígio nos Países Baixos e na Espanha do Século

\footnotetext{
${ }^{76}$ Ibid., pp. 121-122.

${ }^{77}$ Ibid., p. 122.

${ }^{78}$ Nadar apud P. Dubois, $O$ ato fotográfico, op. cit., p. 227.
} 
de Ouro, estando não raro associado ao tema da vanitas, em que um conjunto de objetos simbolizava a futilidade e a insignificância da vida terrena: signos de putrefação (moscas a pousar nos alimentos, por exemplo), da passagem do tempo (ampulhetas, relógios), da inevitabilidade da morte (crânios humanos).

Um plano de A erva do rato lembra as naturezas mortas sóbrias e meditativas do pintor espanhol Juan Sánchez Cotán, que, nos primeiros anos do século XVII, dedicou-se a uma série de bodegones que sempre apresentavam uma quantidade restrita de frutas e legumes num espaço delimitado por um nicho retangular.
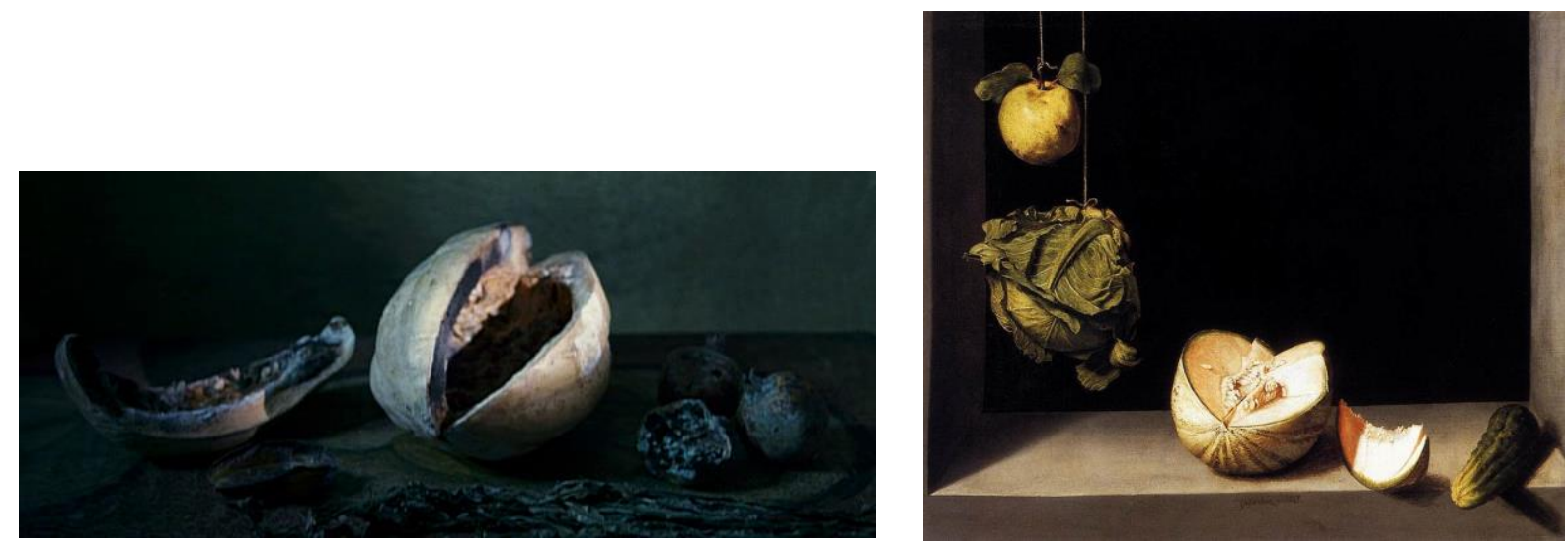

Juan Sánchez Cotán,

Marmelo, repolho, melão e pepino, 1602

Uma das frutas representadas por Bressane, a romã cortada ao meio, era muito comum nas naturezas mortas do século XVII: pela riqueza de detalhes visíveis, o interior da romã era um ótimo motivo para os pintores exibirem seu virtuosismo, exercitarem sua habilidade na representação fidedigna do natural e aprimorarem seu gosto pelas nuanças.

Do bodegón de Sánchez Cotán (que privilegia objetos humildes e em pequeno número - nada de cristais e prataria, nada dos alimentos exóticos, das mesas fartas, da profusão de luxo e ostentação de algumas naturezas mortas holandesas, as chamadas pronkstilleven), Bressane "imita" não apenas o melão cortado (que aqui é substituído por uma abóbora) como também o rigor da composição e a forma de iluminação ao estilo do tenebrismo caravaggesco. Mas à aparência saudável dos alimentos vistos na pintura espanhola contrapõe-se a mensagem de morte contida no plano rodado por Bressane: as frutas e legumes estão apodrecidos, e uma mosca está pousada sobre a abóbora, sua presença sendo enfatizada pelo som, que traz a primeiro plano o zunido da mosca. Esses elementos servem para transformar a imagem numa vanitas. O plano ilustra de certa forma o assunto mais geral de que trata o cinema: a ação do 
tempo sobre as coisas (a morte em andamento). E não é preciso uma ampulheta em quadro a simbolizar esse efeito do tempo: ele já existe na própria duração do plano.

Nesse filme atravessado de erudição, as referências se multiplicam: outra evocação da morte mediada pelo imaginário pictural se dá numa cena em que Negrini tenta se afogar na banheira, remetendo às heroínas lânguidas e cianóticas da pintura romântica, sensualizadas na sua morbidade mesma, a exemplo da Ofélia de John Everett Millais, representação sublime da personagem suicida de Hamlet:

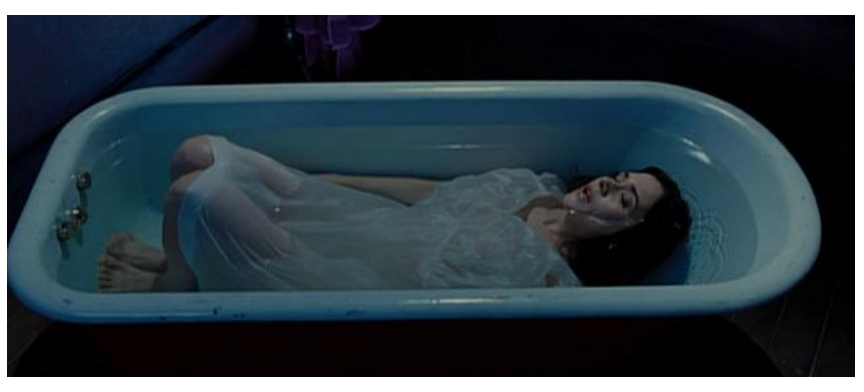

Esse quadro, vale observar, já havia sido a referência visual da cena em que Madeleine, na primeira parte de Vertigo, atira-se na baía de São Francisco, aos pés da Golden Gate Bridge, para ser salva por Scottie. Antes de se jogar, ela enche de flores a água do mar, reforçando a conexão com o quadro de Millais.
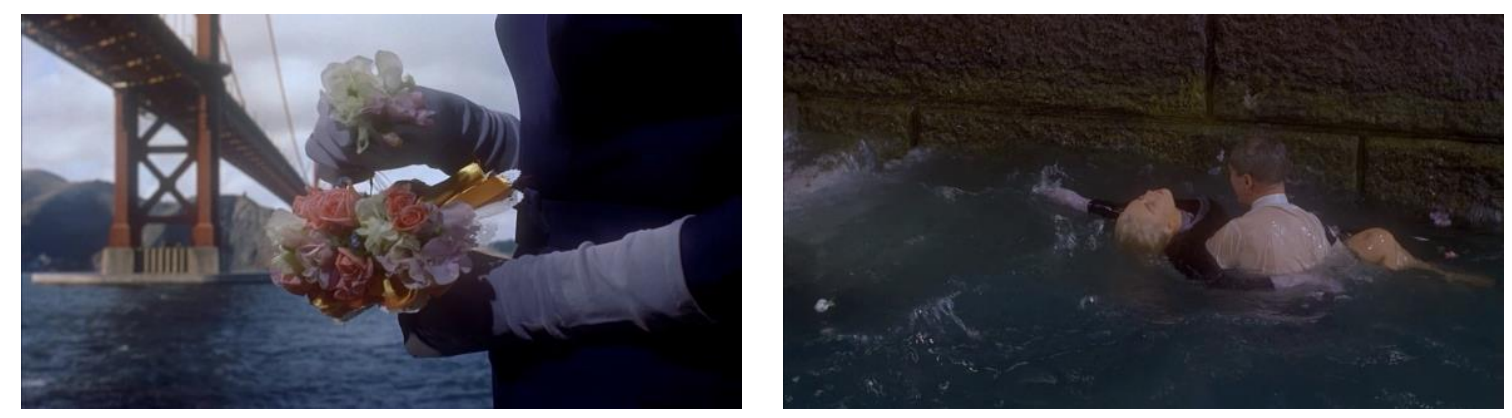

Bressane provavelmente não pensou em Vertigo ao rodar aquele plano da sua atriz na banheira. Mas tinha, decerto, clara noção do lugar que aquela imagem ocupa na tradição romântica. 
Num dos planos mais intrincados de A erva do rato, o fotógrafo decide inserir no contexto da captação das fotos uma instância observante, aí representada por um rosto de papelão desenhado e recortado de perfil. Uma fonte de luz é direcionada a esse espectador fictício, de modo a projetar na parede a sombra do pequeno rosto de papelão, que lá aparece agigantado pela "magia das desproporções"79 própria do jogo de manipulação da luz responsável pelo poder expressivo da sombra projetada.

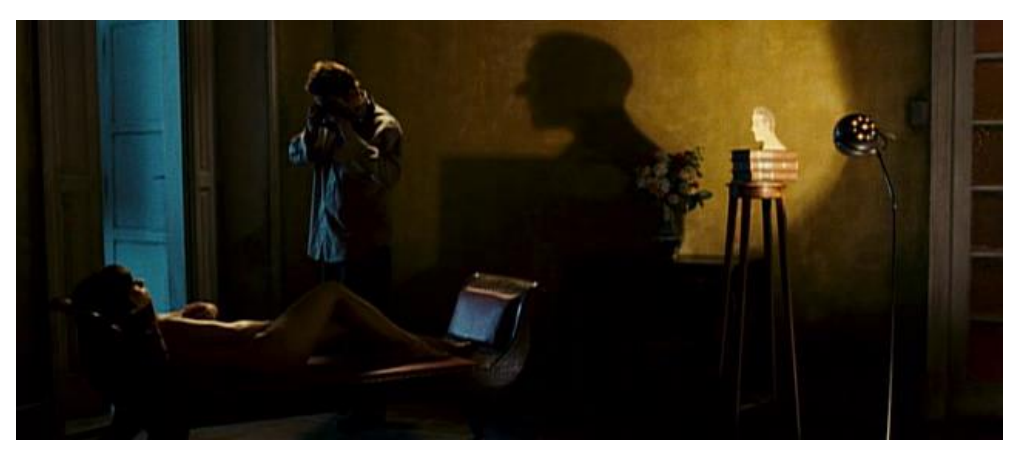

Essa sombra inclui na "cena de ateliê" a presença figurada do espectador, que complica o dispositivo da representação ao se introduzir no campo visual e ocupar o mesmo espaço que o artista e a modelo nua. Esse elemento novo pode ser definido como um olhar que faz sombra dentro da cena, colocando em relevo "o fato de que o 'nu' (o que nossa tradição designa como tal) é o resultado de uma projeção, de uma atividade voyeurística". ${ }^{80}$

A sombra do rosto de papelão será vista também num plano feito com enquadramento aproximado, no decorrer do qual haverá uma metamorfose da sombra, que se transformará na silhueta de um homem-rato. Esse pequeno jogo de animação de sombras nos atenta novamente para a facilidade com que a sombra se presta à magia e à representação ilusória.
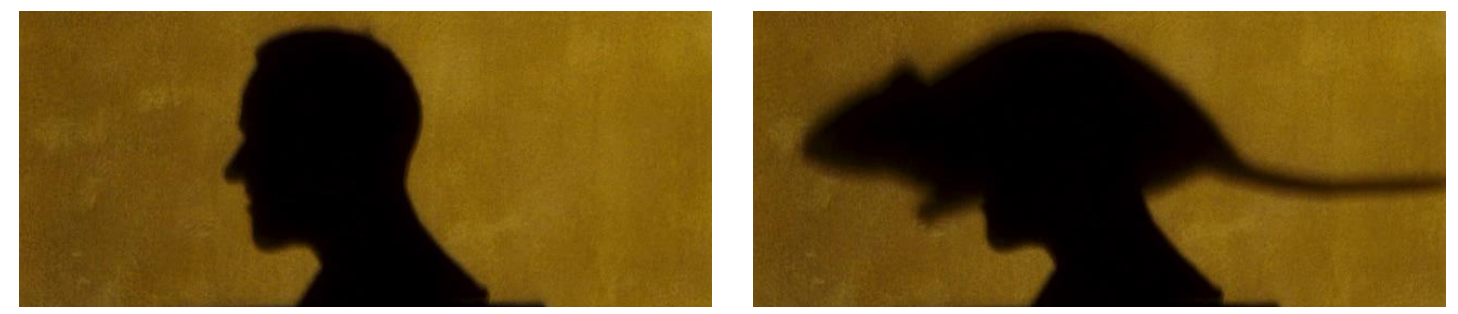

A primeira das duas imagens acima obedece aos mesmos princípios formais das gravuras que ilustram os estudos fisiognomônicos de Johann Caspar Lavater. De acordo com

\footnotetext{
${ }^{79}$ J. Aumont, Le montreur d'ombre, op. cit., p. 36.

${ }^{80}$ V. I. Stoichita, Brève histoire de l'ombre, op. cit., p. 128.
} 
esses estudos, publicados no final do século XVIII, era a sombra fixada de perfil, mais do que a representação do rosto, o que revelava a estrutura profunda da alma: "A sombra desvela o que a pessoa pode esconder". ${ }^{81}$ Projetada para fora do corpo, a sombra se torna uma exteriorização da alma, a visualização de uma verdade obscura que, inscrita numa superfície, torna-se legível.

Há aí toda uma história que vai da cena primitiva da pintura à fotografia e ao cinema, passando pelas máquinas de desenhar silhuetas do século XVIII, pela camera lucida e tantos outros dispositivos que confirmam a persistência da forma simbólica do perfil como convenção representativa ao longo da história das imagens.

${ }^{81}$ Ibid. p. 170. 


\section{Conclusão}

Avaliada em retrospecto, esta tese apresenta pelo menos duas grandes linhas de força. A primeira delas compreende um estudo iconológico do que podemos denominar os motivosVertigo, isto é, uma investigação estética e histórica das formas de Vertigo reincidentes em diversas obras do cinema moderno e contemporâneo - o que não exclui o mapeamento e a análise de tropos hitchcockianos provenientes de outros filmes (Janela indiscreta, Interlúdio, Psicose). A segunda linha de força corresponde a uma tarefa hermenêutica mais exigente, que consiste em tentar entender os atributos teóricos das imagens que compõem a série-Vertigo, o que implica acessá-las em seu modo próprio de produzir um discurso figurativo que identificamos como sendo um discurso metarreflexivo, uma teoria da arte que se confunde à própria fenomenalidade das obras: se as imagens teorizam, é em sua própria apresentação como imagem, em sua mostração icônica mesma; não se trata de um processo em que as imagens serviriam como mediadores discursivos - elas são a própria teoria em ato.

A principal dificuldade desta segunda empreitada - indissociável da primeira, por exigência interna dos filmes analisados - reside em conseguir se inserir numa lógica de teorização que difere do discurso escrito e demanda outros critérios interpretativos. Compreender em que medida uma obra de arte pode ser uma reflexão teórica não é o mesmo que ler uma teoria enunciada por intermédio de signos linguísticos convencionais. "A experiência da arte jamais compreende apenas um sentido cognoscível, tal como acontece na questão da hermenêutica histórica e em sua lida com os textos." ${ }^{11}$ Em outras palavras, na obra de arte existe aquilo que Gadamer denomina o "encantamento". A linguagem da arte visa ao "excesso de sentido que reside na própria obra. Sobre esse excesso repousa a sua inesgotabilidade, que a distingue de toda transposição conceitual". 2 A experiência da obra de arte ultrapassa a mens auctoris, ou seja, ela se situa para além do próprio ponto de vista do seu autor. É nesse sentido que se prova legítimo interpretar Vertigo como um dispositivo epistemológico que engatilha uma reflexão sobre a arte e a produção das imagens (bem como

\footnotetext{
${ }^{1}$ Hans-Georg Gadamer, Hermenêutica da obra de arte; seleção e tradução Marco Antonio Casanova; São Paulo: WMF Martins Fontes, 2010, p. 7.

${ }^{2}$ Ibid., p. 8.
} 
sua recepção) independentemente de Hitchcock ter almejado um discurso meta-artístico ou simplesmente ter juntado - o que é pouco provável - de forma menos sistemática do que parece uma certa variedade de referências iconográficas e literárias.

As duas linhas de força que enervam esta tese definem, a priori, duas ações contraditórias. De um lado, a vertigem do elenco, da lista, da enumeração compulsiva; o dilúvio de títulos, de signos, de analogias; a eterna cadeia de imagens da série-Vertigo, que não pede para ser fechada, mas infinitamente ampliada. Do outro lado, a necessidade de ordenação, de sistematização da história das formas que buscamos traçar e comentar; a exigência de definir um círculo epistêmico dentro do qual o ato analítico possa se mover com liberdade e desenvoltura, mas acima de tudo com coerência. Foi a partir da dialética entre essas duas ações - o mergulho na vertigem das imagens e a compreensão do sistema que as unifica - que o trabalho lutou para ganhar forma (uma luta prazerosa, apesar de tudo). Esperamos ter alcançado o objetivo de identificar, em cada filme abordado, o tipo de contribuição que ele trazia para o conjunto de reflexões estéticas a que resolvemos dar o nome de teoria artística de Alfred Hitchcock.

É evidente que a série-Vertigo aqui elencada e analisada não se pretende definitiva e completa, ou seja, ela não se encerra no lugar em que colocamos o ponto final. Muitos filmes, quadros, livros, vídeos etc. ficaram de fora, isso é inegável. Por exemplo: seria interessante incluir a instalação "Two Bedrooms in San Francisco" (1992), de David Reed (por mais que só tenhamos conseguido acesso a documentações dessa instalação, e não à obra propriamente dita), em que o artista incrusta pinturas de sua própria autoria nas imagens de uma cópia em vídeo de Vertigo (ele substitui os quadros vistos nos quartos de Judy e Scottie pelos seus), expondo as imagens em monitores localizados em espaços onde se encontram também réplicas das camas das personagens do filme. Poderíamos também pensar no remake plano a plano de Psicose dirigido por Gus Van Sant em 1998, empreitada eminentemente conceitual, um filme inteiro concebido como um comentário crítico e uma exegese artística de uma obra anterior - e que tem tudo, portanto, para se encaixar em nosso percurso, ainda que o filmematriz neste caso seja Psicose e não Vertigo. E o que dizer de Fedora (1978), de Billy Wilder? E de Le Vertige (1926), de Marcel L’Herbier? Enfim, há ainda muitas voltas a dar na espiral hitchcockiana. Basta querer se aventurar. 


\section{Referências bibliográficas}

ACHEMCHAME, Julien. "Essence du cinéma en miroir: regarder le désir en face". In: Cinergon, $\mathrm{n}^{\circ}$ 19-20, 2010.

. Entre l'oeil et la réalité: le lieu du cinéma (Mulholland Drive de David Lynch). Paris: Publibook, 2010.

ALLEN, Richard e ISHII-GONZÁLES, Sam (orgs.). Hitchcock: Past and Future. Londres: Routledge, 2004.

ALLEN, Richard. Hitchcock's Romantic Irony. Nova York: Columbia University Press, 2007.

AMIOT-GUILLOUET, Julie. "Obscène/pudeur, masculin/féminin: les termes d'un débat visuel et discursif au cinéma". In: SEGUIN, Jean-Claude (org.). L'obscène. Lyon: Le Grimh-LCE-Grimia, 2006.

ARASSE, Daniel. Le Détail. Pour une histoire rapprochée de la peinture. Paris: Flammarion, 1996.

Le Sujet dans le tableau. Paris: Flammarion, 1997, 2006.

. L'Annonciation Italienne: une histoire de perspective. Paris: Hazan, 2010.

ARNAUD, Philippe. Les paupières du visible. Yellow Now, 2001.

ASTIC, Guy. Le purgatoire des sens: Lost Highway de David Lynch. Pertuis: Rouge Profond, 2004.

ASTRUC, Frédéric. "Le miroir aux abysses”. In: Cinergon, n 19-20, 2010.

AUMONT, Jacques. "O ponto de vista". In: GEADA, Eduardo. Estéticas do cinema. Lisboa: Dom Quixote, 1985, pp. 125-152.

. De l'esthétique au présent. Paris/Bruxelas: De Boeck Université, 1998.

$\mathrm{n}^{\mathrm{o}} 1$, outono de 2003

"L’objet cinématographique et la chose filmique". In: Cinémas, vol. 14, O olho interminável. São Paulo: Cosac \& Naify, 2004.

Matière d'images. Paris: Éditions Images Modernes, 2005.

Le montreur d'ombre. Paris: Vrin, 2012. 
BACHELARD, Gaston. $O$ ar e os sonhos: ensaio sobre a imaginação do movimento. Trad. Antonio de Pádua Danesi. $2^{a}$ ed. São Paulo: Martins Fontes, 2001.

BARTHES, Roland. A câmara clara. Rio de Janeiro: Nova Fronteira, 1984.

BAUDRILLARD, Jean. Simulacros e simulação. Trad. Maria João da Costa Pereira. Lisboa: Relógio d'Água, 1991.

BAUDRY, Jean-Louis. "Cinema: efeitos ideológicos produzidos pelo aparelho de base". In: XAVIER, Ismail (org.). A experiência do cinema. Rio de Janeiro: Graal/Embrafilme, 1983, pp. 383-399.

BAZIN, André. O Cinema - Ensaios. São Paulo: Brasiliense, 1991.

BELLOUR, Raymond. "O espectador pensativo". In: Entre-imagens: Foto, Cinema, Vídeo. Campinas-SP: Papirus, 1997.

. “Sylvia quitte ou double". In: Trafic, n. 86, verão de 2013.

BELTING, Hans. Likeness and Presence. Chicago: The University of Chicago Press, 1994.

BENJAMIN, Walter. "Pequena história da fotografia". In: Obras escolhidas, vol. 1: Magia e técnica, arte e política. $3^{\mathrm{a}}$ ed. São Paulo: Brasiliense, 1987, pp. 91-107.

BENOLIEL, Bernard. "La Captive: Le temps retrouvé de Chantal Akerman”. In: Cahiers du cinéma, n. 550, outubro de 2000.

BERGALA, Alain. "D'une certaine manière". Cahiers du Cinéma n 370, Paris, abril de 1985. Nul mieux que Godard. Paris: Ed. Cahiers du cinéma, 1999.

BLANC, Jan. Peindre et penser la peinture au XVIIe siècle: La théorie de l'art de Samuel van Hoogstraten. Berna: Peter Lang, 2008.

BLOOM, Michelle E. "Pygmalionesque Delusions and Illusions of Mouvement: Animation from Hoffmann to Truffaut". Comparative Literature, 52, 4, outono de 2000.

BONFAND, Alain. Le cinéma de Michelangelo Antonioni. Paris: Images Modernes, 2003.

Le cinéma saturé : Essais sur les relations de la peinture et des images en mouvement, Paris: PUF, 2007.

BONITZER, Pascal. Le champ aveugle: essais sur le cinema. Paris: Gallimard; Cahiers du Cinéma, 1982.

. Décadrages. Paris: Éditions Cahiers du Cinéma, 1987.

BORGES, Jorge Luis. Ficções. Tradução Davi Arrigucci Jr.. São Paulo: Companhia das Letras, 2007. 
BRENEZ, Nicole. "Puissance d'une forme cinématographique: l'étude visuelle [d'Al Razutis à Brian De Palma]". In: AUMONT, Jacques (org.). Pour un cinéma comparé: Influences et répétitions. Paris: Cinémathèque Française, 1996.

BROOKS, Peter. The Melodramatic Imagination: Balzac, Henry James, Melodrama and the Mode of Excess. New Haven/Londres: Yale University Press, 1995.

BRUSATIN, Manlio. Histoire de la ligne. Paris: Flammarion, 2013.

BURCH, Noel. Práxis do cinema; trad. Marcelle Pithon e Regina Machado. São Paulo: Perspectiva, 1992.

CAMPAN, Véronique e MENEGALDO, Gilles. Du maniérisme au cinéma. Poitiers, La Licorne $\mathrm{n}^{\circ}$ 66, novembro de 2003.

CASTRO DE PAZ, José Luis. Alfred Hitchcock. Madri: Cátedra, 2000.

CHABROL, Claude e ROHMER, Éric. Hitchcock. Paris: Éditions Ramsay, 2011.

CHASTEL, André. Le tableau dans le tableau. Paris: Flammarion, 1978, 2012.

CHATEAU, Dominique. La subjectivité au cinéma: Représentations filmiques du subjectif. Presses Universitaires de Rennes, 2011.

CHAUVIN, Jean-Sébastien. "Mécanique des liquides". In: Cahiers du Cinéma, n. 550, outubro de 2000.

CHEVRIER, Jean-François. Jeff Wall. Paris: Hazan, 2013.

CHION, Michel. David Lynch. Paris: Cahiers du Cinéma, 2007.

CLOVER, Carol J. "Her Body, Himself: Gender in the Slasher Films". In: GRANT, Barry Keith (org.). The Dread of Difference: Gender and the Horror Film. Austin: University of Texas Press, 1996.

COMOLLI, Jean-Louis. "Machines of the visible". In: Teresa De Lauretis e Stephen Heath (orgs.). The Cinematic Apparatus. Nova York: St. Martin's Press, 1980.

CORNWELL, Regina. Snow Seen: The Films and Photographs of Michael Snow. Toronto: PMA Books, 1980.

CRARY, Jonathan. Técnicas do observador: visão e modernidade no século XIX. Rio de Janeiro: Contraponto, 2012.

Suspensões da percepção: atenção, espetáculo e cultura moderna, trad. Tina Montenegro. São Paulo: Cosac Naify, 2013.

DAMISCH, Hubert. Théorie du nuage. Paris: Éditions du Seuil, 1972. 
. L'origine de la perspective, Paris: Flammarion, 1987, 1993.

DANEY, Serge. A rampa. São Paulo: Cosac \& Naify, 2007.

DAVENNE, Christine. Modernité du cabinet de curiosités. Paris: L'Harmattan, 2004.

DELEUZE, Gilles. Logique du sens, Paris: Les Éditions du Minuit, 1969. . L'Image-mouvement, Paris, Les Éditions de Minuit, 1983.

DELORME, Stéphane e ENCREVÉ, Sylvie. "La main ”. In: Au hasard Balthazar, no 2, maio de 1997.

DÉMORIS, René. "L'Héritage de la peinture: le portrait impossible". In: Iris, n. 14-15, outono de 1992.

DEUTELBAUM, Marshall e POAGUE, Leland (orgs.). A Hitchcock Reader. Blackwell Publishing, 1986.

DIDI-HUBERMAN, Georges. Phasmes: Essais sur l'apparition. Paris: Les Éditions de Minuit, 1998. . L'Image survivante. Paris: Les Éditions de Minuit, 2002.

A pintura encarnada; trad. Osvaldo Fontes Filho e Leila de Aguiar Costa. São Paulo: Escuta, 2012.

DOUCHET, Jean. Hitchcock. Paris: Ed. Cahiers du Cinéma, 1999, 2006. La DVDéothèque de Jean Douchet. Paris: Cahiers du cinéma, 2006.

DUBOIS, Philippe. "La Jetée de Chris Marker ou le cinématogramme de la conscience". In: (org.). Theorème 6: Recherches sur Chris Marker. Paris: Presses Sorbonne Nouvelle, 2002, p. 9-44.

. Cinema, vídeo, Godard. São Paulo: Cosac Naify, 2004.

O ato fotográfico e outros ensaios; tradução Marina Appenzeller. $14^{\mathrm{a}}$ ed. Campinas, SP: Papirus, 2012.

DUBOST, Matthieu. La tentation pornographique: Réflexions sur la visibilité de l'intime. $2^{\mathrm{a}}$ ed. Paris: Ellipses, 2014.

ECO, Umberto. Interpretação e superinterpretação. $2^{\mathrm{a}}$ ed. São Paulo: Martins Fontes, 2005. A vertigem das listas. Trad. Eliana Aguiar. Rio de Janeiro: Record, 2010.

ESQUENAZI, Jean-Pierre. Hitchcock et l'aventure de Vertigo. Paris: CNRS Éditions, 2001. 
FALGUIÈRES, Patricia. Le maniérisme: une avant-garde au XVIe siécle. Paris, Gallimard, 2004.

FIANT, Antony; FRANGNE, Pierre-Henry; MOUËLLIC, Gilles (orgs.). Les oeuvres d'art dans le cinéma de fiction. Presses Universitaires de Rennes, 2014.

FLEISCHER, Alain. "La cinémachine de Micheal Snow". In: DAMISCH, Hubert et alii. Michael Snow: Panoramique. Bruxelas: Cinémathèque Royale de Belgique, 1999.

FOCILLON, Henri. Vie des formes. $9^{\mathrm{a}}$ ed. Paris: Presses Universitaires de France, 2010.

FONT, Domènec. Michelangelo Antonioni. Madrid, Cátedra, 2003.

FOUCAULT, Michel. As palavras e as coisas. São Paulo: Martins Fontes, 2002.

2011. O nascimento da clínica. $7^{\mathrm{a}}$ ed. Rio de Janeiro: Forense Universitária, . A arqueologia do saber; traduçao Luiz Felipe Baeta Neves. $8^{\text {a }}$ ed. Rio de Janeiro: Forense Universitária, 2013.

FREUD, Sigmund. Escritos sobre a Psicologia do Inconsciente, volume 3: 1923-1940. Trad. Luiz Alberto Hanns (coord.). Rio de Janeiro: Imago, 2007.

FRIEDLÄNDER, Walter. Maniérisme et antimaniérisme dans la peinture italienne. Paris: Gallimard, 1991.

GADAMER, Hans-Georg. Hermenêutica da obra de arte; seleção e tradução Marco Antonio Casanova. São Paulo: WMF Martins Fontes, 2010.

GARNER, Philippe e MELLOR, David Alan. Antonioni’s Blow-up. Göttingen: Steidl, 2010.

GUERIN, Marie Anne. Le récit de cinéma. Paris: Cahiers du Cinéma, col. "Les petits cahiers", 2003.

HITCHCOCK, Alfred. “All about melodrama”. In: Cahiers du cinéma, n. 537, julho/agosto de 1999.

HOCKE, Gustav. Maneirismo: o mundo como labirinto. São Paulo: Perspectiva/Edusp, 1974.

HOFFMANN, E.T.A. A janela de esquina do meu primo. São Paulo: Cosac Naify, 2010.

JAMESON, Fredric. La estética geopolítica: Cine y espacio en el sistema mundial. Barcelona: Paidós, 1995.

Ática, 1997. Pós-modernismo - A lógica cultural do capitalismo tardio. São Paulo: 
. "Spacial systems in North by Northwest". In: ZIZEK, Slavoj, Everything you always wanted to know about Lacan... but were afraid to ask Hitchcock. Londres, Nova York: Verso, 1992.

JOUSSE, Thierry. "Lost Highway, l'isolation sensorielle selon Lynch". In: Cahiers du cinéma, n. 511, março de 1997.

JUSSELLE, Jacques. "Un rectangle nommé Ménines ou sage comme une image". In: Champs visuels, $\mathrm{n}^{\circ}$ 12-13, janeiro de 1999.

KATSAHNIAS, Iannis. Francis Ford Coppola. Paris: Éditions de l'Étoile/Cahiers du cinéma, 1997.

KERSWELL, J. A. The slasher movie book. Chicago Review Press, 2012.

KUHN, Annette. The power of the image. Londres, Nova York: Routledge, 1985.

LACAN, Jacques. "La science et la vérité". In: Écrits 2. Paris: Éditions du Seuil, 1971.

Seminário, livro 11: Os quatros conceitos fundamentais da psicanálise; tradução M.D. Magno. Rio de Janeiro: Zahar, 2008.

LAGIER, Luc. Les mille yeux de Brian De Palma. Paris: Cahiers du Cinéma, 2008.

LARDEAU, Yann. “Le sexe froid”. In: Cahiers du cinéma, nº 289, junho de 1978.

LEBENSZTEJN, Jean-Claude. Pygmalion. Bruxelas: Les presses du réel, 2009.

LEDOUX, Aurélie. L'ombre d'un doute: Le cinéma américain contemporain et ses trompel'oeil. Rennes: Presses Universitaires de Rennes, 2012.

LELOUP, Jean-Yves. O ícone: uma escola do olhar. São Paulo: Editora Unesp, 2006.

LICHTENSTEIN, Jacqueline (org.). A Pintura: textos essenciais - Vol. 1: O mito da pintura. Trad. Magnólia Costa (coord.). São Paulo: Ed. 34, 2004.

MAHEO, Michel. "Le suspense hitchcokien, à la source du 'giallo'”. In: CinémAction, n. 71, 1994, pp. 70-75.

MAJOUR, Frédéric. “On ne vit que deux fois”. In: Vertigo, n. 46, outono de 2013.

MALRAUX, André. O museu imaginário; tradução Isabel Saint-Aubyn. Lisboa: Edições 70, 2011.

MARÍAS, Miguel. "Something really new: Starting over". In: Undercurrent, n. 1, abril de 2006. Disponível em: http://www.fipresci.org/undercurrent/issue_0106/guerin_marias.htm.

MARIE, Olivier. “L'indistinct manifeste”. In: Éclipses, nº 42, 2008. 
MARIN, Louis. De la représentation. Paris: Gallimard/Le Seuil, 1994.

MARKER, Chris. “A free replay (notes sur Vertigo)”. In: Positif, n. 400, junho de 1994.

MAURIÈS, Patrick. Maniéristes. Paris, Editions de la Lagune, 1995.

Cabinets de curiosités, Paris: Gallimard, 2011.

METZ, Christian. A significação no cinema. Trad. Jean-Claude Bernardet. $2^{\mathrm{a}}$ ed. São Paulo: Perspectiva, 1977.

MICHAUD, Philippe-Alain. Aby Warburg e a imagem em movimento. Trad. Vera Ribeiro. Rio de Janeiro: Contraponto, 2013.

MICHELSON, Annette. “Toward Snow”. In: SITNEY, P. A. (org.). The Avant-Garde Film: A Reader of Theory and Criticism. Nova York: New York University Press, 1978.

MINAZZOLI, Agnès. La première ombre: Réflexion sur le miroir et la pensée. Paris: Les Éditions de Minuit, 1990.

MODLESKI, Tania. Hitchcock et la théorie féministe. Paris: L'Harmattan, 2002.

MORIN, Edgar. O cinema ou o homem imaginário. Lisboa: Moraes Editores, 1980.

MULVEY, Laura. Visual and Other Pleasures. Indiana: Indiana University Press, 1989.

NACACHE, Jacqueline. O cinema clássico de Hollywood. Lisboa: Edições Texto \& Grafia, 2012.

NANCY, Jean-Luc. Noli me tangere: Ensayo sobre el levantamiento del cuerpo. Madrid: Editorial Trotta, 2006.

Le Plaisir au dessin. Paris: Galilée, 2009.

L'Autre portrait. Paris: Galilée, 2014.

NARBONI, Jean. "Visages d'Hitchcock". In : (org.). Alfred Hitchcock. Paris: Éditions de l'Étoile/Cahiers du Cinéma, 1980.

NATALI, Maurizia. L’Image-paysage: iconologie et cinéma. Saint-Denis: Presses Universitaires de Vincennes, 1996.

NINEY, François. Le subjectif de l'objetif. Paris: Klincksieck, 2014.

NOGUEZ, Dominique. "Sur la longueur d'onde de Michael Snow". In: SAYAG, Alain (org.). Michael Snow. Paris: Centre Georges Pompidou, 1978.

NUNES, Benedito. “A visão romântica”. In: J. Guinsburg (org.). O Romantismo. São Paulo: Perspectiva, 1978. 
PAÏNI, Dominique. Le cinéma, un art moderne. Paris: Ed. Cahiers du Cinéma, 1997.

PANOFSKY, Erwin. Significado nas artes visuais. $3^{\mathrm{a}}$ ed. São Paulo: Perspectiva, 2002.

Idea: a evolução do conceito do Belo; tradução Paulo Neves. $2^{\mathrm{a}}$ ed. São Paulo: Martins Fontes, 2000.

PIDDUCK, Julianne. "La femme fatale hollywoodienne des années 90: Basic instinct, un cas de figure", in Vertigo, no 14 (dossiê "Féminin/masculin"), janeiro de 1996.

PLASSERAUD, Emmanuel. Cinéma Baroque. Paris: Presses Universitaires du Septentrion, 2001.

PLATÃO. Oeuvres complètes - Tome VIII, $3^{e}$ partie: Le sophiste. Paris: Les Belles Lettres, 2003.

POMMIER, Edouard. Théories du portrait. De la Renaissance aux Lumières. Paris: Gallimard, 1998.

PREDAL, René. Michelangelo Antonioni ou la vigilance du désir. Paris: Les Éditions du Cerf, 1991.

PRINCE, Stephen. A New Pot of Gold: Hollywood under the electronic rainbow, 1980-1989. Los Angeles: University of California Press, 2002.

RANCIÈRE, Jacques. La fable cinématographique. Paris, Éditions du Seuil, 2001. Janeiro: Contraponto, 2012.

As distâncias do cinema.; tradução Estela dos Santos Abreu. Rio de O espectador emancipado; trad. Ivone C. Benedetti. São Paulo: WMF Martins Fontes, 2012.

RAUGER, Jean-François. "La mise en scène de l'acte sexuel: focalisation/fuckalization". In: AUMONT, Jacques (org.). La mise en scène. Bruxelas: De Boeck Université, 2000.

ROBERT, Valentine. "Le tableau vivant chez Raoul Ruiz: l'extension de la perception". In: Décadrages, n. 15, outono de 2009.

ROBIC, Jean-François. Blowup: une seconde vue. Paris: L'Harmattan, 2012.

ROCHE, Thierry. Blow up: un regard anthropologique. Paris, Yellow Now, 2010.

ROHMER, Éric. Le goût de la beauté. Paris: Éditions de l'Étoile/Flammarion, 1989.

ROTHMAN, William. “Scottie's dream, Judy's plan, Madeleine's revenge”. In: MAKKAI, Katalin (org.). Vertigo. Londres: Routledge, 2013.

RUIZ, Raúl. Poetics of cinema. Paris: Éditions Dis Voir, 2005. 
SALT, Barry. Film Style and Technology: History and Analysis. $3^{\mathrm{a}}$ ed. Londres: Starword, 1983, 1992, 2009.

SCHEFER, Jean Louis. Du monde et du mouvement des images. Paris: Éditions Cahiers du Cinéma, 1997.

SCHEINFEIGEL, Maxime. "Revenir dans les miroirs du cinéma". In: Cinergon, no 19-20, 2010.

SEMIN, Didier. "Ce que j'aurais fait si j'avais repêché Kim Novak inconsciente dans la baie de San Francisco”. In: Cinéma, n. 5, Paris, Éditions Léo Scheer, 2003.

SERVOIS, Julien. Le cinéma pornographique. Paris: Vrin, 2009.

SIETY, Emmanuel. Fictions d'images: Essai sur l'attribution de propriétés fictives aux images de films. Presses Universitaires de Rennes, 2009.

SIMSOLO, Noël. Le Film Noir: Vrais et faux cauchemars. Paris: Ed. Cahiers du Cinéma, 2005.

SITNEY, P. Adams. Visionary Film: The American Avant-garde 1943-1978. 2a. ed. Nova York: Oxford University Press, 1979.

SNOW, Michael. Des écrits: 1958-2001. Paris: Centre Pompidou, 2002.

STOICHITA, Victor I. L'instauration du tableau: Métapeinture à l'aube des temps modernes. Genebra: Droz, 1999. . Brève histoire de l'ombre. Genebra: Droz, 2000.

O efeito Pigmalião - Para uma antropologia histórica dos simulacros; tradução Renata Correia Botelho e Rui Pires Cabral. Lisboa: KKYM, 2011.

TESSON, Charles. Luis Buñuel. Paris: Cahiers du Cinéma/Éditions de l’Étoile, 1995.

THORET, Jean-Baptiste. 26 secondes: L'Amérique éclaboussée. Pertuis: Rouge Profond, 2003.

2008 .

Dario Argento: Magicien de la peur. Paris: Ed. Cahiers du Cinéma, “Qui sont ces chiens?”. In: Cahiers du cinéma, no 649, outubro de 2009.

TRIAS, Jean-Philippe. “L’oeil du cinéma”. In: Cinergon, n. 6/7: "Histoires de l'oeil”, 1999. . "Doublure \#1: le rêve du modèle". In: Cinergon, n. 16, 2003.

TRUFFAUT, François. Hitchcock-Truffaut. 2a ed. São Paulo: Brasiliense, 1986. 
WARBURG, Aby. O Nascimento de Vénus e a Primavera de Sandro Botticelli. Trad. Artur Morão. Lisboa: KKYM, 2012.

WILLIAMS, Linda. Hard core: power, pleasure, and the frenzy of the visible. Los Angeles: University of California Press, 1989.

Paris: Capricci, 2014.

Screening Sex: Une histoire de la sexualité sur les écrans américains.

WILLIAMS, Tony. Larry Cohen: The radical allegories of an independent filmmaker. Carolina do Norte: McFarland, 1997.

WILSON, Michael Henry. Jacques Tourneur ou la magie de la suggestion. Paris: Éditions du Centre Pompidou, 2003.

WOOD, Robin. Hitchcock’s Films Revisited. Nova York: Columbia University Press, 2002.

VERNET, Marc. "Dictatures du pignoché: les fictions du portrait”. In: Iris, n. 14-15, outono de 1992. . Figures de l'absence. Paris: Éditions de l'Étoile, 1988.

VINCENDEAU, Ginette. “Lectures féministes”. In: CinémAction, n. 60, 1991

XAVIER, Ismail. O olhar e a cena. São Paulo: Cosac \& Naify, 2003.

O discurso cinematográfico: a opacidade e a transparência. $2^{\mathrm{a}}$ ed. São Paulo: Paz e Terra, 2008. (org.). A experiência do cinema. Rio de Janeiro: Graal; Embrafilme, 1983.

ZAGARRIO, Vito (org.). Argento vivo. Veneza: Marsilio, 2008.

ZIZEK, Slavoj (org.). Everything you always wanted to know about Lacan ... but were afraid to ask Hitchcock. Londres, Nova York: Verso, 1992.

. "Vertigo: The Drama of a Deceived Platonist". In: ALLEN, Richard e GOTTLIEB, Sidney (orgs.). The Hitchcock Annual Anthology - Selected Essays from Volumes 10-15. Londres/Nova York: Wallflower Press, 2009, pp. 211-222. 